\title{
Site Observational Work Plan For the Umtra Project Site At Falls City, texas
}

\author{
RECEIVED \\ JUL 281995 \\ OSTI
}

June 1995

\section{DISCLAIMER}

This report was prepared as an account of work sponsored by an agency of the United States

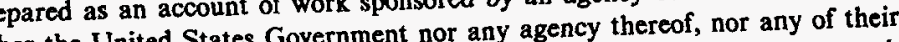
Government. Neither the United States Government nor any agency legal liability or responsiemployees, makes any warranty, express or implied, or ass information, apparatus, product, or bility for the accuracy, completeness, or usefulness of any information, apparatus, product, or process disclosed, or represents that its use would not infringe privately owame, trademark, proce herein to any specific commercial product, process, or service by trade name, trademark, manufacturer, or otherwise does not necessarily constitute or imply its endorsement, recomor mendation, or favoring by the United States Government or an state or reflect those of the

and opinions of authors expressed herein do not
United States Government or any agency thereof.

\section{DISTRIBUTION OF THIS DOCUMENT IS UNLIMITED


This report has been reproduced from the best available copy. Available in paper copy and microfiche.

Number of pages in this report: 70

DOE and DOE contractors can obtain copies of this report from:

Office of Scientific and Technical Information

P.O. Box 62

Oak Ridge, TN 37831

(615) 576-8401

This report is publicly available from:

National Technical Information Service

Department of Commerce

5285 Port Royal Road

Springfield, VA 22161

(703) $487-4650$ 


\section{DISCLAIMER}

Portions of this document may be illegible in electronic image products. Images are produced from the best available original document. 


\section{SITE OBSERVATIONAL WORK PLAN FOR THE UMTRA PROJECT SITE AT FALLS CITY, TEXAS}

June 1995

Prepared for

U.S. Department of Energy

UMTRA Project

Albuquerque, New Mexico

Prepared by

Jacobs Engineering Group Inc.

Albuquerque, New Mexico 


\section{EXECUTIVE SUMMARY}

The requirements for ground water compliance for Uranium Mill Tailing Remedial Action (UMTRA) Project sites, including the Falls City site, are found in the Uranium Mill Tailings Radiation Control Act (42 USC $\$ 7901$ et seq.) and the U.S. Environmental Protection Agency's Health and Environmental Protection Standards for Uranium and Thorium Mill Tailings (40 CFR Part 192; 60 FR 2854).

Ground water beneath the Falls City site was contaminated by uranium ore processing activities, open pit mining, and in situ solution leaching of tailings. Open pit mining occurred at the Falls City site before the milling activities. The mines were on parcels $A$ and $B$ of the site. Also, the shallow ground water in the mined areas is often of naturally poor quality because of ore bodies in the aquifer matrix.

A total of 2.5 million tons (2.3 million tonnes) of uranium ore were extracted and processed on the site. An acid-leach, countercurrent-decantation solvent extraction system was used to extract and concentrate uranium. The Deweesville sandstone containing the uranium was mined, ground, and then agitated in a sulfuric acid solution. An organic solution (tertiary amine and kerosene) was added during the extraction circuit. The uranium was stripped from the organic solution with either a sodium carbonate or an acidified sodium chloride solution. The residue sands, sandy-slimes, and slimes from processing uranium ore (tailings) were left on the mill site.

During surface remedial action, an estimated 7.0 million tons (6.4 million tonnes) of uranium mill tailings and other contaminated materials were consolidated and stabilized on the site. The ground water protection strategy at the Falls City disposal site for the UMTRA Surface Project was an application for supplemental standards, based on limited use ground water in the uppermost aquifer. This water is not a current or potential source of drinking water. Ground water from the uppermost aquifer (ground water from the Deweesville/Conquista Members and the Dilworth Member) contains widespread ambient contamination resulting from naturally occurring conditions and from the effects of human activity not related to uranium milling operations (uranium exploration and mining activities). The ground water cannot be effectively cleaned up for drinking purposes with treatment methods reasonably employed by public water supply systems. The U.S. Nuclear Regulatory Commission (NRC) and the state of Texas concurred with the ground water protection strategy for the disposal site in September 1992. Surface remedial action in accord with 40 CFR Part 192 Subpart A was completed in April 1994.

The proposed ground water compliance strategy at the Falls City site is to perform no remedial action based on application for supplemental standards because the ground water in the uppermost aquifer is classified as limited-use ground water. Limited-use ground water includes ground water that is not a current or potential source of drinking water because of widespread, ambient contamination that cannot be cleaned up using treatment methods reasonably employed by public water supply systems (40 CFR $\$ 192.11(\mathrm{e})$ ). 


\section{TABLE OF CONTENTS}

\section{Section}

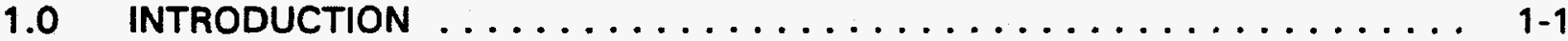

1.1 Ground water compliance strategy ................... 1-1

1.2 UMTRA Project programmatic documents . . . . . . . . . . . . 1-1

1.3 Relationship to site-specific documents . . . . . . . . . . . . . 1-2

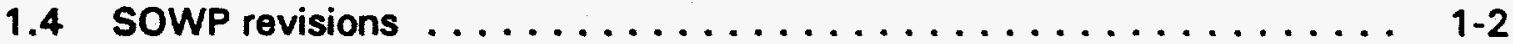

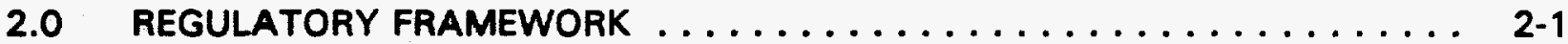

2.1 Uranium mill tailings radiation control act . . . . . . . . . . . . . 2-1

2.1.1 EPA ground water protection standards .......... 2-1

2.1.2 Cooperative agreements ................. 2-4

2.2 National Environmental Policy Act $\ldots \ldots \ldots \ldots \ldots \ldots \ldots . \ldots \ldots$

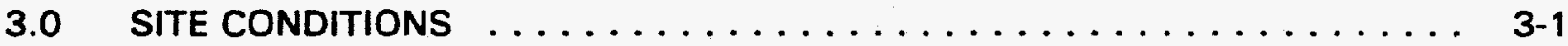

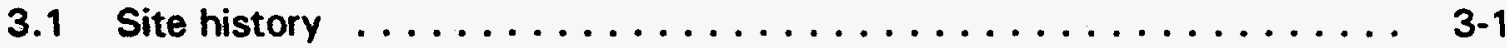

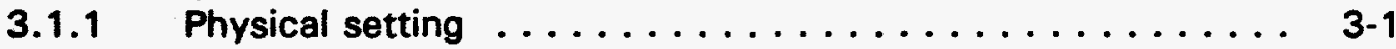

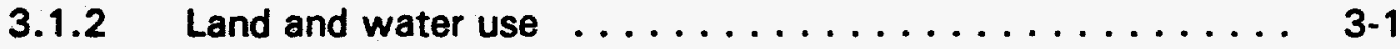

3.1.3 History of operations .................. 3-1

3.1 .4 Milling process .................... 3 .5

3.1 .5 Surface remedial action .................. $3-5$

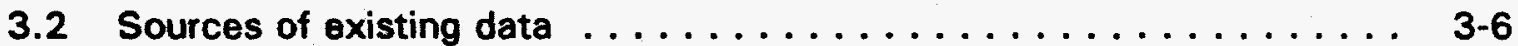

3.3 Conceptual site model . . . . . . . . . . . . . . . . . 3-7

3.3.1 Hydrogeologic setting ................... $3-9$

3.3.2 Background ground water quality ... . . . . . . . . . 3-16

3.3.3 Magnitude of site-related ground water contamination ..... 3-34

3.3.4 Contaminant fate and transport ............. 3-36

3.3.5 Risk evaluation ..................... 3-38

3.4 Evaluation of interim action opportunities $\ldots \ldots \ldots \ldots \ldots \ldots$ 3-42

4.0 GROUND WATER COMPLIANCE STRATEGY SELECTION . . . . . . . . . 4-1

4.1 Compliance strategy selection process . . . . . . . . . . . . . 4 4-1

4.2 Falls City, Texas, compliance strategy selection . . . . . . . . . . 4-1

4.3 Deviations, contingencies, and decision rules . . . . . . . . . . 4-5

5.0 DATA COLLECTION AND ASSESSMENT $\ldots \ldots \ldots \ldots \ldots \ldots \ldots \ldots \ldots$

5.1 Statement of data needs . . . . . . . . . . . . . . . . $5-1$

5.1.1 Qualitative analysis of background ground water quality ... . 5-1

5.1 .2 Land and water use survey ............... 5-1

5.1.3 Hydrogeologic investigations ................ 5-1

5.2 Data collection objectives .................... 5-2

5.3 Data quality objectives ...................... $5-3$

5.3.1 Qualitative analysis of background ground water quality ... 5-3

5.3.2 Land and water use survey ................ 5-3

5.3.3 Hydrogeologic investigations ............... 5-3

5.4 Data collection activities .................... 5 .5 
TABLE OF CONTENTS (Concluded)

Section

Page

5.4.1 Qualitative analysis of background ground water quality ... 5 5-5

5.4 .2 Land and water use survey ............... 5-5

5.4.3 Hydrogeologic investigations .............. 5-7

5.5 Results and evaluation of data collection activities . . . . . . . . . 5-11

$6.0 \quad$ LIST OF CONTRIBUTORS $\ldots \ldots \ldots \ldots \ldots \ldots \ldots \ldots \ldots \ldots \ldots \ldots$

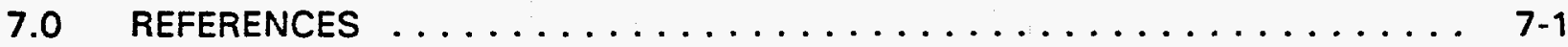

APPENDIX A,

CALCULATION FCT-06-91-12-01-00

APPENDIX B, WELL LOGS 


\section{LIST OF FIGURES}

Figure

Page

3.1 Location of the Falls City, Texas, site $\ldots \ldots \ldots \ldots \ldots \ldots \ldots \ldots$. . . . . . . . . .

3.2 Topographic map of the disposal site area . . . . . . . . . . . . . 3-3

3.3 Locations of monitor wells, former tailings piles, and disposal cell, Falls City, Texas, site ... . . . . . . . . . . . . . . . . . . . 3-8

3.4 Surface geology and cross section locations, Falls City, Texas, site $\ldots \ldots \ldots$ 3-10

3.5 Cross section of uppermost aquifer A-A', Falls City, Texas, site . . . . . . . 3-11

3.6 Potentiometric surface of the Deweesville/Conquista aquifer, Falls City, Texas, site . . . . . . . . . . . . . . . . . . . . . . . . 3-14

3.7 Locations of the Dilworth background wells and the Deweesville/Conquista

3.8 Trilinear plot of data from Deweesville/Conquista monitor wells 667,668 , and selected Hobson monitor wells, Falls City, Texas, site . . . . . . . . . . 3-25

3.9 Trilinear plot of Dilworth background ground water and Deweesville/ Conquista reference water, Falls City, Texas, site . . . . . . . . . . . . 3-26

3.10 Approximate distribution of tailings-contaminated ground water in Deweesville/Conquista aquifer, Falls City, Texas, site . . . . . . . . . 3-35

4.1 Framework application of contaminants of potential concern in the

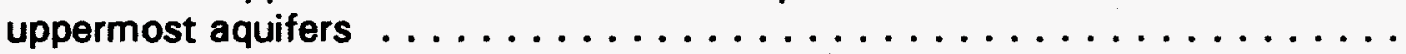

5.1 Areal coverage of land and water use survey $\ldots \ldots \ldots \ldots \ldots \ldots \ldots$

5.2 Proposed monitor well locations, Deweesville/Conquista aquifer, Falls City, Texas, site 


\section{LIST OF TABLES}

Table

2.1 Maximum concentration of inorganic constituents for ground water protection for UMTRA Project sites . . . . . . . . . . . . . . . . . . 2-3

3.1 Typical water quality data for Dilworth and Deweesville/Conquista background wells .......................... 3-17

3.2 Water quality in the Deweesville/Conquista aquifer at the Falls City, Texas, site . . . . . . . . . . . . . . . . . . . . . . . . . . 3-20

3.3 Statistical summary of the Dilworth ground water quality at the Falls City, Texas, site . . . . . . . . . . . . . . . . . . . . . 3-27

3.4 Contaminants of potential concern in the Dilworth aquifer . . . . . . . . 3-40

4.1 Framework application of contaminants of potential concern for the Dilworth aquifer . . . . . . . . . . . . . . . . . . . . . 4-4

5.1 Construction summary of proposed monitor well $\ldots \ldots \ldots \ldots \ldots$ 


\section{LIST OF ACRONYMS AND ABBREVIATIONS}

\section{Acronym Definition}

$A C L$

ASTM

DOE

DOO

EPA

FM

GPS

$M C L$

NEPA

NRC

PEIS

PVC

QA

RAP

RRM

SOP

SOWP

SWI

TAC

TDS

TKA

$\mathrm{U}_{3} \mathrm{O}_{8}$ UMTRA

UMTRCA

USGS alternate concentration limit

American Society for Testing Materials

U.S. Department of Energy

data quality objective

U.S. Environmental Protection Agency

Farm-to-Market

global positioning system

maximum concentration limit

National Environmental Policy Act

U.S. Nuclear Regulatory Commission

programmatic environmental impact statement

polyvinyl chloride

quality assurance

remedial action plan

residual radioactive materials

standard operating procedure

site observational work plan

Susquehanna-Western, Inc.

Technical Assistance Contractor

total dissolved solids

Turk, Kehle \& Associates

uranium oxide

Uranium Mill Tailings Remedial Action

Uranium Mill Tailings Radiation Control Act

U.S. Geological Survey 


\subsection{INTRODUCTION}

Produced by the U.S. Department of Energy (DOE), this site observational work plan (SOWP) will be used to determine site-specific activities to comply with the U.S. Environmental Protection Agency (EPA) ground water standards at this Uranium Mill Tailings Remedial Action (UMTRA) Project site. The purpose of the SOWP is to recommend a site-specific ground water compliance strategy at the Falls City UMTRA Project site. The Falls City SOWP presents a comprehensive summary of site hydrogeological data, delineates a conceptual model of the aquifer system, and discusses the origins of milling-related ground water contamination. It also defines the magnitude of ground water contamination, potential environmental and health risks associated with ground water contamination and data gaps, and targets a proposed compliance strategy.

\subsection{GROUND WATER COMPLIANCE STRATEGY}

The proposed ground water compliance strategy for the Falls City site is no remediation, with an application for supplemental standards based on the following criteria:

- The ground water is considered limited-use ground water. Limited-use ground water is ground water that is not a current or potential source of drinking water because widespread ambient contamination cannot be cleaned up with treatment methods reasonably employed by public water supply systems (60 FR 2854). However, U.S. Environmental Protection Agency (EPA) standards require the DOE to consider the impact of milling contamination on current or future beneficial uses of ground water. In Falls City, potential beneficial uses would be limited to watering livestock and gardens because the quality of naturally occurring ground water is poor and the yield is low.

Section 2.0 describes the requirements for meeting standards at UMTRA Project sites. Section 3.0 provides site-specific data that support the proposed ground water compliance strategy. Section 4.0 justifies the proposed ground water compliance strategy.

\subsection{UMTRA PROJECT PROGRAMMATIC DOCUMENTS}

The programmatic documents that guide the SOWP include the UMTRA Groundwater Program Plan (DOE, 1992a) the Programmatic Environmental Impact Statement (PEIS) (DOE, 1995), and Technical Approach to Groundwater Restoration (DOE, 1993a). The Groundwater Program Plan states the mission and objectives of the UMTRA Project Ground Water Program and provides a technical and management approach for conducting the program. The PEIS is the proposed programmatic decision-making framework for conducting the UMTRA Ground Water Project. DOE will follow PEIS guidelines to assess the potential programmatic impacts of the Ground Water Project, to determine site-specific ground water compliance strategies, and to prepare site-specific environmental impacts analyses more efficiently. Technical guidelines for 
conducting the ground water program are found in the Technical Approach to Ground Water Restoration.

\subsection{RELATIONSHIP TO SITE-SPECIFIC DOCUMENTS}

The surface remedial action plan (RAP) provides site characterization information (DOE, 1992b). This information was updated in developing the SOWP to formulate the site conceptual model. If a ground water compliance strategy requiring remedial action activities is selected for this site, a ground water RAP or surface RAP modification will be prepared.

In 1994, a baseline risk assessment was prepared (DOE, 1994) identifying potential public health and environmental risks at the site. Potential risks identified in the risk assessment are considered in this SOWP to ensure that the proposed compliance strategy is protective of human health and the environment.

After identification of a proposed compliance strategy in the SOWP, a sitespecific National Environmental Policy Act (NEPA) document (e.g., environmental assessment) will be prepared to determine the potential impacts, if any, of implementing the proposed compliance strategy.

\subsection{SOWP REVISIONS}

This SOWP presents a summary of existing data, a conceptual model, a recommended compliance strategy based on this conceptual model, and data needed to further support the selected strategy. This document will be revised as more information is collected. The final document will describe the additional data and correlate it to previous information, update the site conceptual model, and, if necessary, will revise the proposed ground water compliance strategy. 


\subsection{REGULATORY FRAMEWORK}

This section identifies the requirements for selecting a ground water compliance strategy for the Falls City, Texas, processing site to achieve compliance with Subpart B of the EPA health and environmental protection standards for uranium and thorium mill tailings (40 CFR Part 192), and the final rule to the standards published in 60 FR 2854.

\section{$2.1 \quad$ URANIUM MILL TAILINGS RADIATION CONTROL ACT}

The United States Congress passed the Uranium Mill Tailings Radiation Control Act (UMTRCA) (42 USC $\$ 7901$ et seq.) in 1978 in response to public concerns about potential health hazards from long-term exposure to uranium mill tailings. The UMTRCA authorized DOE to stabilize, dispose of, and control uranium mill tailings and other contaminated materials at inactive uranium mill processing sites.

Title I of the UMTRCA designates 22 inactive processing sites for remediation. It directs the EPA to promulgate standards; mandates remedial action in accordance with these standards; stipulates that remedial action be selected and performed with the concurrence of the U.S. Nuclear Regulatory Commission (NRC), and in consultation with the states and Indian tribes; directs the NRC to license the disposal sites; and directs the DOE to enter into cooperative agreements with the affected states and Indian tribes. Title II applies to active uranium mills. Title III applies only to certain uranium mills in New Mexico. The UMTRA Project is responsible for administering only Title I of the UMTRCA.

In 1988, Congress passed the Uranium Mill Tailings Remedial Action Amendments Act (Amendments Act) (42 USC $\$ 7922$ et seq.), authorizing the DOE to extend without limitation the time needed to complete ground water remediation activities at the processing sites.

\subsubsection{EPA ground water protection standards}

The UMTRCA requires EPA to promulgate standards for protecting public health, safety, and the environment from radiological and nonradiological hazards associated with uranium processing and the resulting residual radioactive materials (RRM). On 5 January 1983, the EPA published standards (40 CFR Part 192) for RRM disposal and cleanup. The standards were revised and a final rule was published 11 January 1995 (60 FR 2854).

The standards address two ground water contamination scenarios: future ground water contamination that might occur from tailings piles after disposal, and the cleanup of contamination resulting from the milling process at the processing sites (60 FR 2854). The UMTRA Surface Project is designed to control and stabilize tailings and contaminated soil. The Ground Water Project addresses residual contamination at the processing sites and is regulated by Subparts $B$ and $C$ of the EPA standards. 
Subpart B, "Standards for Cleanup of Land and Buildings Contaminated with Residual Radioactive Materials From Inactive Uranium Processing Sites," requires remedial action at the former processing sites to ensure the RRM in ground water meets any of the following three criteria:

- Background levels. Concentrations of constituents in nearby ground water not contaminated by processing activities.

- Maximum concentration limits (MCL). Maximum concentrations set by the EPA for certain hazardous constituents in ground water, proposed for the UMTRA Project (Table 2.1).

- Alternate concentration limits (ACL). An alternate concentration limit for a hazardous constituent that does not pose a substantial hazard (present or potential) to human health or the environment as long as the limit is not exceeded. An ACL maybe applied after considering options to achieve background levels or MCLs (60 FR 2867).

Subpart B also allows natural flushing to meet the standards. Natural flushing allows natural ground water processes to reduce the contamination in ground water to acceptable standards (background levels, MCLs, or ACLs). Natural flushing must allow the standards to be met within 100 years. In addition, institutional controls to protect human health and an adequate monitoring program must be established and maintained during the period of natural flushing; institutional controls restrict access to contamination. The ground water also must not be a current or projected source of drinking water during the period of natural flushing, and beneficial uses of ground water must be protected (60 FR 2867).

Subpart C, "Implementation," provides guidance for implementing methods and procedures to reasonably ensure the provisions of Subpart B are satisfied. Subpart $\mathrm{C}$ requires the following:

- The conditions of Subpart B must be met on a site-specific basis, using information gathered during site characterization and monitoring. The plan to meet the conditions of Subpart B must be stated in a site-specific compliance strategy plan or RAP; either plan must contain a compliance strategy and a monitoring program and must demonstrate effectiveness (60 FR 2868).

Subpart $C$ also describes the conditions under which DOE may apply supplemental standards to contaminated ground water, rather than meeting background levels, MCLs, or ACLs. The standards define limited use ground water as ground water that is not a current or potential source of drinking water because total dissolved solids (TDS) exceed 10,000 milligrams per liter (mg/L); widespread ambient contamination cannot be cleaned up using treatment methods reasonably employed by public water supply systems; the quantity of water available is less than 150 gallons (570 liters) per day; or because cleanup 
Table 2.1 Maximum concentration of inorganic constituents for ground water protection for UMTRA project sites

\begin{tabular}{lc}
\hline Constituent & Maximum concentration $^{\mathrm{a}}$ \\
\hline Arsenic & 0.05 \\
Barium & 1.0 \\
Cadmium & 0.01 \\
Chromium & 0.05 \\
Lead & 0.05 \\
Mercury & 0.002 \\
Molybdenum & 0.1 \\
Nitrate (as N) & $10.0^{\mathrm{b}}$ \\
Selenium & 0.01 \\
Silver & 0.05 \\
Combined radium-226 and radium-228 & $5 \mathrm{pCi} / \mathrm{iter}$ \\
Combined uranium-234 and uranium-238 & $30 \mathrm{pCi} / \mathrm{liter}$ \\
Gross alpha-particle activity (excluding radon and uranium) & $15 \mathrm{pCi} / \mathrm{liter}$ \\
\hline
\end{tabular}

${ }^{a}$ Concentrations reported in milligrams per liter $(\mathrm{mg} / \mathrm{L})$ unless otherwise noted.

bquivalent to $44 \mathrm{mg} / \mathrm{L}$ nitrate as nitrate.

Cquivalent to $0.044 \mathrm{mg} / \mathrm{L}$, assuming secular equilibrium of uranium-234 and uranium-238.

pCi - picocuries.

Ref: 60 FR 2854. 
of ground water would cause excessive environmental harm, or because cleanup is technically impractical (60 FR 2867). Subpart C requires the DOE to inform private owners and occupants of the area affected by hazardous constituents and to solicit their comments before applying supplemental standards. The DOE has implemented a public participation program in Falls City to meet the requirements of Subpart $C$.

The DOE proposes a no remediation/supplemental standards compliance strategy for the Falls City, Texas, site. This strategy will achieve compliance with the EPA ground water standards applicable to Title I UMTRA Project sites. To protect ground water and to achieve compliance with the proposed EPA ground water standards under Subpart A (UMTRA Surface Project), a narrative supplemental standard for the Falls City site was proposed and approved. The supplemental standard application for the surface remedial action was based on widespread ambient contamination that could not be cleaned up with methods reasonably employed by public water supply systems. Therefore, the DOE concluded that ground water in the uppermost aquifer meets the widespread ambient contamination criteria of limited use ground water. The NRC and the state of Texas concurred with the DOE ground water protection strategy for the UMTRA Surface Project in 1992. The Falls City ground water compliance strategy (to meet Subpart B requirements) is identical to the Surface Project ground water protection strategy. The regulatory drivers that guide the selection of the proposed ground water compliance strategy for the Falls City, Texas, site and all other UMTRA sites are identified below.

\subsubsection{Cooperative agreements}

The UMTRCA requires remedial action to include full participation of the states and Indian tribes that own land containing uranium mill tailings. The UMTRCA also directs DOE to enter into cooperative agreements with the states and Indian tribes.

\subsection{NATIONAL ENVIRONMENTAL POLICY ACT}

The UMTRCA is a major NEPA activity (42 USC $\$ 4321$ et seq.). Regulations of the Council on Environmental Quality (to implement the NEPA) are codified in 40 CFR Part 1500; these regulations require each federal agency to develop its own implementing procedures (40 CFR \$1507.3). The DOE-related NEPA regulations are contained in 10 CFR Part 1021, National Environmental Policy Act; Implementing Procedures. Guidance is provided in Recommendations for the Preparation of Environmental Assessments and Environmental Impact Statements (DOE, 1993b).

Pursuant to the NEPA, in 1994 the DOE drafted a PEIS for the UMTRA Ground Water Project to analyze the potential impacts of implementing four programmatic alternatives for ground water compliance at the designated processing sites. Once the preferred alternative for the UMTRA Ground Water Project is selected, that alternative will be published in a record of decision. All 
subsequent action on the UMTRA Ground Water Project must comply with that record of decision. 


\subsection{SITE CONDITIONS}

This section discusses past uranium mining and milling activities at and in the vicinity of the site, the surface remedial action, and the status of surface cleanup efforts. Site characterization data are summarized and the site conceptual model is presented. The site conceptual model is based on the ground water characterization data and is intended to enhance understanding of contaminant fate and transport, exposure pathways, risk to public health and the environment, and the remediation strategy. The model also provides the rationale for the proposed ground water compliance strategy.

Hydrogeologic and geochemical characterization efforts at the Falls City site began before surface cleanup and continued throughout surface remedial action. Thus, sufficient data are available to develop conceptual model for the former processing site. Section 3.3 presents a conceptual model and discusses contaminant fate and transport.

\subsection{SITE HISTORY}

\subsubsection{Phrsical setting}

The Falls City site is in Karnes County. Texas, approximately 8 miles (mi) [13 kilometers (km)] southwest of the town of Falls City and $46 \mathrm{mi}(74 \mathrm{~km})$ southeast of San Antonio, Texas (Figure 3.1). Before surface remedial action, the tailings site consisted of two parcels. Parcel A consisted of the mill site, one mill building, five tailings piles, and one tailings pond south of Farm-to-Market (FM) Road 1344 and west of FM 791. A sixth tailings pile designated Parcel B was north of FM 791 and east of FM 1344 (Figure 3.2).

\subsubsection{Land and water use}

Most of the land surrounding the former processing site is used for cattle grazing and dry farming. Local residents primarily grow hay and other livestock feed crops. Most livestock in the site area are beef cattle; some residents keep small poultry flocks.

The Deweesville/Conquista and the Dilworth aquifers are not used as domestic or potable water supplies in the immediate site vicinity, although the Dilworth aquifer is occasionally used within a $2-\mathrm{mi}(3-\mathrm{km})$ radius of the site to water stock (DOE, 1992b). The Three Oaks Water Company supplies residences within the site area with water from a Carrizo Sandstone well. This well is 2000 feet ( $\mathrm{ft}$ ) $(600$ meters [m]) deep and is approximately $10 \mathrm{mi}(16 \mathrm{~km})$ northwest of the site. Livestock are watered primarily from surface collection tanks or stock ponds.

\subsubsection{History of operations}

In late 1955, the Climax Molybdenum Company identified uranium ore deposits averaging 0.20 percent uranium oxide $\left(\mathrm{U}_{3} \mathrm{O}_{8}\right)$ in an area $8 \mathrm{mi}(13 \mathrm{~km})$ west of 


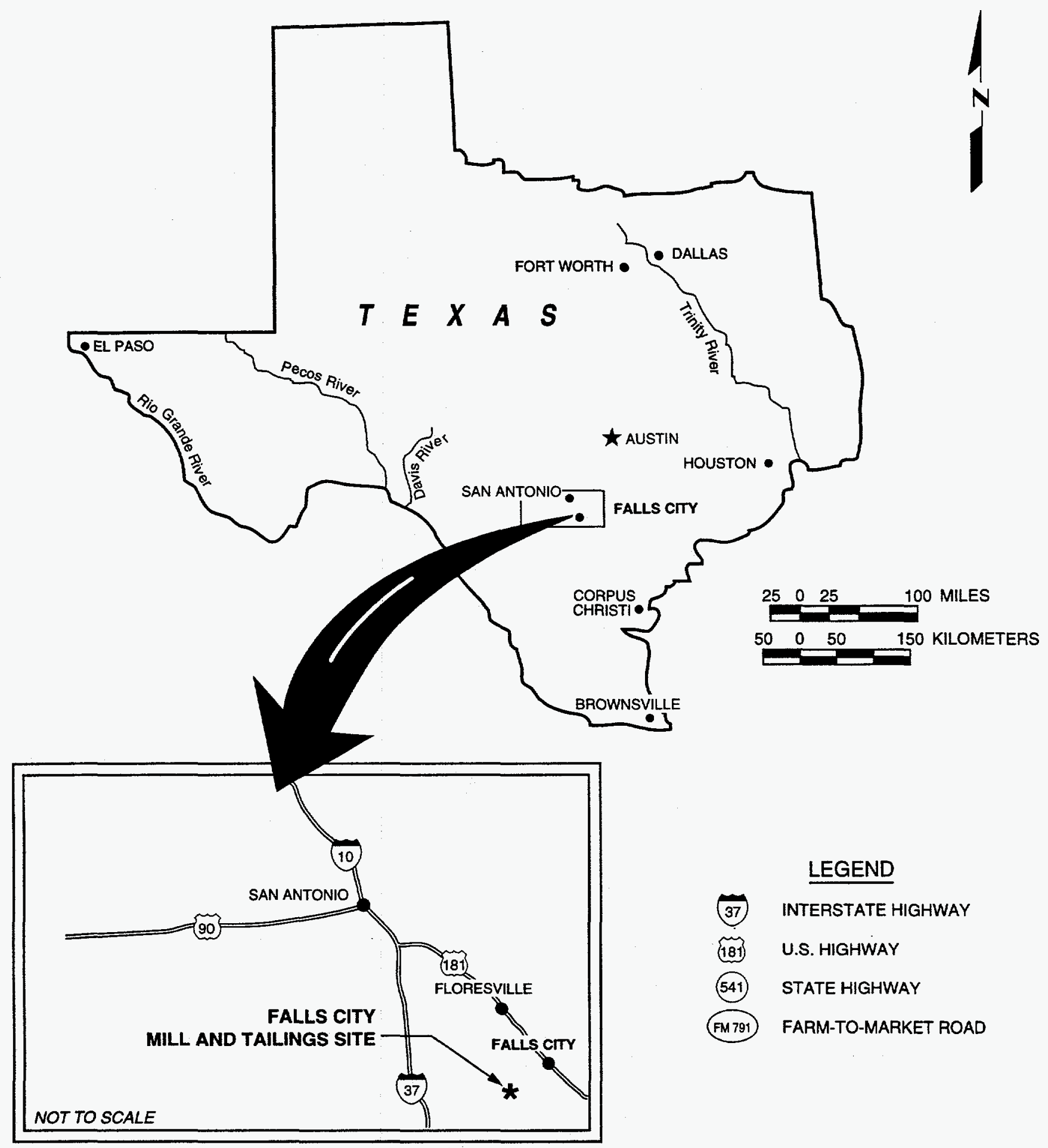

FIGURE 3.1

LOCATION OF THE FALLS CITY, TEXAS, SITE 


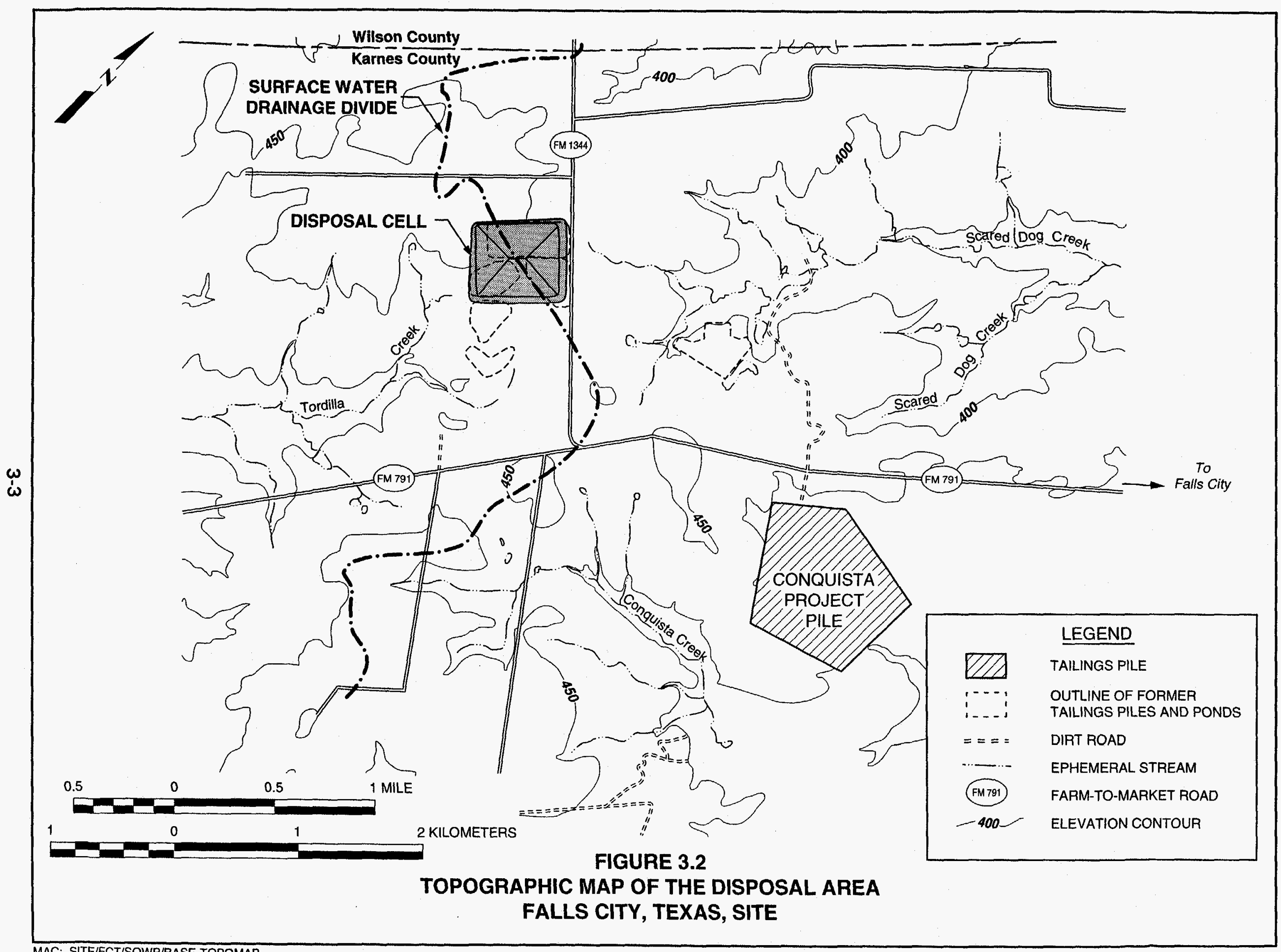


Falls City. Open pit mining occurred from 1959 to 1960 and was completed when Susquehanna-Western, Inc. (SWI), acquired the property as a mill site in 1961. Open pit mining occurred at the former locations of piles $3,4,5$, and 6 . The mill was constructed as a nominal 300-ton-per-day (tpd) operation, but operated at 220 tpd from April 1961 until early 1968 (Merritt, 1971). In 1968, the mill expanded to operate at 900 tpd and, for short periods, up to $1000 \mathrm{tpd}$ (Merritt, 1971). In August 1973, the mill ceased operations, having treated 2.5 million tons (2.3 million tonnes) of ore (FBDU, 1981).

During mill operations, ground water from a well adjacent to the mill building was the only source of processing water. The well was $3650 \mathrm{ft}(1110 \mathrm{~m})$ deep in the Carrizo Sandstone; the state decommissioned the well in 1991.

An SWI solid waste registration application submitted in 1973 stated that fresh water consumption ranged from 50 to 150 gallons (190 to 570 liters) per minute. Consumption depended on the ore, amount of rainfall and/or tailings pond solution available for recycle (in 1973 ponded water from tailings pile 7 was the only solution in active use), and reagent consumption required by the process. SWI also stated in the application that " $75 \mathrm{gpm}$ [gallons per minute] fresh water consumption may be considered a fair average." That measurement represents a net discharge to tailings pile 7 of approximately 121 acre (ac)-ft per year. The ponds on the tailings piles were not lined, but sumps along the pile perimeters pumped runoff and seepage back to the tailings piles. During mill operation (1961 to 1973), approximately 865 ac-ft of ore-processing water and precipitation that fell on the ponds might have infiltrated the Deweesville/ Conquista aquifer. This calculation is included as an appendix to this document.

At the completion of SWI operations in 1973, a 40-ac (16-hectare [ha]) pond had been created at the top of pile 7 . The liquids in this pond were acidic raffinates. In August 1978, Solution Engineering, Inc., of Alice, Texas, initiated in situ extraction mining on the tailings piles, installing an injection/withdrawal system in pile 7 . Fluids from the raffinate pond were injected to a depth of 30 to $45 \mathrm{ft}$ ( 9 to $14 \mathrm{~m}$ ) at a rate of about 500 gallons (1900 liters) per minute. Between 300 and 550 gallons (1140 to 2100 liters) per minute of fluids were extracted from the pile; those uranium-bearing solutions were processed at the mill. Eventually, the operation expanded to piles 1, 2, 4, and 5. In situ solution mining ended in February 1982. In 1983, after 3.5 years of leaching operations, the state of Texas annulled Solution Engineering's operating license and directed the company to conduct interim restoration activities. Interim restoration consisted of spray-evaporating the large ponds on top of piles 7 and 2, capping piles 7 and 2 with a 1-to 2-ft (0.3- to 0.6-m)-thick clay cover, and dismantling the mill. The interim restoration was completed in 1986 and probably reduced the rate of pore fluid seepage into the aquifer (DOE, 1992b). 


\subsubsection{Milling process}

An acid-leach countercurrent-decantation solvent-extraction system extracted and concentrated the uranium (as $\mathrm{U}_{3} \mathrm{O}_{8}$ ). This process is described below (Merritt, 1971).

Sulfuric acid was added as a leaching agent to the ore slurry, producing a slurry with a pH near 1.0. A five-stage, countercurrent washing circuit included a polyacrylamide-type flocculent to assist in separating the slimes from the process stream. The solvent extraction circuit included an organic solution containing 7.5 percent tertiary amine and 2.5 percent isodecanol in kerosene. Uranium was stripped from the loaded organic with either a sodium carbonate or acidified sodium chloride solution. The final uranium product ("yellow cake") was precipitated by adding caustic soda.

\subsubsection{Surface remedial action}

Remedial action consolidated and stabilized 7.0 million tons $(6.4$ million tonnes) of tailings and contaminated materials into a disposal cell covering 132 ac (53.4 ha) in the vicinity of piles 7 and 2. The approximate footprint of these piles is $2600 \times 2200 \mathrm{ft}(790 \times 670 \mathrm{~m})$. At least 30 monitor wells within or around the construction area were decommissioned (cutoff and grouted) during surface remedial action.

The DOE is required to demonstrate that RRM surface cleanup and disposal will not impact (or further impact) ground water in the vicinity of the former processing site. Thus, the NRC required the site-specific RAP to include a ground water protection strategy.

To protect the ground water and achieve compliance with the EPA ground water standards, a narrative supplemental standard for the Falls City site was proposed. The supplemental standard for the surface remedial action was based on widespread ambient contamination that could not be cleaned up using methods reasonably employed by public water supply systems. Also, there were few potential beneficial uses of the ground water due to poor quality and low yield. Historically, the uppermost aquifer has not been used as a drinking water source for those two reasons. Because the ground water quality is so poor (TDS $7500 \mathrm{mg} / \mathrm{L}$ ) in the upper aquifers, they are rarely used except as a water source for limited stock watering and occasional home garden irrigation. Therefore, ground water in the uppermost aquifers meets the widespread ambient contamination criterion of limited use ground water (DOE, 1992b).

The NRC and the state of Texas concurred with the surface RAP and ground water protection strategy in September 1992. Surface remedial action was completed in May 1994. 


\subsection{SOURCES OF EXISTING DATA}

The UMTRA Project and other investigators conducted several hydrologic, geologic, and geochemical studies at and in the vicinity of the Falls City processing site.

In a U.S. Geological Survey (USGS) report based largely on data from the exploratory drilling programs conducted in the late 1950s, Bunker and MacKallor (1973), describe the geology of uranium ore deposits in the Falls City area. The USGS report includes detailed discussions of the stratigraphy and mineralogy of several ore deposits in the Tordilla Hill-Deweesville area, including the two deposits (Nuhn and Luckett) mined at the Falls City site (open pit mines).

Kallus (1975) prepared a report for EPA Region VI on the general environmental impacts of uranium mining and milling in the South Texas uranium district. That report summarizes surface and ground water monitoring data compiled from USGS and Texas Water Quality Board records. Ground water data were derived from approximately 100 samples, with complete chemical analyses performed on one-third of the samples. Kallus found highly variable natural levels of radioactivity, arsenic, molybdenum, and selenium in South Texas ground water. The only reported health impact from uranium mining was molybdenosis in cattle that grazed in runoff-contaminated areas near overburden piles.

Turk, Kehle \& Associates (TKA) conducted the first site-specific hydrogeologic study at the Falls City mill site in 1976 (TKA, 1976). This study was a reconnaissance-level investigation that relied on existing water level and water quality data from 26 monitor wells around the site and included a general characterization of the local climate, geology, surface water quality, and ground water conditions. The TKA study concluded radioactive contamination (gross alpha and beta activity) was not evident in the aquifer system beneath the site.

Ford, Bacon \& Davis Utah Inc. (FBDU, 1981) prepared an engineering assessment of the Falls City site that included field sampling of the 14 monitor wells installed by Solution Engineering Inc. around the tailings piles. Analyses of samples from these wells indicated contamination of the shallow aquifer in the vicinity of the tailings piles.

In 1983, Geochemistry and Environmental Chemistry Research, Inc. (GECR, 1983), initiated a geochemical investigation of the Falls City site.

Approximately 50 surface water and soil core samples were analyzed to define the extent of surficial contamination on and around the tailings piles. However, only two wells in the vicinity of the site were sampled.

The recent site characterization program conducted by the UMTRA Project included a three-phase hydrogeologic field investigation. In the first phase (December 1985 through May 1986), 39 new 4-inch (100 millimeter [mm]) polyvinyl chloride (PVC) cased monitor wells were installed and sampled; 25 existing wells were sampled as well. 
The second phase of the investigation (December 1988 through March 1990) was designed to gather supplemental data from the site to fill data gaps and achieve full compliance with the EPA ground water protection standards. In addition, 12 more monitor wells were installed at depths ranging from 40 to $230 \mathrm{ft}(2$ to $70 \mathrm{~m})$, completed primarily in the Dilworth Sandstone Member and the upper Manning Clay Formation; ground water from 50 to 55 monitor wells was sampled, including the 12 new wells and selected Conoco background wells in the site vicinity; and 16 lysimeters were installed to characterize the water quality of tailings fluids in piles $1,2,4,5,7$, and pond 6 .

Between 1990 and 1992, with the assistance of the Texas Bureau of Economic Geology, the UMTRA Project conducted a third phase of the field program to further characterize site geochemistry. The program included drilling 13 coreholes, analyzing the geochemistry of the cores, and installing 17 new monitor wells.

In 1991 and in early spring of 1994, domestic well surveys were conducted of a $2-\mathrm{mi}(3-\mathrm{km})$ radial area centered upon the site. The survey determined the historical and current use of ground water in the Deweesville/Conquista and Dilworth aquifers. Figure 3.3 shows locations of all wells drilled or sampled by the DOE at the Falls City site.

\subsection{CONCEPTUAL SITE MODEL}

A conceptual model of the site was developed to understand the site and to support the proposed ground water compliance strategy and remediation objectives. The conceptual model is summarized below; Sections 3.3.1 through 3.3.5 provide details of the model.

Two low-yield (generally less than 1 gallon [4 liters] per minute) aquifers underlying the site have been identified: the Deweesville/Conquista and the Dilworth. The Deweesville and Conquista Members are grouped together as one aquifer because no impermeable strata separates them and there are no apparent restrictions in ground water movement between the two members.

Several investigators, including the Technical Assistance Contractor (TAC) and the Texas Bureau of Economic Geology, concluded the upper portions of the Deweesville/Conquista Formations (the subsurface at the processing site) historically were unsaturated, and milling and in situ mining activities caused the current saturated conditions beneath the site. The TAC and the Texas Bureau of Economic Geology determined that processing and mining water created a ground water mound under the site and that ground water from the mound moves radially outward and downdip. The TAC used MODFLOW (USGS, 1988) to simulate ground water flow at the site; preliminary modeling results support the hydrologic representation of site conditions suggested by the TAC and Texas Bureau of Economic Geology. 


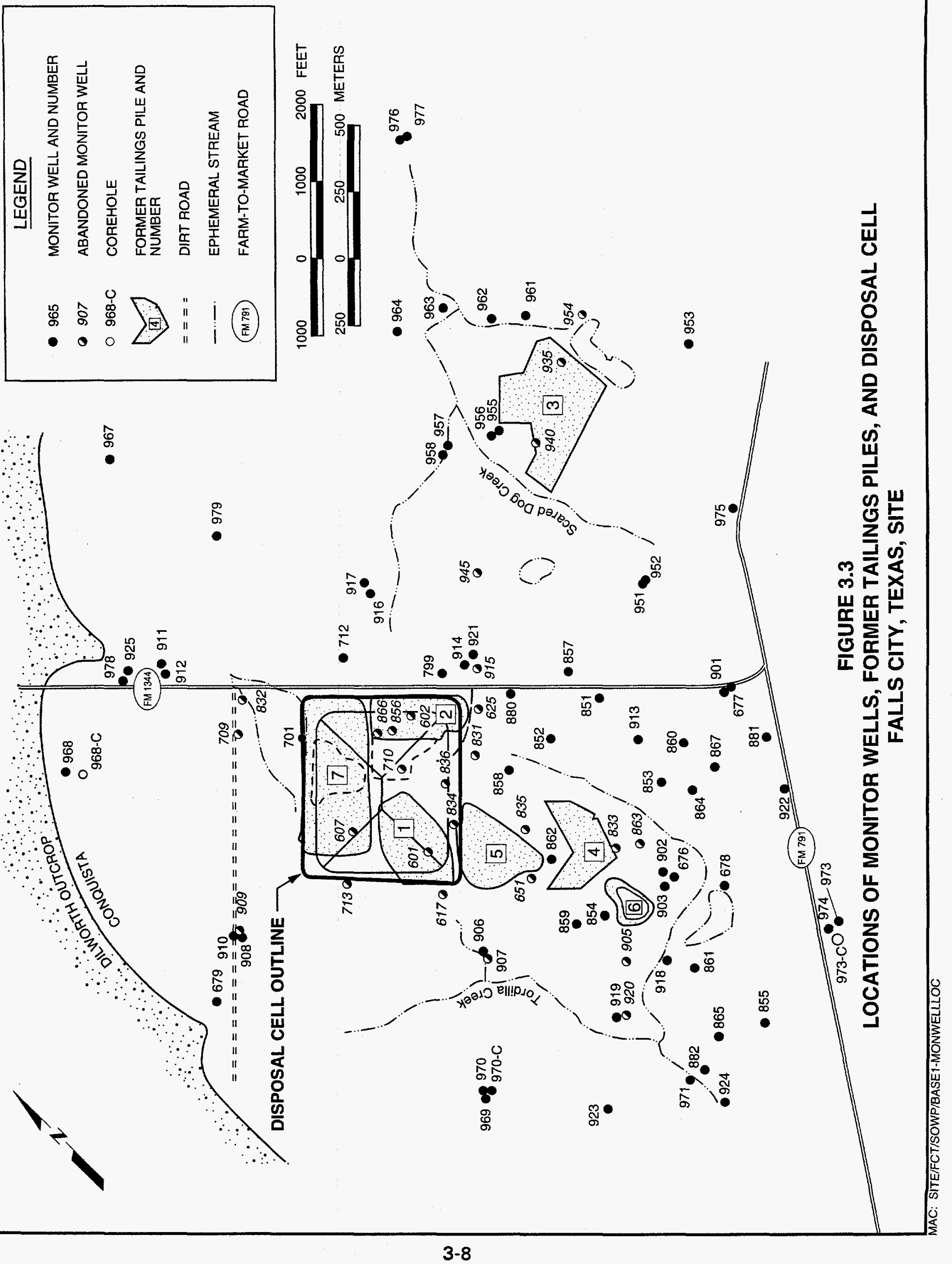


The principal ore-bearing unit at the site is the Deweesville Sandstone. Because the uranium mineralization associated with the ore bodies causes background ground water quality in both the Deweesville/Conquista and Dilworth aquifers to vary with depth and location, the ground water quality is difficult to define deterministically. Thus, a complete understanding of geochemical conditions at the site has not been established. However, the contaminants of concern in the aquifer that are related to the mill processing have been identified.

\subsubsection{Hydrogeologic setting}

The Falls City site is on the coastal plain of the Gulf of Mexico. The main topographic element in the Karnes County area is a series of ridges trending predominantly northeast to southwest. These ridges are mainly cuestas (sloping plains) formed by resistant gulfward-dipping strata, although some river terrace gravels also form local topographic highs. Small intermittent streams follow the easily eroded strata between cuestas, producing a pronounced northeast trend in the drainage pattern in the site area. Relief from ridges to intervening drainage pathways is generally less than $100 \mathrm{ft}(30 \mathrm{~m})$ (TKA, 1976). Figure 3.2 presents a topographic map of the site area.

Mean annual precipitation in the site area is 30 inches $(760 \mathrm{~mm}$ ) (NOAA, 1979). Virtually all measurable precipitation is in the form of rain, which reaches monthly maxima in both May and September (NOAA, 1979). Most precipitation occurs as heavy rainfall during brief thunderstorms, which causes great spatial and temporal variability in rainfall distribution.

The Falls City site is underlain by clastic sedimentary strata that dip gently southeast (approximately $20 \mathrm{ft}$ per $1000 \mathrm{ft}$ ) as part of the thick homoclinal sequence of the Gulf Coastal Plain. The local sedimentary strata are comprised of generally unlithified sand, silt, and clay deposits of the Whitsett and Manning Clay Formations. The site rests on outcrops of the Dubose Clay, Deweesville Sandstone, and Conquista Clay Members of the Whitsett Formation (Figure 3.4). Tailings were placed in several old open pits excavated through the ore-bearing Deweesville and upper Conquista Members. Underlying the Conquista Clay is the Dilworth Sandstone Member, which, in turn, overlies the Manning Clay Formation. The Manning Clay is the oldest geologic unit encountered during the site drilling program. The site is located on a ground water divide. This divide coincides with a surface drainage divide oriented west-northwest through the disposal cell area.

Three low-yield water-bearing strata are within the upper $200 \mathrm{ft}(60 \mathrm{~m})$ of the Whitsett Formation sediments underlying the site. These water-bearing strata in descending order are the Deweesville Sandstone Member, the Conquista Clay Member, and the Dilworth Sandstone Member. The Conquista Clay Member is composed of three subunits: an oxidized upper Conquista Clay/silt, the Conquista Sandstone, and a lower Conquista Clay (Figure 3.5). The Conquista Sandstone extends downdip into the subsurface but thins significantly and becomes considerably finer-grained. The Deweesville Sandstone Member, upper 


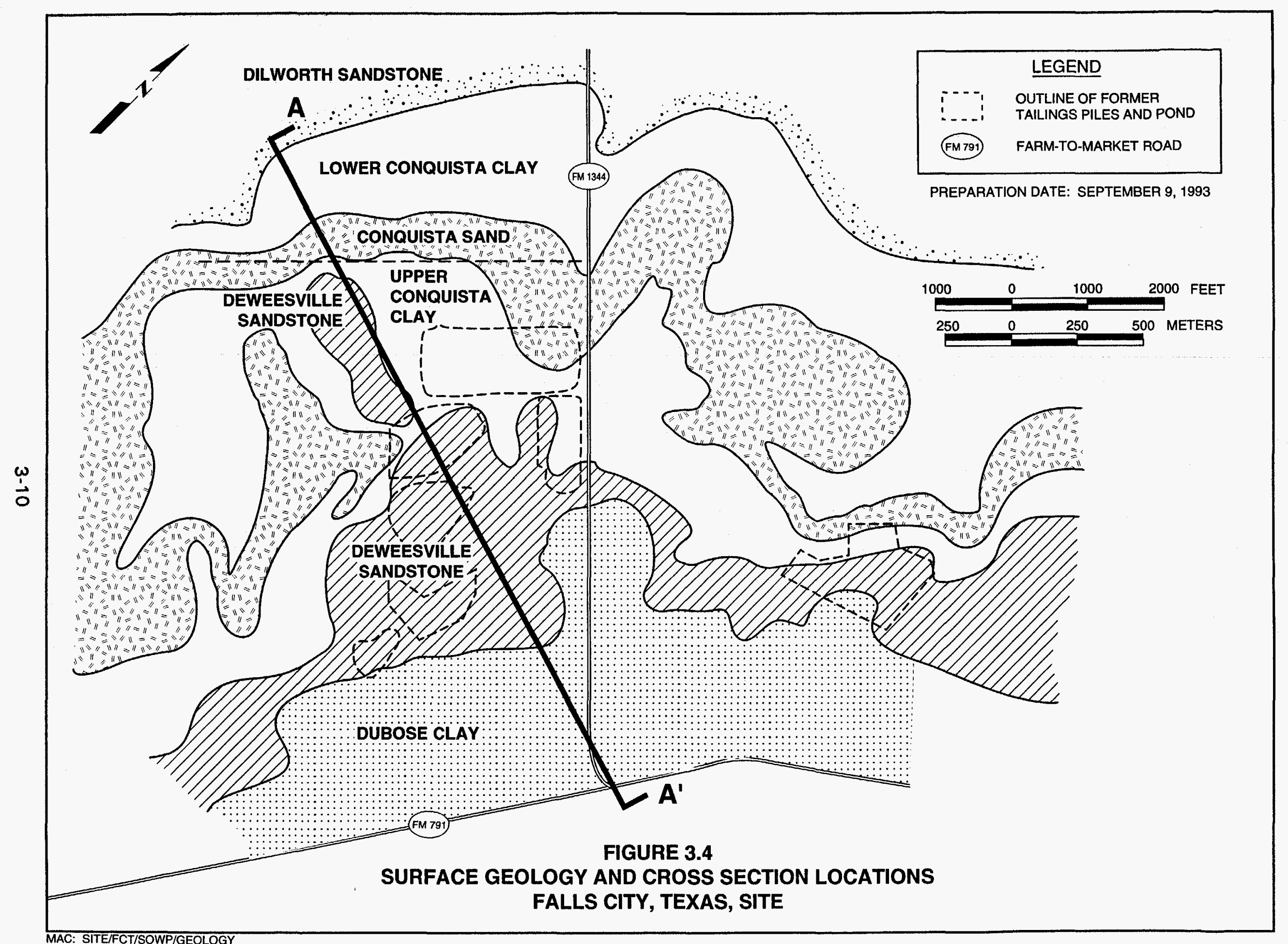




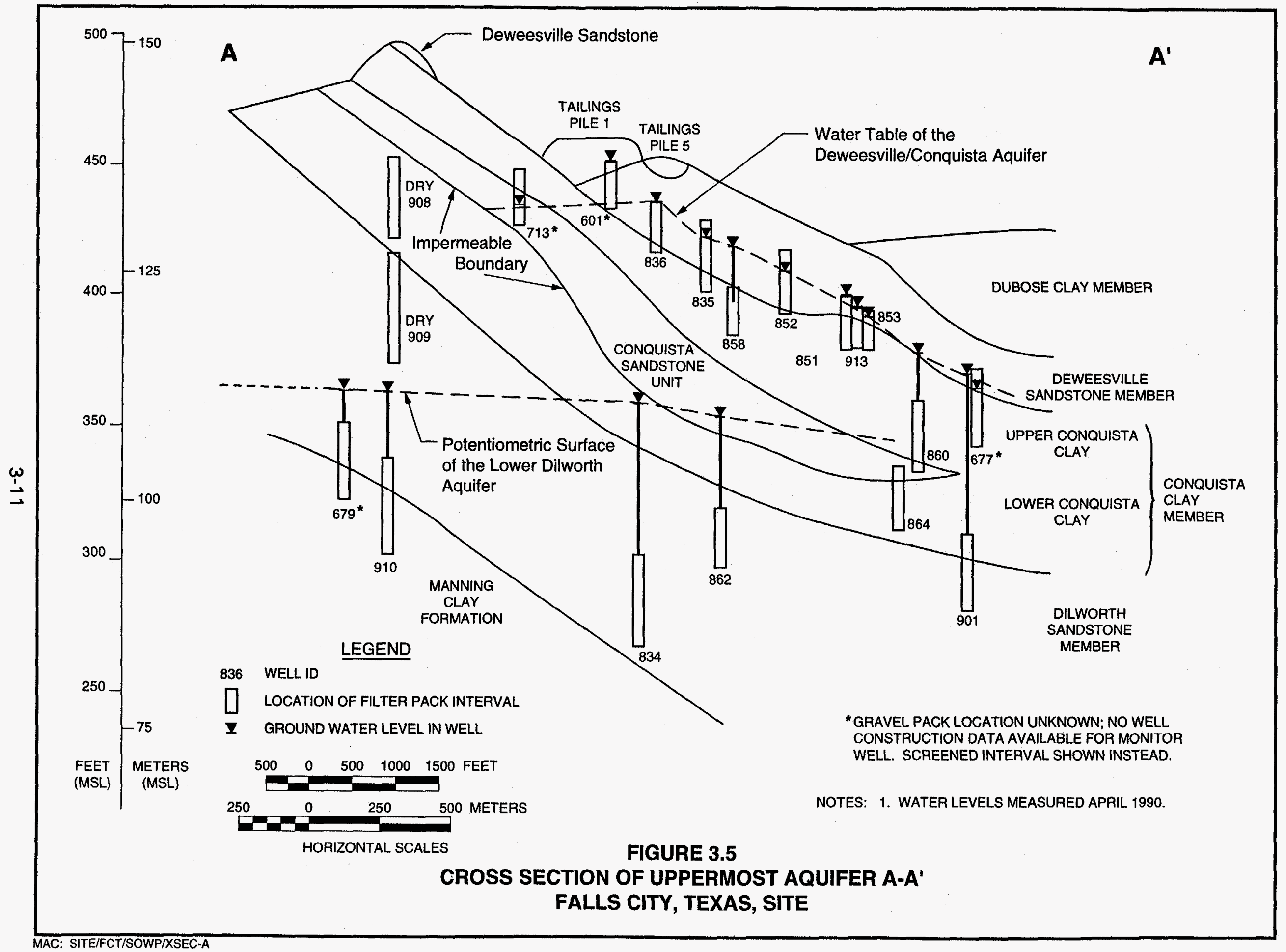


Conquista Clay, and Conquista Sandstone subunits are grouped together as one aquifer because impermeable strata do not separate the members, with no apparent restrictions in ground water movement between the two members. Although the Deweesville/Conquista and Dilworth are referred to as aquifers in this document, these members have never been developed as a source for drinking water supply because of their low yield (generally less than 1 gallon [4 liters] per minute) and poor water quality.

\section{Deweesville/Conquista aquifer}

Shallow ground water in the site vicinity is found in the Deweesville/Conquista aquifer at depths of 5 to $30 \mathrm{ft}(2$ to $9 \mathrm{~m})$ below land surface. Ground water within the aquifer occurs under unconfined conditions in the northern and western portions of the site vicinity and along creek beds. In areas where the Deweesville/Conquista aquifer is unconfined, the potentiometric surface generally is a subdued replica of the surface topography. The saturated condition of the Deweesville/Conquista in the immediate vicinity of the disposal cell is due, in part, to the discharge of milling-process water

The top of the lower Conquista Clay defines the lower boundary of the Deweesville/Conquista aquifer. The intersection of the Deweesville/Conquista water table and the top of the lower Conquista Clay marks the updip limit of saturation in the Deweesville/Conquista aquifer (Figure 3.5). Monitor wells 908 and 923 are completed updip of this intersection and consequently are dry. Because the tailings piles overlie outcrops of the Deweesville Sandstone and the upper Conquista Clay at the surface, it is impossible to install upgradient, background monitor wells screened in the Deweesville/Conquista aquifer.

Ground water within the Deweesville/Conquista aquifer is recharged by infiltrating precipitation in the Deweesville/Conquista outcrop areas, seepage of tailings fluids, and interformation leakage in downdip areas. Ground water within the Deweesville/Conquista aquifer immediately downgradient of the disposal cell discharges to the eastern tributary of Tordilla Creek. Ground water discharge might continue downdip into the subsurface, where some ground water might discharge into Conquista Creek, southeast of FM 791. North of former tailings pile 3, ground water flows locally to the north toward Scared Dog Creek.

Seepage from tailings disposed of in old pits and on the outcrop of the Deweesville Sandstone and upper and middle Conquista subunits has resulted in a ground water mound in the Deweesville/Conquista aquifer. The Deweesville/Conquista potentiometric surface beneath tailings piles 1, 2, 4, and 5 is higher than background ground water levels. Ground water levels near the tailings have risen since initial mining. Before milling and tailings disposal activities, there was little water in the Deweesville/Conquista from the tailings area down to the tributary of Tordilla Creek (BEG, 1992). A review of the scientific literature on this site suggests this zone of the Deweesville/Conquista might have contained very little water prior to milling activity. The floor of open 
pit mine 5 (former tailings pile 5) extended several feet below the Deweesville/ Conquista interface; a 1960 photograph of this pit (Bunker and MacKallor, 1973) shows the contact between the Deweesville and the Conquista was dry. After these pits were filled with saturated tailings and the later leachate injection/in situ leaching began, large volumes of tailings pore water were introduced to the Deweesville/Conquista. Consequently, a ground water mound developed on the processing site in and around the tailings piles. Currently, the water table in the outcrop area of the Deweesville is 8 to $17 \mathrm{ft}(2$ to $5 \mathrm{~m}$ ) above the base of the Deweesville. The Conquista Clay also was affected by these milling-related processes and water levels beneath pile 7 (on the Conquista outcrop) may have been as much as $40 \mathrm{ft}(10 \mathrm{~m})$ higher than the background water table elevation (BEG, 1992). Background ground water conditions do not exist in the outcrop area of the Deweesville Sandstone immediately east of the site. Naturally occurring ground water might only exist where the Deweesville/ Conquista aquifer dips below the Dubose (BEG, 1992). As shown on the map of the potentiometric surface contours developed from water levels measured in 1993 (Figure 3.6), ground water from the tailings flows in three directions: east, away from former tailings pile 2; south, toward the eastern tributary of Tordilla Creek; and southeast, down the structural dip of the Deweesville beneath FM 791 and into the deeper subsurface.

\section{Dilworth aquifer}

The Dilworth aquifer is a sandstone member of the Whitsett Formation. It is separated from the Deweesville/Conquista aquifer by 30 to $50 \mathrm{ft}(9$ to $15 \mathrm{~m})$ of carbonaceous clay of the lower Conquista Clay subunit, which acts as an aquitard to downward seepage. The Dilworth aquifer extends approximately $100 \mathrm{ft}(30 \mathrm{~m})$ below the disposal cell.

Near the outcrop of the Dilworth sandstone (Figure 3.4), ground water is unconfined. Depths to ground water in the Dilworth aquifer range from approximately 30 to $100 \mathrm{ft}(9$ to $30 \mathrm{~m})$ below land surface. Downdip to the southeast, ground water in the Dilworth aquifer becomes confined by the lower Conquista clay. A cross-sectional view of the potentiometric surface of the Dilworth aquifer is shown on Figure 3.5.

A downward hydraulic gradient occurs between the Dilworth aquifer and the overlying Deweesville/Conquista aquifer. The potentiometric surface in the lower Dilworth aquifer shows ground water flows generally southeast beneath the site from the Dilworth outcrop (recharge area) northwest of the site. Thus, ground water from the Deweesville/Conquista aquifer could recharge the Dilworth aquifer. The Texas Bureau of Economic Geology identified three discrete potentiometric highs as an indication of leakage from the Deweesville/Conquista aquifer into the Dilworth aquifer. These leakages were caused by extensive deep drilling by mining companies exploring for ore. The potentiometric highs are near monitor wells 901,915 and 917 , and 905 and 907. The mining exploration programs drilled approximately 370 boreholes that typically penetrated through the Dilworth and were not abandoned properly 


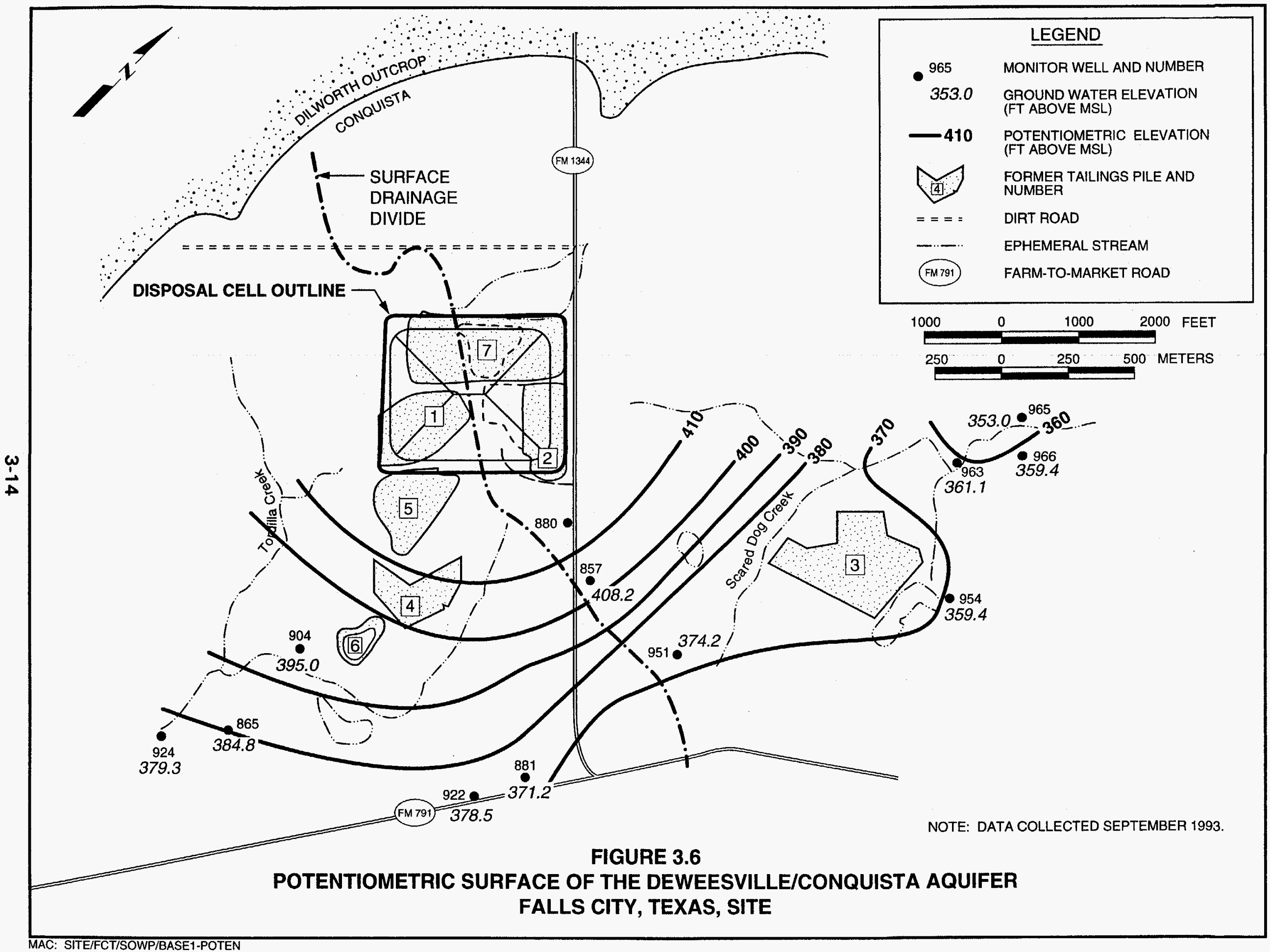


(BEG, 1992). The monitor wells were constructed with the filter pack interval placed across the Conquista/Dilworth contact. The elevated water levels might be influenced by drainage from the Deweesville/Conquista aquifer through the well bore annulus rather than drainage through the formations. The Dilworth is underlain by the carbonaceous clays and lignite seams of the Manning Clay Formation, effectively forming a 300-ft (90-m)-thick aquitard.

Because improperly abandoned exploratory boreholes form a potential hydraulic interconnection between the Deweesville/Conquista aquifer and the Dilworth unit, the Dilworth unit is included as part of the uppermost aquifer.

\section{Hydraulic and transport properties}

The saturated hydraulic conductivities of the most permeable beds of the Whitsett Formation aquifer system, as determined by aquifer tests and single-packer pressure testing, range from approximately 0.5 to $2.6 \mathrm{ft}$ per day $\left(1.8 \times 10^{-4}\right.$ to $9.0 \times 10^{-4}$ centimeters per second $\left.[\mathrm{cm} / \mathrm{s}]\right)$. The TAC conducted this aquifer test (and all other aquifer tests discussed here) in the spring of 1991. The hydraulic conductivities are consistent with the ranges generally reported in the hydrologic literature for sandy clays, silty to clayey sands, and fine sandstones. The sandy members contain a high percentage of silts and clays, and yield small amounts of water ( 1 to 2 gallons [ 4 to 8 liters] per minute) to extraction wells. The lowest hydraulic conductivities are found in the carbonaceous clays of the lower Conquista Clay unit and the silty to clayey sands of the upper Dilworth Sandstone unit. The most permeable intervals tested are the fossiliferous sands of the middle Conquista Clay Member and the unconsolidated, fine-to-medium sands of the lower Dilworth Sandstone.

The horizontal hydraulic conductivities in the Deweesville and Conquista units are highly variable, with a value range of 2 orders of magnitude. The maximum horizontal hydraulic conductivity for the Deweesville/Conquista aquifer was $2.6 \mathrm{ft}$ per day $\left(9.0 \times 10^{-4} \mathrm{~cm} / \mathrm{s}\right)$, calculated from aquifer test data from a well screened in the Conquista Sandstone (DOE, 1992b). Using Darcy's Law, an assumed effective porosity of 0.1 , and an average hydraulic gradient of 0.013 to the east-southeast, the maximum average linear ground water velocity is $130 \mathrm{ft}(40 \mathrm{~m})$ per year.

Average linear ground water velocities in the Dilworth aquifer were calculated using a hydraulic conductivity of $0.68 \mathrm{ft}$ per day $\left(2.4 \times 10^{-4} \mathrm{~cm} / \mathrm{s}\right.$ ) (approximate maximum value from aquifer test), a hydraulic gradient of 0.009 to the eastsoutheast, and an assumed effective porosity of 0.1 for the fine sands of this zone (DOE, 1992b). The average linear velocity for ground water flow in the lower Dilworth aquifer is approximately $22 \mathrm{ft}(6.7 \mathrm{~m})$ per year.

A downward hydraulic potential flow exists between the Deweesville/Conquista and Dilworth aquifers. During a 10-hour aquifer test of monitor well 902 completed in the Dilworth, drawdown was observed in an adjacent monitor well (676) screened in the Deweesville. Vertical leakage was calculated to be 
$7.4 \times 10^{-5}$ day $^{-1}$ from the analysis of time-drawdown data. Considering an aquitard thickness of $60 \mathrm{ft}(20 \mathrm{~m})$, the vertical hydraulic conductivity is $4.4 \times 10^{-3} \mathrm{ft}$ per day $\left(1.6 \times 10^{-6} \mathrm{~cm} / \mathrm{s}\right)$.

\subsubsection{Background around water quality}

Background ground water quality for the Deweesville/Conquista and Dilworth aquifers is defined as the quality of ground water at the Falls City site that would be present if uranium processing activities had not occurred.

There is no single background ground water quality for each of these aquifers. The natural ground water quality varies within these aquifers as a function of residence time and aquifer matrix composition. The Deweesville/Conquista and Dilworth aquifers can each be separated into three general regions or zones with different mineralogical and compositional characteristics. These zones are defined as the oxidized, transitional, and reduced zones. Although these zones overlap, the ground water in each zone typically is distinct in composition from the ground water in the other zones. Table 3.1 summarizes the range of background ground water quality at the site. The constituents and concentrations presented in Table 3.1 are based on the latest available data. Other background water quality data are presented in the Falls City RAP (DOE, 1992b). The numerous unmined and mined ore bodies in the oxidizing, transitional, and reducing zones of the regional sediments cause considerable variation in the concentrations of hazardous constituents from zone to zone.

\section{Deweesville/Conquista}

The oxidized zone of the Deweesville/Conquista is defined as the outcrop area and shallow subsurface. At the Falls City UMTRA site, this zone was largely unsaturated before mining and milling. The oxidized zone later became saturated by the influx of large volumes of tailings leachate and mill processing water. Thus, ground water in this zone at the mill site is not the result of natural processes, and a background ground water quality for the oxidized, outcrop zone of the Deweesville/Conquista aquifer does not exist in the mill site area.

The transitional zone begins at the downdip edge of the Deweesville/Conquista outcrop (where the sediments are dominantly oxidized) and ends before the downgradient limit of the DOE monitor well array (e.g., 922 and 881, where the sediments are dominantly reduced). Ground water quality before mining and milling activities in the uranium mineralized zone might have varied from conditions found in monitor well 951 to the much poorer quality ground water found in monitor well 922. The interaction of oxidizing water from the recharge area with the pyrite- and ore-bearing sediments causes high variability in the background ground water in the transitional zone.

The upgradient limit of the reduced zone for the Deweesville/Conquista is defined by the DOE and Texas Bureau of Economic Geology as the 


\begin{tabular}{|c|c|c|c|c|c|c|c|c|}
\hline \multirow[b]{2}{*}{ Constituents } & \multirow{2}{*}{$\begin{array}{c}\begin{array}{c}\text { Tailings } \\
\text { fluid }^{a}\end{array} \\
607\end{array}$} & \multicolumn{2}{|c|}{ Reduced zone } & \multicolumn{2}{|c|}{ Transitional zone } & \multicolumn{3}{|c|}{ Oxidized zone (outcrop area) } \\
\hline & & 667 & 668 & 951 & 969 & 967 & 968 & 979 \\
\hline Alkalinity $^{b}$ & & 252 & 250 & 307 & 291 & 116 & 226 & 193 \\
\hline Calcium & 494 & 335 & 405 & 364 & 495 & 278 & 90 & 258 \\
\hline Chloride & 1210 & 785 & 944 & 708 & 779 & 793 & 338 & 672 \\
\hline Iron & 430 & 0.45 & 0.19 & 0.03 & 0.87 & $<0.03$ & $<0.03$ & $<0.03$ \\
\hline Magnesium & 185 & 31.8 & 45.1 & 29 & 61 & 30.5 & 8.1 & 28.3 \\
\hline Manganese & 21.8 & 0.21 & 0.78 & 0.21 & 2.94 & 0.02 & $<0.01$ & 0.07 \\
\hline Nitrate & 0.5 & 4.9 & 3.5 & 4 & 1.3 & 10.2 & 12.4 & 4.4 \\
\hline $\mathrm{pH}$ & 2.95 & 6.65 & 6.63 & 6.75 & 6.70 & 5.98 & 6.58 & 6.08 \\
\hline Potassium & 1.77 & 43 & 29 & 45 & 43 & 30 & 18 & 36 \\
\hline Sodium & 739 & 678 & 583 & 652 & 550 & 675 & 121 & 531 \\
\hline Sulfate & 7700 & 1043 & 930 & 856 & 1290 & 817 & 156 & 569 \\
\hline $\begin{array}{l}\text { Total dissolved } \\
\text { solids }\end{array}$ & 12900 & 3120 & 3310 & 2291 & 3650 & 2750 & 624 & 2210 \\
\hline Uranium & 1.19 & 0.015 & 0.017 & 0.008 & 0.010 & 0.003 & 0.068 & 0.25 \\
\hline
\end{tabular}

${ }^{a}$ Water quality data from January 1991.

$b_{\mathrm{mg} / \mathrm{L} \mathrm{CaCO}}$.

Note: 1. Water quality data from June 1991 and July 1991 from Dilworth background wells 967, 968, 969, and 979; and Deweesville/Conquista background wells 951,667 , and 668 , except where noted.

2. Concentrations are reported in milligrams per liter except for $\mathrm{pH}$. 
downgradient edge of the DOE monitor well array (beginning at FM 791). Ground water quality data from Conoco monitor wells 667 and 668 suggest the ground water quality of the Deweesville/Conquista in parts of this zone is lower in sulfate, chloride, and many other constituents than water from the transitional zone. Figure 3.7 shows the locations of the Conoco monitor wells (657 and 668) and Dilworth background monitor wells.

To expand the background water quality data base for the Deweesville/ Conquista aquifer, ground water quality data from other areas in the Deweesville/Conquista were evaluated. Thirty-nine monitor wells were completed in the Deweesville Sandstone before mining activities began at the Hobson in situ uranium mine site, 8 or 9 mi (about $13 \mathrm{~km}$ ) east of the UMTRA site. Of those 39 wells, 28 were completed in the ore body and the remaining 11 were completed nearby. Table 3.2 presents a statistical summary of water quality data obtained from the Deweesville monitor wells.

The Deweesville wells at the Hobson site are generally screened between 300 and $450 \mathrm{ft}(90$ to $140 \mathrm{~m}$ ) below land surface. Therefore, ground water from the Hobson site has probably migrated farther into the reduced zone of this aquifer than ground water from monitor wells 667 and 668. The greater residence time of contaminants in deeper ground water is reflected in the lower concentrations of sulfate, chloride, and other major and minor constituents in the Hobson ground water relative to the 600 series wells (Table 3.2).

Nonetheless, the ground water from the 600 series wells and the Hobson wells might have followed a similar ground water quality evolutionary trend. Figure 3.8 shows a trilinear plot of wells 667 and 668 and the 11 Hobson wells drilled around the ore body.

Unlike the major and minor element data, the trace element data from the Hobson area ground water differ from those of monitor wells 667 and 668 . The Hobson data show significantly elevated levels of lead, radium-226, and uranium (Table 3.2) because most of the Hobson samples were Deweesville ground water equilibrating with uranium ore.

\section{Dilworth}

Four upgradient Dilworth monitor wells $(967,968,969$, and 979) are used to delineate the background water quality of this aquifer at the Falls City site. As shown on a trilinear plot (Figure 3.9), the upgradient Dilworth ground waters are dominated by no single anionic species, and they contain subequal milliequivalents of sulfate and chloride with lesser bicarbonate. Sodium and calcium are the dominant cations. Table $\mathbf{3 . 3}$ presents a statistical summary of the water quality of Dilworth background ground water.

Of the four DOE Dilworth background wells at the UMTRA site, three 1967, 968, and 979) are completed in the oxidized zone, and one (969) is screened in the transitional zone of the aquifer. The ground water quality of monitor well 969 is more representative of the remaining Dilworth wells at the site. 


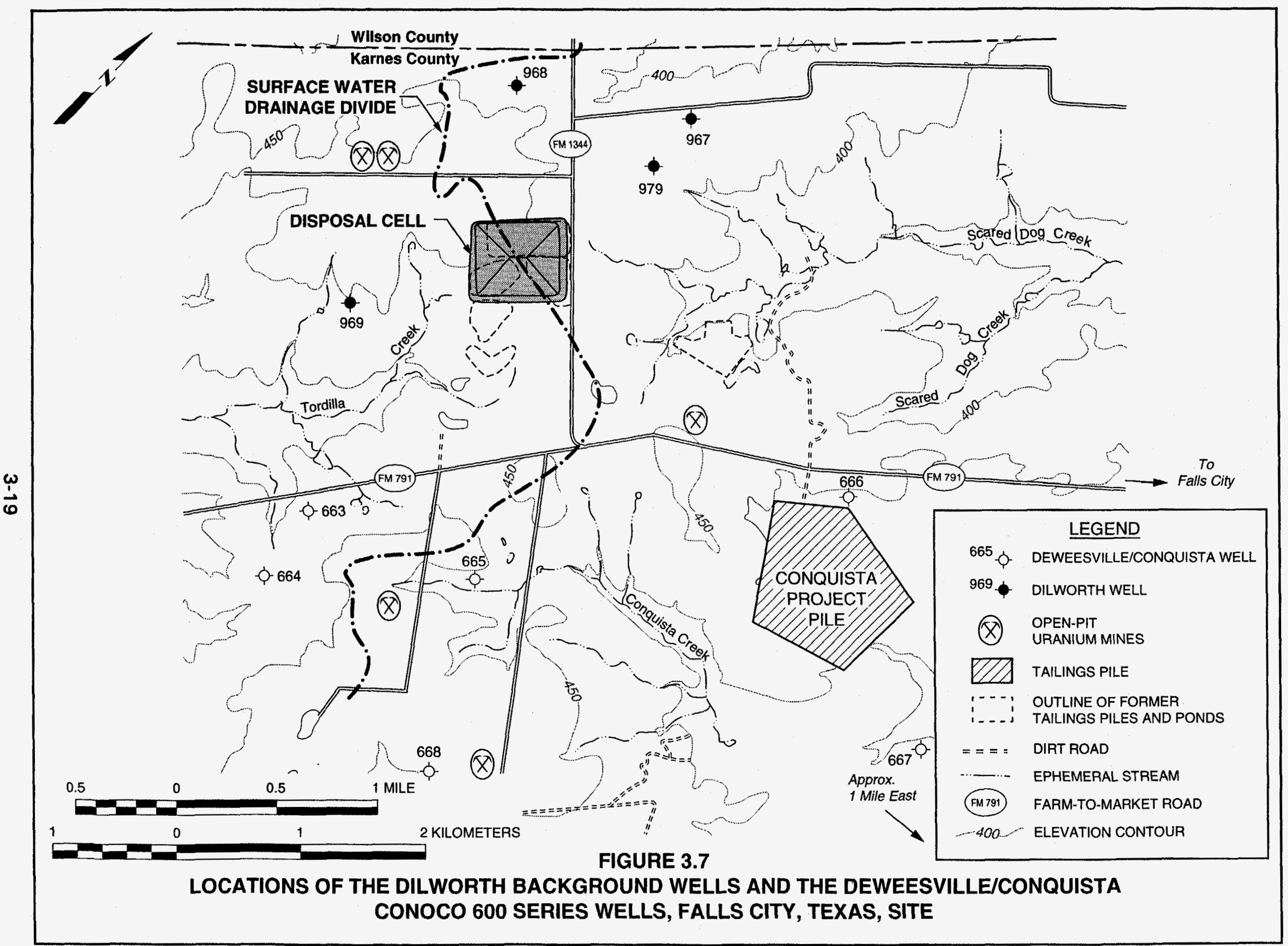




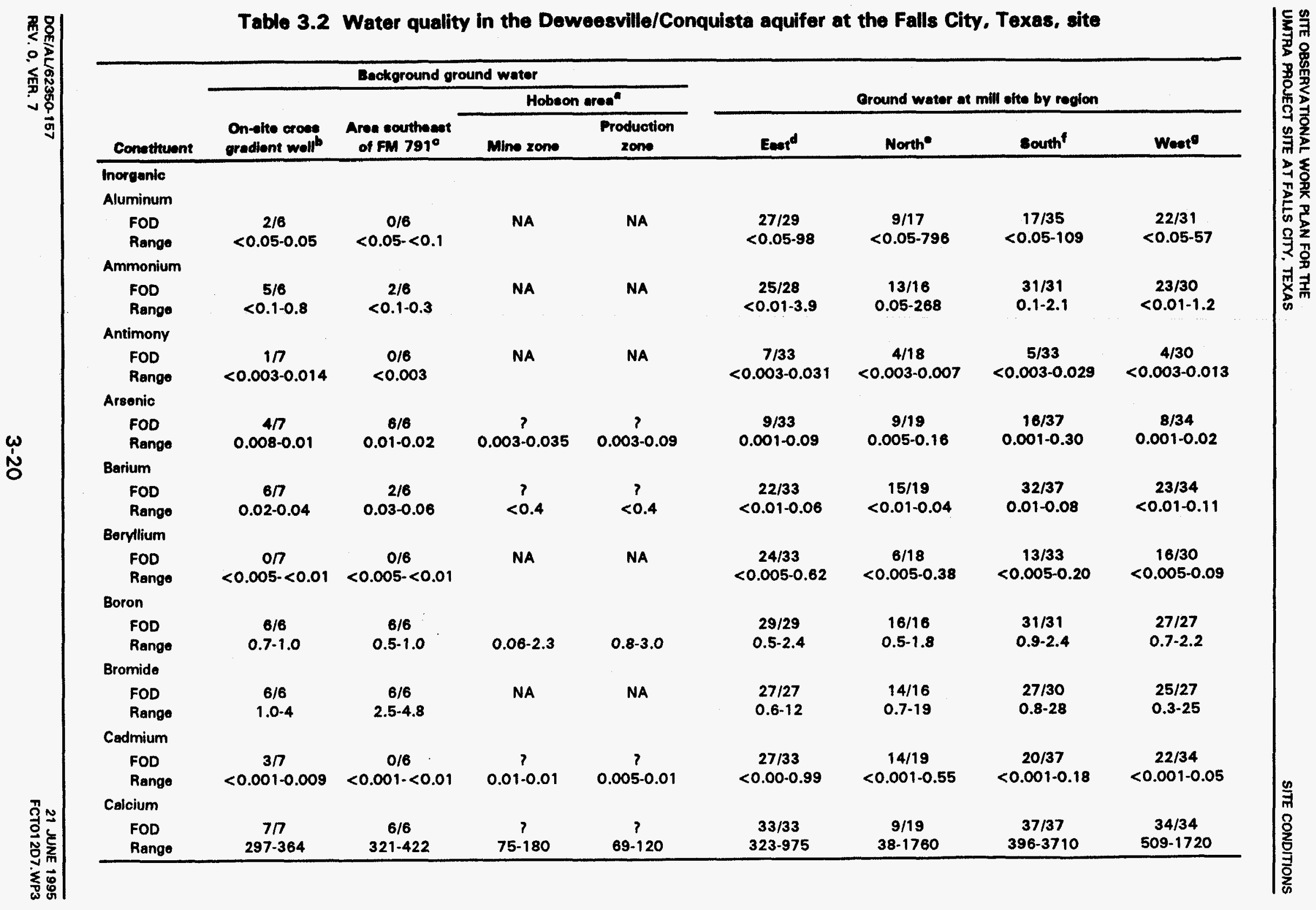




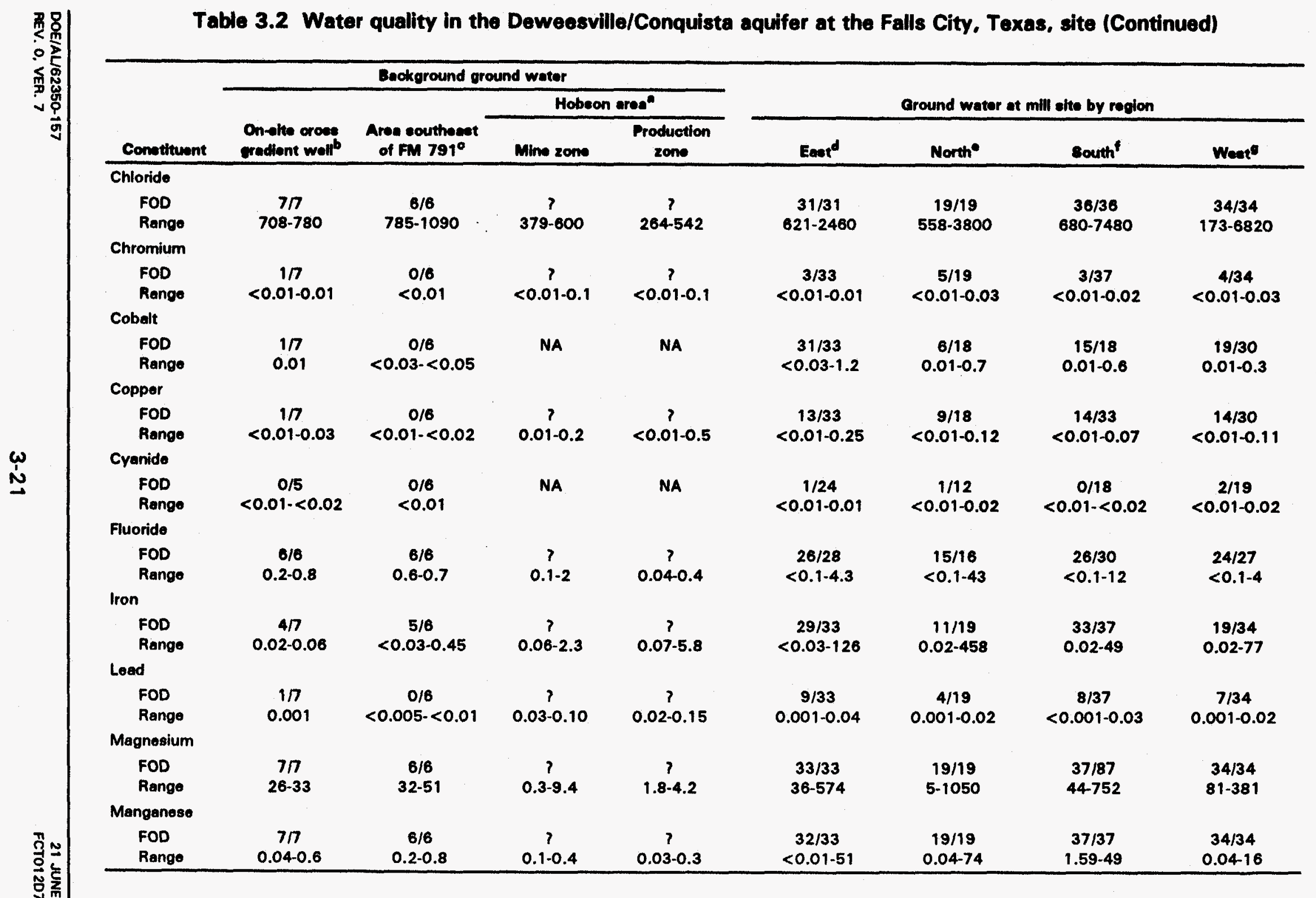




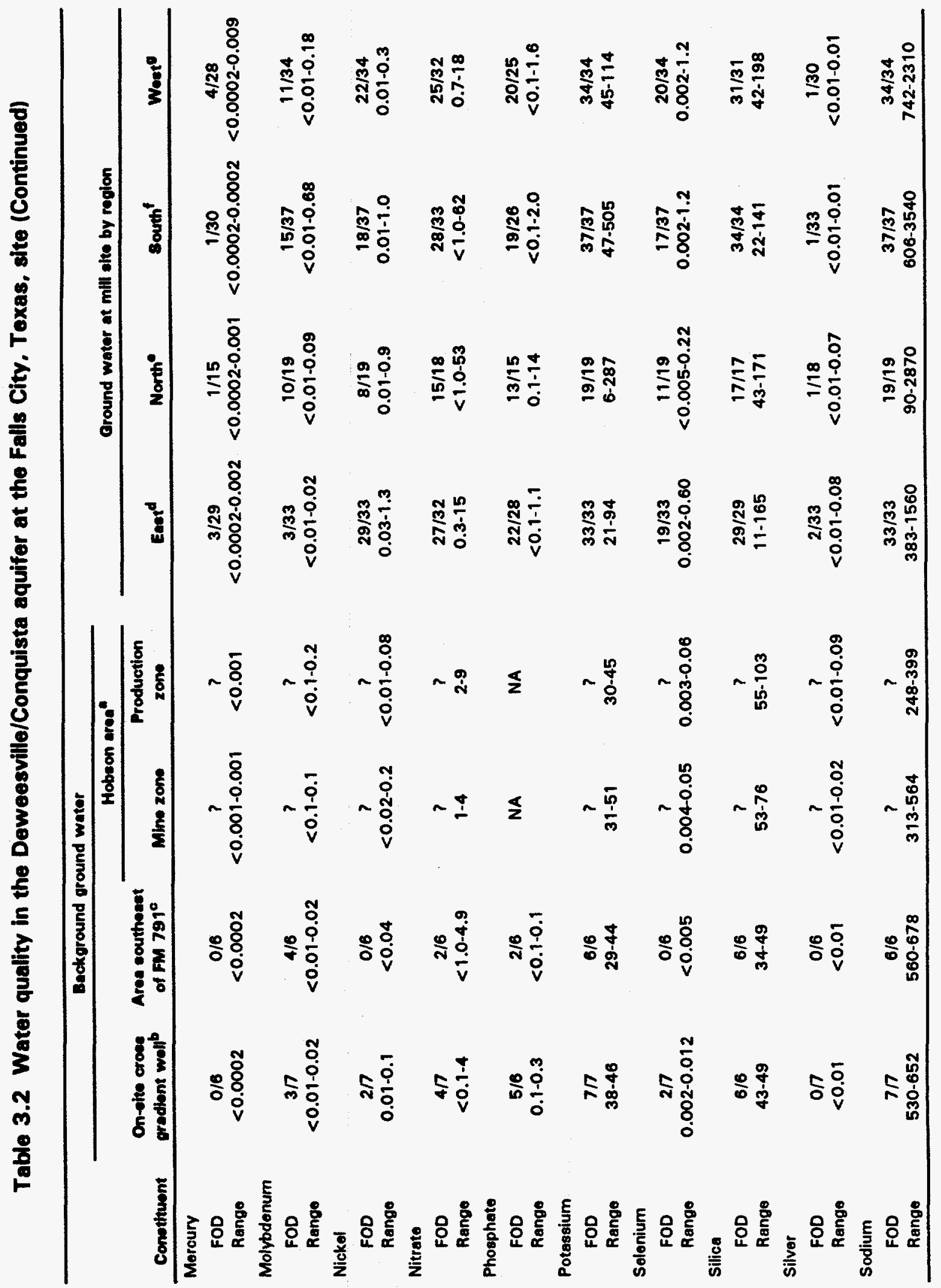




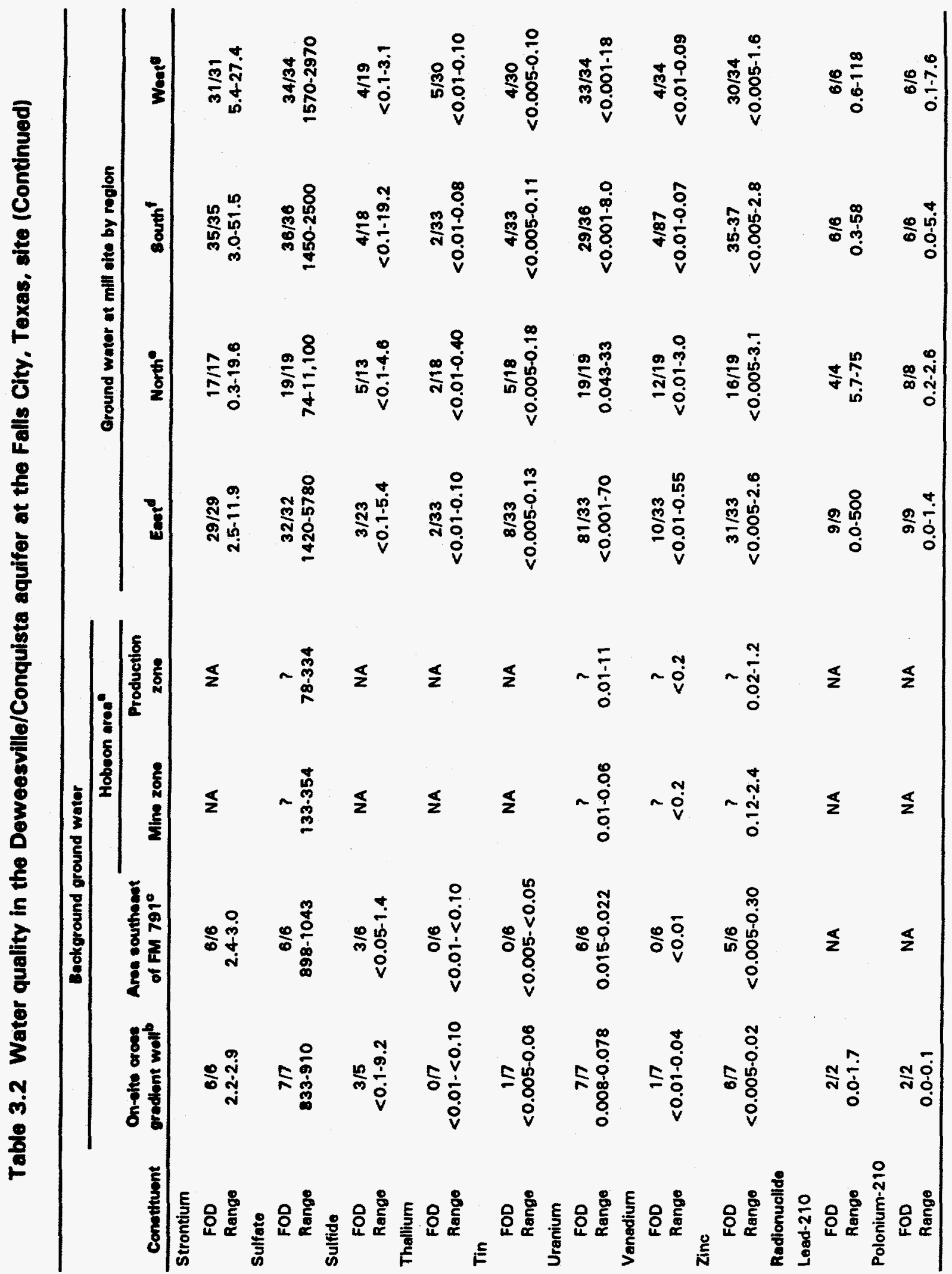


Table 3.2 Water quality in the Deweesville/Conquista aquifer at the Falls City. Texas, site (Concluded)

\begin{tabular}{|c|c|c|c|c|c|c|c|c|}
\hline \multirow[b]{3}{*}{ Conotituent } & \multicolumn{4}{|c|}{ Background ground water } & & & & \\
\hline & \multirow[b]{2}{*}{$\begin{array}{l}\text { On-oite oroes } \\
\text { oredient well }\end{array}$} & \multirow[b]{2}{*}{$\begin{array}{c}\text { Area southeset } \\
\text { of FM } 791^{\circ}\end{array}$} & \multicolumn{2}{|c|}{ Hobseon area" } & \multicolumn{4}{|c|}{ Ground wator at mill site by region } \\
\hline & & & Mine zone & $\begin{array}{l}\text { Production } \\
\text { zone }\end{array}$ & Eest & North" & south & Woet" \\
\hline \multicolumn{9}{|l|}{ Radium-226 } \\
\hline $\begin{array}{l}\text { FOD } \\
\text { Rango }\end{array}$ & $\begin{array}{c}7 \pi \\
1.3-2.7\end{array}$ & $\begin{array}{c}6 / 6 \\
1.9-2.8\end{array}$ & $\stackrel{?}{0.4-15.5}$ & $\stackrel{7}{3.7-1023}$ & $\begin{array}{l}33 / 33 \\
0.0-14\end{array}$ & $\begin{array}{l}18 / 18 \\
0.9-34\end{array}$ & $\begin{array}{c}36 / 36 \\
0.4-140\end{array}$ & $\begin{array}{c}34 / 34 \\
0.2-654\end{array}$ \\
\hline \multicolumn{9}{|l|}{ Thorium-230 } \\
\hline $\begin{array}{l}\text { FOD } \\
\text { Range }\end{array}$ & $\begin{array}{c}2 / 2 \\
0.1-0.4\end{array}$ & NA & NA & NA & $\begin{array}{c}9 / 9 \\
0.0-8.1\end{array}$ & $\begin{array}{c}6 / 6 \\
0.0-46\end{array}$ & $\begin{array}{c}11 / 11 \\
0.2-3.6\end{array}$ & $\begin{array}{l}10 / 10 \\
0.0-54\end{array}$ \\
\hline
\end{tabular}

- Noar mine zone- H102, H48, B110, B46, B98, B99, B100, B108, B109, B40, B42, with 11 ground water samples collected from these wells from 1979 to 1981. Production zone wells - T6-A, M95, M94, M93, T92, M10, M9, M7, M5, M3, T95A, M96, M97, M98, P100, P101, 1102, 1103, 1104, 1105, 1106, 1107, M16, M96, M97, M98, H96, H97; 28 ground water samples were collected from these wells from 1978 to 1979.

bMonitor well 951 .

Monitor wells 867 and 868 . Filtered-sample data are from 1991

dWells $940,953,955,963,965,966$

Wolls 625, 713, 799, 880, $914,921$.

'Wolls 677, 853, 860, 864, 867, 881, 913.

Wells 854, 859, $882,904,918,919$

NA - data not available (sample was not analyzed for this constituent).

? - detection limit not reported.

FOD - frequency of detection; the number of measurements at or above detection limits divided by total number of measurements.

Notos: 1. Filtored samples 1989 to April 1993, except as noted.

2. Concentrations are reported in milligrams per liter, except radionuclides which are reported in picocuries per liter. 

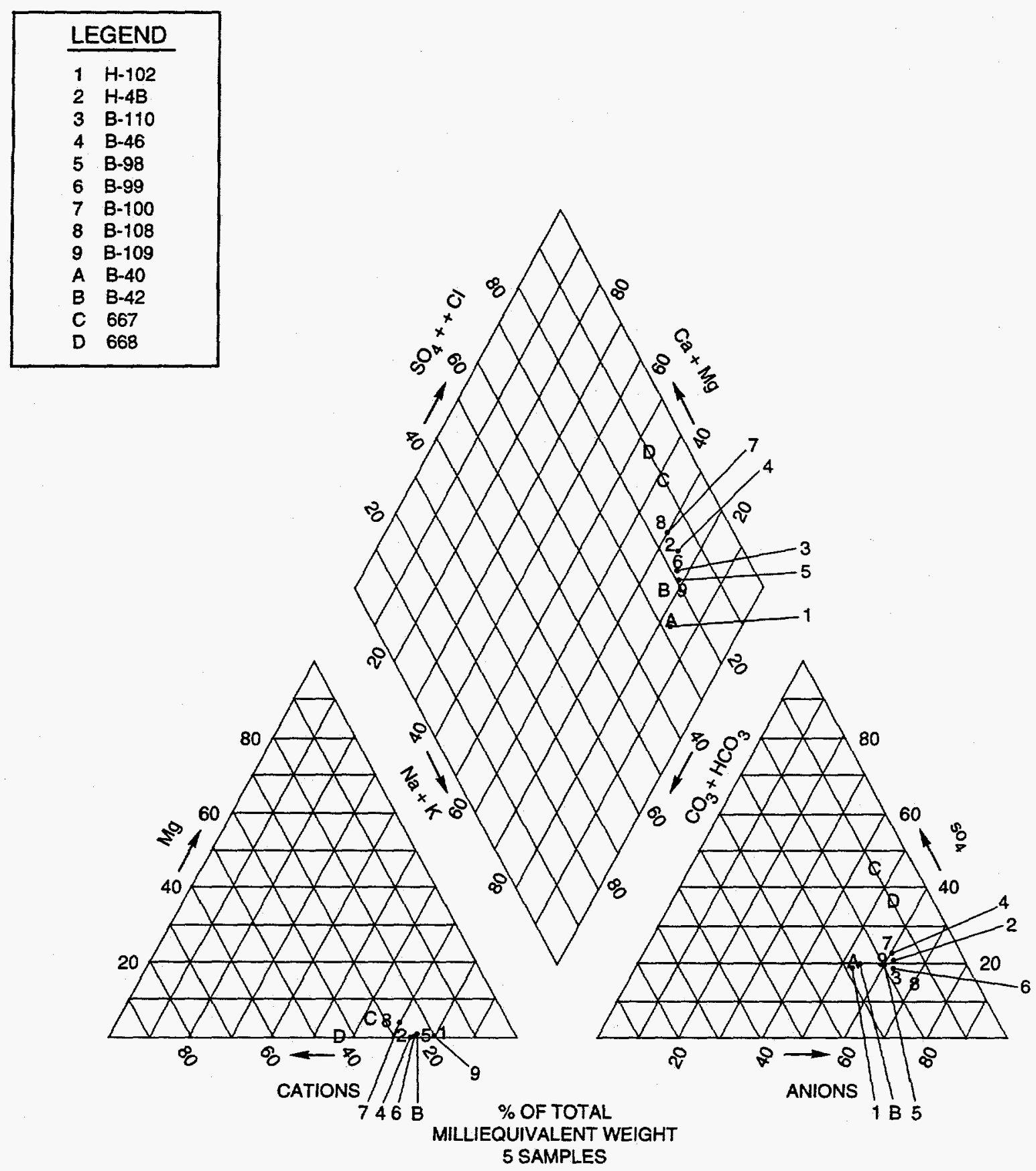

FIGURE 3.8

TRILINEAR PLOT OF DATA FROM DEWEESVILLE/CONQUISTA MONITOR WELLS 667,668 , AND SELECTED HOBSON MONITOR WELLS

FALLS CITY, TEXAS, SITE 


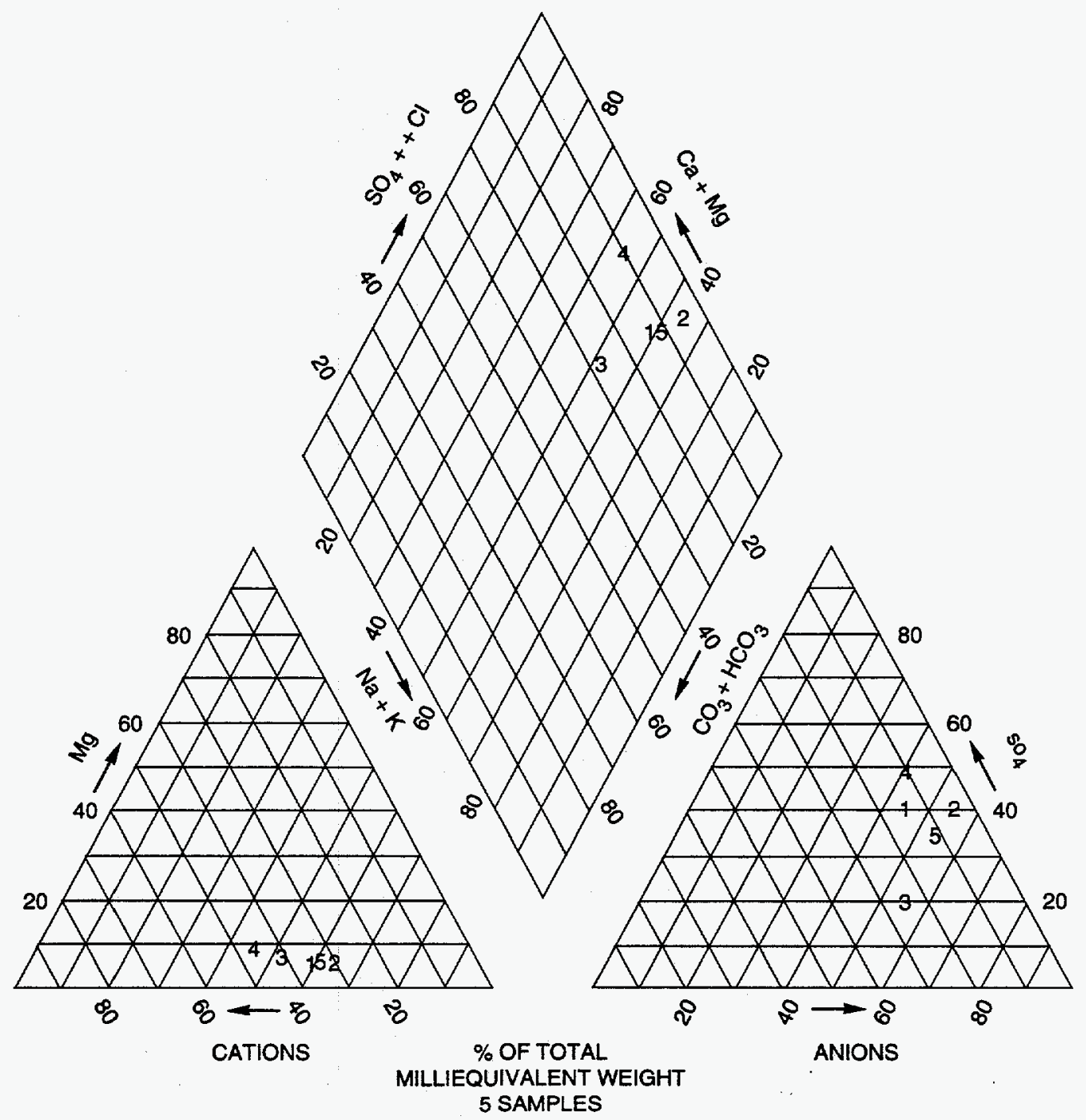

\section{LEGEND}

MW 951 - DEWEESVILLE/CONQUISTA REFERENCE WELL MW 967 - DILWORTH BACKGROUND WELL

MW 968 - DILWORTH BACKGROUND WELL

MW 969 - DILWORTH BACKGROUND WELL

MW 979 - DILWORTH BACKGROUND WELL

FIGURE 3.9

TRILINEAR PLOT OF DILWORTH BACKGROUND GROUND WATER AND DEWEESVILLE/CONQUISTA REFERENCE WATER FALLS CITY, TEXAS, SITE 
Table 3.3 Statistical summary of the Dilworth ground water quality at the Falls City, Texas, site

\begin{tabular}{|c|c|c|c|c|}
\hline \multirow[b]{3}{*}{ Constituent } & \multirow{3}{*}{$\begin{array}{l}\text { Frequency of } \\
\text { detection }\end{array}$} & \multicolumn{3}{|c|}{ Observed concentration } \\
\hline & & Minimum & Median ${ }^{\mathbf{a}}$ & Maximum \\
\hline & & (mg/L) & (mg/L) & (mg/L) \\
\hline \multicolumn{5}{|l|}{ Chemical } \\
\hline \multicolumn{5}{|l|}{ Aluminum } \\
\hline Background ${ }^{b}$ & $2 / 18$ & $<0.05$ & c & 0.05 \\
\hline $833^{c}$ & $1 / 1$ & d & 0.71 & d \\
\hline $977^{e}$ & $4 / 4$ & 0.45 & 0.71 & 1.02 \\
\hline \multicolumn{5}{|l|}{ Ammonium } \\
\hline Background ${ }^{\mathbf{b}}$ & $12 / 18$ & $<0.1$ & 0.1 & 2.0 \\
\hline $833^{b}$ & $1 / 1$ & d & 5.7 & d \\
\hline $977^{c}$ & $3 / 4$ & $<0.1$ & 0.2 & 0.9 \\
\hline \multicolumn{5}{|l|}{ Antimony } \\
\hline Background & $2 / 22$ & $<0.003$ & d & 0.008 \\
\hline 833 & $0 / 1$ & d & d & d \\
\hline 977 & $1 / 5$ & $<0.003$ & d & 0.004 \\
\hline \multicolumn{5}{|l|}{ Arsenic } \\
\hline $\begin{array}{l}\text { Background } \\
(969)\end{array}$ & $6 / 6$ & 0.10 & 0.28 & 0.39 \\
\hline 833 & $1 / 1$ & d & 0.05 & d \\
\hline 977 & $0 / 5$ & d & d & d \\
\hline \multicolumn{5}{|l|}{ Barium } \\
\hline $\begin{array}{l}\text { Background } \\
(969)\end{array}$ & $6 / 6$ & 0.04 & 0.05 & 0.10 \\
\hline 833 & $1 / 1$ & d & 0.03 & d \\
\hline 977 & $4 / 5$ & 0.01 & $0.01-0.02$ & 0.02 \\
\hline \multicolumn{5}{|l|}{ Beryllium } \\
\hline Background $b$ & $0 / 22$ & d & d & d \\
\hline $833^{c}$ & $0 / 1$ & d & d & d \\
\hline $977^{e}$ & $1 / 5$ & $<0.005$ & d & 0.005 \\
\hline
\end{tabular}


Table 3.3 Statistical summary of the Dilworth ground water quality at the Falls City, Texas, site (Continued)

\begin{tabular}{|c|c|c|c|c|}
\hline \multirow[b]{3}{*}{ Constituent } & \multirow{3}{*}{$\begin{array}{l}\text { Frequency of } \\
\text { detection }\end{array}$} & \multicolumn{3}{|c|}{ Observed concentration } \\
\hline & & Minimum & Median" & Maximum \\
\hline & & $(\mathrm{mg} / \mathrm{L})$ & $(\mathrm{mg} / \mathrm{L})$ & $(\mathrm{mg} / \mathrm{L})$ \\
\hline \multicolumn{5}{|l|}{ Boron } \\
\hline $\begin{array}{l}\text { Background } \\
(967)\end{array}$ & $4 / 4$ & 0.88 & 1.03 & 1.10 \\
\hline 833 & $1 / 1$ & d & 0.85 & d \\
\hline 977 & $4 / 4$ & 0.72 & 0.83 & 0.98 \\
\hline \multicolumn{5}{|l|}{ Bromide } \\
\hline $\begin{array}{l}\text { Background } \\
(969)\end{array}$ & $5 / 5$ & 2.6 & 3.2 & 5.8 \\
\hline 833 & $1 / 1$ & d & 1.0 & d \\
\hline 977 & $4 / 4$ & 1.7 & 1.8 & 2.1 \\
\hline \multicolumn{5}{|l|}{ Cadmium } \\
\hline Background & $6 / 22$ & $<0.001$ & d & 0.005 \\
\hline 833 & $0 / 1$ & d & d & $d$ \\
\hline 977 & $5 / 5$ & 0.013 & 0.020 & 0.022 \\
\hline \multicolumn{5}{|l|}{ Calcium } \\
\hline $\begin{array}{l}\text { Background } \\
(969)\end{array}$ & $6 / 6$ & 481 & 502 & 560 \\
\hline 833 & $1 / 1$ & d & 367 & d \\
\hline 977 & $5 / 5$ & 188 & 242 & 282 \\
\hline \multicolumn{5}{|l|}{ Chloride } \\
\hline $\begin{array}{l}\text { Background } \\
(967,969)\end{array}$ & $11 / 11$ & 680 & 793 & 1020 \\
\hline $833^{c}$ & $1 / 1$ & d & 472 & d \\
\hline $977^{e}$ & $5 / 5$ & 280 & 374 & 553 \\
\hline \multicolumn{5}{|l|}{ Chromium } \\
\hline Background & $4 / 22$ & $<0.01$ & d & 0.02 \\
\hline 833 & $0 / 1$ & d & d & d \\
\hline 977 & $1 / 5$ & $<0.01$ & d & 0.01 \\
\hline \multicolumn{5}{|l|}{ Cobalt } \\
\hline Background & $3 / 22$ & 0.01 & d & 0.05 \\
\hline 833 & $1 / 1$ & d & 0.08 & d \\
\hline 977 & $5 / 5$ & 0.06 & 0.08 & 0.09 \\
\hline
\end{tabular}


Table 3.3 Statistical summary of the Dilworth ground water quality at the Falls City, Texas, site (Continued)

\begin{tabular}{|c|c|c|c|c|}
\hline \multirow[b]{3}{*}{ Constituent } & \multirow{3}{*}{$\begin{array}{c}\text { Frequency of } \\
\text { detection }\end{array}$} & \multicolumn{3}{|c|}{ Observed concentration } \\
\hline & & Minimum & Median $^{\mathbf{a}}$ & Maximum \\
\hline & & $(m g / L)$ & $(\mathrm{mg} / \mathrm{L})$ & $(\mathrm{mg} / \mathrm{L})$ \\
\hline \multicolumn{5}{|l|}{ Copper } \\
\hline Background & $4 / 22$ & $<0.01$ & d & 0.06 \\
\hline 833 & $0 / 1$ & d & d & d \\
\hline 977 & $2 / 5$ & $<0.01$ & d & 0.03 \\
\hline \multicolumn{5}{|l|}{ Cyanide } \\
\hline Background & $2 / 20$ & $<0.01$ & d & 0.02 \\
\hline 833 & d & $d$ & d & d \\
\hline 977 & $1 / 5$ & $<0.01$ & d & 0.01 \\
\hline \multicolumn{5}{|l|}{ Fluoride } \\
\hline $\begin{array}{l}\text { Background } \\
(979)\end{array}$ & $5 / 5$ & 0.4 & 0.4 & 0.5 \\
\hline $833^{c}$ & $1 / 1$ & d & 1.0 & d \\
\hline $977^{e}$ & $1 / 4$ & $<0.1$ & d & 0.2 \\
\hline \multicolumn{5}{|l|}{ Iron } \\
\hline $\begin{array}{l}\text { Background } \\
(969)\end{array}$ & $6 / 6$ & 0.24 & 0.78 & 2.70 \\
\hline 833 & $1 / 1$ & d & 127 & d \\
\hline 977 & $5 / 5$ & 0.14 & 0.53 & 1.43 \\
\hline \multicolumn{5}{|l|}{ Lead } \\
\hline Background & $2 / 22$ & 0.001 & $d$ & 0.002 \\
\hline 833 & $0 / 1$ & $d$ & d & d \\
\hline 977 & $0 / 5$ & d & d & d \\
\hline \multicolumn{5}{|l|}{ Magnesium } \\
\hline $\begin{array}{l}\text { Background } \\
(969)\end{array}$ & $6 / 6$ & 54 & 57 & 65 \\
\hline 833 & $1 / 1$ & d & 67 & d \\
\hline 977 & $5 / 5$ & 20 & 27 & 33 \\
\hline \multicolumn{5}{|l|}{ Manganese } \\
\hline $\begin{array}{l}\text { Background } \\
(969)\end{array}$ & $6 / 6$ & 2.8 & 3.2 & 3.7 \\
\hline 833 & $1 / 1$ & d & 3.3 & d \\
\hline 977 & $5 / 5$ & 1.4 & 1.7 & 2.4 \\
\hline
\end{tabular}


Table 3.3 Statistical summary of the Dilworth ground water quality at the Falls City, Texas, site (Continued)

\begin{tabular}{|c|c|c|c|c|}
\hline \multirow[b]{3}{*}{ Constituent } & \multirow{3}{*}{$\begin{array}{c}\text { Frequency of } \\
\text { detection }\end{array}$} & \multicolumn{3}{|c|}{ Observed concentration } \\
\hline & & Minimum & Median $^{\mathbf{a}}$ & Maximum \\
\hline & & (mg/L) & (mg/L) & (mg/L) \\
\hline \multicolumn{5}{|l|}{ Mercury } \\
\hline Background ${ }^{b}$ & $0 / 22$ & $d$ & d & d \\
\hline $833^{c}$ & $0 / 1$ & d & d & d \\
\hline $977^{e}$ & $0 / 5$ & d & d & d \\
\hline \multicolumn{5}{|l|}{ Molybdenum } \\
\hline $\begin{array}{l}\text { Background } \\
(968,969)\end{array}$ & $11 / 11$ & 0.02 & 0.04 & 0.07 \\
\hline 833 & $1 / 1$ & d & 0.02 & d \\
\hline 977 & $1 / 5$ & $<0.01$ & d & 0.01 \\
\hline \multicolumn{5}{|l|}{ Nickel } \\
\hline Background & $2 / 22$ & 0.01 & d & 0.01 \\
\hline 833 & $1 / 1$ & d & 0.09 & d \\
\hline 977 & $5 / 5$ & 0.07 & 0.10 & 0.11 \\
\hline \multicolumn{5}{|l|}{ Nitrate } \\
\hline Background & $16 / 22$ & $<1.0$ & 3.3 & 13.0 \\
\hline 833 & $1 / 1$ & d & 1.8 & d \\
\hline 977 & $4 / 5$ & $<1.0$ & 3.1 & 6.4 \\
\hline \multicolumn{5}{|l|}{ Phosphate } \\
\hline Background & $16 / 18$ & 0.3 & 0.5 & 1.1 \\
\hline 833 & $1 / 1$ & d & 0.5 & d \\
\hline 977 & $3 / 4$ & $<0.1$ & 0.2 & 0.2 \\
\hline \multicolumn{5}{|l|}{ Potassium } \\
\hline $\begin{array}{l}\text { Background } \\
(969)\end{array}$ & $6 / 6$ & 37 & 42 & 44 \\
\hline $833^{c}$ & $1 / 1$ & d & 44 & d \\
\hline $977^{e}$ & $5 / 5$ & 24 & 30 & 37 \\
\hline \multicolumn{5}{|l|}{ Selenium } \\
\hline Background & $8 / 22$ & 0.002 & d & 0.024 \\
\hline 833 & $0 / 1$ & d & d & d \\
\hline 977 & $1 / 5$ & $<0.005$ & d & 0.007 \\
\hline
\end{tabular}


Table 3.3 Statistical summary of the Dilworth ground water quality at the Falls City, Texas, site (Continued)

\begin{tabular}{|c|c|c|c|c|}
\hline \multirow[b]{3}{*}{ Constituent } & \multirow{3}{*}{$\begin{array}{c}\text { Frequency of } \\
\text { detection }\end{array}$} & \multicolumn{3}{|c|}{ Observed concentration } \\
\hline & & Minimum & Median & Maximum \\
\hline & & (mg/L) & (mg/L) & $(\mathrm{mg} / \mathrm{L})$ \\
\hline \multicolumn{5}{|l|}{ Silica } \\
\hline $\begin{array}{l}\text { Background } \\
(968)\end{array}$ & $4 / 4$ & 88 & 91 & 100 \\
\hline 833 & $1 / 1$ & d & 45 & d \\
\hline 977 & $4 / 4$ & 88 & 102 & 121 \\
\hline \multicolumn{5}{|l|}{ Silver } \\
\hline Background & $1 / 22$ & $<0.01$ & d & 0.02 \\
\hline 833 & $0 / 1$ & d & d & d \\
\hline 977 & $0 / 5$ & d & $d$ & $d$ \\
\hline \multicolumn{5}{|l|}{ Sodium } \\
\hline $\begin{array}{l}\text { Background } \\
(967,969)\end{array}$ & $11 / 11$ & 482 & 550 & 675 \\
\hline 833 & $1 / 1$ & d & 604 & d \\
\hline 977 & $5 / 5$ & 412 & 484 & 520 \\
\hline \multicolumn{5}{|l|}{ Strontium } \\
\hline $\begin{array}{l}\text { Background } \\
\text { (979) }\end{array}$ & $5 / 5$ & 1.5 & 1.8 & 77 \\
\hline $833^{c}$ & $1 / 1$ & d & 3.3 & $d$ \\
\hline $977^{e}$ & 100 & 1.7 & 2.3 & 2.6 \\
\hline \multicolumn{5}{|l|}{ Sulfate } \\
\hline $\begin{array}{l}\text { Background } \\
(969)\end{array}$ & $6 / 6$ & 1220 & 1300 & 1440 \\
\hline 833 & $1 / 1$ & d & 1930 & d \\
\hline 977 & $5 / 5$ & 1160 & 1320 & 1580 \\
\hline \multicolumn{5}{|l|}{ Sulfide } \\
\hline Background & $6 / 20$ & $<0.1$ & d & 55 \\
\hline 833 & d & d & d & $d$ \\
\hline 977 & $0 / 5$ & d & d & d \\
\hline \multicolumn{5}{|l|}{ Thallium } \\
\hline Background & $1 / 22$ & $<0.01$ & d & 0.1 \\
\hline 833 & $0 / 1$ & d & d & d \\
\hline 977 & $0 / 5$ & d & d & d \\
\hline
\end{tabular}


Table 3.3 Statistical summary of the Dilworth ground water quality at the Falls City, Texas, site (Continued)

\begin{tabular}{|c|c|c|c|c|}
\hline \multirow[b]{3}{*}{ Constituent } & \multirow{3}{*}{$\begin{array}{c}\text { Frequency of } \\
\text { detection }\end{array}$} & \multicolumn{3}{|c|}{ Observed concentration } \\
\hline & & Minimum & Median ${ }^{\mathbf{a}}$ & Maximum \\
\hline & & (mg/L) & (mg/L) & $(\mathrm{mg} / \mathrm{L})$ \\
\hline \multicolumn{5}{|l|}{ Tin } \\
\hline Background & $5 / 22$ & $<0.005$ & d & 0.019 \\
\hline 833 & $0 / 1$ & d & d & d \\
\hline 977 & $2 / 5$ & 0.01 & d & 0.02 \\
\hline \multicolumn{5}{|l|}{ Uranium } \\
\hline $\begin{array}{l}\text { Background } \\
(968)\end{array}$ & $5 / 5$ & 0.026 & 0.056 & 0.068 \\
\hline $833^{C}$ & $1 / 1$ & d & 3.04 & d \\
\hline $977^{e}$ & $5 / 5$ & 0.016 & 0.023 & 0.054 \\
\hline \multicolumn{5}{|l|}{ Vanadium } \\
\hline Background & $10 / 22$ & $<0.01$ & d & 0.05 \\
\hline 833 & $0 / 1$ & d & d & d \\
\hline 977 & $1 / 5$ & $<0.01$ & d & 0.03 \\
\hline \multicolumn{5}{|l|}{ Zinc } \\
\hline Background & $15 / 22$ & $<0.005$ & 0.012 & 0.544 \\
\hline 833 & $1 / 1$ & d & 0.213 & d \\
\hline 977 & $5 / 5$ & 0.120 & 0.182 & 0.206 \\
\hline
\end{tabular}


Table 3.3 Statistical summary of the Dilworth ground water quality at the Falls City, Texas, site (Concluded)

\begin{tabular}{|c|c|c|c|c|}
\hline \multirow[b]{3}{*}{ Constituent } & \multirow{3}{*}{$\begin{array}{c}\text { Number of } \\
\text { samples }\end{array}$} & \multicolumn{3}{|c|}{ Observed concentration } \\
\hline & & Minimum & Median $^{\mathrm{a}}$ & Maximum \\
\hline & & (pCi/L) & $(\mathrm{pCi} / \mathrm{L})$ & (pCi/L) \\
\hline \multicolumn{5}{|l|}{ Radionuclide } \\
\hline \multicolumn{5}{|l|}{ Lead-210 } \\
\hline Background $^{b}$ & 8 & 0.0 & 1.5 & 6.8 \\
\hline $833^{c}$ & 0 & d & d & $d$ \\
\hline $977^{\ominus}$ & 2 & 0.0 & 0.4 & 0.8 \\
\hline \multicolumn{5}{|l|}{ Polonium-210 } \\
\hline Background & 8 & 0.0 & 0.2 & 0.7 \\
\hline 833 & 0 & d & d & d \\
\hline 977 & 2 & 0.0 & 0.05 & 0.1 \\
\hline \multicolumn{5}{|l|}{ Radium-226 } \\
\hline Background (969) & 6 & 2.0 & 3.3 & 4.6 \\
\hline 833 & 1 & d & 2.4 & d \\
\hline 977 & 5 & 0.7 & 1.2 & 1.9 \\
\hline \multicolumn{5}{|l|}{ Thorium-230 } \\
\hline Background & 8 & 0.1 & 0.3 & 0.9 \\
\hline 833 & 0 & d & d & d \\
\hline 977 & 2 & 0.1 & 0.3 & 0.5 \\
\hline
\end{tabular}

aThe median, or 50 th percentile of the sample data, cannot be determined if 50 percent or less of the data are above detection.

${ }^{b}$ Data are pooled from monitor wells $967,968,969$, and 979 unless one or more of these wells has significantly higher levels than the others. In such cases, background represents the higher levels.

CRepresents the western contaminated zone. Water quality data from one sampling round in December 1991 were used to determine constituents of concern for this contaminated zone.

Data not available.

eRepresents the eastern contaminated zone. Water quality data from 1989 through 1991 were used to determine constituents of concern for the eastern contaminated zone.

Note: Filtered samples, 1989-1992. 
Although more data are needed to verify ambient ground water quality, the three upgradient wells in the oxidized zone of the Dilworth produce ground water of better quality than is probably typical of Dilworth ground water.

\subsubsection{Magnitude of site-related ground water contamination}

A statistical, geochemical, and hydrological analysis of the Falls City water quality data for 1989 through 1993 indicates tailings-related contamination in the Deweesville/Conquista aquifer, with less contamination in the Dilworth aquifer.

\section{Deweesville/Conquista}

Elevated levels of contaminants in the Deweesville/Conquista aquifer generally occur in four distinct contaminant zones (Figure 3.10). Ground water from some wells in these zones shows elevated levels of aluminum, arsenic, cadmium, manganese, molybdenum, selenium, sulfate, and uranium.

Although the four contaminated zones, including a possible southern arm of the eastern zone, show many chemical similarities, each contaminated zone has important chemical differences that give it a distinct geochemical signature. The locations of Deweesville/Conquista monitor wells are shown on Figure 3.10.

\section{Eastern contaminated zone}

The eastern contaminated zone originates from tailings pile 3. A major lobe of contamination extends approximately $3000 \mathrm{ft}(900 \mathrm{~m})$ north-northeast in ground water beneath Scared Dog Creek. The pH of contaminated ground water in several monitor wells along Scared Dog Creek (e.g., 962, 963, 965, and 966) commonly ranges between 3 and 5 ; however, in some areas the contaminated zone is not acidic (e.g., monitor wells 955 and 961) (DOE, 1992b). Monitor well 953, approximately $1200 \mathrm{ft}(3600 \mathrm{~m})$ east-southeast of pile 3 , also shows evidence of tailings-related contamination such as elevated uranium levels and low pH (DOE, 1992b). The lack of monitor wells in this zone south of tailings pile 3 precludes a more precise delineation of a possible southeastern lobe of the eastern contaminated zone.

\section{Northern contaminated zone}

The northern contaminated zone is associated primarily with former tailings piles 2 and 7. The pH of the ground water in this zone varies from about 3 in monitor well 625 to almost 7 in well 921 . Locally in this zone, sulfate leveis are high (approximately 11,000 milligrams per liter $[\mathrm{mg} / \mathrm{L}$ ] in monitor well 625 ). The extremely high sulfate concentrations in this part of the Deweesville/Conquista aquifer were probably generated by a tailings pond that existed in the southern end of pile 2. 


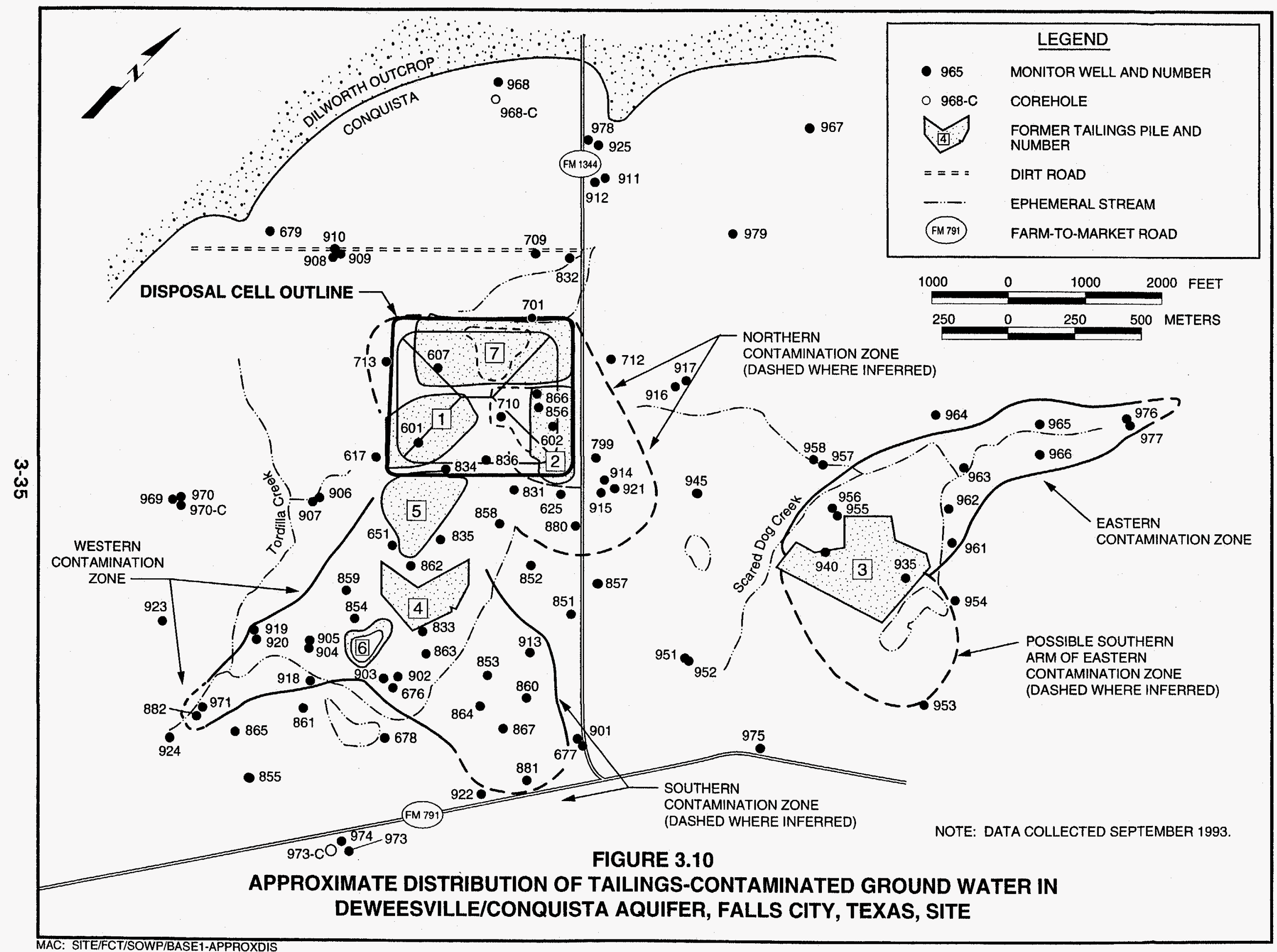




\section{Southern contaminated zone}

The primary source areas of the southern contaminated zone appear to be tailings piles 4 and 5 . The southern contaminated zone appears to extend as far as FM 791, approximately $2500 \mathrm{ft}(760 \mathrm{~m})$ southeast of the former processing site. The contaminated zone is generally acidic, with pH ranging from 3 to 4 and significantly higher chloride concentrations than other contaminated zones.

\section{Western contaminated zone}

Most of the western contaminated zone is acidic (e.g., monitor wells 854,882 , and 904). Ground water from monitor well 918 is only slightly acidic (pH of about 5) (DOE, 1992b). The southwest contaminated zone appears to originate from piles 4 and 5 . This contaminated zone extends more than $3000 \mathrm{ft}(900 \mathrm{~m})$ southwest of pile 4 and pond 6 in ground water beneath Tordilla Creek.

The area between former piles 4 and 5 contains a 1 - to 3-ft $(0.3-$ to 1 -m)-thick zone of acid-, sulfate-, and possibly metals-rich ground water perched on top of a thin but laterally extensive silicified layer in the Deweesville/Conquista. The shallow perched saturated zone was probably generated by horizontal flow along this silicified layer when tailings leachate was injected into piles 4 and 5 during in situ mining operations (DOE, 1992b).

\section{Dilworth}

Contamination in the Dilworth aquifer was identified in monitor well 977 north of pile 3 and in former monitor well 833 at the southern edge of pile 4 . Ground water sampled from monitor well 977 (sampled June 1991) is acidic (pH 4.23) and contains moderately elevated levels of aluminum $(1.02 \mathrm{mg} / \mathrm{L})$, iron (1.4 mg/L), sulfate (1580 mg/L), and uranium (0.054 mg/L) (DOE, $1992 \mathrm{~b})$.

Only two sampling rounds (February 1986 and December 1991) were conducted on monitor well 833 before it was abandoned during construction of the disposal cell. The decrease in alkalinity and $\mathrm{pH}$ and the significant increase in concentrations of ammonium, iron, manganese, sulfate, and uranium in the ground water from this well over time (DOE, 1992b) suggest the Dilworth is being contaminated in this area. New monitor wells at locations beneath the former tailings piles are needed to verify if the Dilworth is contaminated by processing site activities.

\subsubsection{Contaminant fate and transport}

The chemical species present in aqueous systems are a function of $\mathrm{pH}$, Eh, and the concentrations of different anions and cations. Speciation determines the mobility of the chemicals and might also influence their toxicity. The predominant species of the contaminants of concern for human health were predicted through the geochemical model MINTEOA2 (Allison et al., 1991). The contaminants of concern are identified in the site-specific baseline risk 
assessment (in preparation): cadmium, cobalt, fluoride, nickel, iron, sulfate, and uranium.

Constituents in the contaminated zone waters are subject to dilution and to different chemical reactions, including oxidation/reduction, precipitation and coprecipitation, possible reactions with biologic organisms, and adsorption onto aquifer mineral surfaces. Concentrations of the dominantly cationic metals and the major cations calcium, magnesium, potassium, and sodium are controlled by dilution and precipitation and sorption reactions. Cadmium, iron, cobalt, nickel, and fluoride concentrations will also be controlled by these processes. Chloride concentrations are affected only by dilution or evaporation. Attenuation mechanisms that should control the concentrations of the contaminants of concern for the Falls City site are discussed below.

\section{Cadmium}

Cadmium will be removed rapidly by the precipitation of otavite $\left(\mathrm{CdCO}_{3}\right)$ and by hydrolysis reactions as the low $\mathrm{pH}$ of the tailings leachate is neutralized by alkaline ground water and the calcite in the aquifer matrix. Dilution with background water produces cadmium concentrations below detection limits in downgradient ground water. Elevated cadmium levels are restricted to the areas underneath or immediately adjacent to the tailings pile.

\section{Iron, cobalt, and nickel}

Aqueous species of iron are typically not stable in ground water that is oxidizing and that has a pH near or above 6 . Dissolved iron in oxidizing water with a pH of 7 should oxidize rapidly and remove as iron oxyhydroxides. Although ground water from many downgradient monitor wells in the Deweesville/Conquista vields pH measurements below 4 and has iron levels significantly higher than reference well 951, ground water from only one Dilworth well (977) has an acidic $\mathrm{pH}$. The $\mathrm{pH}$ in ground water from Dilworth background well 969 is historically between 6.5 and 7 (DOE, 1992b). Nonetheless, iron concentrations in these waters are well above the values present in the other Dilworth background wells at the site.

Elevated cobalt levels might have been introduced to the aquifer by acidic tailings leachate. Because of its chemical similarity to iron, however, cobalt typically coprecipitates during the precipitation of manganese and iron hydroxides. At the typical pH range $(6$ to 8$)$ observed for ground water in the Dilworth aquifer at the Falls City site, cobalt should be present at levels below or near the detection limit. Slightly elevated cobalt levels $(e . g$. , up to $0.05 \mathrm{mg} / \mathrm{L}$ in monitor well 969) and iron levels could be expected in naturally reducing, alkaline, background Dilworth ground waters. More elevated cobalt concentrations can occur in low-pH contaminated ground water (up to $0.09 \mathrm{mg} / \mathrm{L}$ in acidic Dilworth monitor well 977). When the $\mathrm{pH}$ of this oxidizing water rises above 5.5, cobalt concentrations should be much lower. 


\section{Sulfate}

Sulfate concentrations in the contaminated zones of the aquifer immediately adjacent to the processing site are controlled primarily by gypsum solubility. Farther downgradient, sulfate concentrations are controlled largely by physical processes such as dispersion and dilution. Reduction of sulfate to sulfide is also possible if the contaminated zone interacts with reducing sediment or ground water.

Presently, gypsum precipitation predominantly controls sulfate concentrations because the shallow ground water in and around the tailings piles was saturated with gypsum. As the tailings piles are consolidated and covered, the sulfate level in ground water around the former piles will decrease. Eventually, as sulfate levels drop below gypsum saturation, the gypsum that precipitated previously will begin to redissolve. The dissolution of gypsum will buffer the sulfate concentrations at fairly high levels until the gypsum supply is exhausted. At this point, natural flushing with background water will substantially lower the sulfate concentrations in the former tailings pile area.

Because the sulfate concentrations are high, adsorption reactions probably will not significantly affect sulfate concentrations in the shallow ground water. Given the high redox potential of the shallow ground water in the Deweesville/Conquista and Dilworth aquifers, sulfate removal by reduction to sulfide is not likely until the contamination migrates well off the site.

\section{Uranium}

Uranium is mobile in acidic ground water (e.g., pH is 3 to 4 ) where it typically exists as positively charged uranyl, uranium hydroxyl, and (in high sulfate systems) uranium sulfate complexes. In oxidizing, alkaline ground water over a range of elevated pH values (e.g., between 6.5 and 8.5 ), uranium can form stable anionic carbonate complexes that facilitate uranium transport in ground water.

Uranium levels are elevated in both acidic and alkaline ground water at the Falls City site. In both these environments, uranium concentrations will be reduced mainly by adsorption onto aquifer materials and by dilution with uncontaminated ground water.

\subsubsection{Risk evaluation}

The uranium milling activities at the Falls City site led to ground water contamination in the Deweesville/Conquista and Dilworth aquifers. The nearsurface geologic members include the Deweesville, the Conquista, and the Dilworth. For assessing risk to potential ground water users, the Deweesville and Conquista water-bearing members are evaluated as a single aquifer. 
Residents near the site use ground water from the deeper Carrizo aquifer $(2000$ to $3000 \mathrm{ft}[600$ to $900 \mathrm{~m}]$ below the surface). Because of its depth below the land surface and the confining layer overlying the aquifer, the Carrizo aquifer is not affected by mining and milling activities at the Falls City site.

\section{Dilworth aquifer}

Ground water from the Dilworth aquifer was historically considered to be poor quality. No drinking-water wells are screened in the Dilworth aquifer within a 2-mi (3-km) radius of the site (DOE, 1994). This is because historically the Dilworth ground water was considered to be of poor quality. Although the DOE does not have evidence of its use, ground water from the Dilworth aquifer might have been used for watering livestock in the vicinity of the site. Using these livestock for food could create an exposure pathway to humans. Therefore, the potential current and future use of the Dilworth aquifer at the site was evaluated.

Levels of aluminum, ammonium, cadmium, cobalt, fluoride, iron, nickel, sulfate, uranium, and zinc in ground water from two monitor wells completed in the Dilworth aquifer were significantly higher (at the 0.10 level of significance) than the concentrations reported in ground water from background wells (DOE, 1994). As discussed in Section 3.3.1, ground water contamination in monitor well 833 (Figure 3.3) may be due to vertical leakage through exploratory borings and/or the monitor well's annulus. Ground water contamination in monitor well 977 (Figure 3.3) is derived from the zone of contamination along Scared Dog Creek that intercepts the Dilworth outcrop. Therefore, the contamination in the Dilworth appears to be confined to a few isolated areas. The constituents elevated above background are presented in Table 3.4. High levels of arsenic and manganese occur naturally in some areas of the Dilworth aquifer. Both arsenic and manganese typically are associated with the uranium ore deposits found in the Falls City site area. Also, high levels of sulfate occur naturally in the Dilworth ground water and are associated with gypsum deposits.

Although zinc was observed above background, it was eliminated as a contaminant of potential concern because it is an essential nutrient and because the levels at which it is observed are within nutritional ranges, even when added to expected dietary intake. Ammonium and aluminum were eliminated as contaminants of potential concern based on low toxicity, and because the levels at which they are observed in the most contaminated downgradient monitor wells will not produce adverse health effects. Cadmium, cobalt, fluoride, iron, nickel, sulfate, and uranium remain as the contaminants of potential concern for the Dilworth.

Potential adverse health effects are a function of the contaminant amount an individual takes into his or her body. The risk of exposure to humans was estimated by examining the three ways in which contaminants can enter the body: drinking the water, eating meat from livestock which drank the water, or drinking milk from livestock which drank the water. 
Table 3.4 Contaminants of potential concern for the Dilworth aquifer

\begin{tabular}{|c|c|c|c|}
\hline $\begin{array}{l}\text { Contaminant levels } \\
\text { exceed background }\end{array}$ & $\begin{array}{l}\text { Contaminant levels } \\
\text { in nutritional range }\end{array}$ & $\begin{array}{l}\text { Contaminants of low } \\
\text { toxic potency and/or } \\
\text { high dietary range }\end{array}$ & $\begin{array}{l}\text { Contaminants of } \\
\text { potential concern }\end{array}$ \\
\hline $\begin{array}{l}\text { Aluminum } \\
\text { Ammonium } \\
\text { Cadmium } \\
\text { Cobalt } \\
\text { Fluoride } \\
\text { Iron } \\
\text { Nickel } \\
\text { Sulfate } \\
\text { Uranium } \\
\text { Zinc }\end{array}$ & Zinc & $\begin{array}{l}\text { Aluminum } \\
\text { Ammonium }\end{array}$ & $\begin{array}{l}\text { Cadmium } \\
\text { Cobalt } \\
\text { Fluoride } \\
\text { Iron } \\
\text { Nickel } \\
\text { Sulfate } \\
\text { Uranium }\end{array}$ \\
\hline
\end{tabular}

ascreening process has started with the first column; constituents listed in the second and third columns were subtracted from the list of constituents in the first column; the remaining constituents form the list shown in the last column. 
It should be kept in mind that the highest contaminant concentrations from the most contaminated wells were used to estimate the amount of exposure.

Therefore, this evaluation provides the upper limit of possible risks resulting from Dilworth ground water contamination; real risks are not likely to reach that limit. Only people who drilled a drinking water well in the most contaminated area (a small portion of the site) could experience the health problems discussed below.

Considering these relevant human exposure pathways, small amounts of the contaminants could be passed from the livestock to humans or from garden produce to humans. The estimated amounts of contaminants that could be ingested could cause adverse health effects if the Dilworth aquifer background ground water were used to water domestic stock and irrigate gardens.

Iron and sulfate concentrations in the ground water make the human health risks associated with the potential future use of this ground water as a drinking water source unacceptable. However, such consumption is unlikely because of the water's unpleasant taste and odor, historical knowledge of poor water quality, and the presence of better quality water from other sources. Nevertheless, the estimated iron exposure level could be associated with elevated levels of iron (above normal values) in internal organs such as the liver and pancreas. Elevated levels of iron in the body would lead to increased skin pigmentation and possibly cirrhosis of the liver. Although no drinking water wells are within a $2-\mathrm{mi}(3-\mathrm{km})$ radius of the site, if the Dilworth ground water were used as untreated drinking water for infants, sulfate levels could result in severe persistent diarrhea, potentially leading to dehydration, because infants are sensitive to sulfate toxicity. Laxative effects could be produced in adults who drink the water. Moreover, natural levels of sulfate present in the Dilworth ground water near the site, and typically found in this area of Texas, are known to produce diarrhea in some individuals.

Human health would not be at risk from exposure to cadmium, cobalt, fluoride, or nickel through these pathways. Exposure to uranium may be of health concern due to its chemical toxicity and potential radiological damage. Chemical toxicity from exposure to uranium is not anticipated if humans drink the Dilworth ground water. The additional cancer risk from radioactive uranium and longer-lived progeny of the uranium decay series, however, is at an unacceptable level of 1 in 1000 over a lifetime. Any excess lifetime cancer risks associated with radionuclides due to human consumption of meat or milk from cattle that drank this water as their sole drinking water source are within an acceptable range as defined by the National Contingency Plan range, which is between 1 in 10,000 and 1 in $1,000,000$.

The levels of manganese and arsenic observed in the natural Dilworth ground water that is unaffected by the former mill tailings could lead to an increased risk of developing nervous system disorders resembling Parkinson's disease and/or skin cancer if the water were used as the sole source for a prolonged 
period. Naturally occurring manganese and arsenic, therefore, limit the potential use of ground water in some areas as a source for drinking water.

An evaluation of the potential effects on livestock, if the Dilworth ground water were used to water cattle, showed livestock would suffer no adverse health effects from drinking Dilworth ground water. The Dilworth ground water is also suitable for crop irrigation.

\section{Deweesville/Conquista aquifer}

Although no livestock, domestic, or drinking water wells are screened in the Deweesville/Conquista aquifer within a $2-\mathrm{mi}(3-\mathrm{km})$ radius of the site, the use of Deweesville/Conquista ground water downgradient and farther than $2 \mathrm{mi}(3 \mathrm{~km})$ from the site has not been evaluated. The shallow ground water at the Falls City site appears to have originated largely from past in situ mining and milling operations, and its use as a water supply is unlikely. Although the DOE has not determined whether the ground water in the Deweesville/Conquista farther downgradient from the site is a usable water resource, it has not historically been used as a drinking-water source.

The background water quality in the Deweesville/Conquista aquifer was partially assessed before surface remedial action began. Sulfate, manganese, and uranium concentrations in the Deweesville/Conquista ground water are high enough to cause serious adverse health effects. The health effects associated with exposure to sulfate, manganese, and uranium make the ground water unsuitable for drinking, irrigating crops, or watering livestock (DOE, 1994).

\subsection{EVALUATION OF INTERIM ACTION OPPORTUNITIES}

The DOE has determined there is no immediate danger to public health and the environment from contaminated ground water because no wells are completed in the systems, thereby eliminating an exposure pathway to a receptor. Furthermore, a rural water supply system provides good quality water to residents in the site vicinity. Interim action opportunities at the Falls City site will be evaluated as a research-and-development application supporting innovative technological approaches. 


\subsection{GROUND WATER COMPLIANCE STRATEGY SELECTION}

The ground water compliance strategies for the Falls City site and an explanation of the application of site-specific data to the ground water compliance selection framework are presented below (Figure 4.1).

\subsection{COMPLIANCE STRATEGY SELECTION PROCESS}

A health- and environmental risk-based framework for selecting site-specific compliance strategies is being applied to each UMTRA Project processing site. This compliance selection framework was developed in the UMTRA Ground Water PEIS. The framework enables the DOE to apply the same criteria to determine the ground water compliance strategy at each site and to determine the appropriate compliance strategy.

A step-by-step approach is followed until one or a combination of three compliance strategies below is selected for a specific site.

- No remediation. Compliance with the EPA ground water protection standards would be met without altering the ground water or cleaning it up in any way. This strategy could be applied at sites with contamination at or below MCLs or background levels or at sites that have contamination above MCLs or background levels but qualify for supplemental standards or ACLs.

- Natural flushing. Allows natural ground water movement and geochemical processes to decrease contaminant concentrations to levels within regulatory limits within a given time period. This strategy could be applied at sites where ground water compliance would be achieved with natural flushing within 100 years, where effective monitoring and institutional controls could be maintained, and where the ground water is not and is not projected to be a drinking water source.

- Active ground water remediation. Requires application of engineered ground water remediation methods such as gradient manipulation, ground water extraction and treatment, and in situ ground water treatment to achieve compliance with the standards.

\subsection{FALLS CITY, TEXAS, COMPLIANCE STRATEGY SELECTION}

The ground water compliance selection framework was applied to the uppermost aquifer known to be affected by activities at the processing site. Site conditions were used to determine that the no-remediation (with additional characterization) application of supplemental standards strategy could be appropriate for the uppermost aquifer based on widespread ambient contamination and acceptable risks to human health and the environment. Figure 4.1 shows how this target was selected. 
CHARACTERIZE PLUME AND

HYDROLOGICAL CONDITIONS USING

EXISTING DATA AND NEW DATA AS

REQUIRED.

\section{1 \\ IS GROUND WATER CONTAMINATION PRESENT IN EXCESS OF MAXIMUM CONCENTRATION LIMITS OR BACKGROUND?}

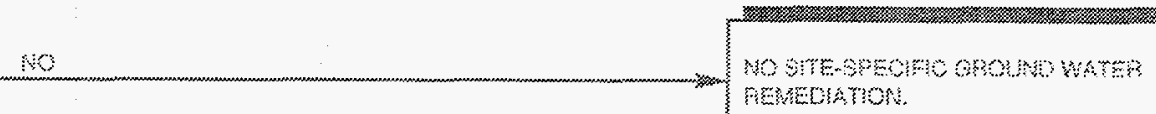

\section{YES}

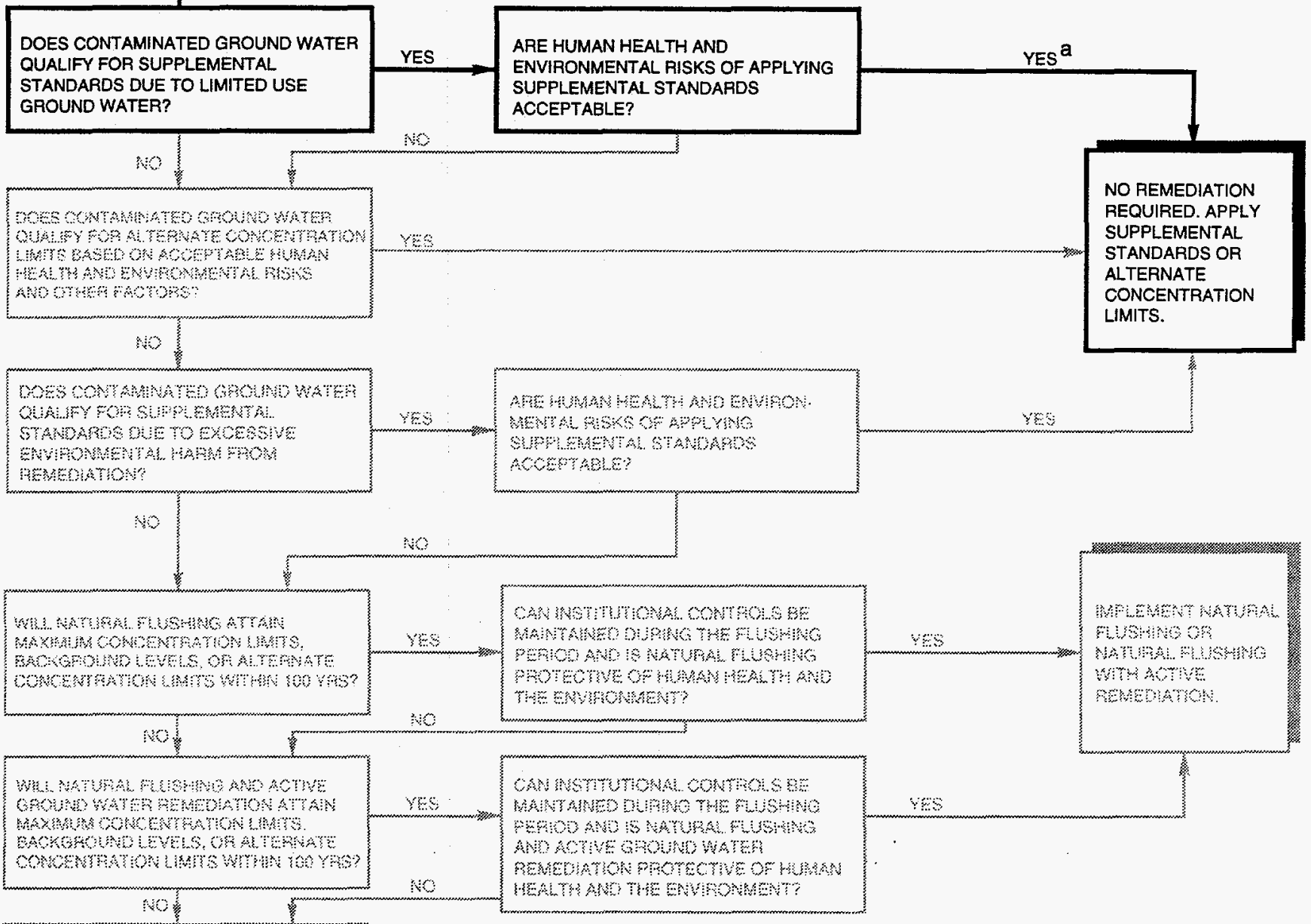

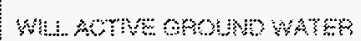

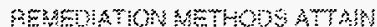

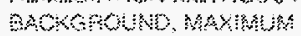

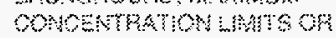

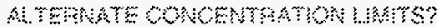

$$
\mathrm{NO}
$$

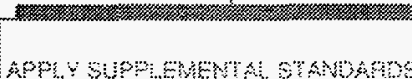

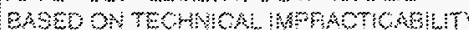

anb apmy

wrane semo

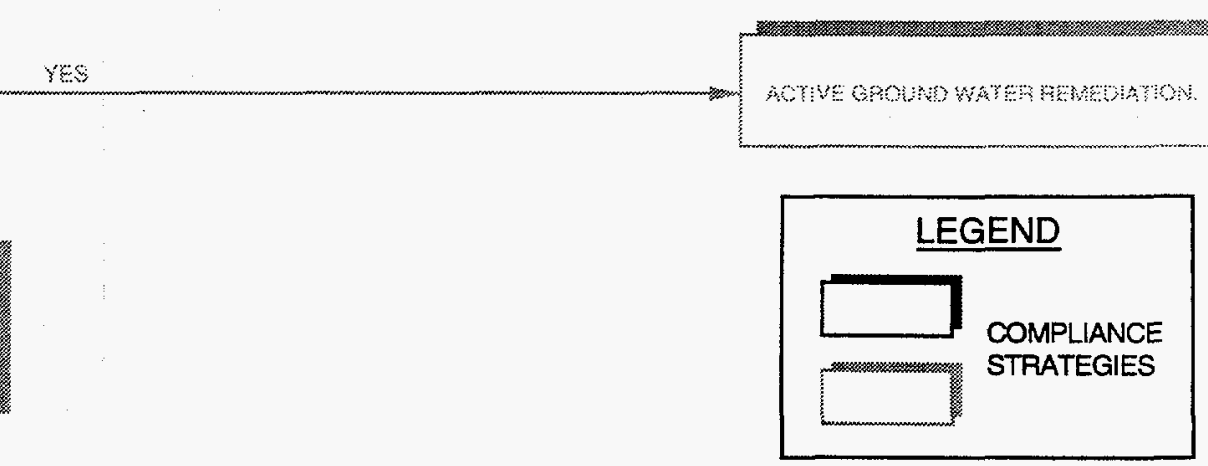

FIGURE 4.1

NOTE: ${ }^{a}$ TO BE DETERMINED.

FRAMEWORK APPLICATION OF CONTAMINANTS OF POTENTIAL CONCERN IN THE UPPERMOST AQUIFERS FALLS CITY, TEXAS, SITE 


\section{Uppermost aquifer compliance strategy}

Figure 4.1 shows how the framework was used to prepare the uppermost aquifer strategy of no remediation and the application of supplemental standards. Table 4.1 shows how each of the contaminants of concern move through the framework.

To protect ground water and to achieve compliance with EPA ground water standards under the UMTRA Surface Project (Subpart A of 40 CFR Part 192), the DOE proposed a narrative supplemental standard for Parcel $A$ of the Falls City site and the disposal site. The supplemental standard for surface remedial action classified ground water from the uppermost aquifer as limited use, based on widespread ambient contamination that could not be cleaned up with methods reasonably employed by public water systems. To demonstrate existing widespread contamination in the uppermost aquifer, the DOE established background ground water quality in the site vicinity (DOE, 1992b). Supplemental standards did not apply to Parcel B. However, there is no evidence that conditions are different in the uppermost aquifer in the vicinity of Parcel B. Background monitor wells were installed and monitored to demonstrate widespread ambient contamination of the uppermost aquifer in the vicinity of the disposal site. The DOE, NRC, and the state concurred with the supplemental standard application and agreed that the uppermost aquifer was limited use in 1992. Thus, the first step toward achieving compliance with the ground water standards was to determine whether widespread, ambient contamination persists in the uppermost aquifer in the site vicinity.

The second step was to determine whether compliance with the standards could still be achieved by applying supplemental standards based on limited use ground water. Regulations define limited use ground water as ground water that is not a current or potential source of drinking water for the following three reasons: the concentration of total dissolved solids exceeds $10,000 \mathrm{mg} / \mathrm{L}$; the ground water contains widespread, ambient contamination, not caused by activities involving RRM from a designated processing site, that cannot be cleaned up with treatment methods reasonably employed by public water-supply systems; or the quantity of water available from a well is less than 150 gallons (570 liters) per day.

Hydrogeologic conditions and ground water contamination conditions at the Falls City site have been characterized and are presented in Section 3.0. The background water in the uppermost aquifer still meets the criteria for limited use ground water based on widespread, ambient contamination not caused by activities involving RRM from a designated processing site. The background water cannot be cleaned up with treatment methods reasonably employed by public water-supply systems. Making water from the uppermost aquifer potable would require multiple treatment technologies not typically used in Texas or in the region. Removing radionuclides from the ground water will produce treatment plant wastes containing both hazardous and radioactive constituents. Also, treated ground water from the uppermost aquifer would cost local 


\begin{tabular}{|c|c|c|c|c|c|}
\hline \multirow[b]{2}{*}{ Contaminant } & \multicolumn{5}{|c|}{ Criteria } \\
\hline & $\begin{array}{c}\text { Are new data } \\
\text { required? }\end{array}$ & $\begin{array}{c}\text { Does contamination } \\
\text { exceed background } \\
\text { or MCLs? } \\
\end{array}$ & $\begin{array}{l}\text { Is contaminant } \\
\text { found in limited } \\
\text { use ground } \\
\text { water? } \\
\end{array}$ & $\begin{array}{l}\text { Are human health } \\
\text { and onvironmental } \\
\text { risks of applying } \\
\text { supplemental } \\
\text { standards } \\
\text { acceptable? }\end{array}$ & $\begin{array}{c}\text { Apply } \\
\text { supplemental } \\
\text { standards? }\end{array}$ \\
\hline Aluminum & No & Yes & Yes & Yes & Yes \\
\hline Ammonium & No & Yes & Yes & Yes & Yes \\
\hline Cadmium & No & Yes & Yes & Yes & Yes \\
\hline Cobalt & No & Yes & Yes & Yes & Yes \\
\hline Fluoride & Yes & Yes & Yes & Yes & Yes \\
\hline Iron & Yes & Yes & Yes & Unknown ${ }^{a}$ & Unknown \\
\hline Nickel & No & Yes & Yes & Yes & Yes \\
\hline Sulfate & Yes & Yes & Yes & Unknown ${ }^{a}$ & Unknown \\
\hline Uranium & Yes & Yes & Yes & Unknowna & Unknown \\
\hline Zinc & No & Yes & Yes & Yes & Yes \\
\hline ther character & of contamina & ed zone is needed. & & & \\
\hline
\end{tabular}


residents considerably more than what they now pay for drinking water (DOE, 1992b).

The DOE has determined from the data that supplemental standards are protective of human health and the environment, and that site-specific remediation is not required. Section 3.3.5 describes the limited uses of ground water from the uppermost aquifer and the risk associated with exposure to iron and sulfate in the ground water. Because the DOE is proposing no remediation as a compliance strategy, however, it will analyze exposure pathways and collect additional data to demonstrate that existing or potentially beneficial uses of ground water are protected; the pathway analysis and data collection activities are discussed further in Section 5.0.

\subsection{DEVIATIONS, CONTINGENCIES, AND DECISION RULES}

The DOE's environmental restoration process generally, and the UMTRA Ground Water Project specifically, must make restoration decisions under conditions of inherent uncertainty. Uncertainties associated with limited site condition information and with uncertain remedial strategy performance are reduced to the extent practicable, in an effort to minimize time and resources spent on studying the problems and to expedite restoration activities. In developing this SOWP, the DOE maximized the use of existing information to select a realistic remedial strategy. This SOWP developed and used a conceptual model to provide a foundation for remediation planning and action. If the proposed remedial strategy is not supported by additional data, the DOE will reevaluate the strategy selection and assess the feasibility of implementing an alternative remedial strategy. 


\subsection{DATA COLLECTION AND ASSESSMENT}

\section{$5.1 \quad$ STATEMENT OF DATA NEEDS}

The DOE has evaluated existing site information and identified data gaps (uncertainties) that must be addressed to confirm the appropriateness of the proposed ground water compliance strategy and the feasibility of alternative strategies if required. An alternate strategy might be required if the proposed primary compliance strategy is unacceptable from a stakeholder's perspective, or if additional characterization leads to a different approach.

The DOE's methods for reducing system uncertainties are described below. These methods are designed to enhance understanding of site conditions and to ensure the appropriate ground water compliance strategy is implemented.

\subsubsection{Qualitative analysis of background ground water quality}

Background ground water quality in the Deweesville/Conquista aquifer has been sufficiently characterized to demonstrate that it qualifies for a supplemental standard application (DOE, 1992b). However, a literature search and a review of ground water quality data from monitor wells and other wells near the site will be conducted to demonstrate qualitatively that the supplemental standards are protective of potential beneficial uses of ground water in the site vicinity.

\subsubsection{Land and water use survey}

The DOE must demonstrate that the ground water compliance strategy will protect human health and the environment and protect potential beneficial uses of the ground water. To evaluate the health risks and environmental impacts associated with ground water contamination, investigators will continue the process of identifying potential exposure pathways within and downgradient from the contaminated zones and further assess the likelihood of direct or indirect human contact with contaminated ground water through the exposure pathways (DOE, 1994).

\subsubsection{Hydrogeologic investigations}

\section{Installing monitor wells and ground water sampling}

The DOE must further define the extent and magnitude of contamination in the uppermost aquifer, refine its understanding of ground water flow direction(s), further assess the potential affects of the contamination on other aquifers, and further assess potential beneficial uses of those aquifers. 


\section{Water level monitoring}

Water levels will be monitored during routine ground water sampling and during aquifer tests in the uppermost aquifer to observe short- and long-term fluctuations in ground water levels. Long-term fluctuation of ground water levels will be monitored with dedicated ground water level recording data loggers. Water levels will also be monitored during aquifer tests in the Dilworth aquifer to observe the degree of interconnection between the Deweesville/Conquista and Dilworth aquifer.

\section{Aquifer testing}

Aquifer tests are proposed to quantify aquifer properties more accurately to determine ground water velocities and to obtain the data needed to perform computer simulations of the ground water flow system.

\section{Core analysis}

Core analyses will be conducted on newly collected core samples to estimate bulk density and effective porosity.

\subsection{DATA COLLECTION OBJECTIVES}

This investigation has established the following data collection objectives:

- Further define background ground water quality data of the uppermost aquifer. Background ground water quality will be defined qualitatively through a literature search and by reviewing ground water quality data from existing wells.

- Continue the process of identifying potential exposure pathways downgradient of the site (DOE, 1994). This includes collecting data to help identify potential routes of contaminant migration from the site to an existing or potential point of contact.

- Determine the nature and occurrence of ground water recharge for the uppermost aquifer.

- Define the extent of downgradient contamination in the uppermost aquifer in each of the contaminated zones described in Section 3.3.2.

- Estimate the volume of contaminated ground water and the mass of constituents of concern.

- Define the area of variability in aquifer hydraulic conductivity to estimate advective velocities. 
- Determine the degree of interconnection between the Deweesville/Conquista and Dilworth aquifers.

- Understand the major solute transport phenomenon.

\subsection{DATA QUALITY OBJECTIVES}

The purpose of data quality objectives $(D Q O)$ is to ensure that data of known and appropriate quality are obtained during an investigation and to ensure the data are adequate to support DOE, state, and public decisions for remedial action. The DQOs for each task proposed in Section 5.1 are presented below.

\subsubsection{Qualitative analysis of background ground water quality}

Literature and records will be searched for data. The quality of the data sources will be based on its merits and its applicability to Falls City site conditions. For example, reports issued by state or federal agencies are assumed to be accurate and reliable sources of information.

\subsubsection{Land and water use survey}

For the water use survey, investigators will attempt to obtain well construction and water use information from at least 90 percent of the former and existing domestic wells in the uppermost aquifer. The horizontal positions of domestic wells and stock ponds will be determined with a global positioning system (GPS) instrument. The horizontal accuracy of most GPS terminals is 1 radial meter or less.

\subsubsection{Hydrogeologic investigations}

\section{Installing monitor wells, and ground water sampling and analysis}

A hydrogeologist will be present during all phases of borehole drilling and well installation. Boreholes will be logged and monitor wells will be installed following procedures described in standard operating procedures (SOP) 14.1.3, 14.4.1, 16.1.5.4.3.2, and 16.1.2 (JEG, n.d.). The TAC has specified or established procedures for installing and developing monitor wells, sampling water and soil, preserving and transporting samples, filing procedures, chain-ofcustody, analyzing sample, quality assurance (QA), and managing and validating analytical data. Fieldwork is conducted in accordance with these SOPs, which are reviewed annually and updated (as appropriate) to reflect changes in industry standards, best management practices, and DOE or EPA guidelines.

Each well site will be properly permitted, and as much as possible, restored to preinstallation conditions. Wastes generated by the drilling operations (drilling fluid and well water) will be disposed of according to approved procedures. 
The well casing will consist of 4-inch-(100-mm) diameter, schedule 40 PVC pipe with flush-threaded joints. Solvent glues will not be used and couplings will not obstruct the well annulus, with no potential for screws to enter the inside of the casing and obstruct placement of the pump. Schedule 40 PVC pipe is large enough to allow the placement of a standard electric submersible pump designed for 4-inch $(100 \mathrm{~mm})$ diameter wells.

New monitor wells were sampled twice in 1994 and will be sampled twice in 1995 to determine different water quality parameters. Samples will be collected, preserved, and shipped according to the UMTRA Project SOPs (JEG, n.d.).

\section{Water level monitoring}

The purpose of water level monitoring is to observe short- and long-term fluctuations in ground water levels and determine the rate of ground water mound dissipation immediately downgradient of the disposal cell. Sufficient sensitivity, accuracy, and temporal recording resolution are needed to ensure the collected data can be used for their intended purpose. Standard pressure transducers (e.g., In Situ $\left.{ }^{\oplus}\right)$ have a resolution of $0.004 \mathrm{ft}(0.001 \mathrm{~m})$ with an accuracy of $0.035 \mathrm{ft}(0.01 \mathrm{~m})$. Using standard equipment and procedures should provide sufficient accuracy to compute declining or rising ground water elevations. Water level data will be measured daily with data loggers for a minimum of 2 years. The data loggers will be routinely calibrated with measurements made with a steel tape.

\section{Aquifer testing}

Slug tests and short- and long-term aquifer testing and analyses will determine the spatial distribution of hydraulic conductivity and the degree of interconnection between the Dilworth and Deweesville aquifers; quantify how the aquifer would respond to stressed conditions, and (combined with core and slug test data) provide a data base sufficient for stochastic modeling analysis. Standard data loggers and pressure transducers, used in accordance with the manufacturer's instructions, will produce reliable data for the analyses. Tests will be designed and analyzed according to standards, such as American Society for Testing Materials (ASTM) standard D4050-1991 (ASTM, 1994a). The pH, oxidation/reduction potential, specific conductivity, and temperature of the water will be checked every 15 minutes using standard field instrumentation and operating procedures.

A potential problem with analyzing aquifer pumping tests is the possibility that pumping rate variations can create multiple solutions (Horne, 1994). To alleviate the problem of nonunique solutions, each test will be analyzed during both the drawdown and recovery phases. The recovery phase has a constant rate of zero and will provide a more accurate result. Slug tests are useful for estimating near-well bore parameters. 


\section{Core/analysis}

Core analysis for porosity, bulk density, and grain size analysis will provide more detailed, small-scale information on aquifer characteristics. Core tests will relate the parameters determined on a small portion of the aquifer (cubic centimeters) to the macroscopic behavior of the aquifer (cubic kilometers). Laboratories qualified by the DOE will conduct the tests.

\section{$5.4 \quad$ DATA COLLECTION ACTIVITIES}

To achieve the data collection objectives of this investigation, the DOE will collect ground water quality data for the uppermost aquifer to reconfirm that ground water still meets limited use ground water criteria. In addition, land and water use in the site vicinity will be defined to demonstrate that the proposed ground water compliance strategy will be protective of human health and environment, and protect beneficial uses of the ground water.

\subsubsection{Qualitative analysis of backoround oround water quality}

A literature search and a review of ground water quality data for former and current wells will be used to qualitatively assess background ground water quality in the site area. The literature search will locate relevant reports or documents from state and federal agencies, professional journals, and information collected by mining companies that worked in the area. The water use survey discussed below will obtain relevant data from local property owners.

\subsubsection{Land and water use survey}

The survey will extend up to $3 \mathrm{mi}(5 \mathrm{~km})$ radially from the site (Figure 5.1$)$. This survey will expand the area of the previous survey, which was conducted within a 2-mi $(3-\mathrm{km})$ radius of the site. The survey will cover an area that extends well beyond the current, known lateral extent of ground water contamination.

During the land and water use survey, the following activities will be conducted:

- A literature search and review of ground water quality data from existing wells to further define background ground water quality.

- A well record search by reviewing appropriate files from the state of Texas. The well records will help to determine well construction information, depth to water, well productivity information, and water quality.

- Aerial photography of the region to quickly locate and identify stockponds that could be used to water livestock.

- A door-to-door survey to interview local landowners regarding past and present land and water use. Domestic wells and stock ponds will be 


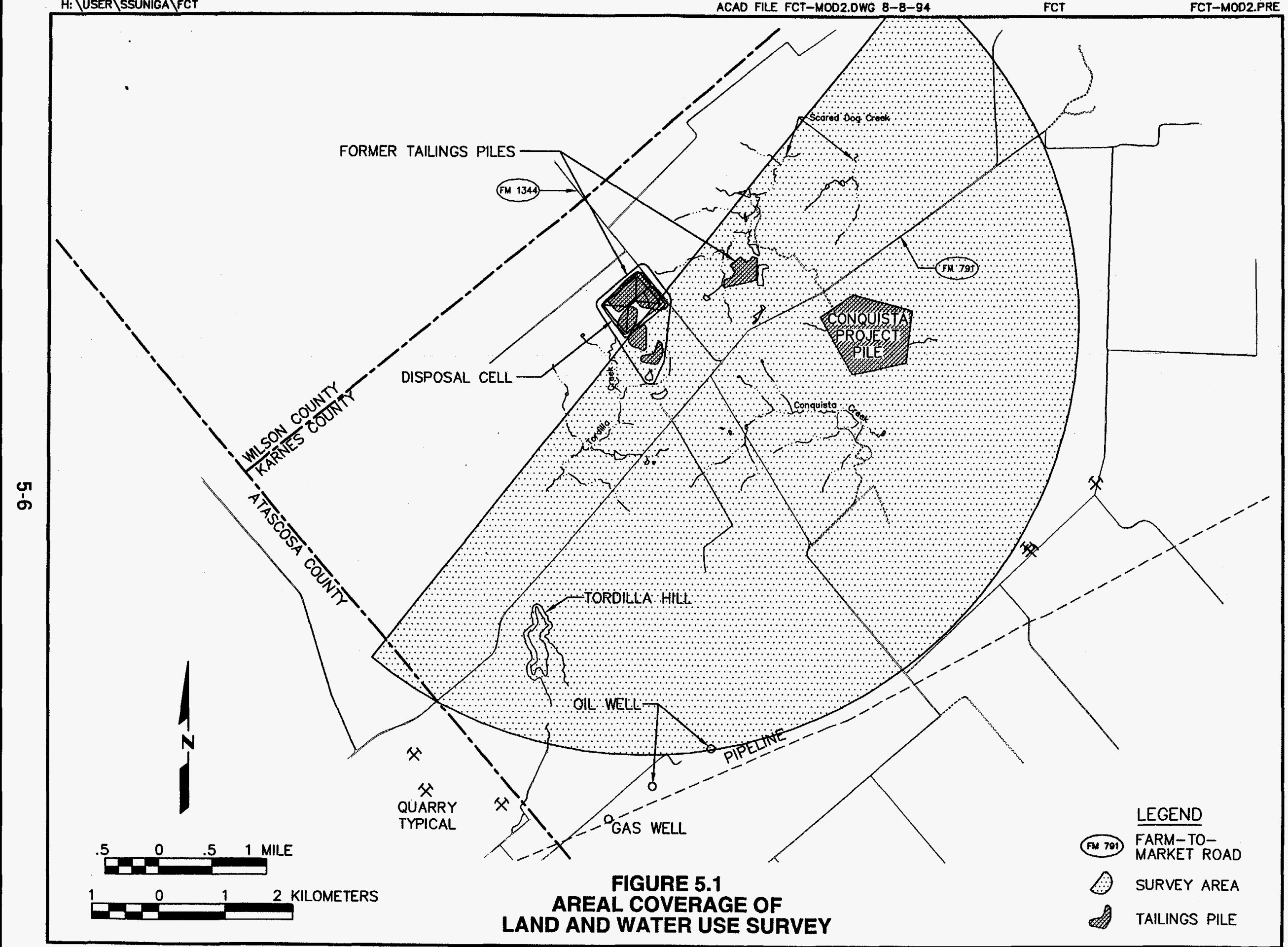


located and sampled, if possible. Depth-to-water will be measured in domestic wells.

- Determine the horizontal and vertical position of domestic wells and surface water bodies, including those that have been identified but not located. Because of the size of the survey area lapproximately 25 square miles [65 square kilometers]), the DOE proposes using a GPS to locate the position of domestic wells and stock ponds with respect to the site.

\subsubsection{Hydrogeologic investigations}

Twelve additional monitor wells will be installed on the site. Table 5.1 summarizes the proposed depth, screened interval, and the purpose of each new well. Figure 5.2 shows the proposed locations of these new wells. The exact locations are dependent on obtaining access agreements from landowners. After the monitor wells are installed, they will be surveyed by a registered land surveyor or with a GPS.

- One well (883) will be installed in the Deweesville/Conquista aquifer immediately downgradient of the site southeast of FM 791 (Figure 5.2) to determine the extent of contamination in the southern contaminated zone.

- Four monitor wells will determine the extent of ground water contamination in the Deweesville/Conquista aquifer caused by former tailings pile 3 . These monitor wells $(884,885,886$, and 887$)$ will be south and east of former tailings pile 3 and north of FM 791 (Figure 5.2) to determine the extent and magnitude of contamination in the southern arm of the eastern contaminated zone. These monitor wells may help determine the impact of the Conquista tailings pile on ground water flow and quality in the Deweesville/Conquista aquifer.

- One well (888) will be installed in the Dilworth aquifer east of former tailings pile 3 to verify that contamination has not reached the Dilworth aquifer in this area.

- Three monitor wells $(889,890$, and 891) will determine the extent of ground water contamination in the Dilworth aquifer in the northern arm of the eastern contaminated zone along Scared Dog Creek.

- Two monitor wells (892 and 893) will be installed downgradient of the disposal cell near the former location of monitor well 833. Abandoned during surface remediation activities, well 833 is believed to be completed in the Dilworth aquifer. Water samples collected from well 833 have shown evidence of mill-related contamination. This contamination is believed to be caused by improper well construction.

- Monitor well 892 will be installed in the Dilworth aquifer near the former location of monitor well 833 to determine if mill-related contamination is 
Table 5.1 Construction summary of proposed monitor wells

\begin{tabular}{|c|c|c|c|c|}
\hline Well ID & $\begin{array}{l}\text { Estimated } \\
\text { well depth } \\
\text { (ft) }\end{array}$ & $\begin{array}{l}\text { Estimated } \\
\text { depth to } \\
\text { water } \\
\text { (ft) }\end{array}$ & $\begin{array}{l}\text { Screened } \\
\text { interval } \\
(f t)\end{array}$ & Purpose \\
\hline 883 & 90 & 70 & $70-90$ & $\begin{array}{l}\text { Define extent of contamination in southern } \\
\text { contaminated zone in Deweesville/ } \\
\text { Conquista aquifer }\end{array}$ \\
\hline 884 & 110 & 50 & $100-110$ & $\begin{array}{l}\text { Define extent of contamination in } \\
\text { contaminated zone south of former } \\
\text { tailings pile } 3 \text { in Deweesville/Conquista } \\
\text { aquifer }\end{array}$ \\
\hline 885 & 110 & 50 & $100-110$ & $\begin{array}{l}\text { Define extent of contamination in } \\
\text { contaminated zone south of former } \\
\text { tailings pile } 3 \text { in Deweesville/Conquista } \\
\text { aquifer }\end{array}$ \\
\hline 886 & 110 & 50 & $100-110$ & $\begin{array}{l}\text { Define extent of contamination in } \\
\text { contaminated zone south of former } \\
\text { tailings pile } 3 \text { in Deweesville/Conquista } \\
\text { aquifer }\end{array}$ \\
\hline 887 & 110 & 50 & $100-110$ & $\begin{array}{l}\text { Define extent of contamination in } \\
\text { contaminated zone south of former } \\
\text { tailings pile } 3 \text { in Deweesville/Conquista } \\
\text { aquifer }\end{array}$ \\
\hline 888 & 180 & 100 & $170-180$ & $\begin{array}{l}\text { Determine water quality of Dilworth } \\
\text { aquifer east of former tailings pile } 3\end{array}$ \\
\hline 889 & 30 & 20 & $20-30$ & $\begin{array}{l}\text { Define extent of contamination in eastern } \\
\text { contaminated zone along Scared Dog } \\
\text { Creek in Dilworth aquifer }\end{array}$ \\
\hline 890 & 30 & 20 & $20-30$ & $\begin{array}{l}\text { Define extent of contamination in eastern } \\
\text { contaminated zone along Scared Dog } \\
\text { Creek in Dilworth aquifer }\end{array}$ \\
\hline 891 & 30 & 20 & $20-30$ & $\begin{array}{l}\text { Define extent of contamination in eastern } \\
\text { contaminated zone along Scared Dog } \\
\text { Creek in Dilworth aquifer }\end{array}$ \\
\hline 892 & 160 & 80 & $140-160$ & $\begin{array}{l}\text { Define extent of contamination in Dilworth } \\
\text { aquifer immediately downgradient of } \\
\text { disposal cell }\end{array}$ \\
\hline 893 & 30 & 10 & $20-30$ & $\begin{array}{l}\text { Serve as an observation well during } \\
\text { aquifer test of well } 892\end{array}$ \\
\hline 894 & 30 & 10 & $20-30$ & $\begin{array}{l}\text { Serve as an observation well during } \\
\text { aquifer test of existing well } 880\end{array}$ \\
\hline
\end{tabular}




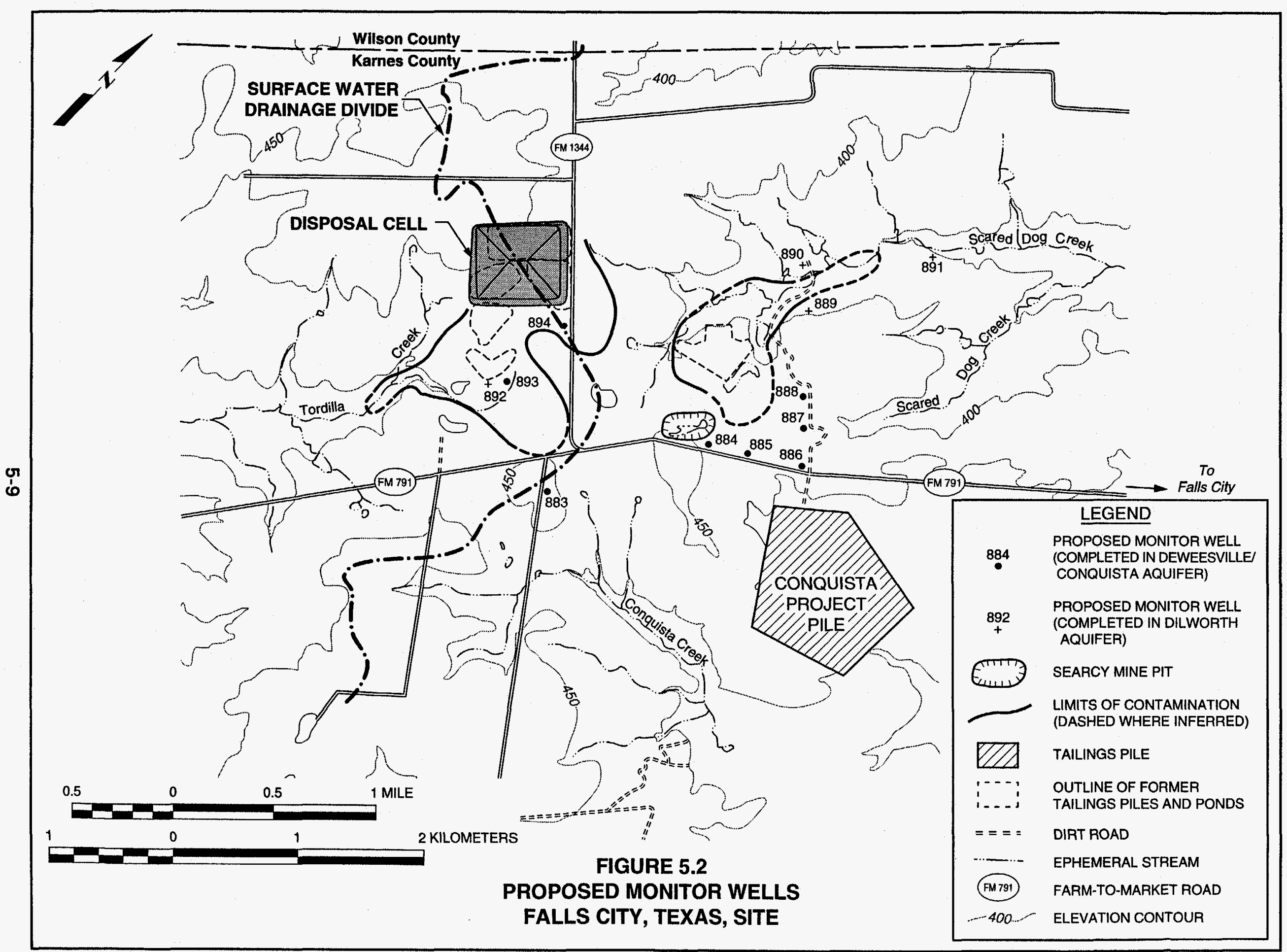

MAC: SITE/FCT/SOWP/BASE-PROPMONWELLS 
present in the Dilworth aquifer in this area. An aquifer test will also be conducted on this well to determine aquifer properties.

Monitor well 893 will be installed in the Deweesville aquifer adjacent to well 892. Well 893 will function as an observation well during the aquifer test and will be used to determine the interconnection between the two aquifers.

Wells installed in the Dilworth aquifer will be constructed using drilling methods that minimize potential cross contamination from the overlying Deweesville/Conquista aquifer.

- Monitor well 894 will be installed in the Deweesville/Conquista aquifer next to existing well 880 . Existing well 880 is completed in the Deweesville/Conquista aquifer. An aquifer test will be performed in well 880 to determine the aquifer characteristics of the Deweesville/Conquista aquifer; well 894 will serve as an observation well during the test.

Additional observation wells may be needed in this area as part of the aquifer test. These additional locations will be determined during the planning stages of the aquifer test.

Each well, including the new monitor wells, will be sampled for the contaminants of concern identified in the baseline risk assessment. The new monitor wells will be sampled for a complete set of parameters during the first two sampling rounds in fiscal year 1995 to identify new potential contaminants of concern. Field analyses will be conducted for $\mathrm{pH}$, oxidation-reduction potential, dissolved oxygen, specific conductance, and temperature.

\section{Water level monitoring}

Water table hydrographs constructed during infiltration events will be used to analyze the nature and occurrence of ground water recharge in the uppermost aquifer. Daily rainfall data will be obtained from an on-site recording rain gauge. The monitoring period will be a minimum of 2 years.

Monitor wells near the disposal cell will be monitored for a minimum of 2 years to determine the rate of ground water mound dissipation immediately downgradient of disposal cell.

\section{Aquifer testing}

Slugs tests will be conducted in a selected group of monitor wells screened in one of the four contaminated zones of the uppermost aquifer (Section 3.3.2). At least three and perhaps four slug tests will be conducted in each contaminated zone to provide adequate information on the spatial distribution of hydraulic conductivity. If possible, at least one monitor well in each contaminated zone will be tested in each aquifer. 
Aquifer tests will be conducted on wells screened within the Deweesville and Dilworth aquifers. During each aquifer test, water levels will be measured in nearby monitor wells to determine the extent of influence of the pumped well and the aquifer hydraulic parameters between the pumped well and each monitor well.

During each aquifer test, $\mathrm{pH}$, oxidation-reduction, and specific conductivity will be measured periodically. Also, time-sequenced ground water sampling will be conducted for selected constituents during each aquifer test.

An aquifer pumping test will be conducted in the newly installed well screened in the Dilworth aquifer downgradient from the disposal cell. An aquifer pumping test will also be conducted in a monitor well completed in the Deweesville/Conquista aquifer. These tests will help determine hydraulic conductivity within the Dilworth and Deweesville aquifers and the degree of interconnection between the Dilworth and the overlying Deweesville/Conquista systems.

The DOE is evaluating the potential use of in situ ground water velocity probes to augment or replace the aquifer pumping tests.

\subsection{RESULTS AND EVALUATION OF DATA COLLECTION ACTIVITIES}

When each data collection activity is complete, results will be compiled and made available to the DOE. The compilation will describe field activities, instrumentation used, and survey locations. It will contain copies of field measurement data, copies of field logs and notebooks, and methods of interpretation; and it will summarize the results relative to the data collection objective. A proposed ground water flow model will integrate detailed, sitespecific information. The model also will allow quantitative evaluation of the flow rates required to meet the selected remedial strategy and the possible effects of the uncertainties in the conceptual model. The modeling, data results, and reports will be incorporated in the final SOWP. 


\subsection{LIST OF CONTRIBUTORS}

The following individuals contributed to the preparation of this report.

\begin{tabular}{ll}
\hline Name & Contribution \\
\hline E. Storms & Principal author \\
J. Crain & Document coordinator \\
E. Storms, J. Crain, J. Blount, & Technical authors \\
P. Dotson, T. Jackson, & \\
B. Malczewska-Toth, & \\
M. Gawthrop-Cooper & \\
E. Storms, P. Dotson & Hydrogeology \\
J. Blount, T. Jackson & Geochemistry \\
J. Crain & Engineering \\
B. Malczewska-Toth & Risk assessment \\
M. Gawthrop-Cooper & Regulatory compliance \\
L. Sanchez & Word processing \\
S. Suniga, B. Harvey & Graphic design \\
J. Torline, J. Bartel & Technical editing, document production coordination \\
\hline
\end{tabular}




\subsection{REFERENCES}

Allison, J. D., D. S. Brown, and K. J. Novo-Gradac, 1991. MINTEQA2/PRODEFA2, A Geochemical Assessment Model for Environmental Systems: Version 3.0 User's Manual, EPA/600/3-91/021, Environmental Research Laboratory, Office of Research and Development, U.S. Environmental Protection Agency, Athens, Georgia.

ASTM (American Society for Testing Materials), 1994a. ASTM Standards on Ground Water and Vadose Zone Investigations, 2nd edition, Philadelphia, Pennsylvania.

ASTM (American Society for Testing Materials), 1994b. Annual book of ASTM Standards1994, Volume 04.08, "Soil and Rock, Building Stones, Geotextiles," Philadelphia, Pennsylvania.

BEG (Bureau of Economic Geology), 1992. Hydrogeology and Hydrochemistry of Falls City Uranium Mine Tailings Remedial Action Project, Karnes County, Texas, The University of Texas at Austin, Austin, Texas.

Bunker, C. M., and J. A. MacKallor, 1973. "Geology of the Oxidized Uranium Ore Deposits of the Tordilla Hill-Deweesville Area, Karnes County, Texas; A Study of a District Before Mining," U.S. Geological Survey Professional Paper 765, Washington, D.C.

DOE (U.S. Department of Energy), 1995. Programmatic Environmental Impact Statement for the Uranium Mill Tailings Remedial Action Ground Water Project, draft, DOE/EIS-0198, Rev. 3, April 1994, prepared by the U.S. Department of Energy, UMTRA Project Office, Albuquerque Operations Office, Albuquerque, New Mexico.

DOE (U.S. Department of Energy), 1994. Baseline Risk Assessment of Ground Water Contamination at the Uranium Mill Tailings Site Near Falls City, Texas, DOE/AL/62350-64, Rev. 1. September 1994, prepared by the U.S. Department of Energy, UMTRA Project Office, Albuquerque Operations Office, Albuquerque, New Mexico.

DOE (U.S. Department of Energy), 1993a. Technical Approach to Groundwater Restoration, final, DOE/AL/62350-20F, November 1993, prepared by the U.S. Department of Energy, UMTRA Project Office, Albuquerque Operations Office, Albuquerque, New Mexico.

DOE (U.S. Department of Energy), 1993b. Recommendations for the Preparation of Environmental Assessments and Environmental Impact Statements, Office of NEPA Oversight, U.S. Department of Energy, Washington, D.C. 
DOE (U.S. Department of Energy), 1992a. UMTRA Groundwater Program Plan, prepared by the U.S. Department of Energy, UMTRA Project Office, Albuquerque Operations Office, Albuquerque, New Mexico.

DOE (U.S. Department of Energy), 1992b. Remedial Action Plan and Site Design for Stabilization of the Inactive Uranium Mill Tailings Site at Falls City, Texas, final, UMTRA-DOE/AL-050520.0000, DOE UMTRA Project Office, Albuquerque Operations Office, Albuquerque, New Mexico.

FBDU (Ford, Bacon, and Davis Utah Inc.), 1981. Engineering Assessment of Inactive Uranium Mill Tailings: Falls City Site, Falls City, Texas, DOENMTRA-0111, FBDU 360-16, UC-70, Contract No. DE-AC04-76GJ01658, prepared by FBDU, Salt Lake City, Utah, for the U.S. Department of Energy, UMTRA Project Office, Albuquerque Operations Office, Albuquerque, New Mexico.

GECR (Geochemistry and Environmental Chemistry Research, Inc.), 1983. Data for the Geochemical Investigation of UMTRAP Designated Site at Falls City, Texas, prepared by GECR for the U.S. Department of Energy, UMTRA Project Office, Albuquerque Operations Office, Albuquerque, New Mexico.

Horne, R. N., 1994. "Advances in Computer-Aided Well-Test Interpretation," in Journal of Petroleum Technology, Vol. 46, No. 7, pp. 599-607.

JEG (Jacobs Engineering Group Inc.), n.d. Albuquerque Operations Manual, standard operating procedures, prepared by Jacobs Engineering Group, Albuquerque, New Mexico, for the U.S. Department of Energy, UMTRA Project Office, Albuquerque Operations Office, Albuquerque, New Mexico.

Kallus, M. F., 1975. "Environmental Aspects of Uranium Mining and Milling in South Texas," EPA-906/9-75-004, U.S. Environmental Protection Agency Region VI, Houston, Texas.

Merritt, R. C., 1971. The Extractive Metallurgy of Uranium, Colorado School of Mines Research Institute, Golden, Colorado.

NOAA (National Oceanic and Atmospheric Administration), 1979. Climatic Atlas of the United States, National Climate Center, Ashville, North Carolina.

TKA (Turk, Kehle, \& Associates), 1976. "Reconnaissance Hydrogeology of Uranium Mill Tailings, Falls City, Texas," report prepared for Ford, Bacon \& Davis Utah Inc., Salt Lake City, Utah.

USGS (U.S. Geological Survey), 1988. A Modular Three-Dimensional Finite-Difference Ground-Water Flow Model, Technique of Water Resource Investigations 06-A1. 


\section{CODE OF FEDERAL REGULATIONS}

10 CFR Part 1021. National Environmental Policy Act; Implementing Procedures and Guidelines Revocation; Final Rule and Notice, National Archives and Records Administration (1994).

40 CFR Part 192, Health and Environmental Protection Standards for Uranium and Thorium Mill Tailings, U.S. Environmental Protection Agency (1994).

40 CFR Part 1500, Purpose, Policy, and Mandate, Council on Environmental Quality (1994).

\section{UNITED STATES CODES}

42 USC $\$ 4321$ et seq., National Environmental Policy Act, January 1, 1970.

42 USC $\$ 7901$ et seq., Uranium Mill Tailings Radiation Control Act, November 8, 1978.

42 USC $\$ 7922$ et seq., Uranium Mill Tailings Remedial Action Amendments Act, November 5, 1988.

\section{FEDERAL REGISTER}

60 FR 2854, Ground Water Standards for Remedial Actions at Inactive Uranium Processing Sites; Final Rule, January 11, 1995. 
APPENDIX A

CALCULATION FCT-06-91-12-01-00 


\section{DE ACOBS ENGNERRNG GROUP NC.}

\section{CALCULATION COVER SHEEI}

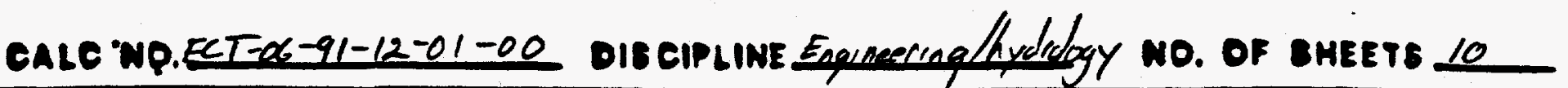
PAOJECT: UMTRA

SITE:

$$
\text { Faces city }
$$

FEATURE:

$$
\text { SURFACE WATER MASS BALANCE }
$$

\section{SOURCES OF DATA:}

see pagel of text

SOURCES OF FORMULAE A REFERENCES:

$$
\text { see text }
$$

\begin{tabular}{|c|c|c|c|c|c|c|c|}
\hline 00 & & Q Cann & $6 k 1 / 9$ & $2 \sin$ & $6 / 24 / 9$ & Chand & a \\
\hline & & & & & & & \\
\hline & & & & & & & \\
\hline & & & & & & & \\
\hline s. & atrision & $\begin{array}{l}\text { EALEULATION } \\
\text { Or }\end{array}$ & Doute & $\begin{array}{l}\text { enEexED } \\
\text { or }\end{array}$ & oure & \begin{tabular}{|l|} 
approved \\
or
\end{tabular} & DATE \\
\hline
\end{tabular}

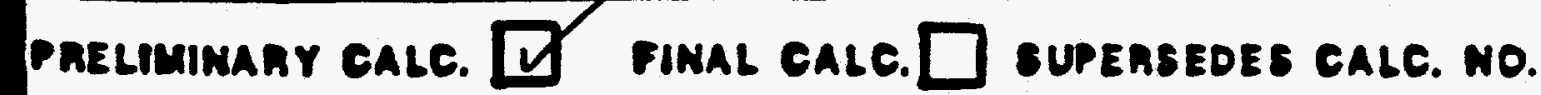


JACOBS ENGINEERING

Date 6/21/91

urger curio.
QUะJECT

SHEET No. $1 / 10$

JOB NO.

Problem statement Est mate the volume of winter that may falls city site during the timers) the mill was

2. Data

1. precipitation dati-National Climatic Data Center, Asheville, North Carolina

a. weather station - located inside city limits Falls City, Texas

b. pericel-if-record: August 1946 through November Rio

2. information on disehang rates to poncho and depth of ponds from former mill supervisor (Susguelianna- Western) fivin E. Wiatre R, phone: $512-780-3911$

3. Assumptions

a. maximum pond area is equal to allow for area of starter dikes 6 acres to

b. rainfall-rolume (column 3 of tables) is inches of precipitation times the maximum pedal area. 
JACOBS ENGINEERING

DATE_ $6 / 21 / 91$

or $20 \mathrm{C}$ CARD
QUEJECT

c for computing evaporative surface area (colum $n$ i. tables)

Where diked drainage areas are used, the water surface aria nay be expressed as a variable function dependent on pond volume Diked rotation areas may. be modeled as conical volumes. The surface area when the pad is less

$$
A=x A_{F}\left(V_{P} / V_{F}\right)^{2 / 3}
$$

where: $A_{f}=$ maximum water surface area

$V_{p}=$ maximum volume

$V_{p}=$ monthly volume (processing

$x=1.0$ for accumulating conditions

d. infiltration is not considered in the mass balance. A diagram of He mass balance is presented below

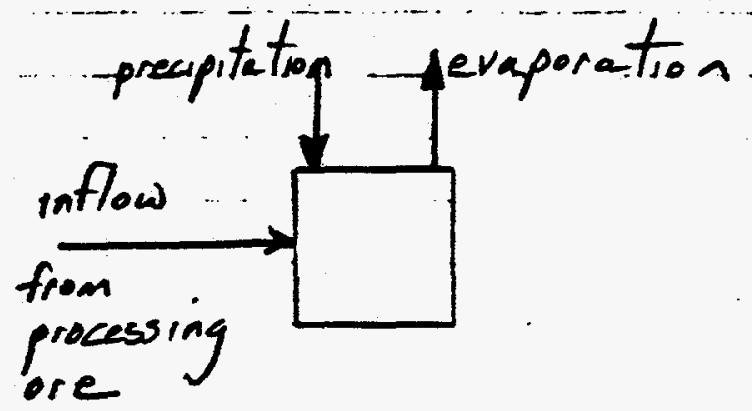


JACOBS ENGINEERING

DATE $6 / 21 / 91$

or gel curio.
SUBJECT

I calculation
t tables en pages
SHEET NO._ $3 / 10$ JOB NO.

$-$

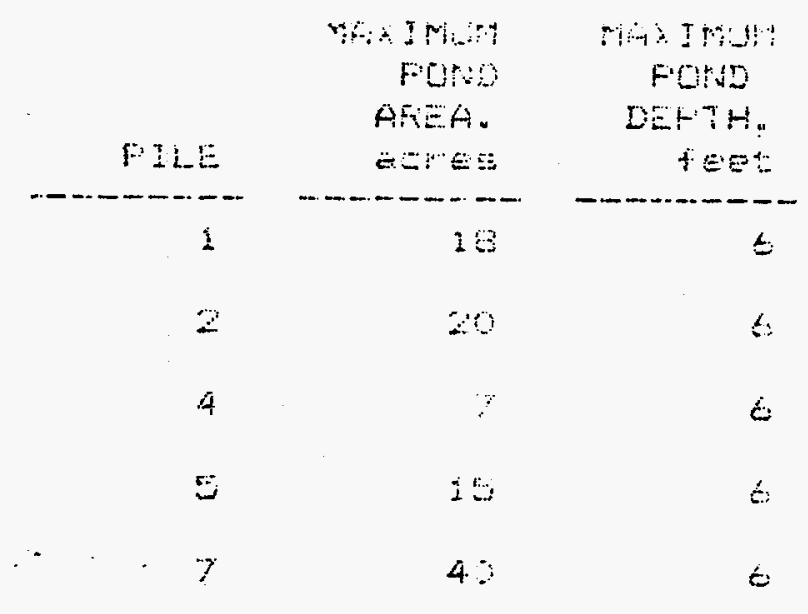

5. Summary

rainfall data (table), page: 10

mass balance (Fables), puges:4-s

mess balance summary, page: 9 
FALLS CITY. TEXAS PILE NO. 1

APNU 1961 TKROUE: DECEMEER 1963

AYERASE AHAUK: LAKE EVAFORATION $=54$ incheE

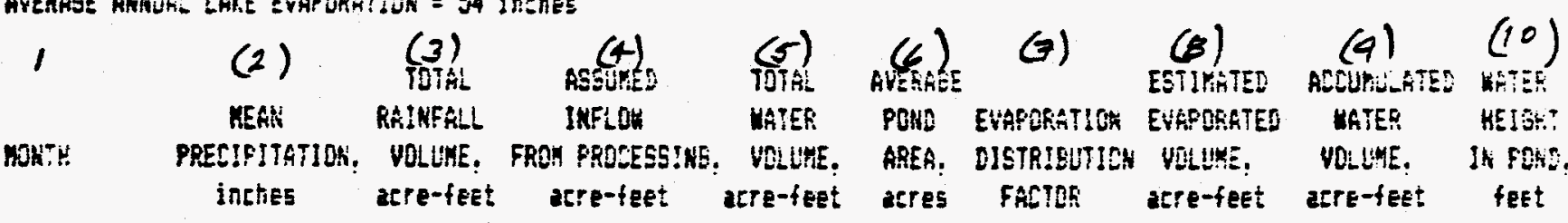

\begin{tabular}{|c|c|c|c|c|c|c|c|c|c|c|}
\hline \multirow[t]{9}{*}{$196:$} & $A 9 \%$ & 2.45 & 3.68 & 3 & 6.68 & 5.85 & 0.082 & 2.16 & 4.52 & 3.42 \\
\hline & Mơr & 3.73 & 5.59 & 3 & 8.60 & 6.95 & 0.102 & 3.18 & 5.42 & 3.72 \\
\hline & Juti & 2.89 & 4.33 & 3 & 7.33 & 6.23 & 0.127 & 3.56 & 3.77 & 3.53 \\
\hline & 214 & 1.53 & 2.75 & 3 & 5.75 & 5.30 & 0.143 & $3.4 !$ & 2.34 & 3.25 \\
\hline & AUE & $2.5 !$ & 3.37 & 3 & 6.76 & 5.91 & $\hat{0.133}$ & 3.53 & 3.23 & 3.44 \\
\hline & SEF & 3.86 & 5.79 & 3 & B. 79 & 7.03 & 0.096 & 3.04 & 5.75 & 3.75 \\
\hline & $00:$ & 2.95 & 4.43 & 3 & 7.43 & $6.2 E$ & 0.071 & $2 . \hat{n} !$ & 5.42 & 3.54 \\
\hline & $\mathrm{k}$ & 2.62 & 3.65 & 3 & 6.63 & 5.47 & 0.049 & $1.2 !$ & 4.E2 & 3.3 \\
\hline & DES & $\therefore .4 E$ & 2.22 & 3 & 5.22 & 4.97 & 0.038 & 0.87 & 4.35 & $3 .: 5$ \\
\hline \multirow[t]{12}{*}{$19: 2$} & JAN & 2.58 & 2.37 & 3 & 5.37 & 5.06 & 0.639 & 0.87 & $4.4 E$ & 3.28 \\
\hline & FEE & 1.70 & 2.55 & 3 & 5.55 & 5.18 & 0.046 & 2.07 & 4.43 & 3.2 \\
\hline & MAS & 1.68 & 1.62 & 3 & 4.62 & 4.58 & 0.073 & 1.50 & 3.12 & 200 \\
\hline & AFE & 2.45 & $3.6 E$ & 3 & $6.6 E$ & 5.25 & 0.082 & 2.16 & 4.5 & 3.42 \\
\hline & KA: & 3.73 & 5.59 & 3 & E.60 & 6.93 & 0.192 & $\Sigma .15$ & 5.42 & 3.72 \\
\hline & 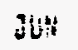 & 2.89 & 4.33 & 3 & 7.53 & 6.23 & 0.127 & 3.56 & $3.7 ?$ & 2.5 \\
\hline & $w_{i}$ & 1.83 & 2.75 & 3 & 5.75 & 5.30 & 6.145 & 3.4 & 2.54 & $\therefore 8$ \\
\hline & HE & $2.5 !$ & $3.7 ?$ & 3 & $5.7 \mathrm{~s}$ & $5.9 !$ & A.:3Z & 3.53 & 3.23 & $3.4=$ \\
\hline & SEF & 3.86 & 5.75 & 3 & 8.79 & 7.6 & C.APt: & 3.6 & 5.5 & 3.75 \\
\hline & DET & 2.95 & $4.4:$ & $\Sigma$ & 7.45 & 4.23 & 0.172 & $2.0 !$ & $5.4=$ & $5.5: 4$ \\
\hline & $\mathrm{HOV}$ & 2.22 & $3 . \hat{3}$ & $?$ & 6.53 & $5.4 ?$ & 6.048 & $\therefore .2 !$ & $4.5 \%$ & $\therefore . Z$ \\
\hline & $r E C$ & $\therefore .4 E$ & 2.22 & 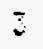 & 5.22 & 4.97 & 0.093 & $\therefore E ?$ & 4.55 & $\therefore:$ \\
\hline \multirow[t]{12}{*}{$: 985$} & Sh & 1.58 & 2.37 & 3 & $5 . ?$ & $5.8 t$ & 0.035 & 0.85 & 4.42 & 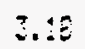 \\
\hline & FEE & $\therefore .70$ & 2.55 & 5 & 5. EE & $5 .: 5$ & $0.04 \mathrm{t}$ & $\therefore .07$ & 4.48 & $\therefore$ \\
\hline & 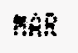 & 1.08 & $\therefore \leq 2$ & 3 & 4.52 & 4.58 & 0.073 & 2.50 & $\therefore .12$ & 36 \\
\hline & AEE & 2.45 & $3.6 E$ & $\Sigma$ & 6.55 & S.ES & 0.682 & 2.16 & 4.52 & 3.42 \\
\hline & HeY & 3.73 & 5.55 & 3 & 8.4 & 6.98 & $\therefore .102$ & $3.1 E$ & 5.4 & 2.72 \\
\hline & Jisk & 2.55 & 4.37 & 3 & 7.33 & 5.23 & $\therefore .: 27$ & 3.55 & 3.77 & 5.5 \\
\hline & 36 & 1.5 & 2.75 & 3 & 5.75 & 5.30 & 6.185 & $3.4:$ & 2.34 & 3.2 \\
\hline & Asto & 2.51 & 3.77 & 3 & $5.7 t$ & $5.9 !$ & 0.133 & 3.53 & 3.23 & 5.45 \\
\hline & SEF & 3.85 & 5.79 & 3 & 8.79 & 7.03 & 0.096 & 3.04 & 5.75 & 3.75 \\
\hline & DCT & 2.95 & $4.4 J$ & 3 & 7.43 & 6.28 & 0.071 & 2.01 & 5.42 & 3.54 \\
\hline & nov & 2.02 & 3.03 & 3 & 6.03 & 5.47 & 0.049 & 1.21 & $4 . E_{2}$ & 3.31 \\
\hline & DEE & 1.48 & 2.22 & 3 & 5.22 & 4.97 & 0.039 & 0.87 & 4.35 & 3.15 \\
\hline 1964 & JAK & 1.58 & 2.37 & 3 & 5.37 & 5.06 & 0.039 & 6.89 & 4.48 & 3.18 \\
\hline
\end{tabular}


FALLE OITY. TELAS PILE NO. 2

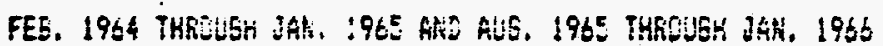

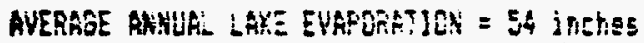

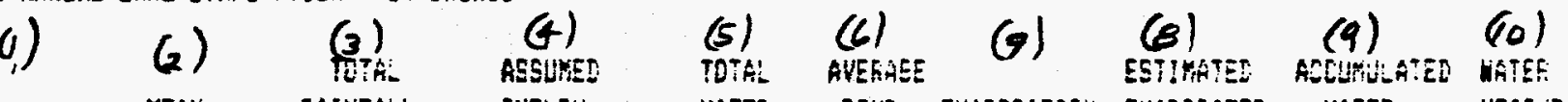

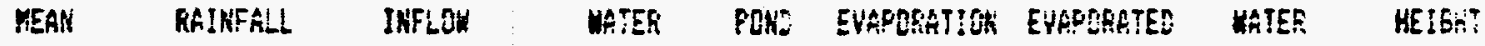

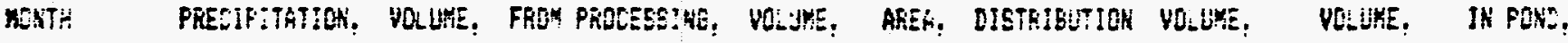
inthes acre-feet acre-fet acre-feE: atres FACTOS acre-tegt acre-feEt feEt

\begin{tabular}{|c|c|c|c|c|c|c|c|c|c|c|}
\hline \multirow[t]{11}{*}{1964} & FEB & 1.70 & 2.83 & 3 & 5.83 & 5.54 & 0.046 & 1.15 & 4.69 & 3.16 \\
\hline & MES & 2.65 & 1.50 & 3 & 4.60 & 4.57 & 0.073 & 1.60 & 3.20 & $2.9 \mathrm{E}$ \\
\hline & Af: & 2.45 & 4.08 & I & 7.08 & 6.31 & 0.082 & 2.38 & 4.76 & 3.37 \\
\hline & MAY & 3.73 & 6.22 & 3 & $\$ .22$ & 7.52 & 0.102 & 3.45 & 5.77 & 3.63 \\
\hline & $d i$ & 2.89 & 4.82 & 3 & 7.82 & 6.73 & 0.127 & 3.85 & 3.97 & 3.48 \\
\hline & $y i$ & 1.EZ & 3.05 & 3 & 6.05 & 5.68 & 0.143 & 3.65 & 2.40 & 3.20 \\
\hline & AUE & $2.5:$ & 4.18 & 3 & 7.18 & 6.37 & 0.133 & $3.8 !$ & 3.37 & 3.95 \\
\hline & SEF & 5.86 & 6.43 & 3 & 9.43 & 7.63 & 0.086 & 3.30 & 6.39 & 3.71 \\
\hline & $\min$ & 2.95 & 4.92 & 3 & 7.92 & 6.79 & $0.07 !$ & 2.17 & 5.75 & 3.50 \\
\hline & tefi & 2.6 & 3.57 & 3 & 6. .77 & 5.67 & $\hat{Q} . \hat{H}+\hat{z}$ & 1.30 & 5.67 & 3.25 \\
\hline & $D E^{P}$ & $1.4 E$ & 2.47 & 3 & $5.4 ?$ & 5.31 & 0.039 & 0.93 & 4.54 & 3.09 \\
\hline \multirow[t]{14}{*}{29.5} & JAki & 1.58 & 2.53 & 3 & 5.65 & $5.4 !$ & 0.038 & 0.95 & $4.6 E$ & $3 .: 2$ \\
\hline & FEE & 2.70 & 2.83 & 0 & 2.87 & 3.42 & $\Delta .14 t$ & $0.7:$ & 2.12 & 2.48 \\
\hline & KAR & 1.68 & 2.80 & 0 & 1.50 & 2.53 & 0.173 & A.ES & 6.97 & 2.53 \\
\hline & $A E R$ & 2.45 & 4.06 & 0 & 4.06 & 4.37 & 0.082 & $1.6 !$ & 2.47 & 2.30 \\
\hline & ReY & 3.73 & 5.22 & 0 & 5.22 & 5.78 & 0.102 & 2.65 & 3.56 & 3.23 \\
\hline & Su! & 2.89 & 4.8 & $\theta$ & 4.82 & $4.8 ?$ & 0.127 & 2.79 & 2.3 & 2.96 \\
\hline & 14 & 1.83 & 3.65 & $\theta$ & 3.05 & 3.60 & 0.145 & $2.3:$ & 6.74 & $2.5 \div$ \\
\hline & ASE & 2.31 & $4.1 E$ & 3 & $7.1 E$ & 6.37 & $0 .: 13$ & $3.8:$ & 3.77 & 3.3 \\
\hline & SEP & $3.8 \mathrm{c}$ & 6.47 & 3 & 9.45 & 7.t3 & 0.096 & 3.30 & 6. : & $3 . Z$ \\
\hline & DCT & 2.55 & 4.92 & 3 & 7.92 & b. 75 & $0.17:$ & $2 . \vdots 9$ & 5.75 & $\sum 5$ \\
\hline & HOS' & $2 . \hat{2}$ & 3.37 & 5 & 6.37 & 5.57 & 6. 049 & 1.30 & $\boldsymbol{\varepsilon}$ & 3.3 \\
\hline & BE: & $1.4 E$ & 2.47 & 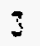 & $5.4 ?$ & $5.3 !$ & 0.038 & D. E: & 4.54 & 3.63 \\
\hline & IA: & ¿.5E & 2.65 & 3 & 5.63 & E.4: & 0.039 & 6.9 & 4.56 & $\therefore: 2$ \\
\hline & $F E E$ & $\therefore .70$ & $2.8 \mathrm{~J}$ & 3 & 5.83 & 5.54 & 1. 1. & 1.25 & 4.5 & 3.16 \\
\hline
\end{tabular}


FALLS CITY. TEXAS PILE NE. 4

JULY 1962 THLDUEH FEBRUARY 1969

AWERABE ANNJALi LAKE EVAPOSATIOL $=54$ jnEhES

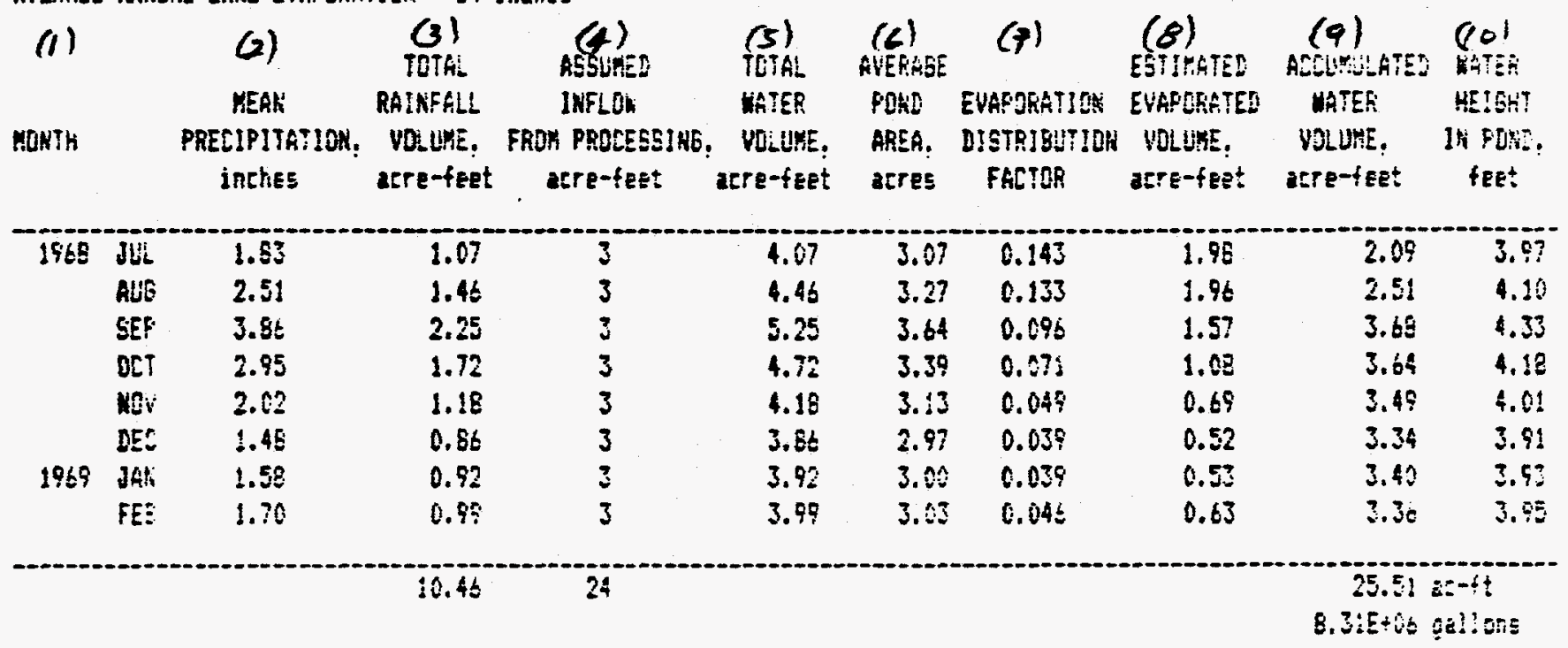


FAL:S CITY, TEUKS PILE HE. S

MAGCH 196S THROUEH FEBRUARY 1976

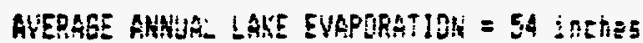

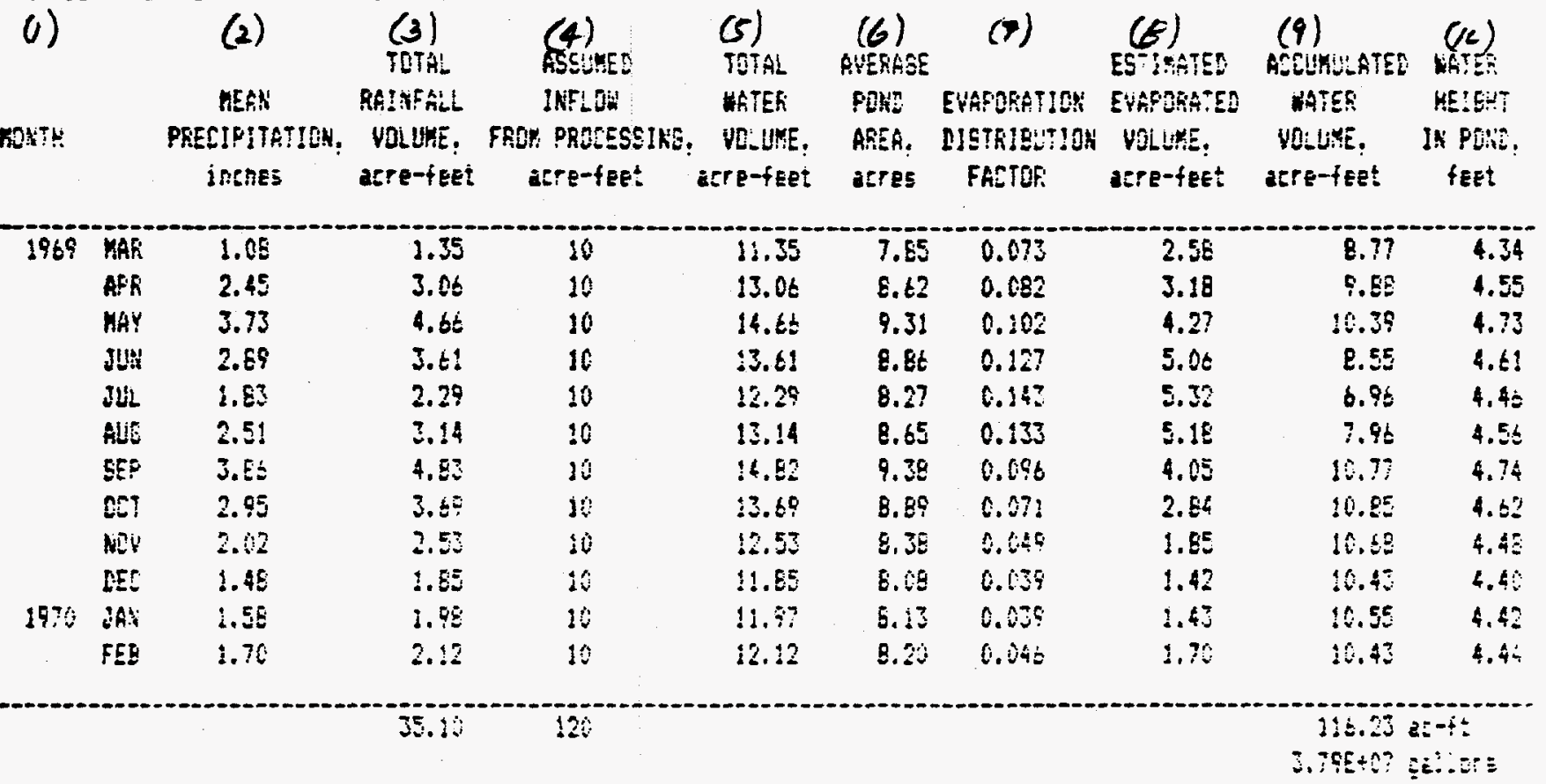


FAL:S CITY, TEXAS PILE NO.?

MACH 1970 THROLSG MAY 1573

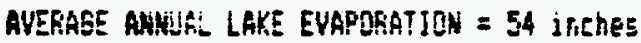

(1)

(2)

(3)

(4)

(5) (6)

(7)

(e)

(7)

EETIMSTED AECLHLLTED WHTE

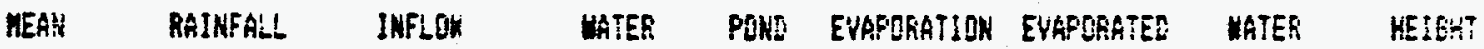

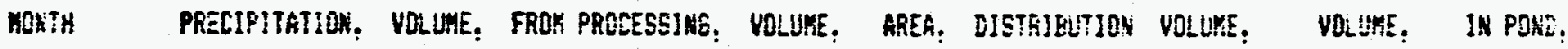
inches arre-feet atre-feet acre-feet acres factor acre-feet acre-feet feet

\begin{tabular}{|c|c|c|c|c|c|c|c|c|c|c|}
\hline \multirow[t]{10}{*}{1970} & HAF & 1.08 & 3.60 & 10 & 13.60 & 12.29 & 0.073 & 4.03 & 9.57 & 3.32 \\
\hline & $A P R$ & 2.45 & 8.17 & 10 & 18.17 & 14.89 & 0.082 & 5.49 & 12.67 & 3.66 \\
\hline & MAY & 3.73 & 12.43 & 10 & 22.43 & 17.14 & 0.102 & 7.87 & $14.5 ?$ & 3.93 \\
\hline & Jux & 2.89 & 9.63 & 10 & 19.63 & 15.68 & 0.127 & 8.96 & $20.6 ?$ & 3.76 \\
\hline & sut & 1.83 & 6.10 & 10 & 16.10 & 13.74 & 0.143 & 8.84 & 7.26 & 3.52 \\
\hline & AUE & $2.5 !$ & 8.37 & 10 & 28.37 & 15.00 & 0.133 & 8.98 & 9.35 & 3.67 \\
\hline & SEF & 3.86 & 12.87 & 10 & $22.8 ?$ & 17.36 & 0.946 & 7.50 & 15.37 & 3.95 \\
\hline & EET & 2.95 & 9.55 & 10 & 19.85 & 15.79 & 0.071 & 5.04 & 14.79 & 3.77 \\
\hline & Wi & 2.82 & 6.73 & 10 & 16.73 & 14.65 & $0.04 \%$ & $3 .: 1:$ & $13.5 ?$ & 3.5 \\
\hline & DEC & 1.48 & 4.93 & 10 & 14.55 & $: 3.26$ & 0.039 & 2.29 & 22.84 & 3.45 \\
\hline \multirow[t]{12}{*}{ 197: } & IAK & 1.58 & 5.27 & 10 & $: 5.27$ & $i 3.26$ & 0.035 & 2.33 & 12.94 & 3.5 \\
\hline & FES & 1.70 & 5.67 & 10 & $15.6 ?$ & $: 3.49$ & $0.04 t$ & $2.7 \%$ & 12.87 & 3.48 \\
\hline & SAT & 1.08 & 3.60 & $: 0$ & 1J.6: & 12.28 & 0.073 & 4.03 & $9.5 ?$ & 3.3 \\
\hline & AP? & 2.45 & E.:7 & 10 & 16.57 & 14.89 & 0.082 & 5.45 & 92.67 & $\therefore .56$ \\
\hline & MeY & 3.73 & 12.47 & 10 & 22.45 & $17 .: 4$ & 0.102 & $7.8 ?$ & 14.57 & 3.93 \\
\hline & $d: u t$ & 2.99 & 9.67 & $: 0$ & 19.63 & I5.bE & 0.327 & $8.7 b$ & $16.6 ?$ & $3.7 \pm$ \\
\hline & dy: & ¿.EZ & 6.16 & $\mathfrak{i c}$ & 16.80 & $: 3.74$ & 5.143 & 8.84 & $3.2 t$ & 3.52 \\
\hline & $\mathrm{ALS}$ & $2 . E:$ & E.37 & 10 & 18.37 & 15.00 & 0.133 & 8.98 & 9.39 & $3.6^{7}$ \\
\hline & SEF & 3.8 .5 & $: 2.87$ & 10 & 24.87 & 17.36 & $0.67 t$ & 7.50 & 25.37 & 3.75 \\
\hline & ECT & 2.95 & 9.83 & 16 & 15.83 & 15.79 & 0.071 & 5.04 & 14.79 & 3.77 \\
\hline & KE: & 2.32 & 5.73 & 10 & 16.73 & 14.09 & $0.34 \%$ & $3.1:$ & $13.4:$ & 3.52 \\
\hline & IEE & 1.48 & 4.93 & 10 & $14.9 j$ & 13.06 & 0.039 & 2.28 & 12.64 & 3.43 \\
\hline \multirow{12}{*}{1972} & $36 ! 4$ & 1.58 & 5.27 & 10 & 15.27 & $23.2 E$ & 0.039 & 2.33 & $12.7^{2}$ & 3.45 \\
\hline & FEE & 1.70 & 5.67 & 10 & 15.67 & 13.49 & $0.04 t$ & 2.73 & 12.87 & 3.42 \\
\hline & VAS & 1.08 & 3.50 & 10 & 13.60 & .2 .23 & 0.673 & 4.03 & 9.57 & 3.32 \\
\hline & AEF & 2.45 & E.:7 & 10 & 18.17 & $14.6 ?$ & 0.052 & 5.47 & 12.67 & 3.6 \\
\hline & HAY & 3.73 & 22.43 & $t$ & $22.4 i$ & 57.14 & 0.982 & 7.87 & 14.5 & 3.93 \\
\hline & JUS & 2.89 & 9.63 & 10 & 19.63 & 15.68 & 0.127 & 8.96 & 20.67 & 3.76 \\
\hline & Jit & $1.8 j$ & 6.10 & 10 & 16.10 & 13.74 & 0.143 & 6.84 & 7.23 & $3.5: 2$ \\
\hline & A 15 & 2.51 & 8.37 & 10 & 18.37 & 15.00 & 0.133 & 8.98 & 9.37 & 3.87 \\
\hline & SEF & 3.96 & $12.8 ?$ & 10 & $22.8 ?$ & 17.36 & 0.095 & 7.50 & 15.37 & 3.95 \\
\hline & BET & 2.95 & 9.83 & 10 & 19.83 & 15.79 & 0.071 & 5.04 & 14.79 & 3.77 \\
\hline & now & $2 .+2$ & 6.73 & 10 & 16.73 & 14.09 & 0.649 & 3.11 & 13.63 & 3.56 \\
\hline & DEC & $1.4 \mathrm{E}$ & 4.93 & 10 & 14.93 & 13.06 & 0.039 & 2.29 & 12.64 & 3.43 \\
\hline \multirow{5}{*}{1573} & dAK & 1.58 & 5.27 & 10 & 15.27 & 13.26 & 0.039 & 2.33 & 12.94 & 3.45 \\
\hline & ELE & 1.70 & 5.67 & 10 & 15.67 & 13.45 & 0.046 & 2.79 & 12.87 & 3.48 \\
\hline & MAS & 1.08 & 3.60 & 10 & 13.60 & $12.2 \mathrm{E}$ & 0.073 & 4.03 & 9.57 & 3.32 \\
\hline & $A P R$ & 2.45 & 8.17 & 10 & $1 \mathrm{E}, 1 ?$ & 14.89 & 0.082 & $5.4 ?$ & 12.67 & 3.66 \\
\hline & YAY & 3.73 & 12.43 & 10 & 22.43 & 17.14 & 0.102 & 7.87 & 14.57 & 3.98 \\
\hline
\end{tabular}


SUKMAEY OF IAEILTKATIOY VULUES

\begin{tabular}{|c|c|c|c|c|c|}
\hline \multirow[b]{2}{*}{ PIIE } & \multirow{2}{*}{$\begin{array}{l}\text { TCTAL } \\
\text { SOLFEE } \\
\text { VOLURE, } \\
\text { gallons }\end{array}$} & \multirow{2}{*}{$\begin{array}{l}\text { FRACT!OH } \\
\text { FSOR } \\
\text { RA:NFALL }\end{array}$} & \multirow{2}{*}{$\begin{array}{l}\text { FRACTIDH } \\
\text { FROM } \\
\text { PRBCESEINE }\end{array}$} & \multicolumn{2}{|c|}{ 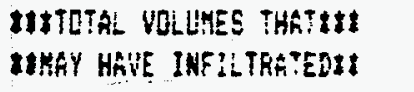 } \\
\hline & & & & $\begin{array}{l}\text { RA!HFALL: } \\
\text { OQI!ORS }\end{array}$ & $\begin{array}{l}\text { ORE PRCCESSIKG } \\
\text { QGllons }\end{array}$ \\
\hline 1 & $4.81 E+07$ & 0.55 & 0.45 & $2.65 E+197$ & $2.16 E+07$ \\
\hline 2 & $3.27 E+\hat{0} 7$ & 0.63 & 0.37 & $2.06 E+07$ & $1.21 E+07$ \\
\hline 4 & B. $3 ! E+0 t$ & 0.30 & 0.70 & $2.49 E+06$ & $5.82 E+16$ \\
\hline 5 & $3.79 E+07$ & 0.23 & 0.77 & $8.72 E+0 b$ & $2.92 E+07$ \\
\hline 7 & 1.55E+60 & 0.47 & 0.53 & $7.28 E+07$ & $8.22 E+07$ \\
\hline & $2 . E 2 E+0 E$ & & & $1.31 E+05$ & $1.5 ! E+08$ \\
\hline
\end{tabular}


FALLS CITY. TEXaS WEATHEK STATIOK

PERIOC OF RECORD AUE 1946 THROUEH HOV 1990

JAN FEB MAR APR MAY JUN JUL AUG SEF OCT NOY DEC

AHHUÁL

RAIMFALL

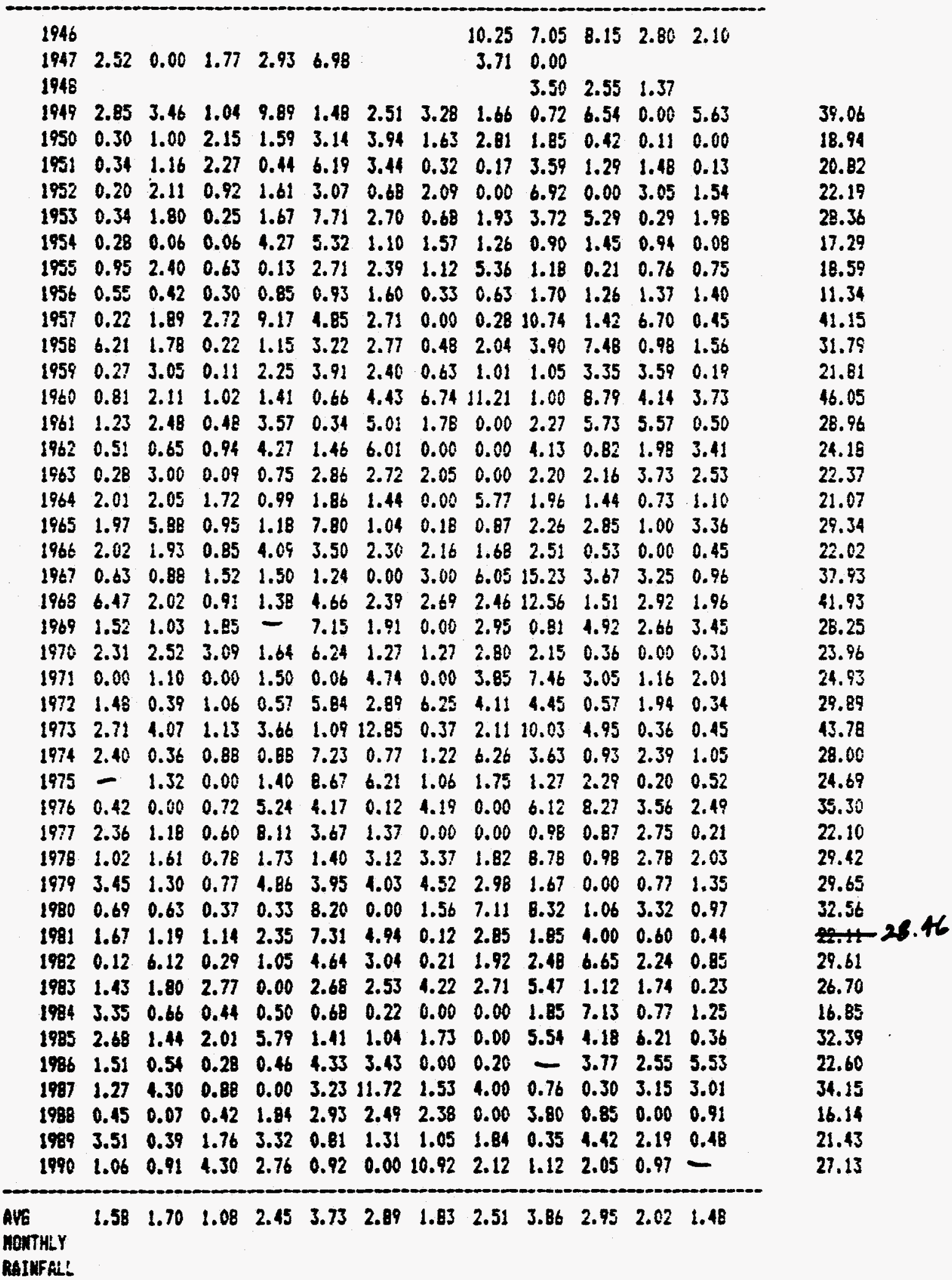


APPENDIX B

WELL LOGS 


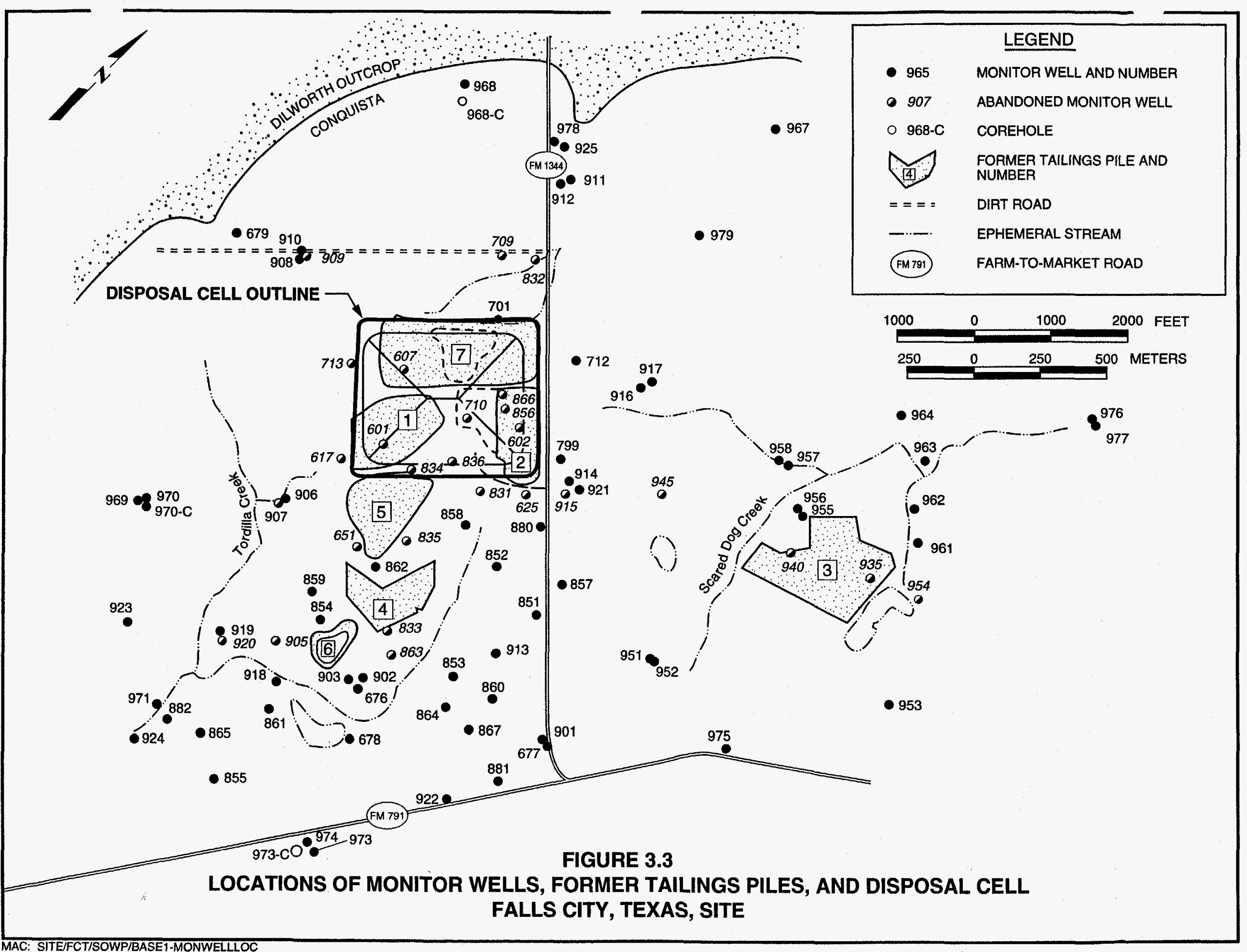




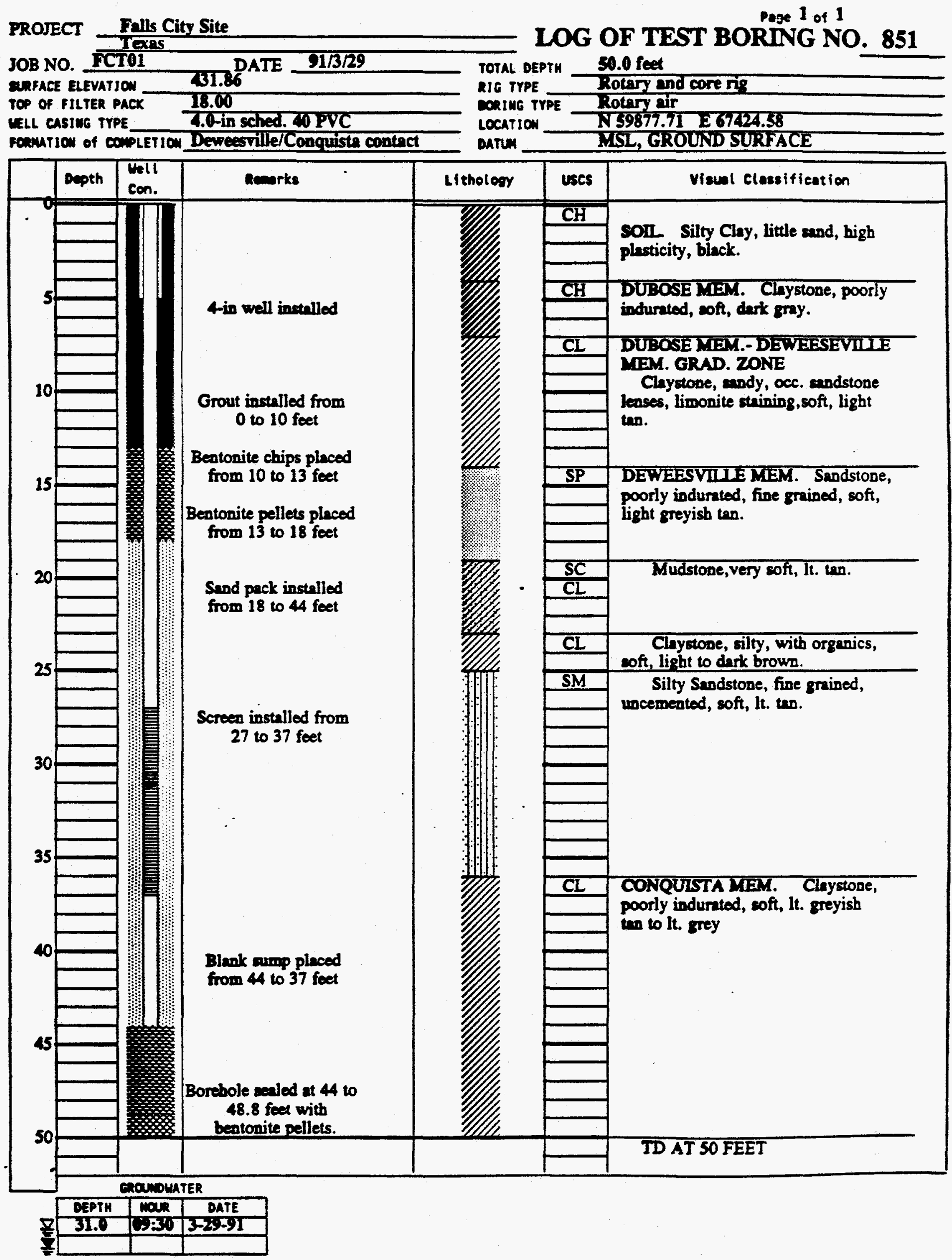




\section{PROJECT Falls City Site}

JOB NO. FCT01

anFACE ELEVATION

TOP OF FILTER PACK

MELL CASING TYPE

POndition of completion Deweesville /Conquists contact
47.0 feet

TOTAL DEPTH

RIG TYPE - ROTARY AND CORE RIG

CORING TYPE ROTARY ALR

LOCATION N39902.03 E 66684.35

DATUM MSI, GROUND SURFACE

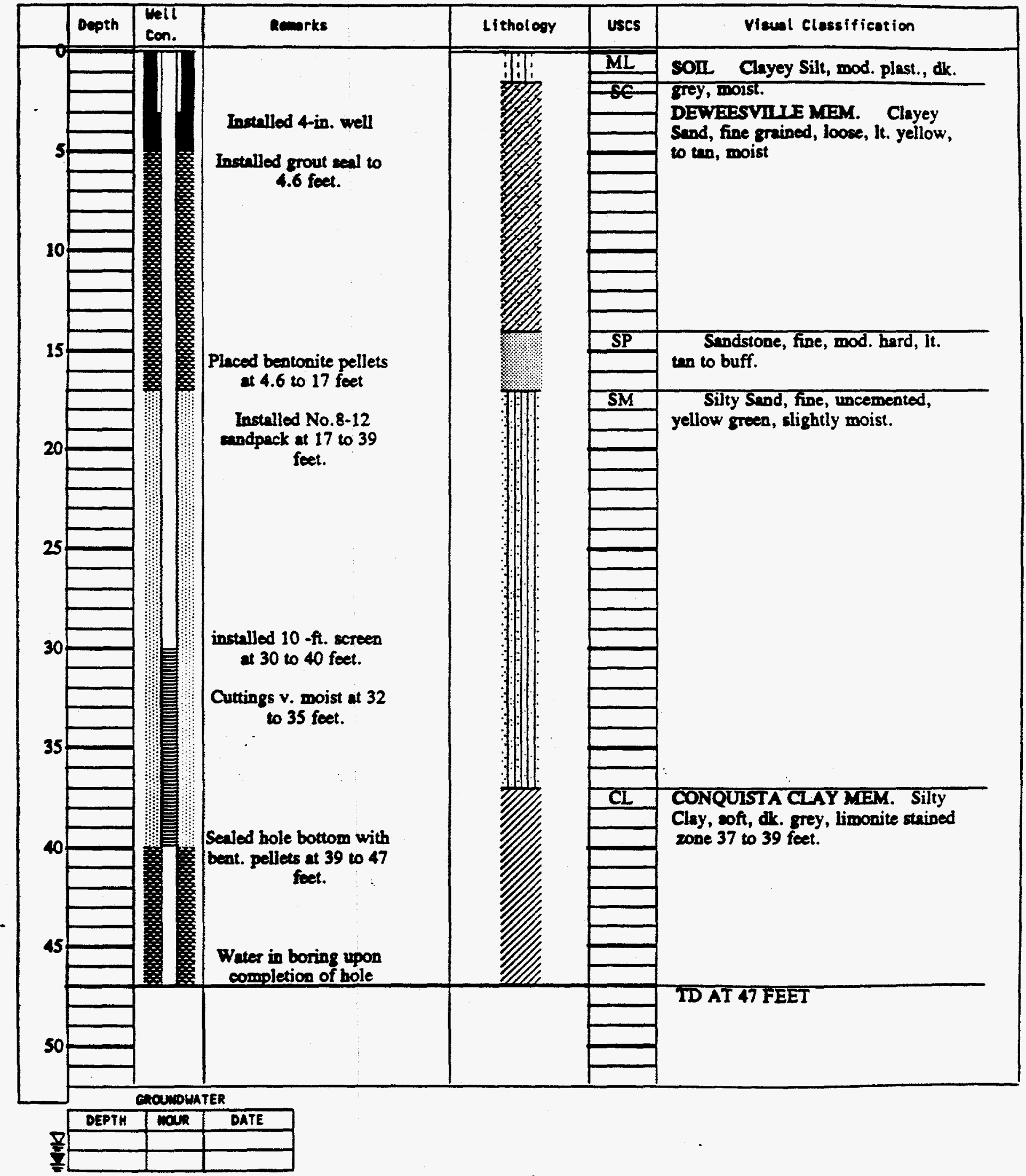


JOB NO. FCTO1

aRFACE ELEVATIOW

TOP OF FILTER PACK

VELL CASIMG TYPE fonurion of conpletion Deweesville Member.
Page 1 of 1

LOG OF TEST BORING NO. 853

TOTAL DEPTH 41.5 feet

LIG TYPE ROTARY AND CORERUG

CORING TYPE ROTARY AIR

LOCATION N\$8402.85 E67051.20

DATUM MSL, GROUND SURFACE

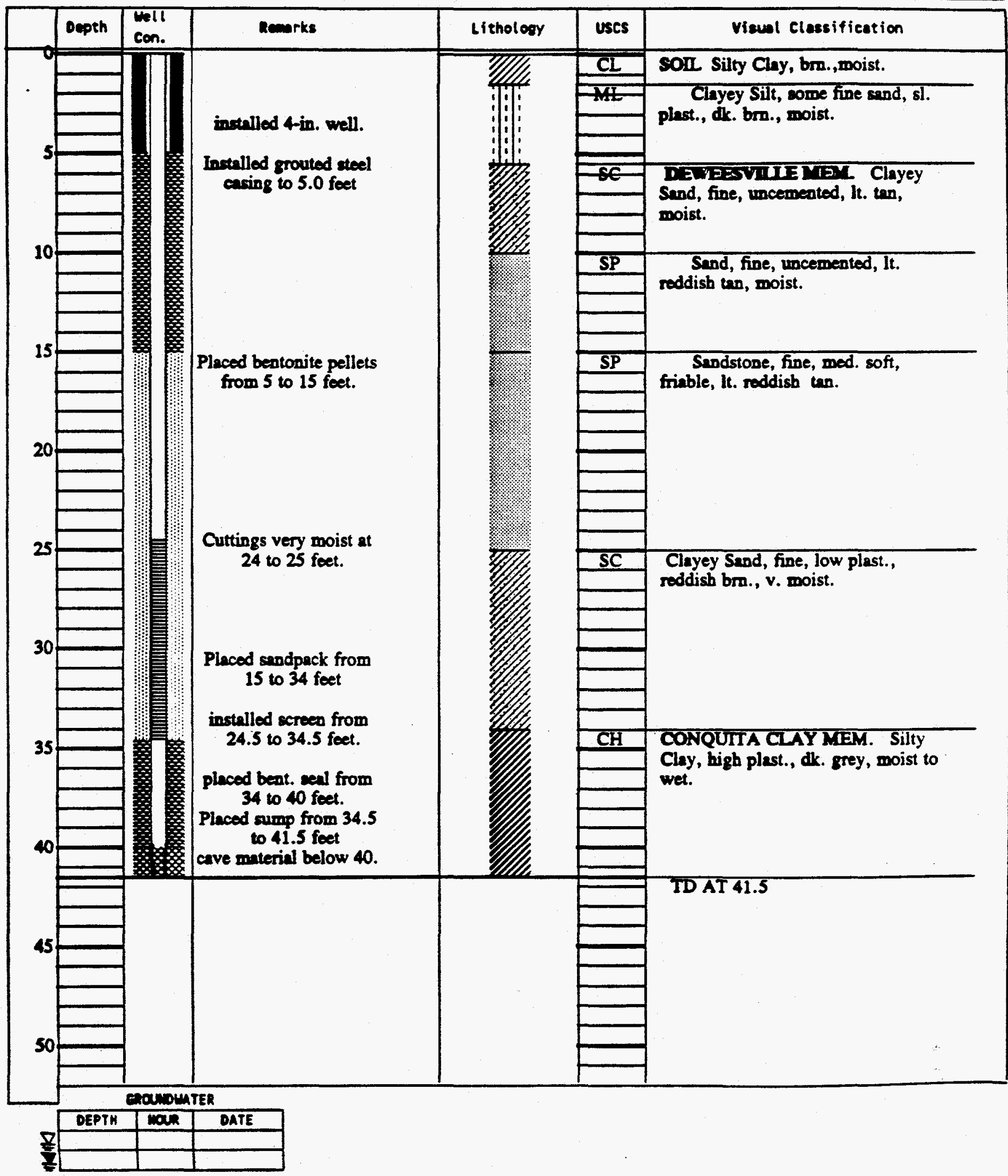




\section{PROJECT Falls City Site}

JOB NO. FCTO1

ERFACE ELEVATION

TOF Of FILTER PACK

VELL CASIMG TYPE

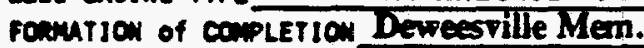

TOTAL DEPTH 34.5 feet

NG TYPE BOTARY AND CORERG

ConING TYPE Kotary air

Location N\$7716.31 265230.62

DATUM MSL, GROUND SURFACE

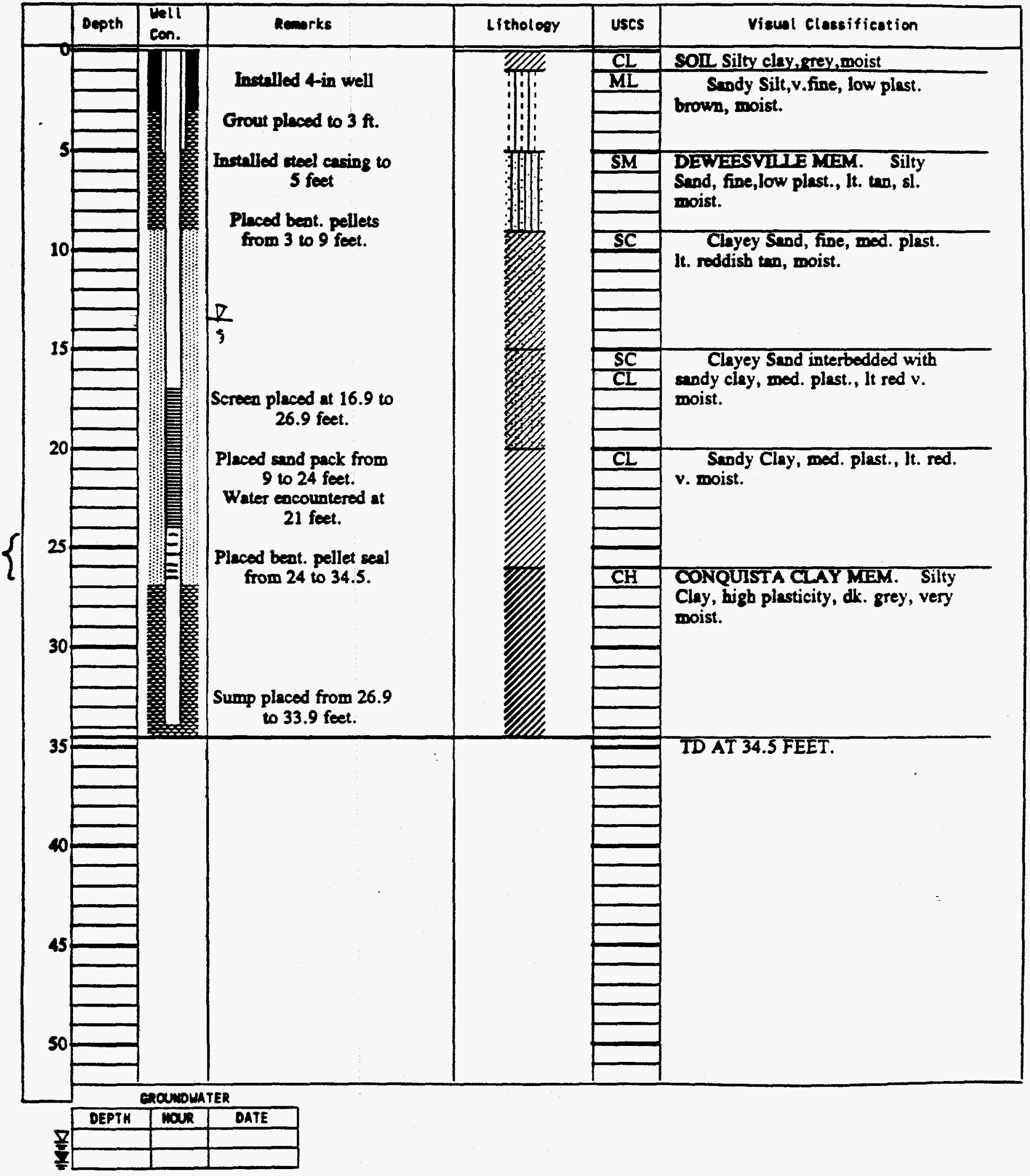


PROJECT $\frac{\text { Falls City Site }}{\text { Texos }}$

JOB NO. FCTOL

ERFACE ELEVATION 712.29

DATE $91 / 4 / 1$

TOP OF FILTER PACK

12.00

MELL CASIMG TYPE

4.0IN.SCHED 40 PVC FOEUTIOW OF COMPLETION CONQUISTA CLA Y MEM.
Page 1 of 1

LOG OF TEST BORNNG NO. 855 TOTAL DEPTH 35.0 feet RIG TYPE DOTARYAND CORENG CORING TYPE ROTARYATR

LOCATION N55380.23 E65392.07 DATUM MSL, GROUND SURFACE

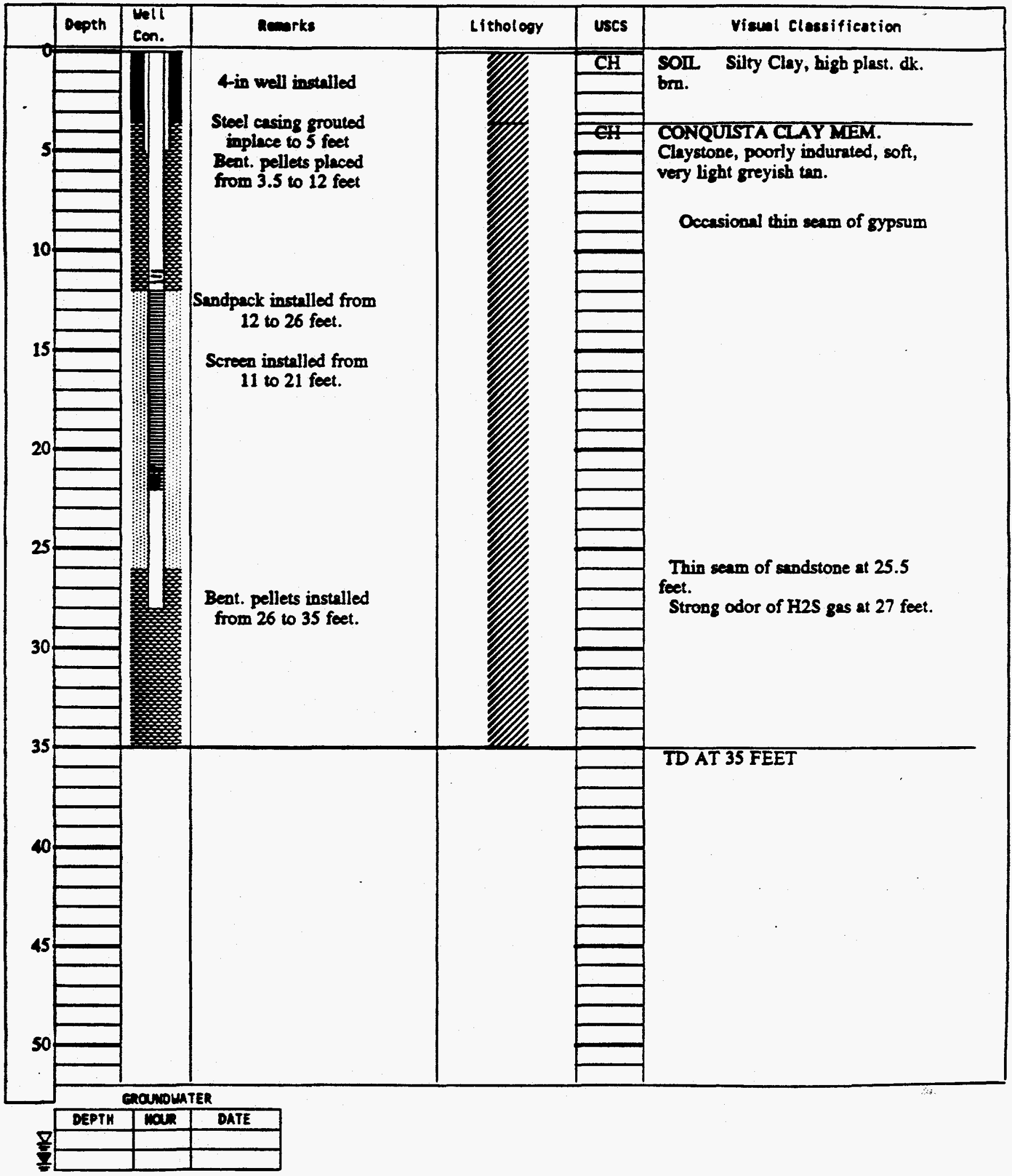


PROJECT $\frac{\text { Falls City Site }}{\text { Texps }}$

Page 2 of 2

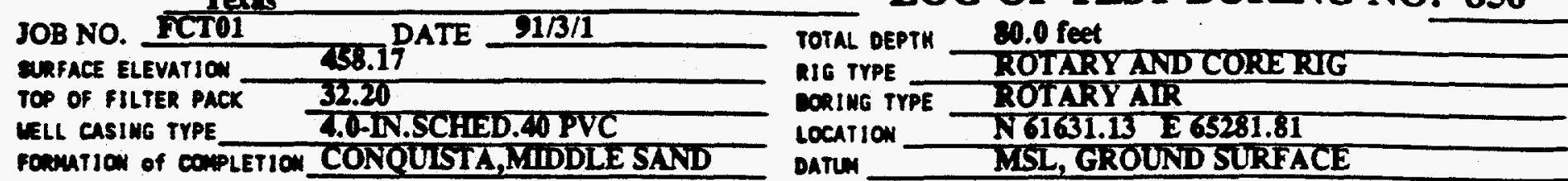

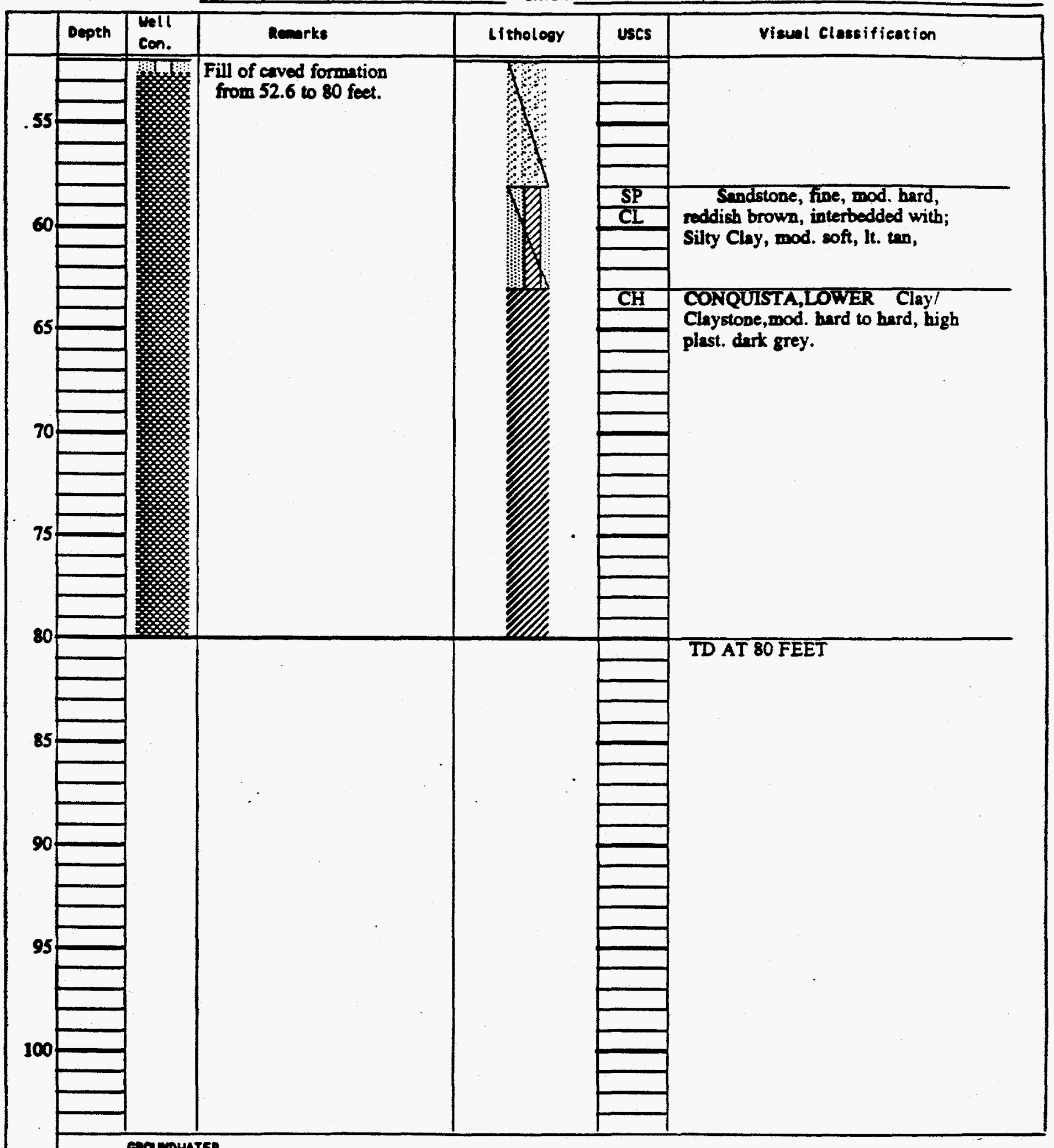

eavrounter

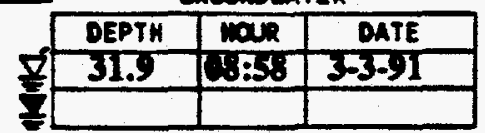


PROJECT Falls City Site

Page 1 of 2

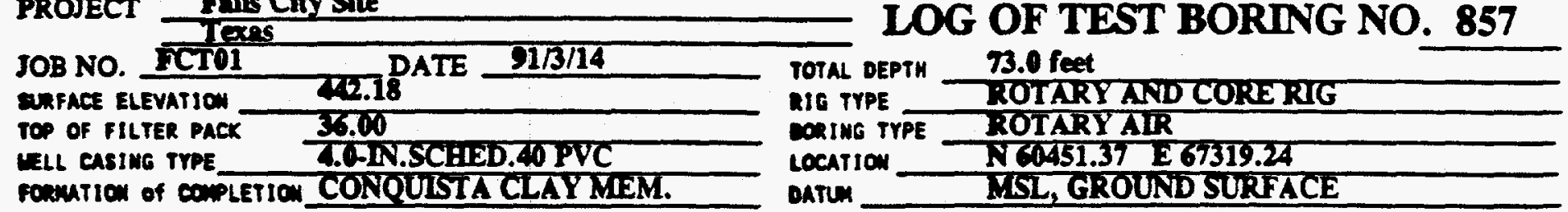

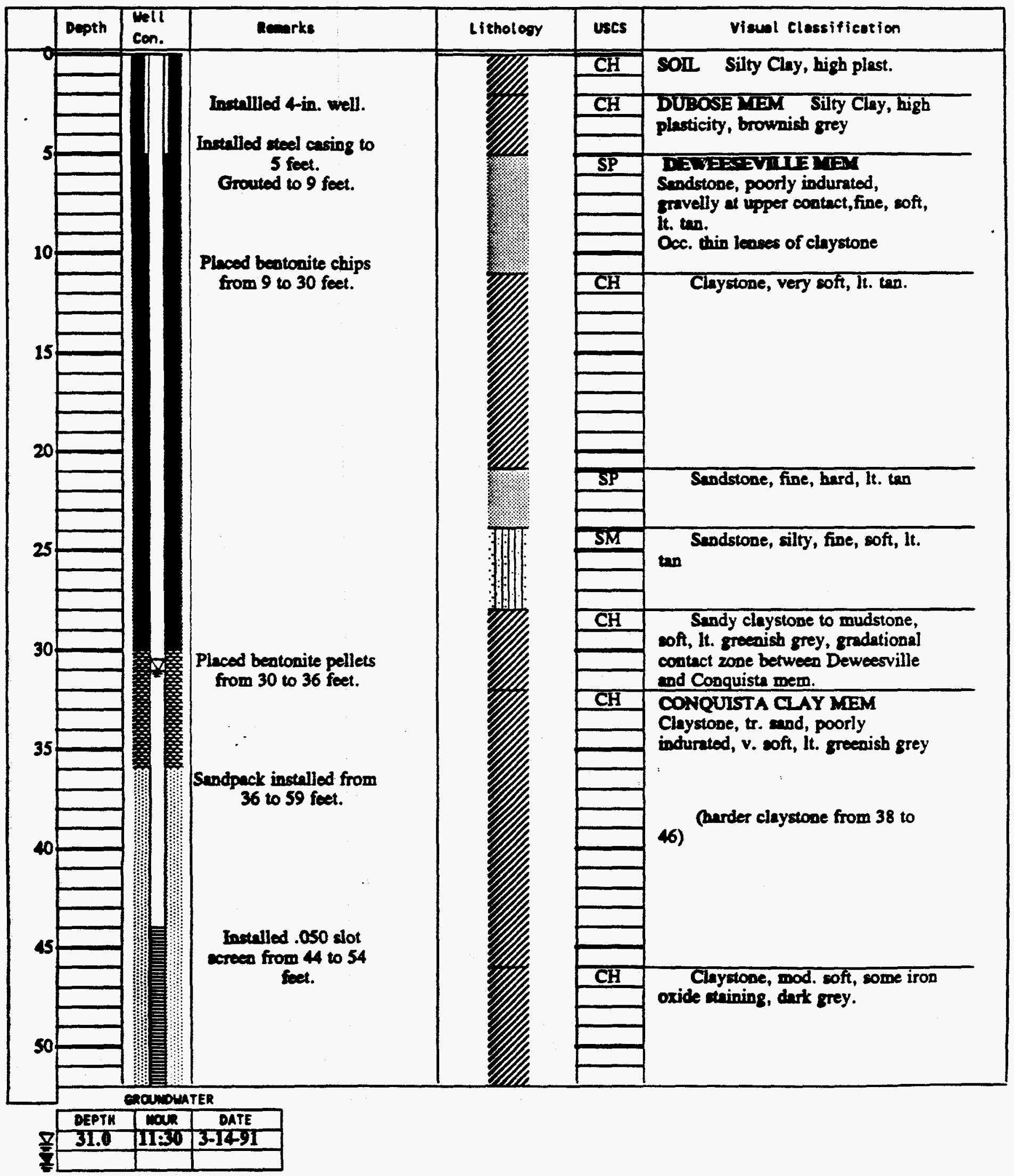


Ireses

JOB NO. FCTO1

ERFACE ELEVATION

DATE $91 / 3 / 14$

TOP OF FILTER PACK

LELL EASING TYPE

73.18

T.AN.SCEED.4O PVC Foumitow of COPLETION CONQUISTA CLAY MEM. 
: PROJECT Falls City Site

Poge 2 of 2

JOB NO. FCT01

enFACE ELEVATION

DATE $91 / 3 / 4$

LOG OF TEST BORING NO. 859

TOP OF FILTER PACK

vil casIMG TrPE. 26.26

27.30

Fomurion of COPLETION CONOUISTA CLAYMEM.

TOTAL DEPTH 79.0 feet

RIG TYPE ROTARY AND CORERIG

DORING TYPE ROTARY AIR

LOCATION N38209.29 E 64798.23

Datum

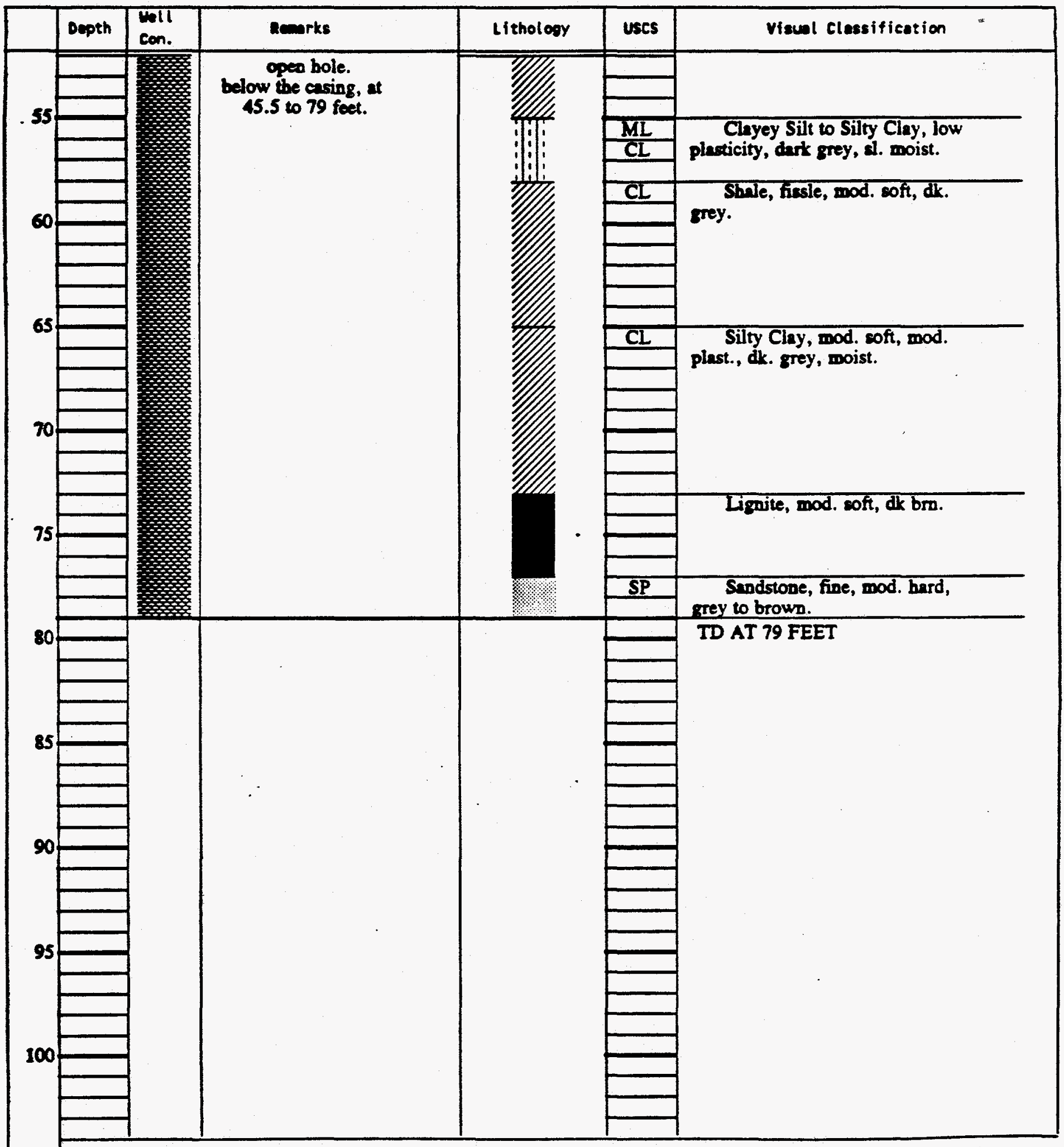

EROUMOUTER

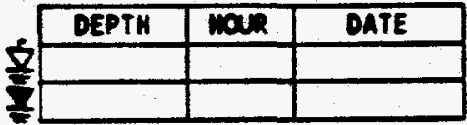




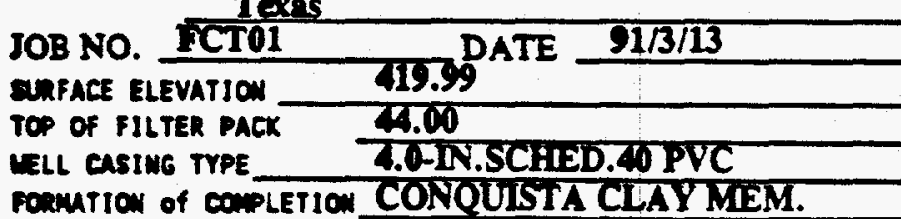

TOTAL DEPTM 83.0 feet

RIG TYPE ZOOTARY AND CORE RIG

CoRING TYPE ROTARY AIR

Location N\$8361.82 E67690.24

FonuTIOW of COPLETIOW CONOUISTA CLAY MEM. oatura MSL, GROUND SURFACE

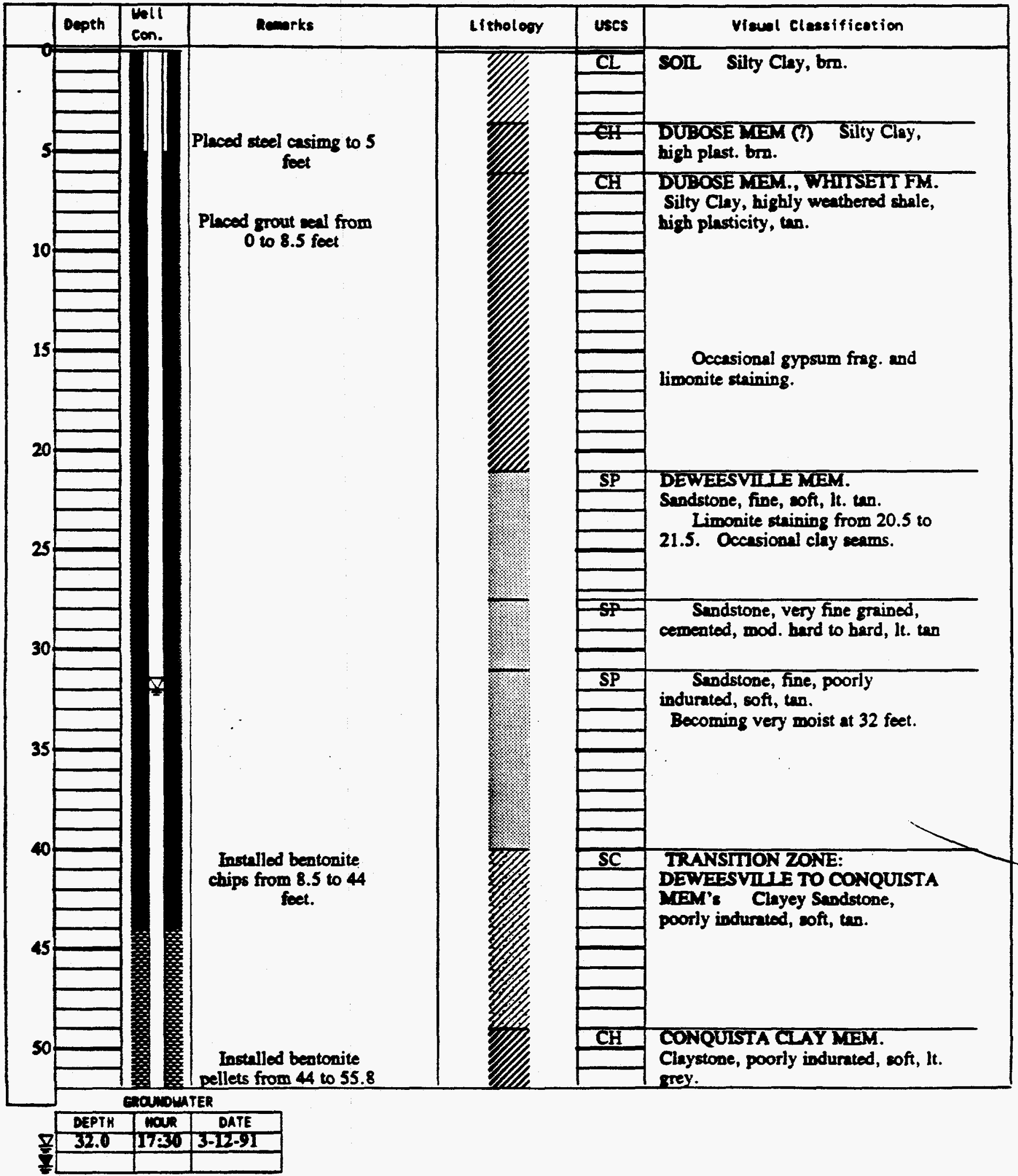


PROJECT

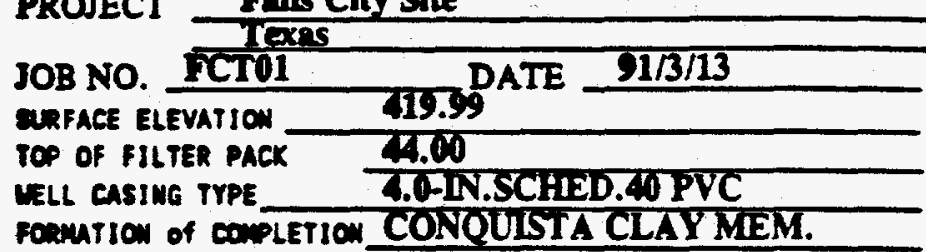

LOG OF TEST BORING NO. 860

TOTAL DEPTH 83.0 feet

RIG TYPE DOTARYAND CORERIG

DOING TYPE ROTARYAIR

LOCATION N\$8361.82 E67690.24

\begin{tabular}{|l|l|l|l|l|l|l|}
\hline & Depth & $\begin{array}{l}\text { Well } \\
\text { con. }\end{array}$ & Remerks & Lithology & uscs & Visual clessification \\
\hline
\end{tabular}

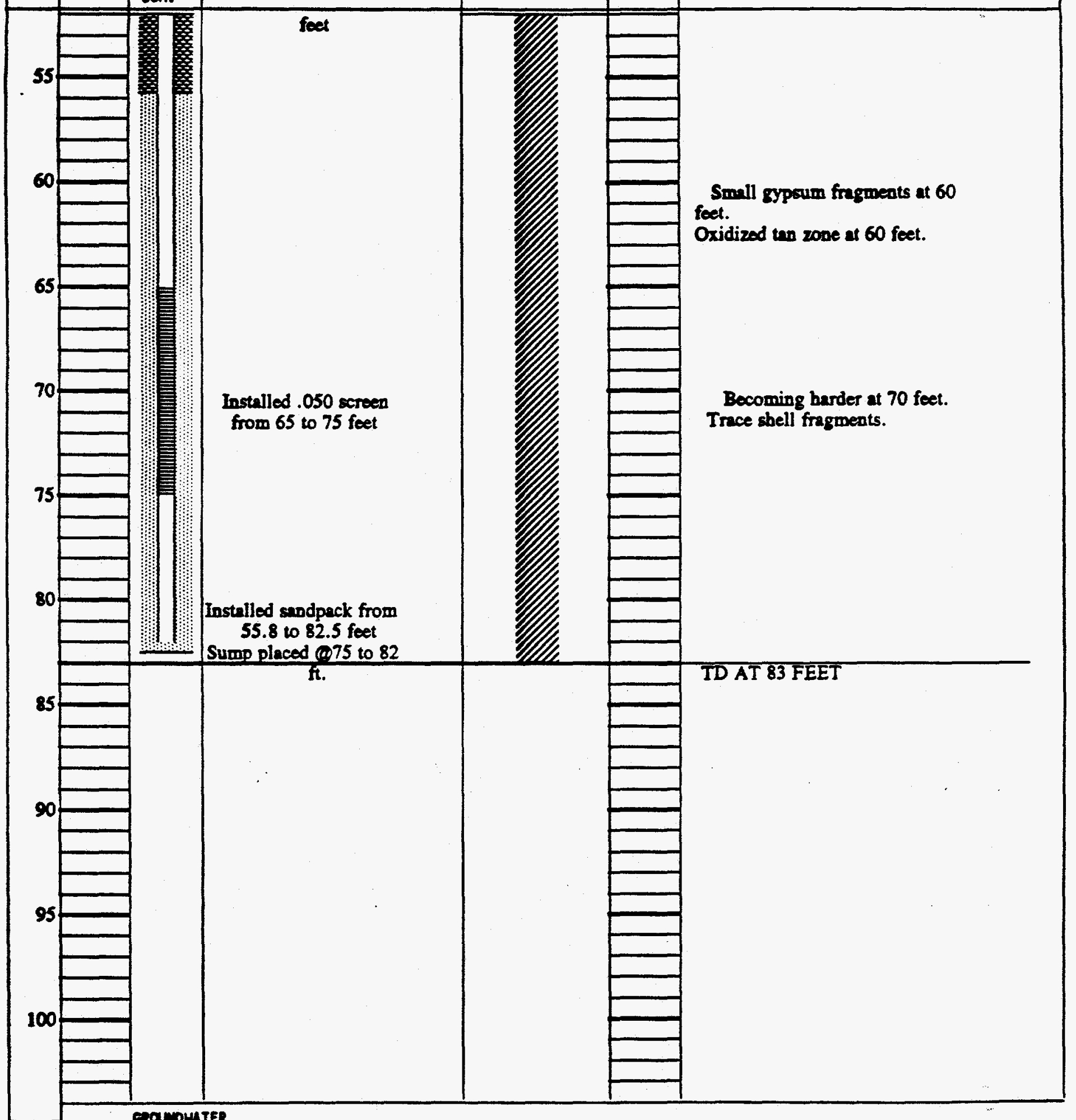

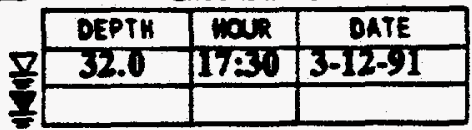




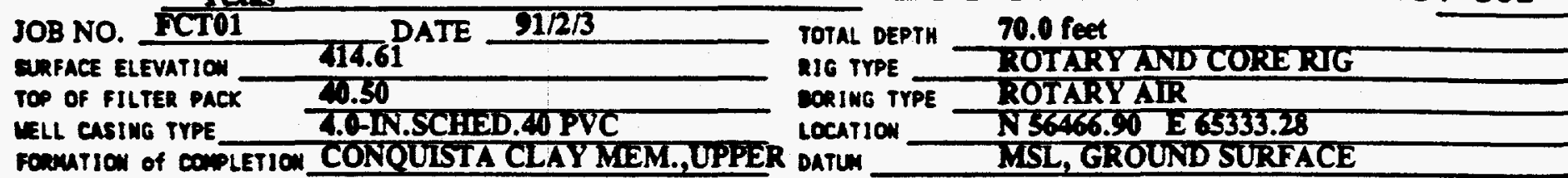

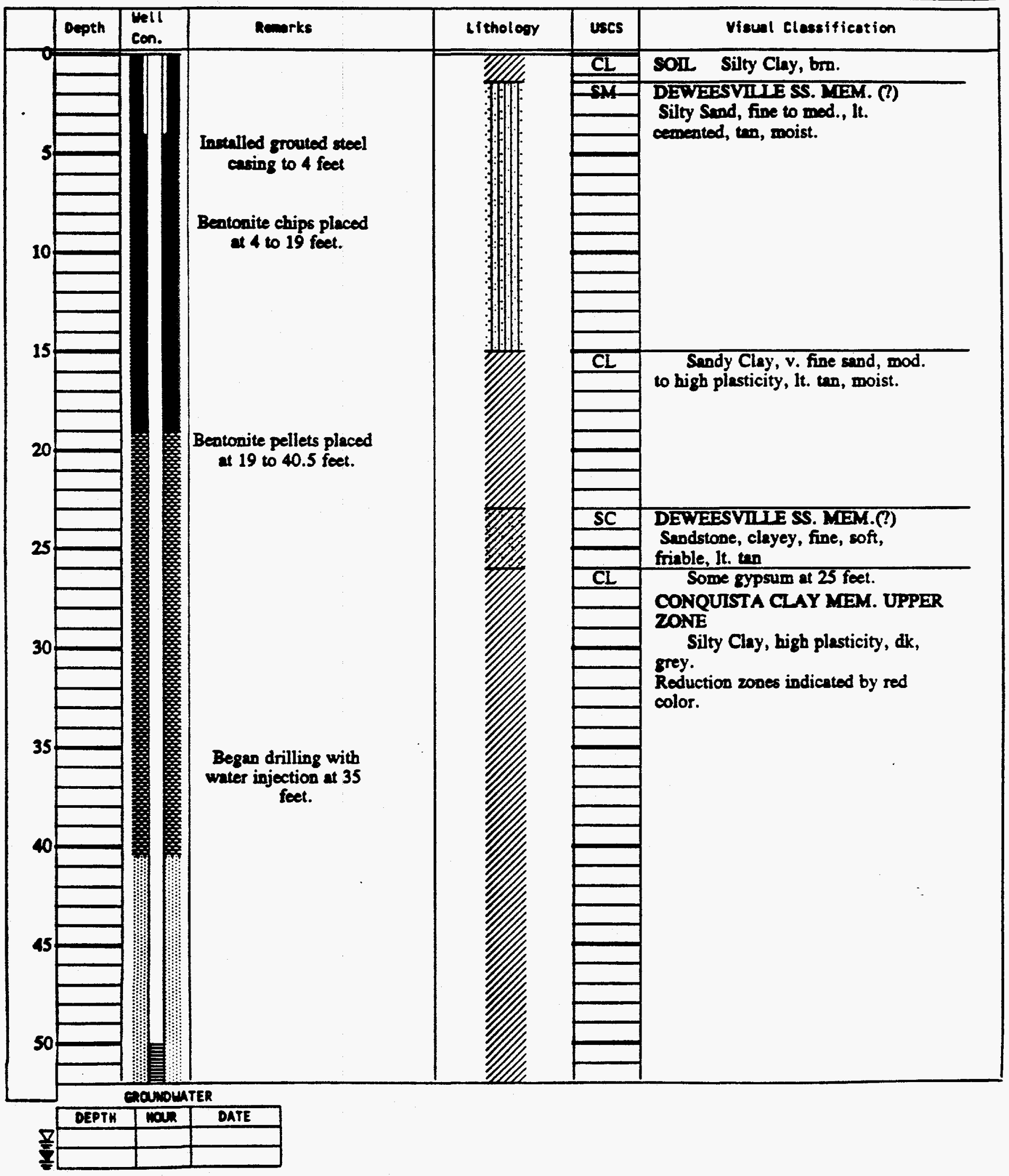


PROJECT $\frac{\text { Palls City Site }}{\text { Tex? }}$

JOB NO. FCTO1 DATE

aRFACE ELEVATION \14.61

TOP OF FILTER PACK TJ.50

VELL CASING TYPE T.O-IN.SCHED.

FORMTION of CONLETION CONOULTA CLAY MEM.,UPPER

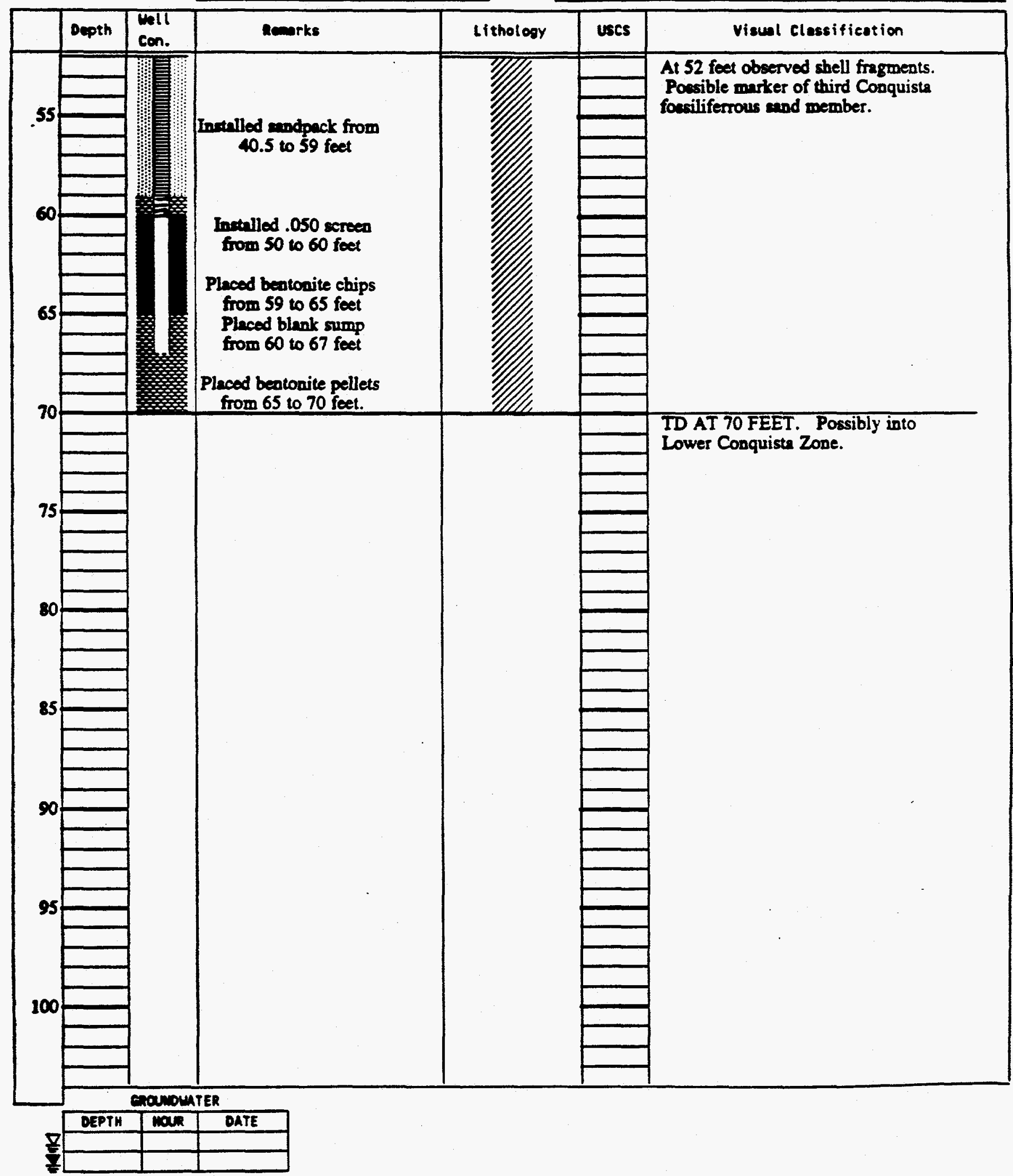


PROFECT Falls City Site

JOB NO. FCTOI

ERFACE ELEVATIOW TOP OF BILTER PACK

VELL CASINE TYPE 237.17

DATE $91 / 4 / 1$ 111.30

4.0-1N.SCHED.40 PVC Fountion of COPLETION DILLWORTH SANDSTONE MEM

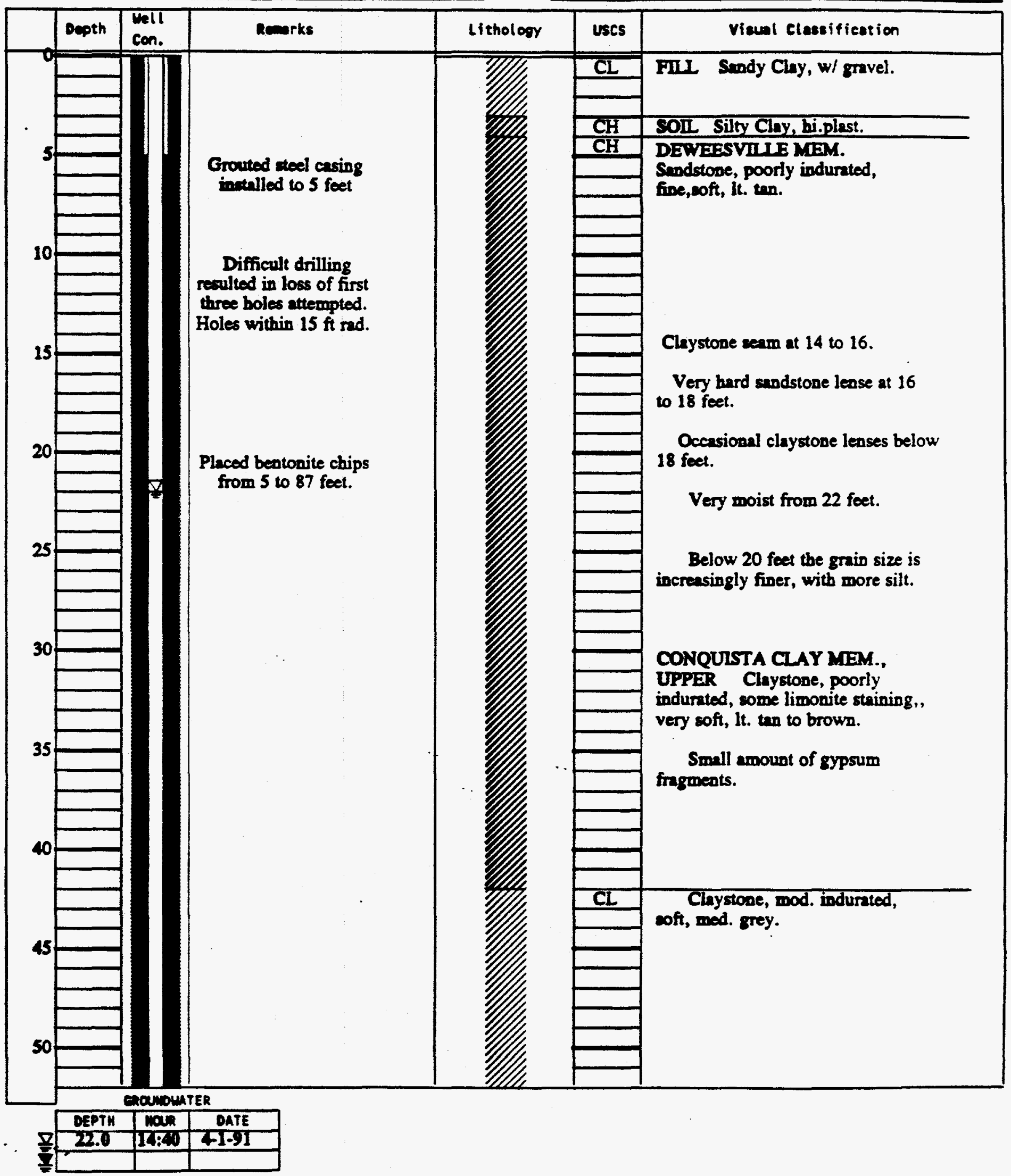

TOTAL DEPTH 150.0 feet

216 TYPE TOTARY AND CORERTG

COUING TYPE ROTARY AIR

Location N38816.97 E63415.51

MSL, GROUND SURACE

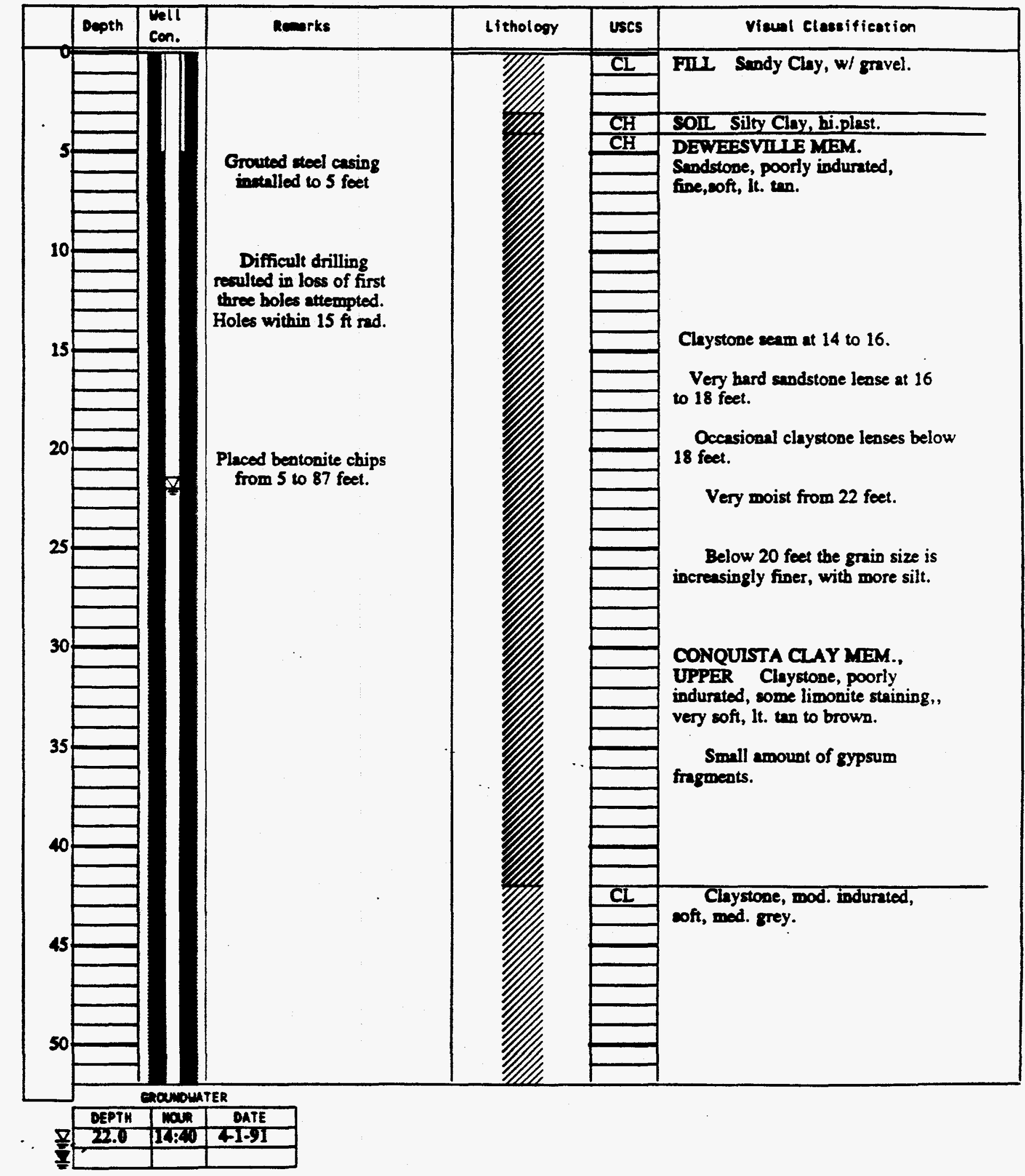


PROJECT Falls City Site

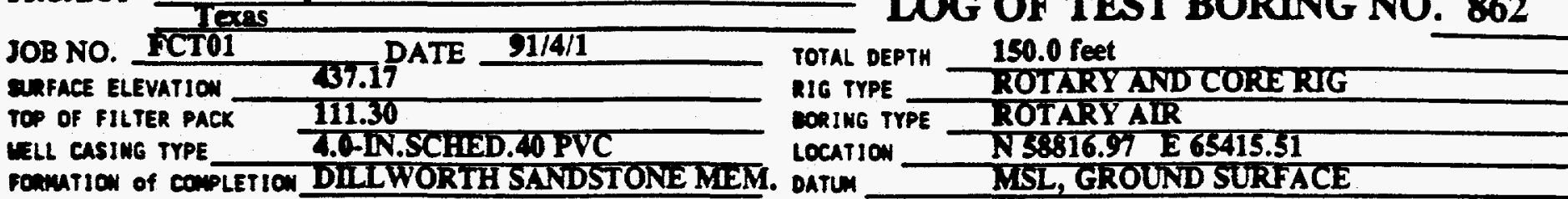

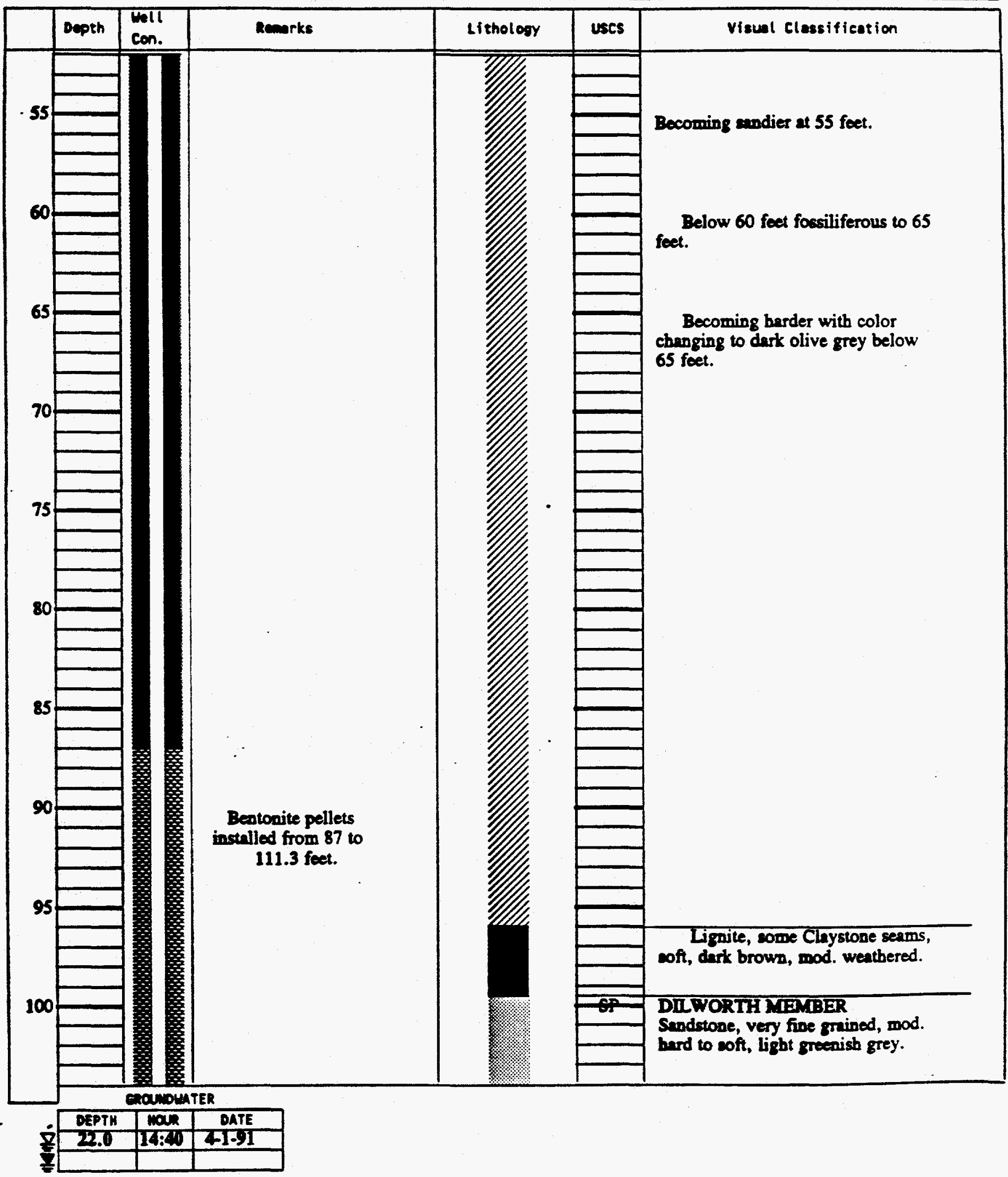


JOB NO. TCTOI

ERFACE ELEVATION

DATE T1/4/1

TOTAL DEPTH

150.0 feet

TOP OF FILTER PACK

37.17

TELL CASING TYPE

Z.VIN.SCHED.WJPVC

RIG TYPE DOTARY AND CORERT

FOAMTION Of COPLETION DILLWORTH SANDSTONE MIEM. OATUH

CORING TYPE DOTARY ATR

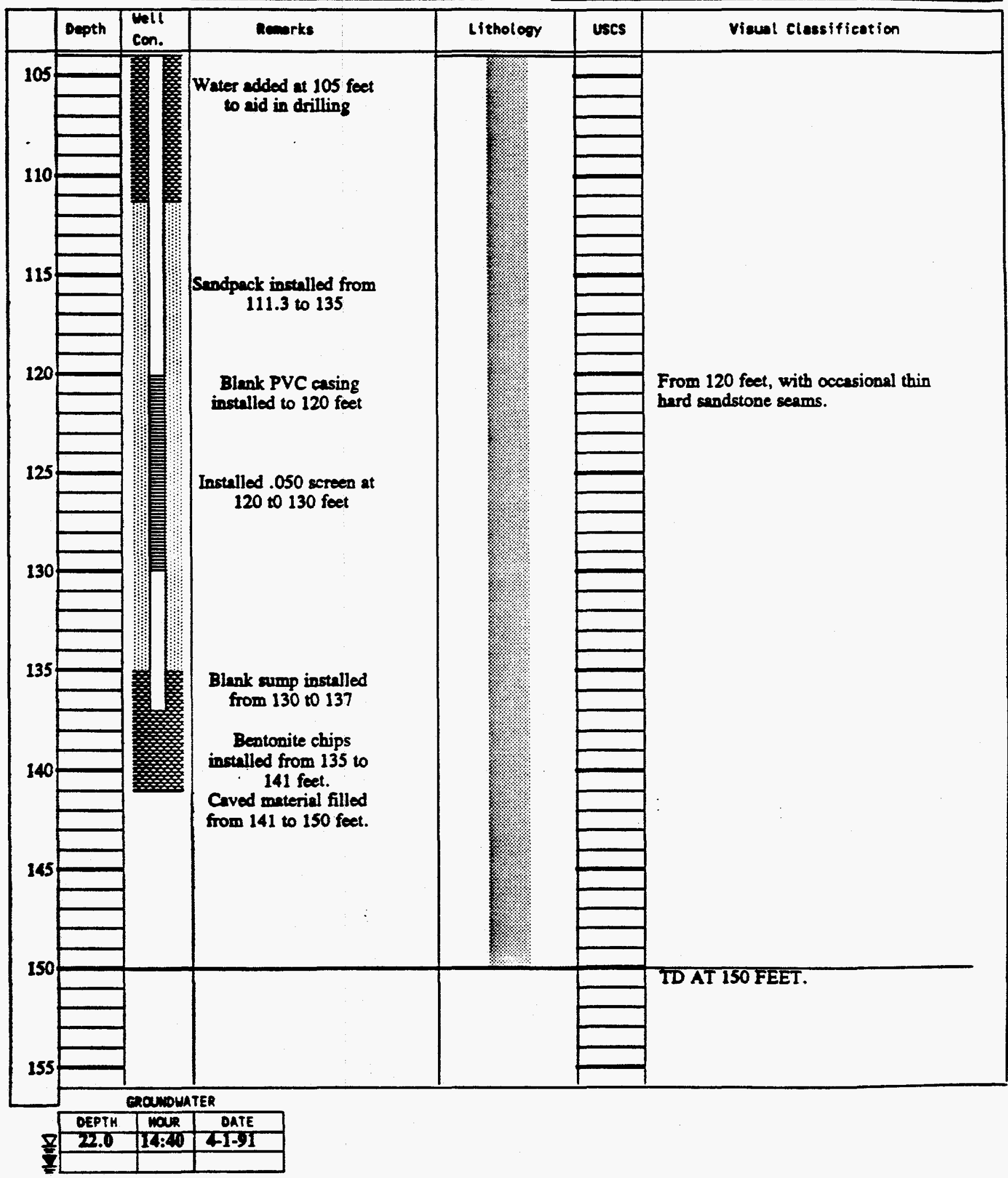




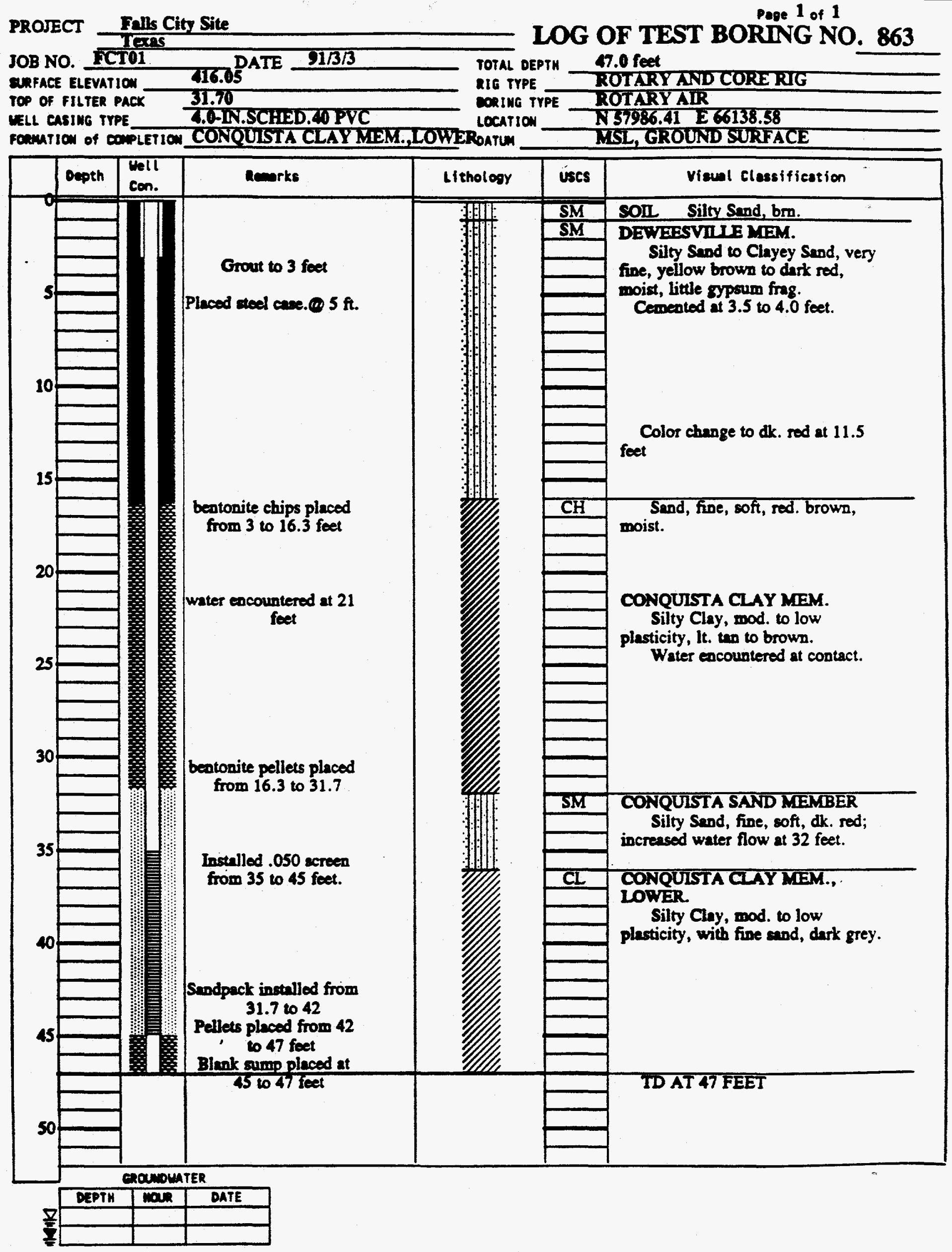


PROJECT Falls City Site

Page 1 of 3

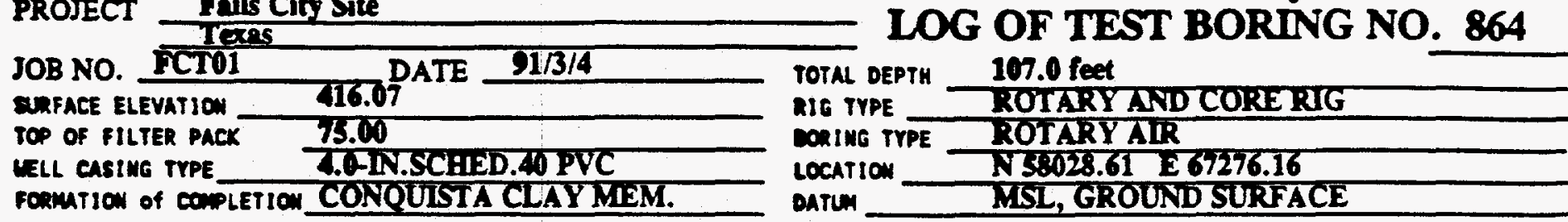

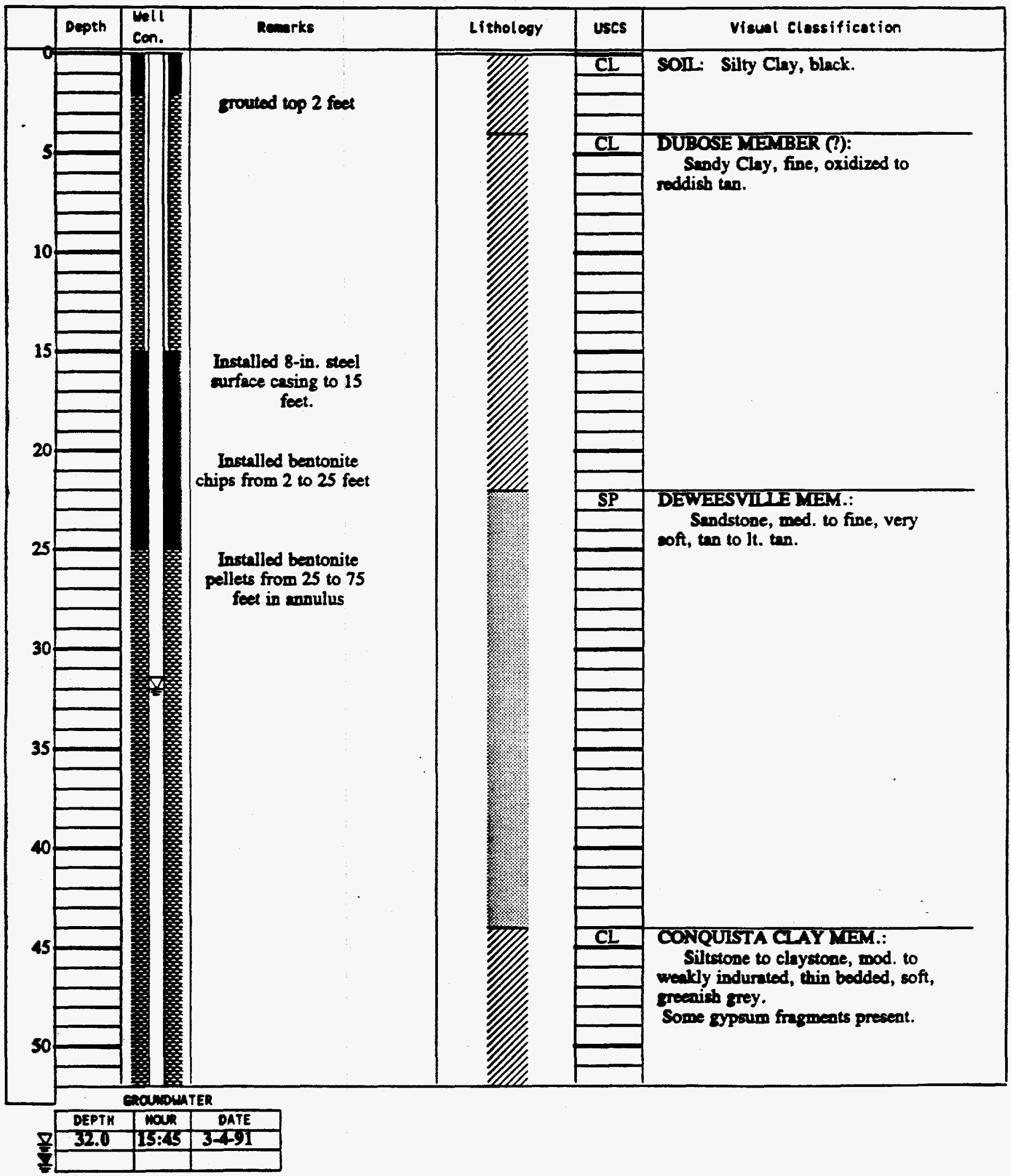


Page 2 of 3

PROJECT Falls City Site

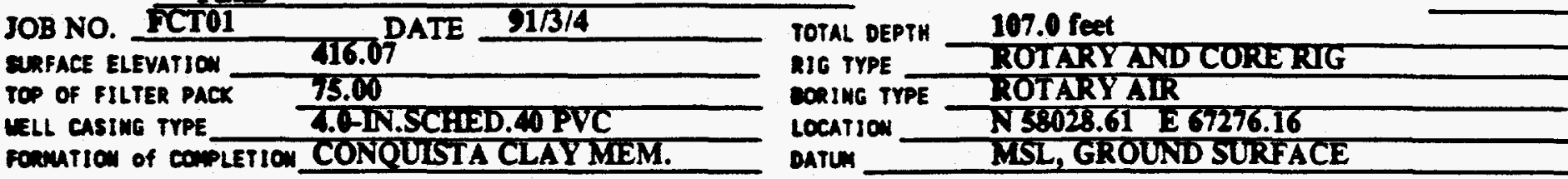

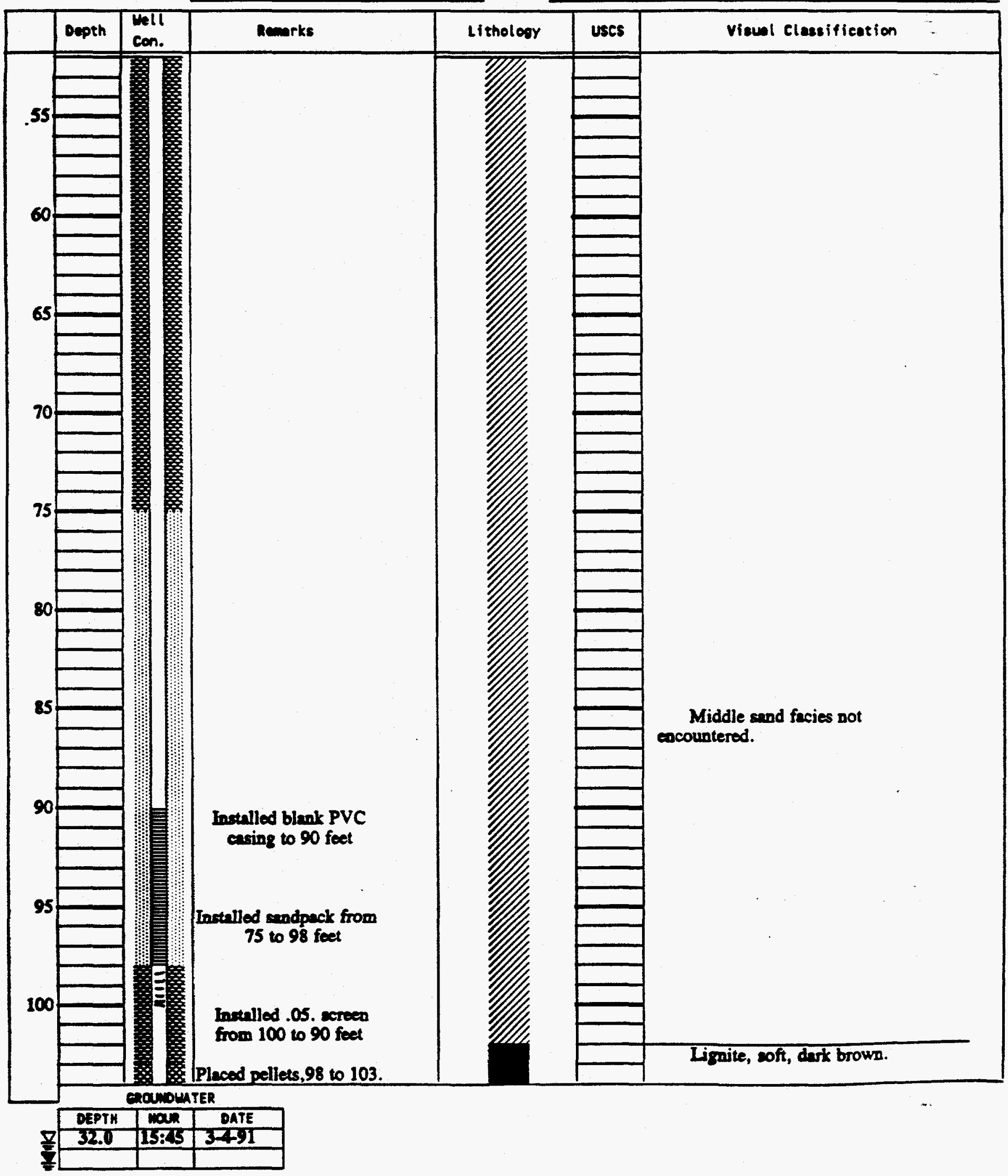


JOB NO. FCTO1

ERFACE ELEVATION

TOP OF FILTER PACK

VELL CASING TYPE 46.07

DATE $91 / 3 / 4$

75.00

T.DIN.SCRED.40PVC

FonUTIOU Of COMPLETION CONOUISTA CLAY MEM.
LOG OF TEST BORING NO. 864

TOTAL DEPTH 107.0 feet

RIG TYPE ROTARYAND CORERG

CORING TYPE ROOTARY AIR

Location N\$8028.61 E67276.16

DATUM MEL, GROUND SURFACE

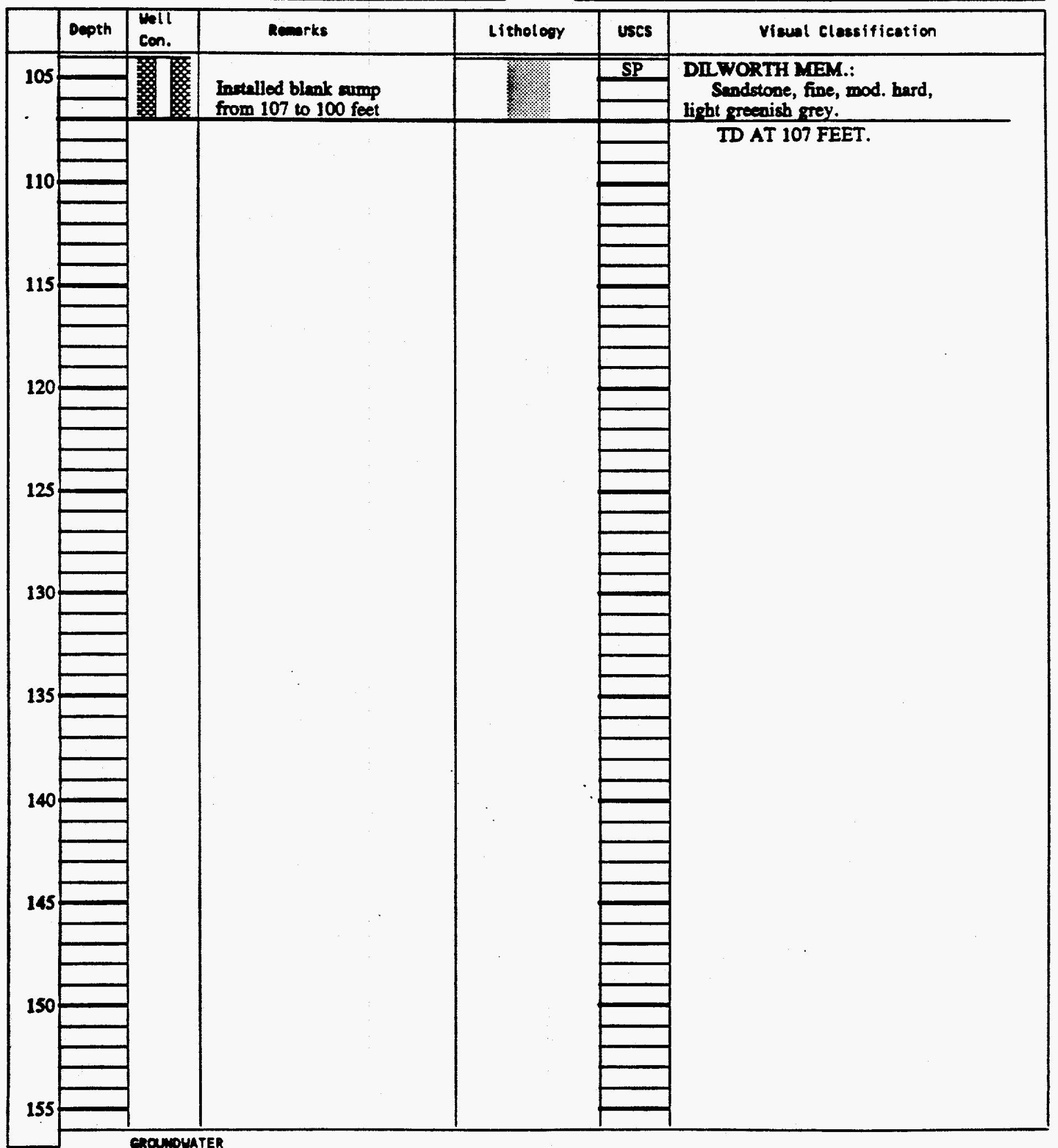

\begin{tabular}{|c|c|c|}
\hline DEPTH & WOWR & OATE \\
\hline 32.0 & $15: 06$ & 3491 \\
\hline & & \\
\hline
\end{tabular}


JOB NO. MCTOI

ERFACE ELEVATIOW

TOP OF FILTER PACK

MELL CASING TYPE

DATE $91 / 3 / 31$
214.96
26.00
4.01N.SCFIED.40 PVC
CONOUISTA CLAYMIEM.

TOTAL DEPTK

co.0 feet

RIG TYPE LOTARY ANDCORERIG

COAIUE TYPE

ROTARY AIR

POAMTITO of COPLETION CONQUISTA CLAYMEM.

LOCATION N35659.62 E44803.20

Datur

MSL, GROUND SURFACE

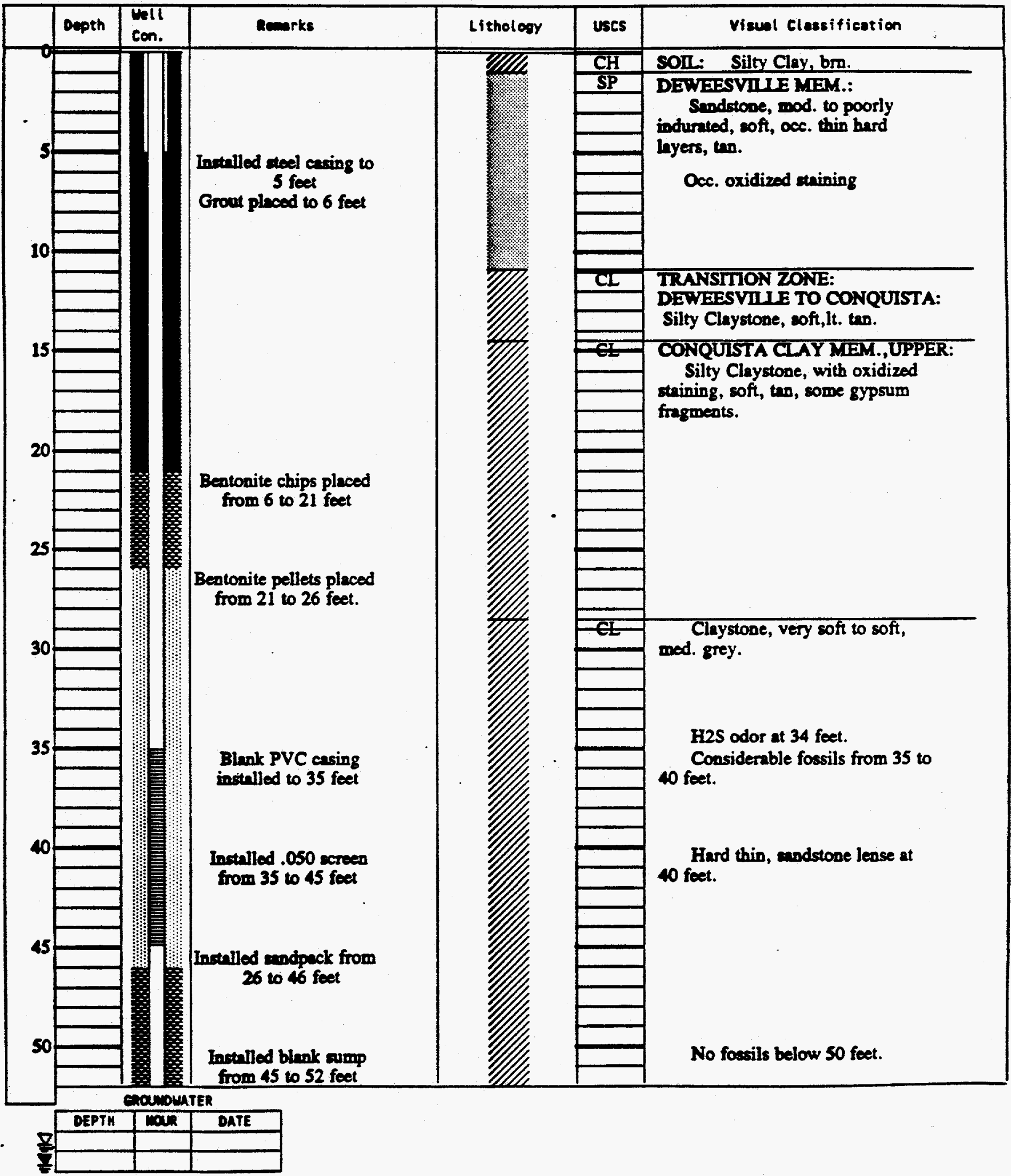


- PROJECT Falls City Site

Poge 2 of 2

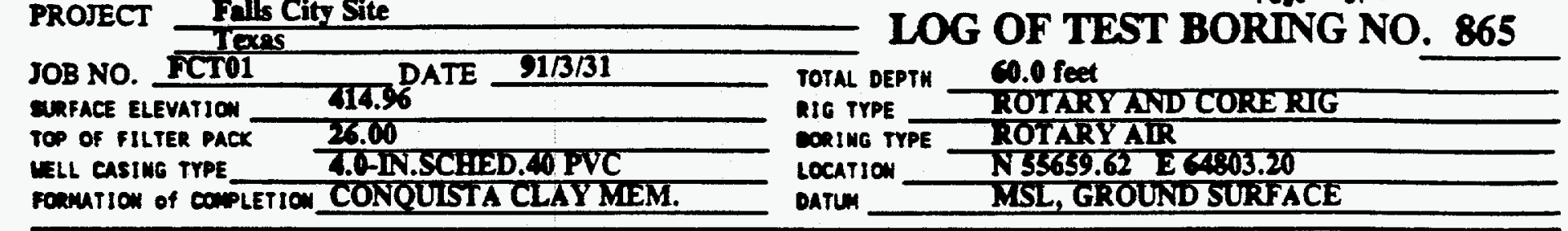

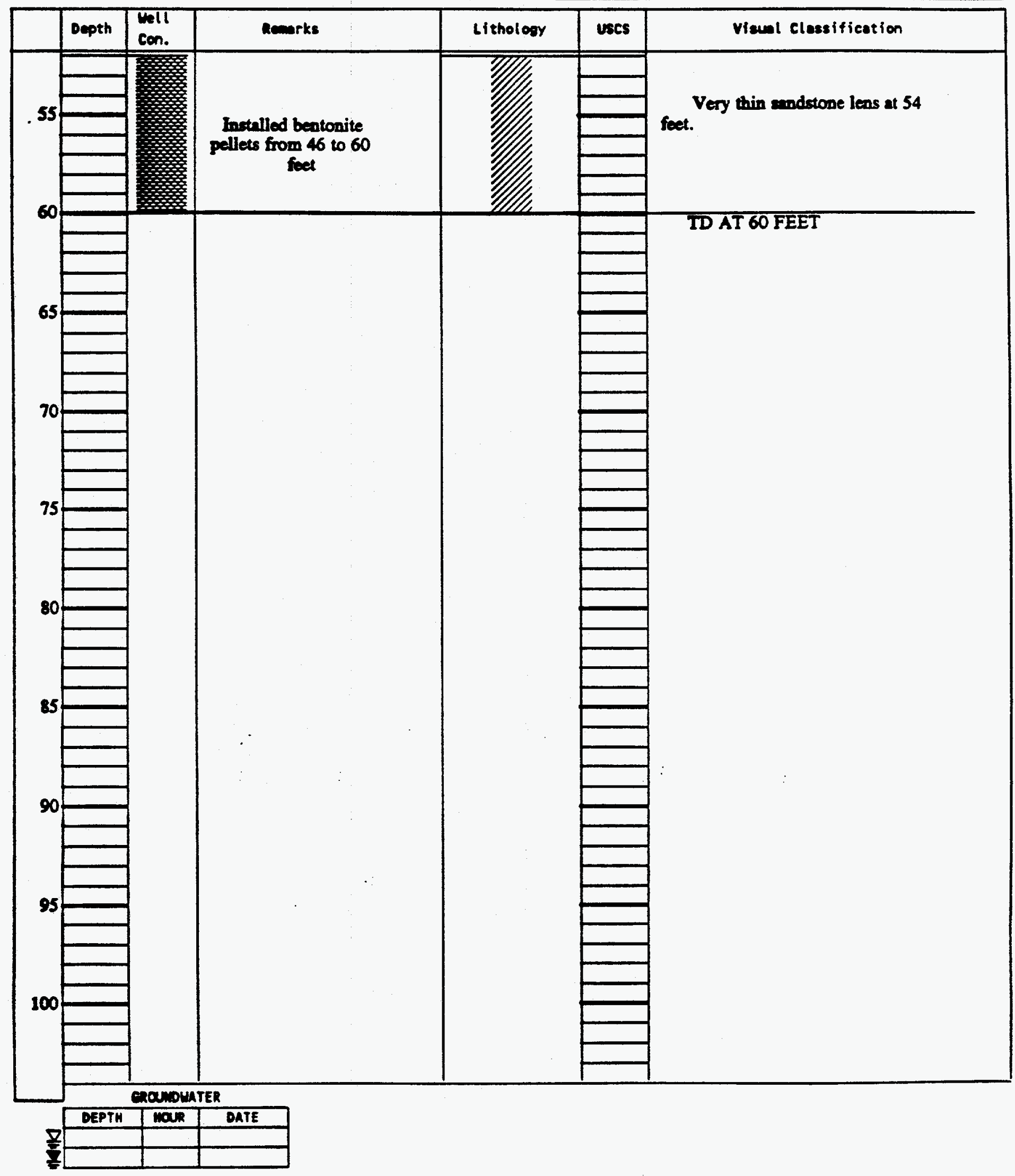




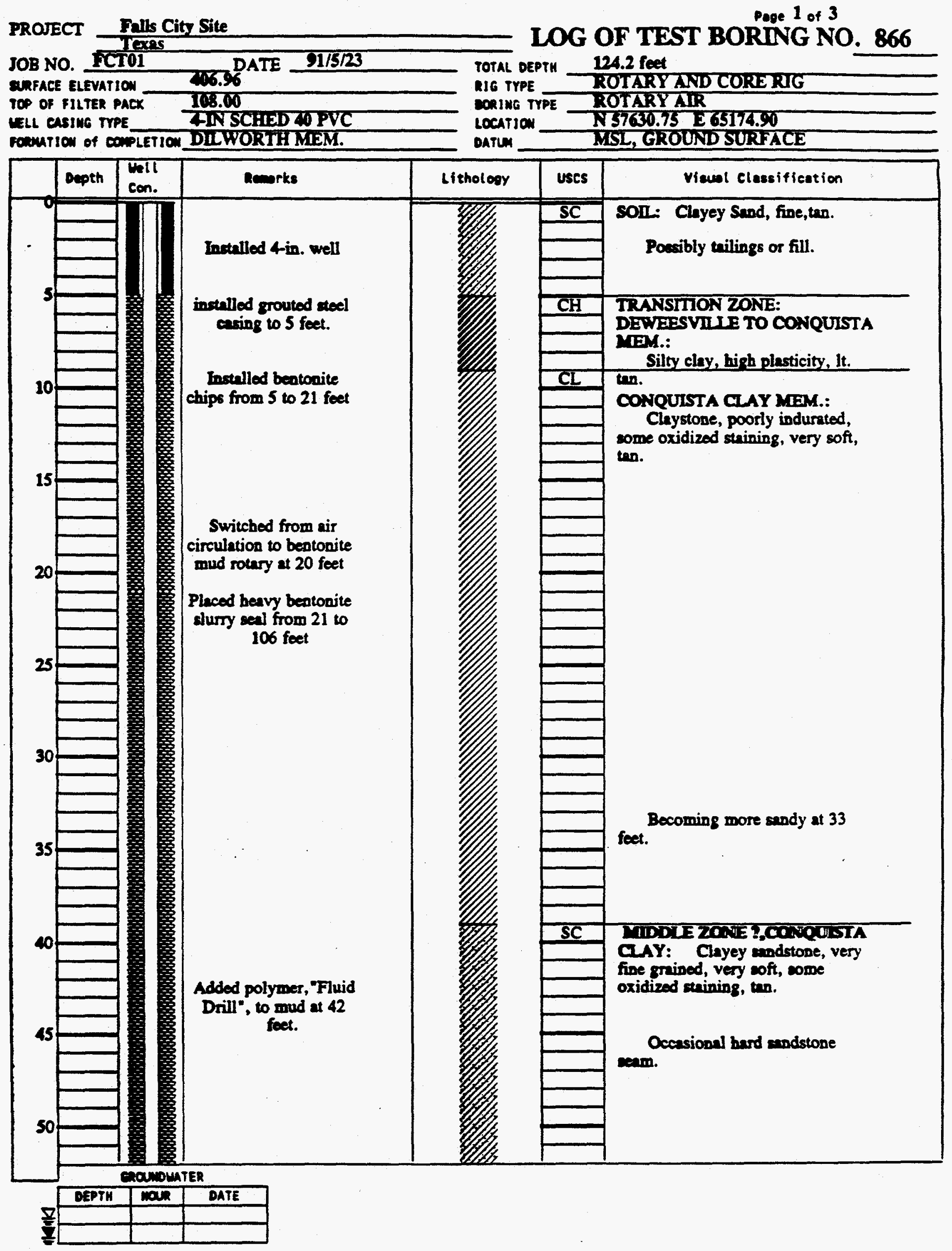




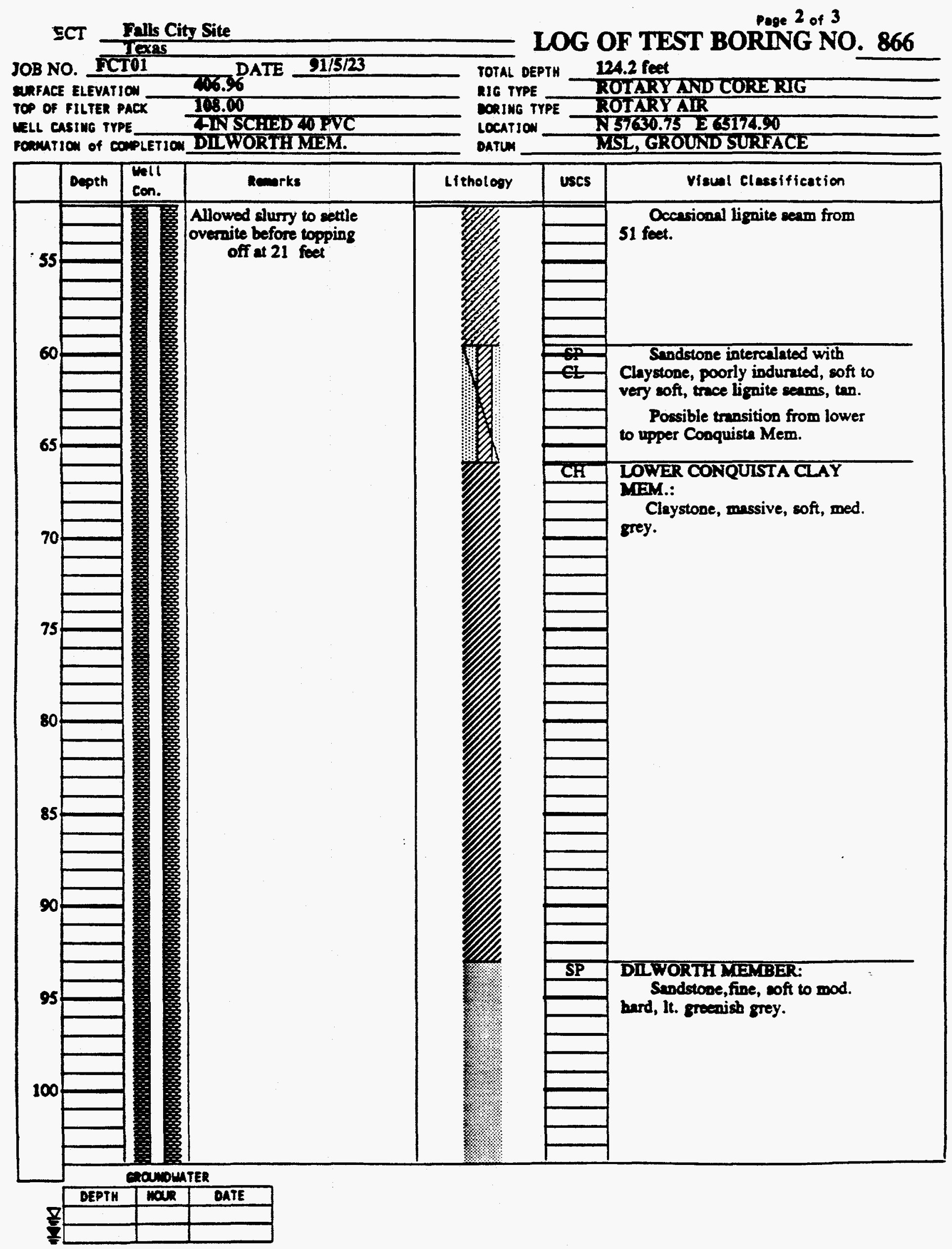


PROIECT Falls City Site

JOB NO. ICTO1

ERFACE ELEVATION

TOP OF FILTER PACK

VELL CASING TYPE

. - Fonution of COPLIION DLWWORTH MEM.

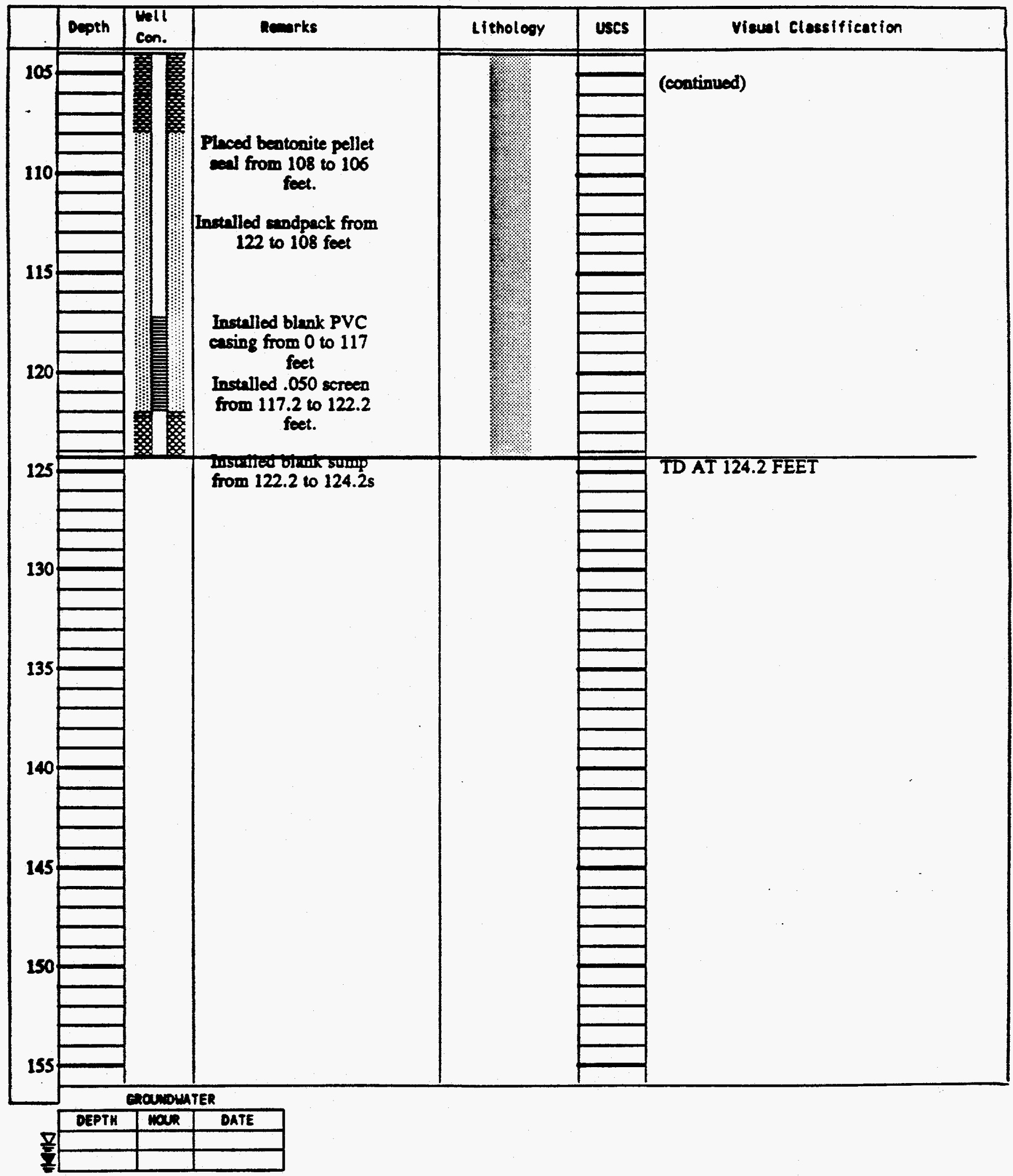

TOTAL DEPTH 124.2 feet

RIG TYPE DOTARYAND CORERIG

CORINE TYPE LOTARYAIR

LOCATION

Datum

DATE $91 / 5 / 23$
SCEIED 40 PVC
WORTH MEM.


JOB NO. FCTO1

arface elevation

TOP OF FILTER PACK

TELL CASING TYPE. 27.99

DATE

25.50

4.0-IN SCHED कW PVC

FORMTION of COPLETION DEWEESVILLE MEM.
LOG OF TEST BORING NO. 867 TOTAL DEPTH 168.0 feet

RIG TYPE ROTARY /CORERG

CONING TYPE ROTARY AIR

Location

DATUA
N56471.97 E67450.59

MSL, GROUND SURFACE

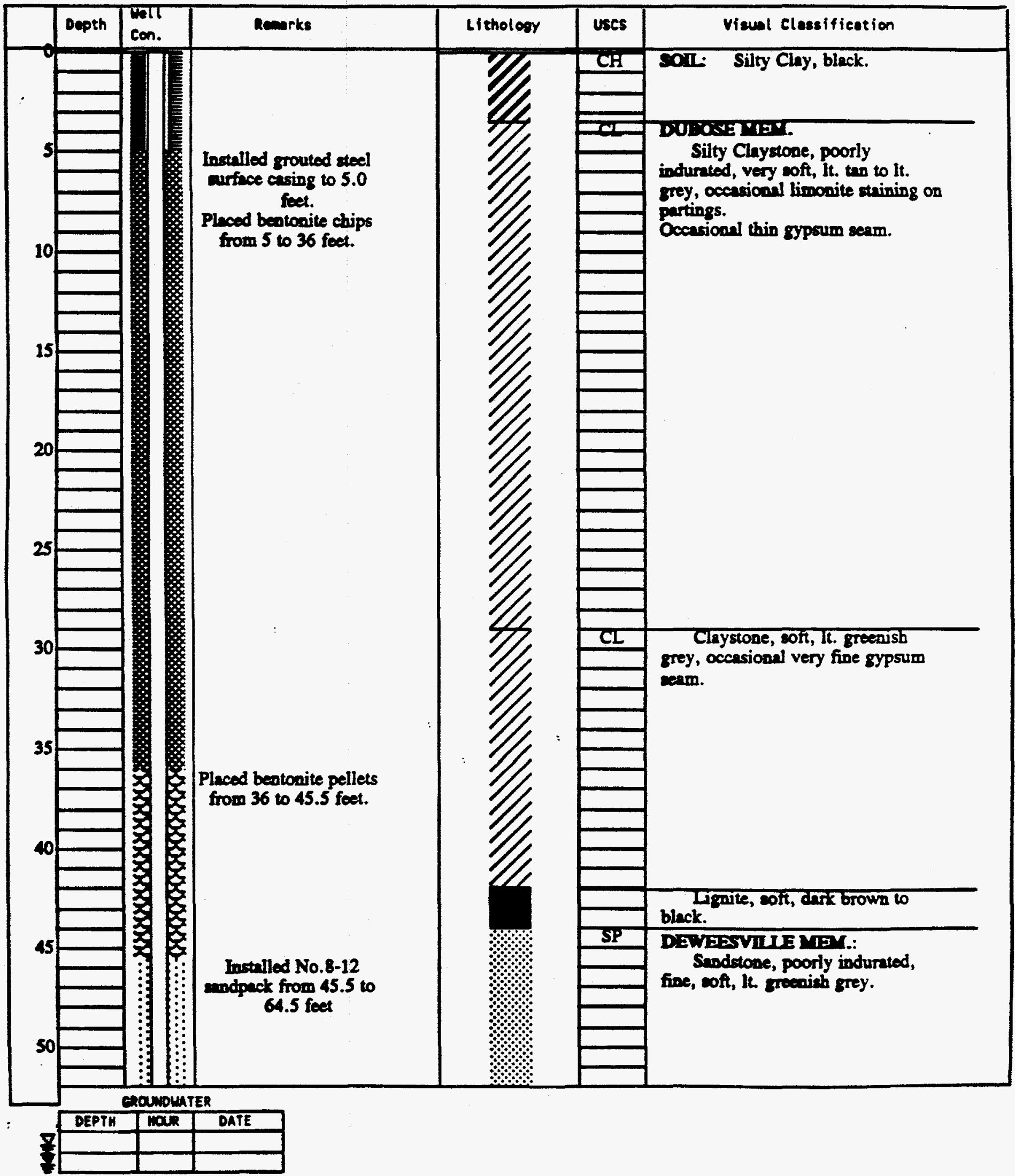




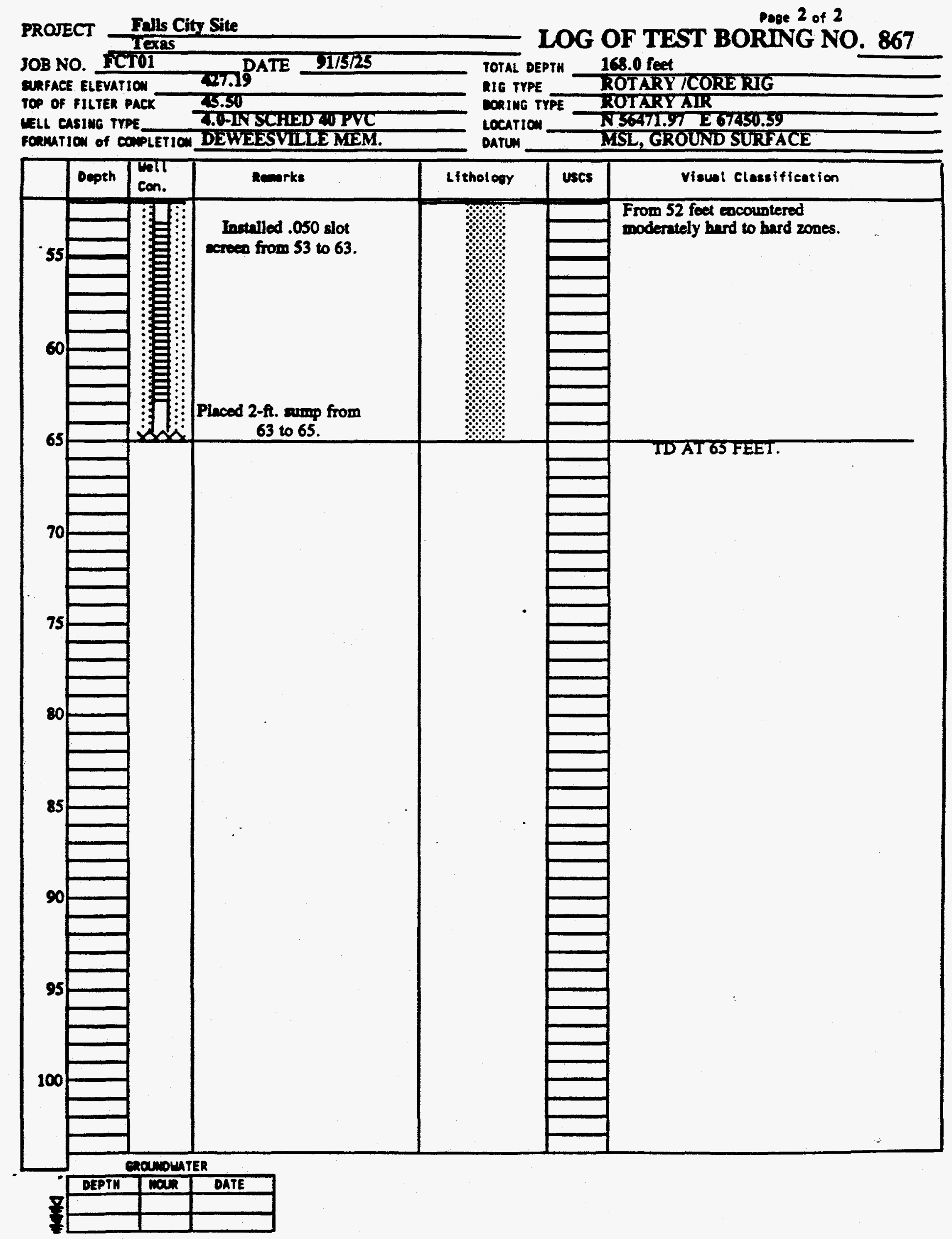




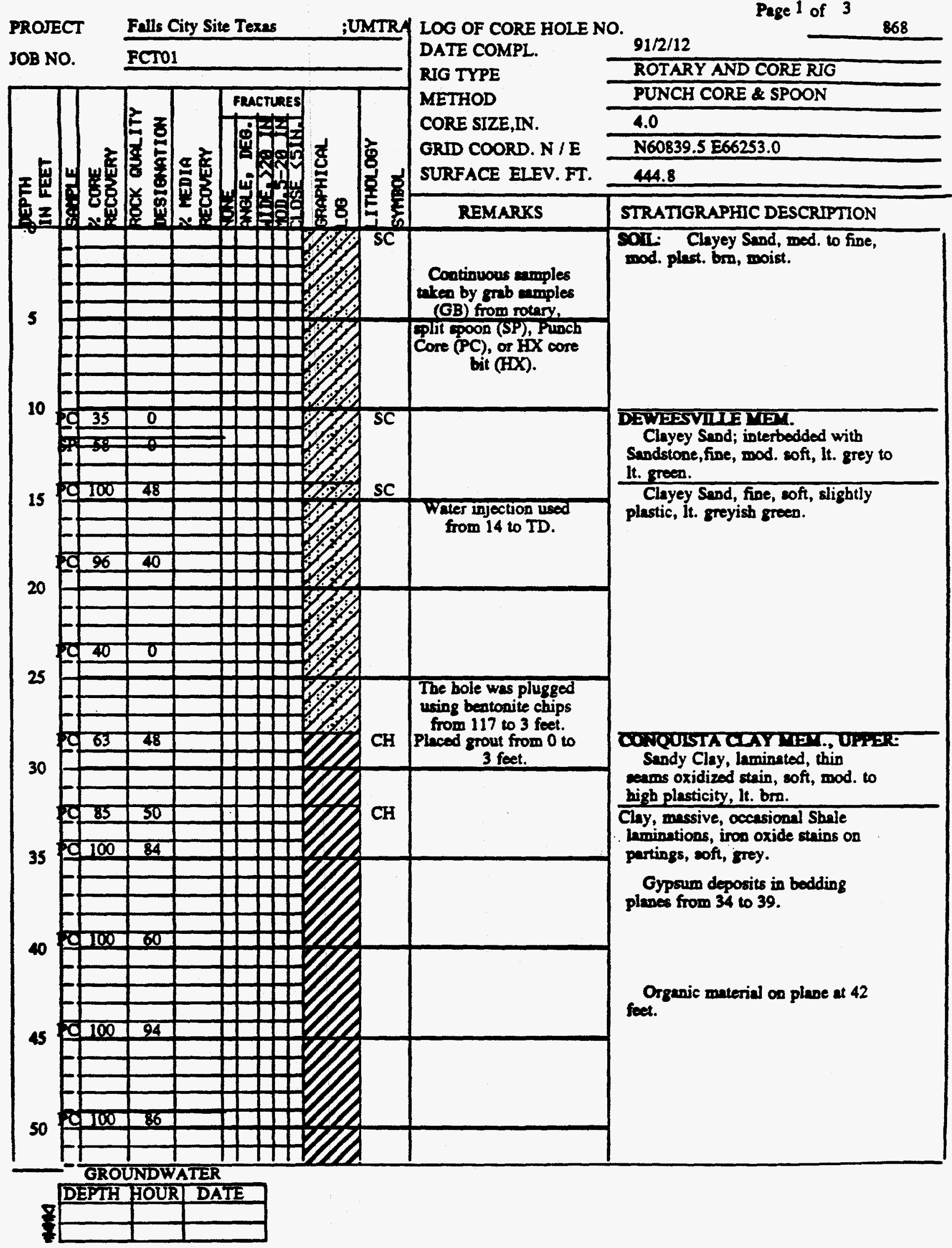


PROTECT Falls City Site Texas

JOB NO. FCTO1

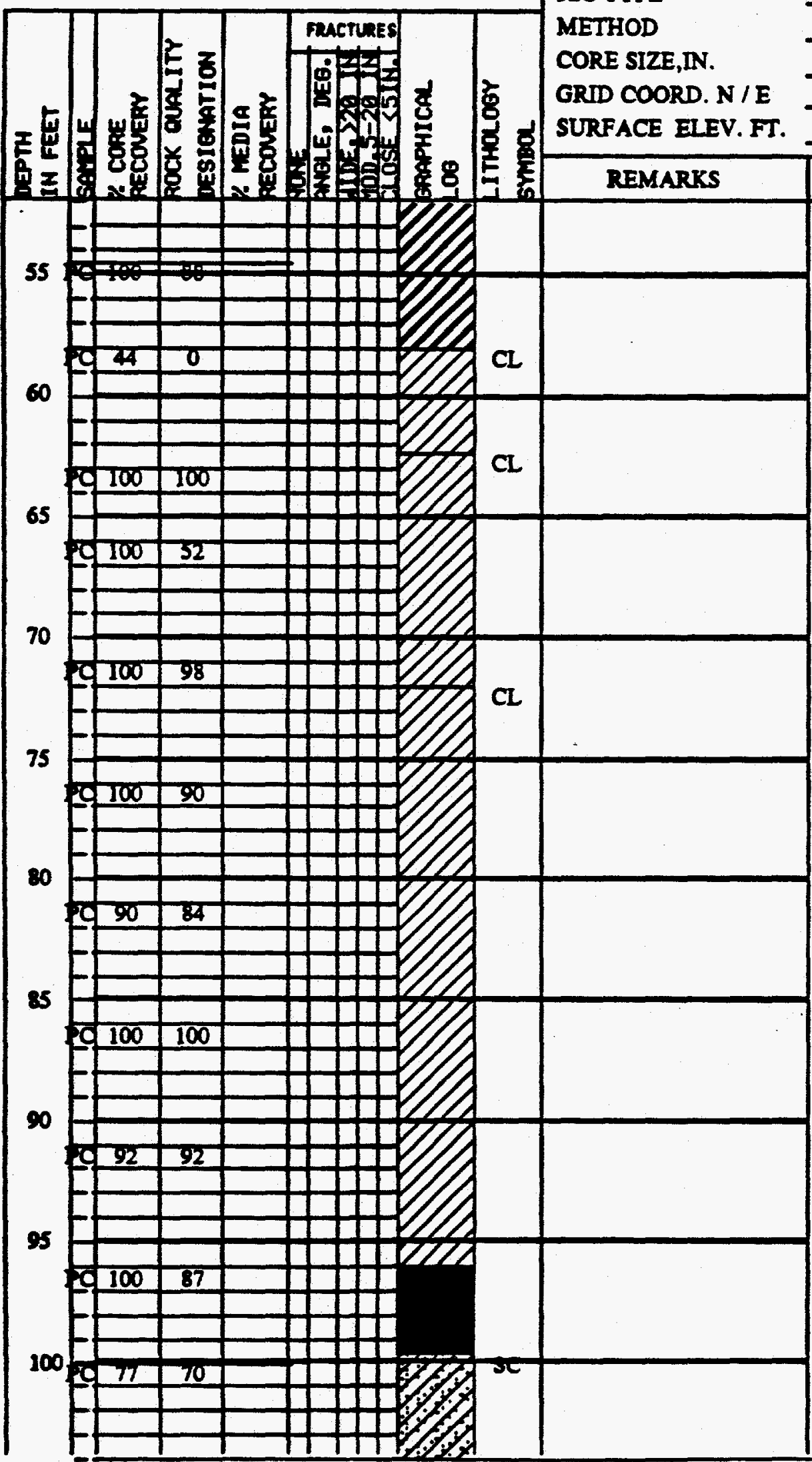

;UMTR LOG OF CORE HOLE NO. DATE COMPL.

91/2/12

Page 2 of 3

ROTARY AND CORE RIG PUNCH CORE \& SPOON 4.0 N60839.5 E66253.0

44.8

STRATIGRAPHIC DESCRIPTION (continued)

Chy/ Clay shate, sell trag. mod. coft, grey.

CNOULTA DIS T; COWDE:

Clay/ Clay Shale, messive, to Inminated, slightly carboniferous at occ. intervals, mod. soft, grey.

Cinystope, sitry, massive to laminnted, mod. indurated, mod. herd, grey.

Fonsilferous from 90.3 to 91.

Lignite, highly carbonecous, mod. coft, di. bm. to black.

\section{DIWOKTA SANTTONE MIS.}

Chyey Seadstone, fine, modium bedded, mod. coft, frisble, greyish green.

GROUNDWATER

DEPTH HOUR DATE

$+$

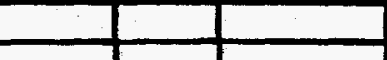




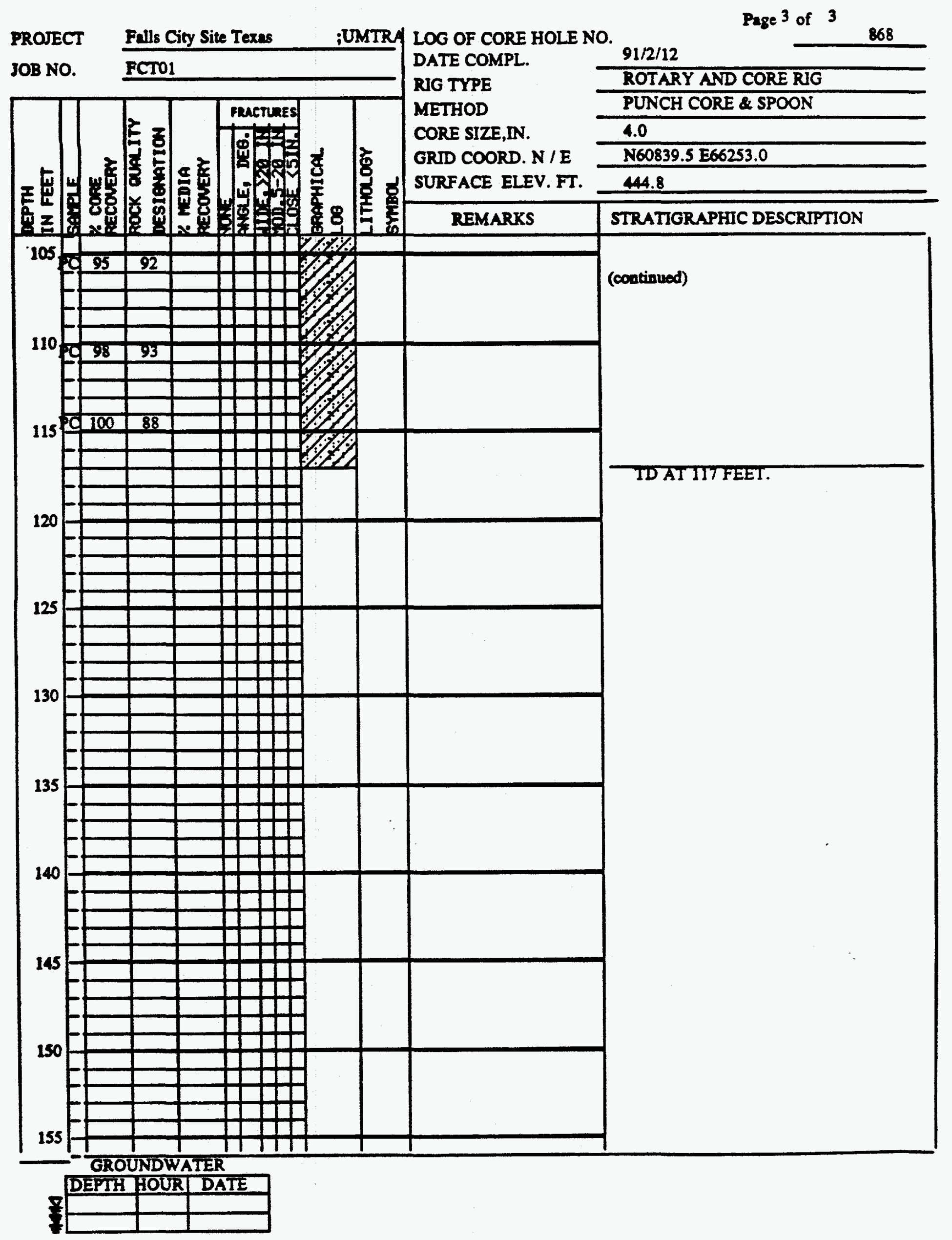


PROFECT Falls City Site Texes ;UMTRA LOG OF CORE HOLE NO.

Page 1 of 3

JOB NO. FCTOI

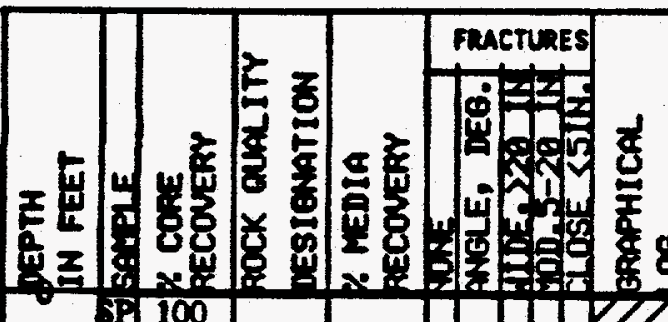

5

ico

10

ic 75
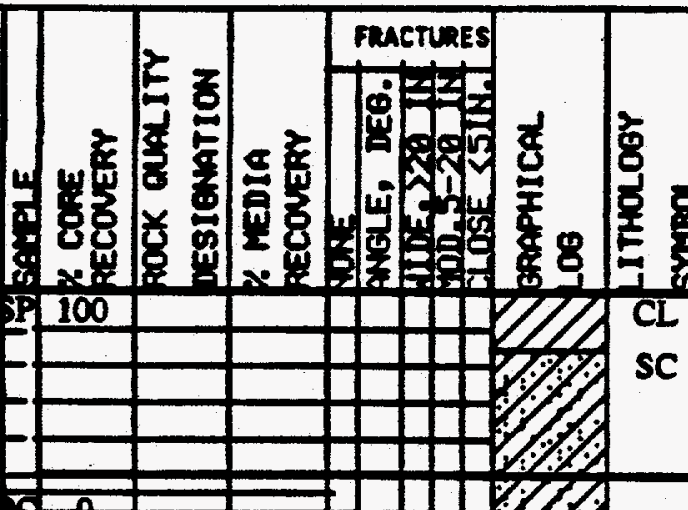

DATE COMPL.

RIG TYPE

METHOD

CORE SIZE,IN.

GRID COORD. N / E

SURFACE ELEV. FT.

\section{$\mathrm{CL}$ \\ SC \\ Continuous anmpling with split epocon, Punch Core, and HX core bit.}

15

0100

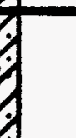

20

0100
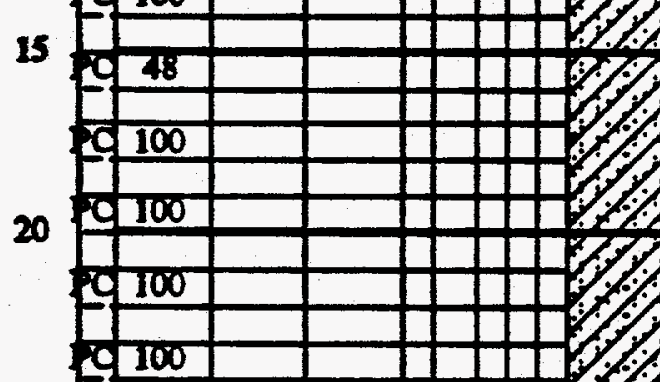

25

$-100$
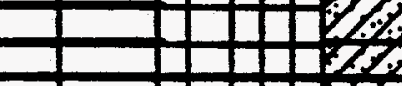

sC

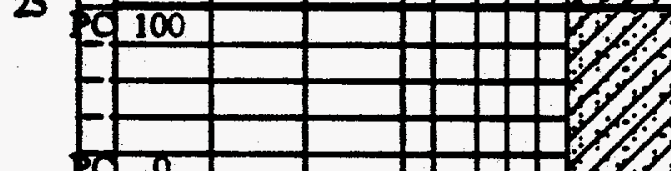

30

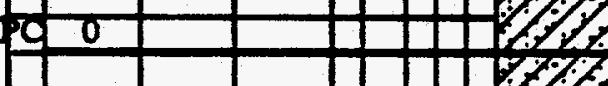

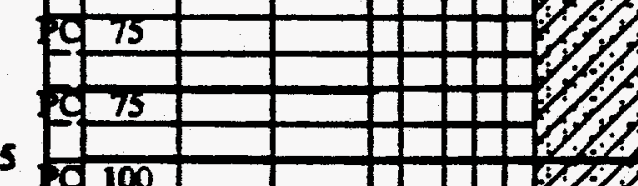

35

100

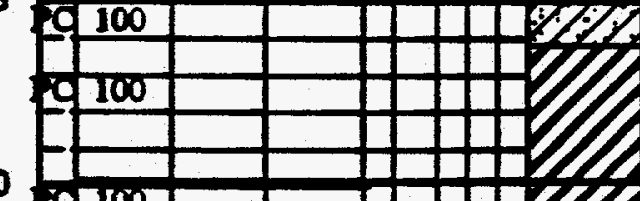

CH

40

ig 100

ict 100

5

0100

45

9100

ic 70

100

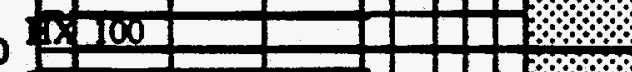

P4

GROUNDWATER

DEPTH HOUR DAT

\section{9}

ROTARY AND CORE RIG

PUNCH-CORE \& SPOON

$$
4.0
$$

N61668.9 E64537.9

468.5

STRATIGRAPHIC DESCRIPTION

Fil. Silty Clay, dk. bro.

TAIDIias:

Sandy Clay to Clayey Sand, fine and, mod. to high plast. grey to sreen, v. moist to wet.

Chayey Send (slimes?), very loose , slightly plastic, grey, very moist to wet.
OI:

Sandy Clay to Clayey Send, fine, high plasticity, yellow brown, moist 10 wet.
DEWESVIRE VIS": SRdstone, fine, mod. to thin bedded, mod. soft, oxidized,It. red/ ton. 


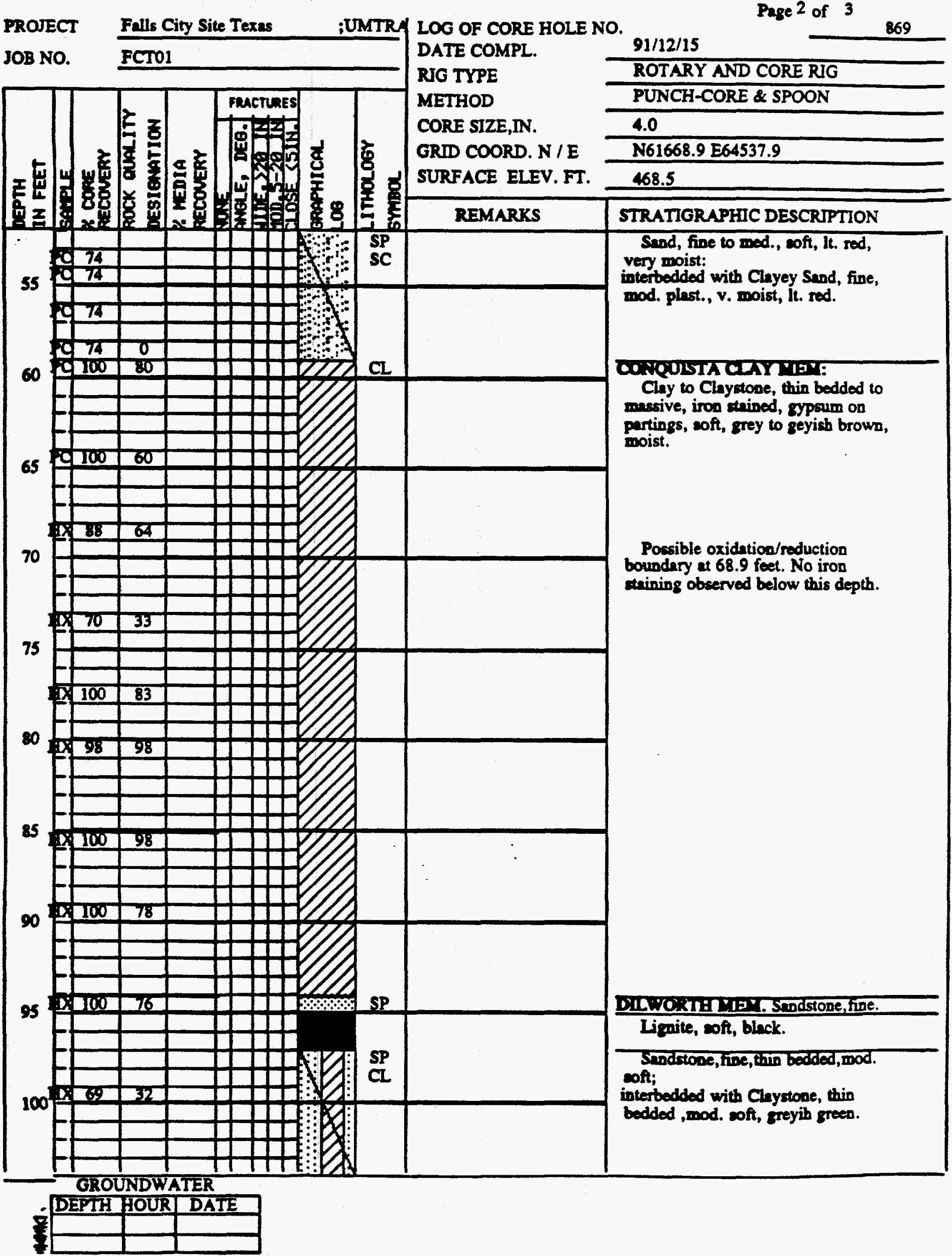




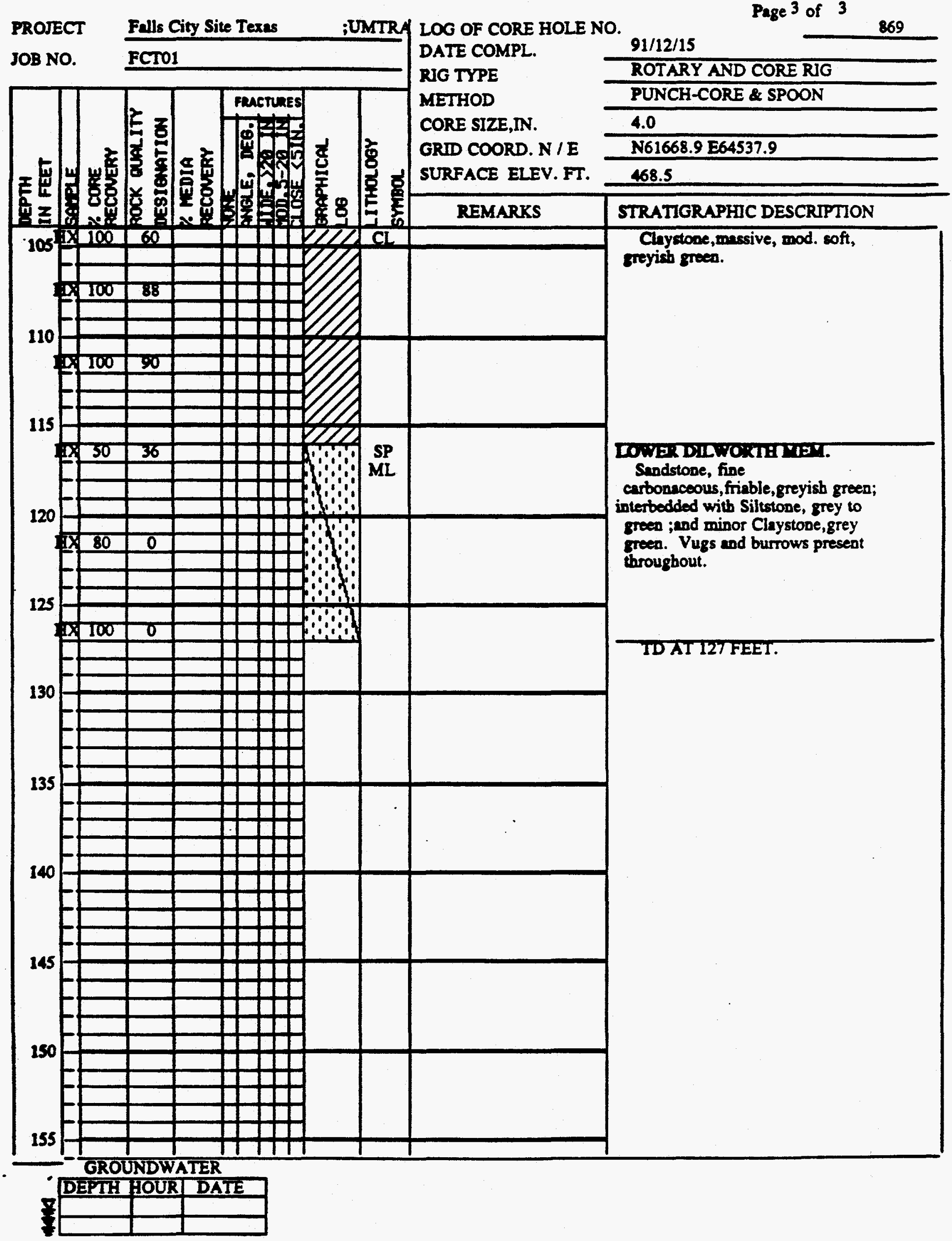


JOB NO. FCTO1

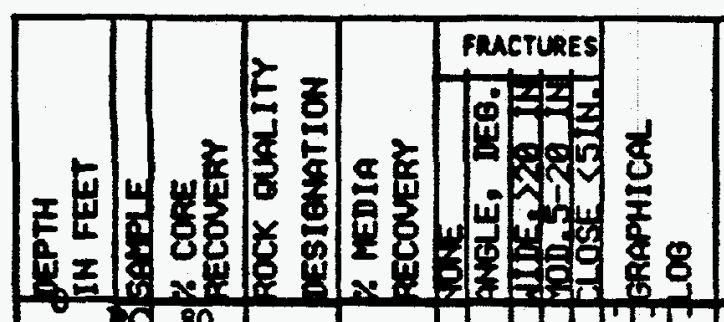

5

10

atro

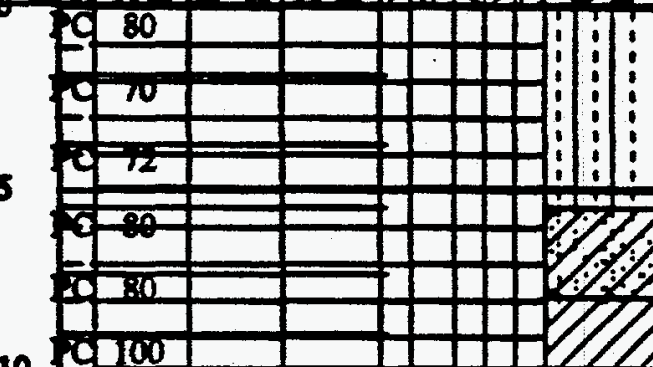

15

-

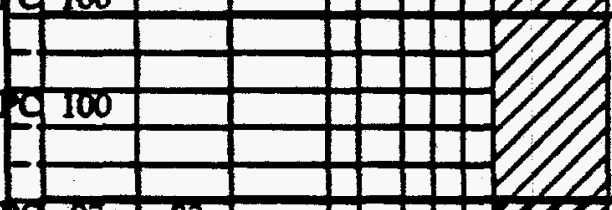

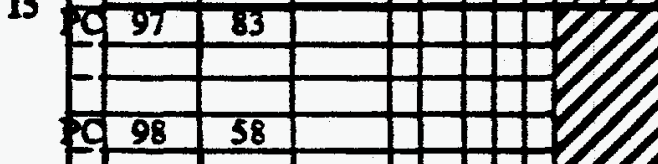

20

25

\begin{tabular}{l|l|l|}
\hline 0 & 30 & 0 \\
\hline
\end{tabular}

25

30 \begin{tabular}{ll}
100 & 25 \\
\hline
\end{tabular}
\begin{tabular}{r|r}
\hline \\
\hline
\end{tabular}

+

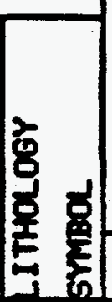

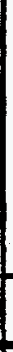
DAIE COMPL. RIG TYPE

METHOD

CORE SIZE,IN.

GRID COORD. N / E

SURFACE ELEV. FT.

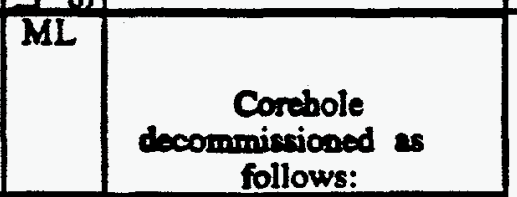

sc

Pleced bentonite pellets

from 110 to 71 feet

The formation caved

CL from 71 to 59 foet.

Bentonite pellets

installed from 59 to 40 feet.

the formation caved at 40 to 29 feet.

Bentonite chips

Ch installed from 29 TO 4 feet.

grout placed from 0 to 4 feet

\section{4 feet}
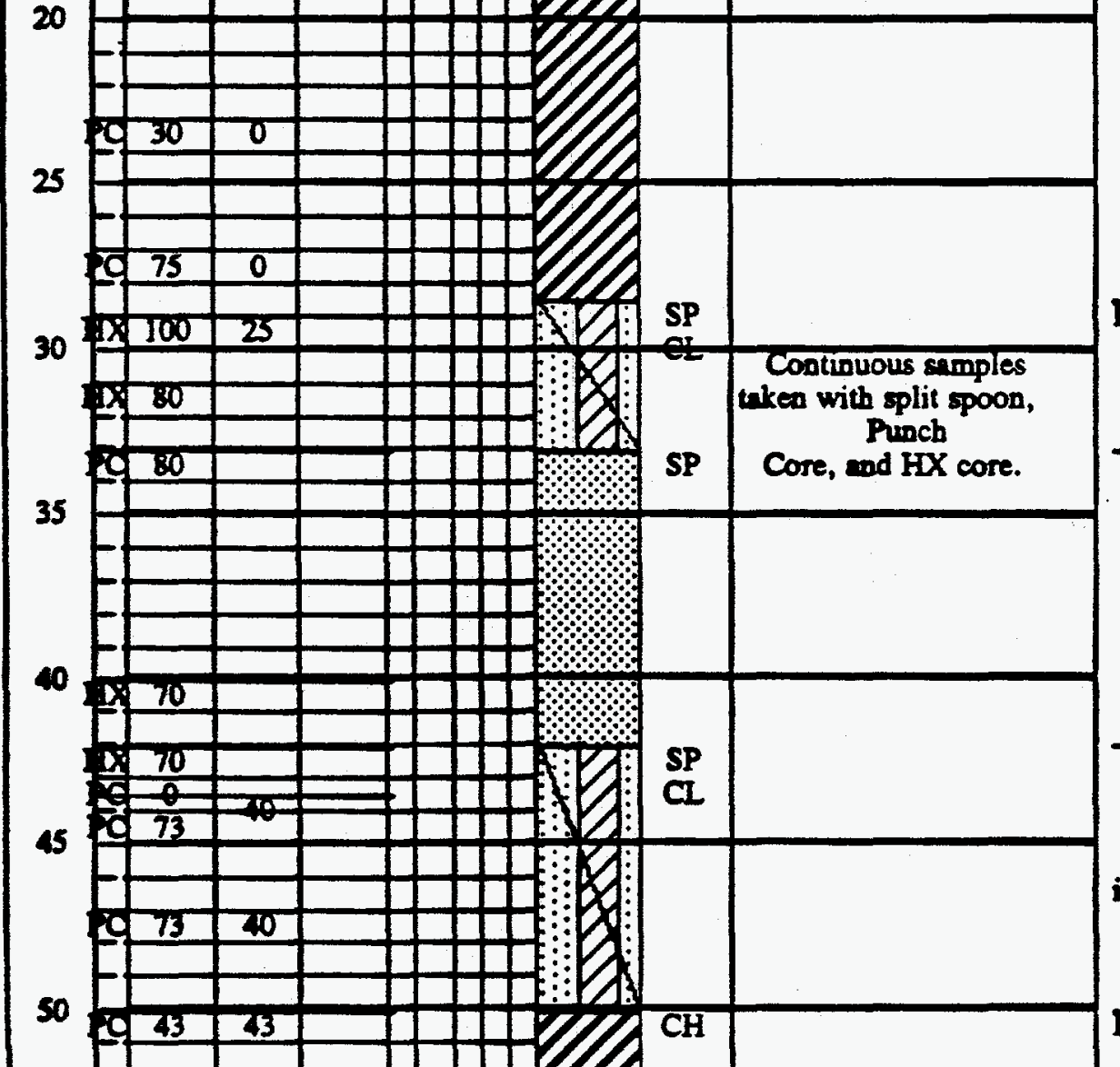

Continuous samples

$91 / 2 / 20$

ROTARY AND CORE RIG PUNCH CORE \& SPOON

4

N60494.5 E63340.0

473.2

STRATIGRAPHIC DESCRIPTION

SOI Clayey Silt, dk. brn.

EEWEEYIULE VIDY. Clayey Send, very fine, ltgrn.

Chy, little and, med. plasticity, iron etaining on partings, lt. tan to yellow, moist.

Occ. zones of Sendy Clay.

Cley/Claystope, high plasticity, messive, mod. soft., lt. yellow to grey, iron staining on partings surfaces.

TIIDDDE CONQUSTA CAY

MEM.: Sendstone, fine, interbedded with Sundy Claystone.

Sind, fine grined, soft, tan.
Sandstone, hioe, medium bedded, mod. coft, to mod. hard, tan, iron tains on partings, filled burrows/vugs preceat: interbedded with Claystone, thin bedded, mod. eot, , It. ten, with iron thin partings.

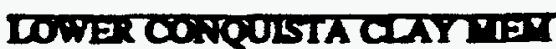

Clay/Claystone, hish plasticity,

GROUNDWATER DEPTH HOUR DATE 


$\begin{array}{ll}\text { PROSECT } & \text { Falls City Site Texes } \\ \text { JOB NO. } & \text { FCTO1 }\end{array}$

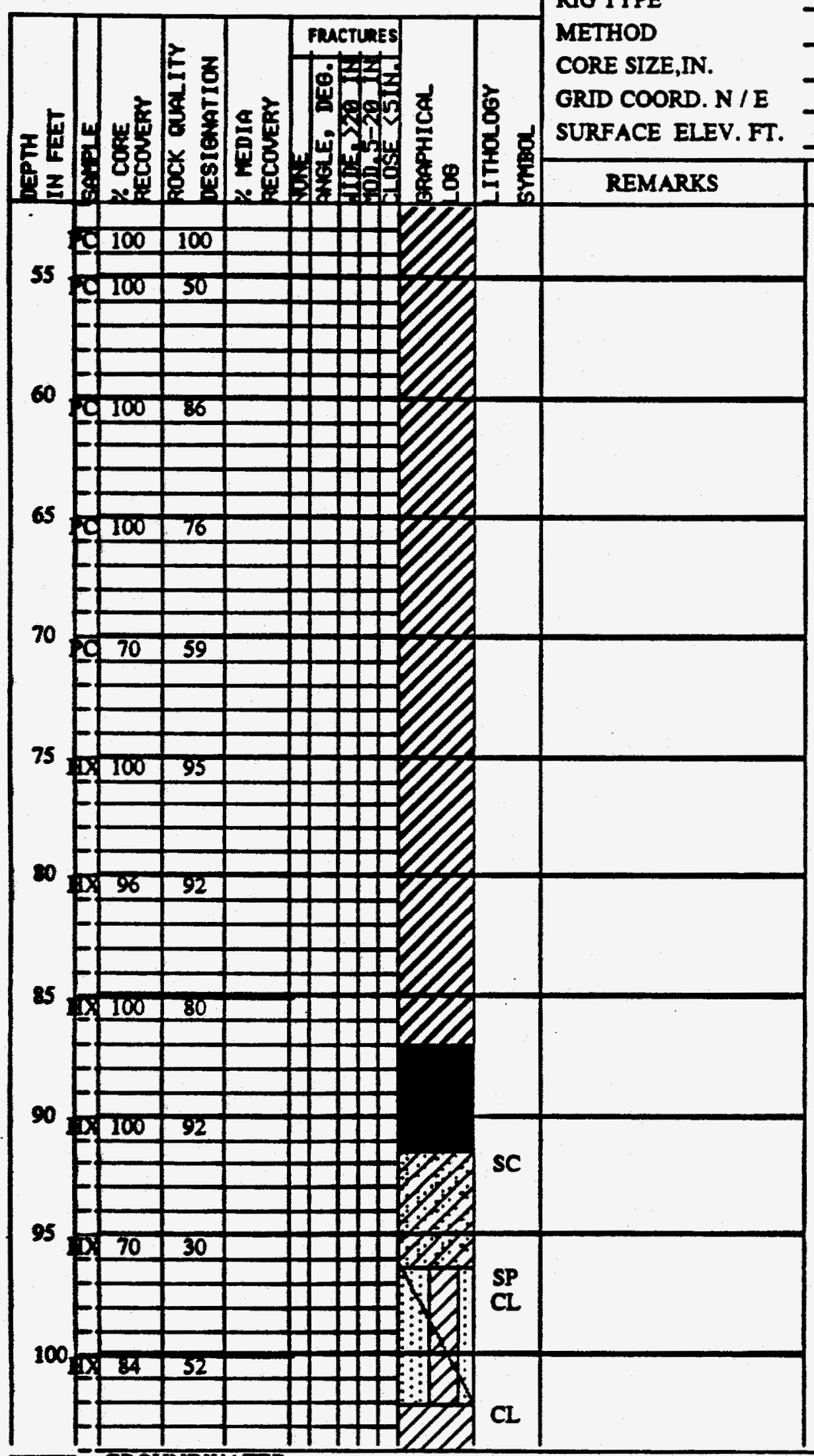

Page 2 of 3

91/2/20

ROTARY AND CORE RIG

PUNCH CORE \& SPOON

STRATIGRAPHIC DESCRIPTION

messive ,indurated, mod. hard, iron tains on partings, lt. grey.

Clayey Sand lens cocountered at 56 to 57 feet.

Encountered gypsum filled fracture (50 deg.) at 66 feet.

No iron staining observed below 67 feet.

Lignite leas at 67.5 to 68.5 feet.

Increasing carbonaceous and shaley from 85 feet.

Lignite (marker bed), shaley to thin bedded, mod. herd, dk. brn.

DITORTH ME.

Clayey Sundstone, fine, carbonnceous, thin bedded, thin clayey Inonin preceat, mod. soft, with fossil burrows. erevish green.

Claystone, thin bedded, med. plast., greyich green. interbedded with Sendstone, five thin bodded, mod. herd, green.

Claystone, massive, mod. herd, greyish green. 


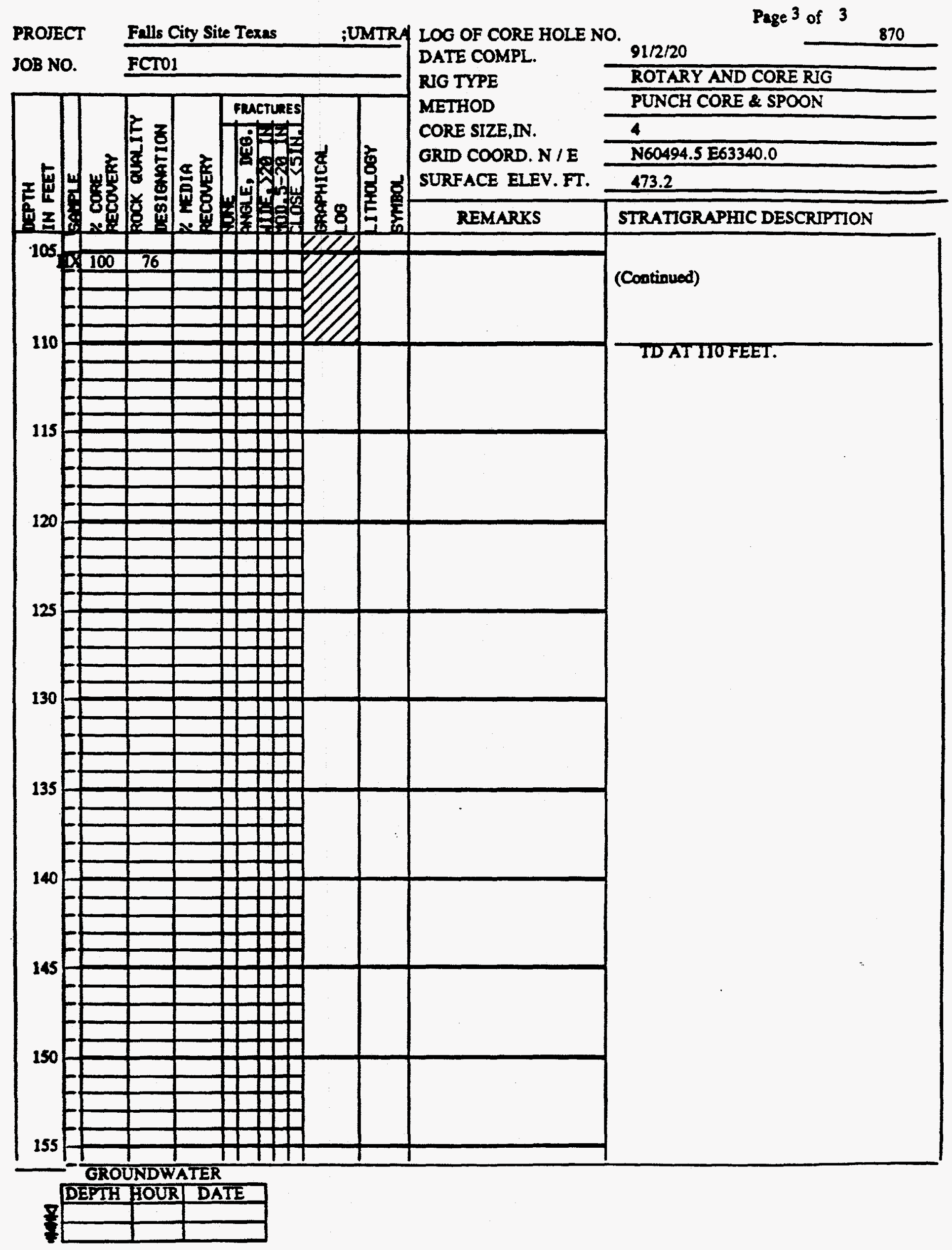




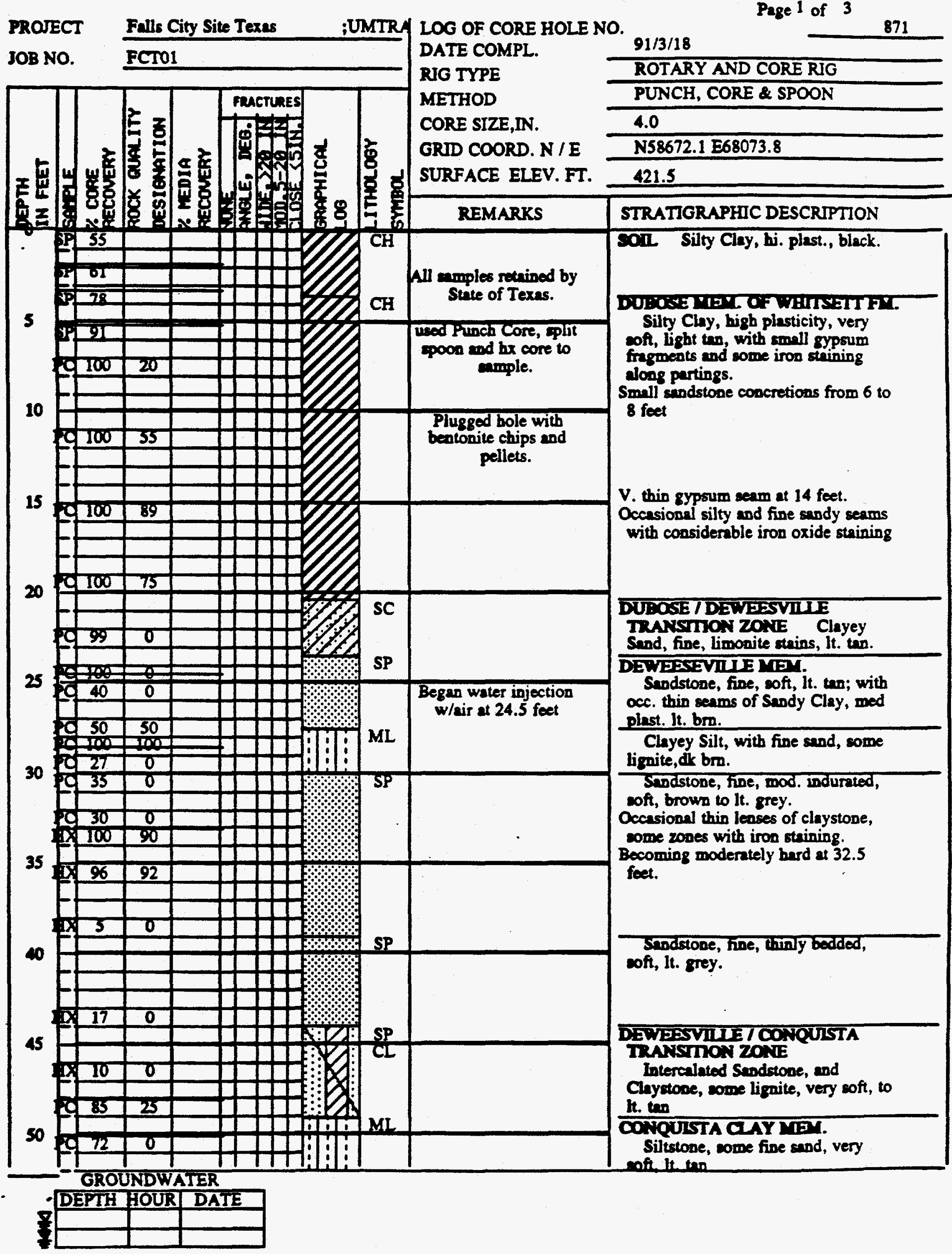


PROJECT Falls City Site Texas ;UMTRA LOG OF CORE HOLE NO.

Page 2 of 3

JOB NO. FCTOI

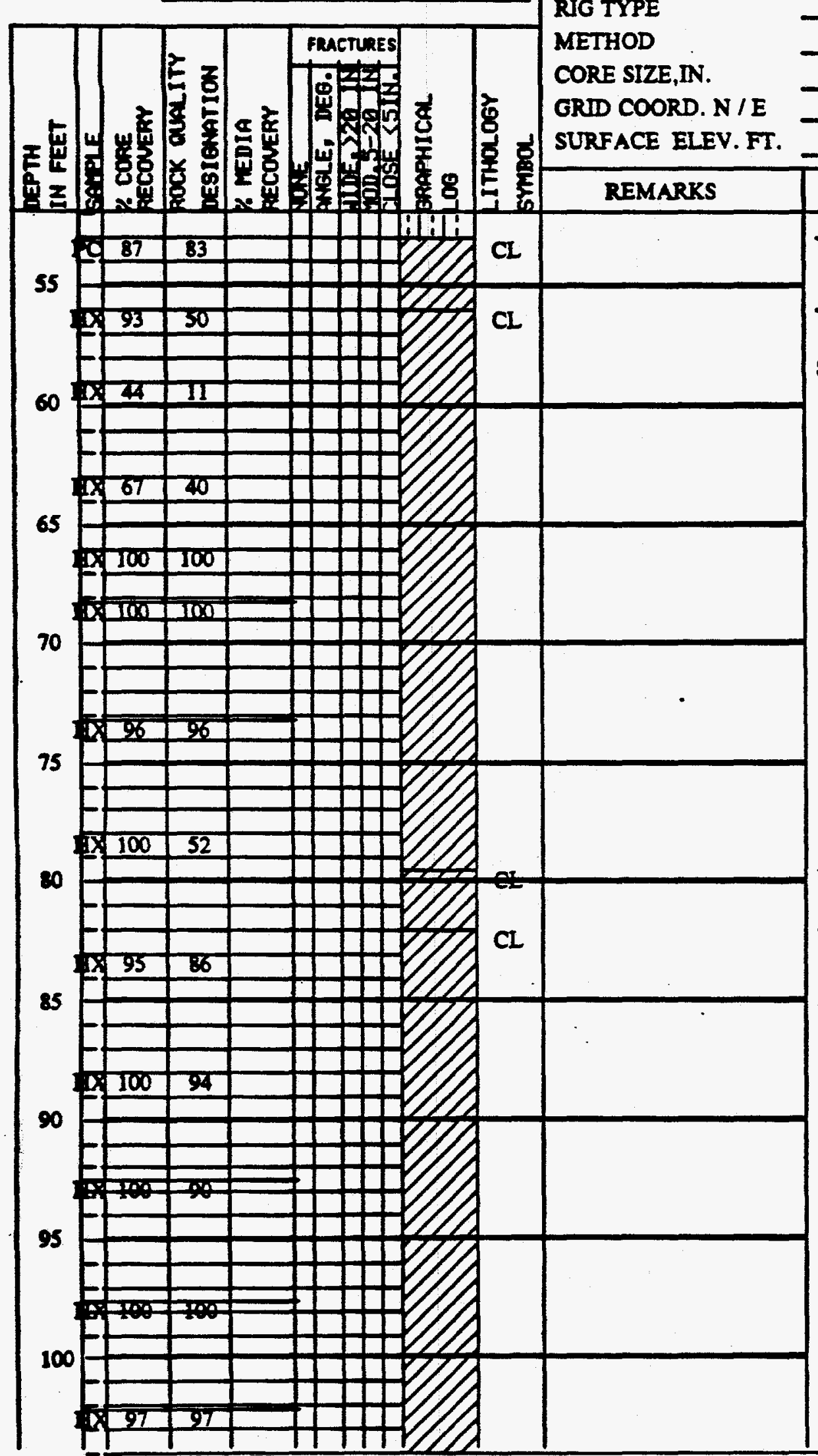

$91 / 3 / 18$

ROTARY AND CORE RIG PUNCH, CORE \& SPOON 4.0 N58672.1 E68073.8

421.5

STRATIGRAPHIC DESCRIPTION

Silty Claystone, w/ gypsum and inos stain.

Claystone, massive, freah, onin bedded, soft, strey;

Some carbonecous fragments on bedding planes.
Clnystone, thin bedded, wh fossil shell frag.

Crystone, fresh, thin bedded, occ. fine sindy lenses, soft, it. grey. Thin fossil zone at $\mathbf{8 2 . 5}$

With bleck carbonnceous partings from 83 feet.

Encountered thin silty straum from 90 to 91.5 feet

From 100 feet observed occsional thin lignite perting. 
PROJECT Falls City Site Texes ;UMTRA LOG OF CORE HOLE NO.

JOB NO. FCTO1

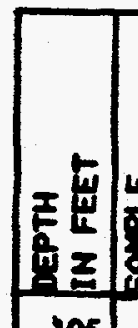

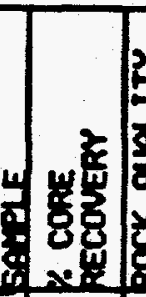

105
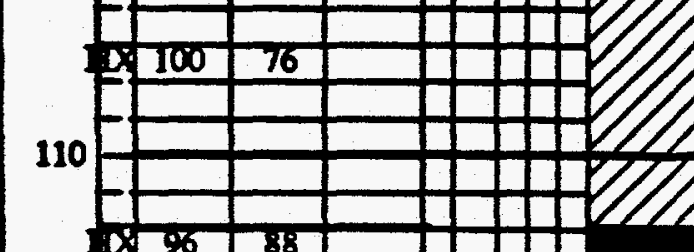

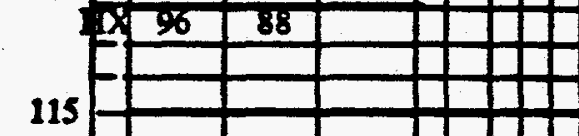

11

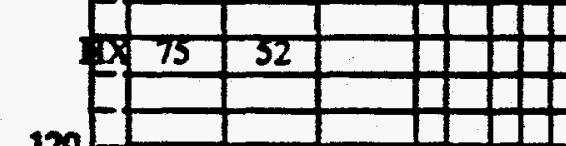

120

\begin{tabular}{rlllllll}
\hline & & & & & & & \\
\hline
\end{tabular}

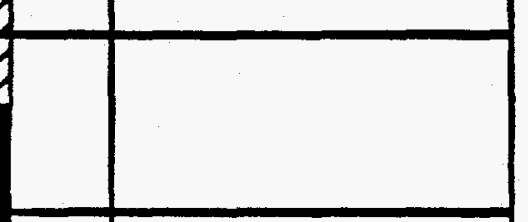

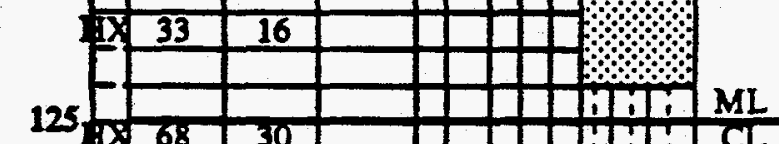

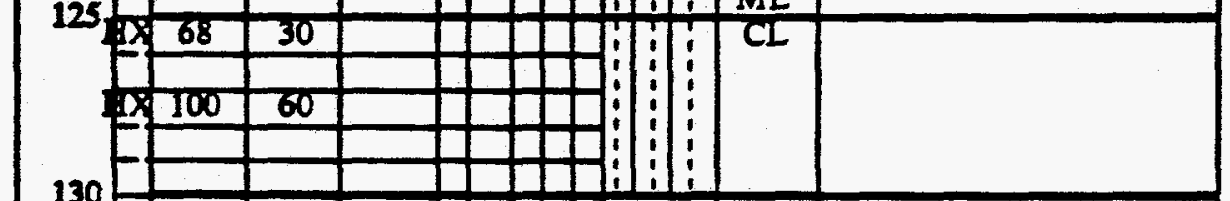

\section{DATE COMPL.}

METHOD

CORE SIZE,IN.

GRID COORD. N / E

SURFACE ELEV. FT.
RIG TYPE

Page 3 of 3

91/3/18

ROTARY AND CORE RIG

PUNCH, CORE \& SPOON

4.0

N58672.1 E68073.8

421.5

STRATIGRAPHIC DESCRIPTION

Scattered occurrences of shell fossil

fing. from 105 to 111 feet.

Obeerved compaction slickenside at 108 feet.

Lignite, very coft, brown to dk. brown with thin claystone seams.

DILWCXTHTET.

Saodstone, fine, fresh, massive, mod. hard, it. greenish grey.

Thin bedded from 118 feet.

Intercalated Siltstone and Sandy claystone, soft to moderately hard, it. grey.

TD AT 130 FEET 
PROJECT Falls City Site Texes ;UMTRY LOG OF CORE HOLE NO.
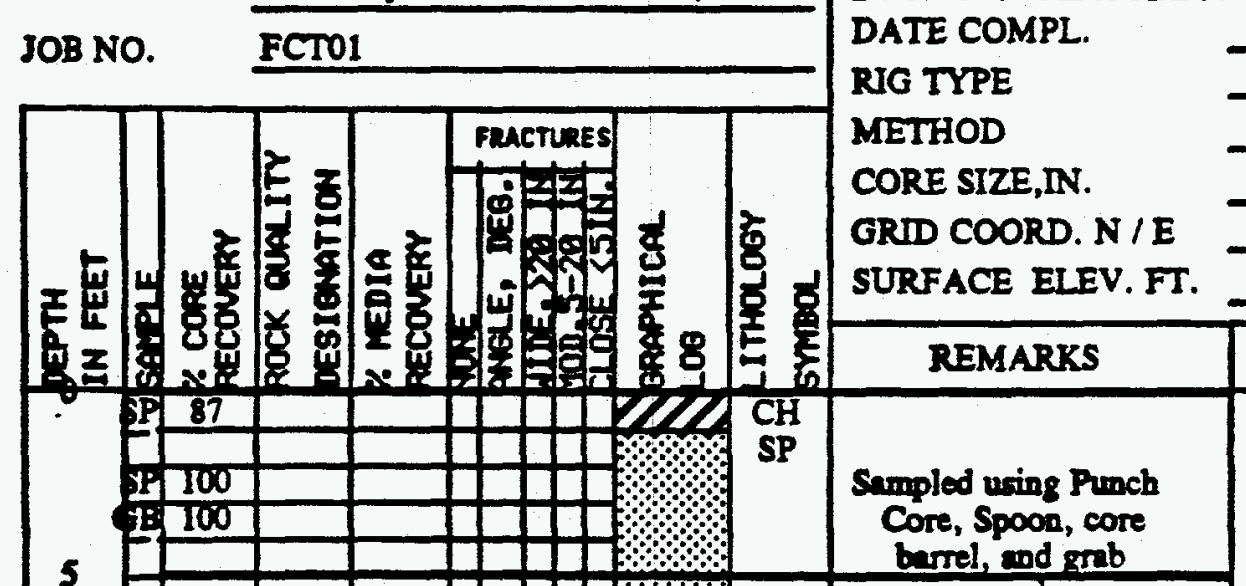

5

10
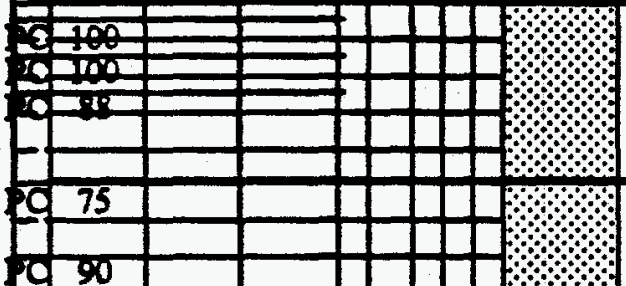

15

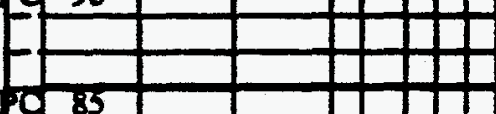

20

100

808353

25

\begin{tabular}{l|l|l|}
\hline 0 & 80 & 50 \\
\hline
\end{tabular}

\begin{tabular}{|c|c|c|c|}
\hline 100 & 0 \\
\hline 180 & 0 & \\
\hline
\end{tabular}

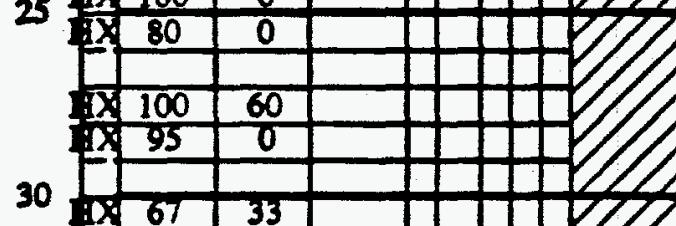

30

\begin{tabular}{|c|c|c|}
\hline 2 & 67 & 33 \\
\hline & & \\
\hline 12 & 100 & 40 \\
\hline
\end{tabular}

35

\begin{tabular}{|l|l|l|}
\hline 100 & 100 & 40 \\
\hline & & \\
\hline
\end{tabular}

10 \begin{tabular}{|l|l|l|}
\hline 100 & 100 \\
\hline 98 & 87 & \\
\hline
\end{tabular}

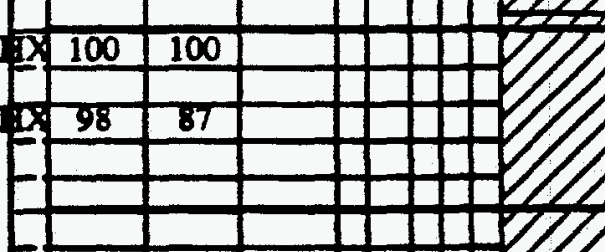

as

$$
0.100793
$$

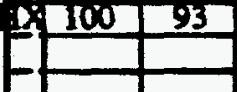

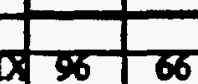

so

\begin{tabular}{|l|l|l|l}
\hline 96 & 66 & \\
\hline & & & \\
\hline & & \\
\hline & & & \\
\hline $1 \times 100$ & 75 &
\end{tabular}

GROUNDWATER

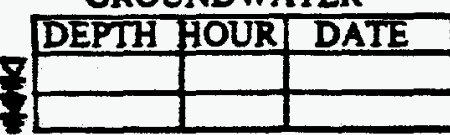

\section{$\mathrm{CH}$}

Sampled using Punch

Core, Spoon, core

barrel, and gmb enmples.

Plugged bole with bentonite pellets and chips.

CL Begen using air/mist at 20.75 foet

$\mathrm{CL}$

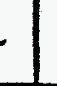

Page 1 of 2 872

$91 / 3 / 30$

ROTARY AND CORE RIG

PUNCH, CORE, \& SPOON

4.0

N55630.2 E64917.2

419.9

STRATIGRAPHIC DESCRIPTION

\section{SoI Silty clay, fine, bro. \\ DEWEXVIUE MFM. \\ Sardstone, fine, mod. hard, It. ton.}

Becoming soft at 5.0 feet.

From 10 feet observed some iron trining and small amount of gypsum frag.

\section{DEWESTIDETCONOULTA}

TRANSTION ZONE

Interbed.Sendstone/ Claystone.

CONeUISTA CLAY MEY.

Claystone, very thinly

bedded, some iroe staining, soft, v. It.

ton to grey

Occasional thin gypsum seam and carbonacoous partings.

Chaystone, some sili,sok, grey.

Eocountered hard andstone seam at 42.7 to 43.0 foet.

Considerable fossil abells from 47 feet.

V. thin berd mandstone lens at 51.7 feet. End of fossils. 


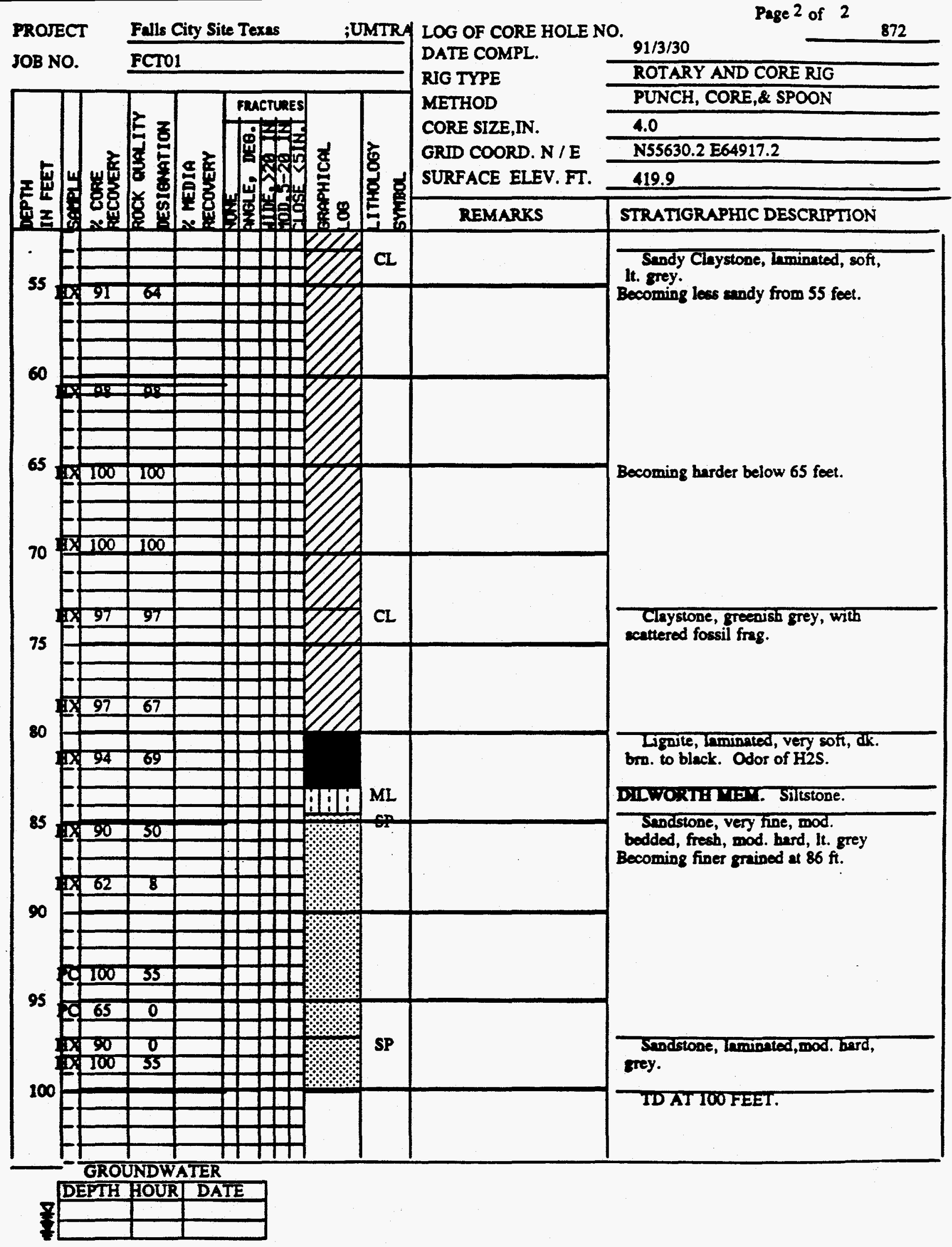


Page 1 of 2

PROJECT Falls City Site Texes ;UMTRA LOG OF CORE HOLE NO.

JOB NO. FCTO1

DATE COMPL.

RIG TYPE

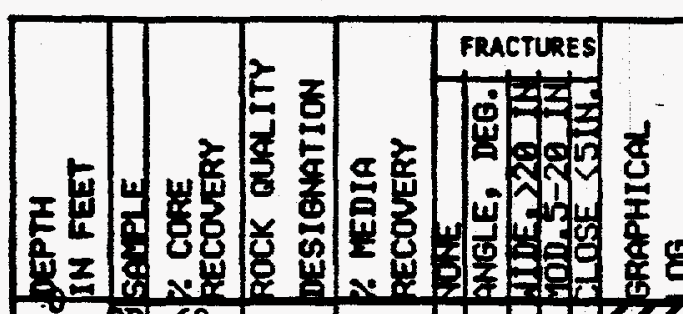

METHOD

CORE SIZE,DN.

GRID COORD. N / E

SURFACE ELEV.FT

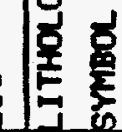

$\mathrm{CH}$

$\mathbf{s}$

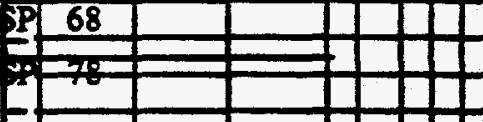

10

92

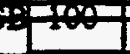

(5)

व 90

9100
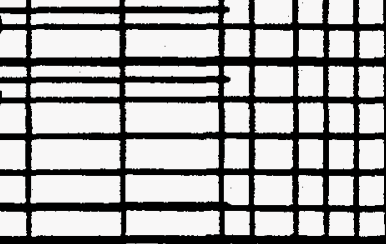

$$
\text { ( }
$$

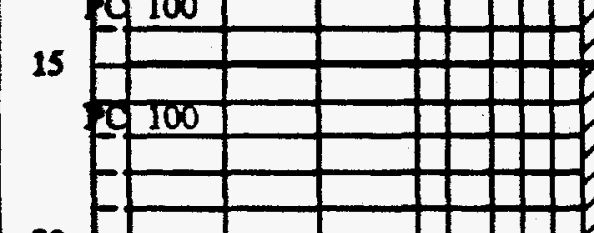

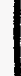

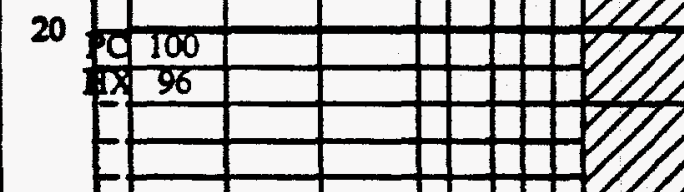

25

25

30

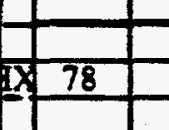
$+12 / A^{M}$

$\mathrm{CL}$

CL Continuous amples

takeo by grab amples, Punch Core.

spoon or, HXX core

barrel.

Hole plugged with bentonite pellets and chips.

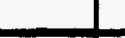

91/4/26

ROTARY AND CORE RJG PUNCH,SPOON \& CORE

4.0

N60405.2 E65278.0

456.5

STRATIGRAPHIC DESCRIPTION

SII Silty Clay, bigh plest. black.

\section{DEWESVIUEMEM}

Sendy Claystone, come iron

thining on partings, very, soft, lt. ton.

Occesional thin seam of gypsum.

UPFE CONOUSIA CAY TIST.

Intercalated Claystone and

Siltstone, laminated, soft, occ. thin gypsum seam, tan to lt. brown.

grey.

40

35

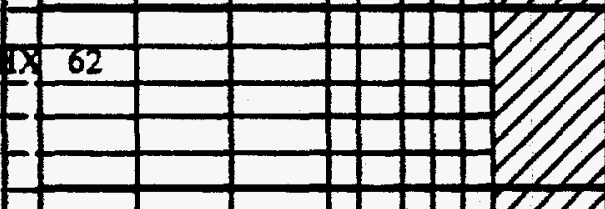

35

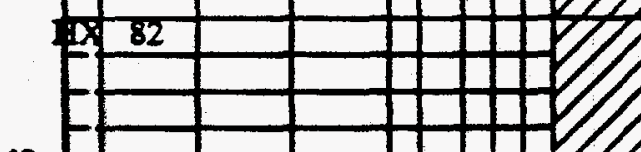

CL

45

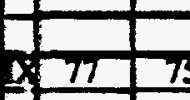

\begin{tabular}{lll|l|lll}
\hline 271 & 75 & & & & \\
\hline & & & & & & \\
\hline
\end{tabular}
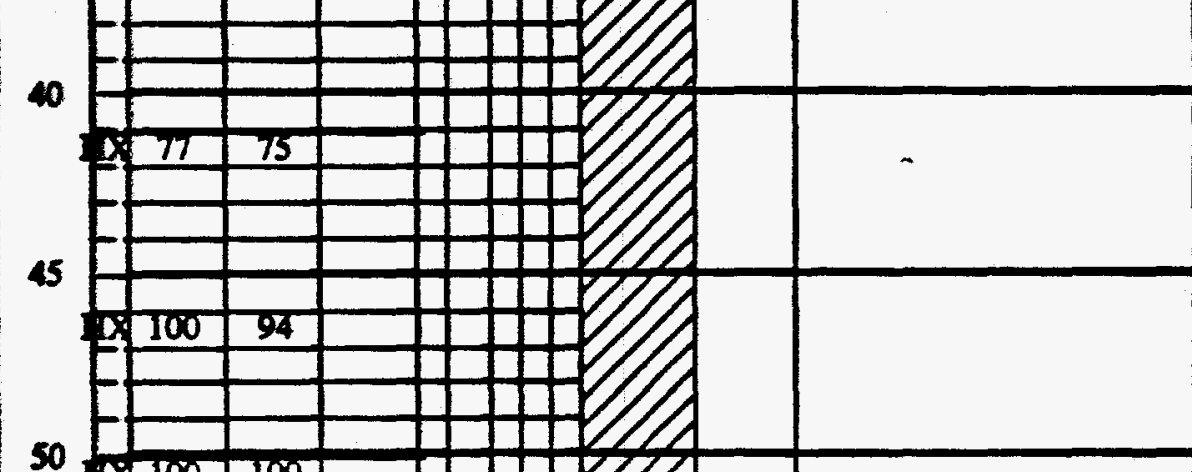

50

\begin{tabular}{ll|l}
\hline$x$ & 100 & 100 \\
\hline
\end{tabular}

GROUNDWATER

DEPTH HOUR DATE 


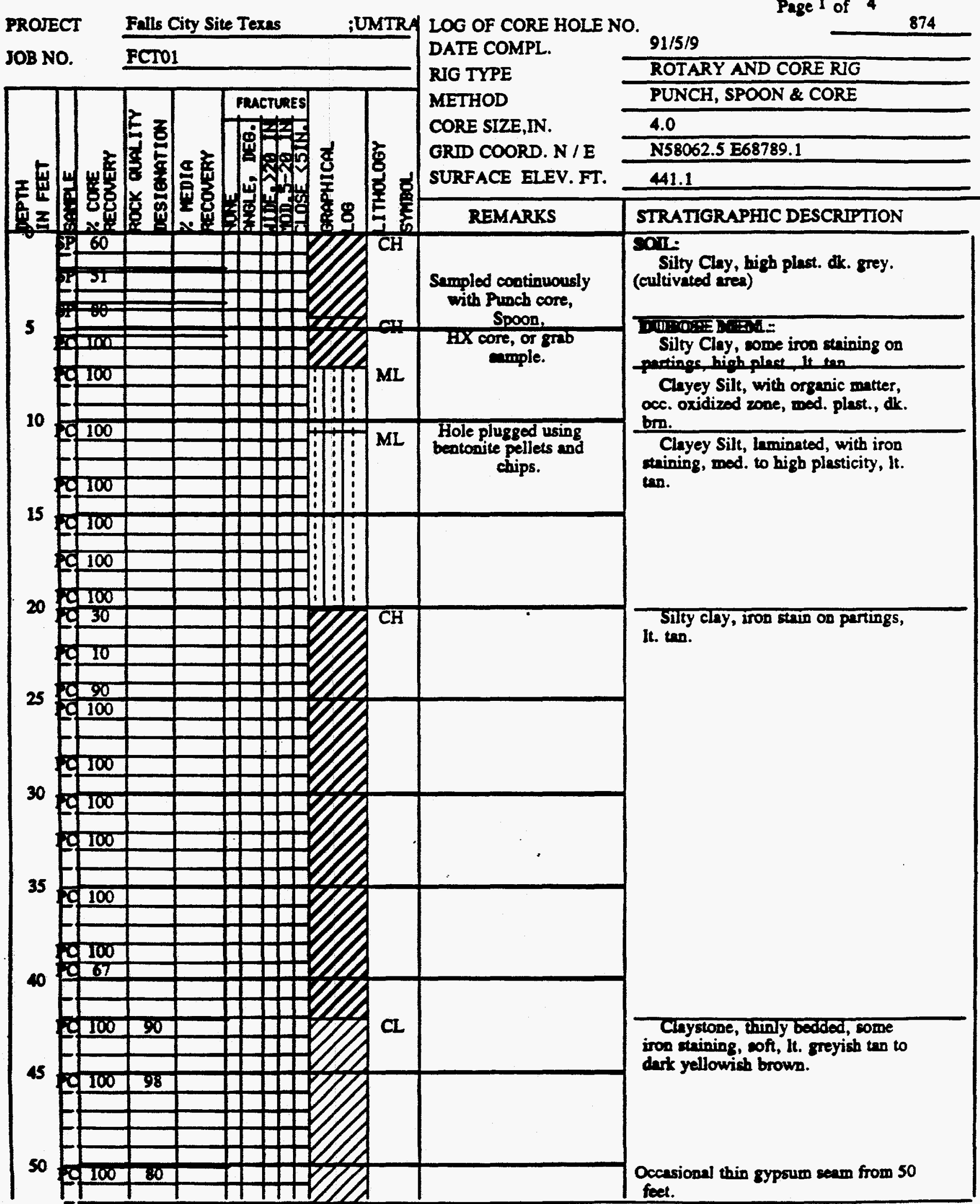

GROUNDWATER

DEPTH HOUR DATE 
PROJECT Falls City Site Texes ;UMTRA LOG OF CORE HOLE NO.

\section{JOB NO. FCTO1}

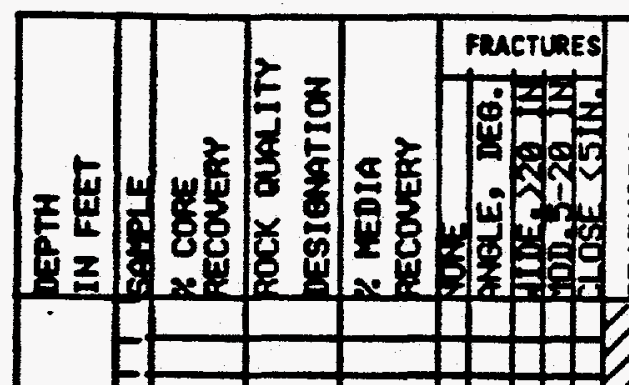

55

60

\begin{tabular}{lll}
\hline 100 & 78 \\
\hline
\end{tabular}

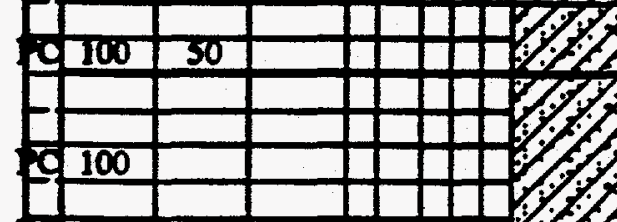

65

0700

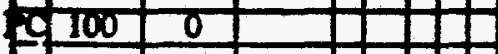

70

75

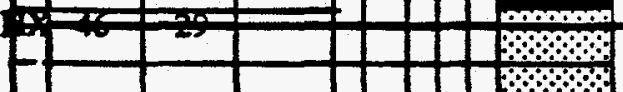

\begin{tabular}{|l|l|l|l|l|l|l|l|}
\hline & & & & & & \\
\hline
\end{tabular}

-

10

7

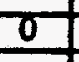

$\longrightarrow$

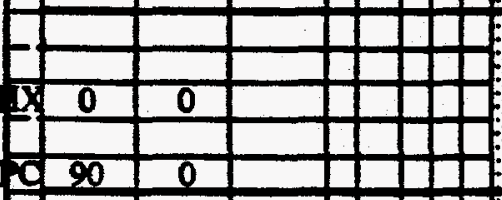

80

co

35

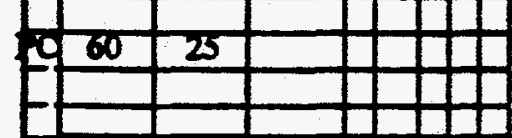

85

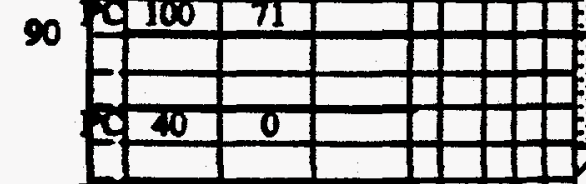

010071

95

\begin{tabular}{|l|l|}
\hline$x+10$ & 31 \\
\hline
\end{tabular}

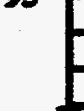

100

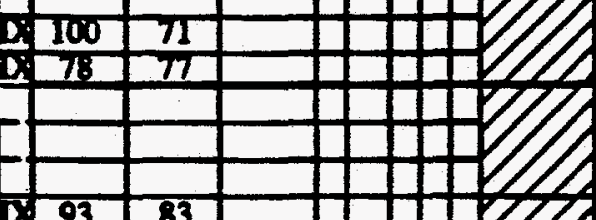

GROUNDWATER
DEPTH HOUR DATE
DATE COMPL.

RIG TYPE

METHOD

CORE SIZE,IN.

GRDD COORD. N / E

SURFACE ELEV. FT.

Page 2 of 4

91/5/9

ROTARY AND CORE RIG

PUNCH, SPOON \& CORE

$$
4.0
$$

N58062.5 E68789.1

441.1

STRATIGRAPHIC DESCRIPTION

DOECNET DSWEATIDE

TRANSTION ZONE Claystone.

sc

DEWESTILIE MTY:

Clayey Sendstone, v. fine, v.

thinly bedded, soft, dk. olive grey.

Occasionel coaly frag.

\section{Liguite, ak. bro.}

Sndstone, mod. herd, grey.
sendstone, hide, son,ti. Olive grey.

mod. hard from 73 to 74 feet.

Occasionel thin carbonaceous parting.

CL

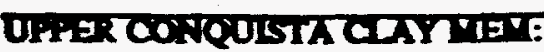

Claystone, fissile, woft, dark grey.

Occasional andy zowes.

Claystone, sligbtly fractured,

7

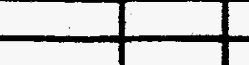


PROJECT Falls City Site Texas ;UMTRA LOG OF CORE HOLE NO.

JOB NO. FCTO1

Page 3 of 4 874

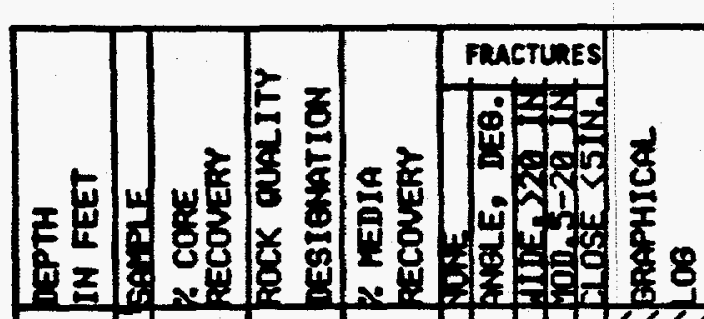
DATE COMPL.

91/5/9

RIG TYPE

ROTARY AND CORE RIG

METHOD

CORE SIZE,IN.

PUNCH, SPOON \& CORE

के GRID COORD. N / E

4.0

SURFACE ELEV. FT.

N58062.5 E68789.1

441.1

105

REMARKS

STRATIGRAPHIC DESCRIPTION

fresh, eoft, veriable color It. olive to

dk. olive grey.

Sndy Claystone, alightly

fractured, fresh, coft, it. olive grey.

Chystone, massive, slightly fractured, mod. hard, It greyish green to dk. olive grey.

115

\begin{tabular}{|l|l|}
\hline $1 \times$ & \\
\hline 13 & 38 \\
\hline
\end{tabular}

CL

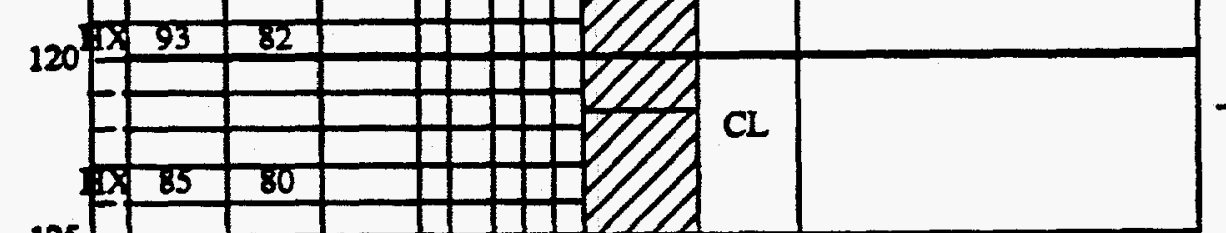

Sendy Claystone, some shell

fossils, mod fractured, very soft, lt. olive grey.

125
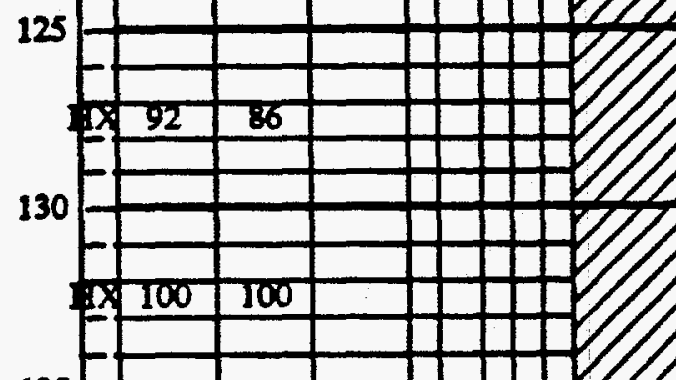

135

\begin{tabular}{ll}
\hline 100 & 100
\end{tabular}

140

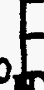<smiles>CC12CC3(C)CC1(C)C3(C)C2</smiles>

$$
\text { t }
$$
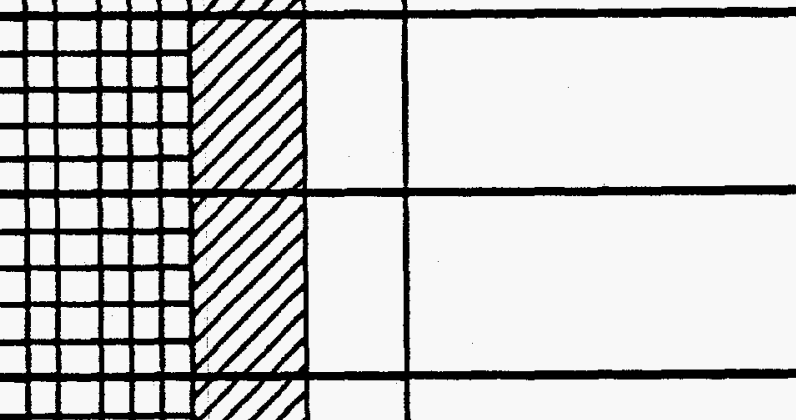

\section{$. M=C L$}

Claystone, fresh, slightly

fractured, massive, mod. herd, dk. olive grey.

Thin lignite seam at 143 foet

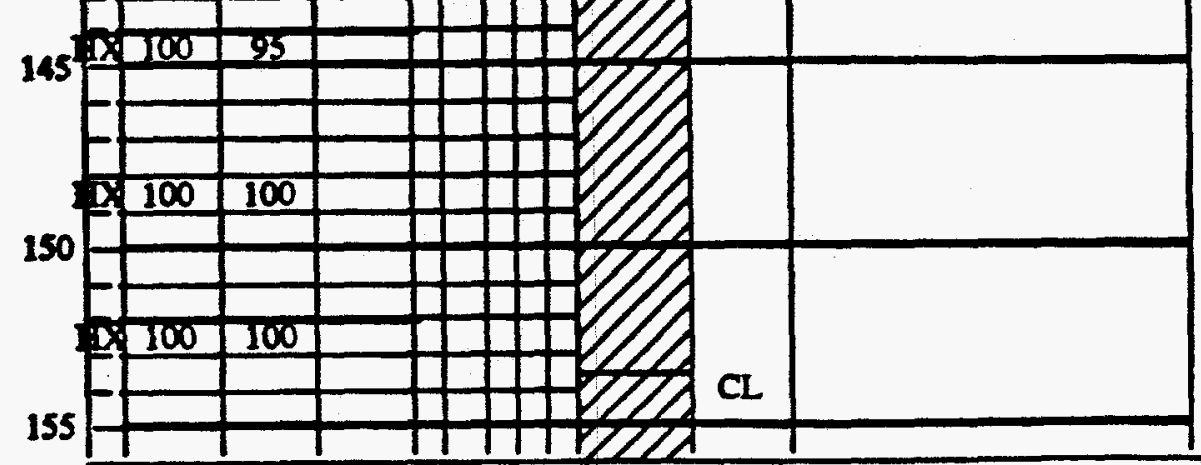

Slightly foesiliferous from 148 feet.

Chystone, considentble higute, slightly fract. 


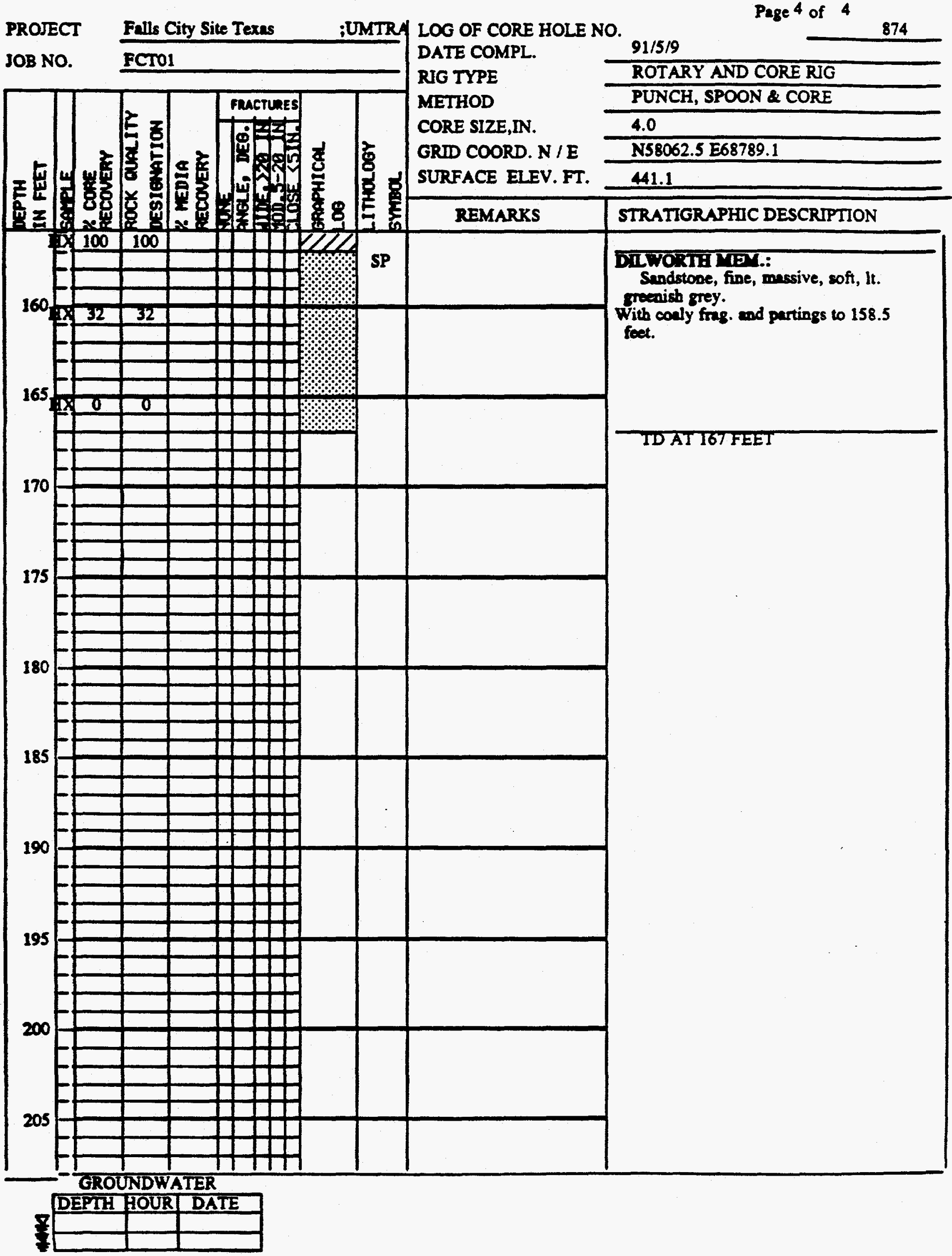


JOB NO. FCTO1

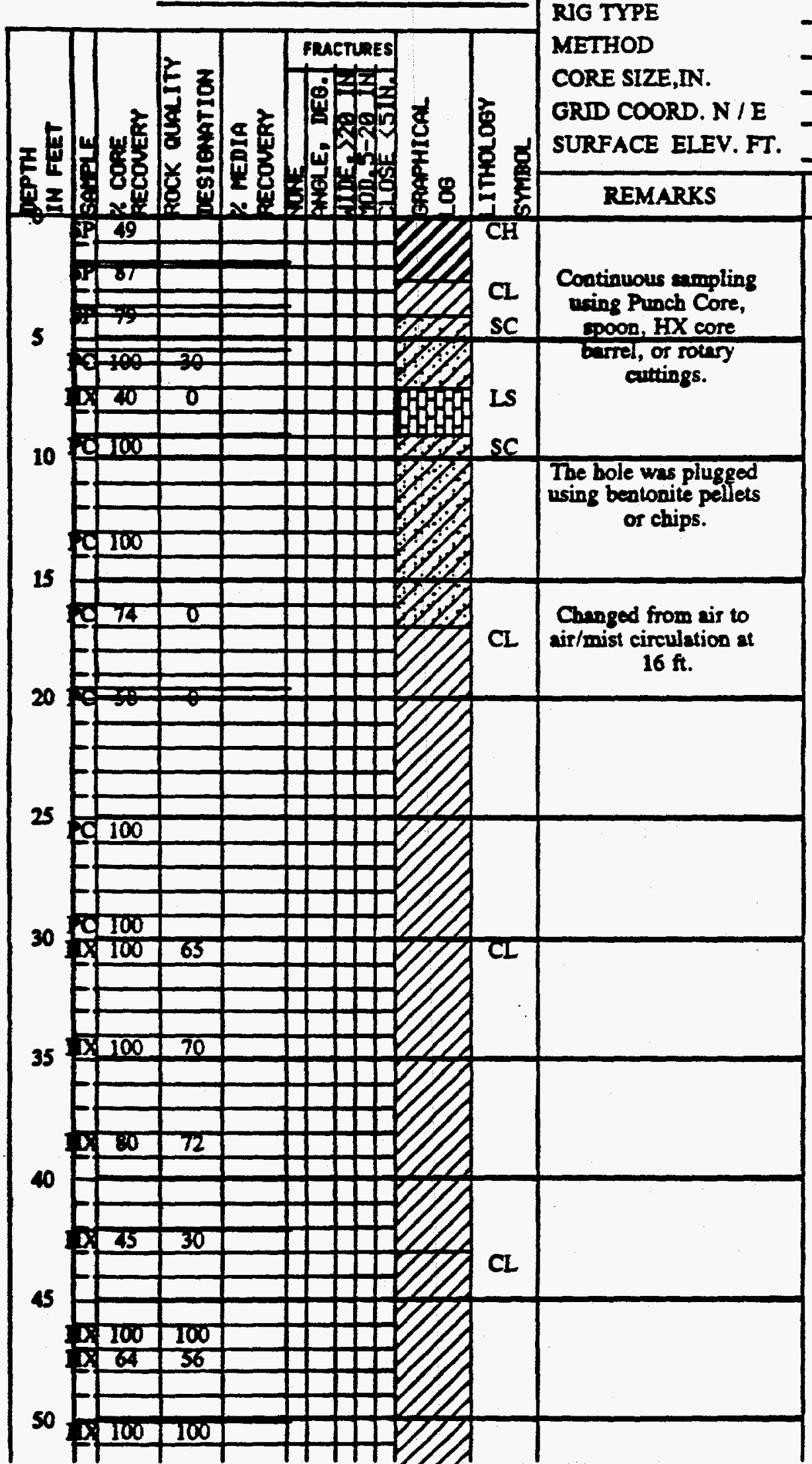

91/5/12
DATE COMPL.

RIG TYPE

ROTARY AND CORE RIG

PUNCH, SPOON \& CORE

4.0

N62305.0 E64184.3

445.6

STRATIGRAPHIC DESCRIPTION

SOI. Silty Clay, high plesticity, black.

swody Chay, oxid. Exining.

TIDDOE CONOULTACDY

MaY. Cluyey Sendstone, soft, with thin clay leases, lt. ton.

Limeotone, mod. close

fract mengenese entine on fouct

Cleyey Sandstone, very soft, with limonite staining, It. greyish tan to tan.

Becoming moist at 16 foet.

Sundstone, sofit to mod. hard, mod. to thin bedded, mod. to closely fractured, lt. greyish ten.

LOWER, CONQUISTA Q AYY MEY.:

Silty Claystone, highly oxidized, very sofi, lt. tan.

Occasional zone of gypsum fragments.

Mineralization becoming more reduced from 25 feet.

Chaystone, thin y bedded, mod. closely fractured, soft, dk. ten. Occesional thin gypsum seams, and limonite staining on partings.

End of oxidation zone at 36 feet. Becoming olive grey. Thin gypsum and lignite seams at 35 feet.

Occasional carbonnceous partings.

Claystone, massive, fresh, mod hard to soft, olive grey.

GROUNDWATER DEPTH HOUR DATE 
PROJECT Falls City Site Texes ;UMTRA LOG OF CORE HOLE NO.

JOB NO. FCTOI

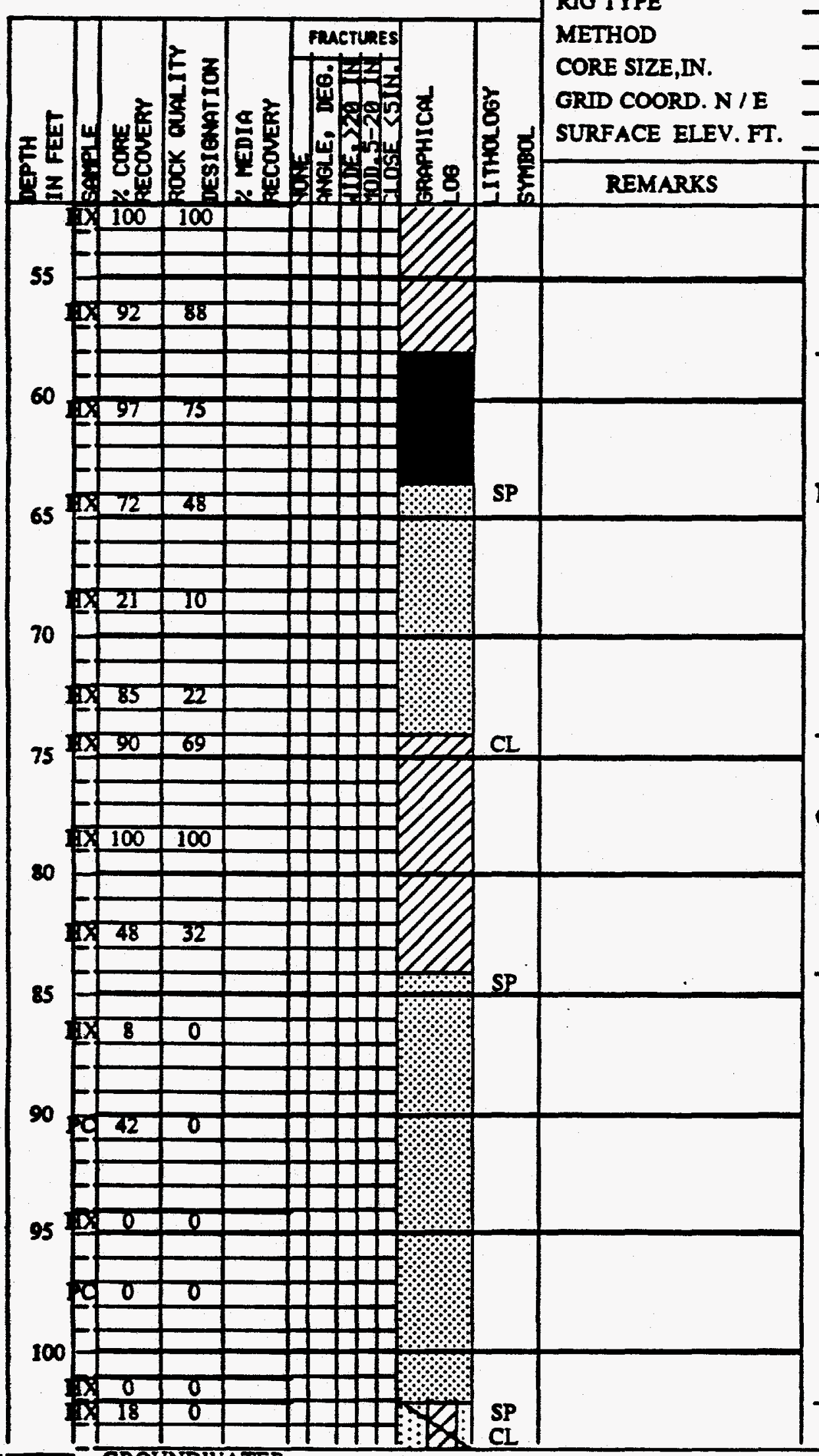

GROUNDWATER

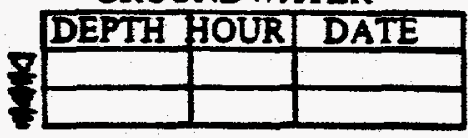

Page 2 of 4

$91 / 5 / 12$

DATE COMPL.

RIG TYPE

METHOD

CORE SIZE,IN.

ROTARY AND CORE RJG

PUNCH, SPOON \& CORE

4.0

N62305.0 E64184.3

445.6

STRATIGRAPHIC DESCRIPTION
Lignile, soft, dark brown to

black. Occasional aeam of bentonitic clay.

\section{DilOKTHDEV.:}

Sendstone, fine, wide spaced fractures, fresh, soft to mod. hard, It. greenish grey.

Clnystone, v. thinly bedded, mod. epaced fractures parallel to bedding. coft, It. olive grey.

Occasional thin sandstone lenses.
Sindstone, fine, sofit to mod. hard, 1t. greevish grey.

Occesional conly freg. Occesional thin claystone reams. 
PROJECT Falls City Site Texes ;UMTRY LOG OF CORE HOLE NO.

JOB NO. FCTO1

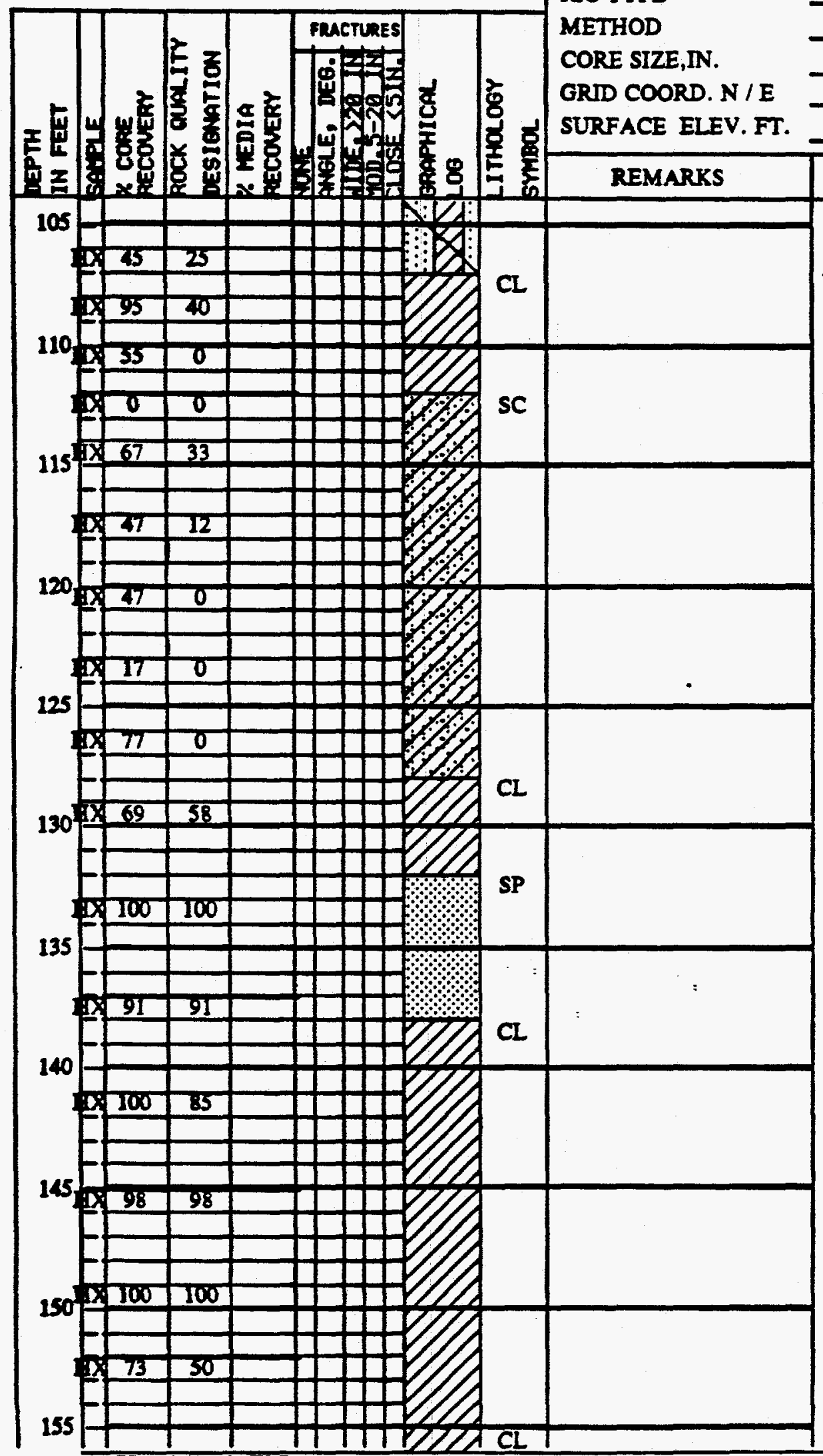

Page 3 of 4

$91 / 5 / 12$

ROTARY AND CORE RIG PUNCH, SPOON \& CORE

\begin{tabular}{l}
4.0 \\
N62305.0 E64184.3 \\
445.6 \\
\hline
\end{tabular}

STRATIGRAPHIC DESCRIPTION

fractures, coft, it. greenish grey to dark olive grey.

Claystone, thickly bedded to laminited, soft to v. coft, dark olive srey. Occasional thin seam of Clayey Sendistone.

\footnotetext{
Clayey Sandstone, very fine, soft, It. greenisb grey.
}

Less clay content from 117 feet.

Sandy Claystone, thinly bedded to massive, widely speced fractures, coft, olive grey.

Occesional coaly frement.

Sendstone, fine, sofi, widely spaced fractures, some carbonecoous partings olive grey.

Claystone, massive, soft, dark olive grey.

Oconsional andy ream.

Very thin Lignite weans at 154 to 155 feet. 


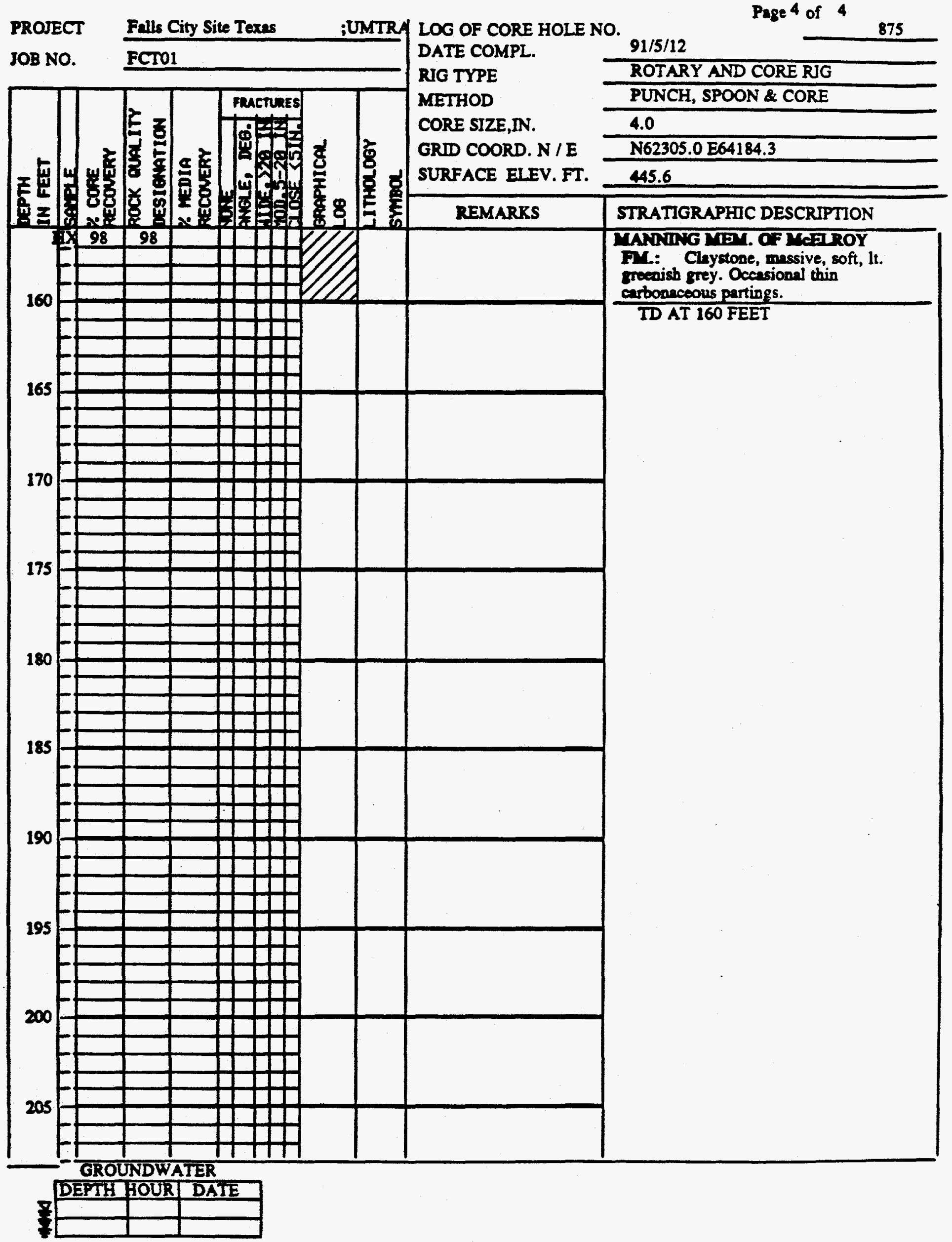


Page 1 of 4

PROJECT Falls City Site Texas ;UMTRA LOG OF CORE HOLE NO.

IOB NO. FCTO1

DATE COMPL.

91/5/15

876

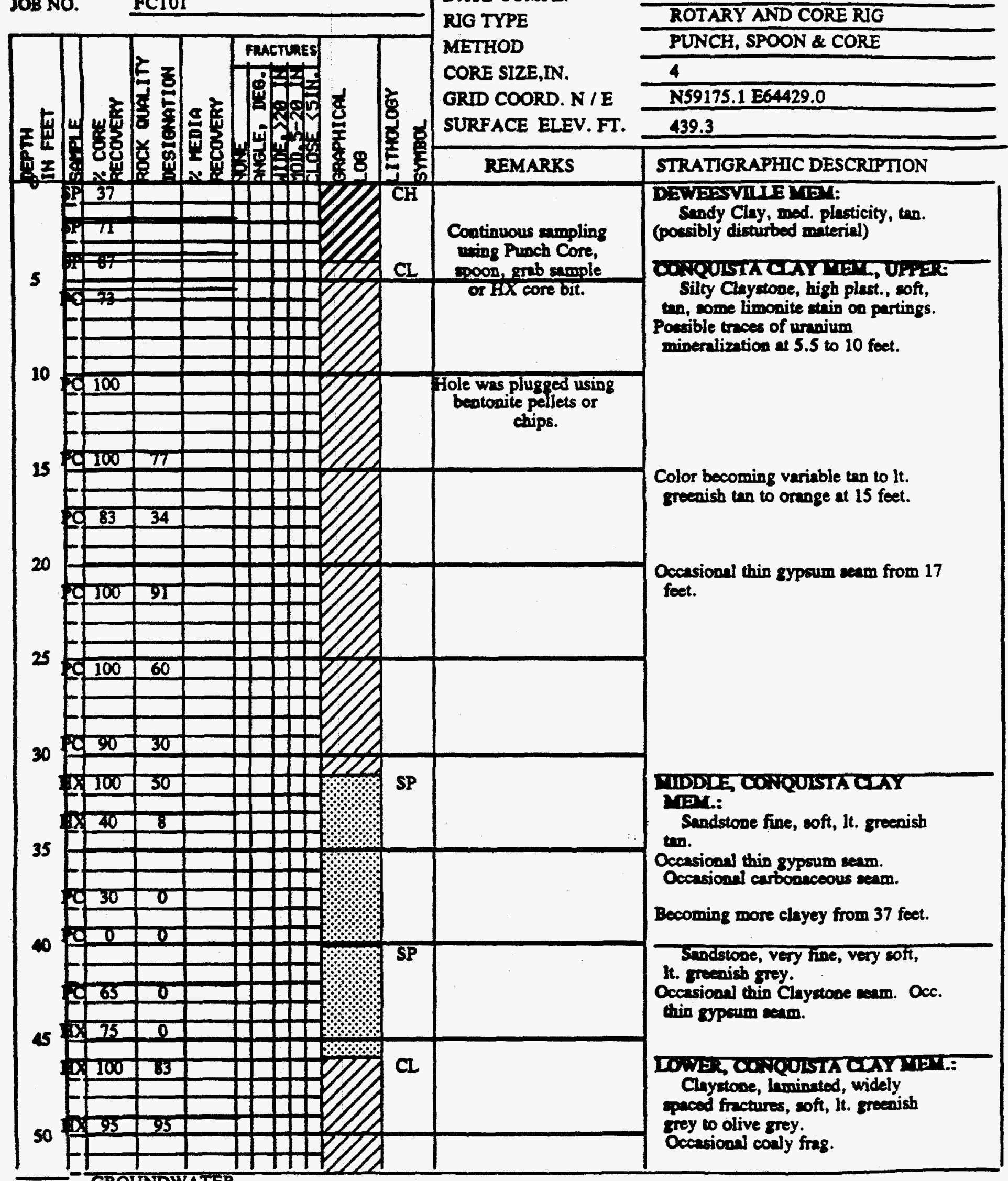

GROUNDWATER

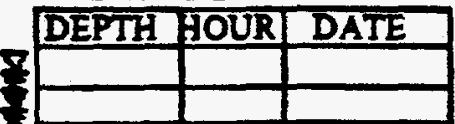




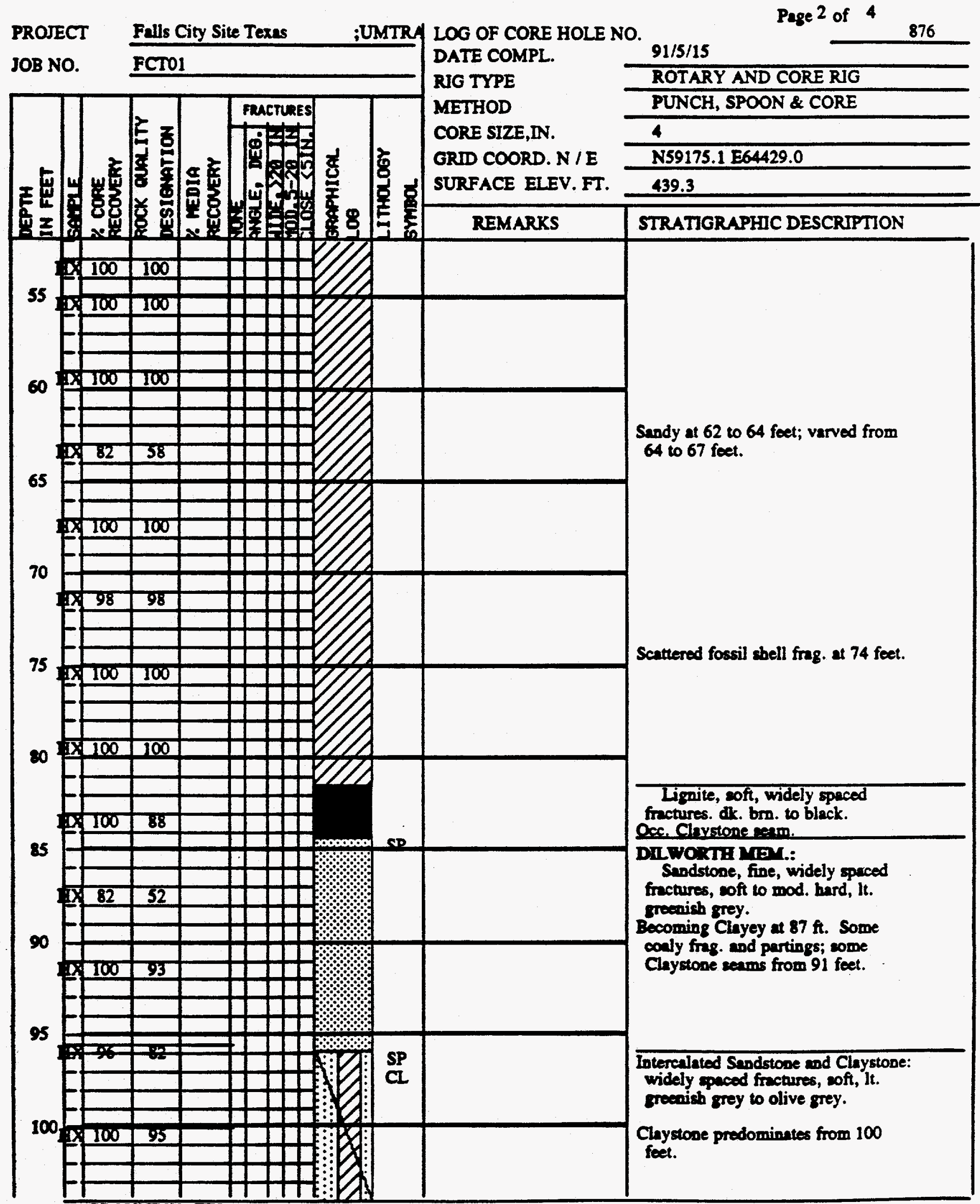

GROUNDWATER

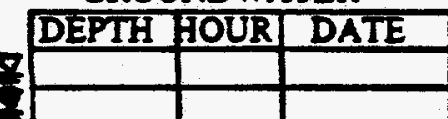


Page 3 of 4

PROTECT Fells City Site Texes ;UMTR IOG OF CORE HOLE NO.

JOB NO. FCTOI

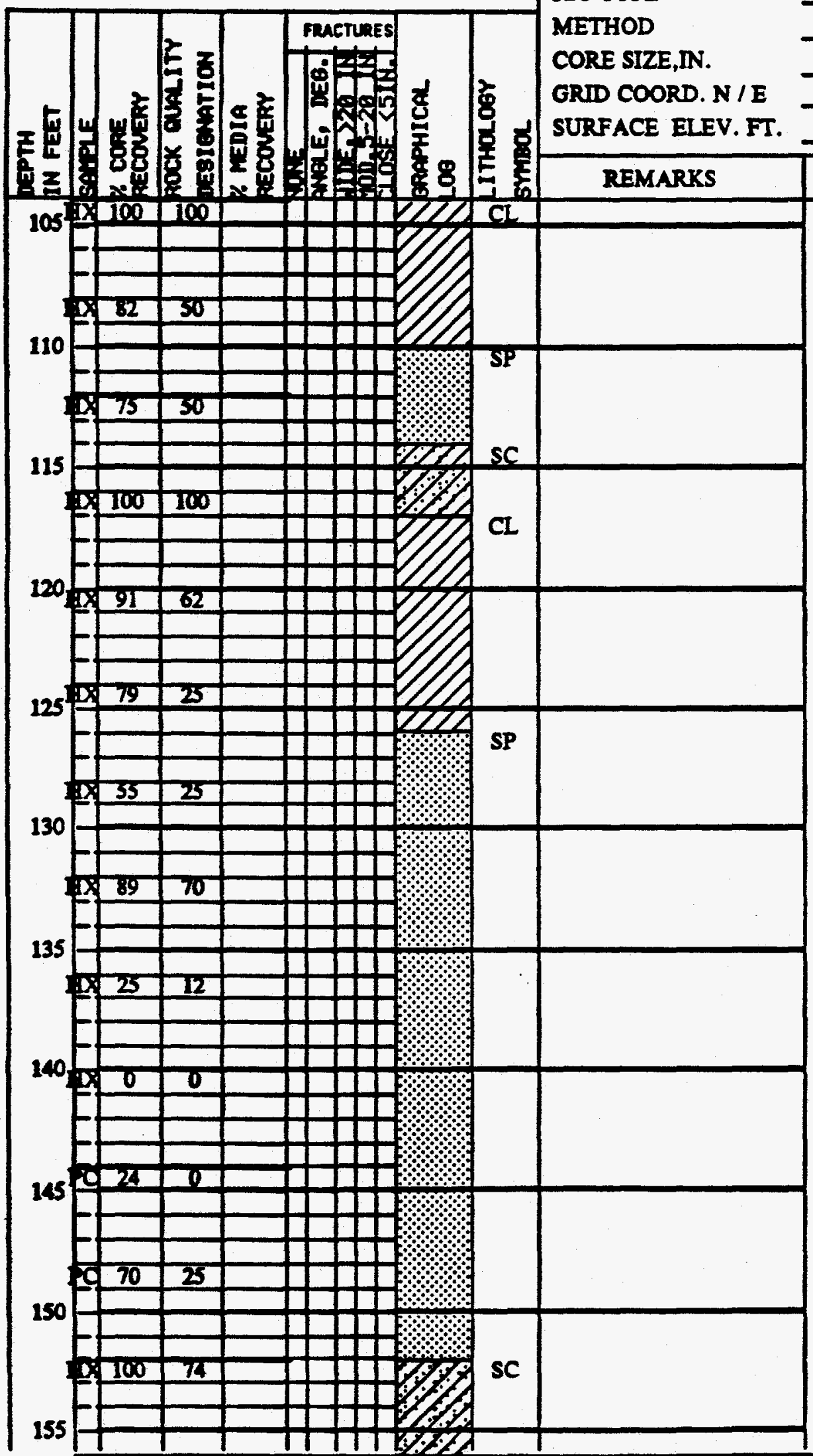

91/5/15

DATE COMPL.

ROTARY AND CORE RIG PUNCH, SPOON \& CORE

4

N59175.1 E64429.0

439.3

STRATIGRAPHIC DESCRIPTION

Clayetone, massive, coft, olive trey.

Occasional mondetone lenses and lignite partings.

Sendstone, tine, mod. speced frectures, soft, It. greenish grey. Two inch thich neam of shell frag. at upper contact.

Clayey Sendstone, v. fine, fractured, soft,lt. olive grey.

Claystone, fractured, soft, olive stey.

Occasional thin Sundstone seam.

micro-compaction slickensides at 118 feet.

andy zoae from 120 to 123 feet.

Sendstone, closely fractured, soft,
lt. greenish grey. Occasional thin Claystone seam.
Clayey soadone, v. fine, soft, It. dive erey.

Occasional colly fing. 


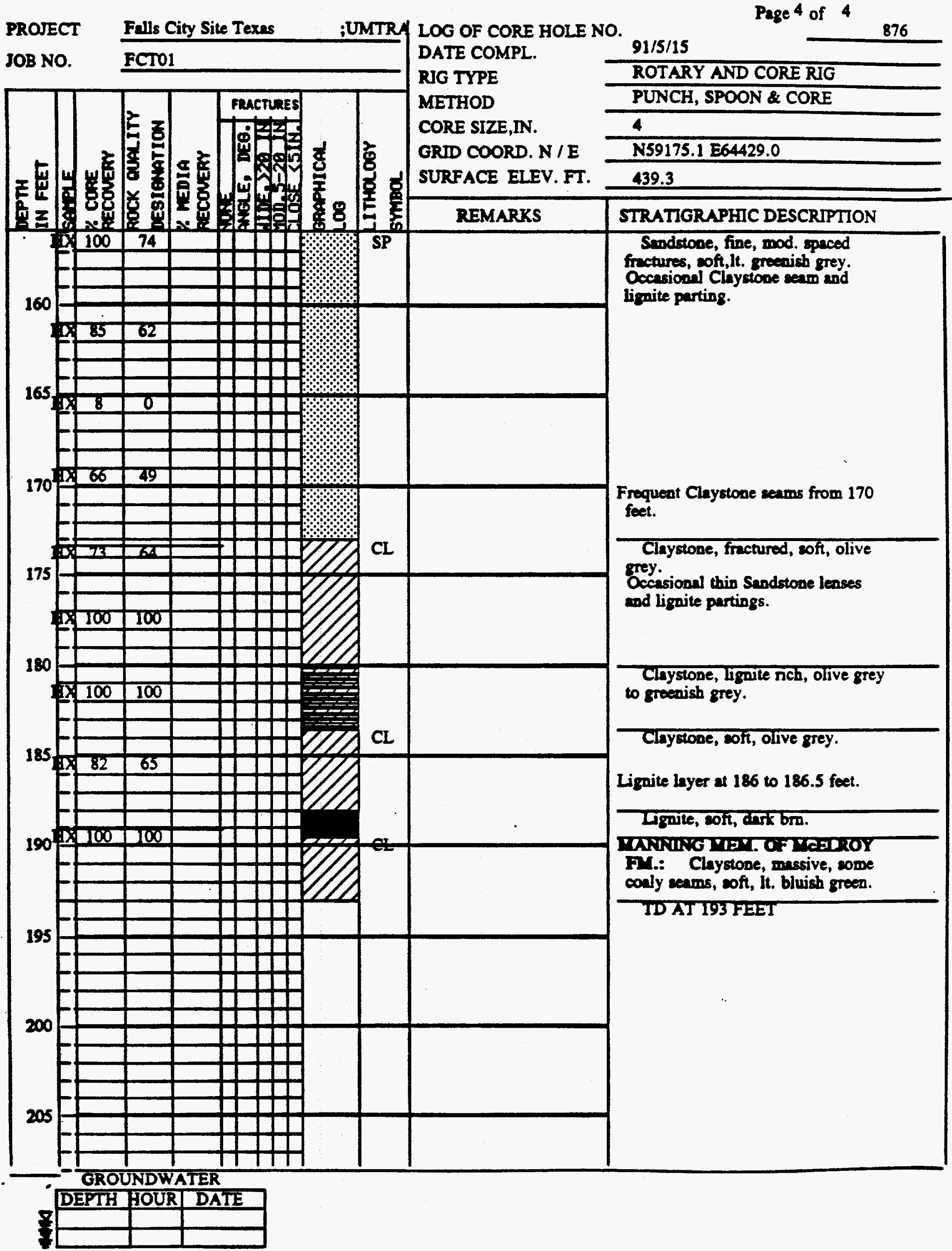


;UMTRA LOG OF CORE HOLE NO.

\section{JOB NO. FCTO1}
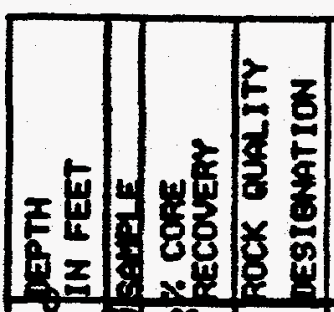

营

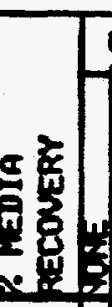

Facerumes

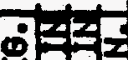

iin
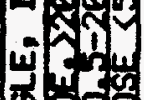

호을
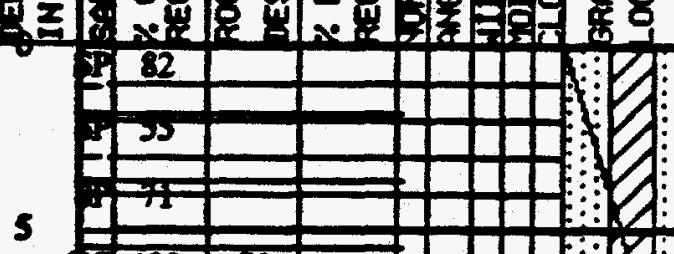

5

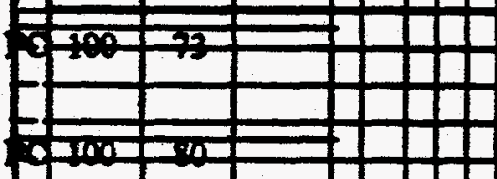

10

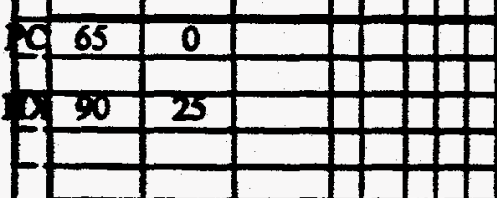

15

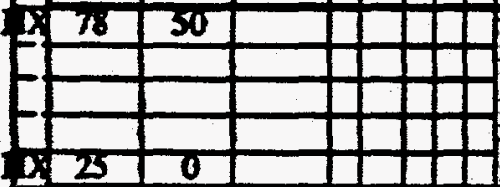

20

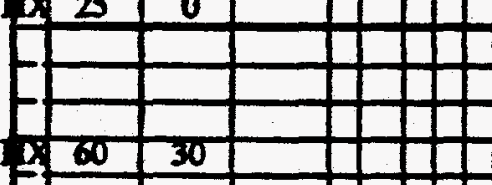

25

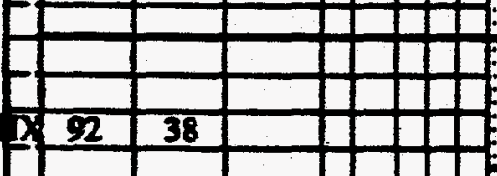

30<smiles>C1CC2CC12</smiles>

35
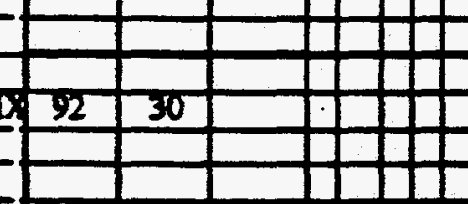

to

2

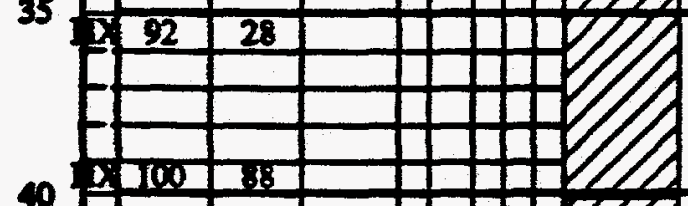

40

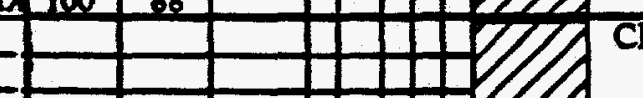

45

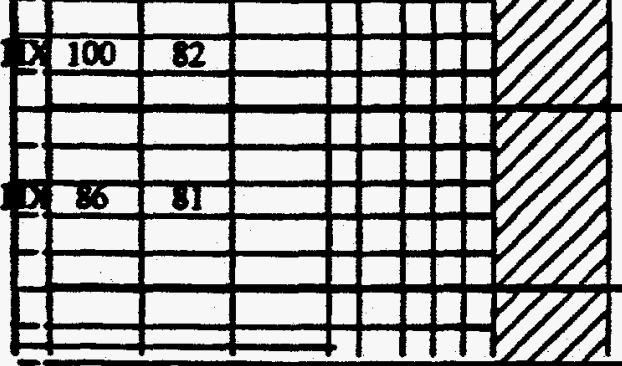

GROUNDWATER

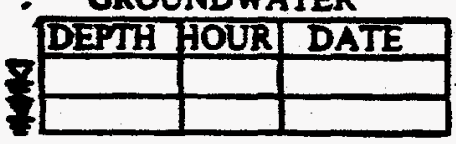

DATE COMPL.

RIG TYPE

METHOD

CORE SIZE,IN.

GRID COORD. N / E

SURFACE ELEV. FT.

REMARKS

SP

Continuous manpling

uaing spoon, Punch

Core or

ix $x$ core bit.

\begin{tabular}{|l|l|} 
SP & $\begin{array}{c}\text { Hole was plugged with } \\
\text { bentonite pellets and } \\
\text { mips. }\end{array}$ \\
\hline
\end{tabular}

\section{St}

$\mathrm{CL}$

CL

Page 1 of 2

91/5/21

ROTARY AND CORE RIG

PUNCH, SPOON \& CORE

\begin{tabular}{|c|}
\hline N58781.7 E65317.1 \\
\hline 433.4 \\
\hline STRATIGRAPHIC DESCRIPTION \\
\hline $\begin{array}{l}\text { DEWESSVIUE MaM.: } \\
\text { Intercalated Sundstone and Sandy } \\
\text { Claystone; very eoft, tan to lt. tan. } \\
\text { With come limonite staining and } \\
\text { minor amounts of carbonaceous } \\
\text { material in partings. }\end{array}$ \\
\hline
\end{tabular}

Increasing clay content with depth.

Sandstone, fine, thinly bedded, mod. herd, lt. brn.

Softer with little orange limonite stain from 13 feet.

Sandstone, with clay, fine mod. spaced fructures, sof, lt. bm. to greenish grey.

Some cross bedding.

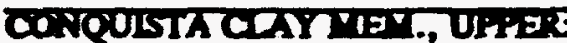

Claystone, soft, it. greenish grey.

Occasional Siltstone leases, and come limonite sthining on partings.

Occesional thin green bending from 31 to 33 feet.

Occ. thin gypsum seam and varigated zone from 35 to 38 feet.

Clnystone, messive, wh, dark olive grey. 


\section{PROJECT \\ JOB NO. FCTO1}

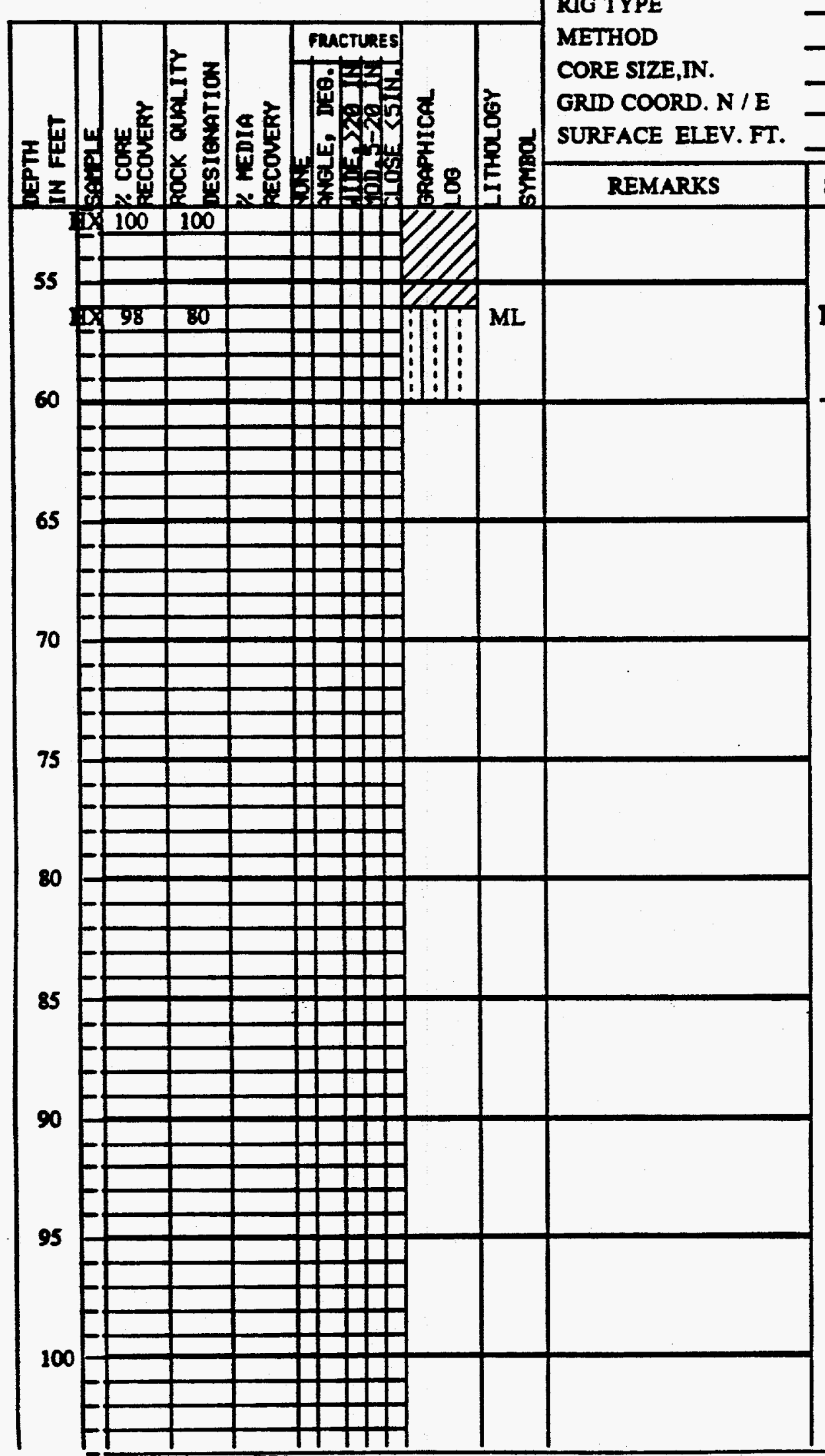

Page 2 of 2

;UMTRA LOG OF CORE HOLE NO.

DATE COMPL.

91/5/21

ROTARY AND CORE RIG PUNCH, SPOON \& CORE

4

N58781.7 E65317.1

433.4

STRATIGRAPHIC DESCRIPIION
TIIDDDE CONOULTA CDY

MISL: Sandy siltstone, with

fossils, very coft, olive grey. Occ.

Cleystone eams. Limestone lens at $59.9 \mathrm{ft}$.

TD AT 60 FEET.

GROUNDWATER

DEPTH HOUR DATE 


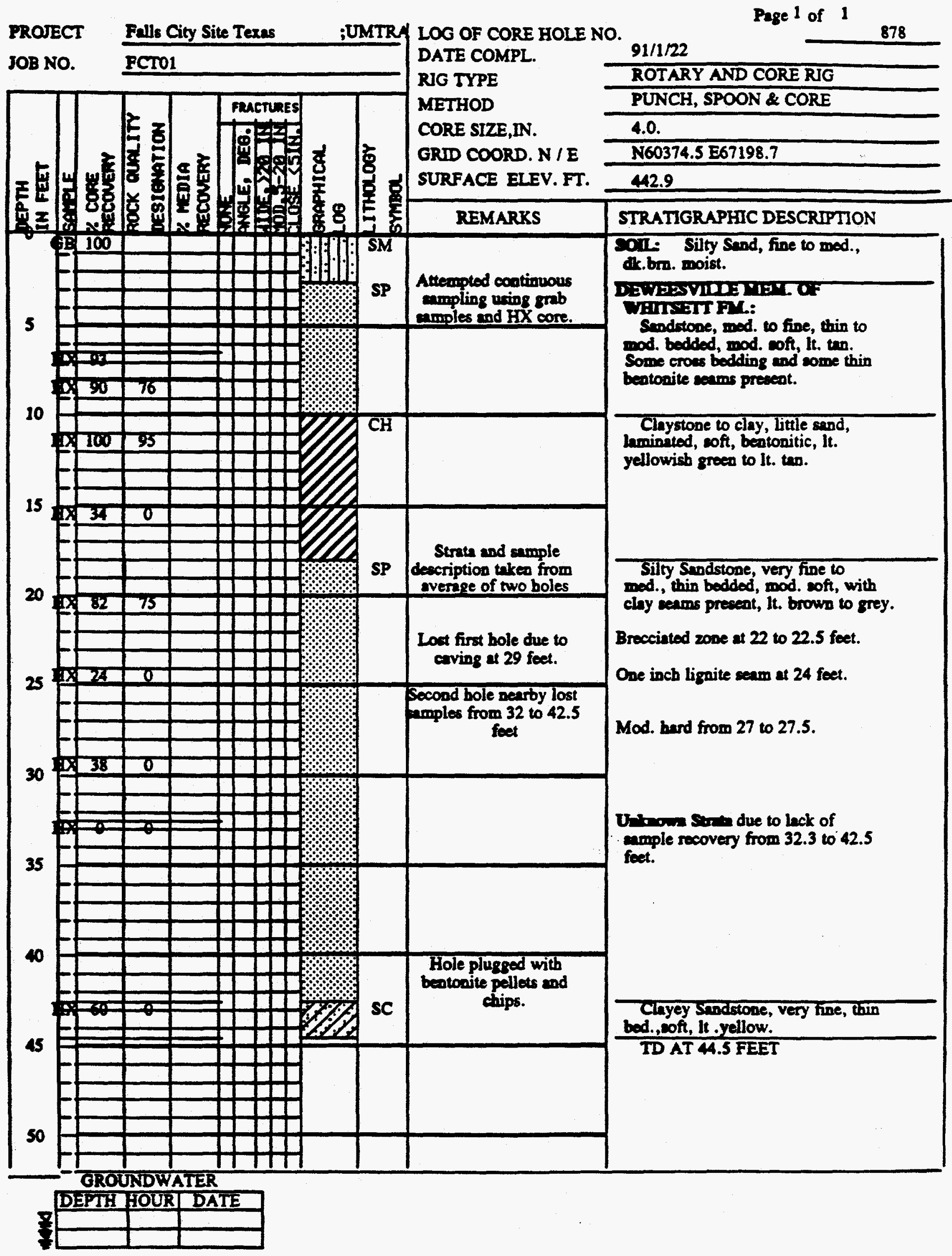




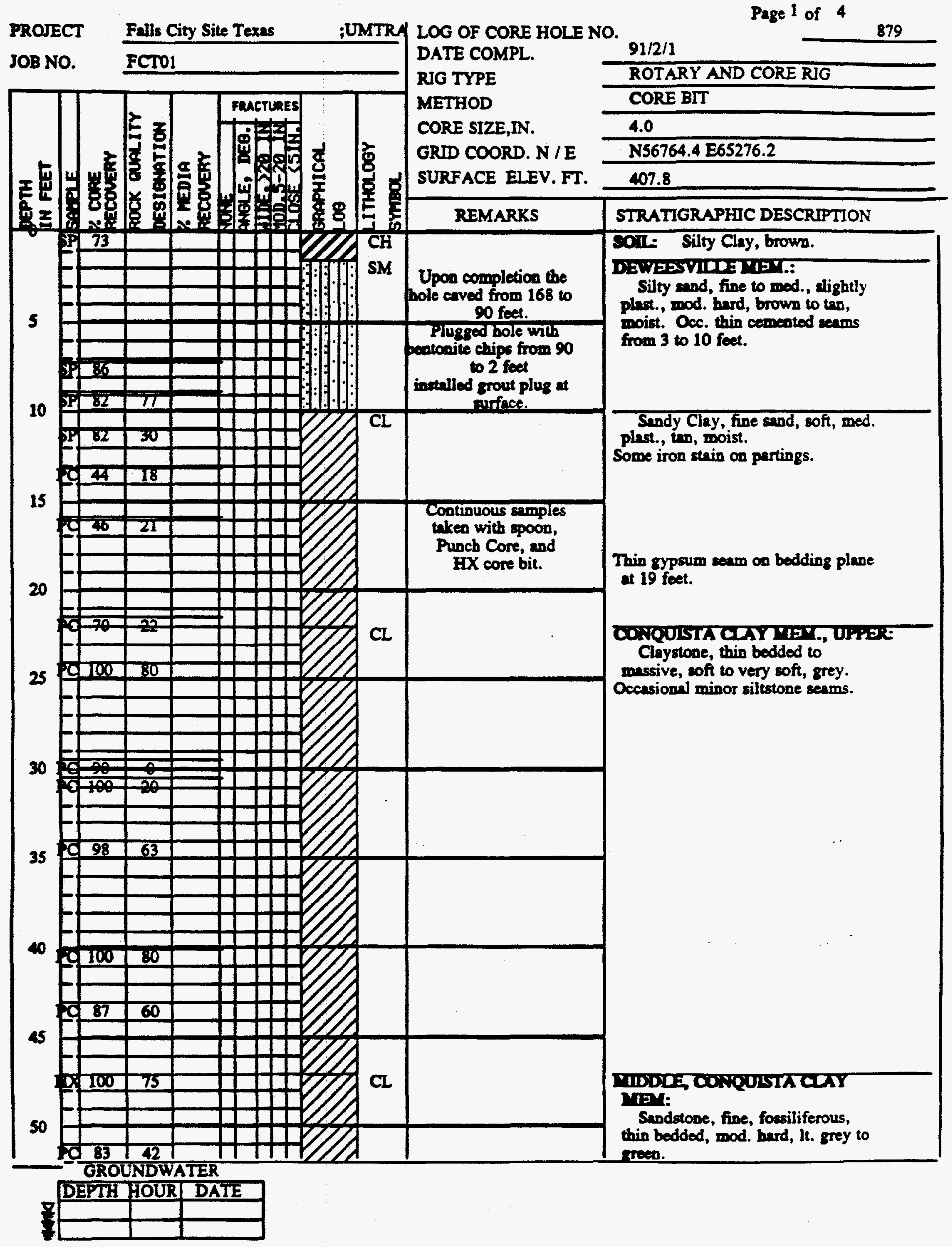


;UMTRA LOG OF CORE HOLE NO.

\section{JOB NO. FCTO1}

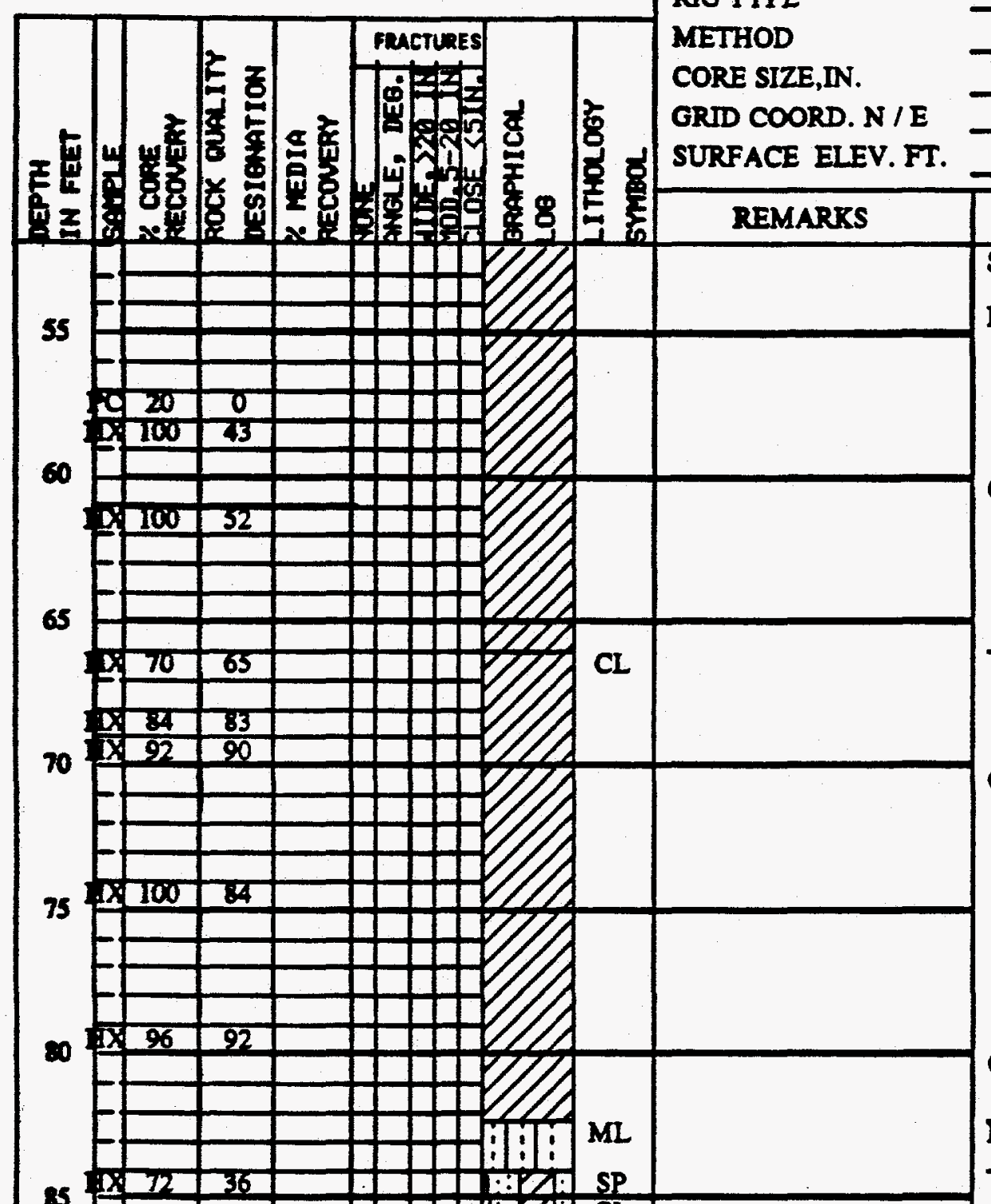

85

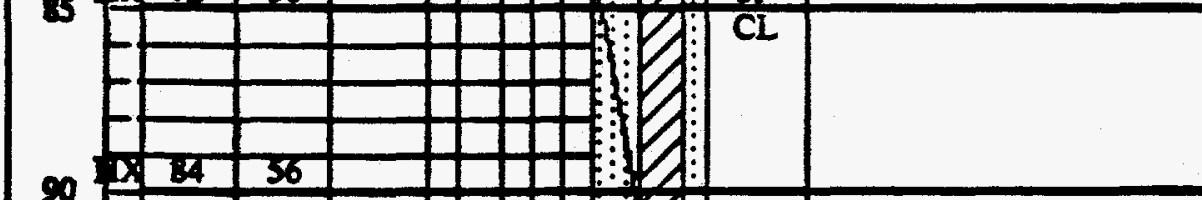

90

\begin{tabular}{l}
104 \\
\hline
\end{tabular}

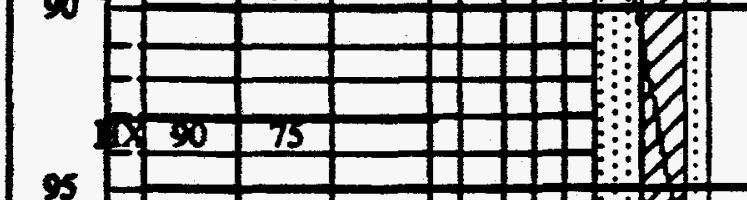

95
$x \times 10075$

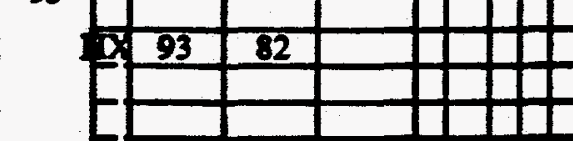

100

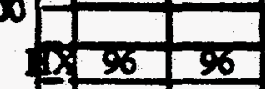

r

GROUNDWATER

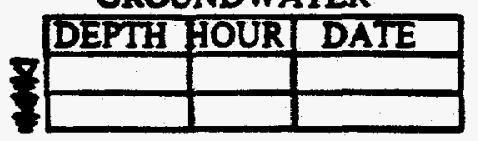

DATE COMPL.

RIG TYPE

METHOD

CORE SIZE, $\mathbb{N}$.

CORD $\mathbf{N} / \mathrm{E}$

REMARKS

91/2/1

Page 2 of 4

ROTARY AND CORE RIG CORE BIT

$$
4.0
$$

$$
\text { N56764.4 E65276.2 }
$$

407.8

STRATIGRAPHIC DESCRIPTION

Some interbedded Shvie and Siltstone, thin bedded.

LOWE, CONQUSTA CLYY ME.:

Claystone to clay, massive to thin bedded, coft, dk. grey moist.

Clayey Siltstone layer at 59 to 60.7 feet

Claystone, Leminated to massive, mod. soft, dk. grey.

Some Siltstone seams and fossil burrows present.

Odor of petroleum on fresh fracture.

Lignite, sandy, soft,black.

Odor of methene present.

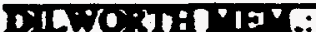

\section{Clnyey Sindstone to Siltstone.}

Silty andstone, fine, carbonsceous, thin bedded, mod. coft, 1t. grees to lt. grey; interbedded with Claystone, massive to thin bedded, mod. coft, dk. grey.

Chystone, massive to thin bedded, mod. hard, interbedded with minor siltstone, thin bedded, mod. 


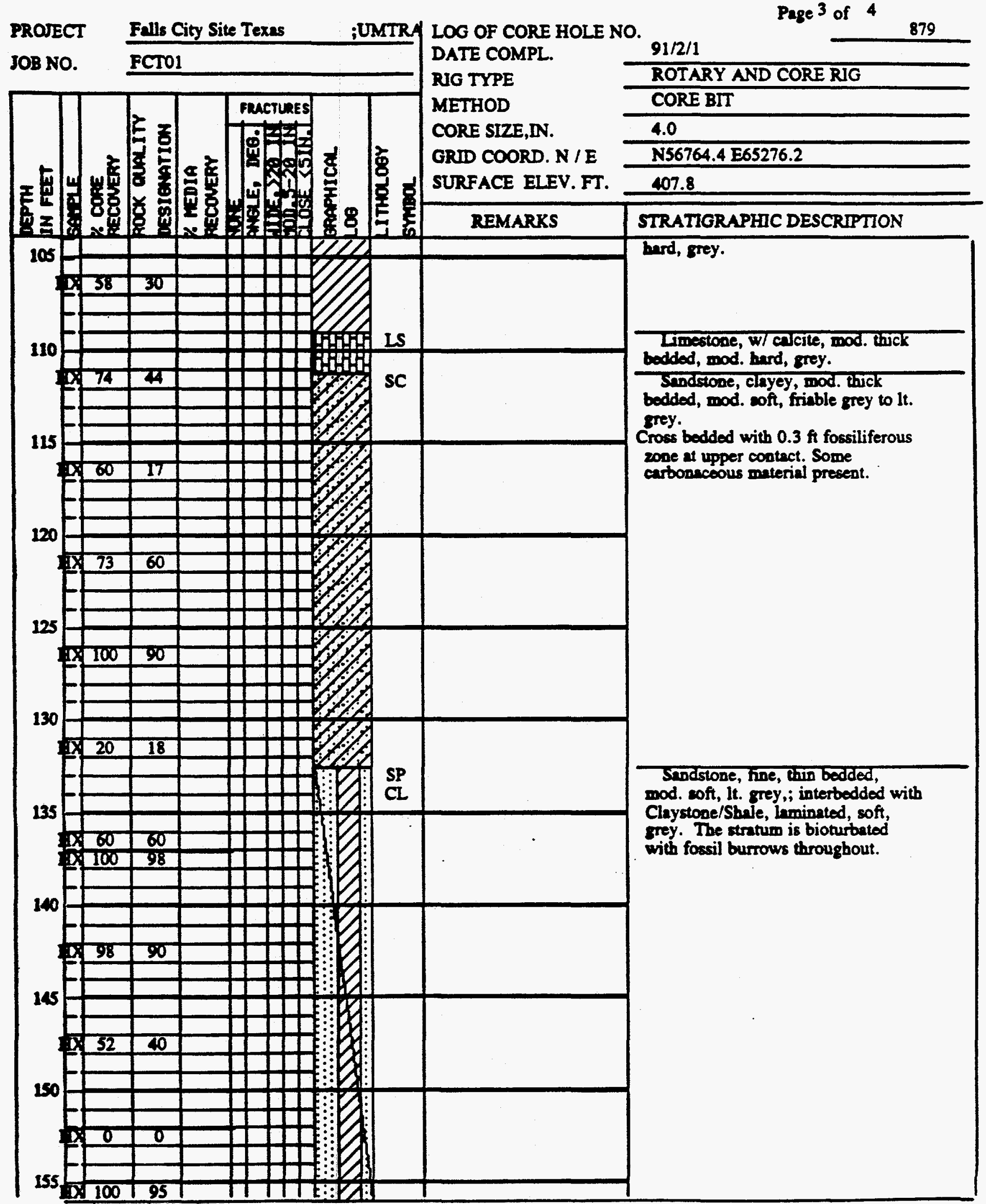

$\frac{\text { X } 100 / 95}{\text { GROUNDWATER }}$

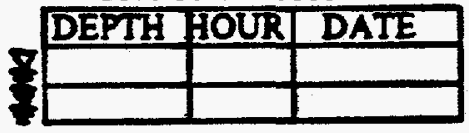




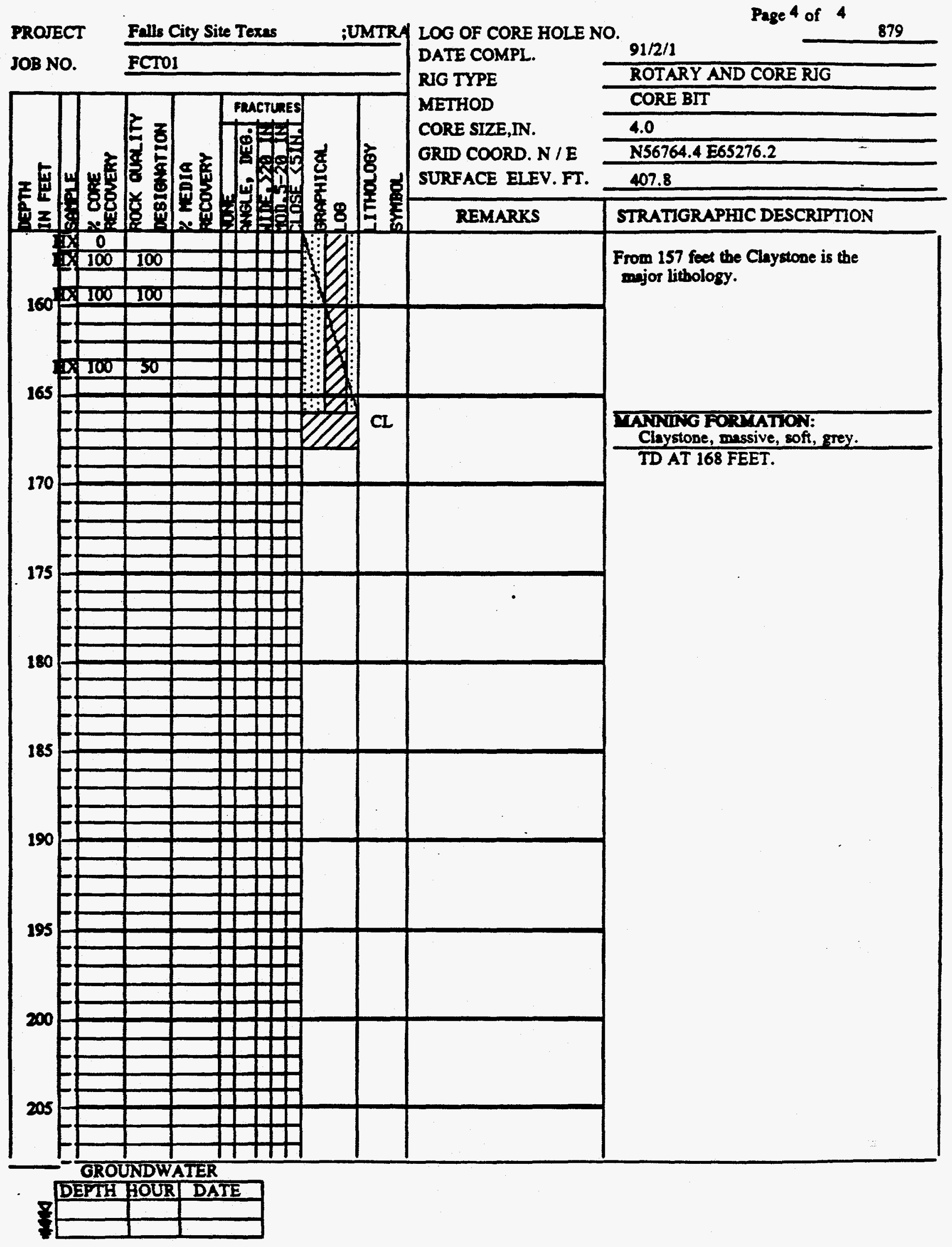


PROJECT Falls Ciry Site

Lower
upper con

20.19 .2

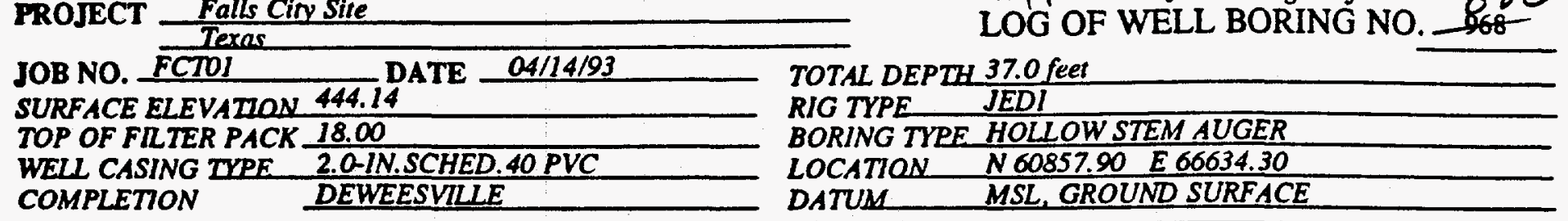

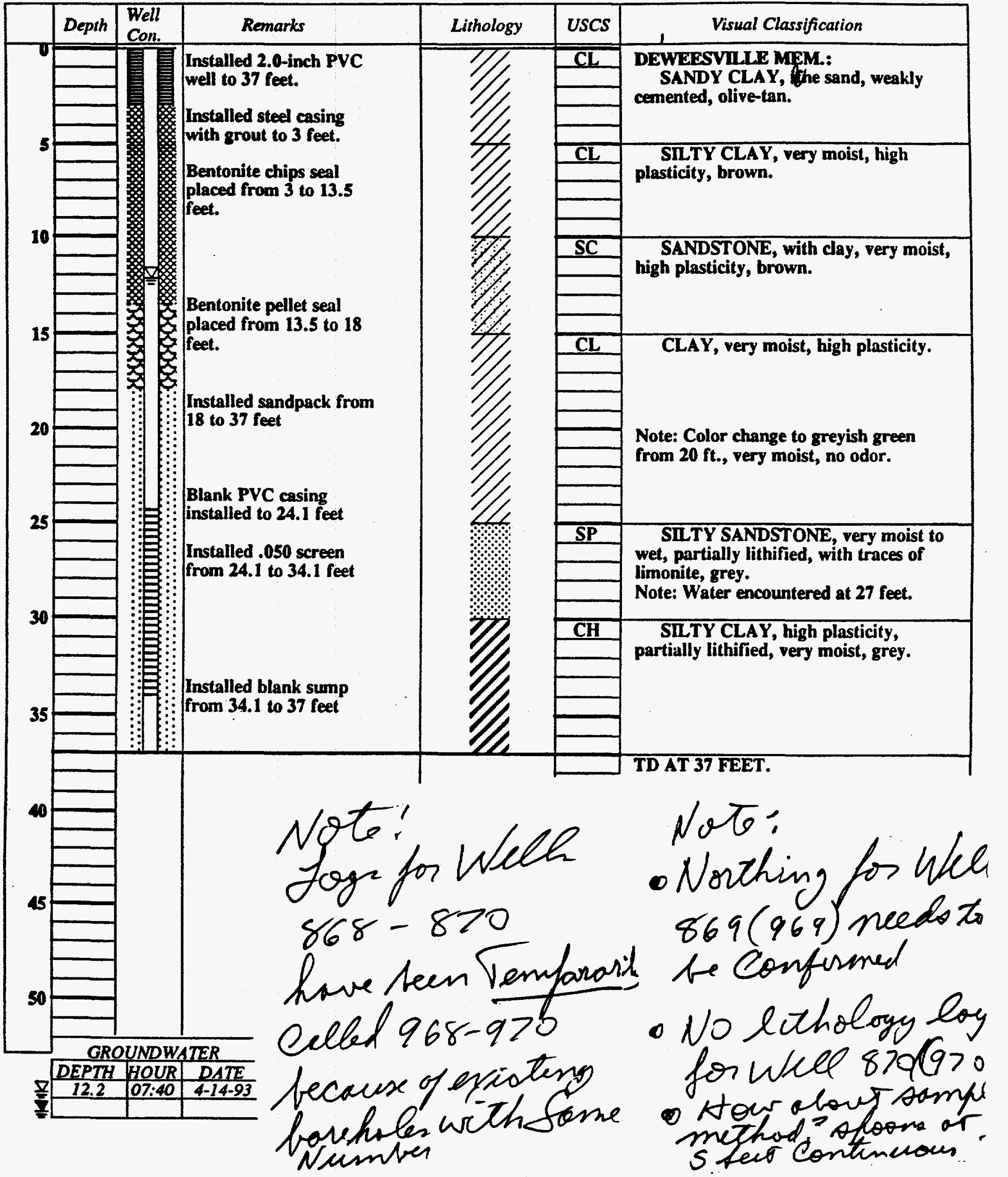


PROJECT Falls Ciry Site

JOB NO. $\frac{\text { Texas }}{\text { FCTOI DATE } 04 / 08 / 93}$

SURFACE ELEVATION 445.68

TOP OF FILTER PACK 71.00

WELL CASING TYPE 2.0-IN.SCHED.40 PVC

COMPLETION CONOUISTA CLAY,

TOTAL DEPTH 93.0 feet

LOG OF WELL BORING NO.

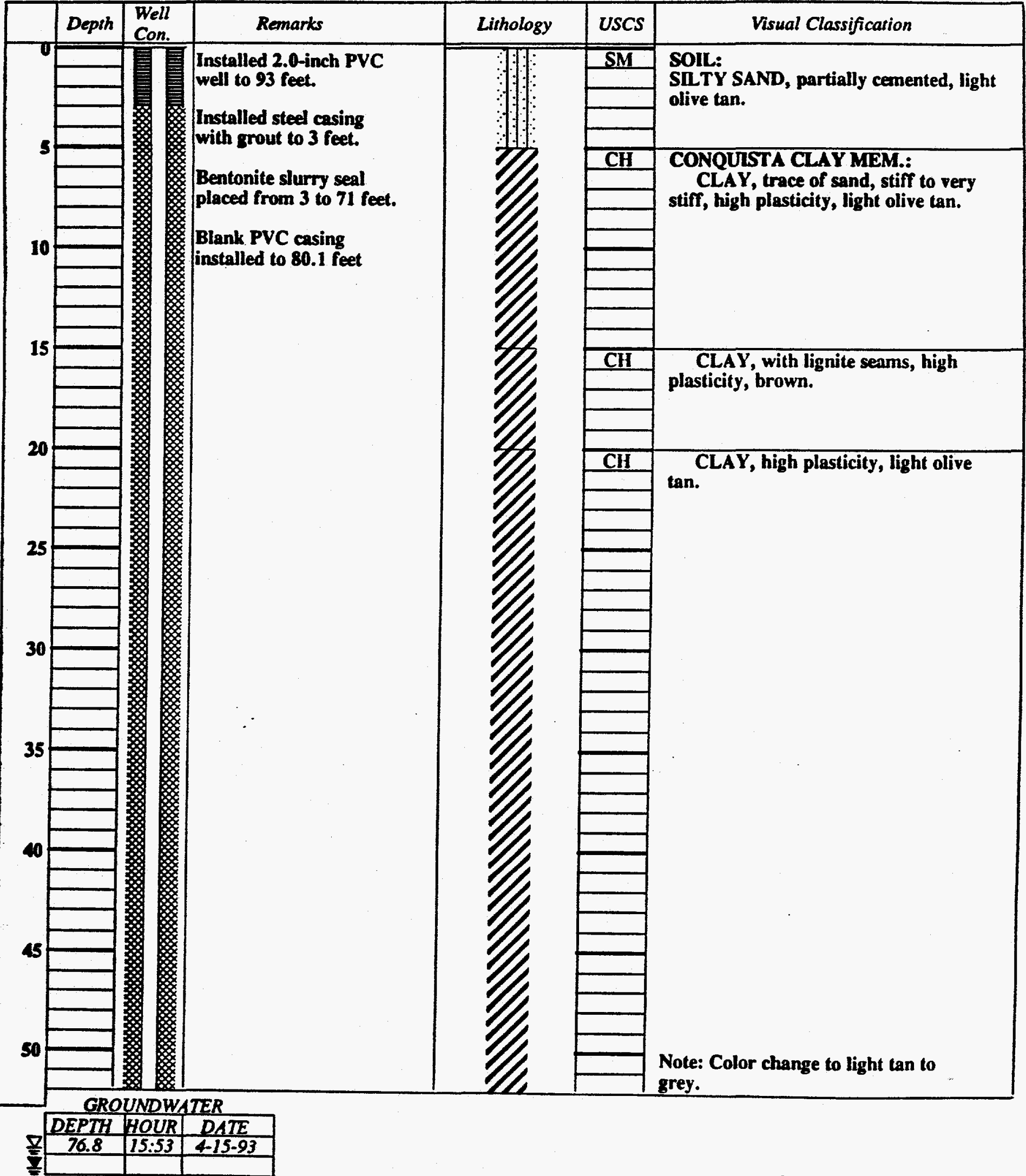


JOB NO. FCTOL DATE 04/08/93

SURFACE ELEVATION 445.68

TOP OF FILTER PACK $\frac{71.00}{201}$

ATE 04/08/93 TOTAL DEPTH 93.0 feet

WELL CASING TYPE 2.0-IN.SCHED.40 PVC COMPLETION CONOUISTA CLAY,northing?

TOTAL DEPTH 93.0 /

BORING TYRE HOLLOW STEM AUGER

LOCATION N 57678.81 E 68468.88

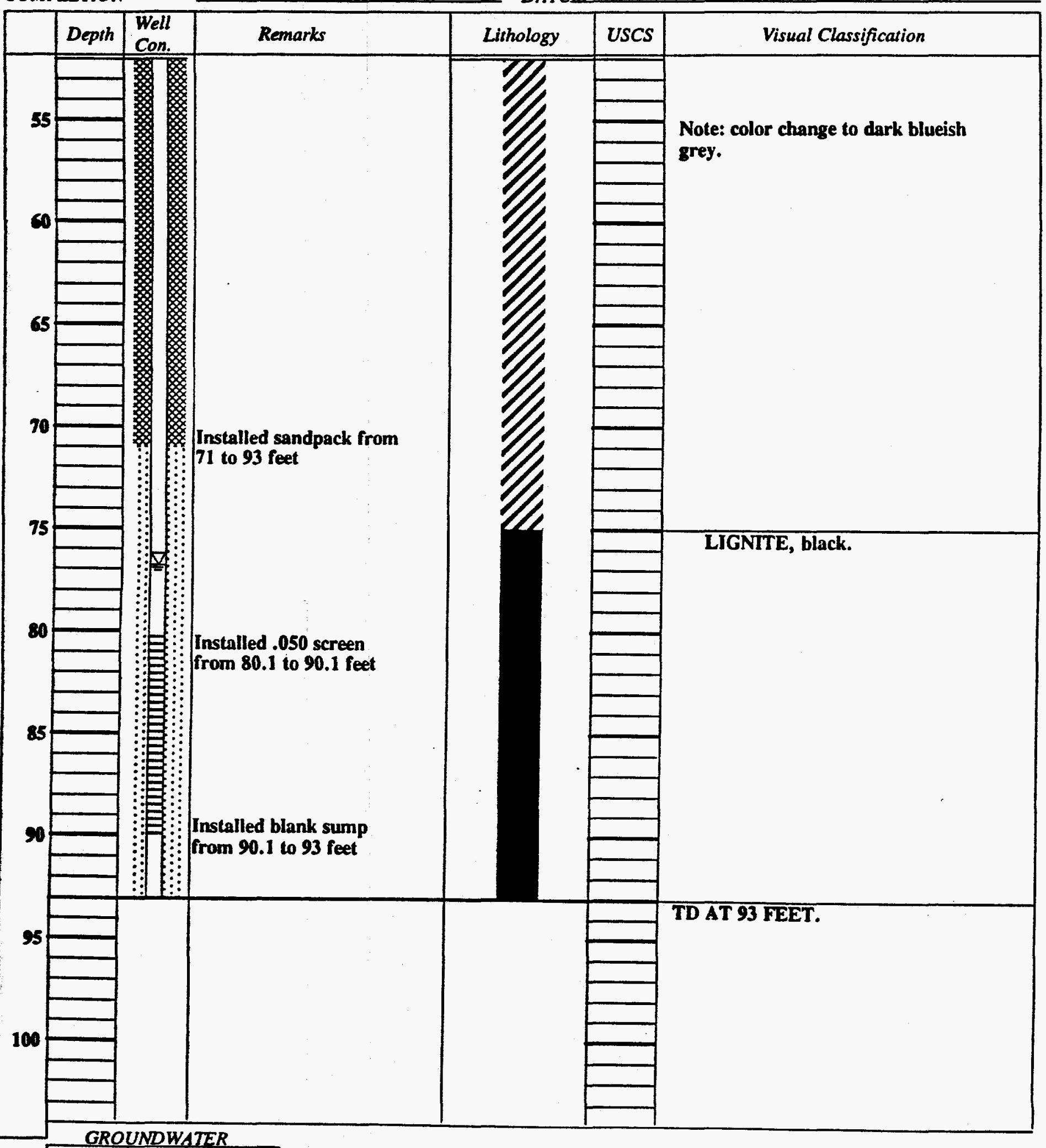

\begin{tabular}{|c|c|c|}
\hline DEPTH & HOUR & DATE \\
\hline 76.8 & 15.53 & $4-15-93$ \\
\hline & & \\
\hline
\end{tabular}


PROJECT $\frac{\text { Falls Ciny Sir. }}{\text { Texas }}$

JOB NO. FCTO1 DATE 04106/93
SURFACE ELEVATION 387.55

TOTAL DEPTH 34.0 feet

TOP OF FILTER PACK

WELL CASING TYPE 2.0-IN.SCHED.40 PVC

COMPLETION CONOUISTA MEM.(SAND)

RIG TYPE

RIG TYPE

COMPLETI

LOCATION N $58793.18 \quad$ E 69389.33

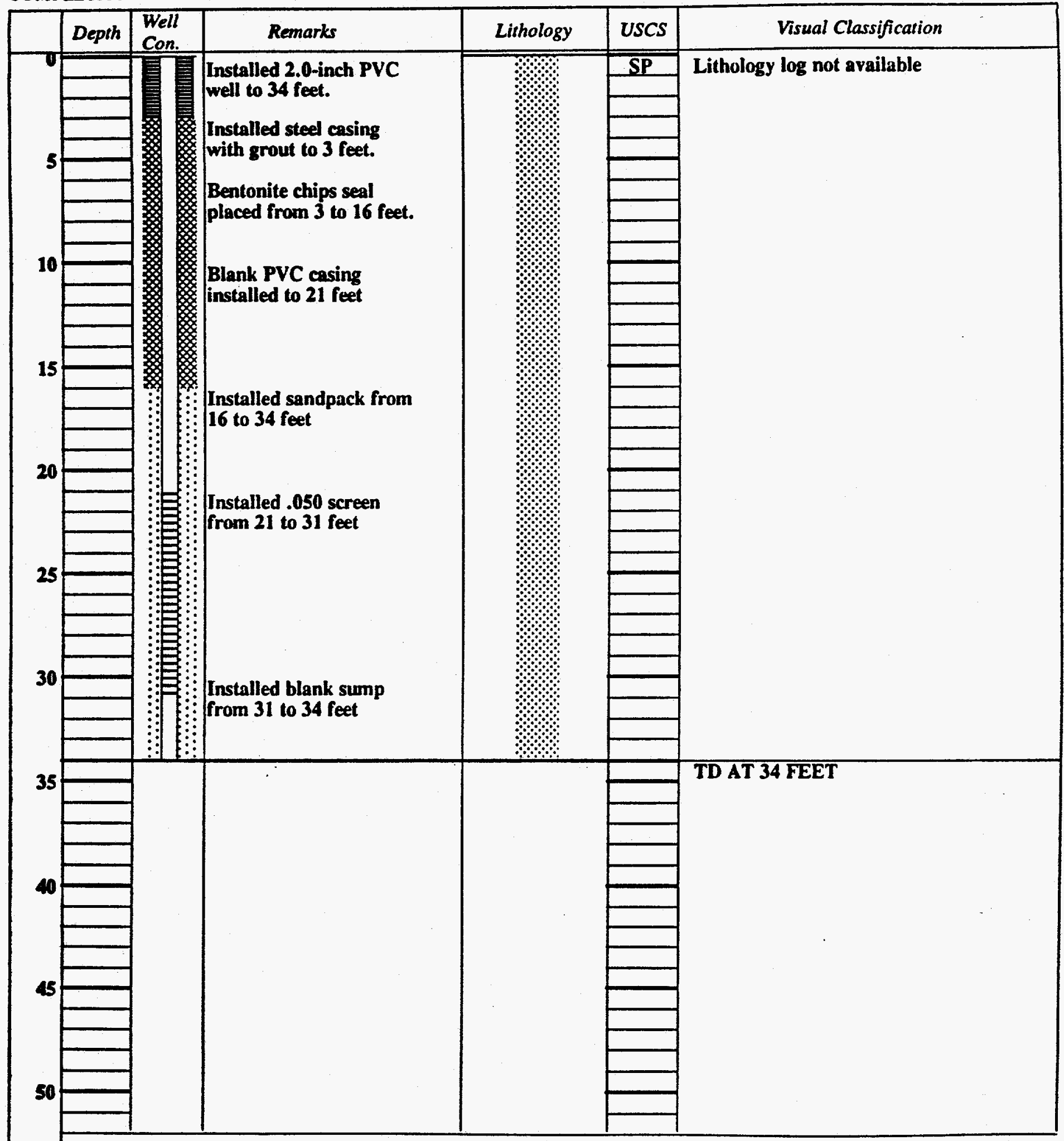

GROUNDWATER

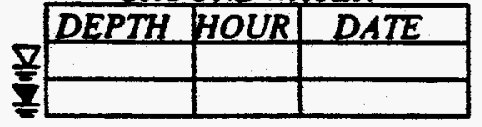


PROJECT UMTRA

Fills Citv. Texas

Poge 1 of 3

- JOB NO. FCT03

DATE $1 / 16 / 86$

LOG OF TEST BORING NO. 901

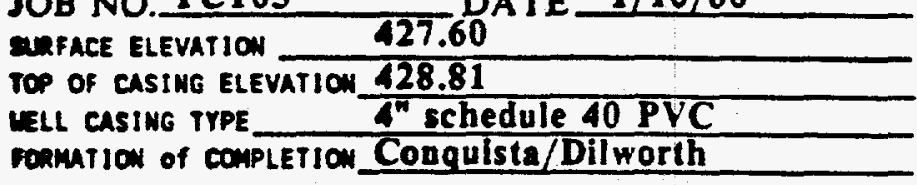

TOTAL DEPTM 145.0 feet

RIG TYPE Mayhew 1500

contwo tYPE $8^{n}$ tricone

Locarion N58597.70 E 68461.80

oAtum MSL

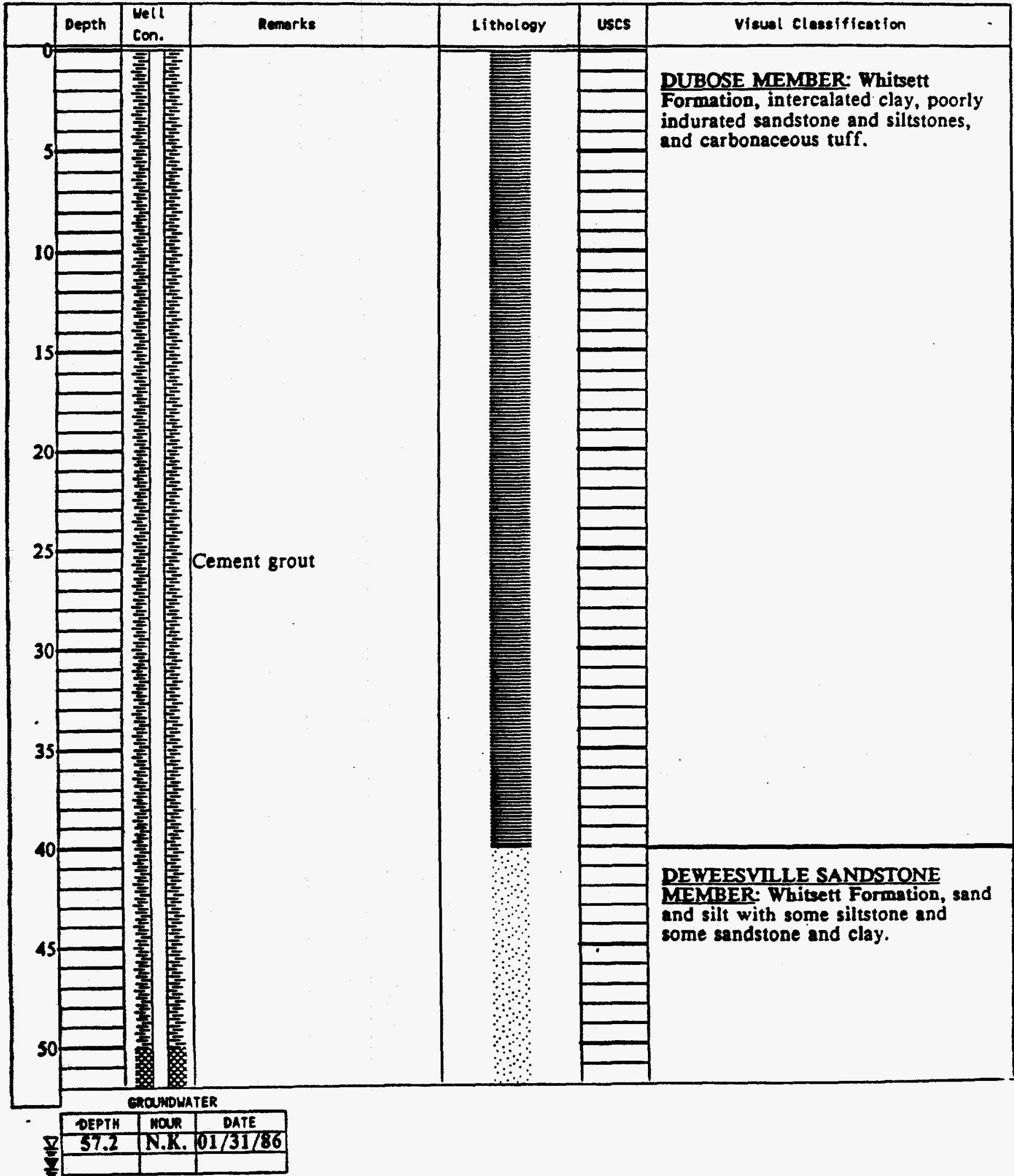


PROJECT UMTRA

Fills dify. Texas

Pege 2 of 3

JOB NO. FCTO3

DATE 1/16/86

LOG OF TEST BORING NO. 901

ERFACE ELEVATION $\quad \mathbf{4 2 7 . 6 0}$

TOP OF CASIMG ELEVATION $\mathbf{4 2 8 . 8 1}$

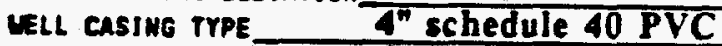

formation of conpletron_Conguista/Dilworth

TOTAL DEPTH
RIG TYPE
DORING TYPE $\frac{145.0 \text { feet }}{8^{n} \text { trichew } 1500}$
LOCATIOW
DATUM

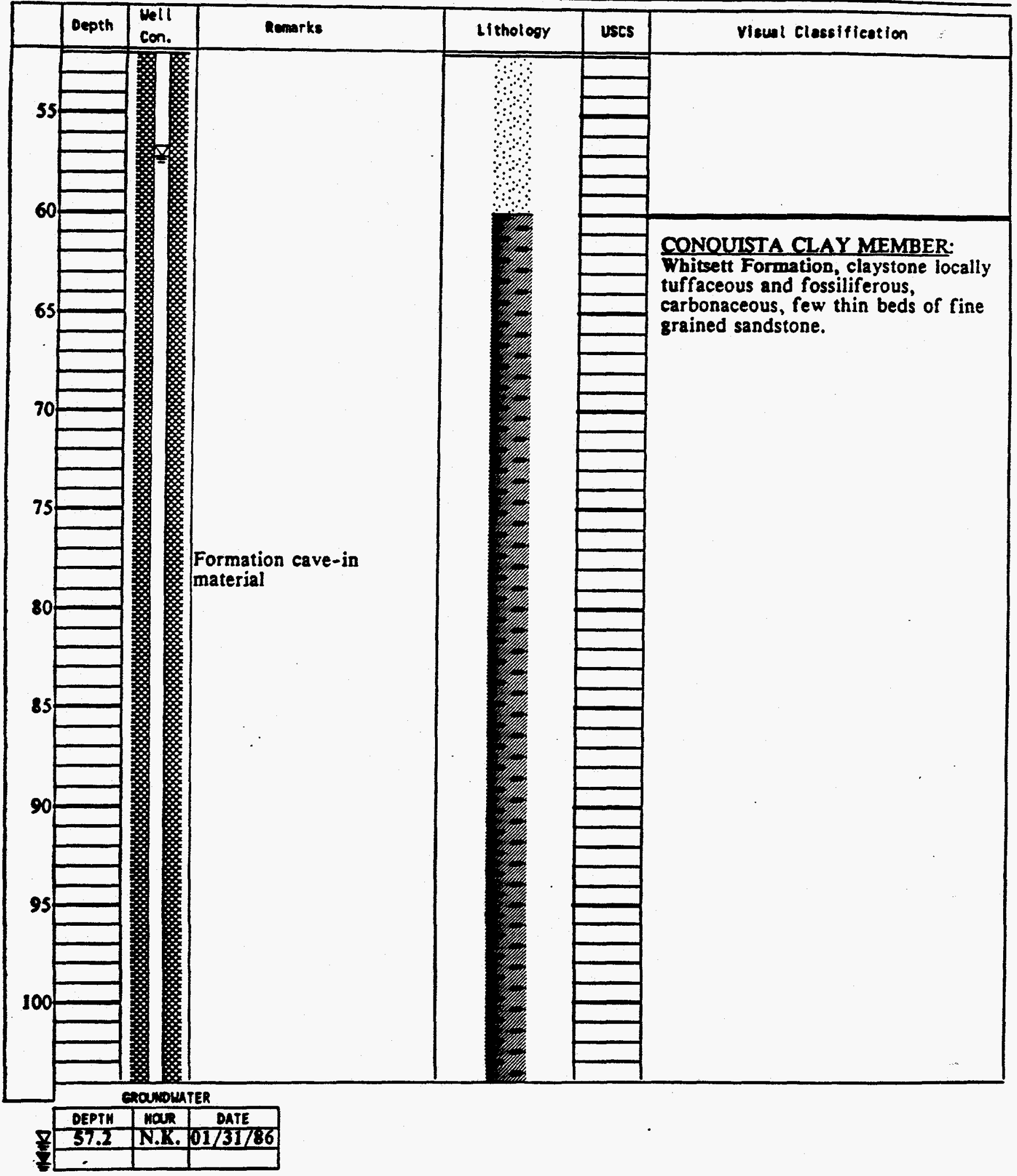


PROJECT UMTRA

JOB NO. FCT03

smFace ELEVATION

TCF Of CASING ELEVATION $\mathbf{2 8 . 8 1}$

ELL CAsing TrPE $4 "$ schedule 10 PVC

ponurion of combetion Conquista/Dilworth

\section{DATE $1 / 16 / 86$}

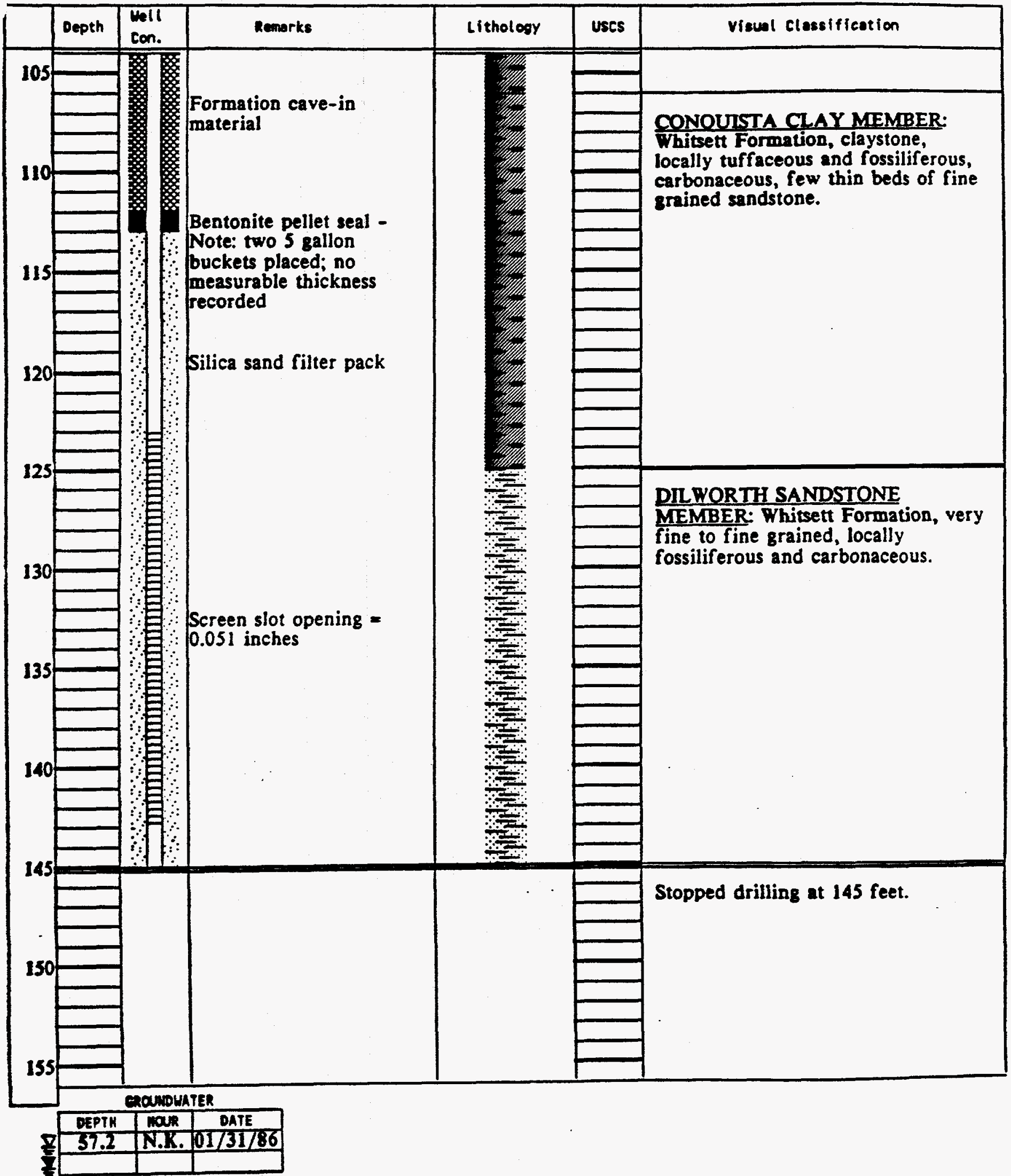


PROJECT UMTRA

Filk City. Texas

JOB NO. FCT03

DATE $12 / 20 / 85$

ERfACE ELEVATION 407.15

ToP of CASING ELEVATION $\mathbf{4 0 8 . 6 9}$

WLL CASING TYPE 4 "schedule 40 PVC

Ponurion of conpletion Dllworth Sandstone

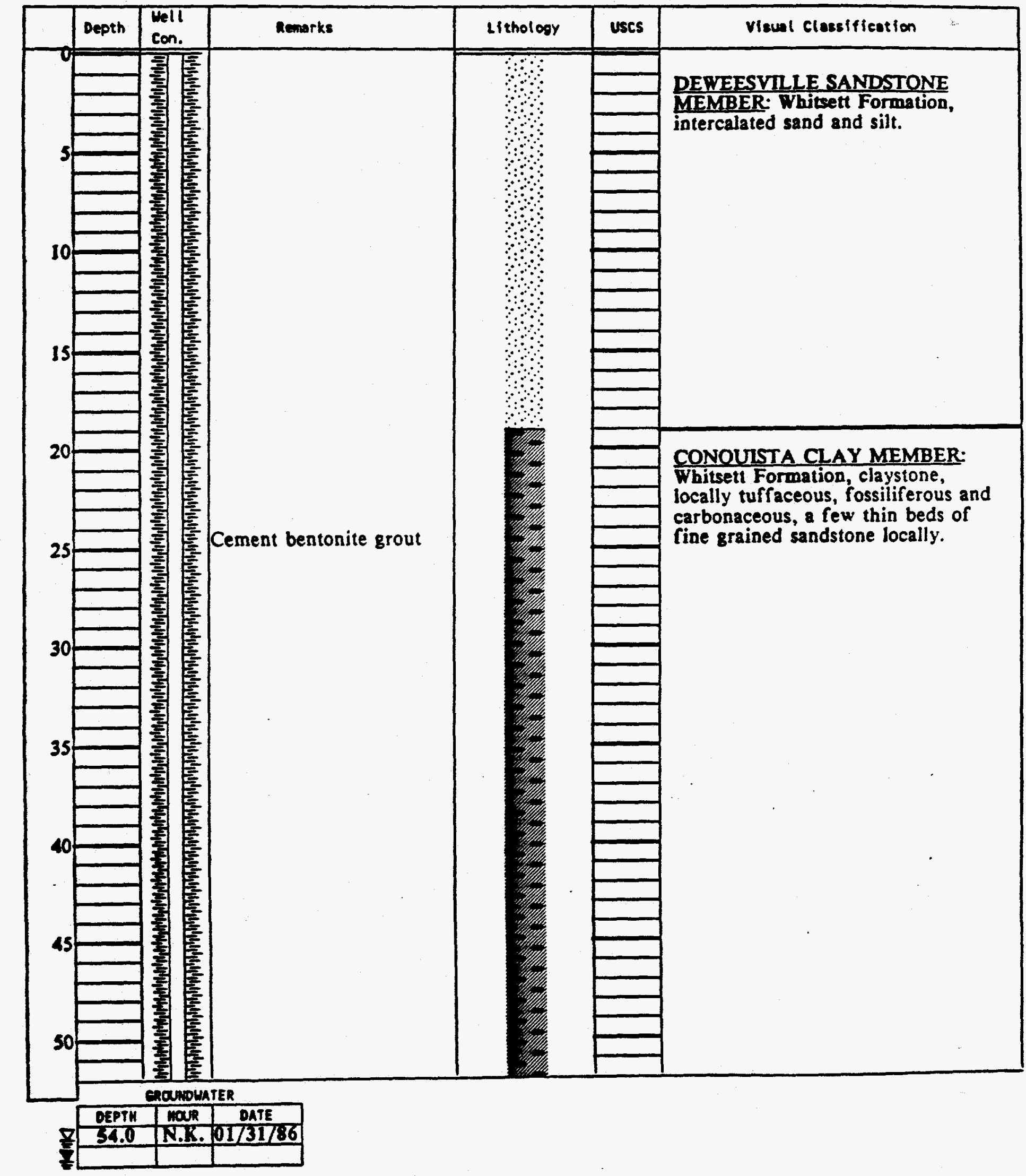

LOG OF TEST BORING NO. 902

TOTAL DEPTH 152.0 reet

Doring trpe $8^{\text {" tricone }}$

LOCATION N 57503.80 E 65983.90

DATUM MSL
RIG TYPE Mayhew 1500 
PROJECT UMTRA

JOB NO. FCT03 DATE $12 / 20 / 85$

LOG OF TEST BORING NO. 902

ERFACE ELEVATION $\quad 007.15$

toP OF Casing ELEVATIOH $\mathbf{4 0 8 . 6 9}$

MeLL Casime IrPE

Fonurion of completion Dilworth Sandstone

TOTAL DEPTI 152.0 feet

RIG TYPE Mayhew 1500

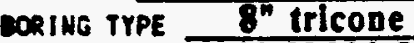

LOCATIOA N 57503.80 E 65983.90 MSL

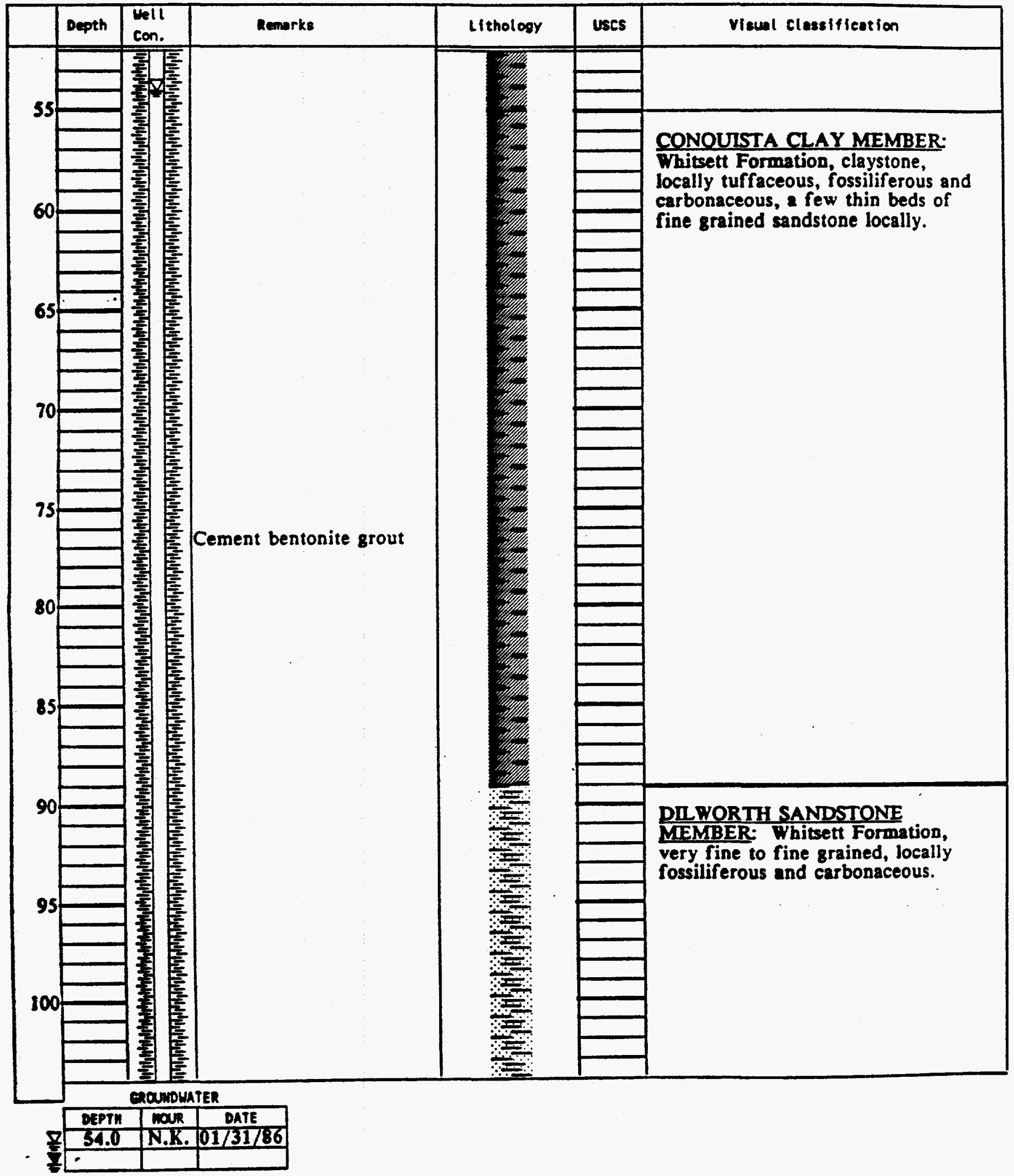


JOB NO. FCTO3 DATE 12/20/85

URFACE ELEVATION 407.15

Top of casing elevation $\mathbf{4 0 8 . 6 9}$

cell casing TrPE 4 schedule 40 PVC

Ponution of completson Dilworth Sandstone
TOTAL DEPTH 152.0 feet

RIG TYPE Mayhew 1500

DORING TYPE $8^{\text {" tricone }}$

LOCATION

DATUM MSL

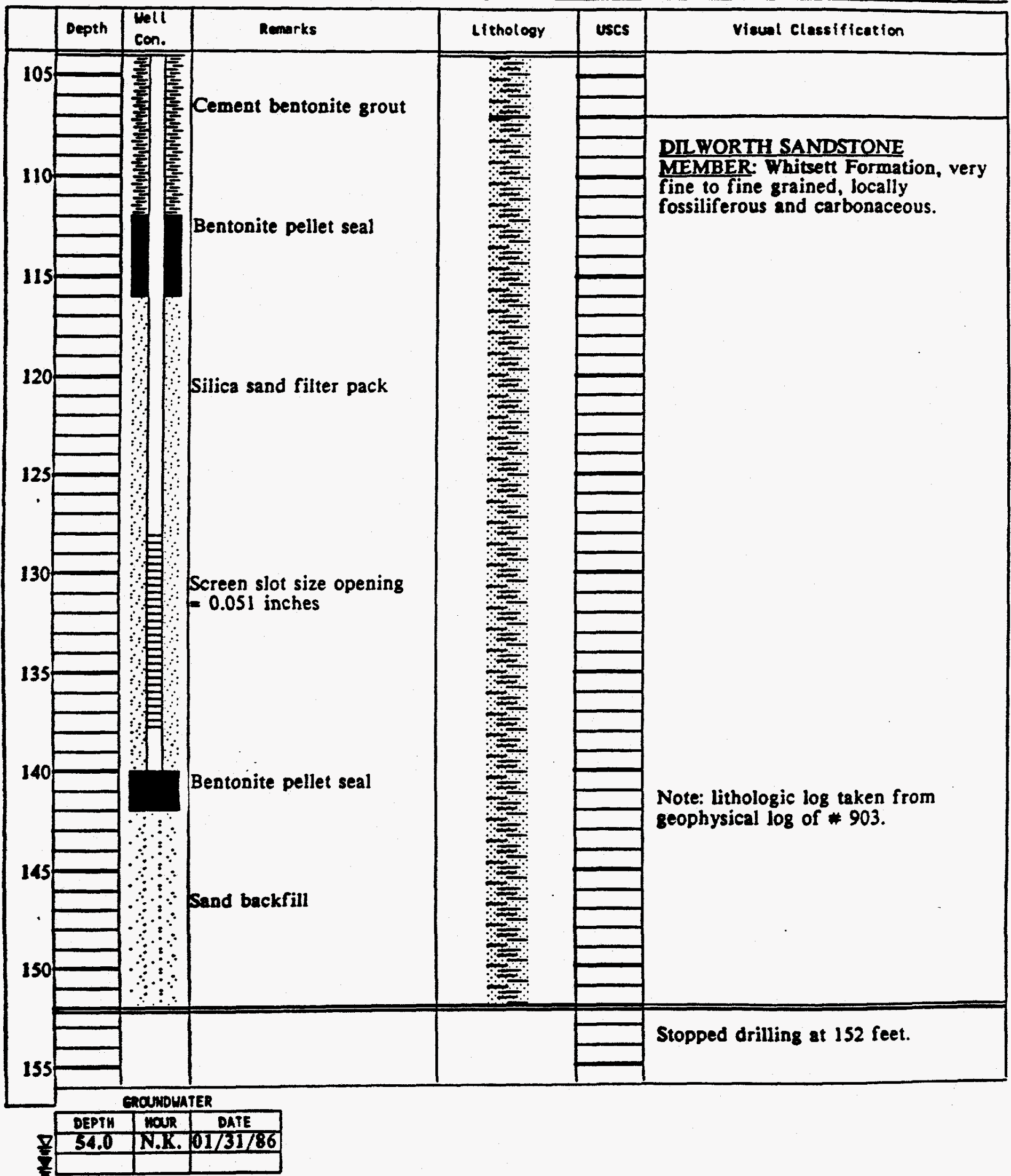


LOCATION N57493.30 E 65971.60

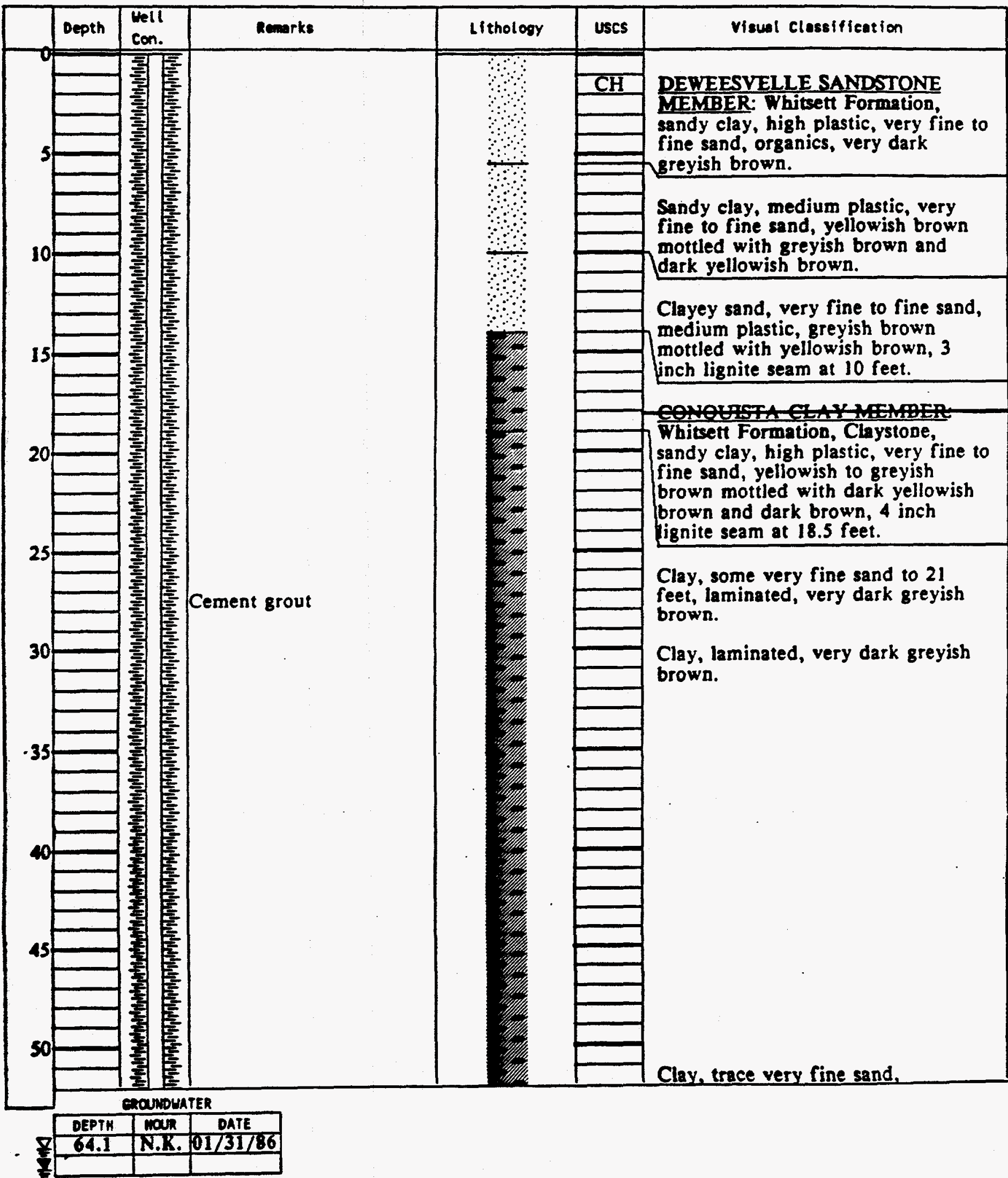


PROJECT UMTRA

JOB NO. FCT03 DATE 12/5/85

LOG OF TEST BORING NO. 903

ERFACE ELEVATIOW $\quad \mathbf{1 0 7 . 2 3}$

TOP OF CASIMG ELEVATION $\mathbf{0 8 . 4 3}$

VELL CASING TYPE

formarjow of completion Manulng Clay Formation

\begin{tabular}{|c|c|}
\hline$\overline{\text { TOTAL DEPTH }}$ & 218.0 feet \\
\hline RIG TYPE & Mayhew 1500 \\
\hline $\begin{array}{l}\text { DORING TYPE } \\
\text { LOCATION }\end{array}$ & $\begin{array}{l}8^{n} \text { tricone } \\
\text { N57493.30 }\end{array}$ \\
\hline
\end{tabular}

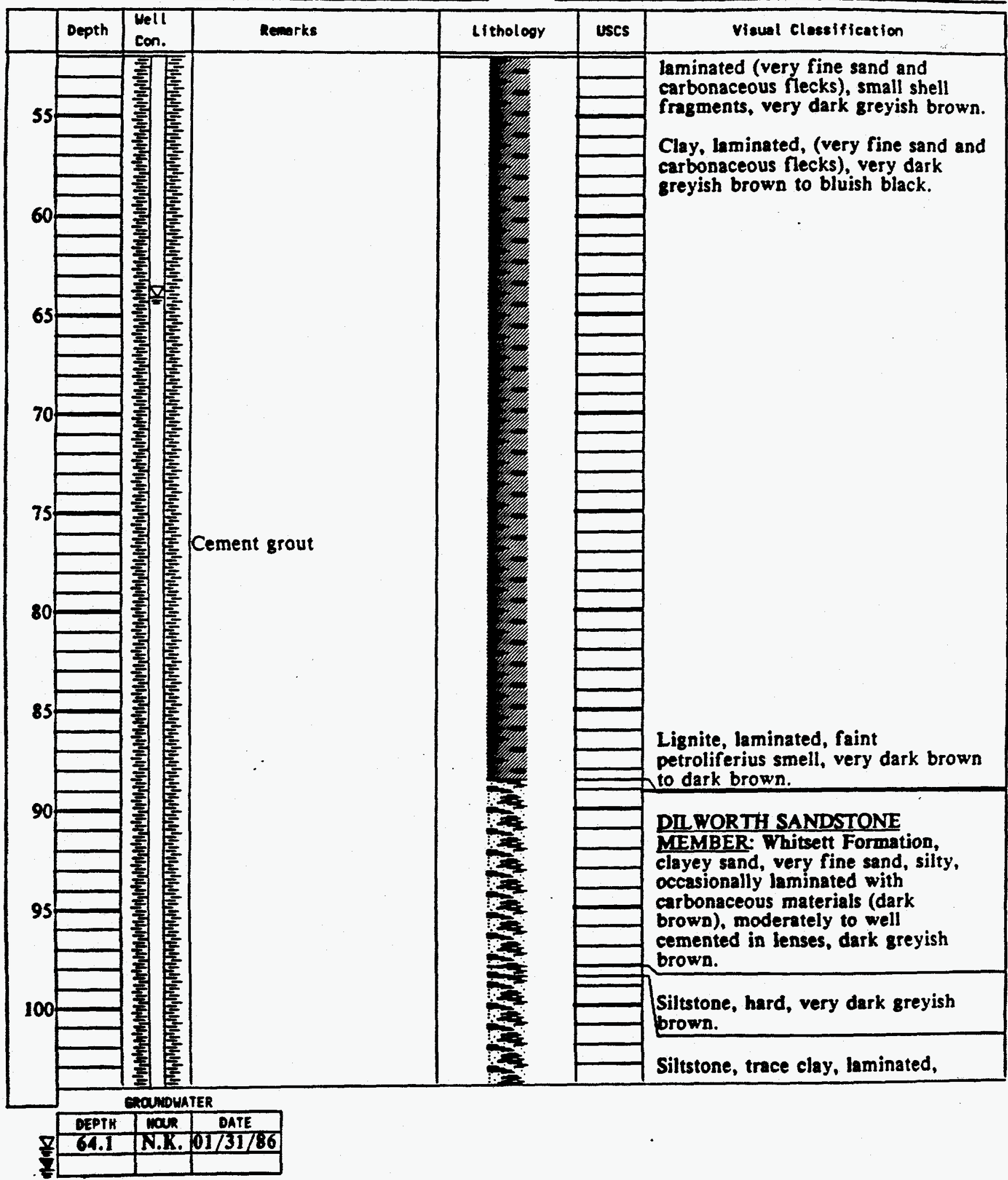




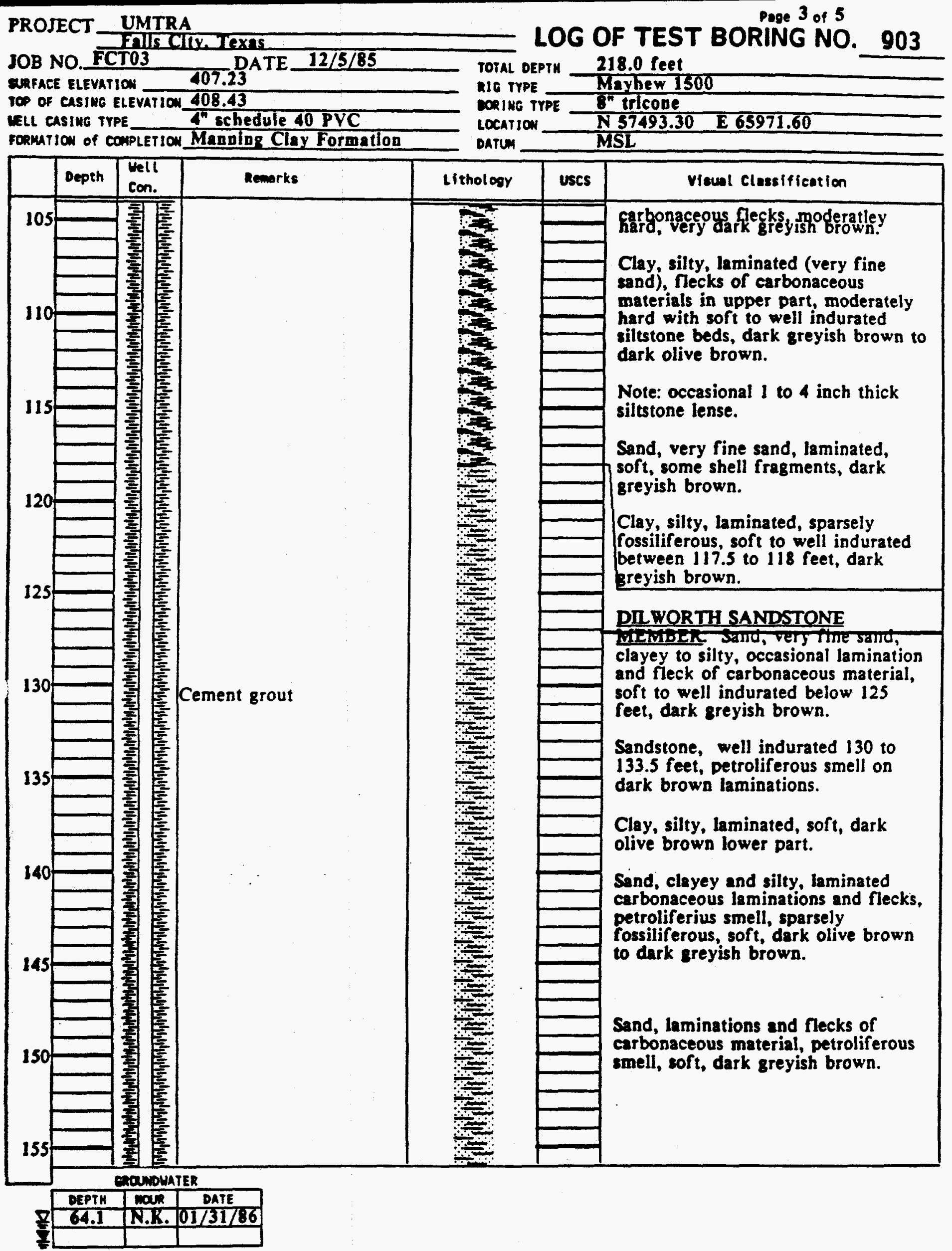


PROJECT UMTRA

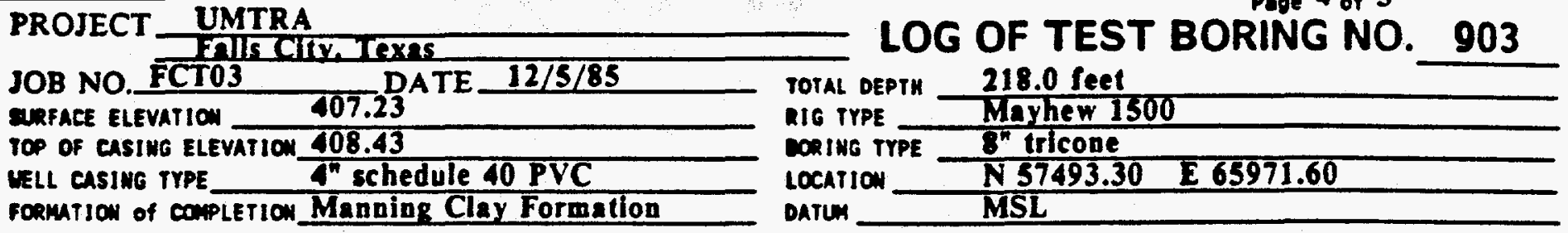

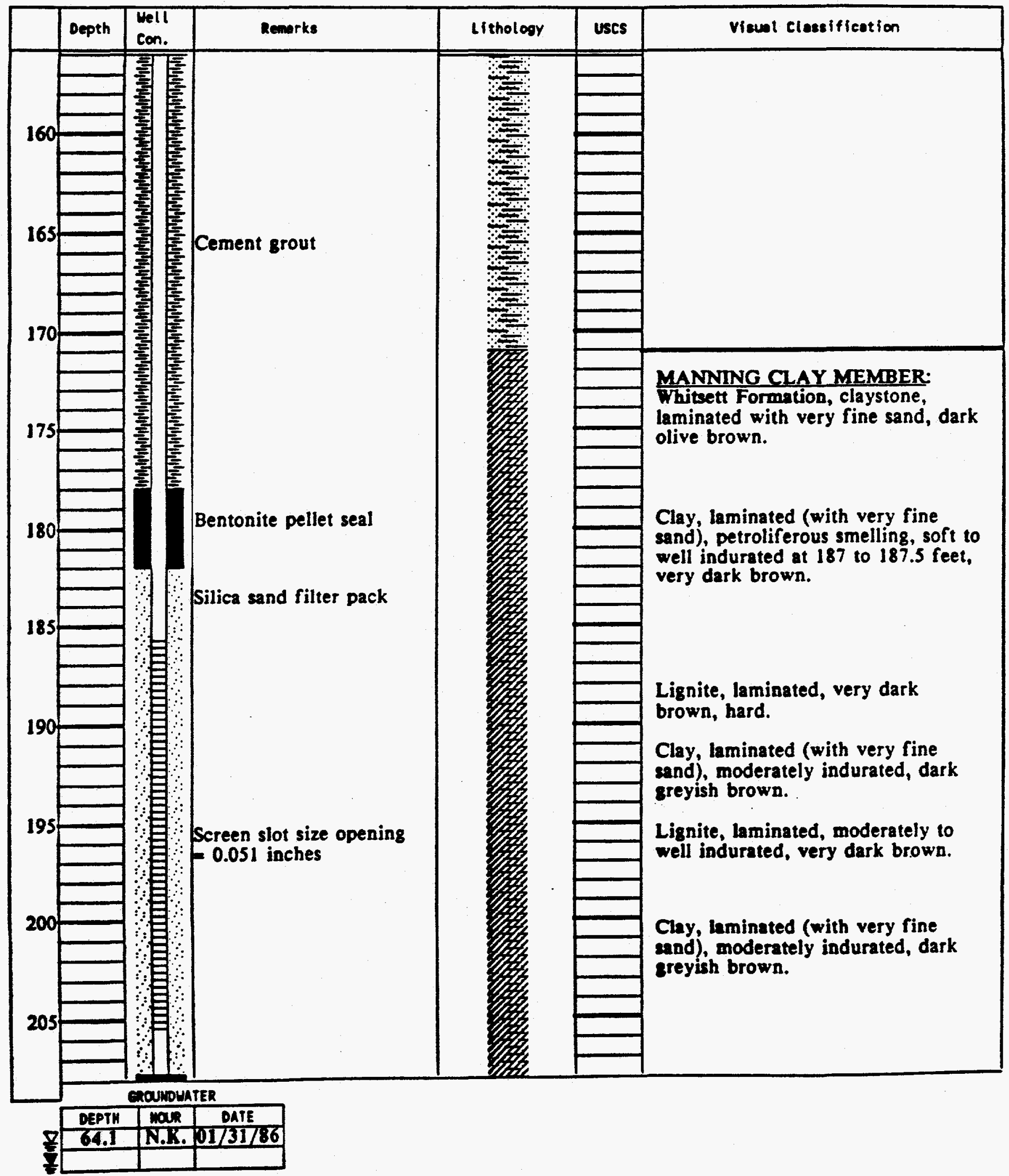




\section{- PROJECT UMTRA}

JOB NO. FCTO3 DATE $12 / 5 / 85$

ERFACE ELEVATIOW 407.23

TOP OF CASING ELEVATION 408.43

IEL CAsine TYPE 4 " schedule 40 PVC rorution of completiow Manning Clay Formation

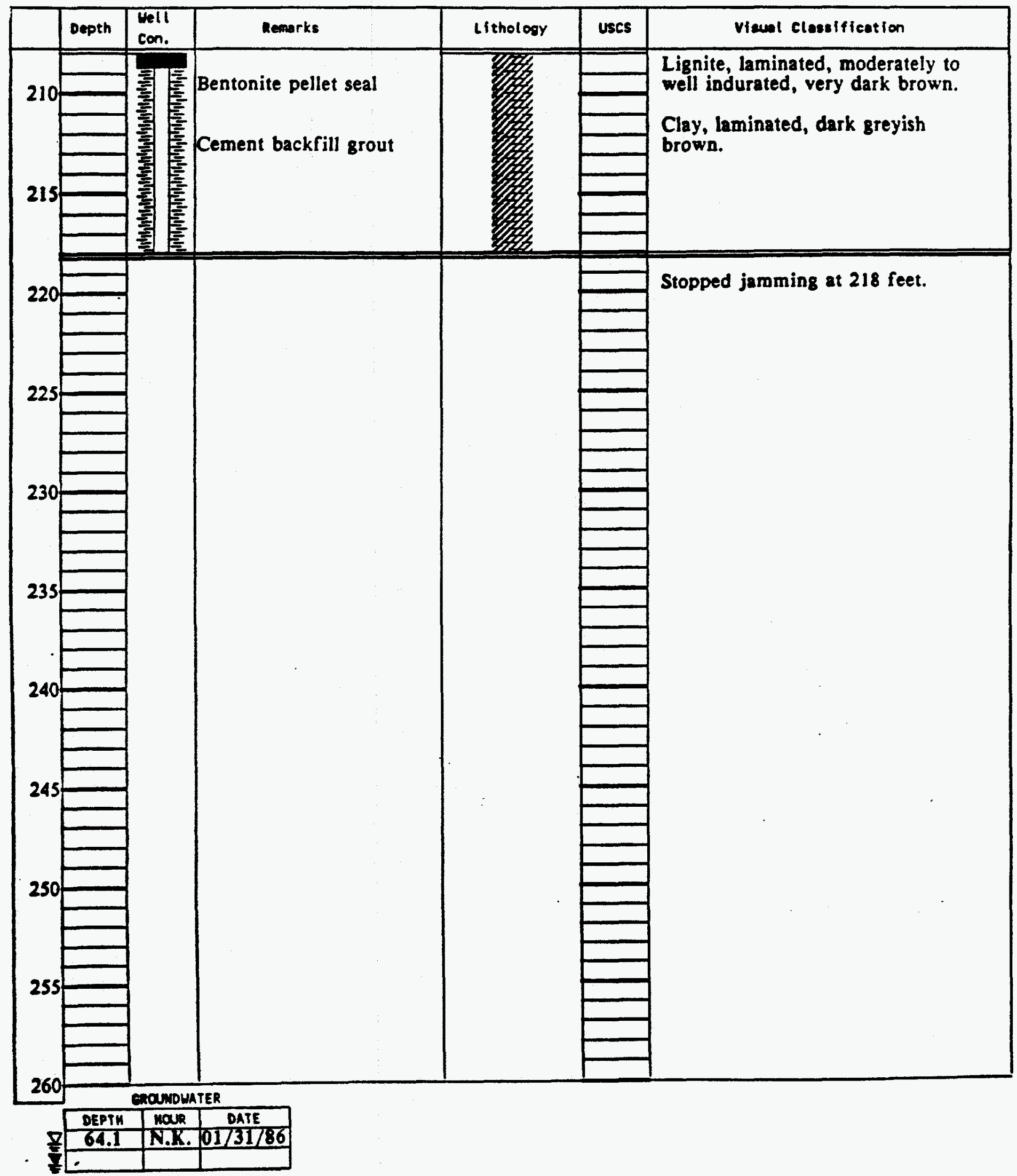

\section{TOTAL OEPTH 218.0 feet}

NIG TYPE Mayhew 1500

CORING TYPE $8^{\text {n }}$ tricone

Location N 57493.30 E 65971.60

MSL

\begin{tabular}{|l|l|l} 
ithology & uscs & Vieual clessification
\end{tabular}

Lignite, laminated, moderately to

well indurated, very dark brown.

Clay, laminated, dark greyish

brown.

Stopped jamming at 218 feet. 

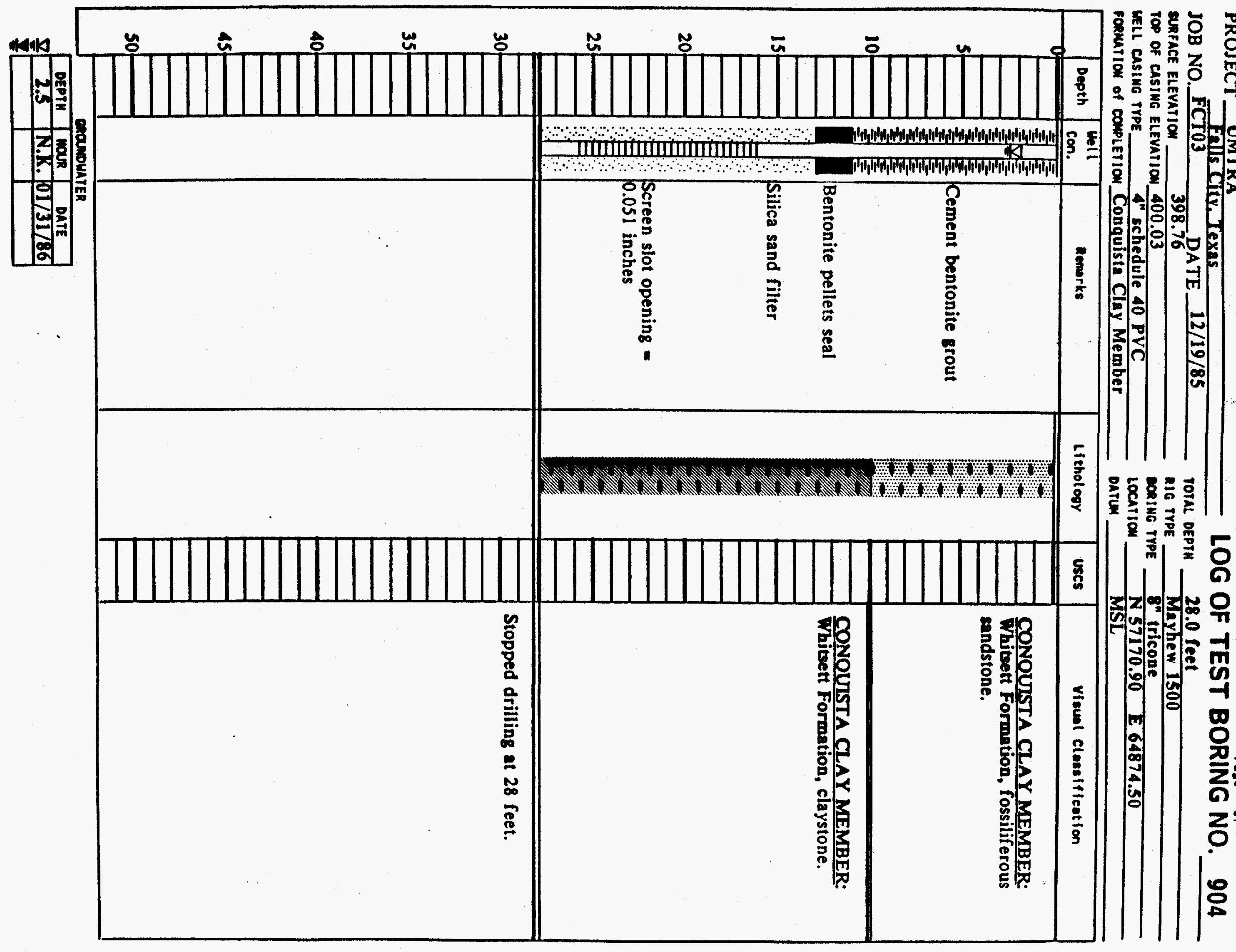


\section{PROJECT UMTRA}

Poge 1 of 2

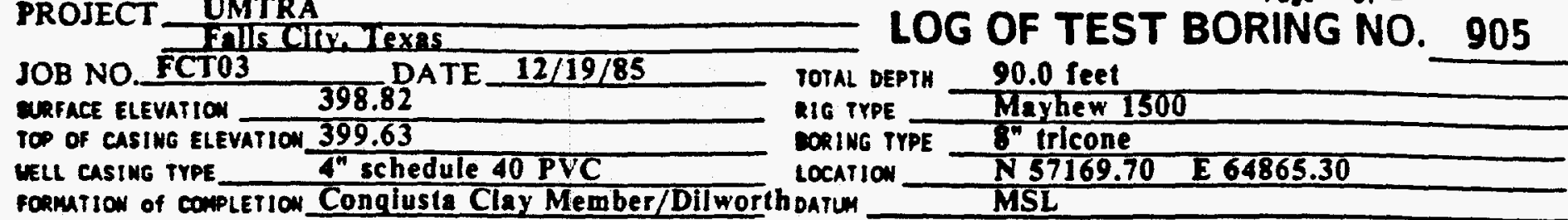

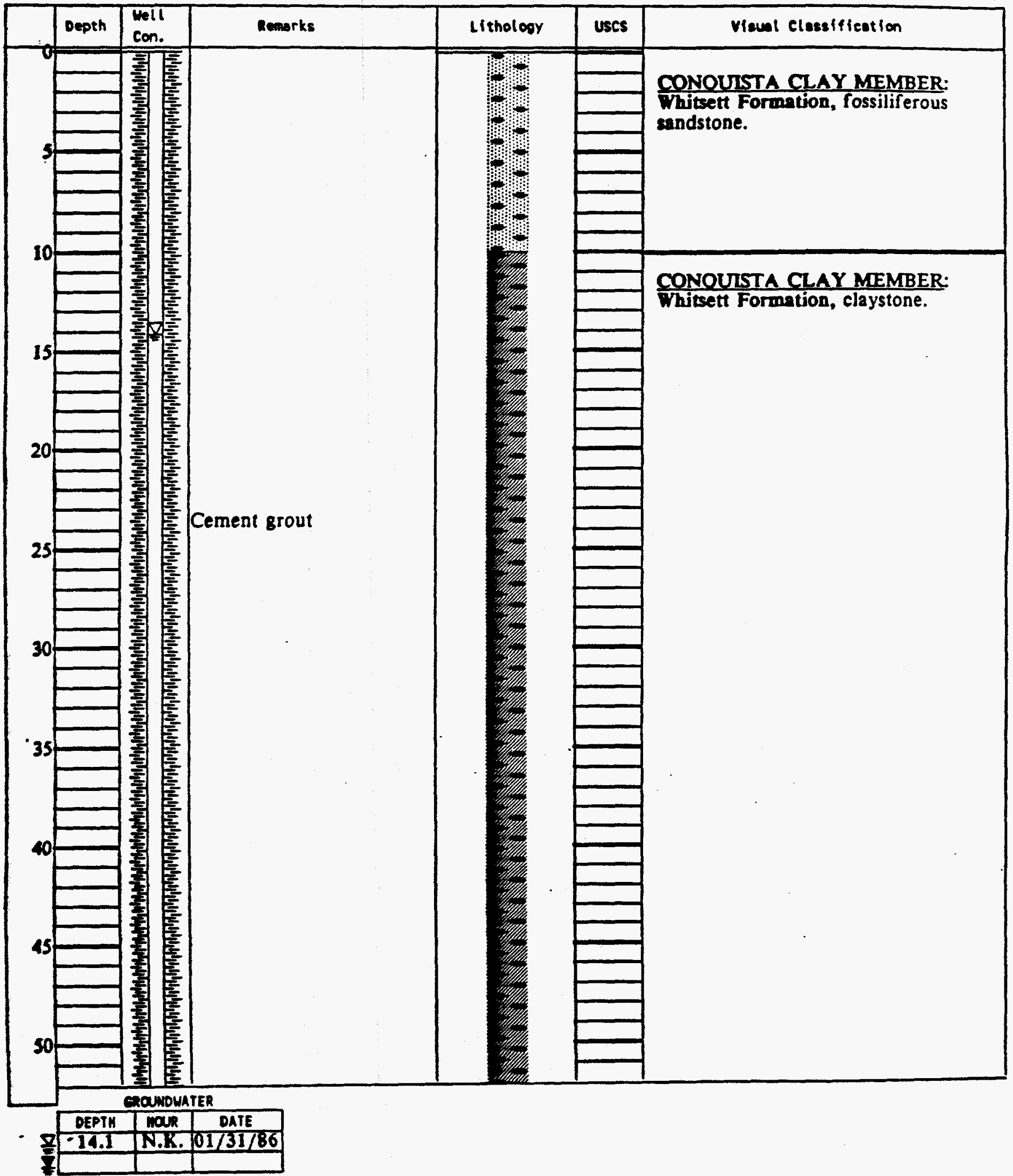


ROJECT UMTRA

LOG OF TEST BORING NO. 905

JOB NO. FCTO

meret Elevation 398.82

DATE $12 / 19 / 85$

TOTAL DEPTH 90.0 feet

Ta or casing Elevation 399.63

IXl chstuG TYPE

A" schedule 40 PVC

RIG IYPE Mayhew 1500

CORING TYPE $g^{\text {n tricone }}$

pominow of combetion Congiusta Clay Member/Dilworth batu

N57169.70 E 64865.30

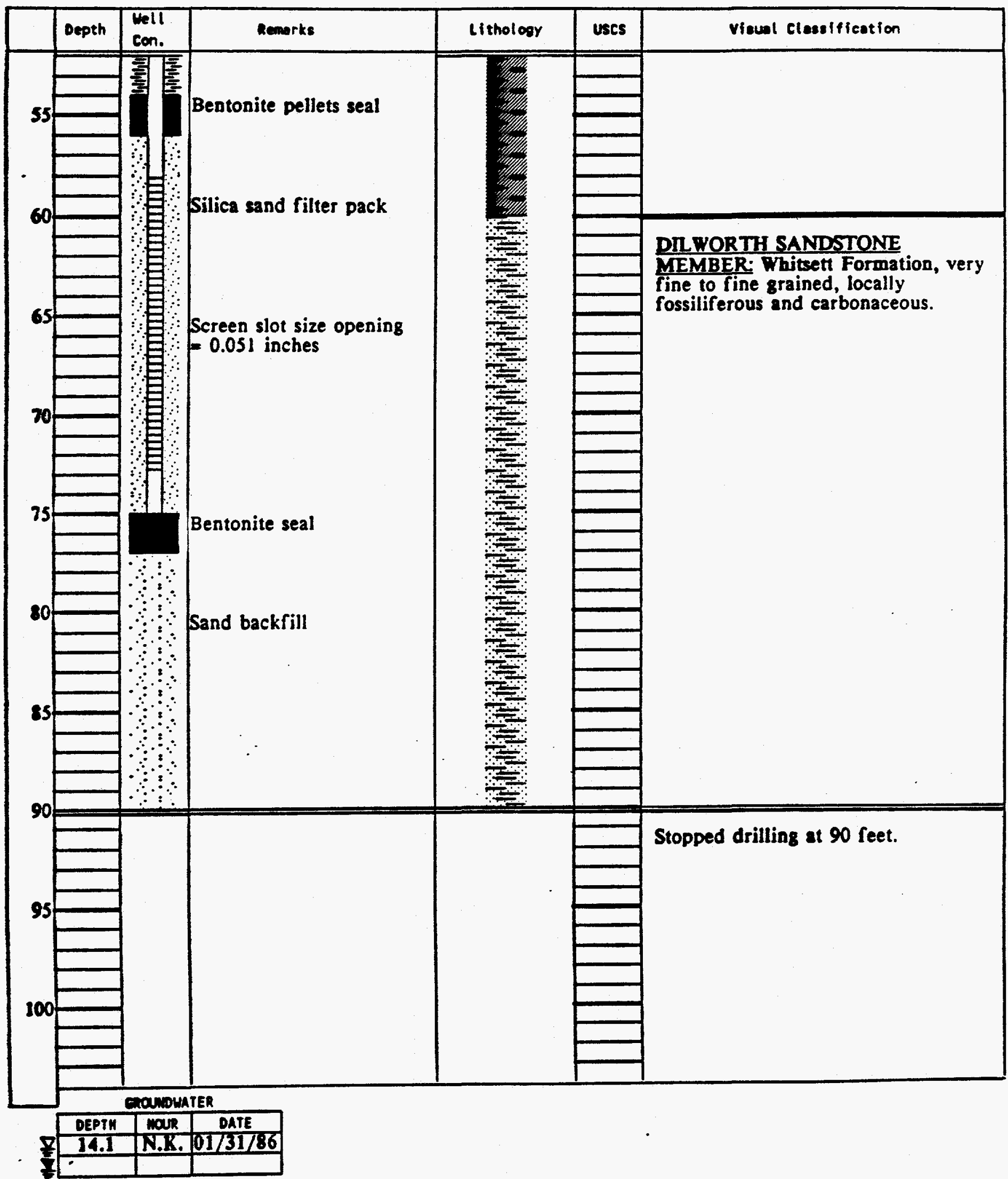




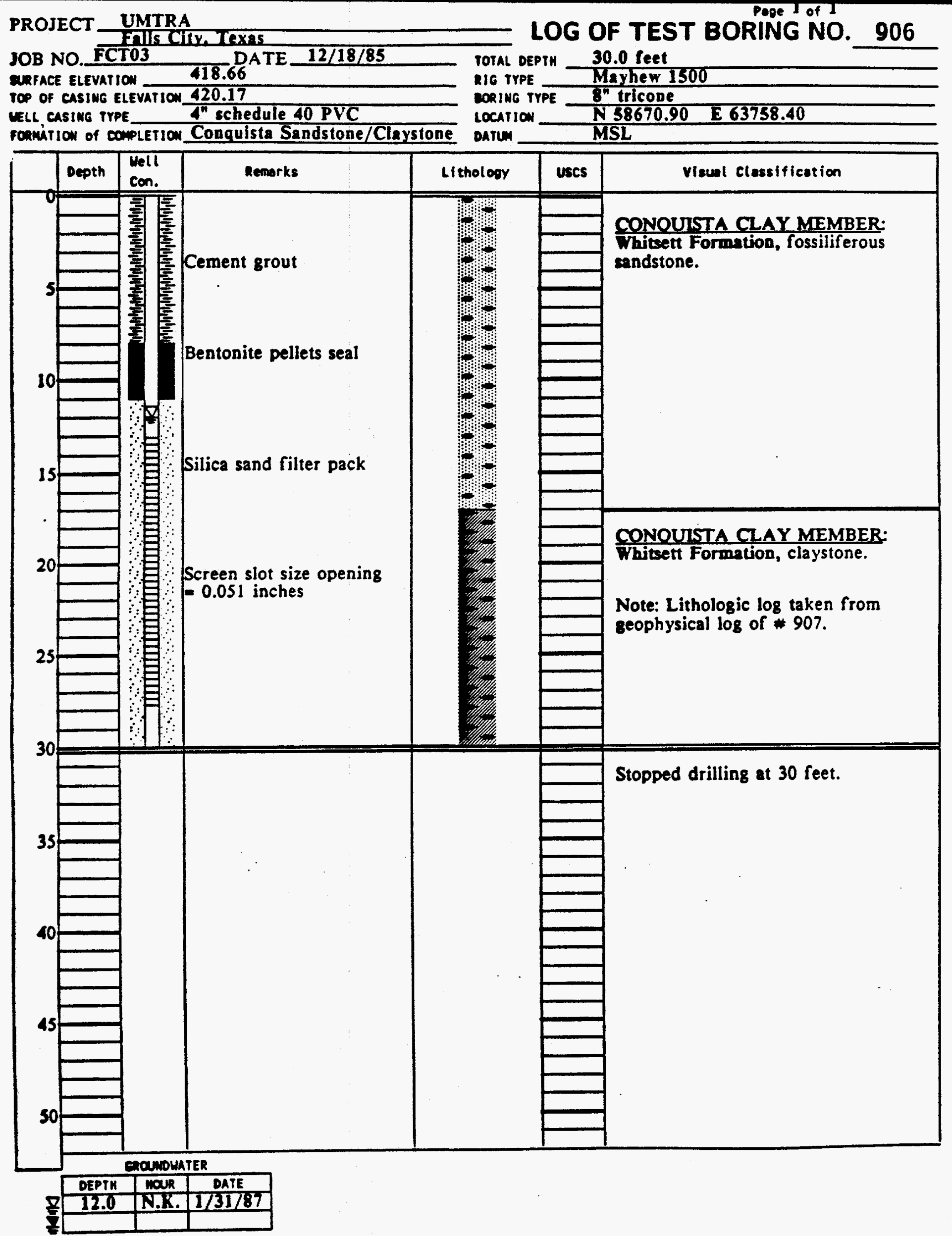


Page 1 of 3

PROJECT UMTRA

JOB NO FCTO3 Cily Texas

DATE $12 / 17 / 85$

LOG OF TEST BORING NO. 907

ERRACE ELEVATION $\quad \mathbf{4 1 8 . 2 4}$

JOP OF CASING ELEVATION 419.77

MELL CAsING TYPE

rormation of conpLetion Dilworth Sandsione

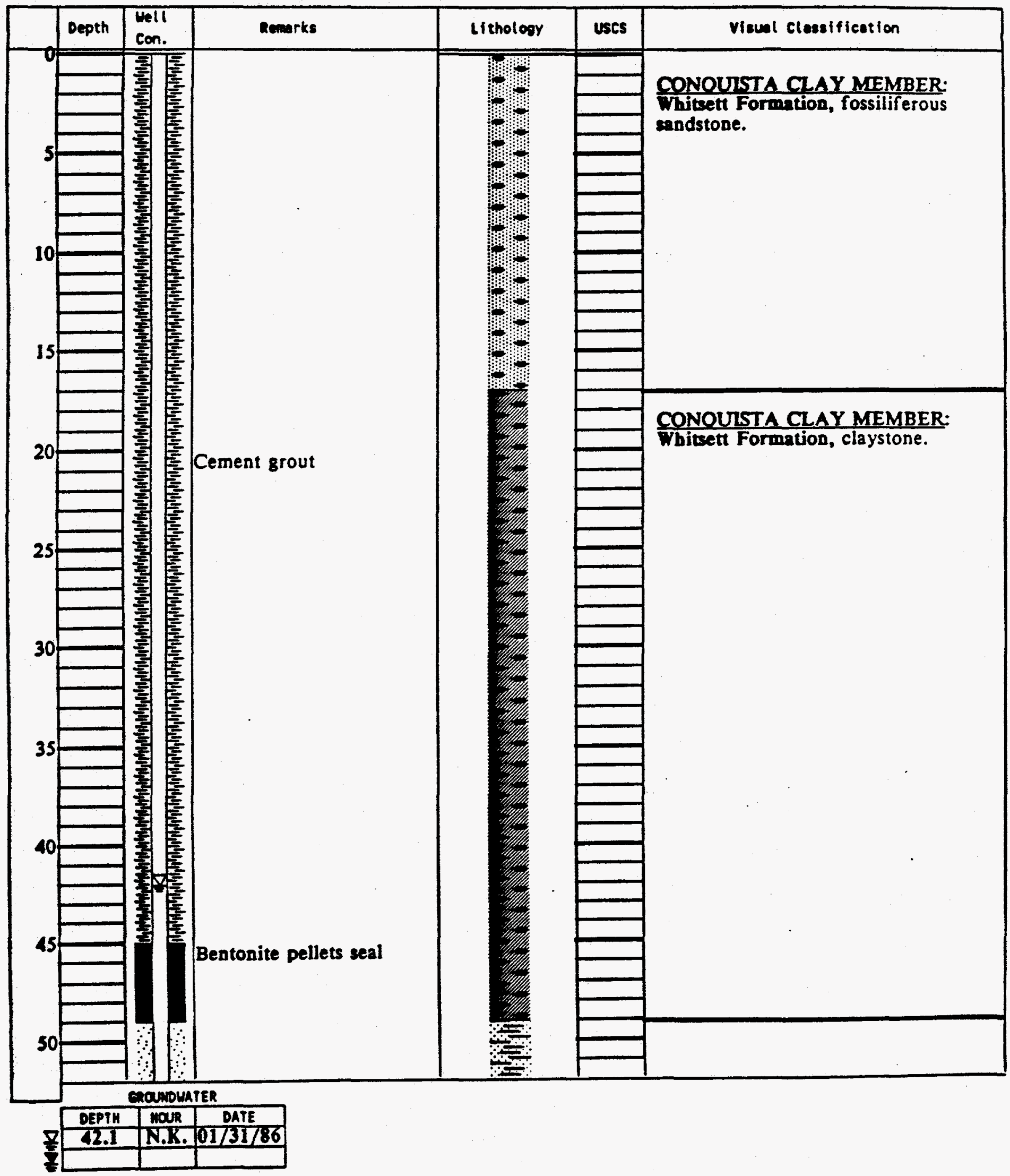


PROJECT UMTRA

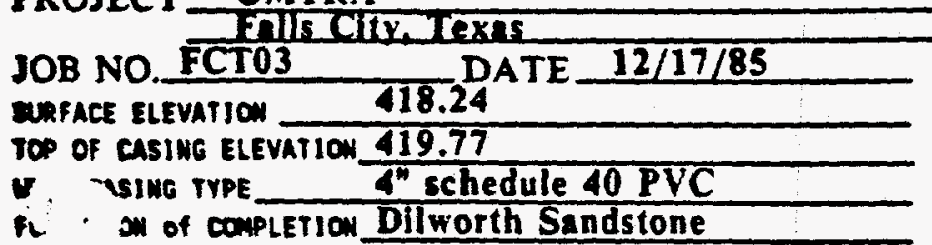

LOG OF TEST BORING INU. gur

TOTAL DEPTH

150.0 feet

RIO TYPE Mayhew 1500

CORING TYPE $8^{\prime \prime}$ tricone

LOCATION N58658.60 E63744.50

DATUM MSL

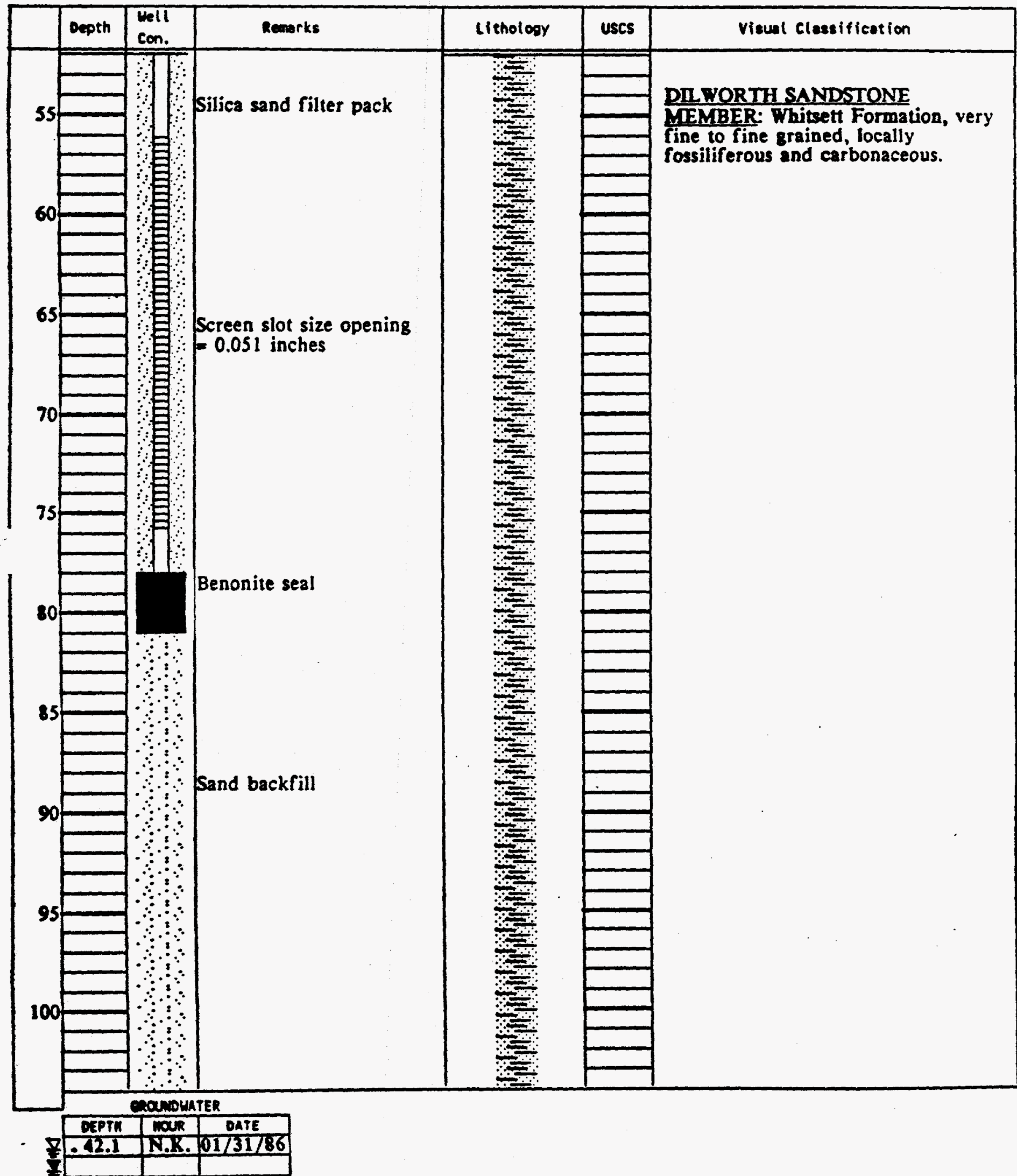


TOTAL DEPTH

RIG TYPE Tayhew 1500

conimg TYPE $8^{n}$ tricone

LOCATION N38658.60 E 63744.50

DATUM MSL

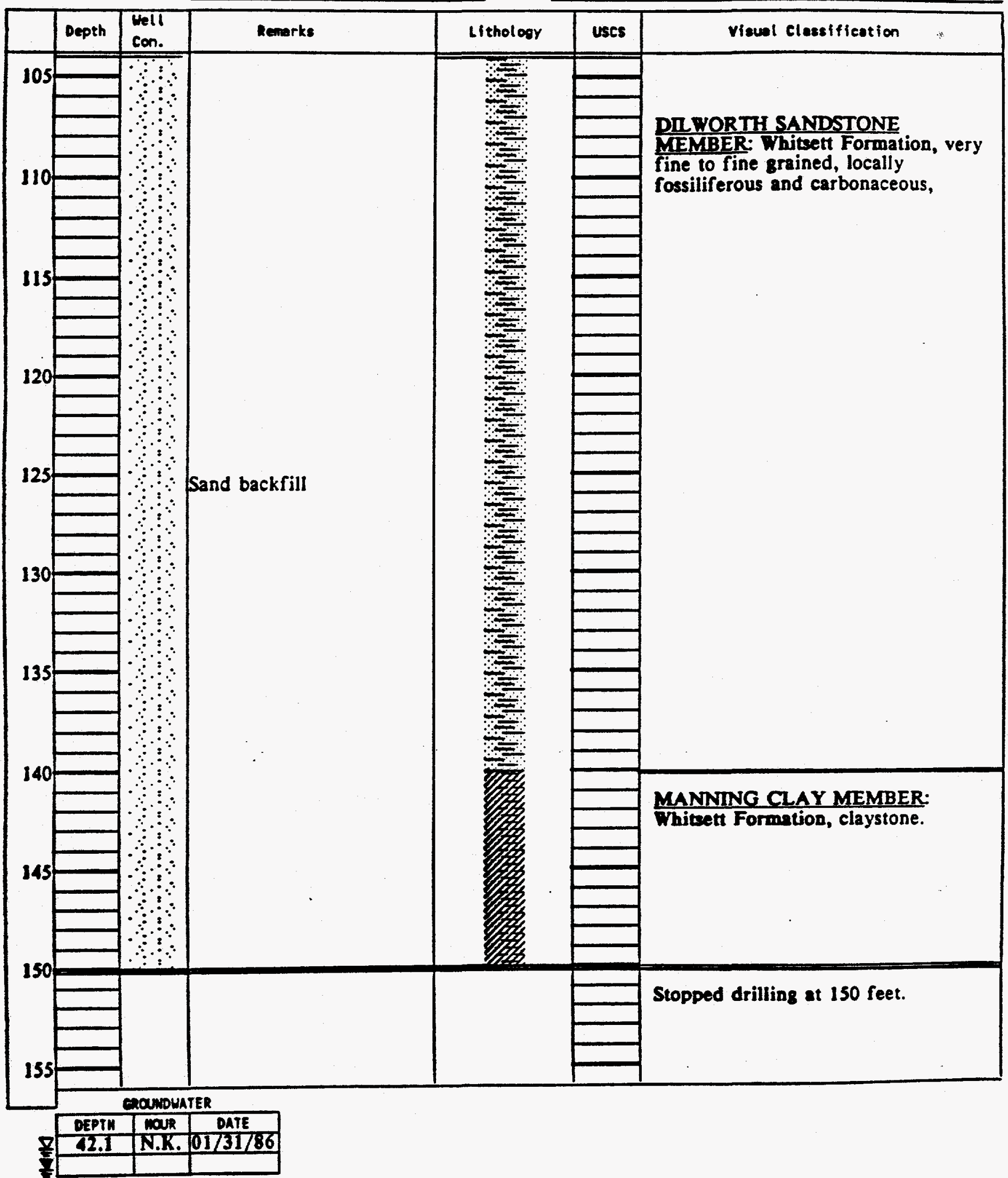


PROJECT UMTRA

Page 1 of 2

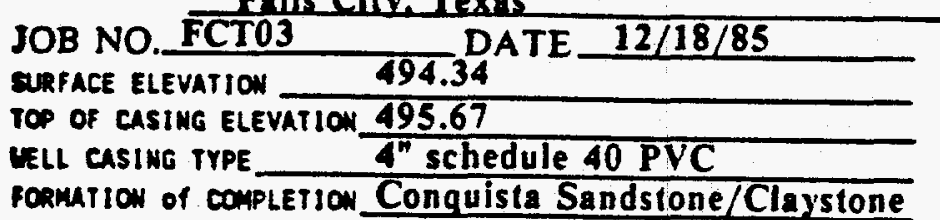

exas

LOG OF TEST BORING NO. 908

TOTAL DEPTH 75.0 feet

RIG TYPE Badger 1400

coring TYPE $8^{\text {" tricone }}$

LOCATION

Datum

N $61478.20 \quad$ E 61847.50

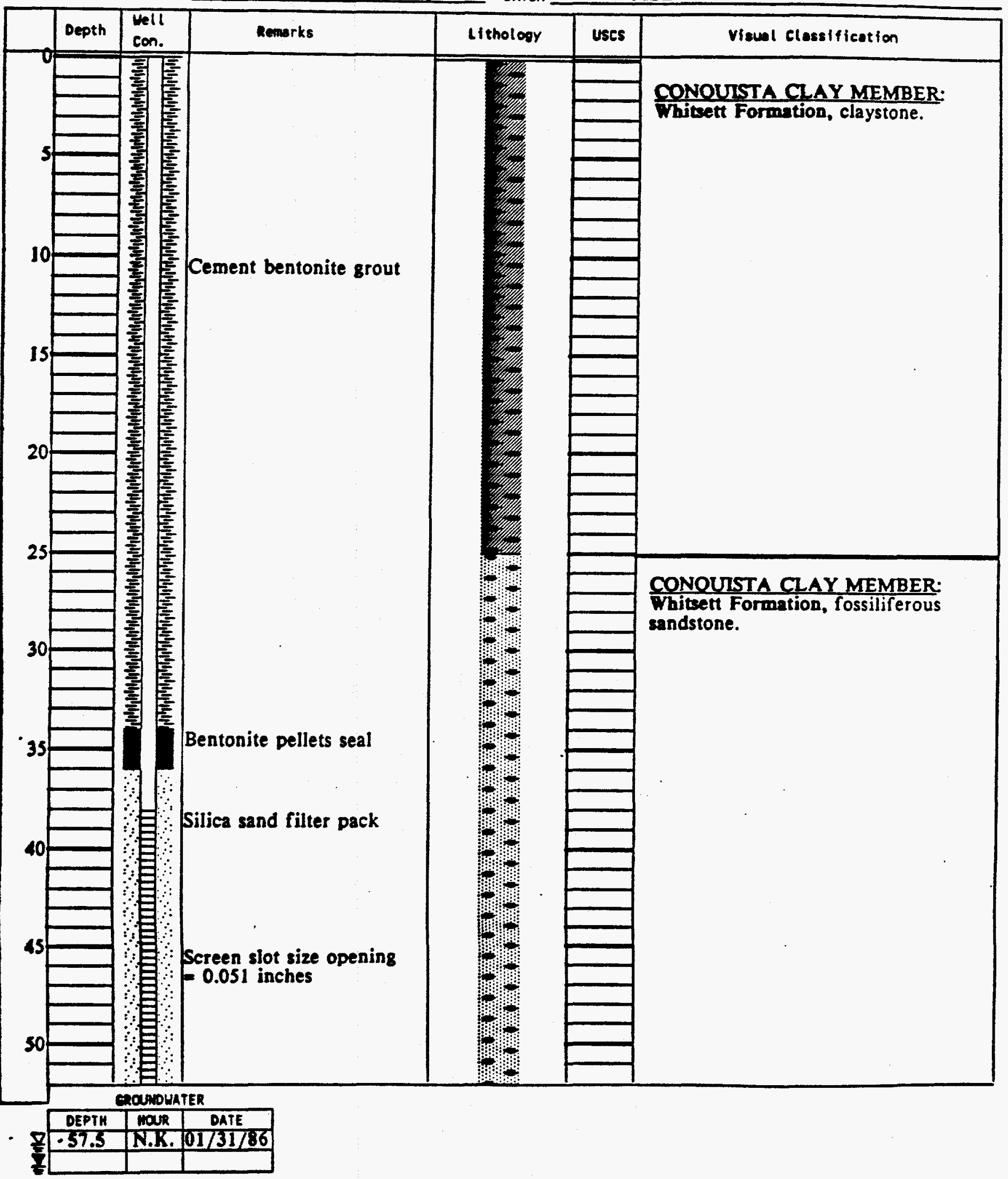


JOB NO. FCTO3

DATE $12 / 18 / 85$

ERFACE ELEVATION

TCP OF CASING ELEVATION 495.67

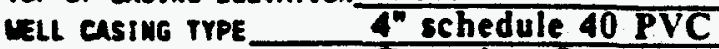

fomution of completion Conguista Sandstone/Claystone

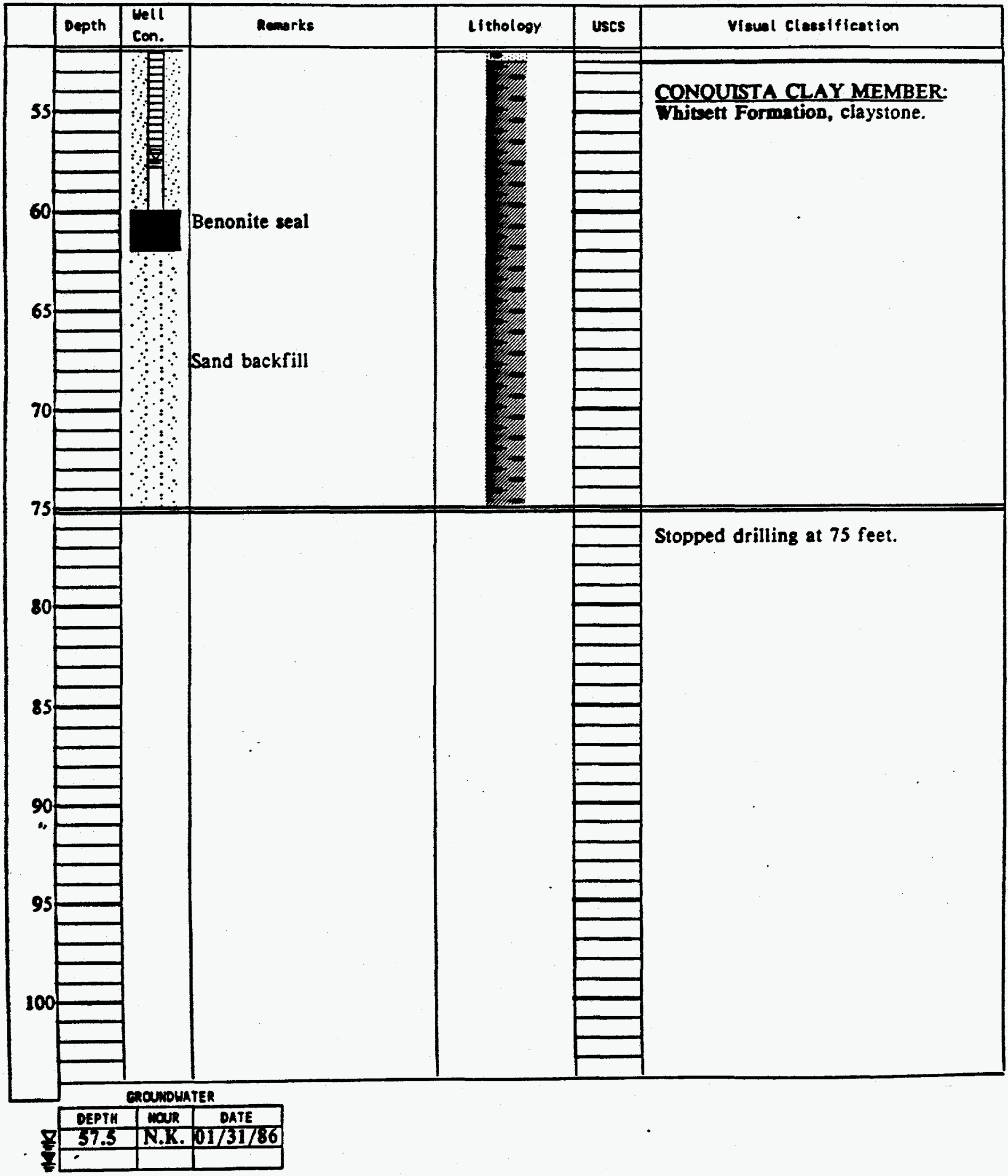

TOTAL DEPTH 75.0 feet

RIG TYPE

coring TYPE gn $^{\text {tricone }}$

LOCATIOO

N61478.20 E 61847.50

MSL

CONOUISTA CLAY MEMBER:

Stopped drilling at 75 feet. 
PROJECT UMTRA

Page 1 of 3

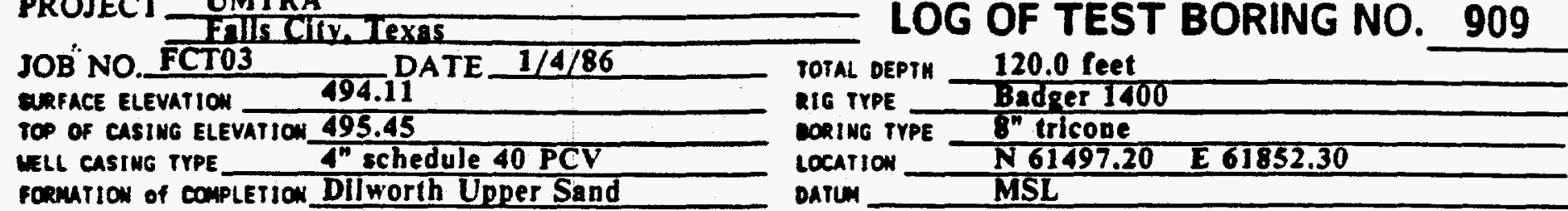

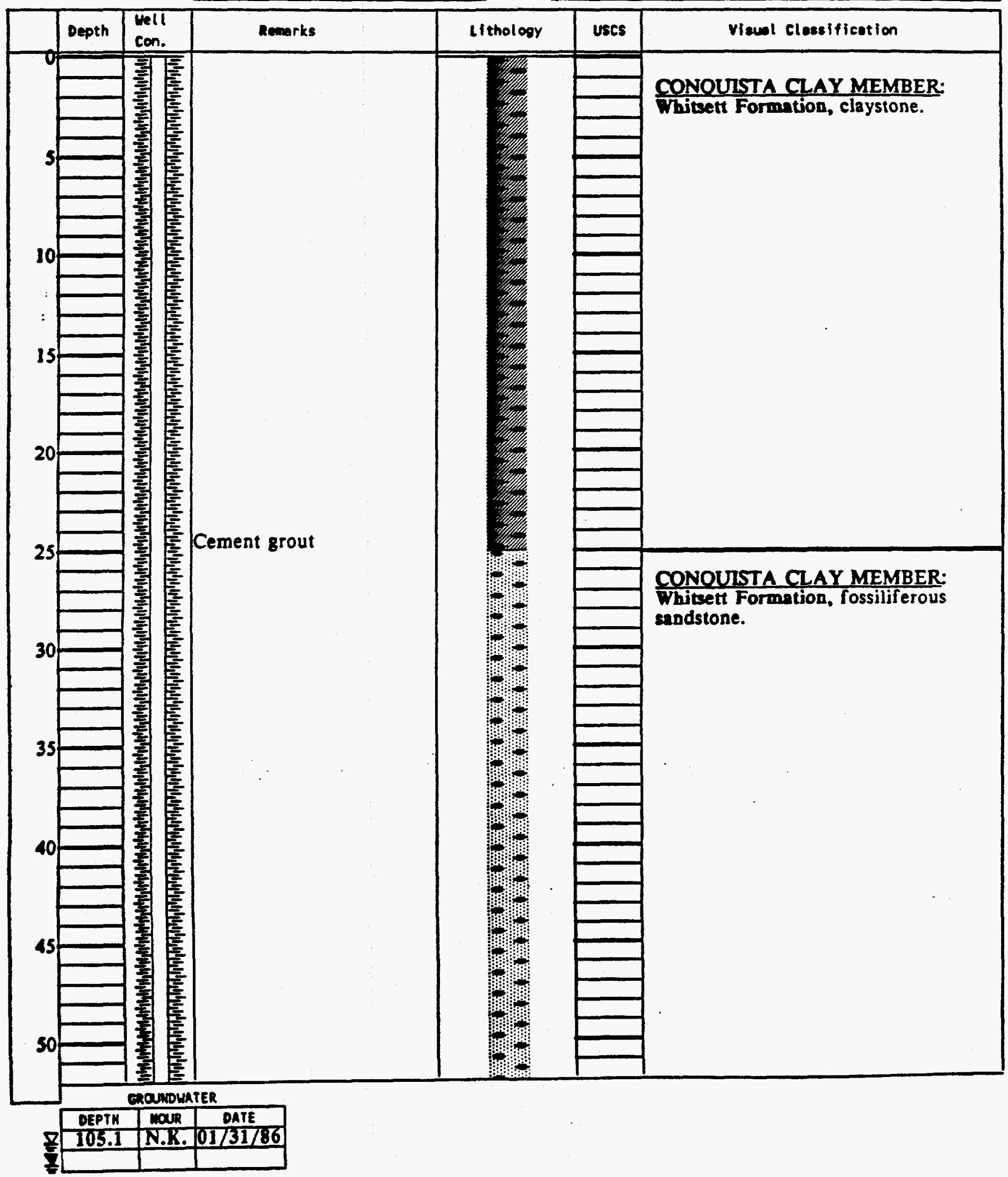


PROJECT UMTRA

JOB NO. FCT03 DATE $1 / 4 / 86$

ERFACE ELEVATION 494.11

TOP OF CASING ELEVATION 495.45

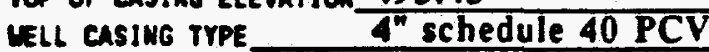

FORMATIOW of COMPLETION Dilworth Upper Sand

TOTAL DEPTM 120.0 feet

RIG TYPE Dadper 1400

CoRING TYPE $8^{n}$ tricone

Location N61497.20 E 61852.30

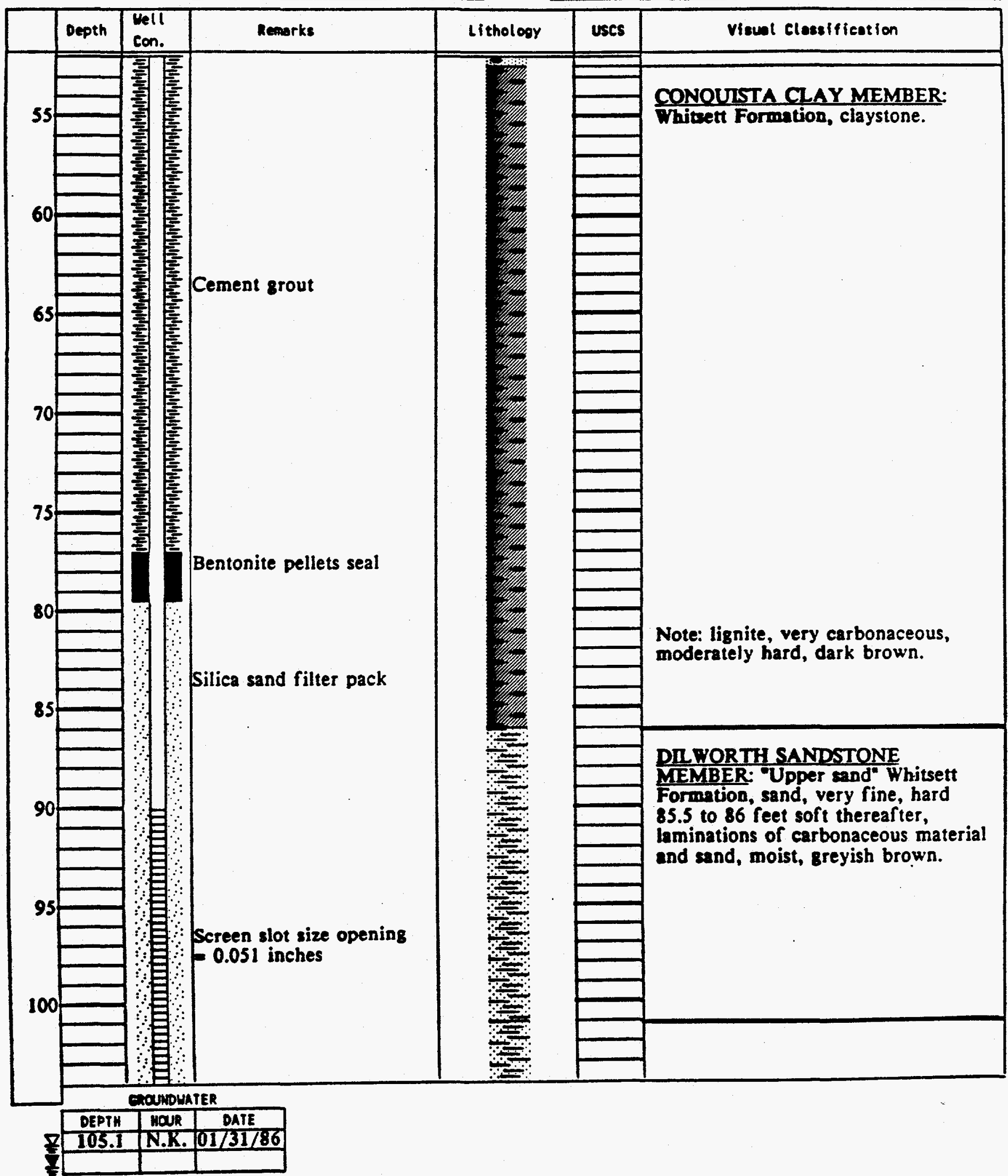


JOB NO. FCTO3

Fills City, Texas

gupace elevation \$94.1

Top of CASINE ELEVATION 495.45

WeLL CASING IYPE_ $4^{n}$ schedule 40 PCV

rormirion of conpletion Dilworth Upper Sand

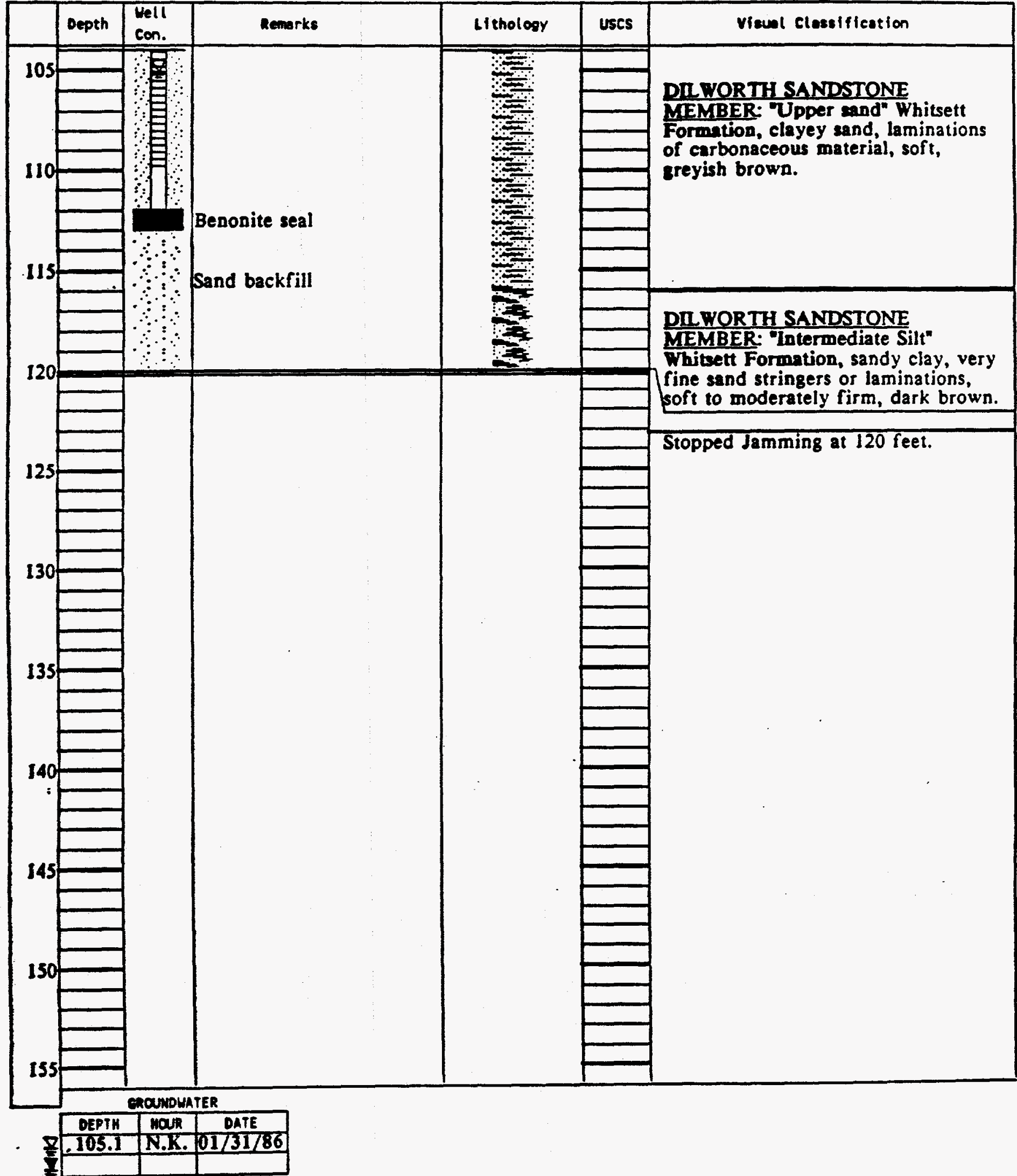


PROJECT UMTRA

Poge 2 of 4

Malls City. Texas

LOG OF TEST BORING NO. 910

JOB NO. FCTO3 DATE $12 / 16 / 85$

ERFACE ELEVATION $\mathbf{4 9 4 . 3 7}$

TOP of CASING ELEvation $\mathbf{4 9 4 . 8 8}$

vLl casing trPe $4^{n}$ schedule 40 PVC

fonmition of conpletion Lower Dilworth/Manning Clay

TOTAL DEPTK 197.0 feet

N16 TYPE Mayhew 1500

coring TYPE $8^{\prime \prime}$ tricone

LOCATION

Datum

N61483.70 E 61836.10

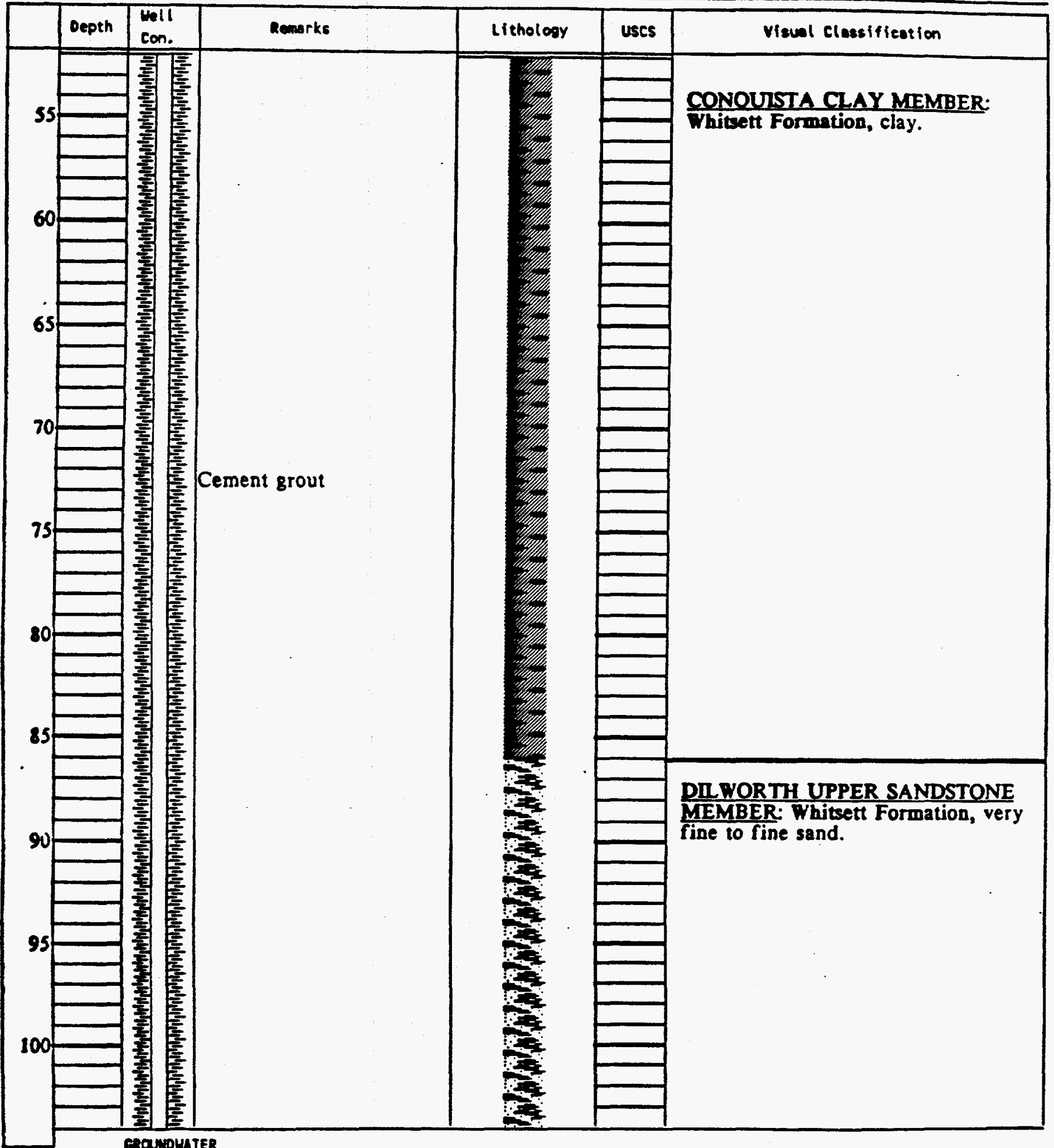

cROMUDUTER

\begin{tabular}{|c|c|c|}
\hline OEPTH & DOR & DATE \\
\hline 141.5 & N.K. & $01 / 31 / 86$ \\
\hline & & \\
\hline
\end{tabular}




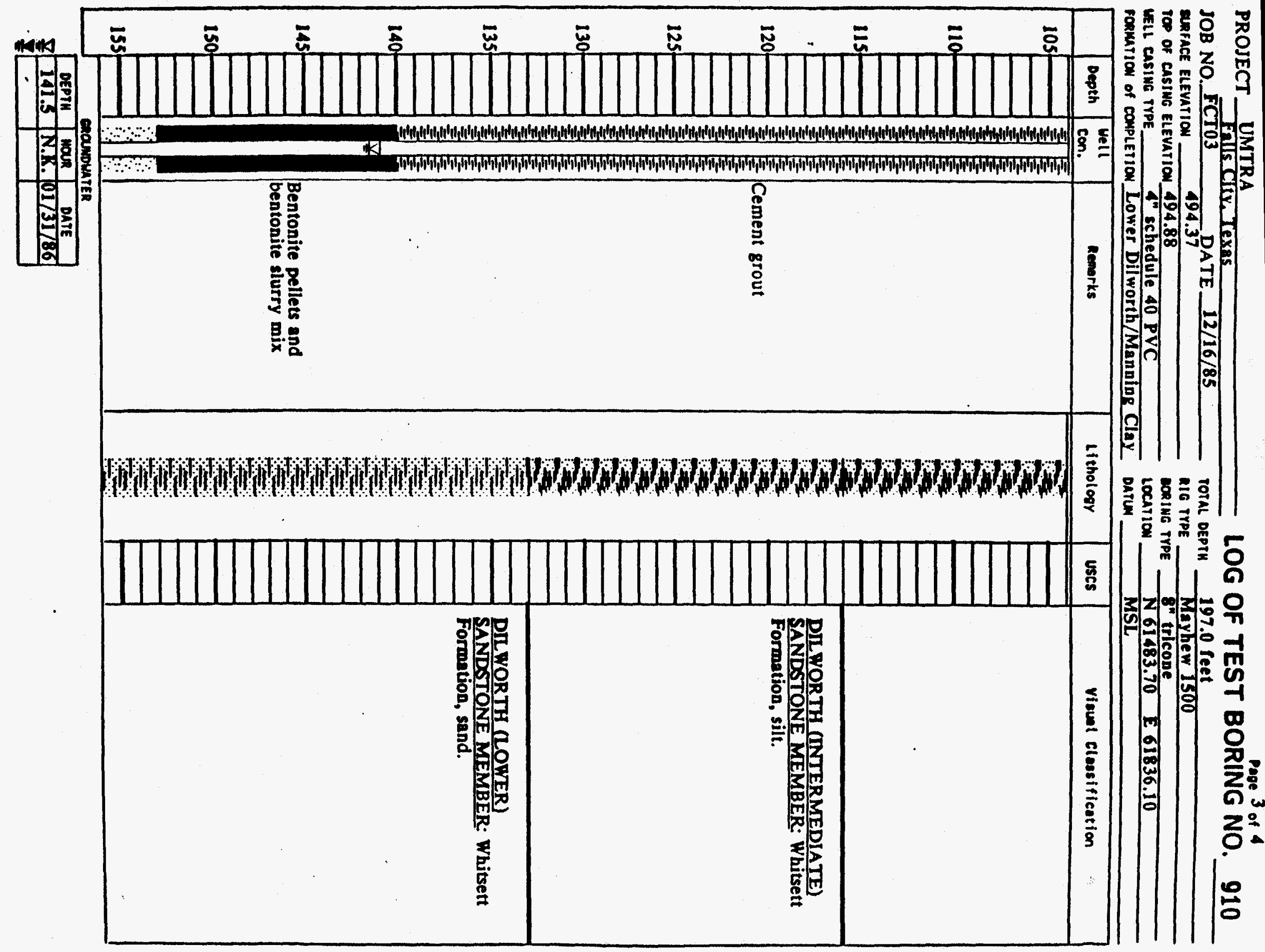


PROJECT UMTRA $\quad$ Poge 4 of 4 Enls City. Texas

JOB NO. FCT03

ERRACE ELEVATION

DATE $12 / 16 / 85$

LOG OF TEST BORING NO. 910

top of CASING ELEVATION 494.88

vell casing TYPE

pormation of conpletion Lower Dilworth/Manning Clay

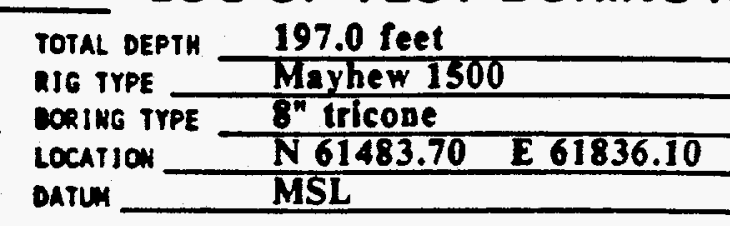

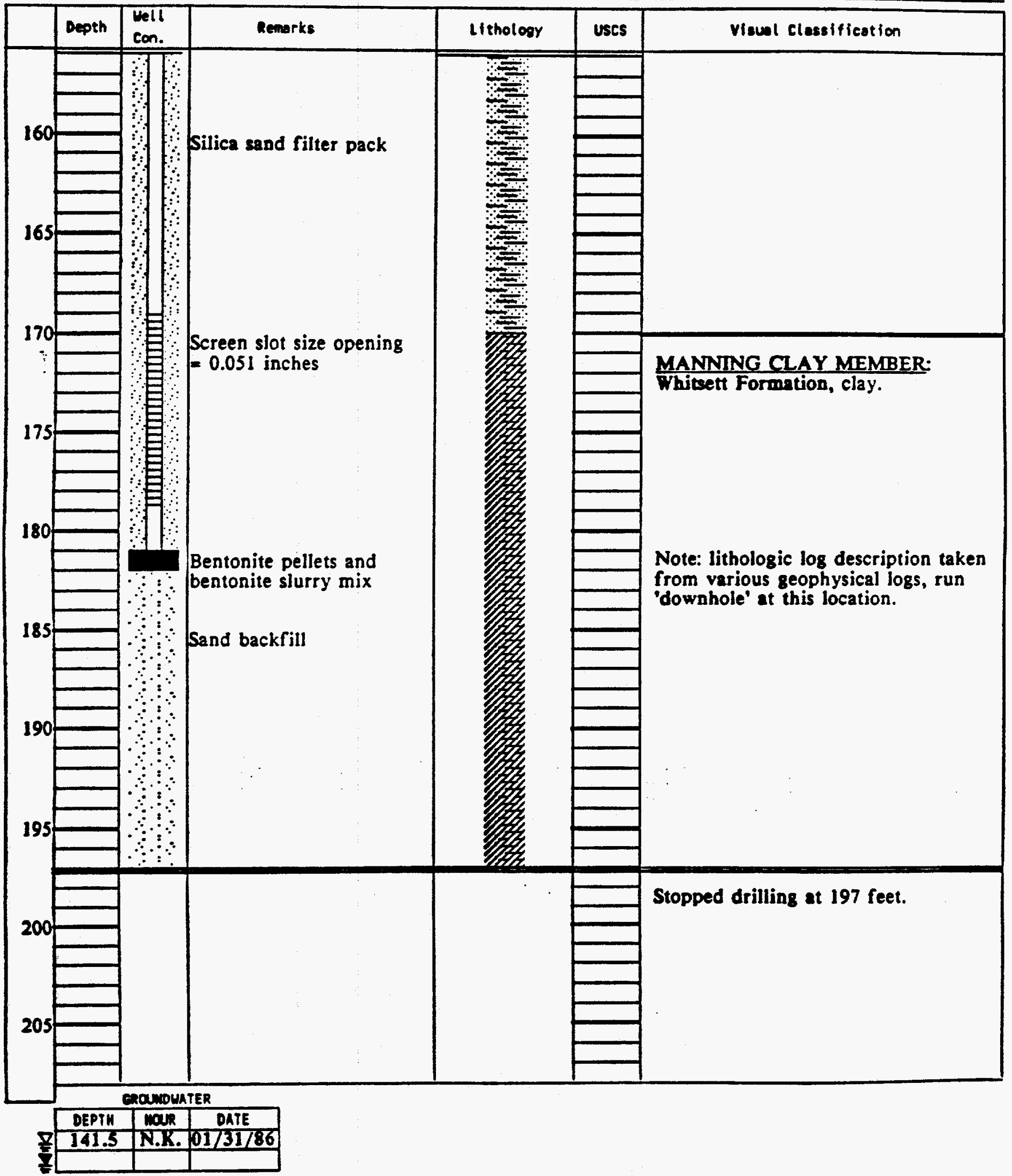


PROJECT UMTRA

JOB NO. FCTO

QRRACE ELEVATIOW

IOP OF CASING ELEVATIOO

VELL CASING IYPE

Poemutrow of compLETION Upper Dilkorth

$$
417.94
$$

Pape 1 of 1

LOG OF TEST BORING NO. 911

DATE $1 / 13 / 86$

TOTAL DEPTH 20.0 feet

RIG TYPE Badper 1400

CORING TYPE $8^{\prime \prime}$ tricone

LOCATION

oarum MSL

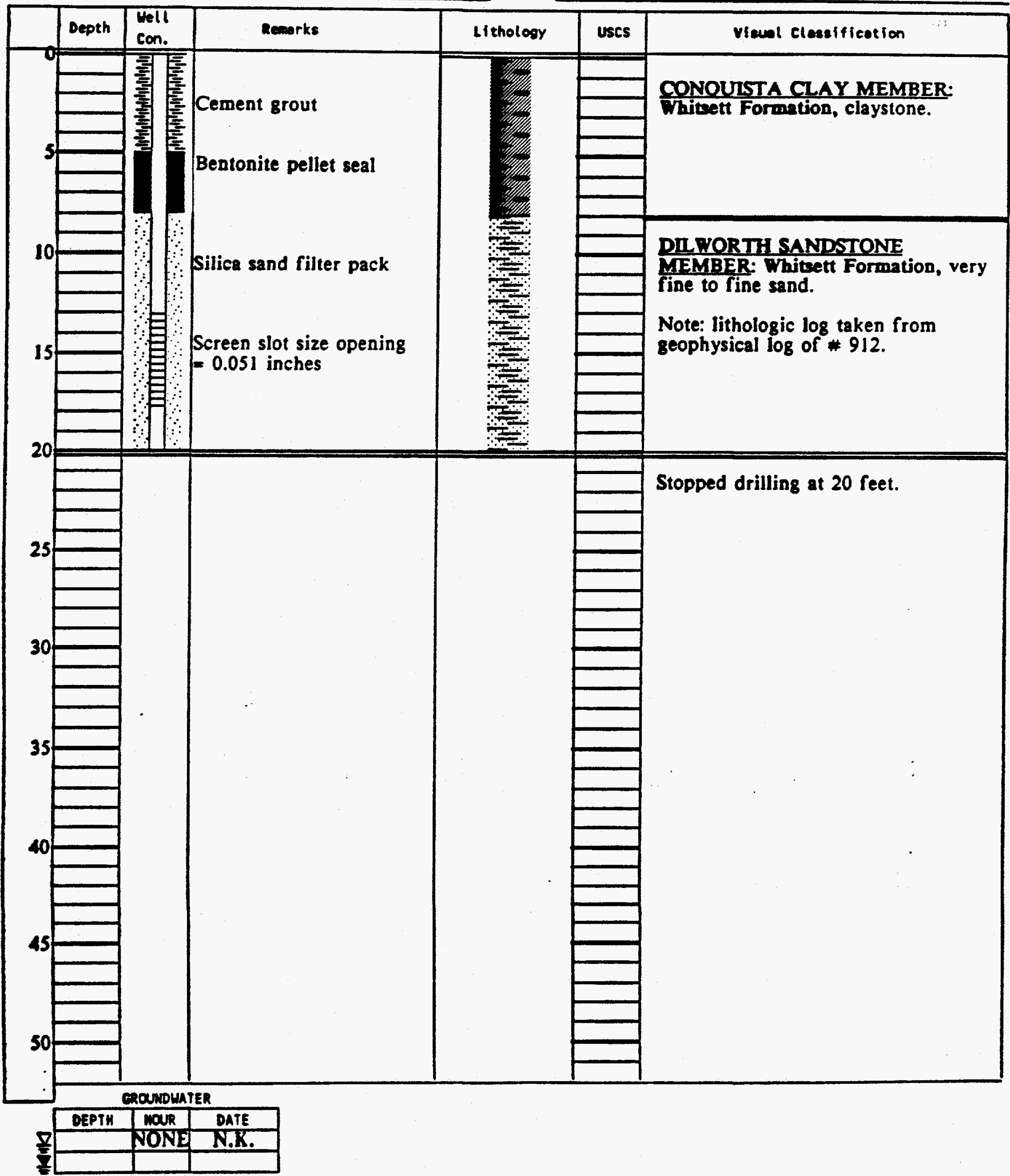


- PROJECT UMTRA

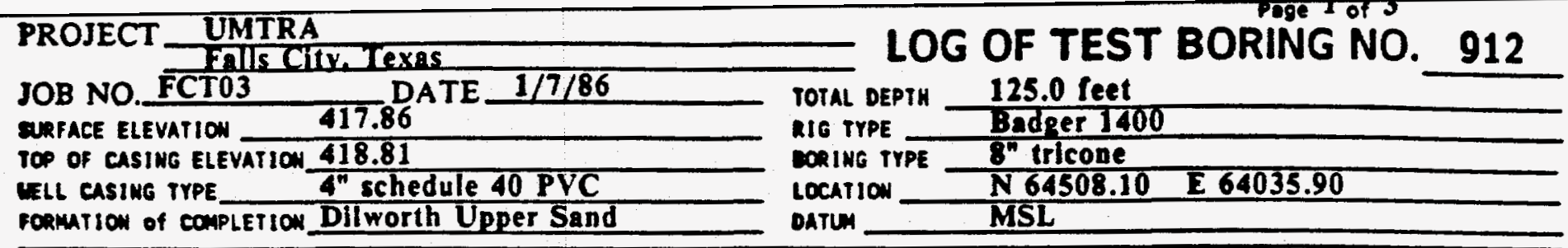

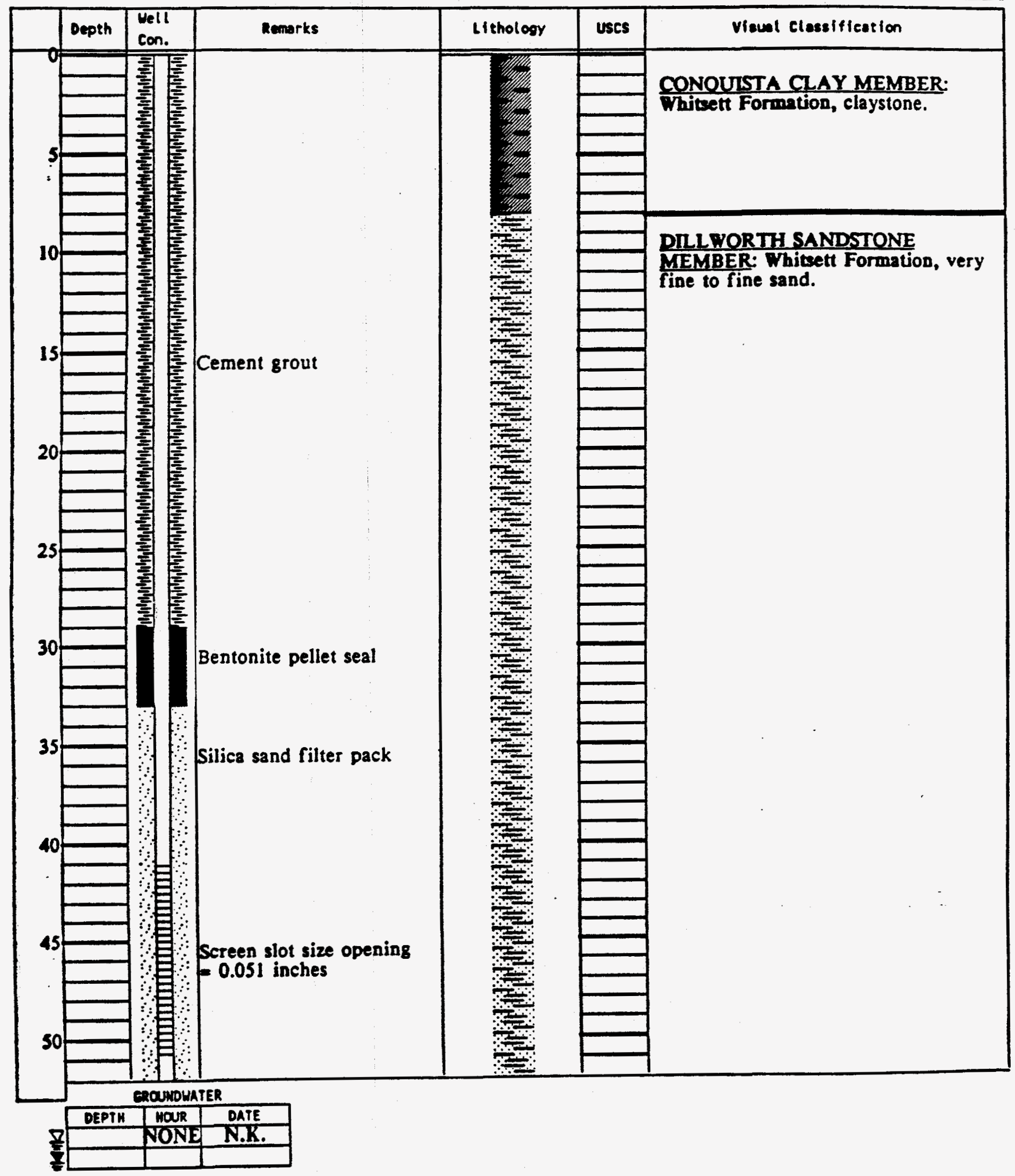


PROJECT UMTRA

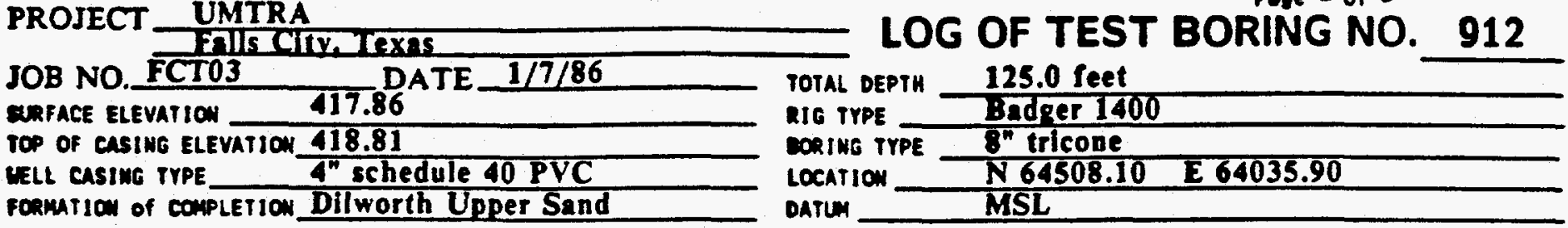

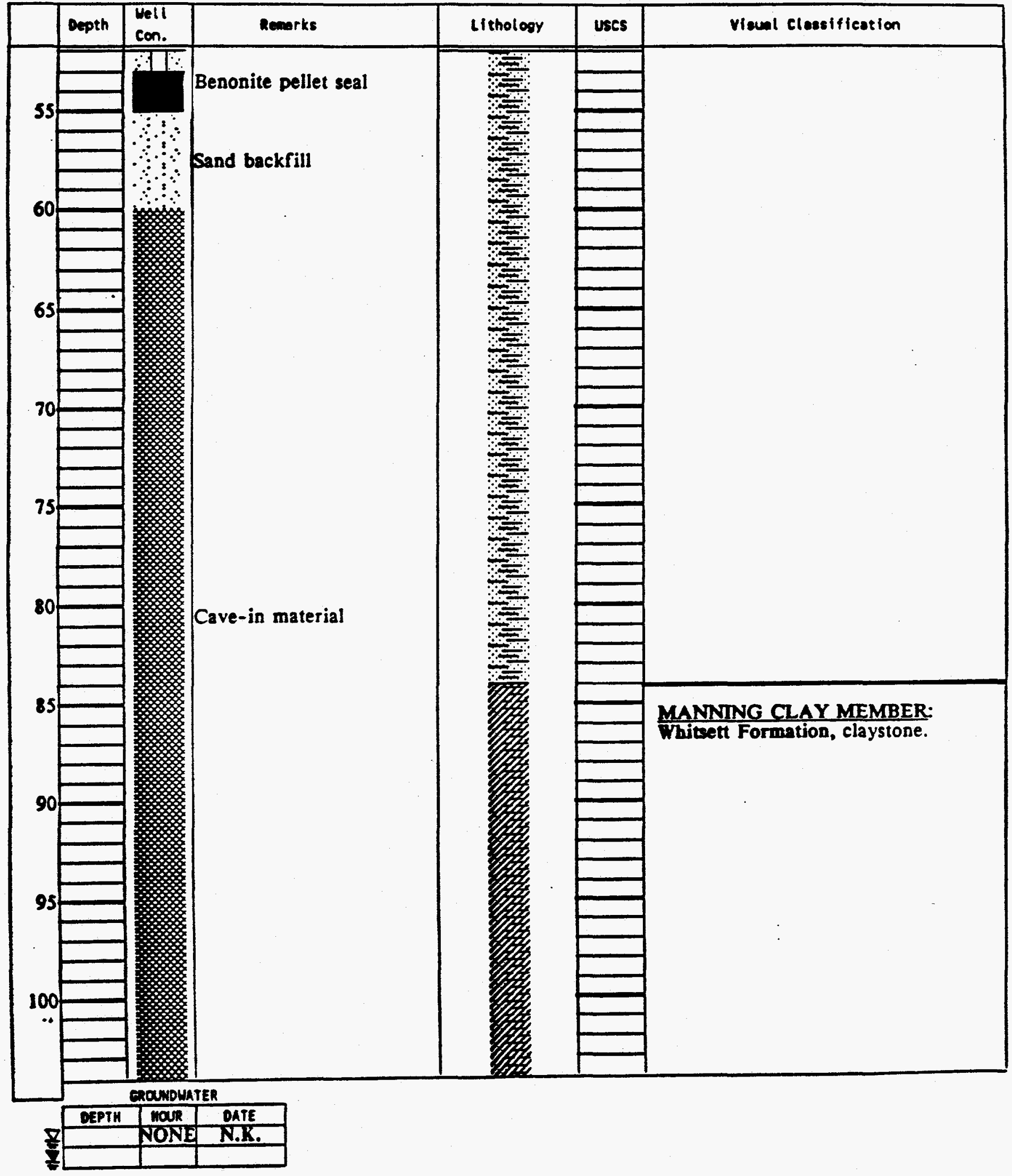


PROJECT UMTRA

Mils cily. Texas

LOG OF TEST BORING NO. 912

JOB NO. FCTO

DATE $1 / 7 / 86$

TOTAL OEPTH
RIG TYPE

MRFACE ELEVATION

TOP OF CASING ELEVATIOW 418.81

cell casing tYPE 4" schedule 40 PVC

Formution of Conpletion Dilworth Upper Sand

RIG TYPE

Location N64508.10 $\quad$ E64035.90

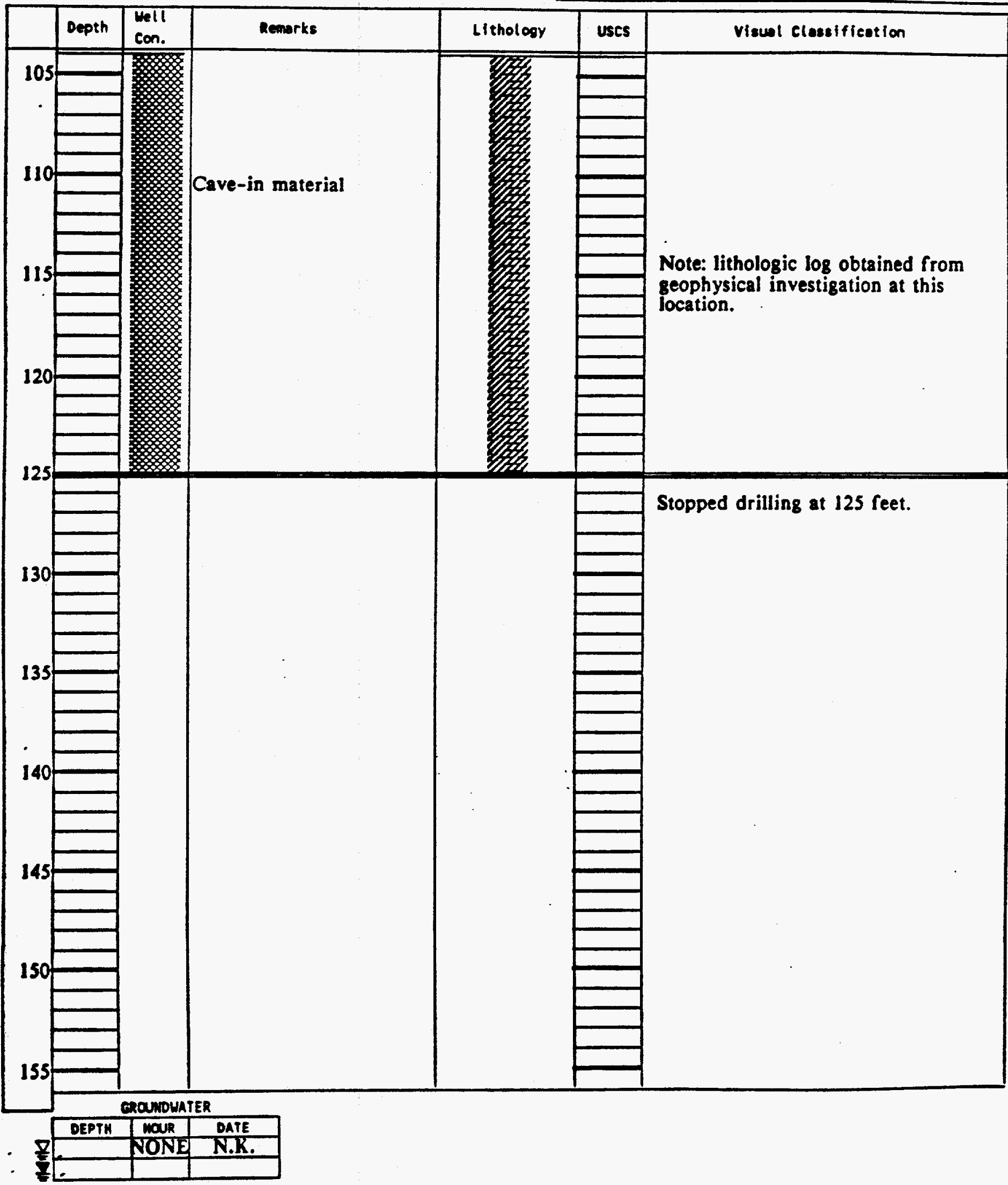




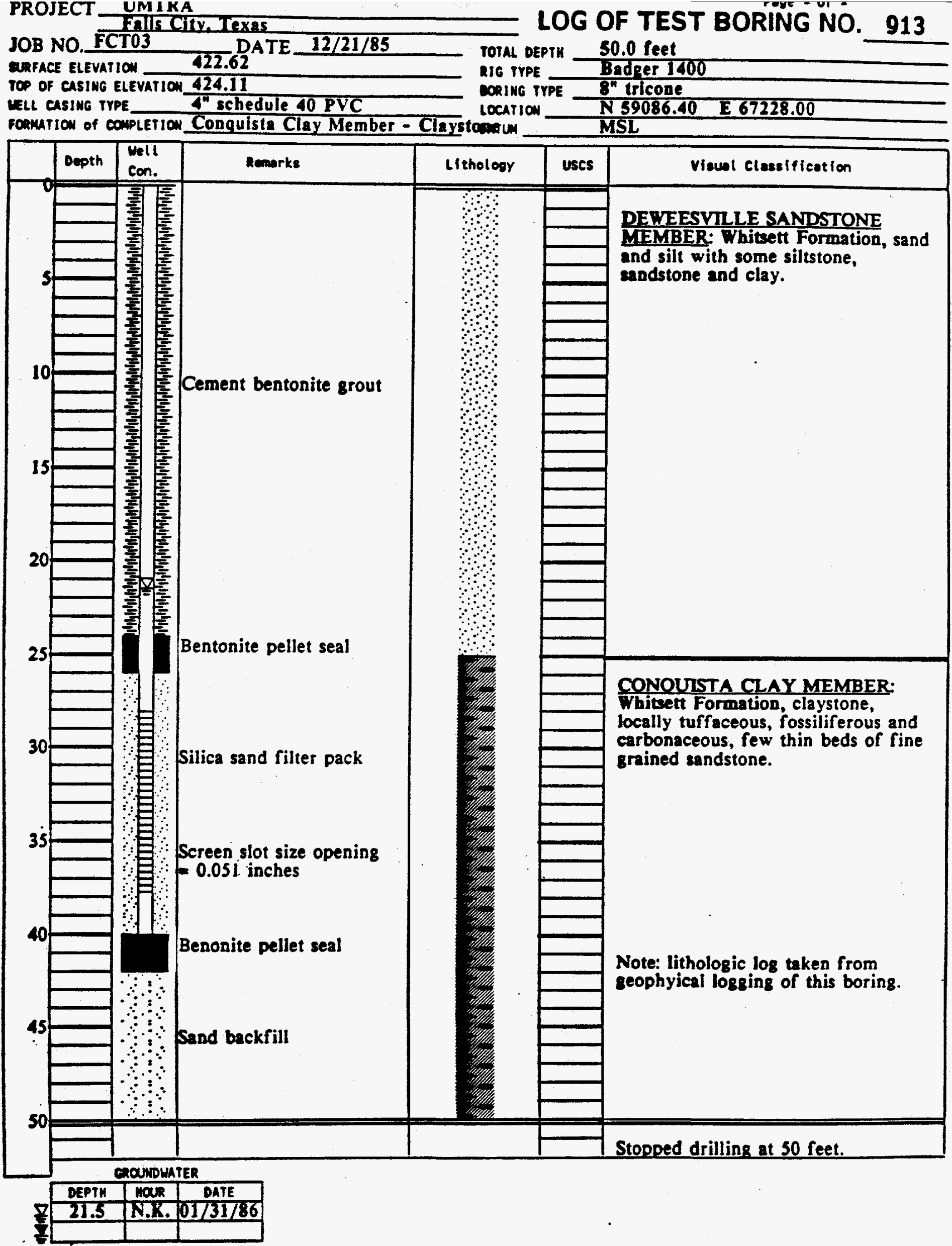


JOB NO. FCTO3

DATE $1 / 14 / 86$

TOTAL DEPTH 20.0 feet

guRACE ELEVATION $\quad \mathbf{4 3 3 . 9 4}$

TOP OF CASING ELEVATION 435.79

LeLL CAsing TYPE

Formation of completion Deweesville/Conquista Member

RIG TYPE Tadrer 1400

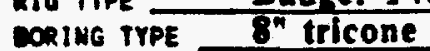

LOCATION N64381.50 E 66677.10

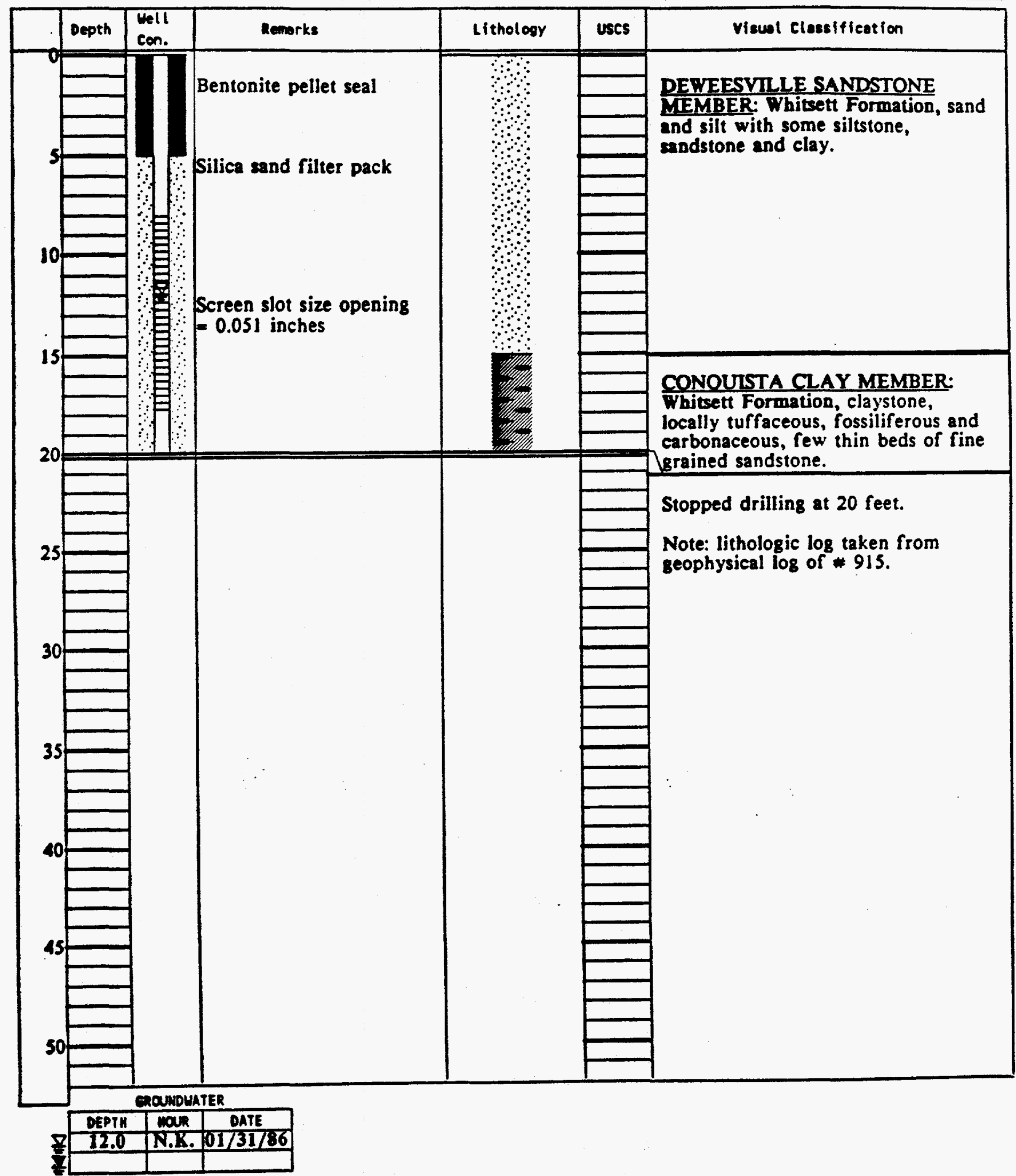




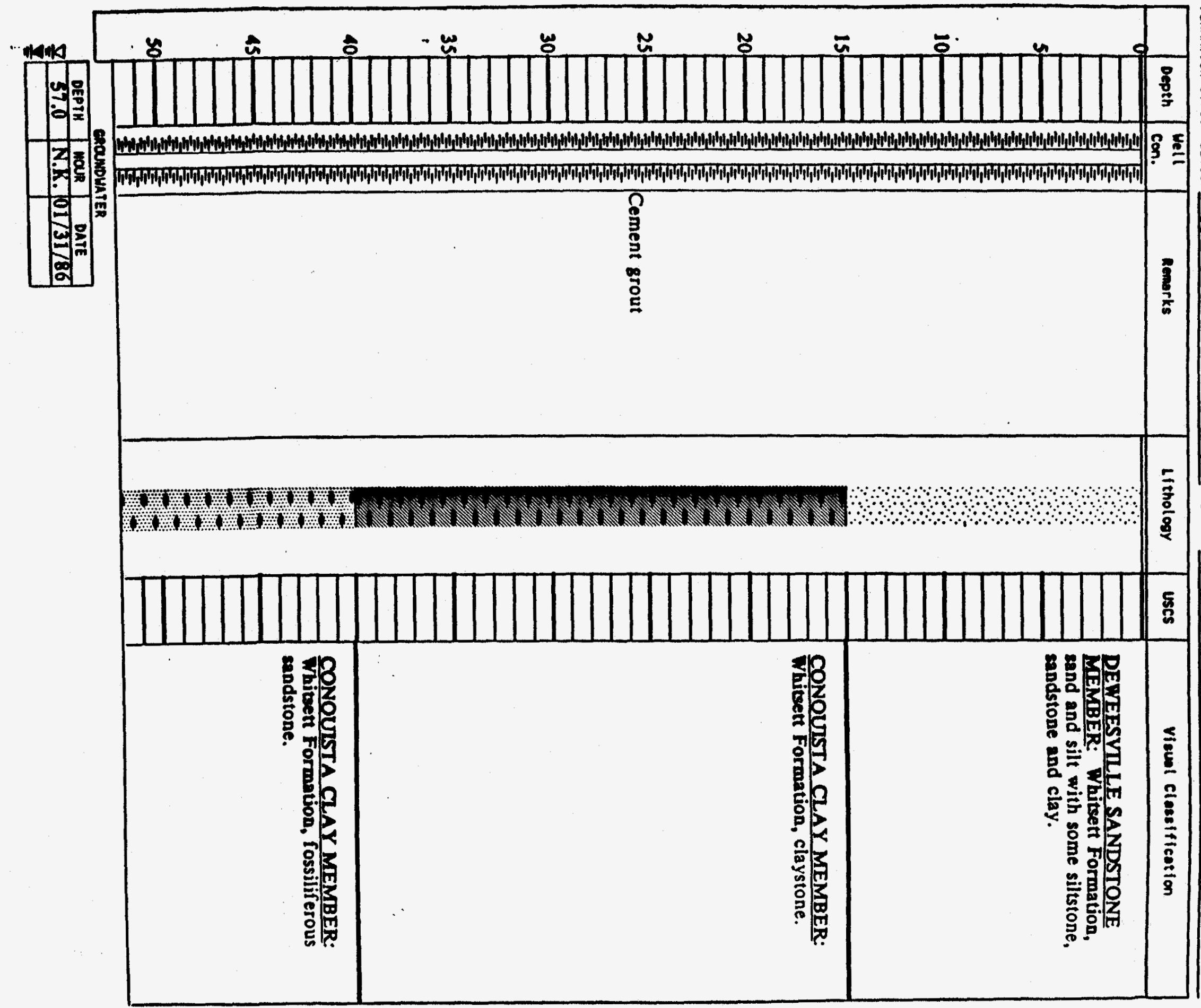

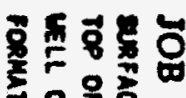

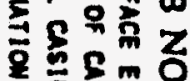
옹 空零 8 素 再是

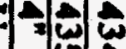
D T) 븨을 
PROJECT UMTRA

JOB NO. FCT03

Mils City Texns

ERFACE ELEVhTION $\mathbf{4 3 4 . 2 0}$

top of castug elevartow 435.55

MLL castwg trPe

sonmution of conpletion Upper Dilworth Sand

TOTAL DEPTK 110.0 feet

NIG TYPE Badger 1400

coring TrPE $g^{\text {"tricone }}$

Location N61371.90 E 66687.60

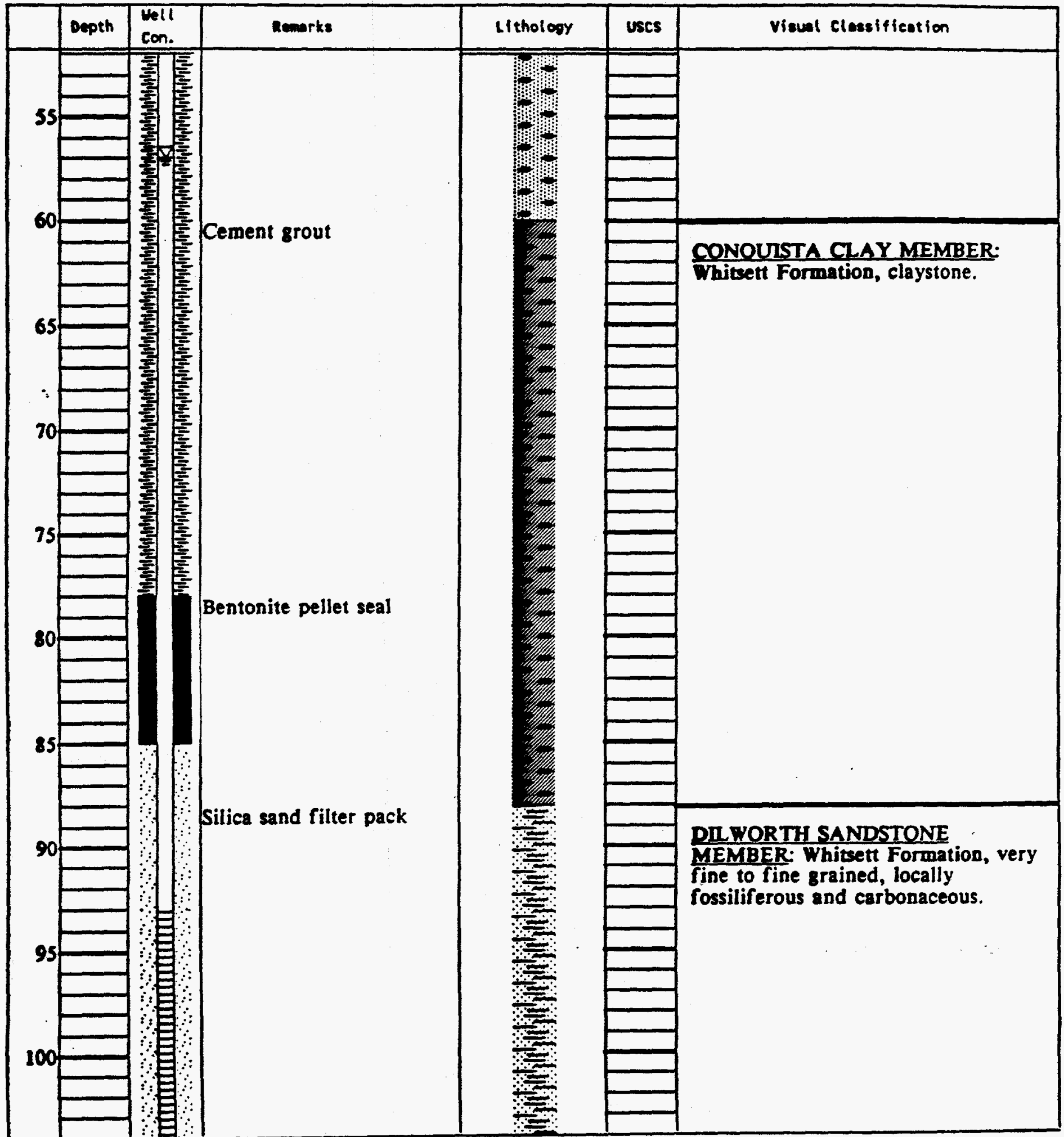

Maviourater

\begin{tabular}{|c|c|c|}
\hline DEPTH & MauR & DATE \\
\hline S7.0 & N.K. & $01 / 31 / 86$ \\
\hline & & \\
\hline
\end{tabular}


PROJECT UMTRA

JOB NO. FCT03

Enls city texas

LOG OF TEST BORING NO. 915

ERFACE ELEVATION

DATE $1 / 14 / 86$

ToP of castwg elevation 435.55

rell casing trpe $4^{n}$ schedule 40 PVC

romation of completion Upper Dilworth Sand

TOTAL DEPTH 110.0 feet

nio TrPe Badger 1400

conINe trPE $8^{n}$ tricone

Location N61371.90 $\mathrm{E} 66687.60$

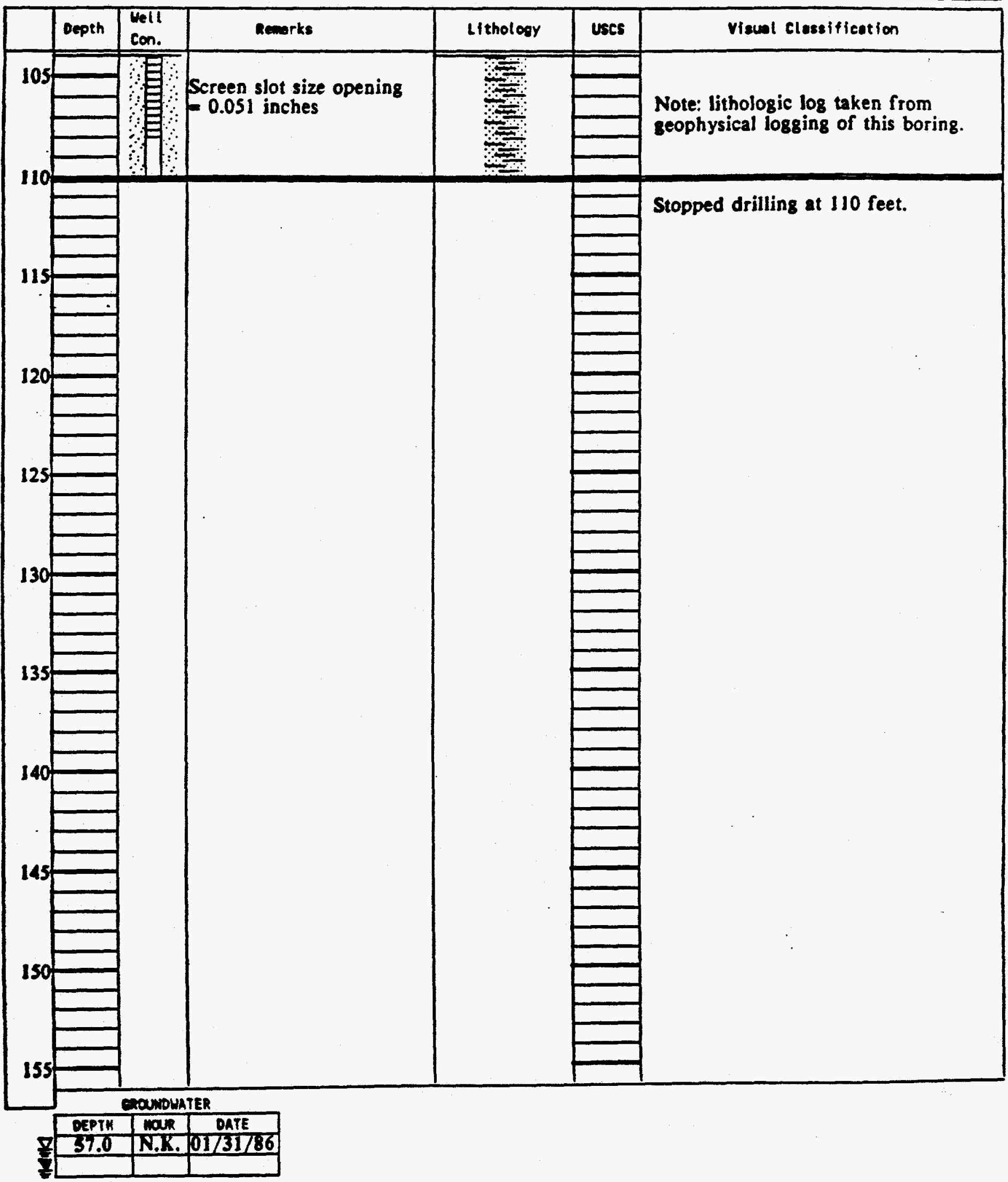


PROJECT UMTRA

Page 1 of 1

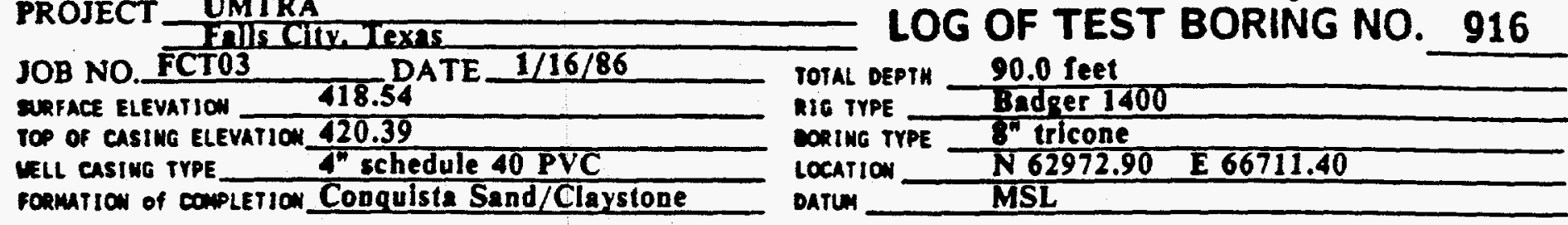

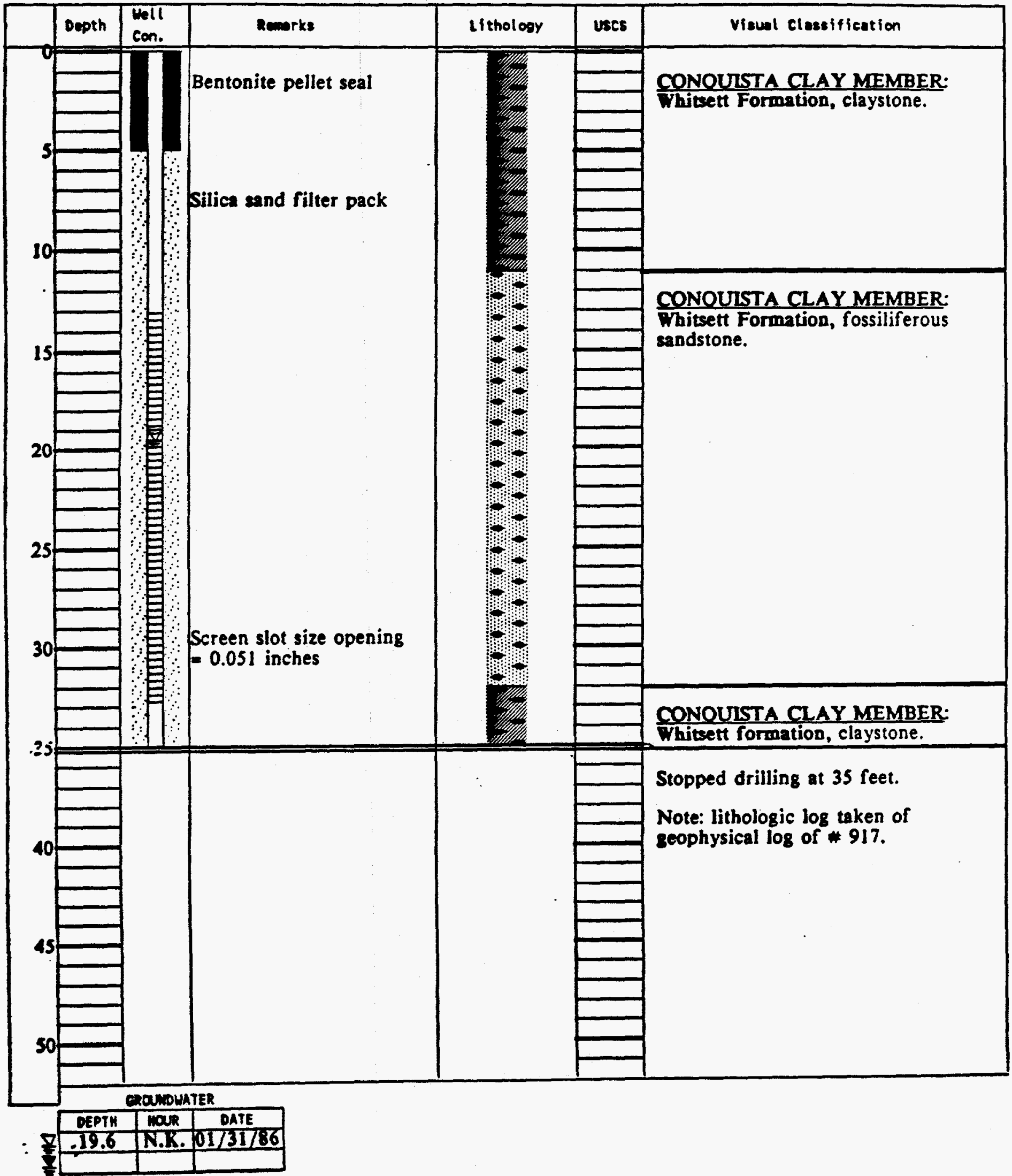




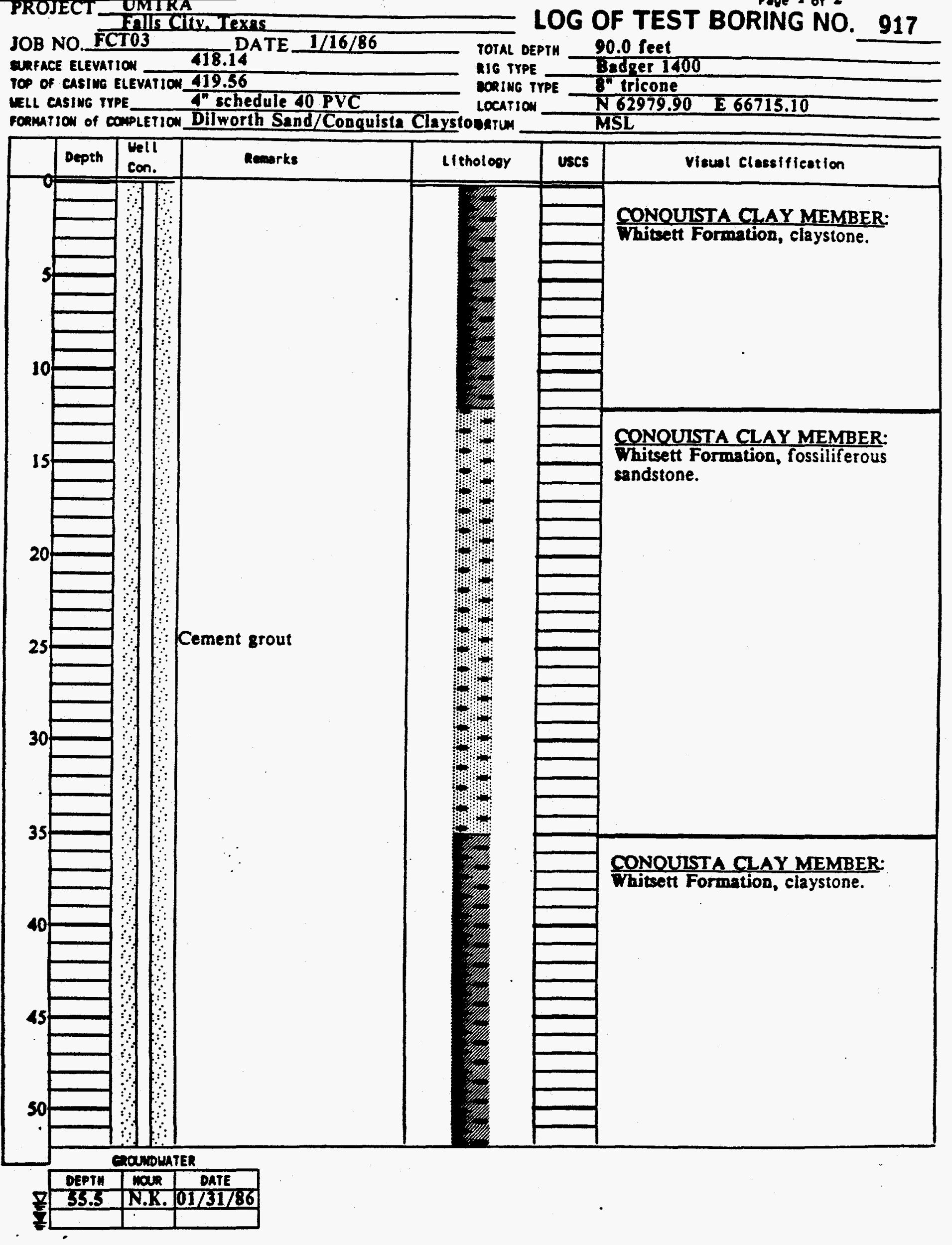


PROJECT UMTRA

Poge 2 of 2

Fallscityetexis

JOB NO. FCT03

DATE $1 / 16 / 86$

LOG OF TEST BORING NO. 917

arface Elevation 418.14

To of CASING ELEVATIOM $\mathbf{4 1 9 . 5 6}$

cell casime trPe 4 schedule 40 PVC

Fonurion of completion Dilworth Sand/Conquiste Claystonerum

TOTAL DEPTH 90.0 feet

RIG TYPE - Badger 1400

conive trae $8^{n}$ tricone

Location N62979.90

MSL

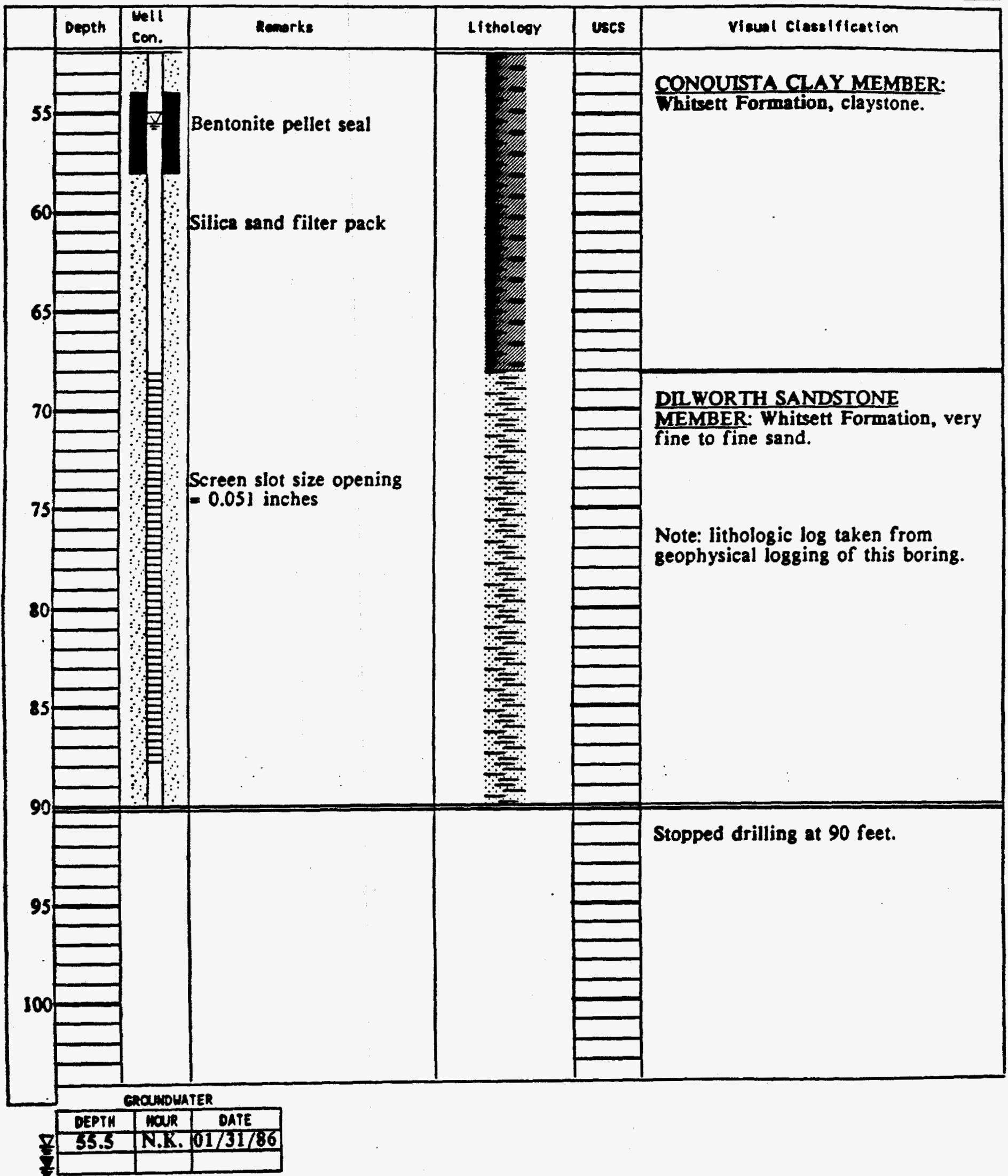


PROJECT UMTRA

JOB NO. FCT03

ERFACE ELEVATION

tY. Texas

LOG OF TEST BORING NO. 918

TOP OF CASINE ELEVATION 404.03

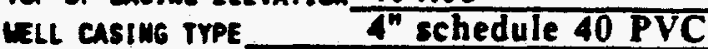

DATE $1 / 7 / 86$

10.0 feet

ronution of conpletion Lower Deweesville Sand Member

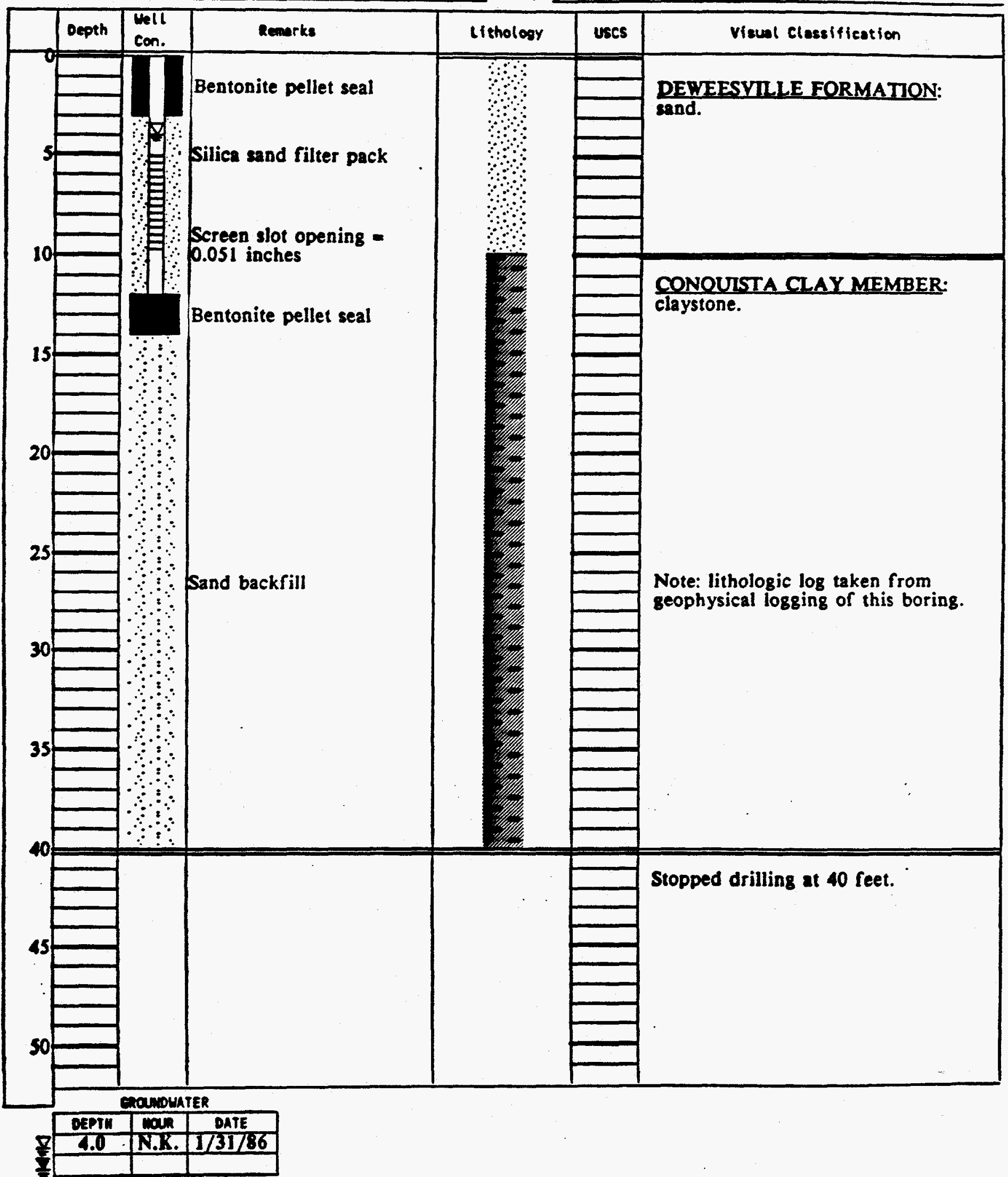


ronurion of conterion Conquista Sandstone/Claystone

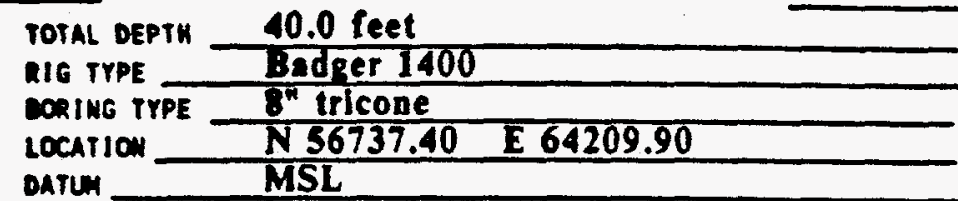

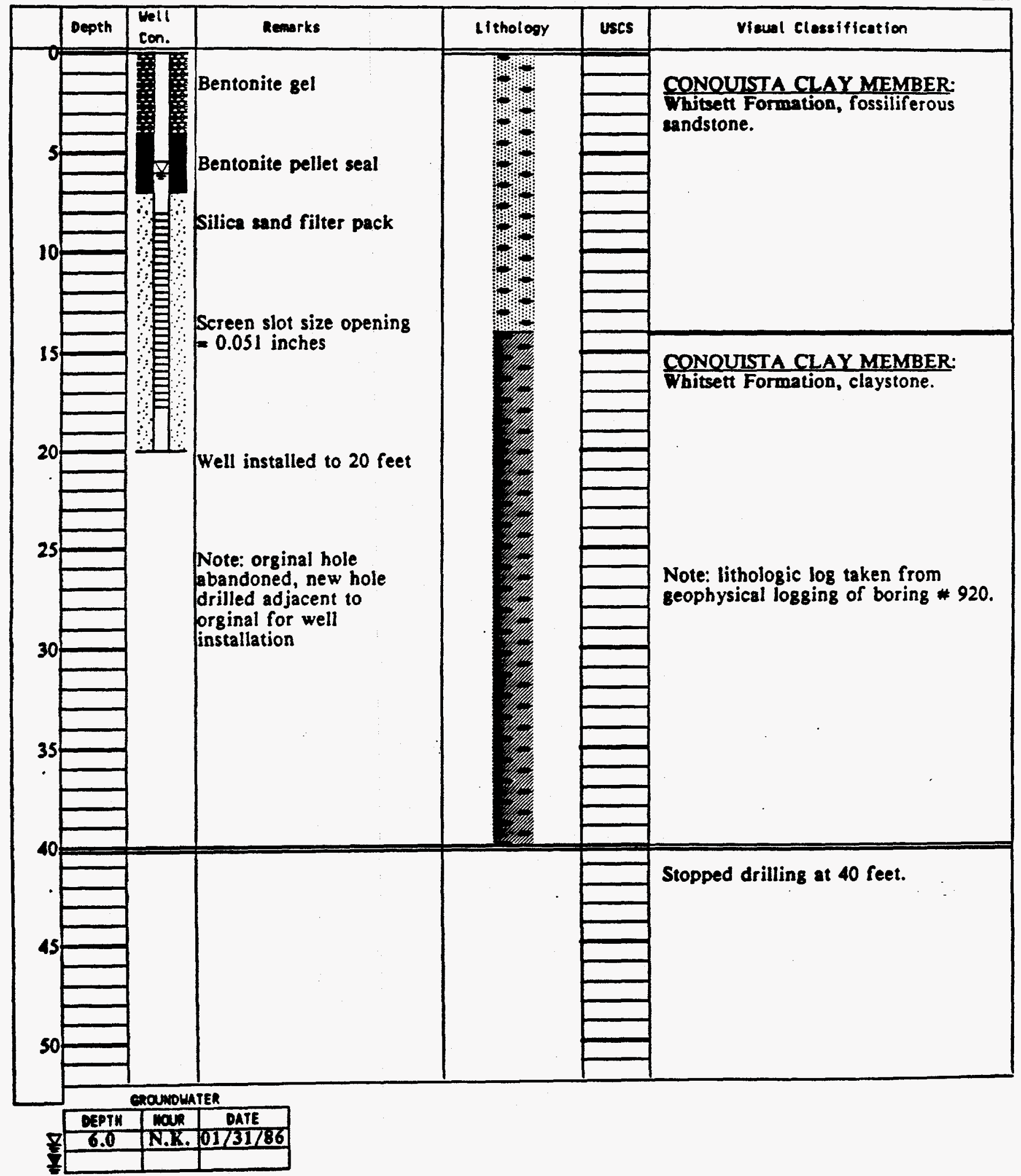


PROJECT UMTRA

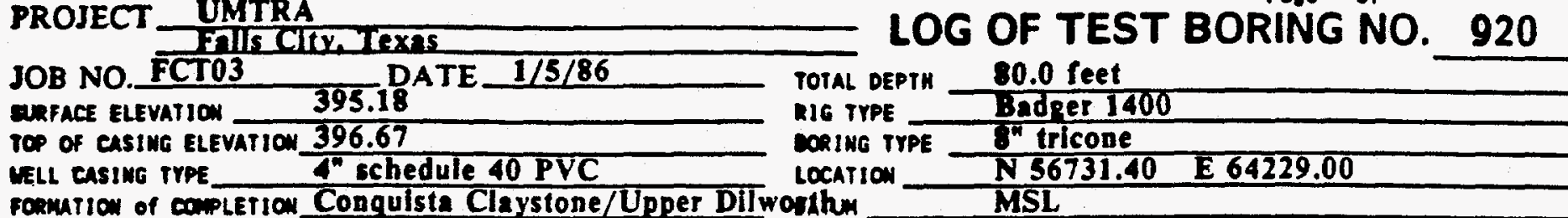

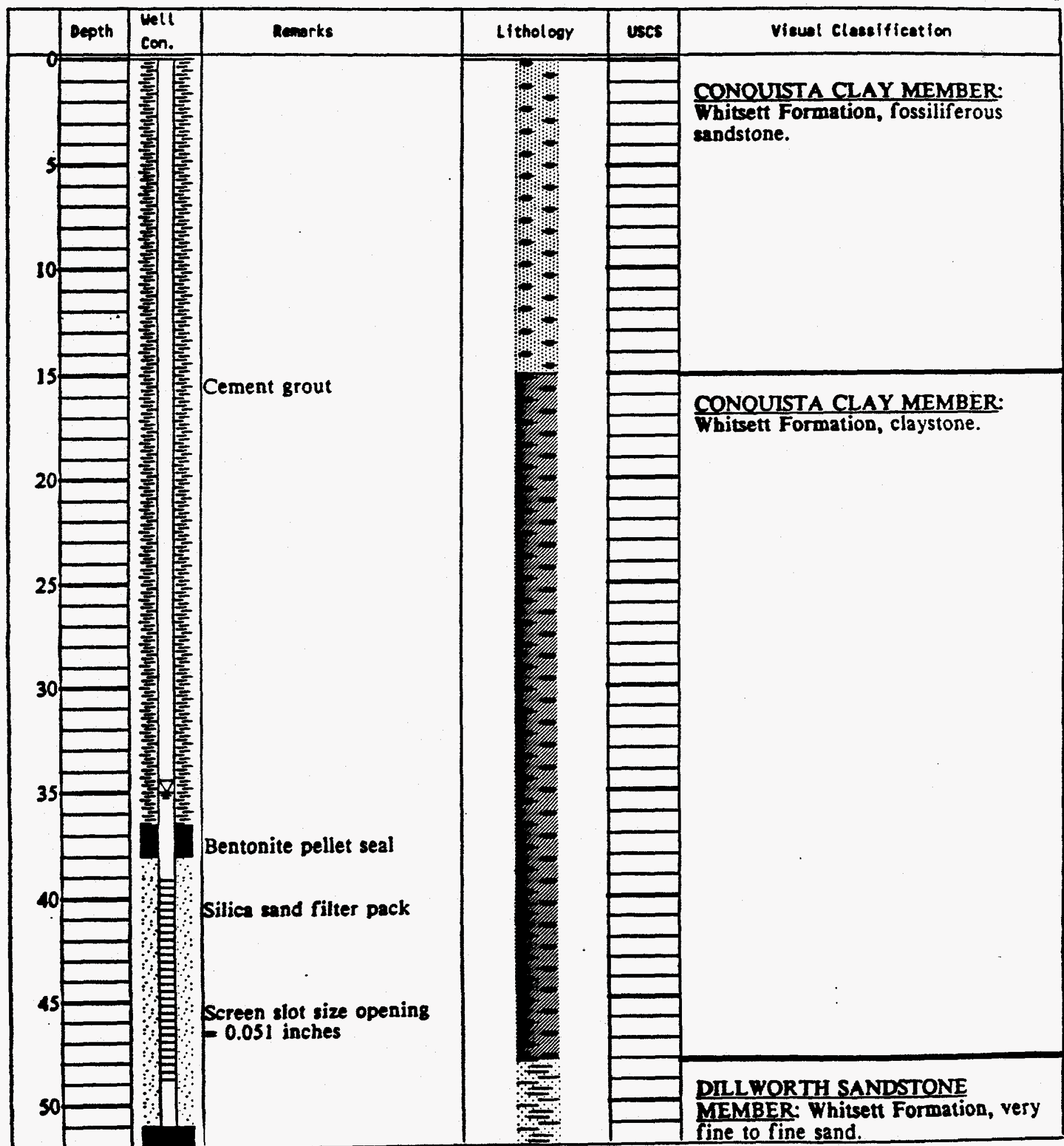

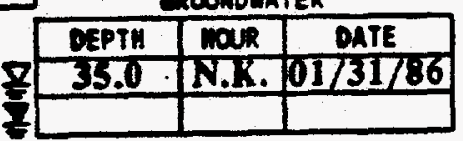


PROJECT UMTRA

JOB NO. FCTO3

ARFACE ELEVATION 395.18

TOP OF CASIMU ELEVATION 396.67

rell casing trPE 4 schedule 40 PVC fonmition of completion Conquists Claystone/Upper Dilworthy

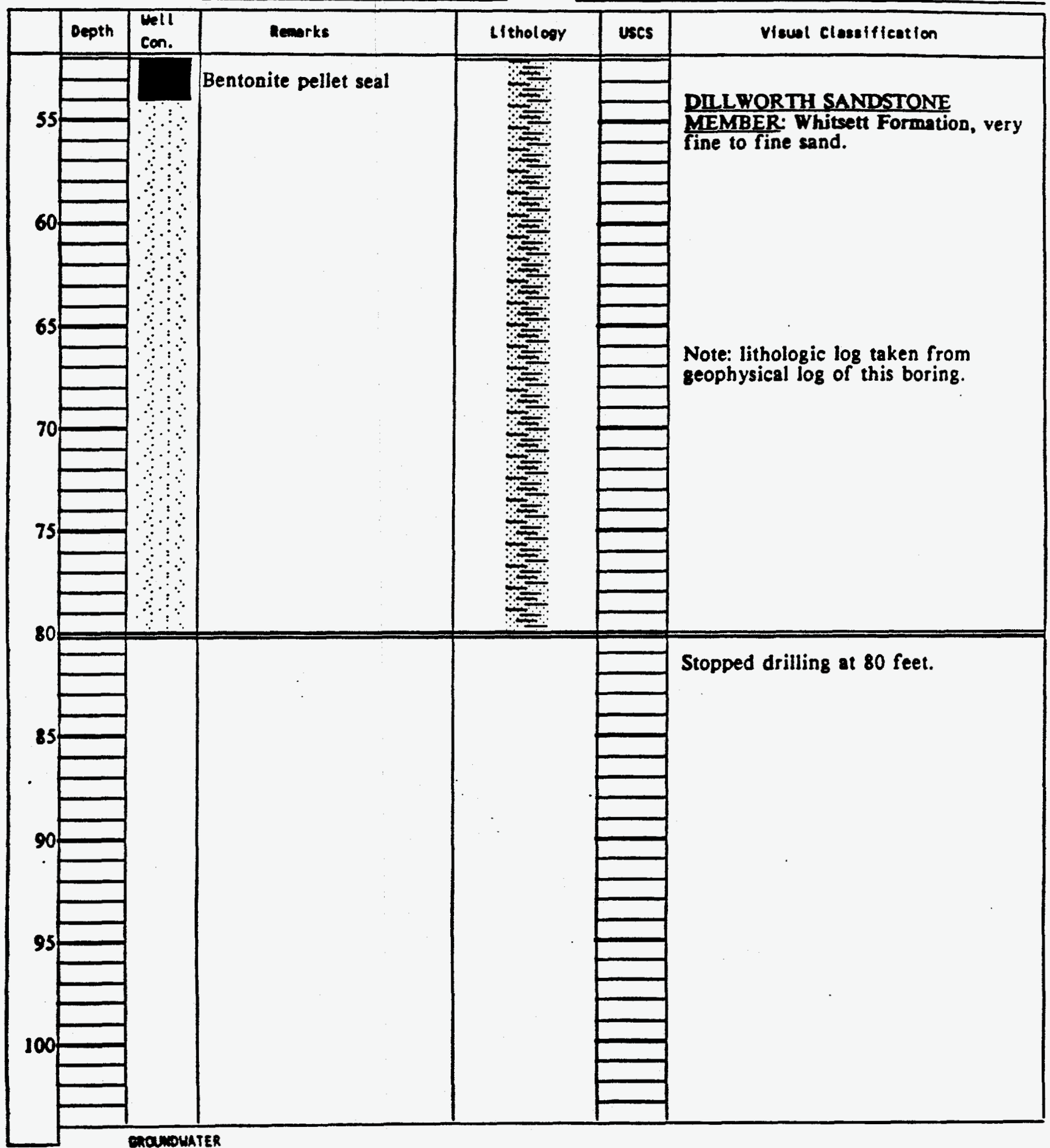

EXA

TOTAL OEPTH $\frac{80.0 \text { feet }}{\text { BAdG TYPE } 1400}$

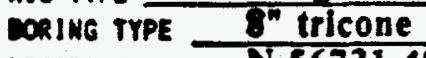

Conino TYPE

N56731.40

MSL
DILLORTH SANDSTONE

MEMBER: Whitsett Formetion, very fine to fine sand.

Note: lithologic log taken from geophysical log of this boring.

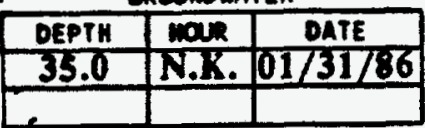


PROJECT UMTRA

LOG OF TEST BORING NO. 921

JOB NO. FCTO3

wRFACE ELEVATION $\quad \mathbf{4 3 4 . 3 0}$

TCP OF CASINE ELEVATION 435.75

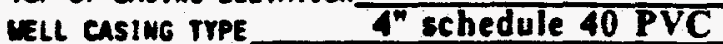

formition of completion Conquista Fossilirerous Sand

ATE $1 / 14 / 86$

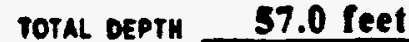

NIG TYPE Badger 1400

CORING TYPE $8^{\text {" tricone }}$

Locariow N61389.40 E 66693.50

oAtum MSL

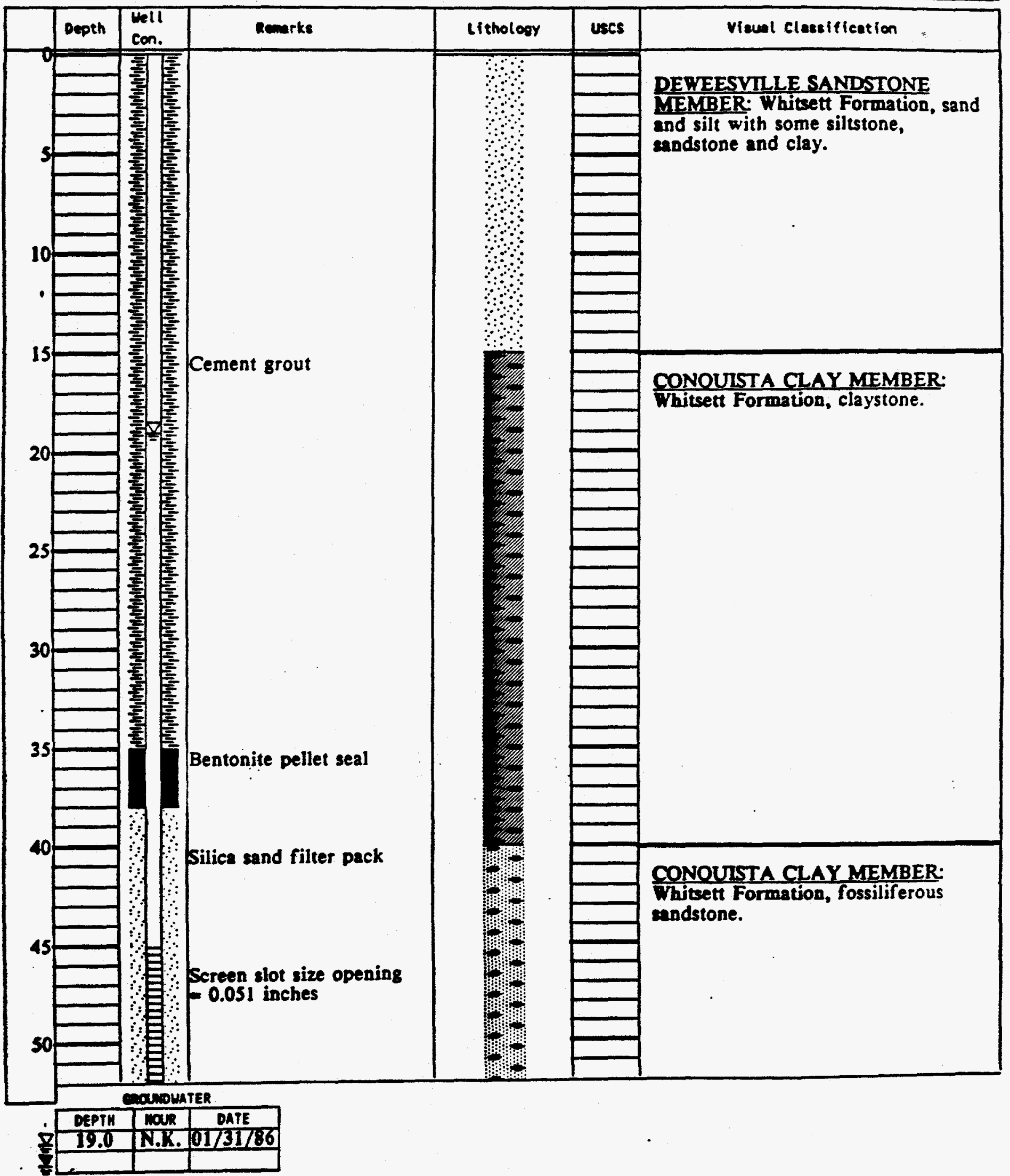


Poge 2 of 2

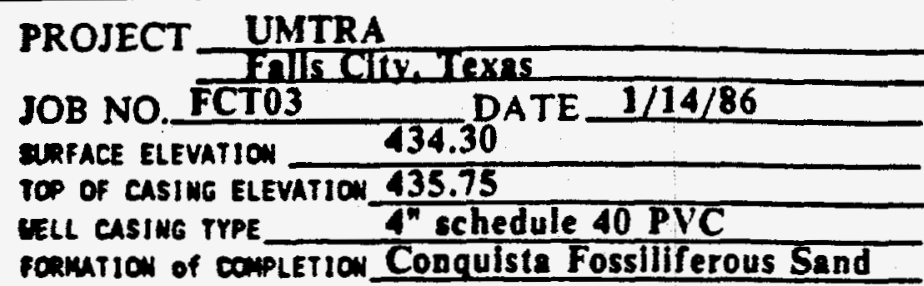

LOG OF TEST BORING NO. 921

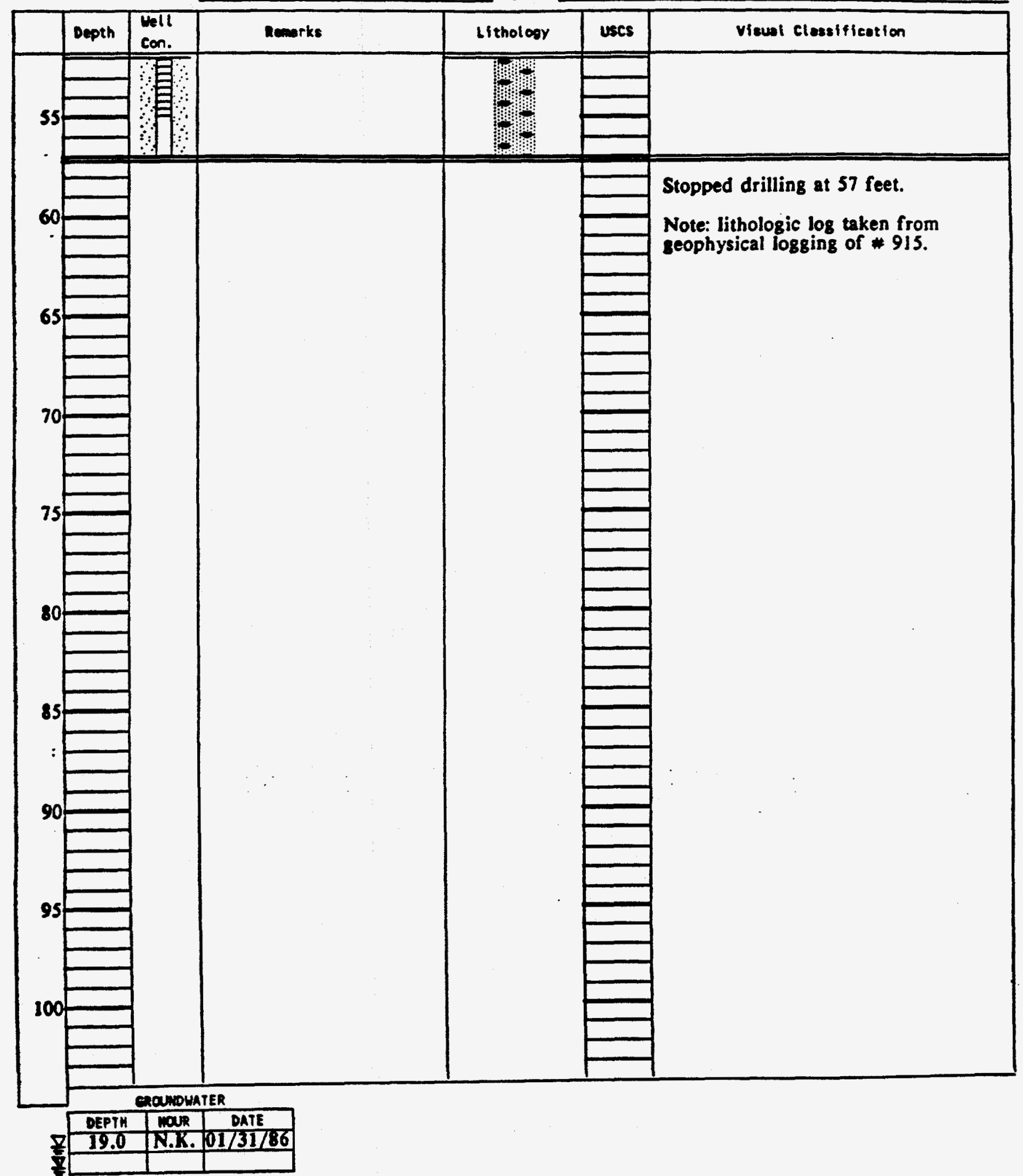


PROJECT UMTRA

Poge 1 of 2

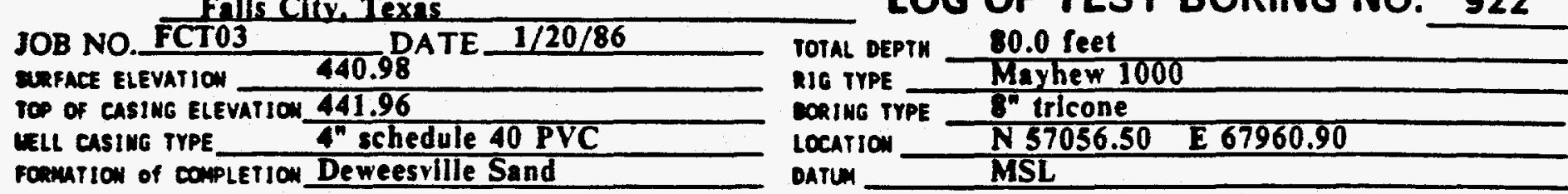

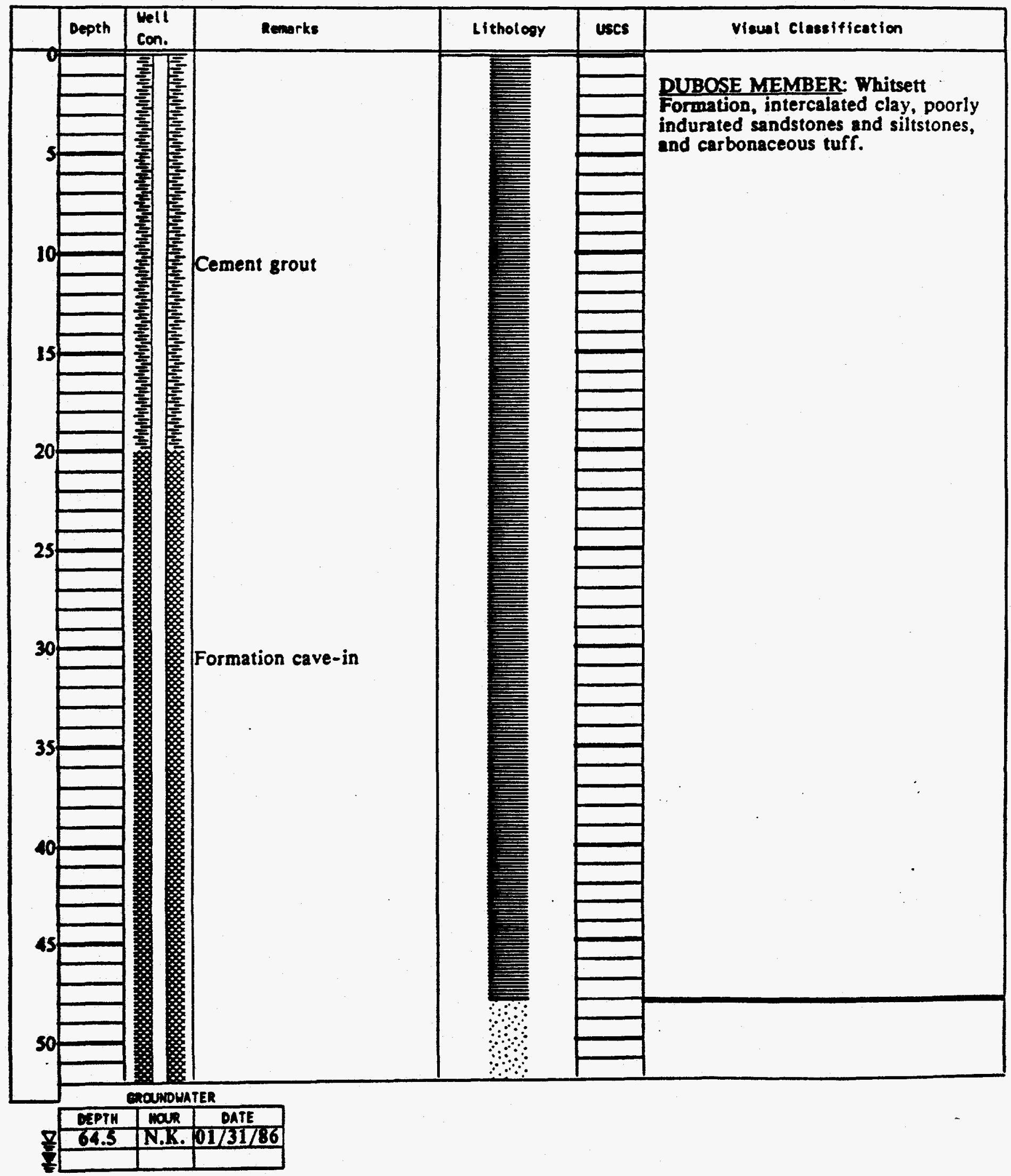




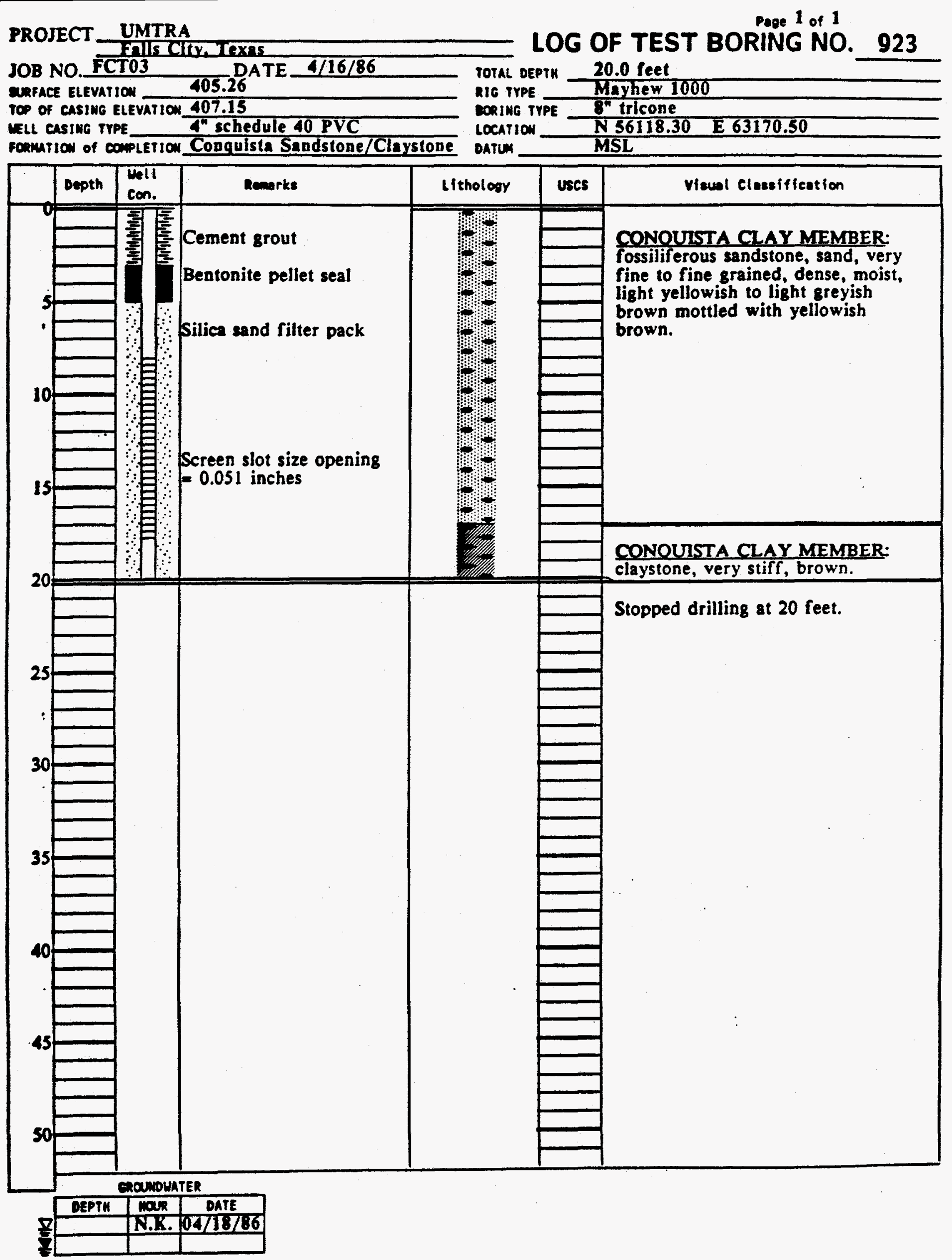




\section{PROJECT UMTRA}

JOB NO. FCTO3

raface ELEVATION 395.14

DATE $4 / 16 / 86$

ToP of CASING ELEVATION 396.44

vell CAsing TYPE $4^{\prime \prime}$ schedule 40 PVC

Fonution of completion Conquista Claystone/Sandstone
Page 1 of 1

LOG OF TEST BORING NO. 924

TOTAL DEPTH 31.0 feet

NIG TYPE - Mayhew 1000

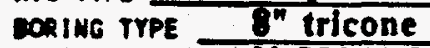

Location N55041.90 E 64049.80

DATUM MSL

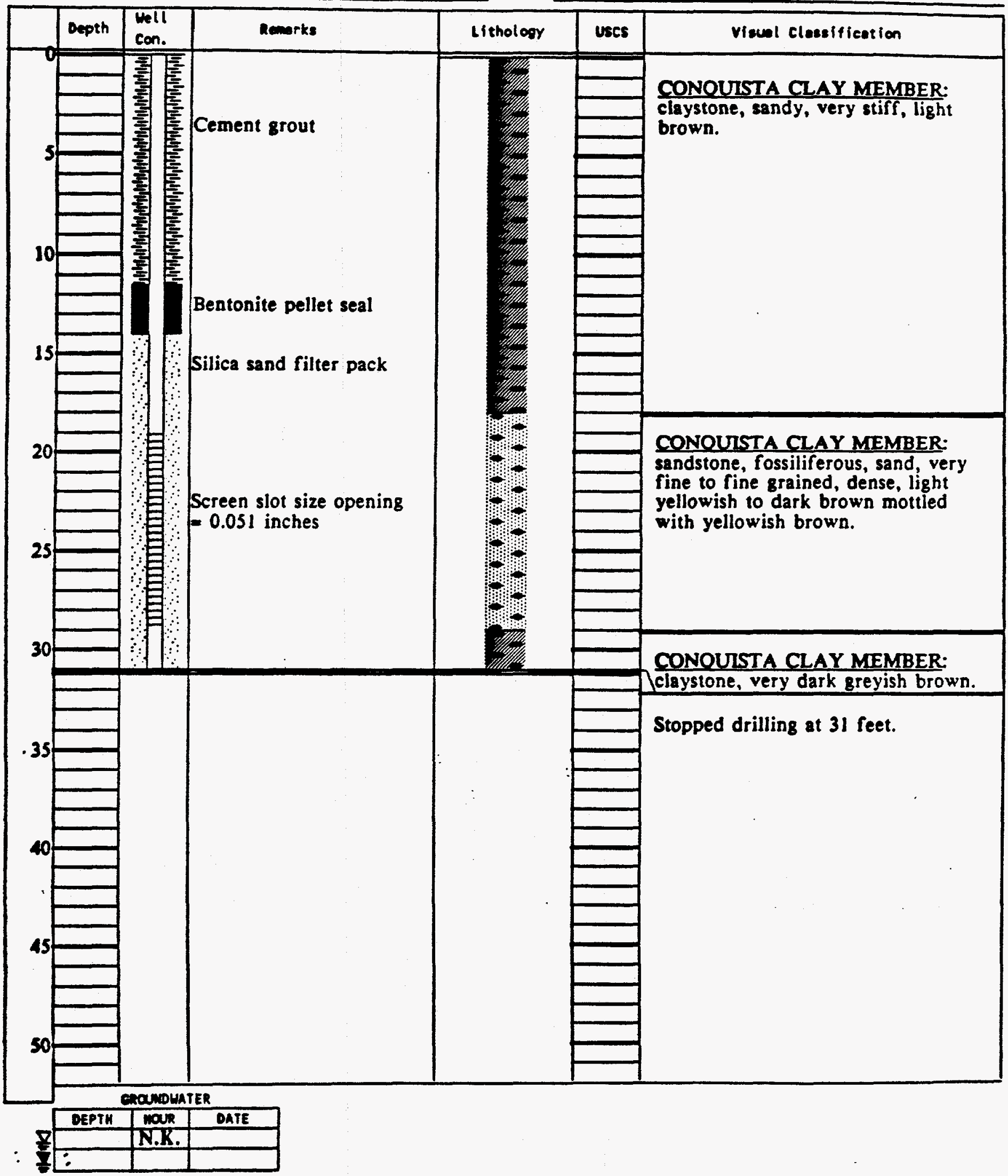


PROJECT UMTRA

Page 1 of 2

Fills cliy Texes

LOG OF TEST BORING NO. 925

JOB NO. FCT03 DATE 4/16/86

TOTAL DEPTH 90.0 feet

Mayhew 1000

URFACE ELEVAIION $\quad \mathbf{1 5 . 8 1}$

top of CASIMG ELEVATION 416.08

VLLL Castue TrPE

pormation of completion Lower Dilworth Sandstone / Manving

NIC TYPE

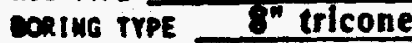

LOcation

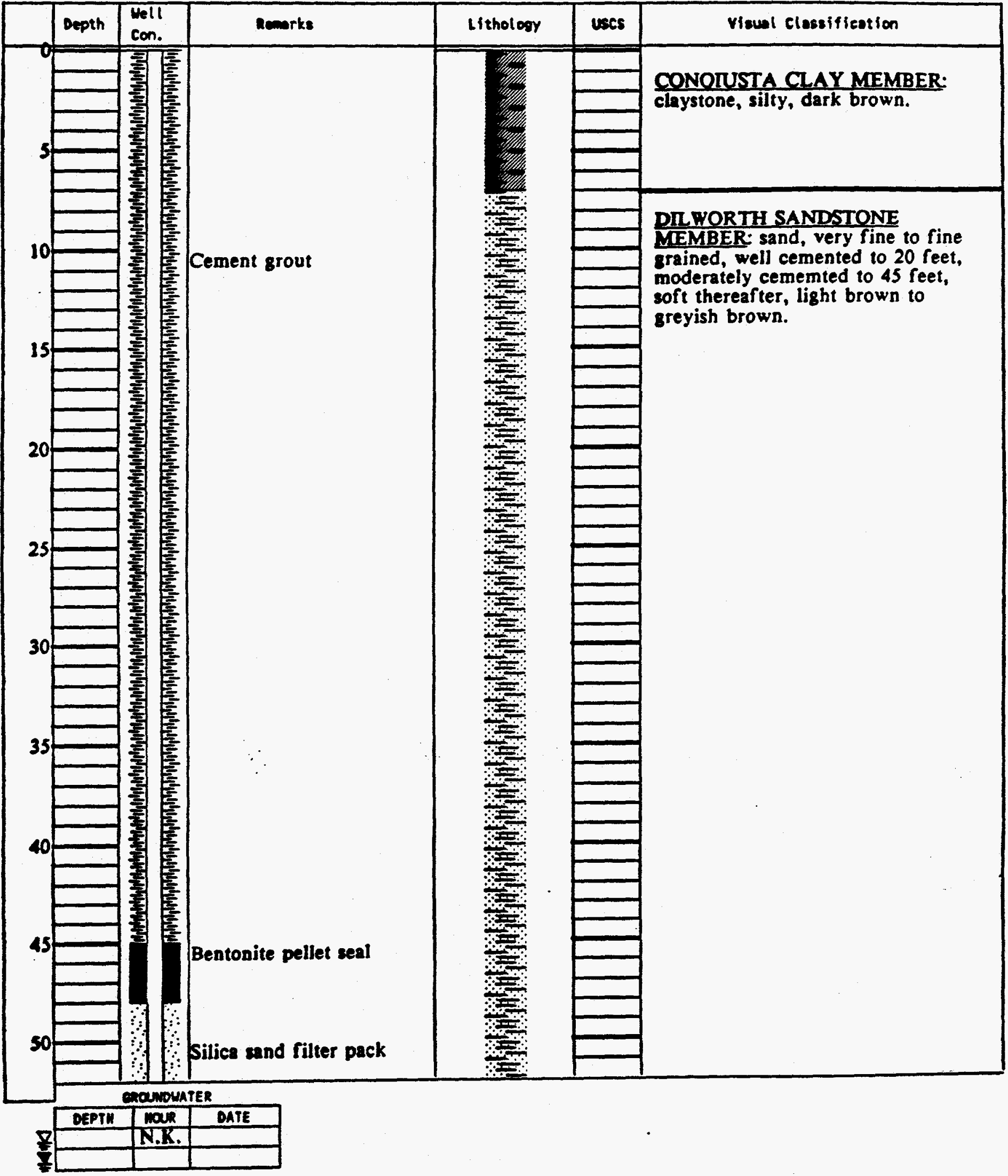


PROJECT UMTRA

JOB NO. FCTO3

enface ELEVATION 415.81

TOP Of CASING ELEVATION $\mathbf{4 1 6 . 0 8}$

rell casing TYPE

$4^{\prime \prime}$ schedule 10 PVC

DATE $4 / 16 / 86$

LOG OF TEST BORING NO. 925

fonution of conpletion Lower Dilworth Sandstone / Manding

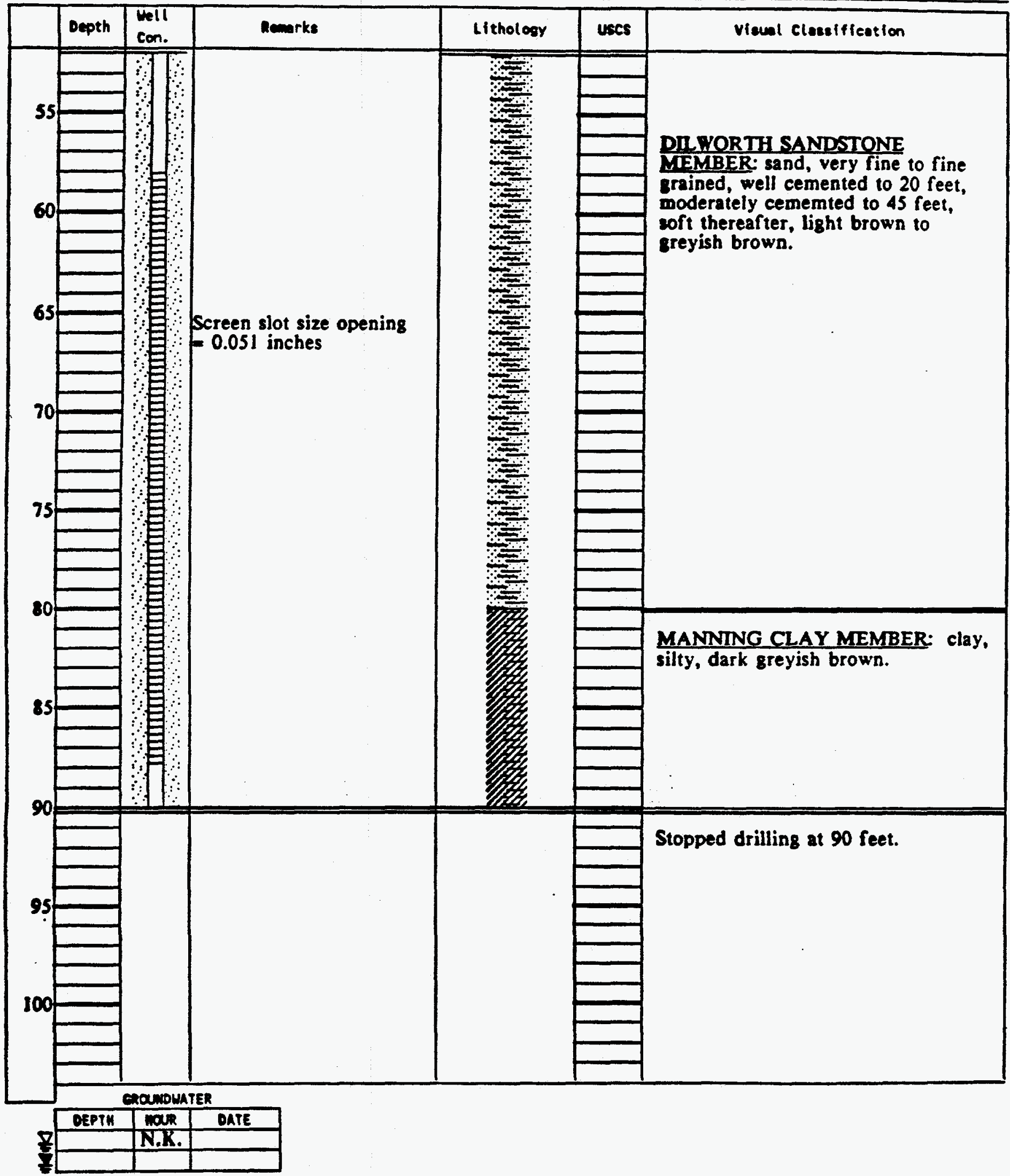


now. $9 / 94$

NoTE:

Logs for Test Boing No's 935,540+345 coulf urt be lrchted in Drcument Controt. Fitiler 


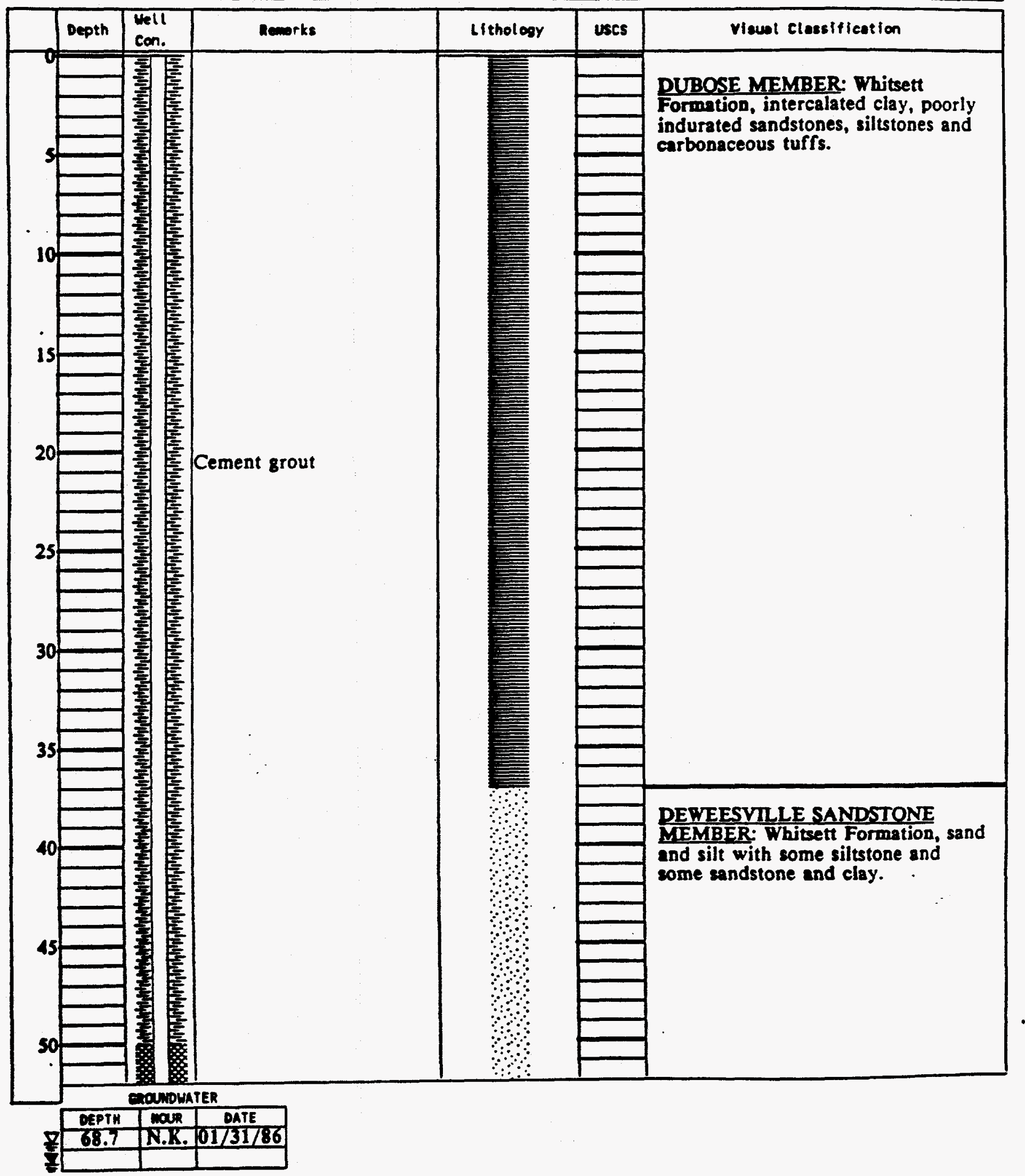


PROJECT UMIRA

CT03

DATE $1 / 16 / 86$

ERFACE ELEVATION $\quad \mathbf{4 3 6 . 3 6}$

TOP OF CASING ELEVATION 437.97

vell casing trpe 4 - schedule 40 PVC

conmition of completion Conguista Claystone

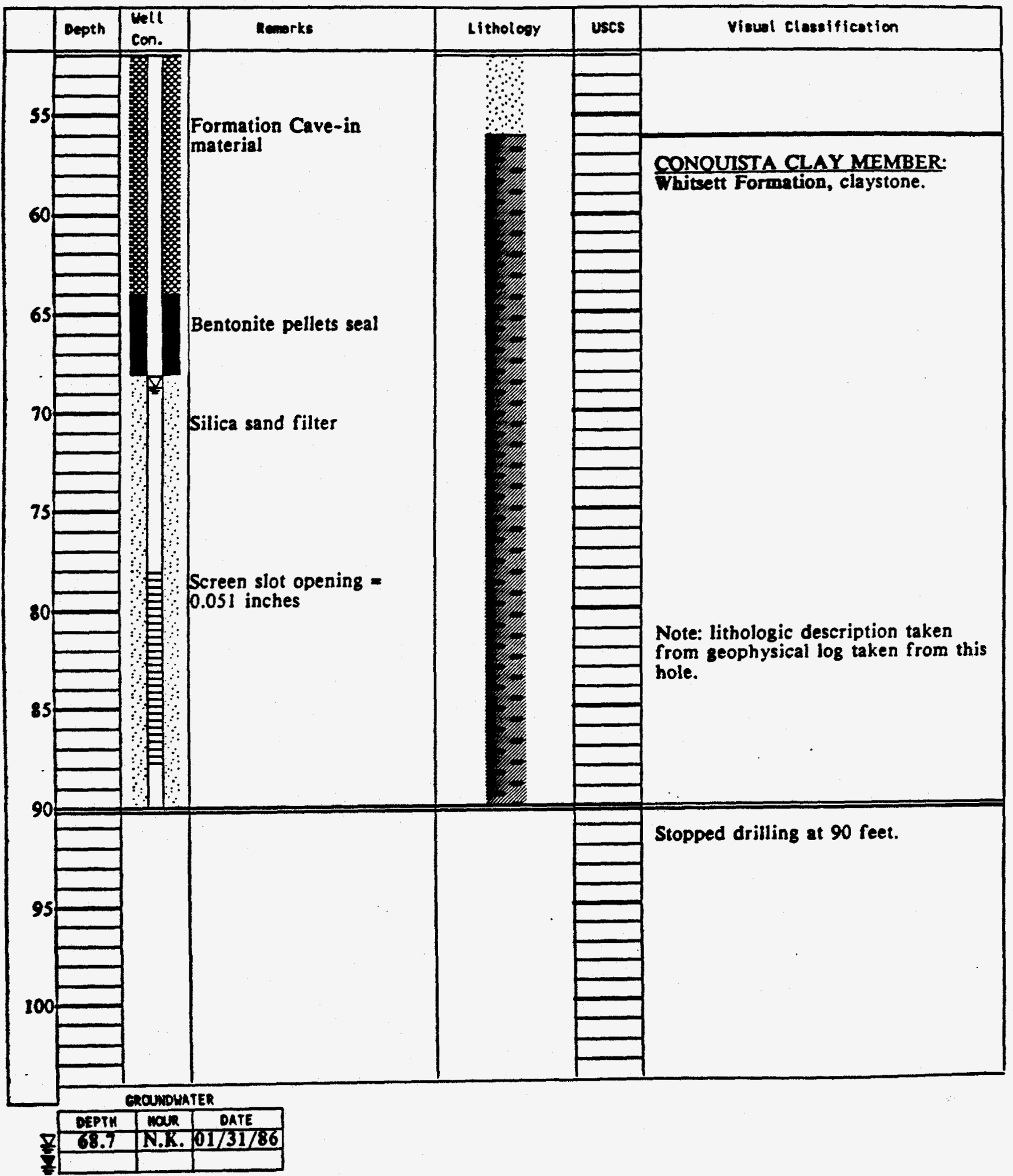

LOG OF TEST BORING NO. 951

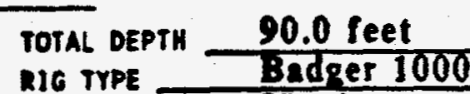

conivg trpe $8^{n}$ tricone

Locarion N60334.90

MSL
Note: lithologic description taken from seophysical log taken from this hole. 


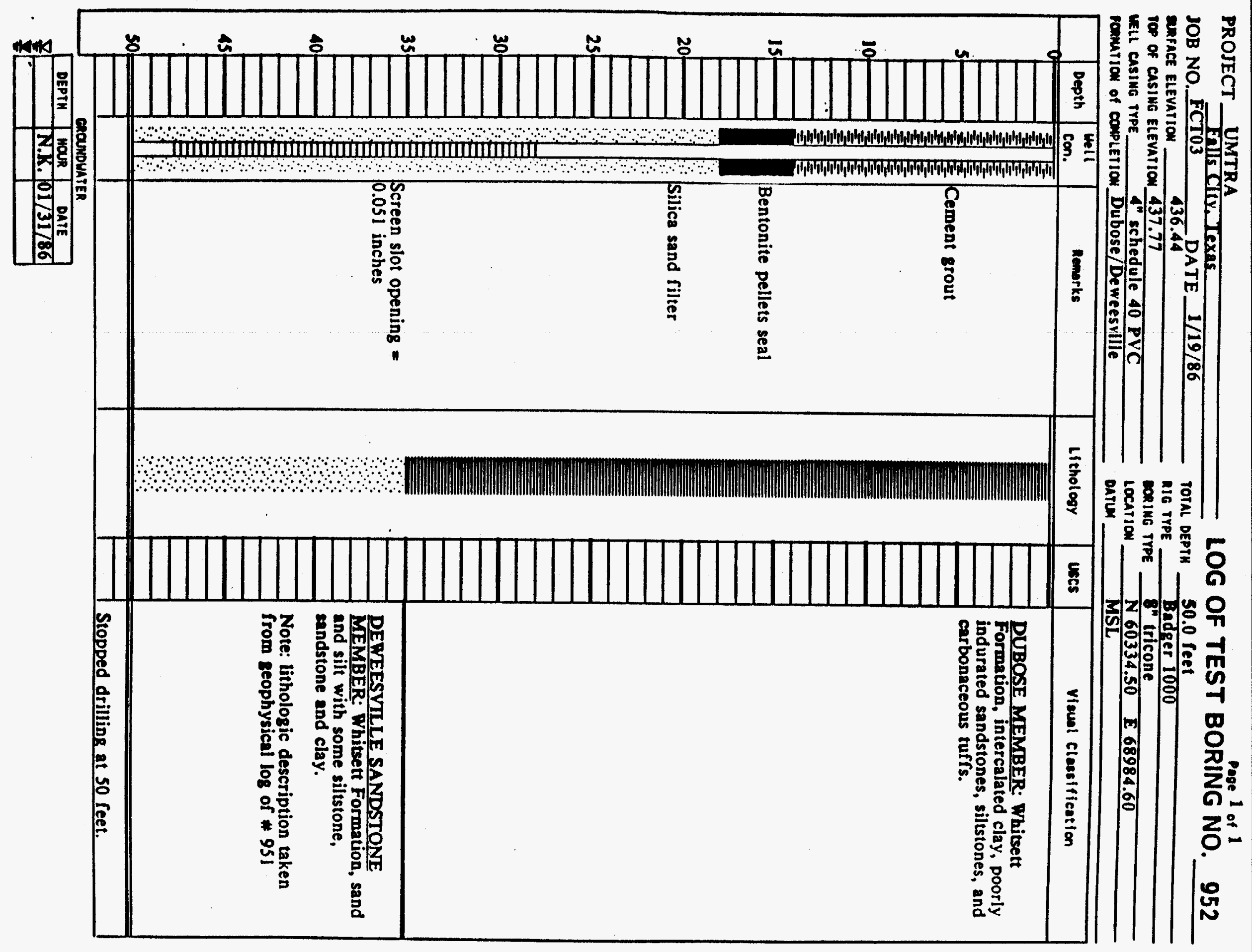




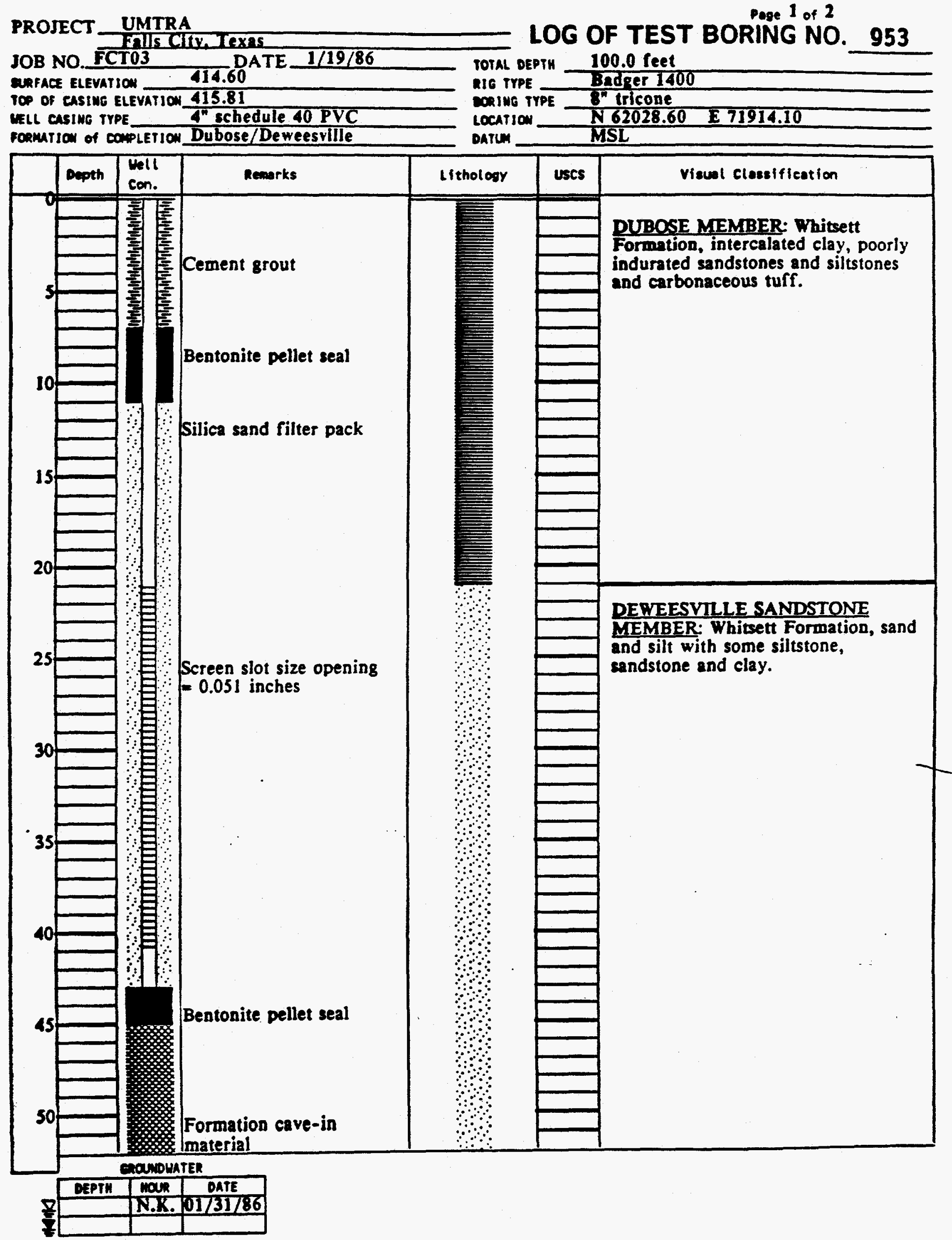


PROJECT UMTRA

Falls City Texas

JOB NO. FCTO3

DATE $1 / 19 / 86$

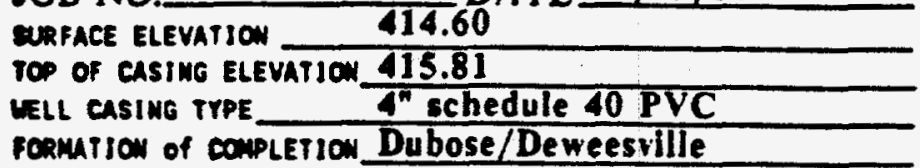

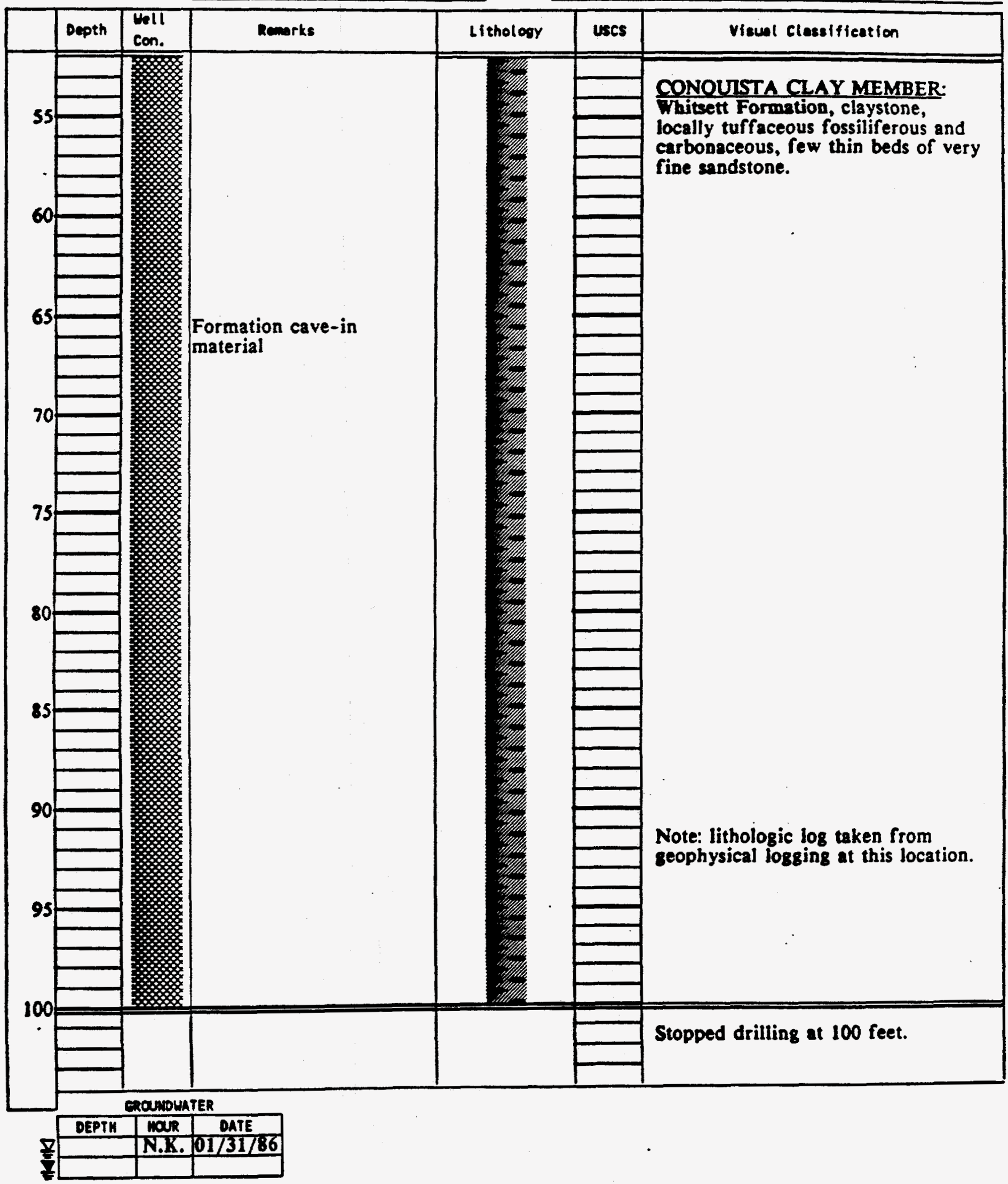

LOG OF TEST BORING NO. 953

TOTAL DEPTM 100.0 feet

aIs TYPE Badger 1400

Locariow N62028.60

MSL
CORING TYPE $8^{\prime \prime}$ tricone
CONOUISTA CLAY MEMBER:

locally tuffaceous fossiliferous and carbonaceous, few thin beds of very fine sandstone.

Note: lithologic log taken from seophysical logging at this location. 
PROJECT UMTRA

Page 1 of 2

JOB NO. FCT03

DATE $1 / 19 / 86$

LOG OF TEST BORING NO. 954

InFACE ELEvation 410.18

to of castug elevarion 411.39

IELL CASING TYPE

4chedule 40 PVC

ronurion of completion Conquista Claystone/Sandstone

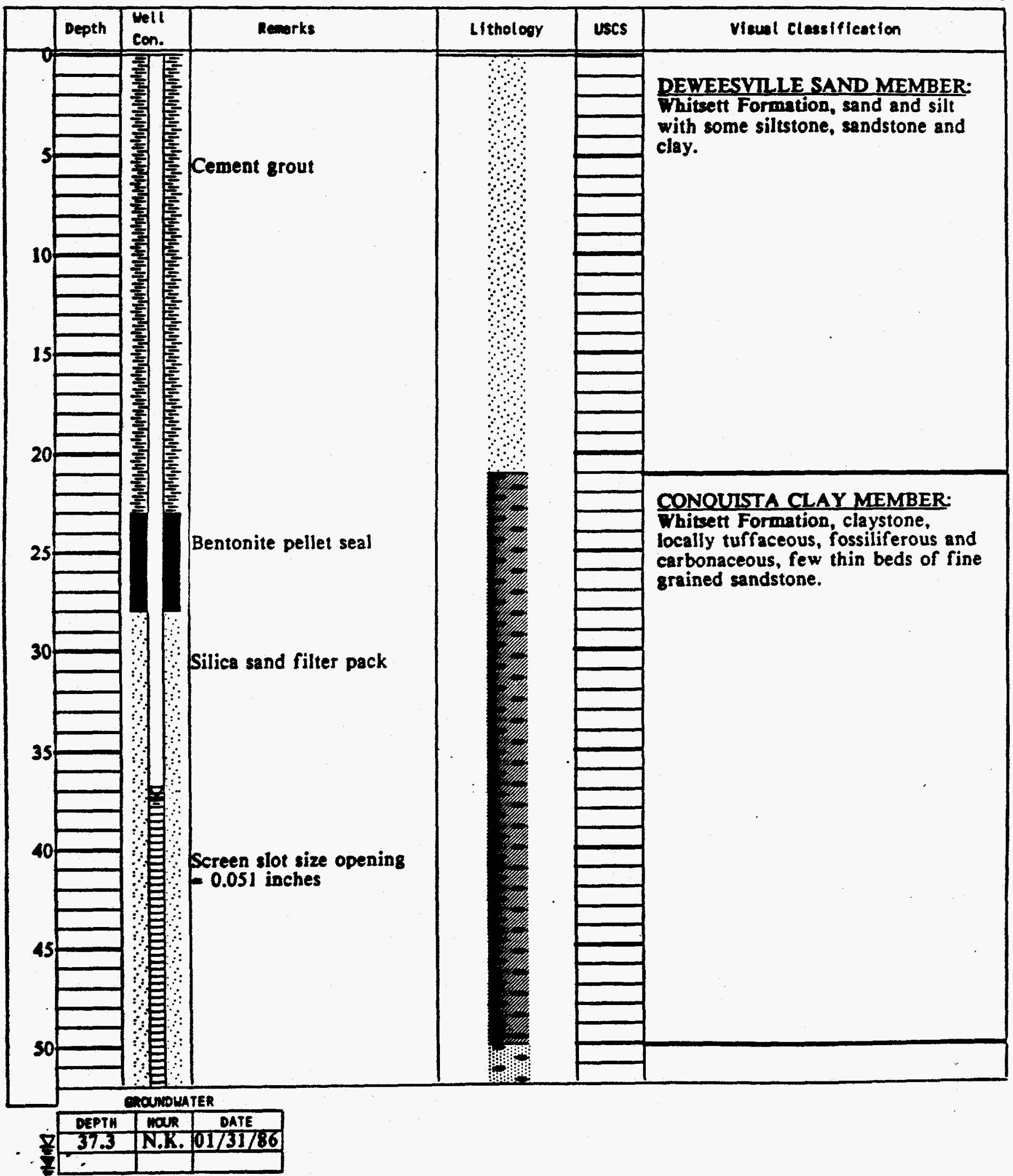


PROJECT UMTRA

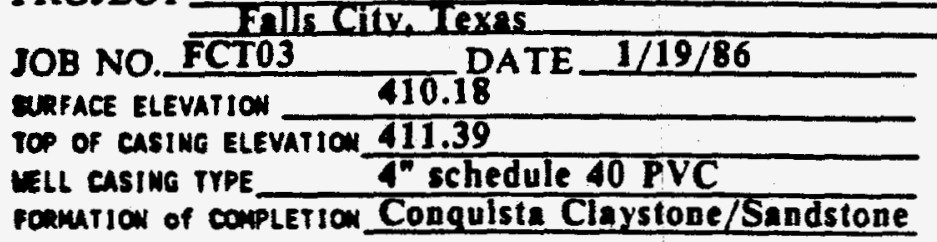

Page 2 of 2

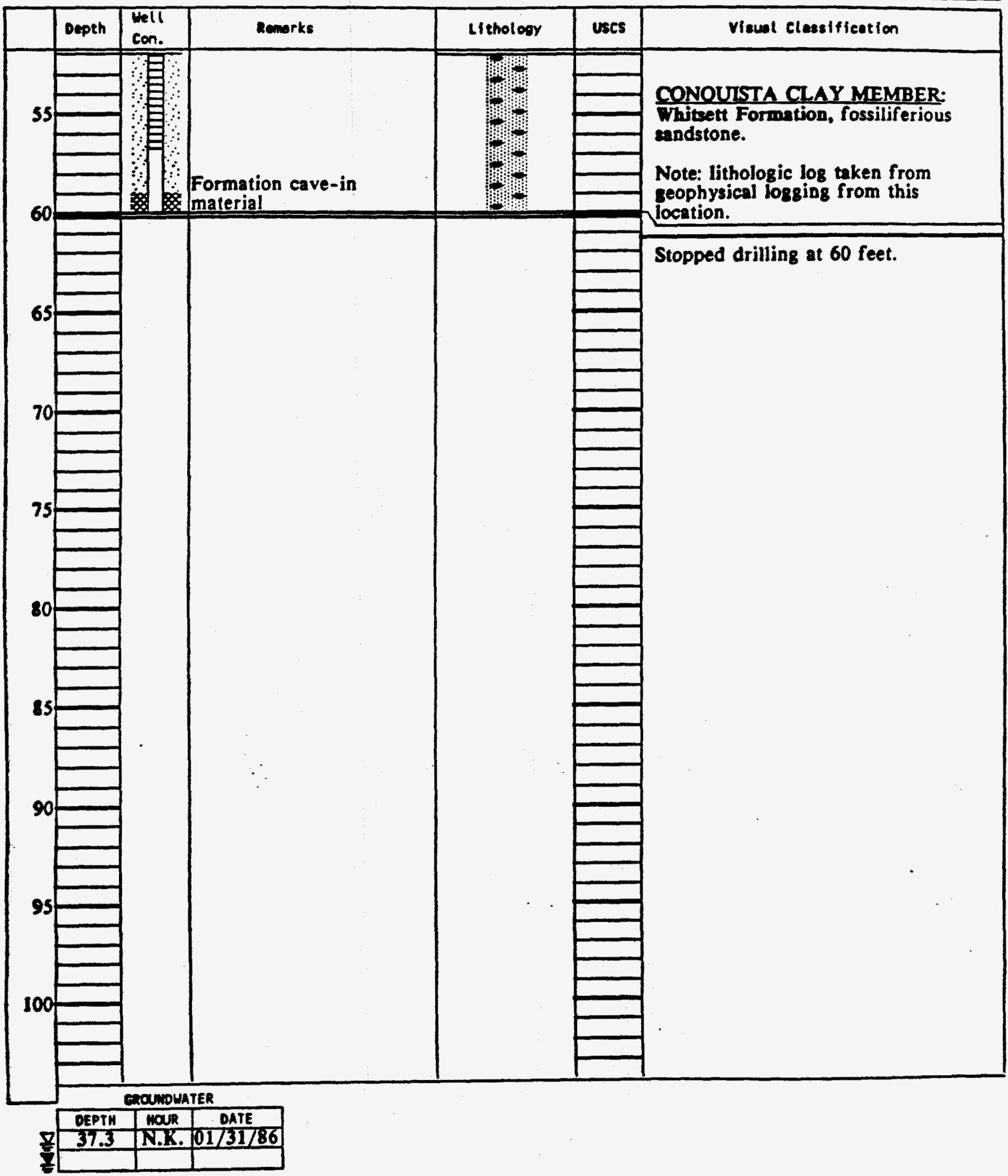


PROJECT UMTRA

Fills city. Texas

JOB NO. $\overline{\text { FCT03 }}$

DATE $1 / 29 / 86$

arFACE ELEVATION $\quad 392.67$

TOP OF CASING ELEVATION 393.67

well casing TYPE $4^{\prime \prime}$ schedule 40 PVC

ronmution of completion Conquista Clay
TOTAL DEPTH 30.0 fEet

RIG TYPE Badjer 1000

CORING TYPE $8^{*}$ tricone

LOCATION N

DATUM MSL

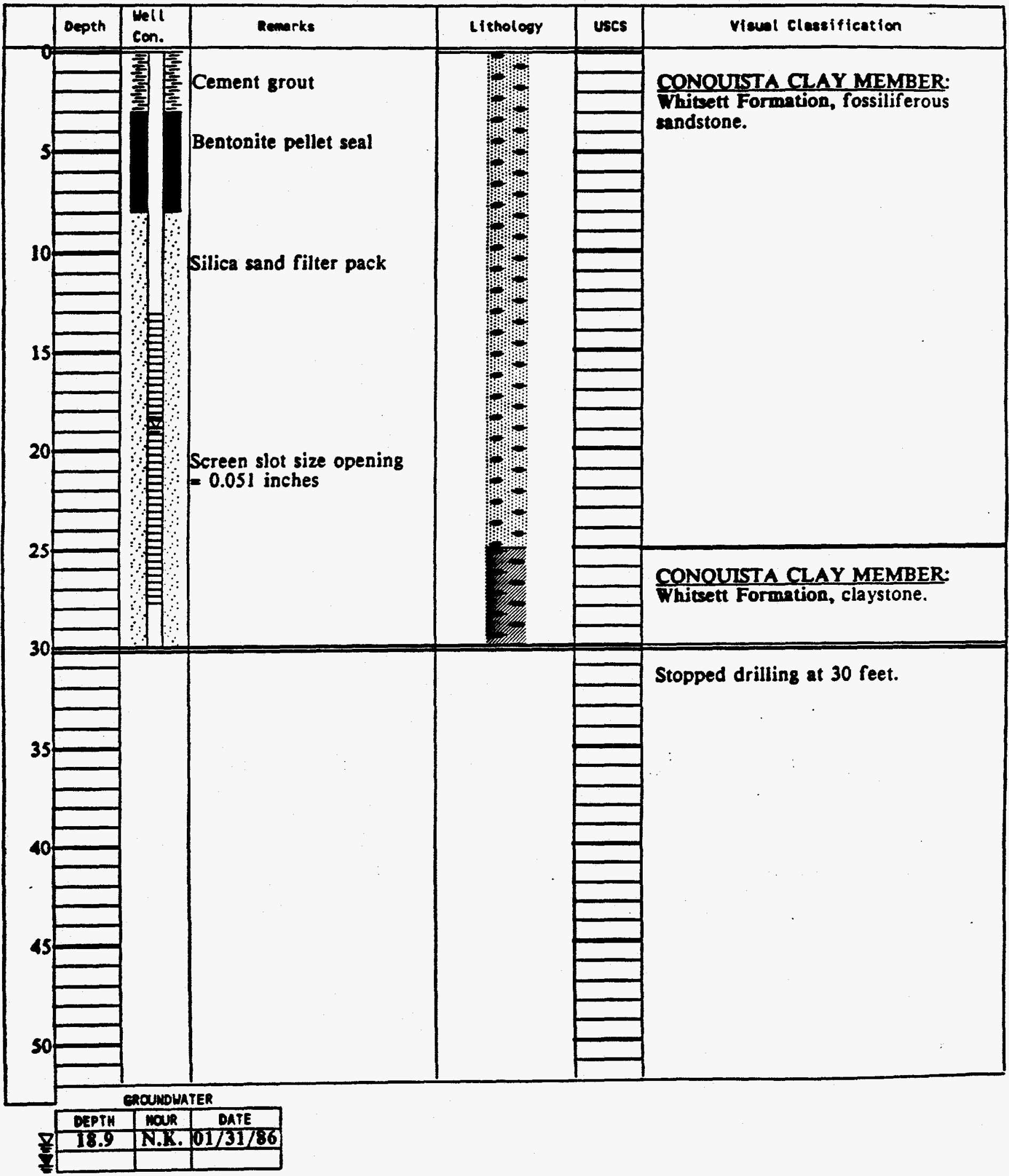


PROJECT UMTRA

LOG OF TEST BORING NO. 956

JOB NO. FCTO

unface ELEVRtion

DATE $1 / 14 / 86$

ToP Of CASIMG ELEVATION 393.25

cul casing IYPE

Ponution of combetiow Conquista/Dilworth

TOTAL DEPTH 70.0 feet

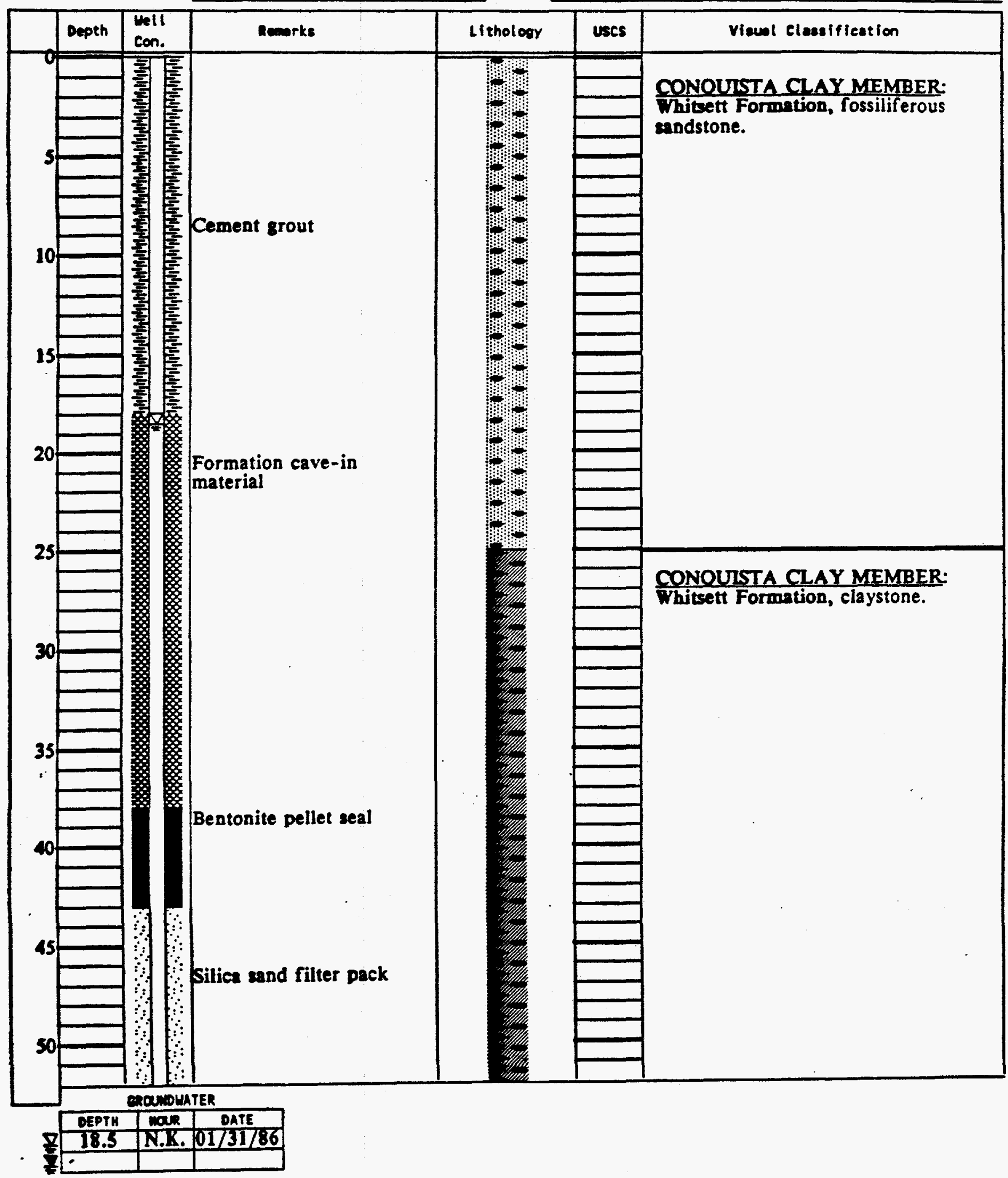


PROJECT UMTRA

LOG OF TEST BORING NO. 956

JOB NO. FCTO

DATE $1 / 14 / 86$

TOTAL DEPTH 70.0 feet

UAFACE ELEVATIOW $\frac{391.80}{393.25}$

vell casing trPe

Fonution of competron Conquista/Dilworth

RIG TYPE - Badrer 1400

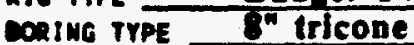

Location N63104.30 E 69434.60

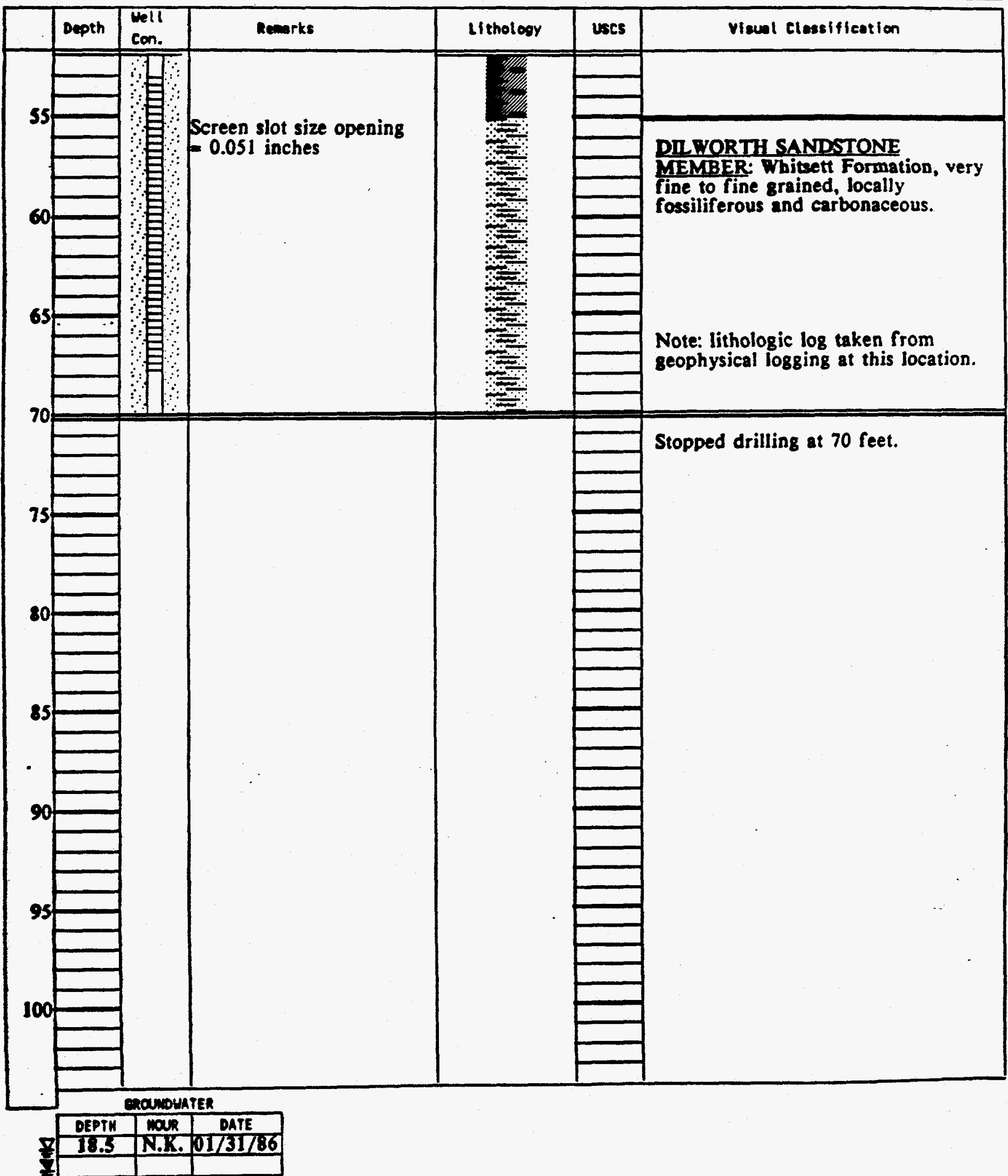


PROJECT UMTRA

LOG OF TEST BORING NO. 957

JOB NO. FCTO3

DATE $1 / 16 / 86$

TOIAL DEPYH
NIG TYPE

MARACE ELEVATION $\mathbf{3 8 6 . 9 7}$

top OF CASING ELEVATION 388.19

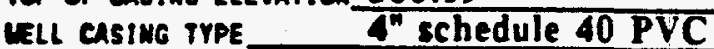

roenurion of conpletron Conquista Sandstone/Claystone

conivg IrPE $8^{\text {m }}$ tricone

Location N 63435.20 E 68807.70

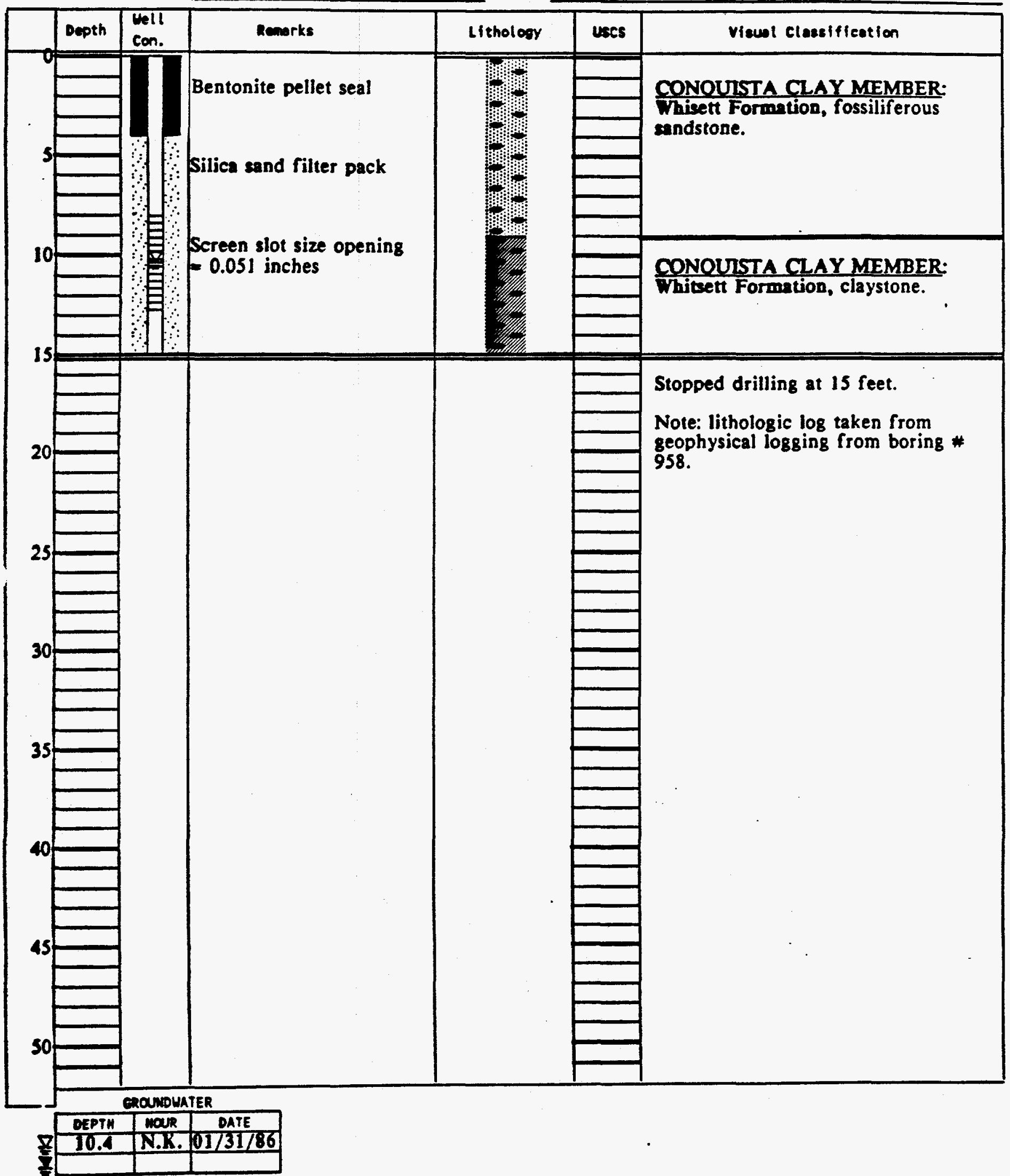


PROJECT UMTRA

LOG OF TEST BORING NO. 958

JOB NO. FCTO3

SURFACE ELEVATION 385.91

DATE $1 / 15 / 86$

TOP OF CASING ELEVATION 388.23

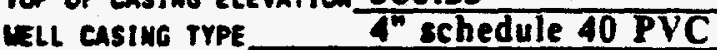
rommuriow of completion Upper Dilworth Sandstone

TOTAL DEPTH 150.0 feet

NIG TYPE Badzer 1400

coning IYPE $8^{n}$ tricone

Locarion N63430.10 E 68799.70

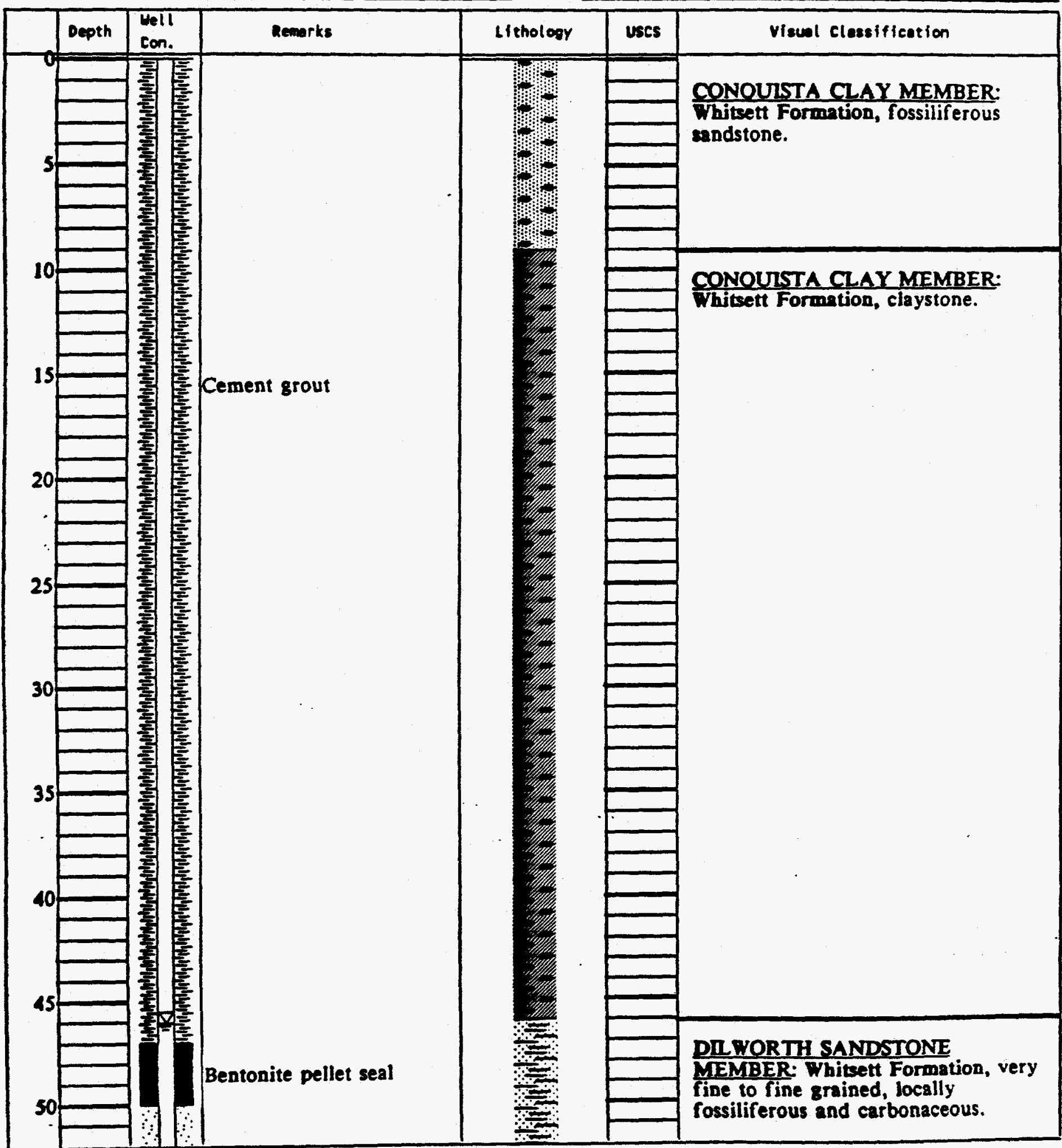

eaOwowhte:

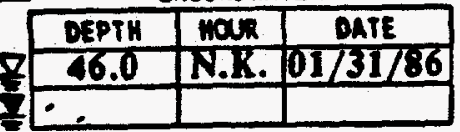


PROJECT UMTRA

Page 2 of 3

JOB NO. FCTO3

Mills Cify. Texns

anFACE ELEVATION

385.91

DATE $1 / 15 / 86$

LOG OF TEST BORING NO. 958

ToP of casing elevation 388.23

vell casimg trpe 4 "schedule 40 PVC

Fonution of completion Upper Dilworth Sandstone

TOTAL DEPTH 150.0 feet

NIG TYPE Badfer 1400

coning tYPE 8 " tricone

Locution N63430.10 E68799.70

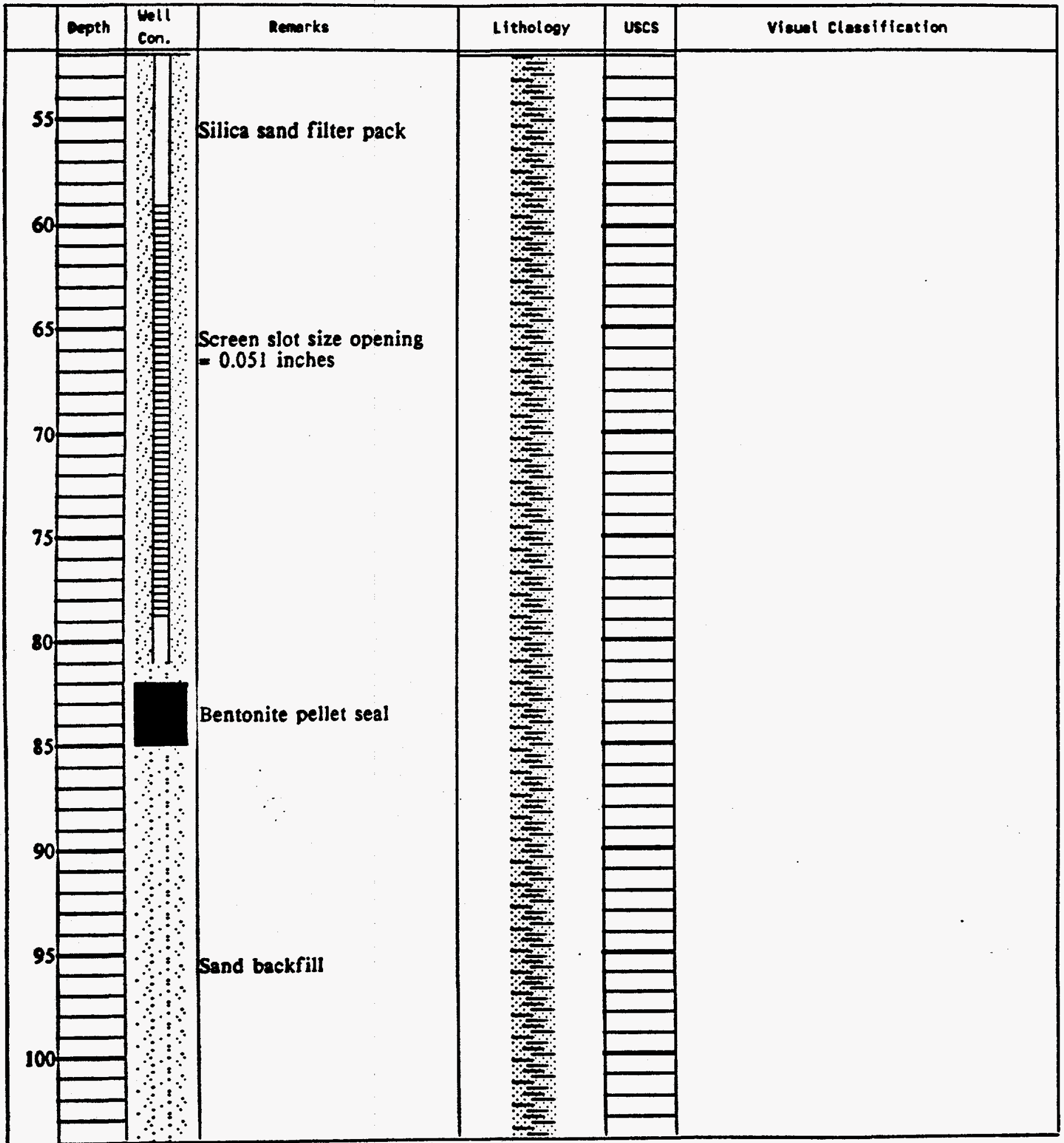

EROMDUATER

\begin{tabular}{|l|l|l|}
\hline DEPTH & HOWR & DATE \\
\hline
\end{tabular}

\begin{tabular}{llll|}
\hline 76.0 & N.K. $01 / 31 / 86$ \\
\hline
\end{tabular} 
PROJECT UMTRA

Tils city texas

JOB NO. FCTO3

virace ELEVATION 385.91

DATE $1 / 15 / 86$

LOG OF TEST BORING NO. 958

TOP of CASING ELEVATION 388.23

Vell casing trPE

formution of completion Upper Dilworth Sandstone

TOTAL DEPTH 150.0 feet

RIG TYPE Badper 1400

con ine trpe

LOCATION

DATUM

N63430.10 E 68799.70

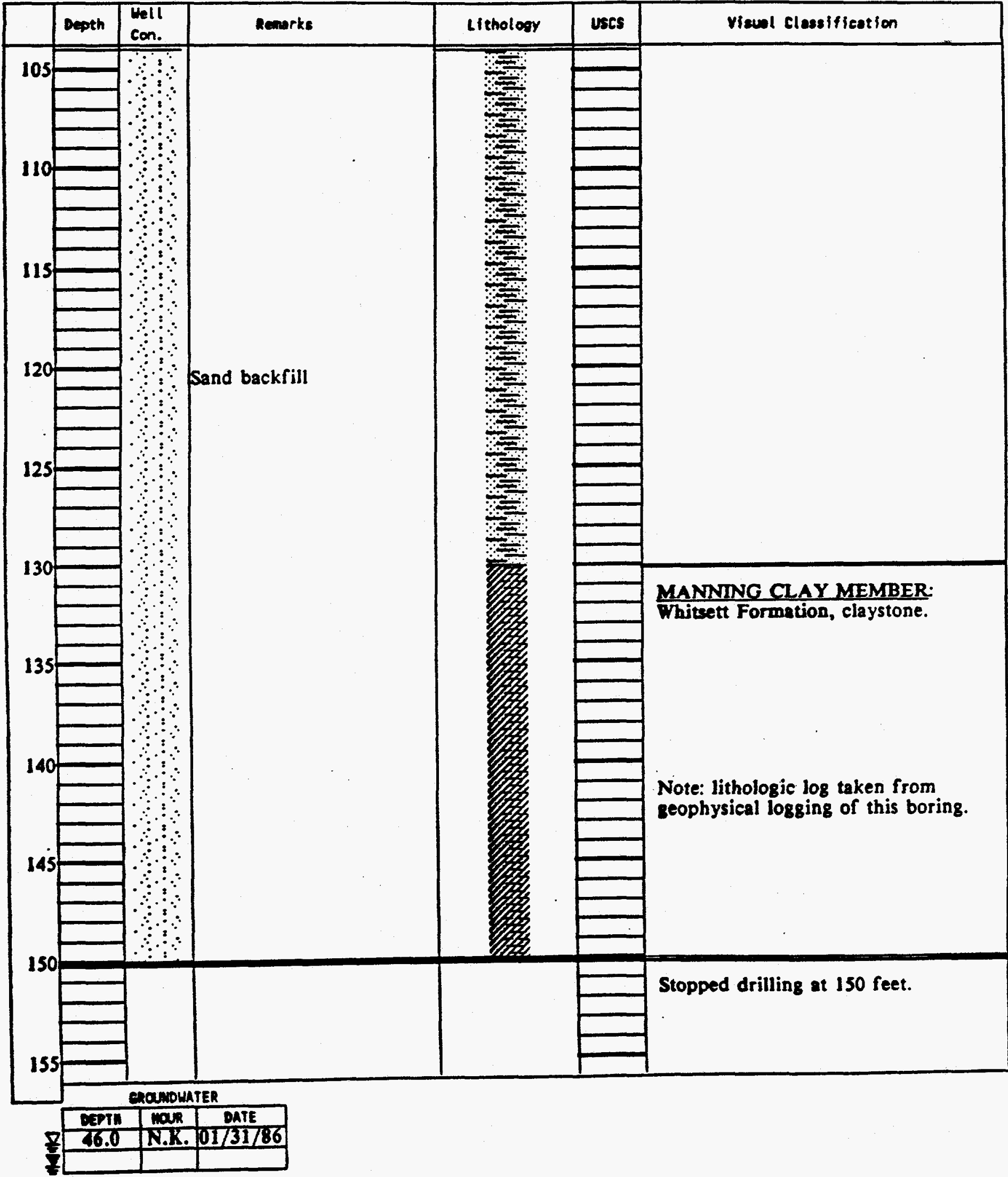


PROJECT UMTRA

Falls city. Texns

DATE $1 / 19 / 86$

LOG OF TEST BORING NO. 961

JOB NO. FCTOS

top of Easing ELEVATIOA 382.98

MeLl casimo tYPE 4 "schedule 40 PVC

manution of conpletion Conquista Clay

TOTAL DEPTH 60.0 feet

RIG TYPE Mayhew 1000

coring TYPE $8^{n}$ tricone

Location N63815.10 E 70828.50

DATLW MSL

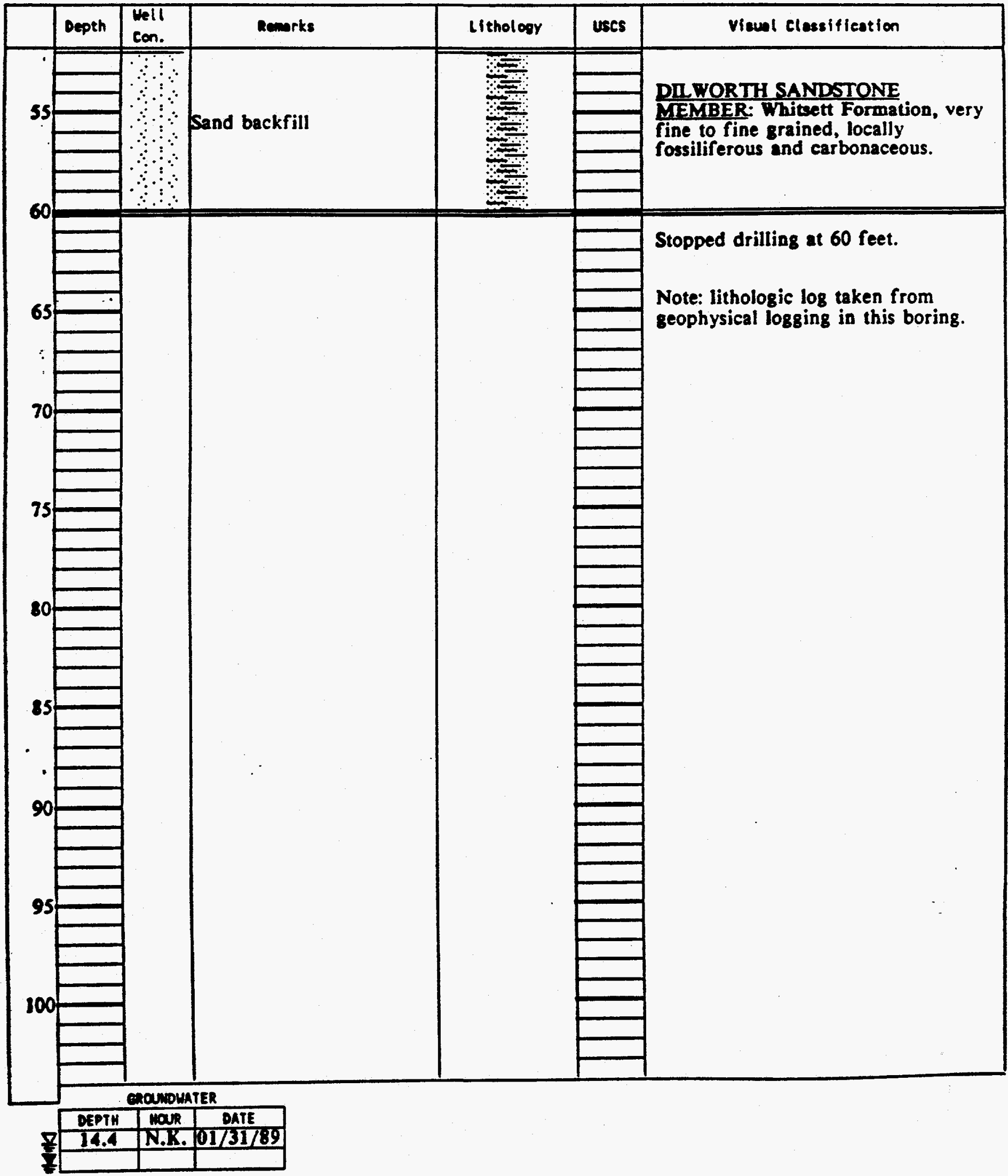




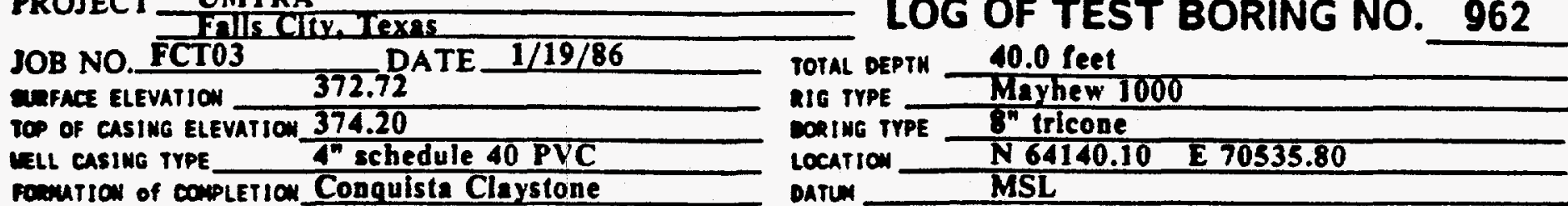

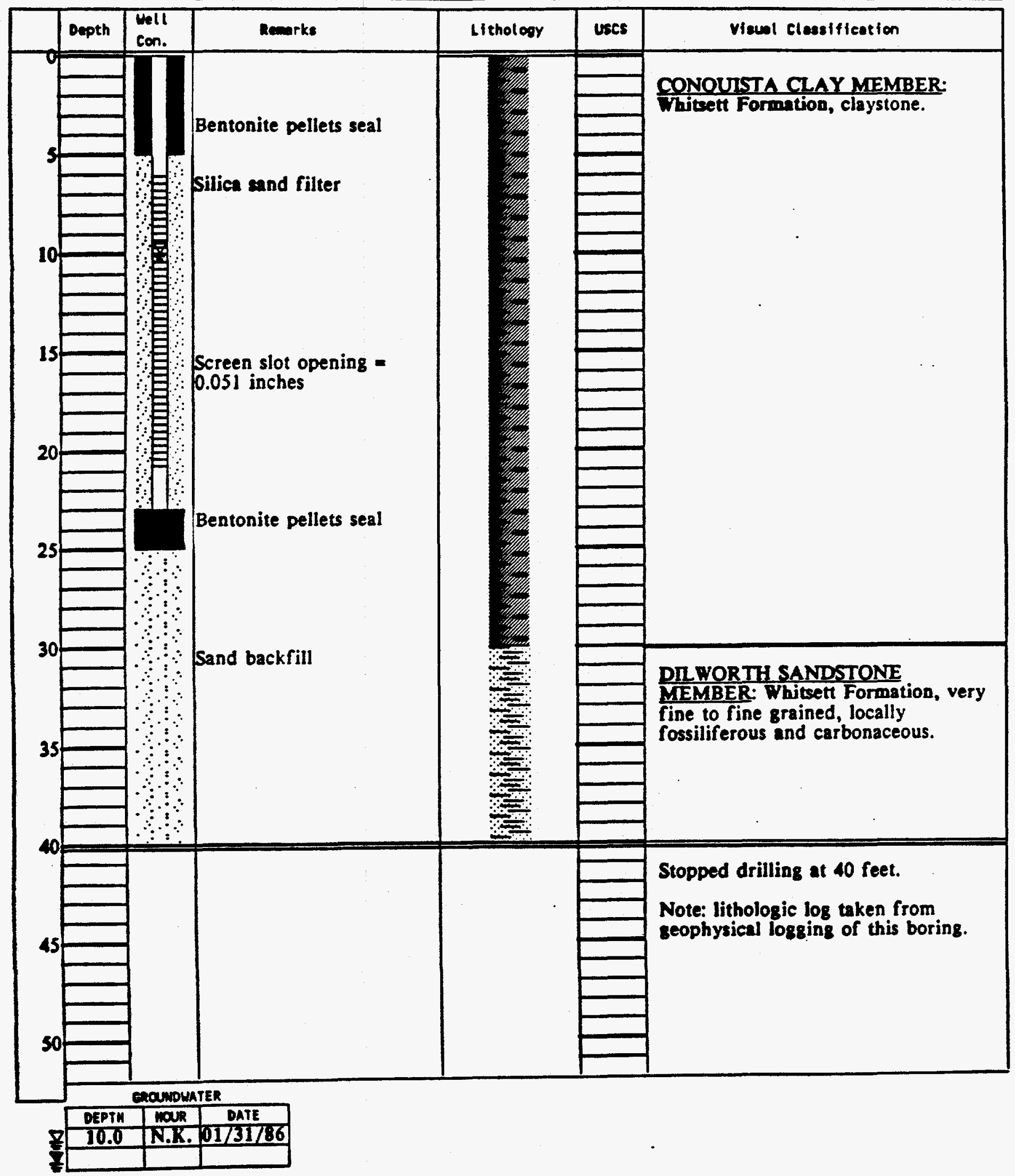


mosecl ompris

JOB NO. FCT03 DATE $1 / 29 / 86$

LOG OF TEST BORING NO. 963

anFACE ELEVATION 368.61

top of castug elevation 370.44

rele ensing TVPE

4" schedule 40 PVC

TOTAL DEPTY 20.0 feet

RIG TYPE - Badper 1400

Fomation of conpletion Conquista Fossillferous Sendstoneparu

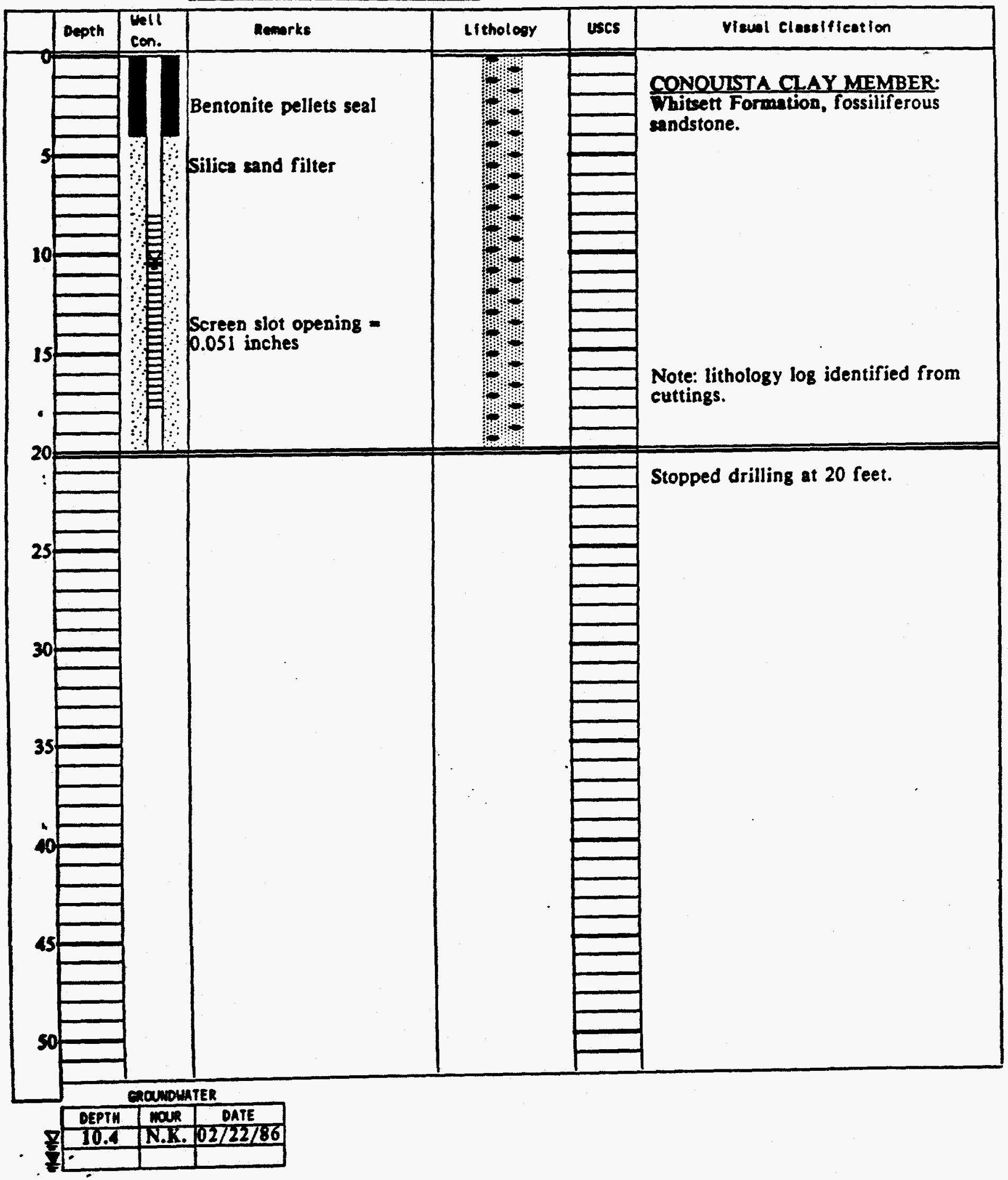


PROJECT UMTRA

Page 1 of 2

JOB NO. FCT03 DATE 4/17/86

anface elevation $\quad \mathbf{3 7 8 . 0 9}$

to of casing elevation 379.39

ixll castuc TrPe 4 schedule 40 PVC

Fonation of completion DIIworth Sand

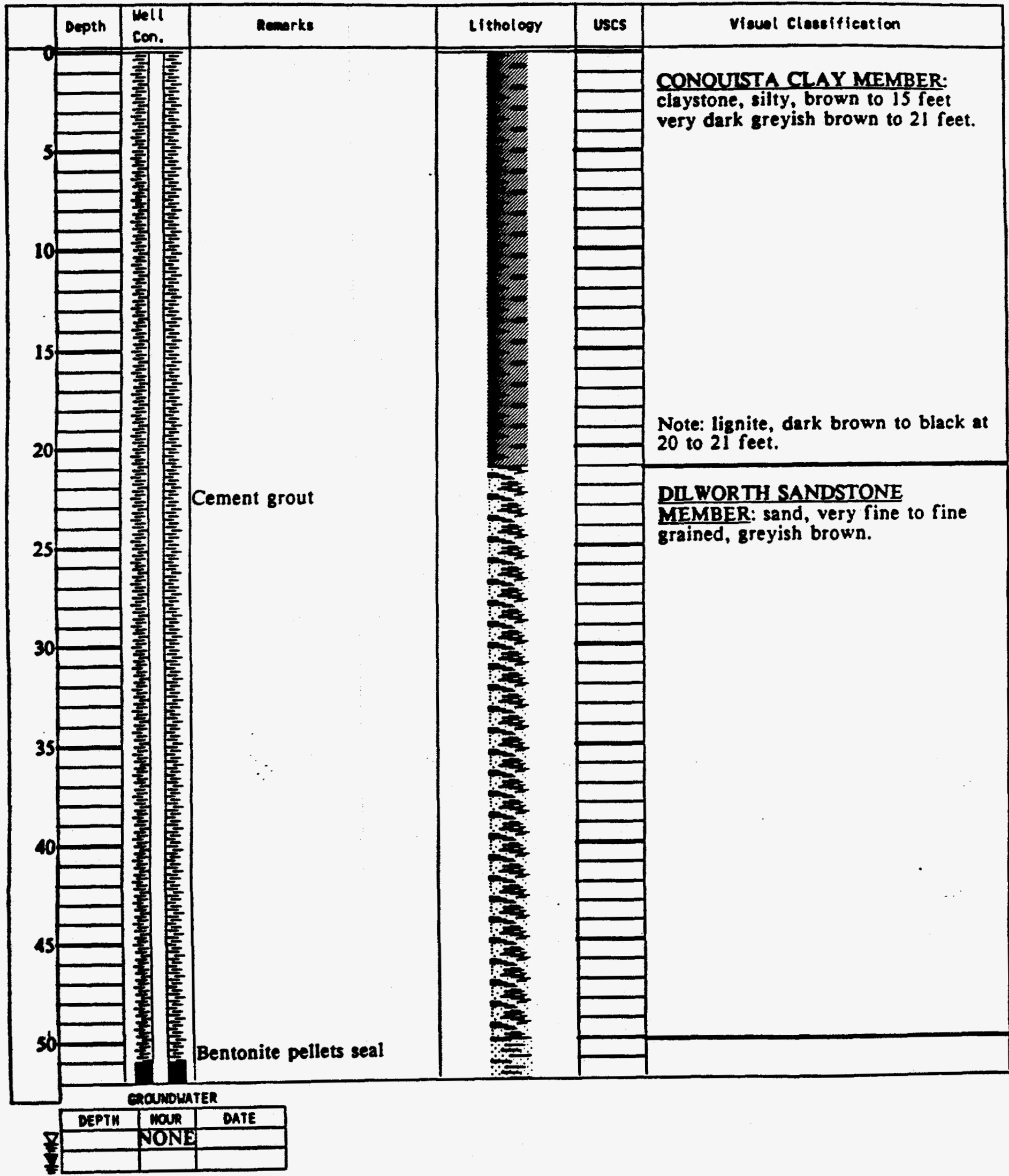


PRUJECT GMTRA

JOB NO. FCT03 DATE 4/17/86

URFACE ELEVATION $\mathbf{3 7 8 . 0 9}$

TOP of CASTHE ELEVATION 379.39

WLL CAsine TrPe $4^{n}$ schedule 40 PVC

Formurion of completion Dilworth Sand

\section{TOTAL DEPTM 90.0 feet}

RIG TrPE Mayhew 1000

(1)

CORING TYPE $8^{\text {thicone }}$

Location N64926.20 E 69745.40

Datum MSL

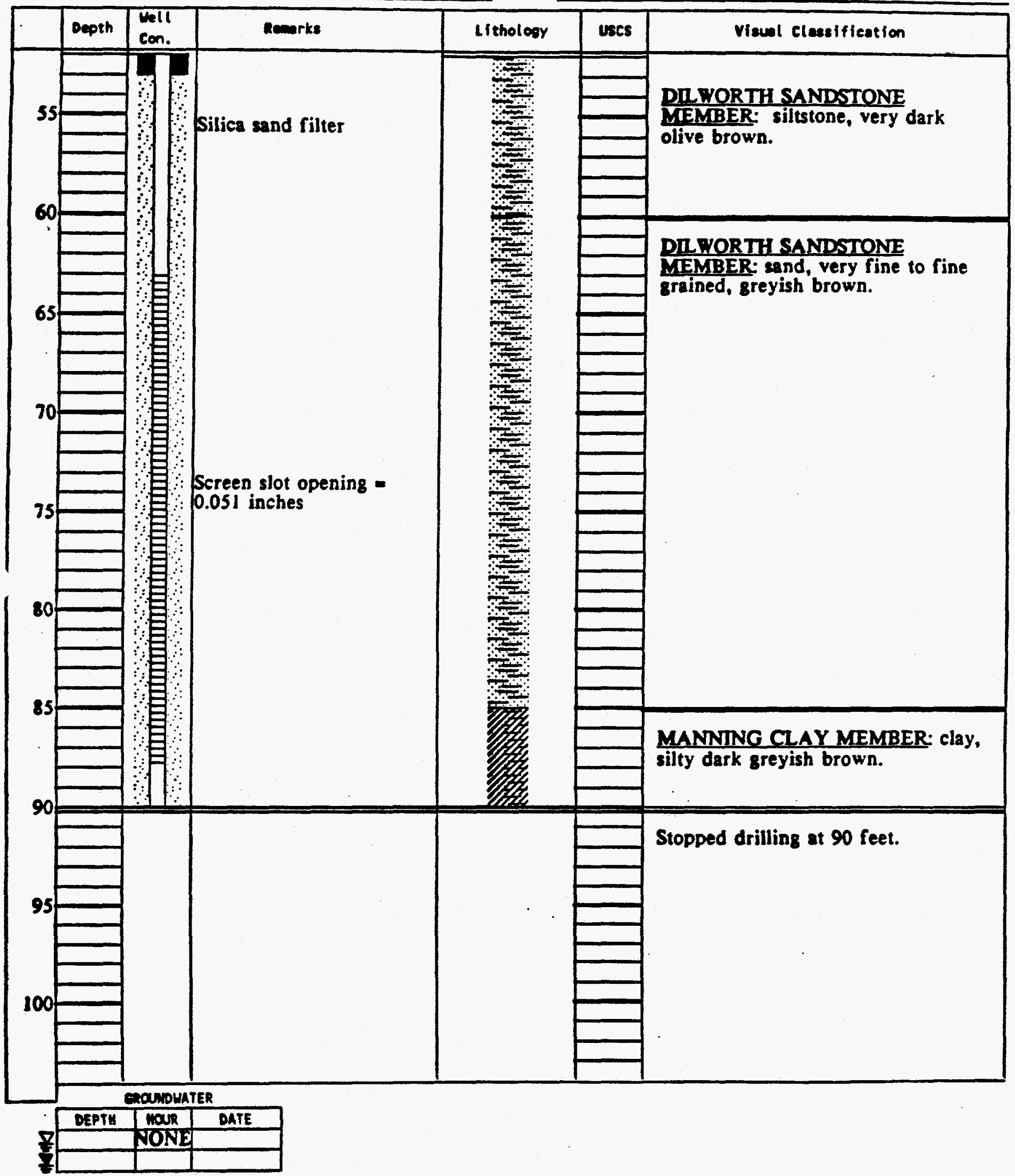


PROJECT UMTRA

Falls City. Texas

JOB NO. FCT03

DATE $4 / 17 / 86$

SURACE ELEVATION $\quad 367.11$

TOP OF CASING ELEVATION $\mathbf{3 6 8 . 3 1}$

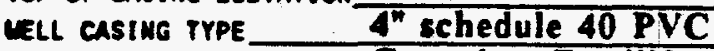

Formation of coupletion Conquista Fossilliferous Sandstonedatum

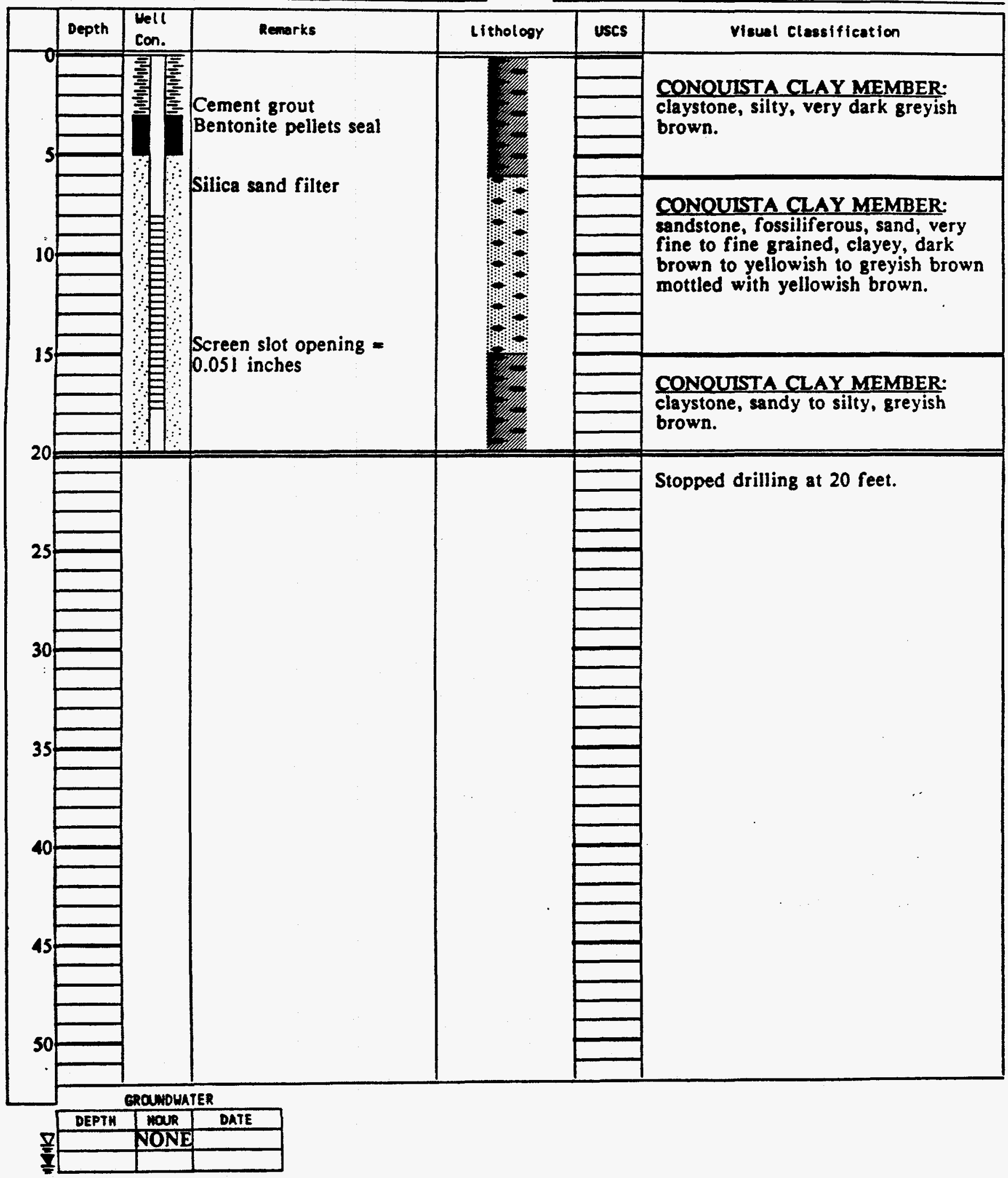

Page 1 of 1
I OG OF TEST RnPING Nin

TOTAL OEPTH $\frac{20.0 \text { feet }}{\text { MIG TYPE }}$

conING TYPE $8^{\prime \prime}$ tricone

N65774.50

MSL

CONOUISTA CLAY MEMBER:

brown to yellowish to greyish brown

claystone, sandy to silty, greyish brown.

Stopped drilling at 20 feet. 
PROJECT UMTRA

LOG OF TEST BORING NO. 967

JOB NO. FCT03 DATE 4/18/89

DRFACE ELEVATION $\mathbf{4 3 0 . 0 2}$

TOP OF CASING ELEVATION 432.11

WELL CASING TYPE Formarion of completion Lower Dilworth Sandstone

TOTAL DEPTH 110.0 feet

RIG TYPE Gardner-Denver 1500

conING TYPE 8 " tricone

Location N 66836.50 E 65846.00

OATUM MSL

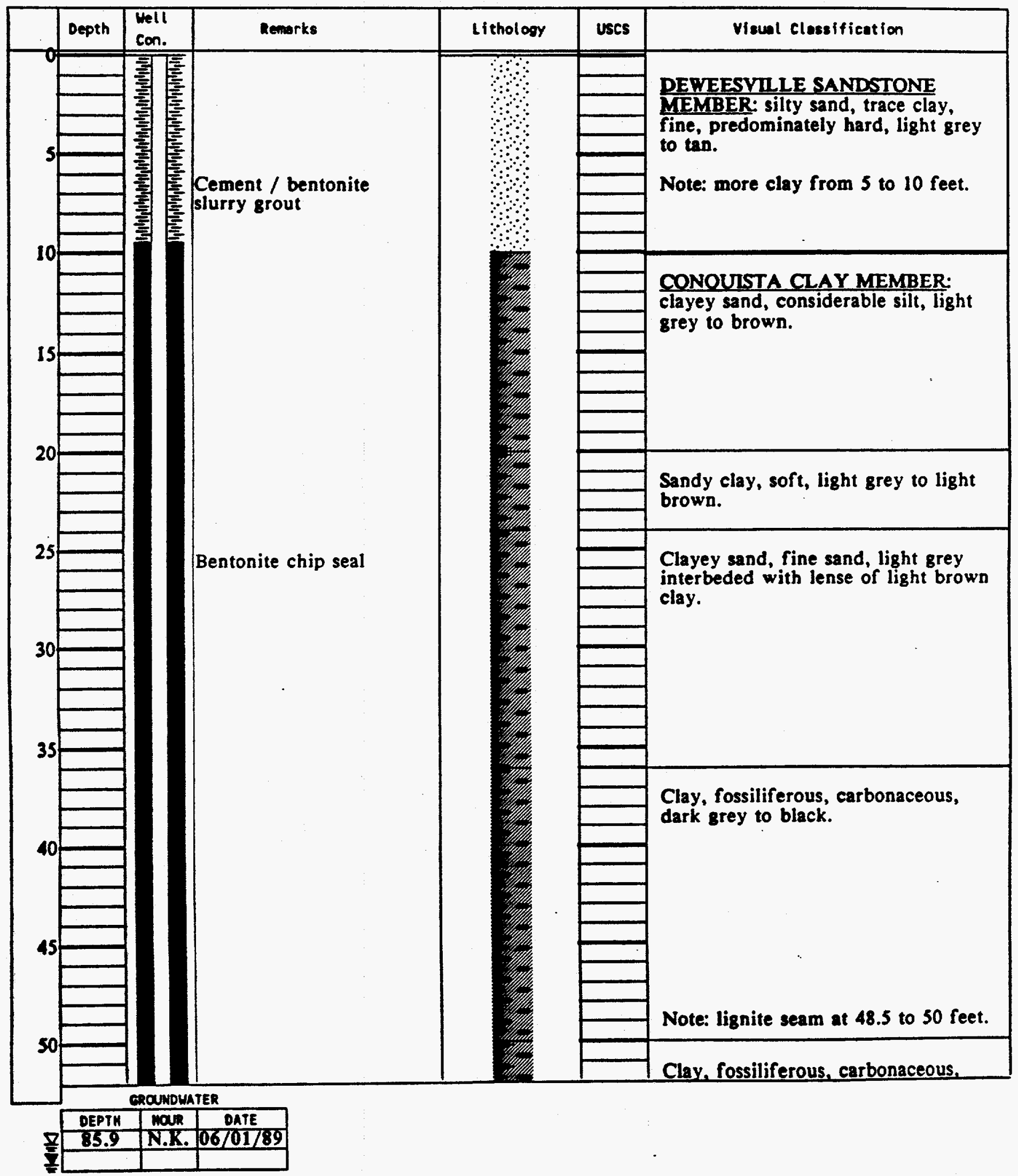


PROJECT UMTRA

Page 2 of 3

JOB NO. FCT03 DATE $4 / 18 / 89$

ERFACE ELEVATION $\mathbf{4 3 0 . 0 2}$

TOP OF CASING ELEVATION $\mathbf{4 3 2 . 1 1}$

"ELL CASING TYPE 4 schedule 40 PVC

foRmution of COMPLETION Lower Dilworth Sandstone

TOTAL DEPTH 110.0 feet

NIG TYPE Gardner-Denver 1300

DORING TYPE $8^{n}$ tricone

LOCATION N N6836.50 E 65846.00

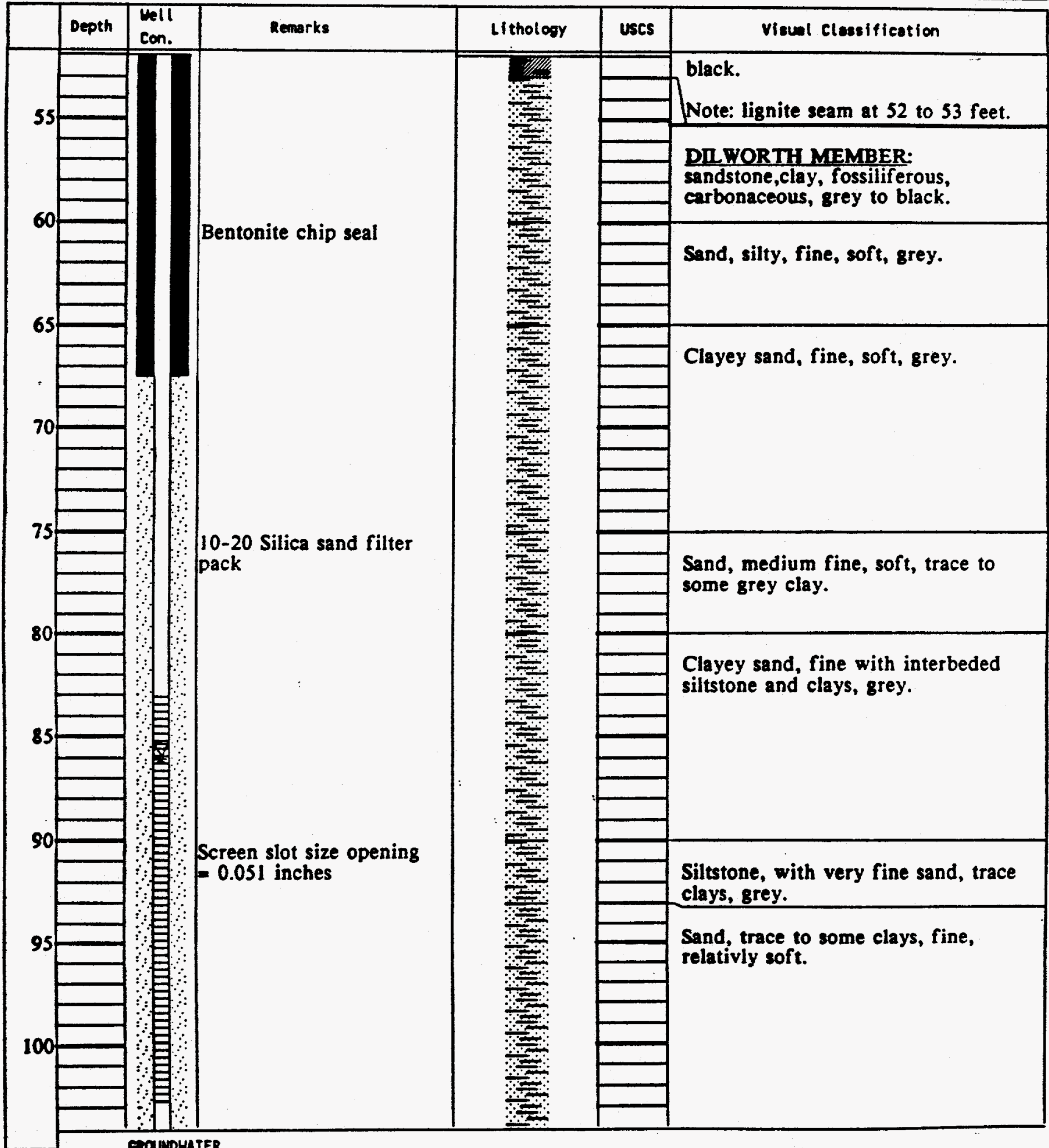

eqOUNDWATER

DEPTI 1 MOUR

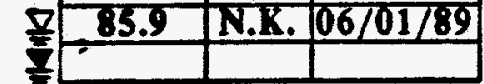


ERFACE ELEVATION 430.02

DATE $4 / 18 / 89$

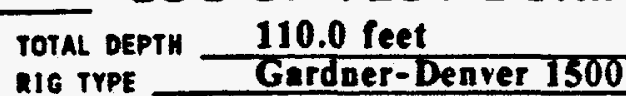

TOP OF CASING ELEVATION $\mathbf{4 3 2 . 1 1}$

VELL CASING TYPE

$4^{\prime \prime}$ schedule 40 PVC

fonmition of completion Lower Dilworth Sandstone

NIG TYPE $\frac{\text { Gardoer- }}{8^{n} \text { tricone }}$

Location N66836.50 E 65846.00

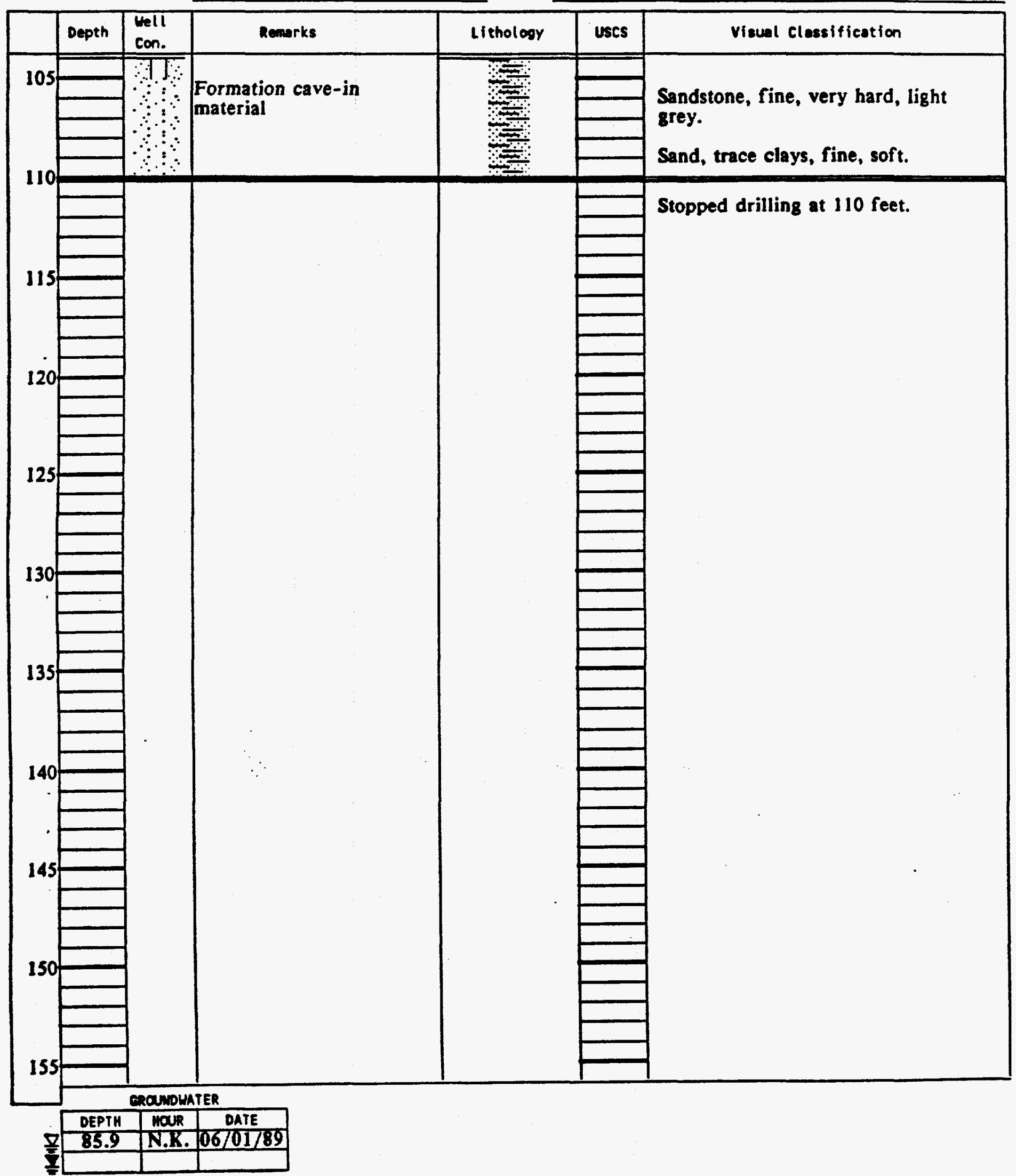




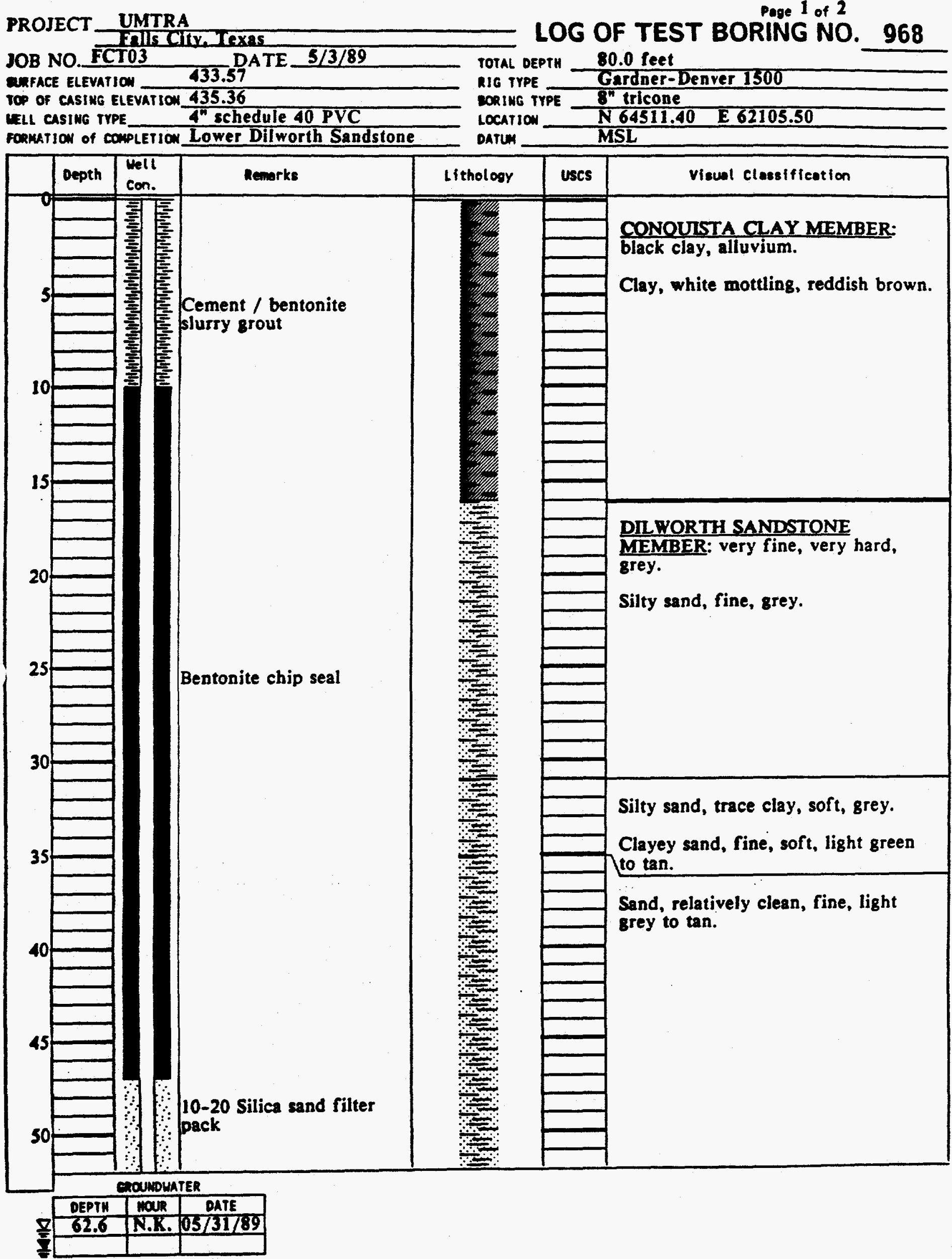




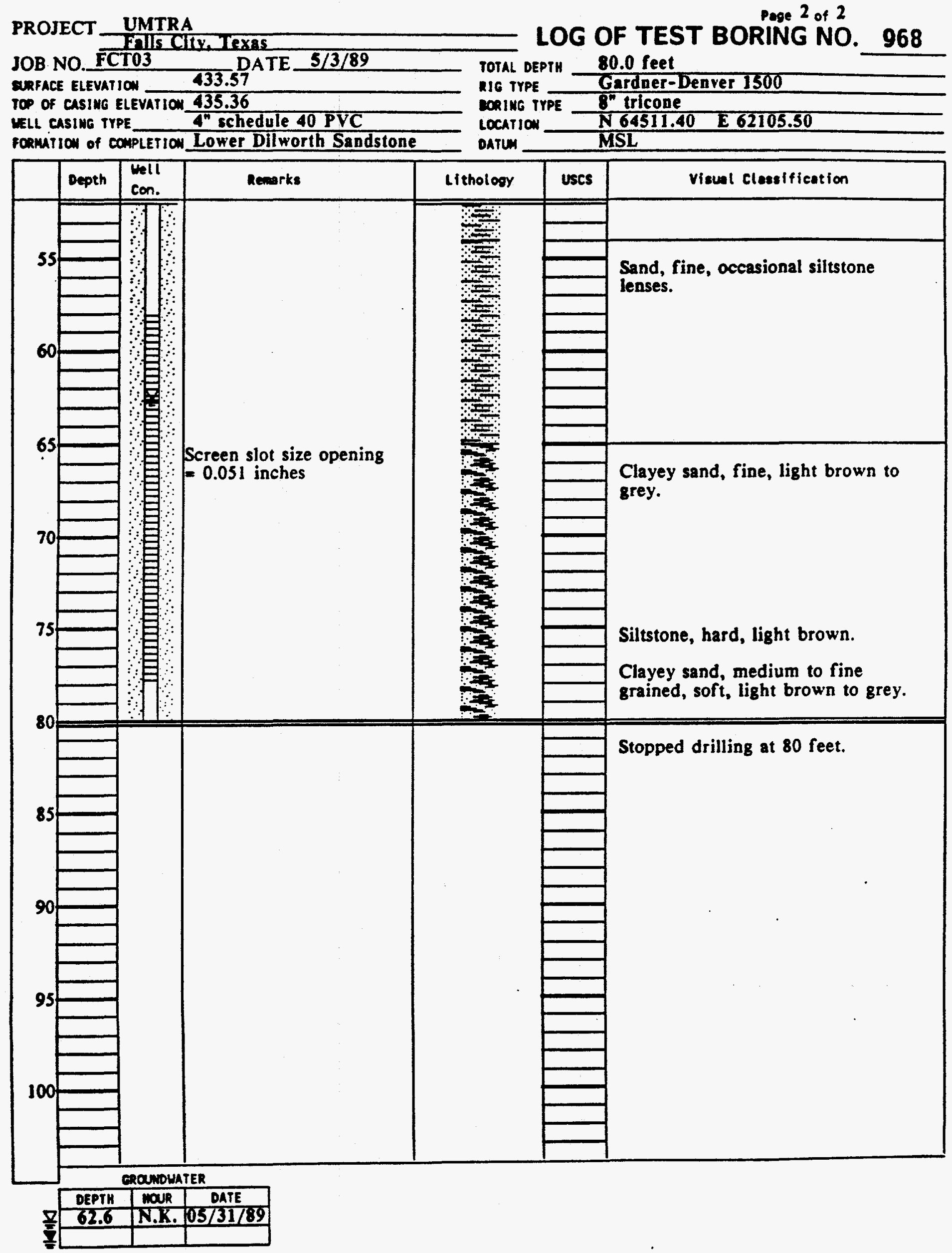


PROJECT UMTRA

Flls Cily. Texas

JOB NO. FCTO3

440.38 ATE $4 / 30 / 89$

TOP OF CASING ELEVATIOW 442.72

vell CAsing trPe 4 " schedule 40 PVC

Formation of completion Dilworth Sandstone

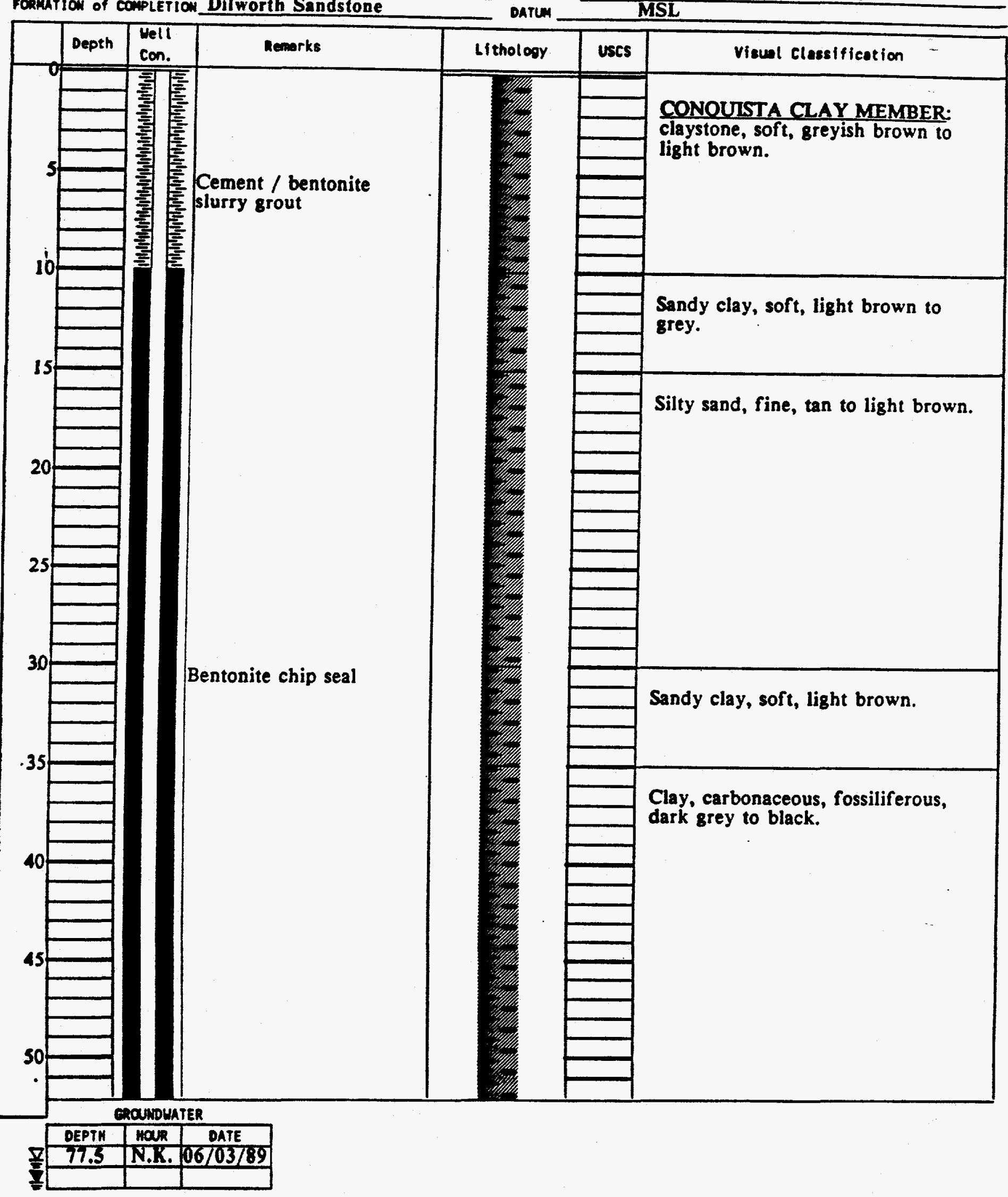

\section{Poge 1 of 3}

LOG OF TEST BORING NO. 969

TOTAL DEPTH 110.0 feet

RIG TYPE Gardaer-Denver 1500

CORING TYPE $8^{n}$ tricone

Locariow N57396.10 E62190.40

Datua

MSL 
ÓJECT UMTRA

Talls dity. Texns

Page 2 of 3

JOB NO. FCT03 DATE $4 / 30 / 8$

SURFACE ELEVATION $\quad 440.38$

TOP OF CASING ELEVATION $\mathbf{4 4 2 . 7 2}$

WELL CASIMG TYPE A" schedule 40 PVC

FORMATION of Completion Dilworth Sandstone

LOG OF TEST BORING NO. 969

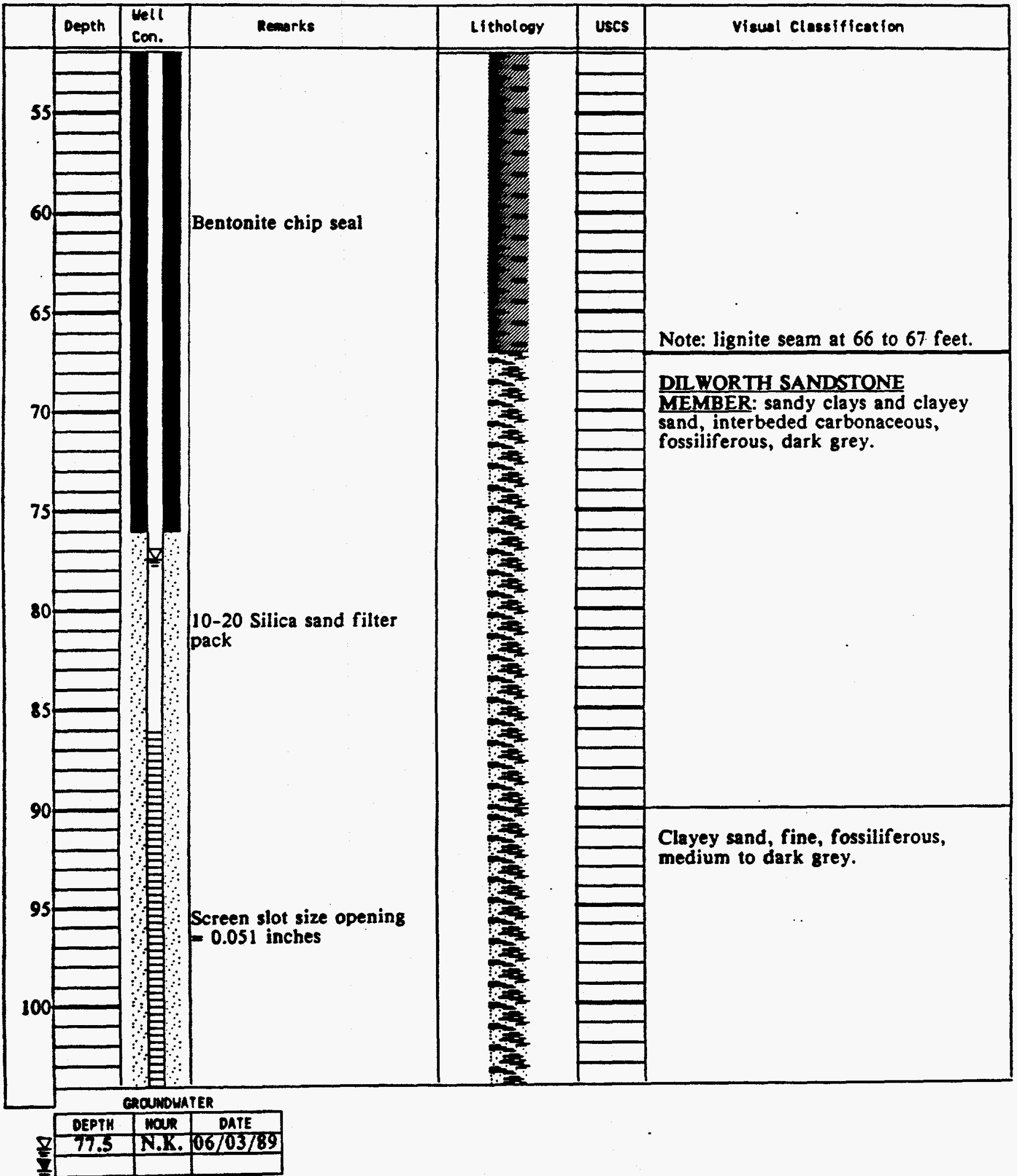


PROJECT UMTRA

Poge 3 of 3

JOB NO. FCT03

EuFACE ELEVATION

als city. Lexas

TOP of CASING ELEVATIOU 442.72

vell casing trpe 4 schedule 40 PVC

Fonution of completion Dilworth Sandstone

LOG OF TEST BORING NO. 969

DATE $4 / 30 / 89$

TOTAL DEPTH 110.0 feet

nIG TYPE Gardner-Denver 1500

DIG TYPE

Location N57396.10 E 62190.40

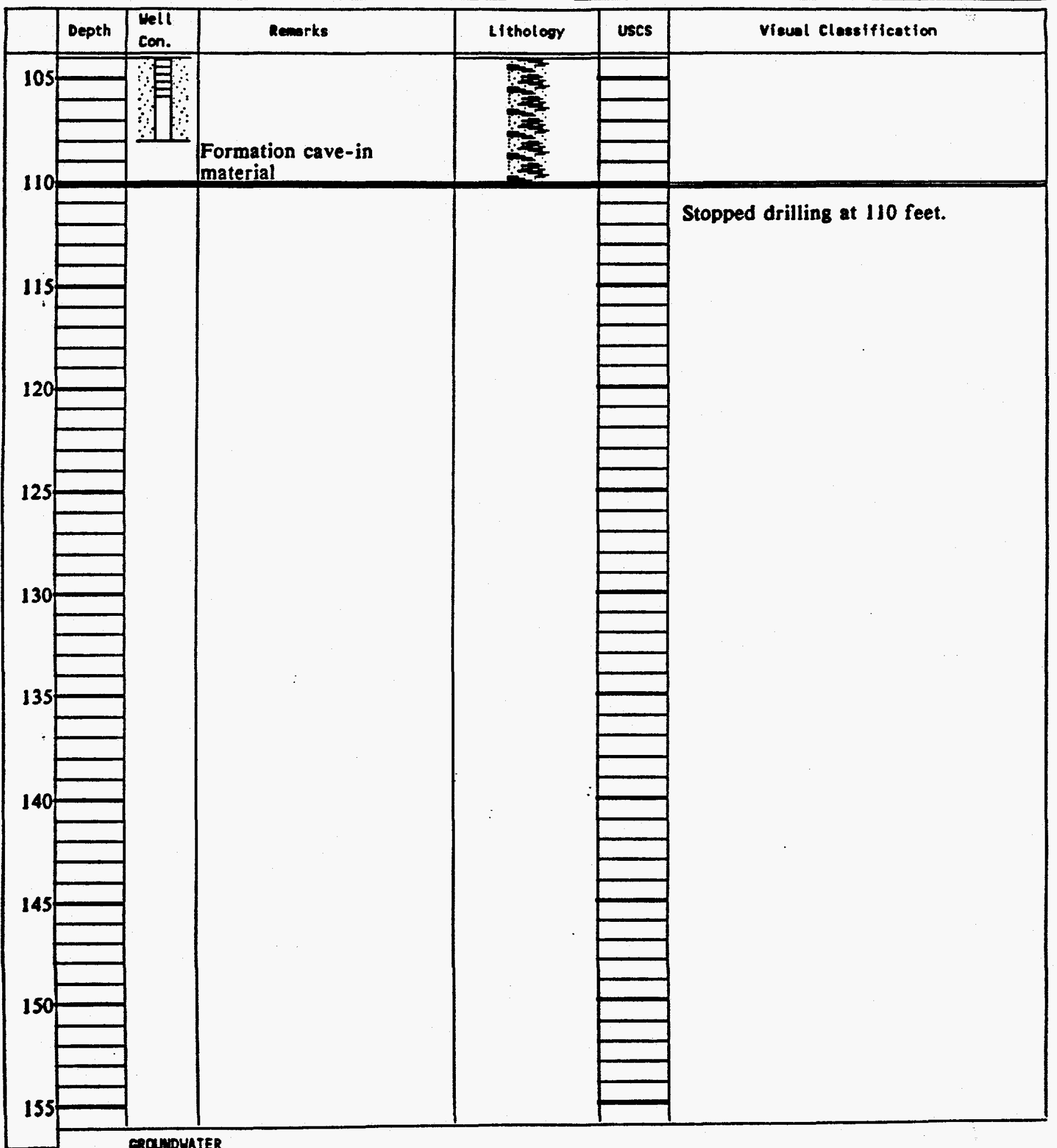

GOMNDATER

\begin{tabular}{|l|l|l|}
\hline DEPTH & MOUR & DAIE \\
\hline
\end{tabular}

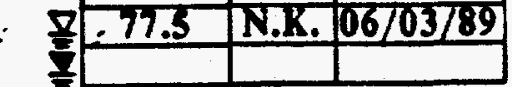


PROJECT UMTRA

JOB NO. FCT03

arface ELEVATION 439.68

DATE $5 / 2 / 89$

TOP OF CASING ELEVATION 441.46

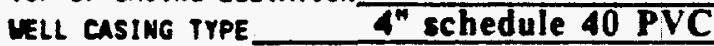

ponmution of completion Manning Clay Formation
Poge 1 of 4

LOG OF TEST BORING NO. 970

TOTAL DEPTH 158.5 feet

RIG TYPE Gardner-Denver 1500

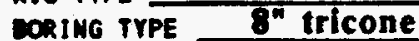

LOCATION N57410.00 E 62203.80

DATUM MSL

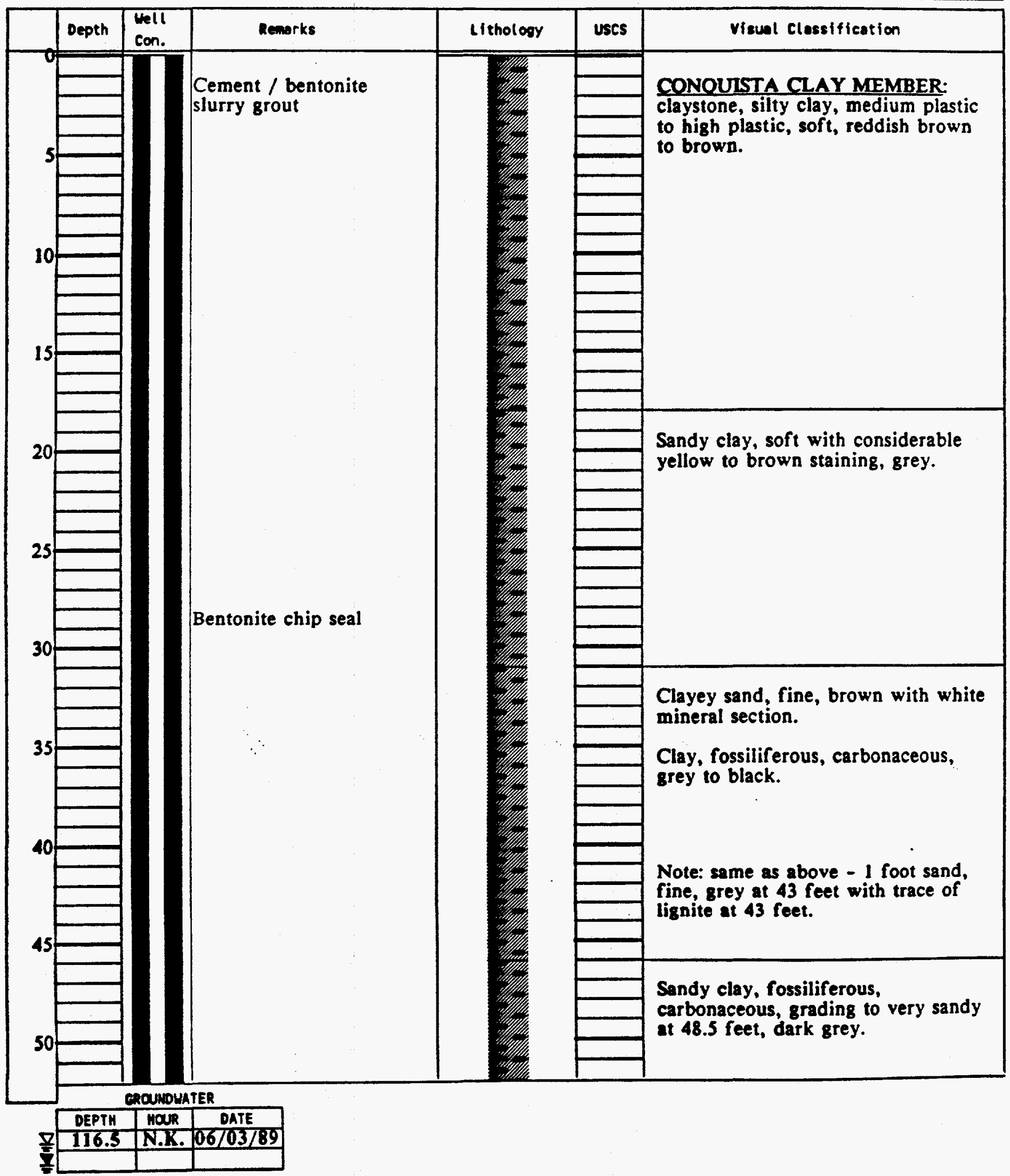




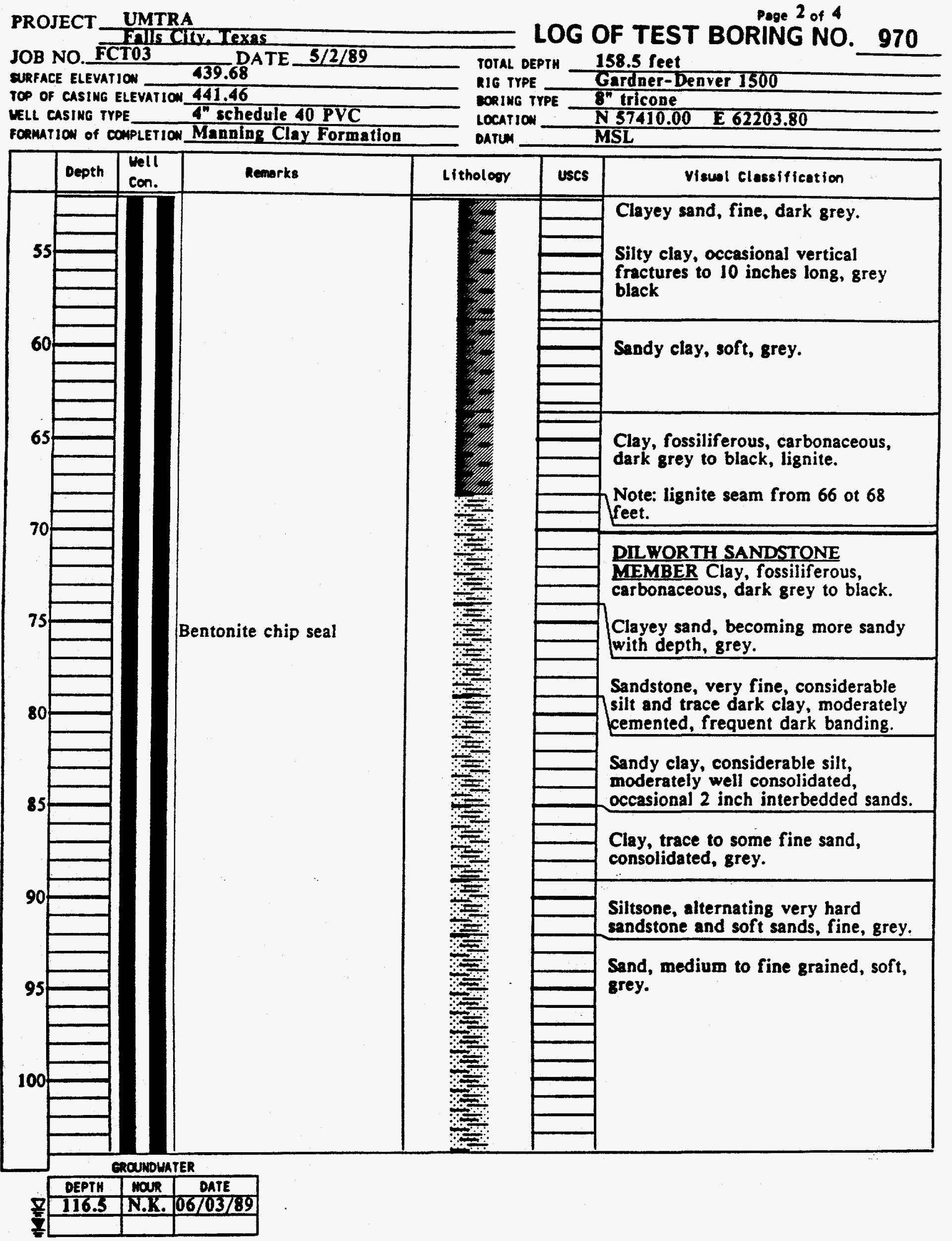


PROJECT UMTRA

Texas

Page 3 of 4

JOB NO. FCT03

DATE $5 / 2 / 89$

ERFACE ELEYATION $\quad \mathbf{4 3 9 . 6 8}$

TOP OF CASING ELEVATION 441.46

vell casing TrPE 4 schedule 40 PVC ronution of conpletion Manning Clay Formation

LOG OF TEST BORING NO. 970
OEPTH $\frac{158.5 \text { feet }}{\text { Pardner }^{3} \text { Denver } 1500}$
$\frac{8^{4} \text { tricone }}{\text { T57410.00 E } 62203.80}$
TSL

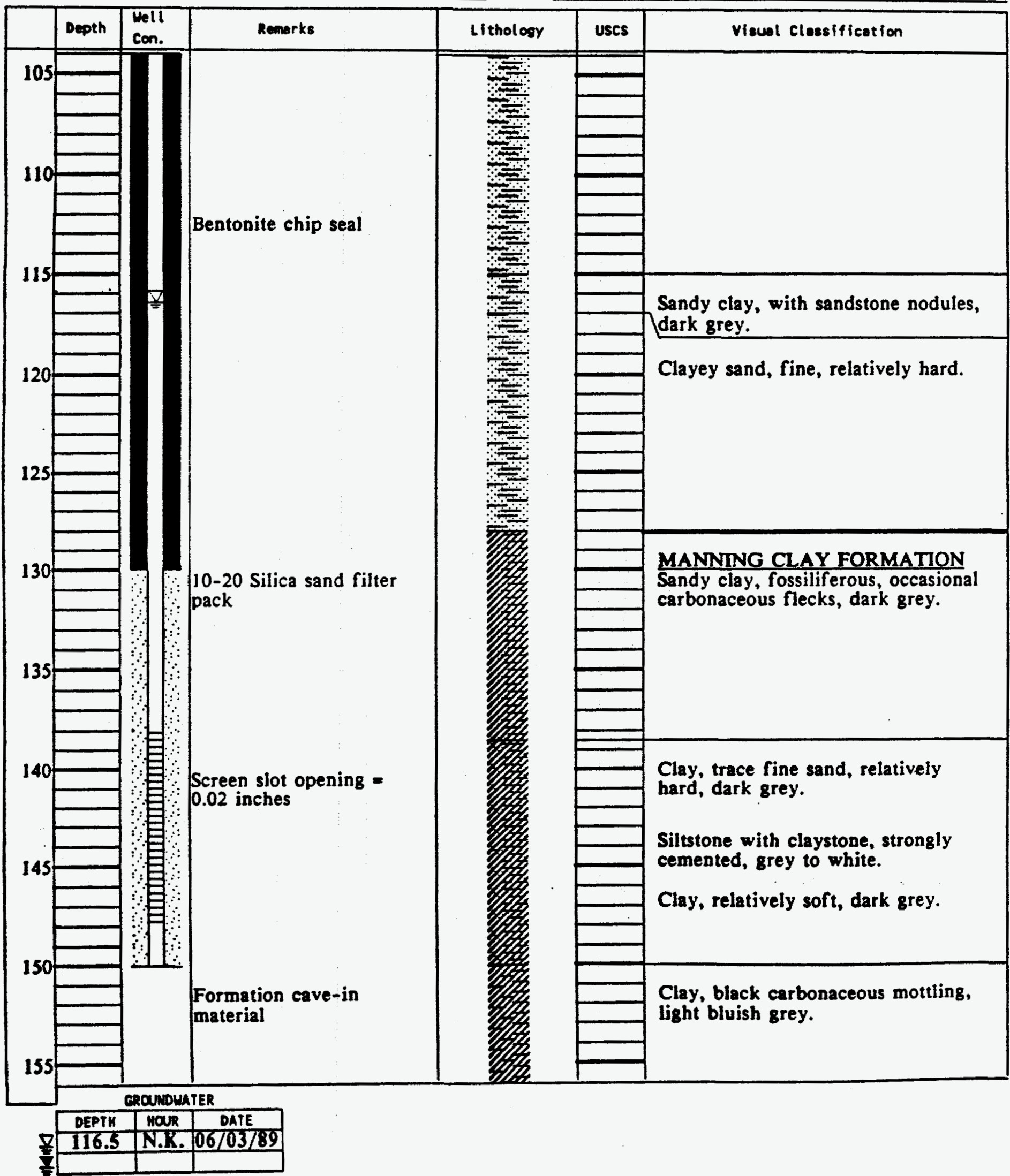


PROJECT UMTRA

Fills cify. Texas

LOG OF TEST BORING NO. 970

JOB NO. FCT03

ERFACE ELEVATION 439.68

DATE $5 / 2 / 89$

TOP OF CASING ELEVATION 441.46

MELL CASING TYPE

$4^{n}$ schedule 40 PVC

fonmition of conpletion Manning Clay Formation

TOTAL DEPTH 158.5 feet

R16 TYPE Gardner-Denver 1500

CORING IYPE $8^{n}$ tricone

LOCATION N 57410.00 E 62203.80

DATUM MSL

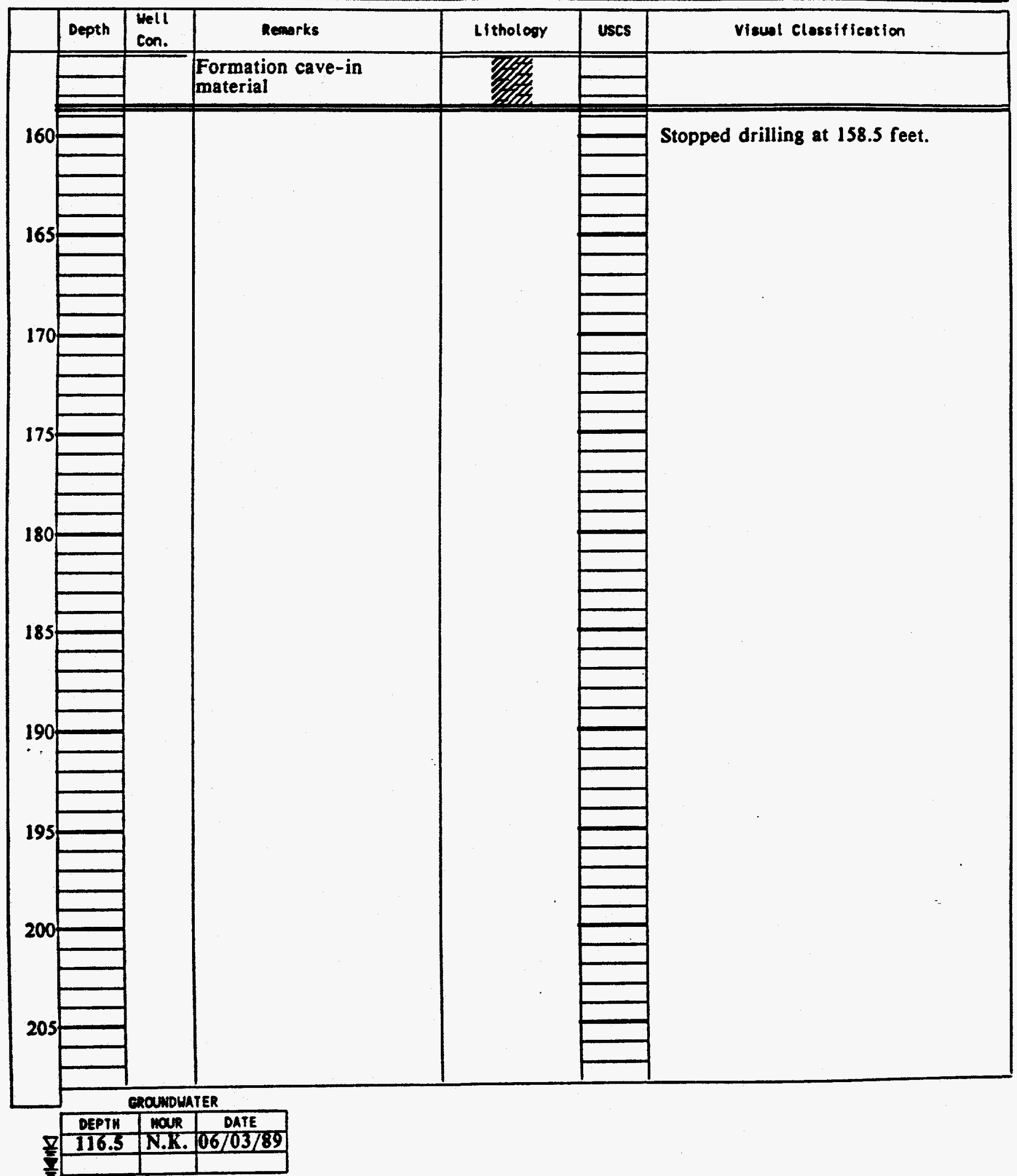




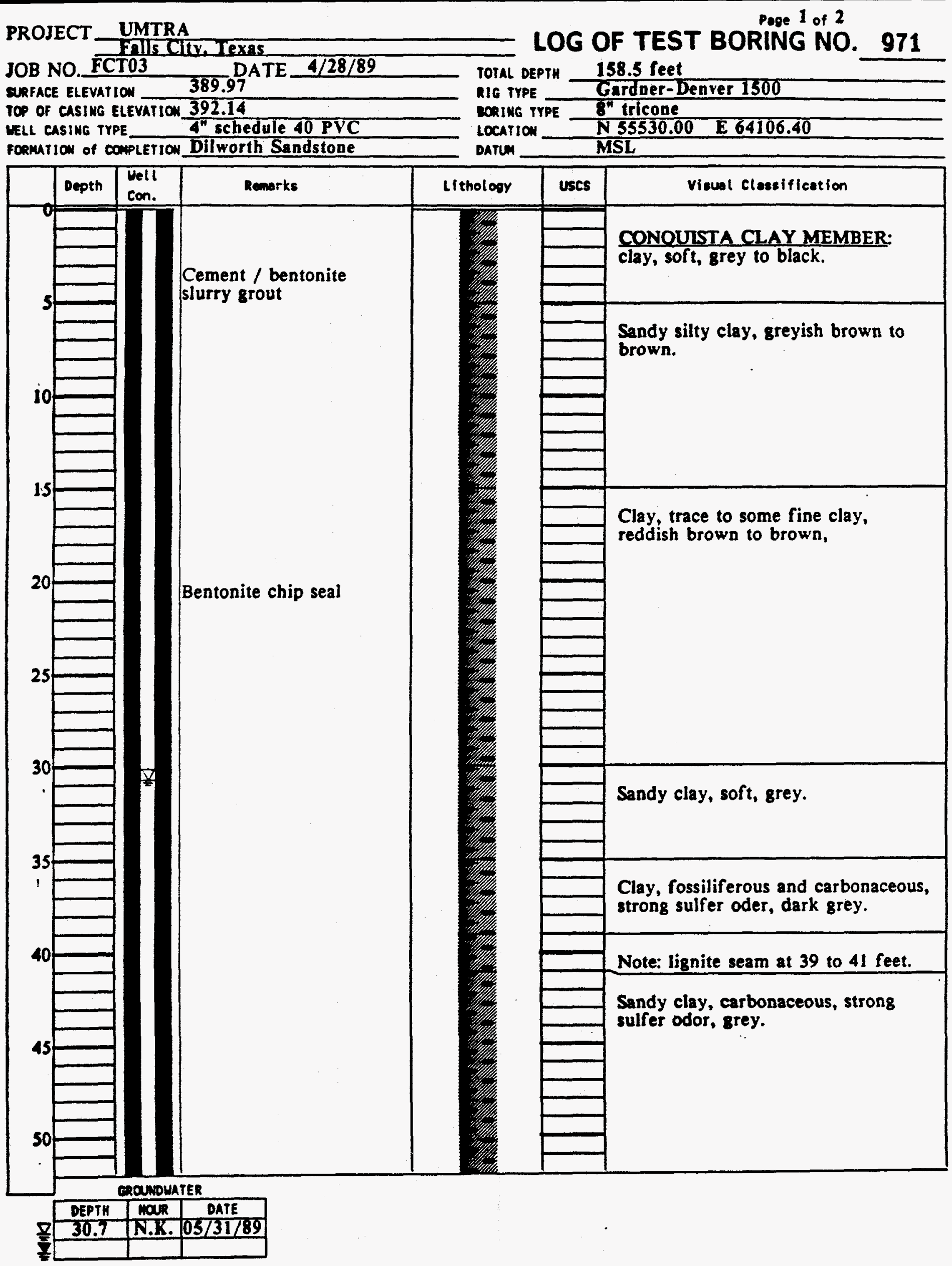


PROJECT UMTRA

Page 2 of 2

JOB NO. FCTO3

FO3

EXRS

LOG OF TEST BORING NO. 971

ERFACE ELEVATION $\mathbf{3 8 9 . 9 7}$

TOP OF CASING ELEVATION $\mathbf{3 9 2 . 1 4}$

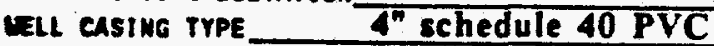

Fonuriow of completion Dilworth Sandstone

TOTAL DEPTY 158.5 feet

RIG TYPE Gardaer-Denver 1500

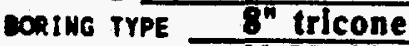

LocAtion N 55530.00 E 64106.40

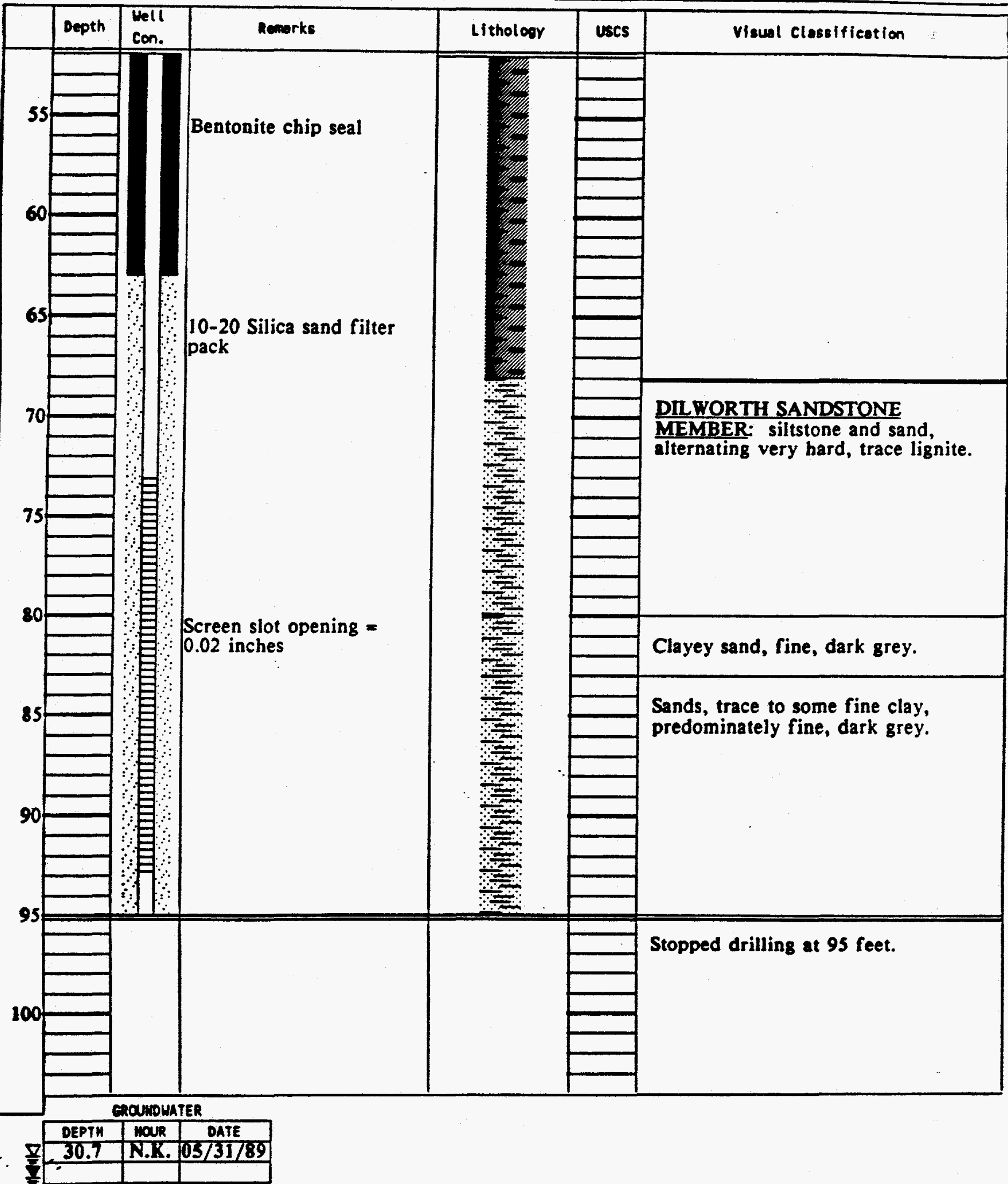




\section{PROJECT UMTRA}

Fils City, Texas

JOB NO. FCTO3

ERFACE ELEVATION 435.94

DATE $4 / 12 / 89$

TOP OF CASING ELEVATION $\mathbf{4 3 7 . 9 9}$

MELL CAsING TYPE

rormation of completion Manning Clay

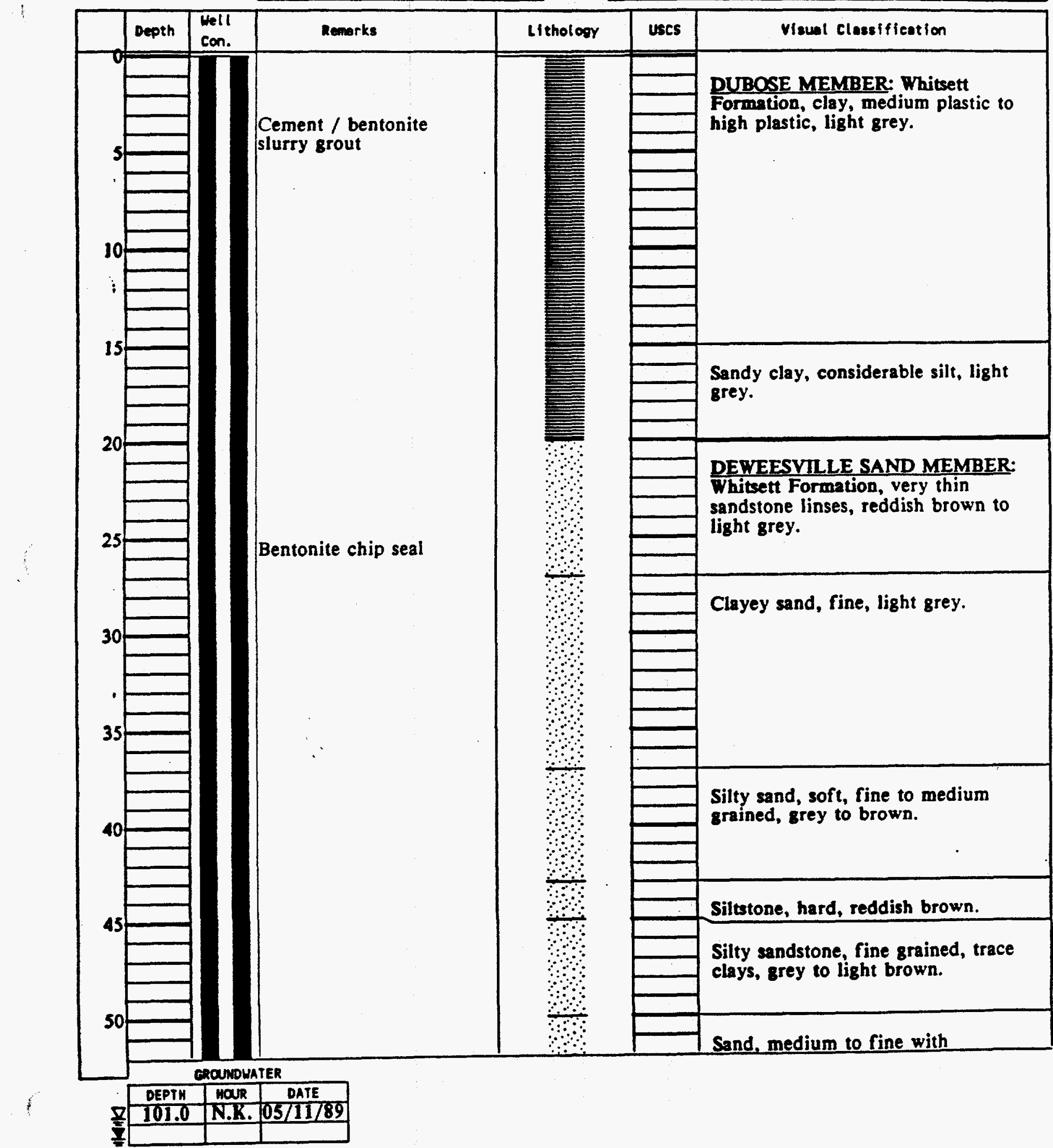

LOG OF TEST BORING NO. 973

TOTAL DEPTH 230.0 feet

coning TrPE $8^{n}$ tricone

LOcarion

N 55362.30

E 66834.00

MSL
MIG TYPE Gardner-Denver 1500 
PROJECT UMTRA

JOB NO. FCT03 Cily. Texns

LOG OF TEST BORING NO. 973

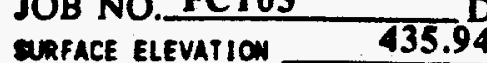

TOP OF CASIMG ELEVATION $\mathbf{4 3 7 . 9 9}$

WELL CASING TYPE

FORMATION Of COMPLETION Manning Clay

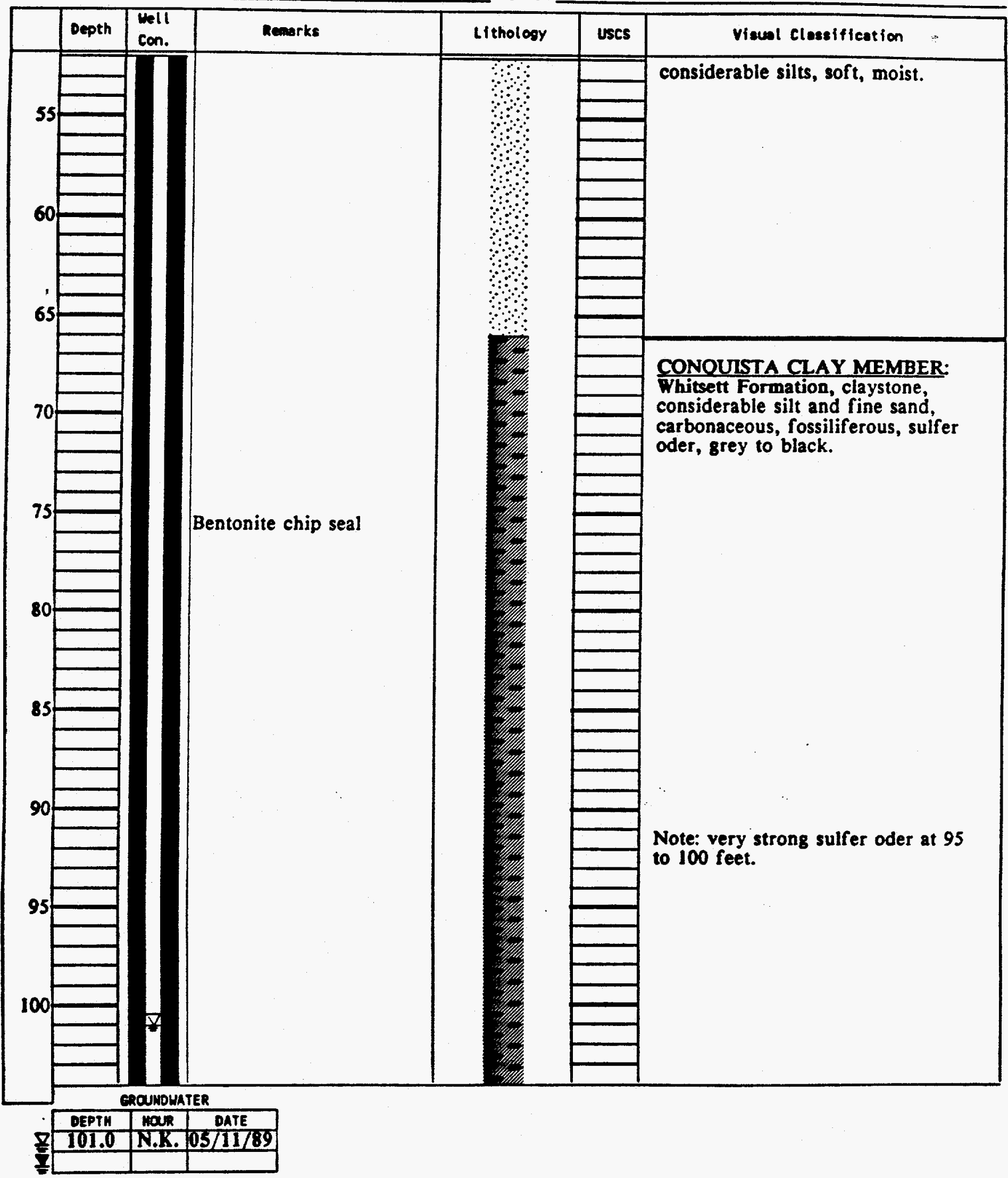


PROJECT UMTRA

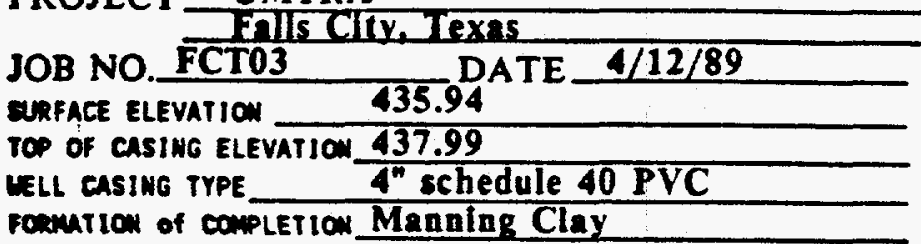

LOG OF TEST BORING NO. 973

TOTAL DEPTH 230.0 feet

nIG IYPE Gardner-Denver 1500

coning trPe $8^{n}$ tricone

Locarton N55362.30 E 66834.00

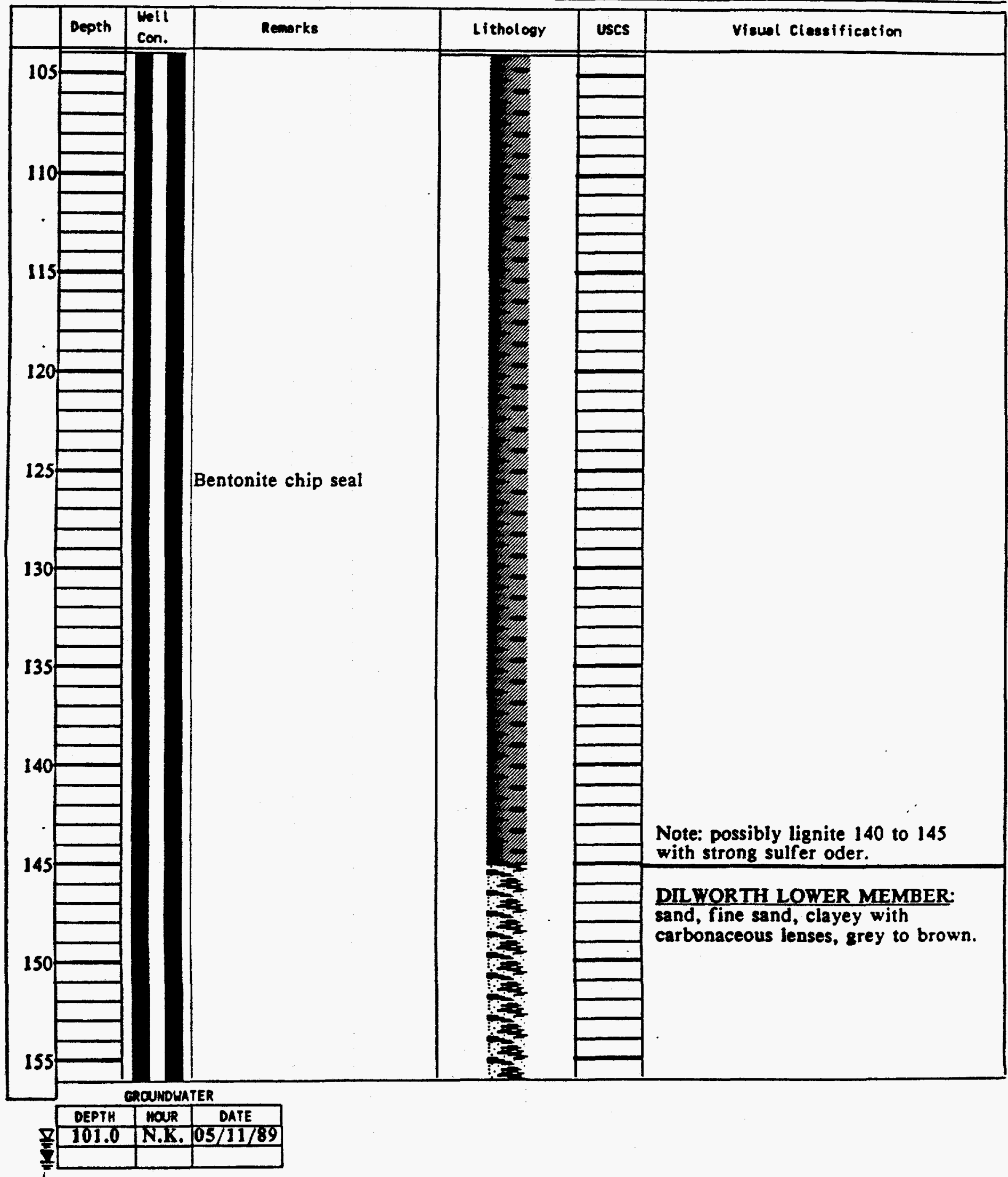


PROJECT UMTRA

JOB NO. FCT03 DATE 4/12/89

JRFACE ELEVATION $\mathbf{4 3 5 . 9 4}$

TOP of CASIMG ELEVATION 437.99

veLL CAsIng TYPE

roamition of completjow Manning Clay

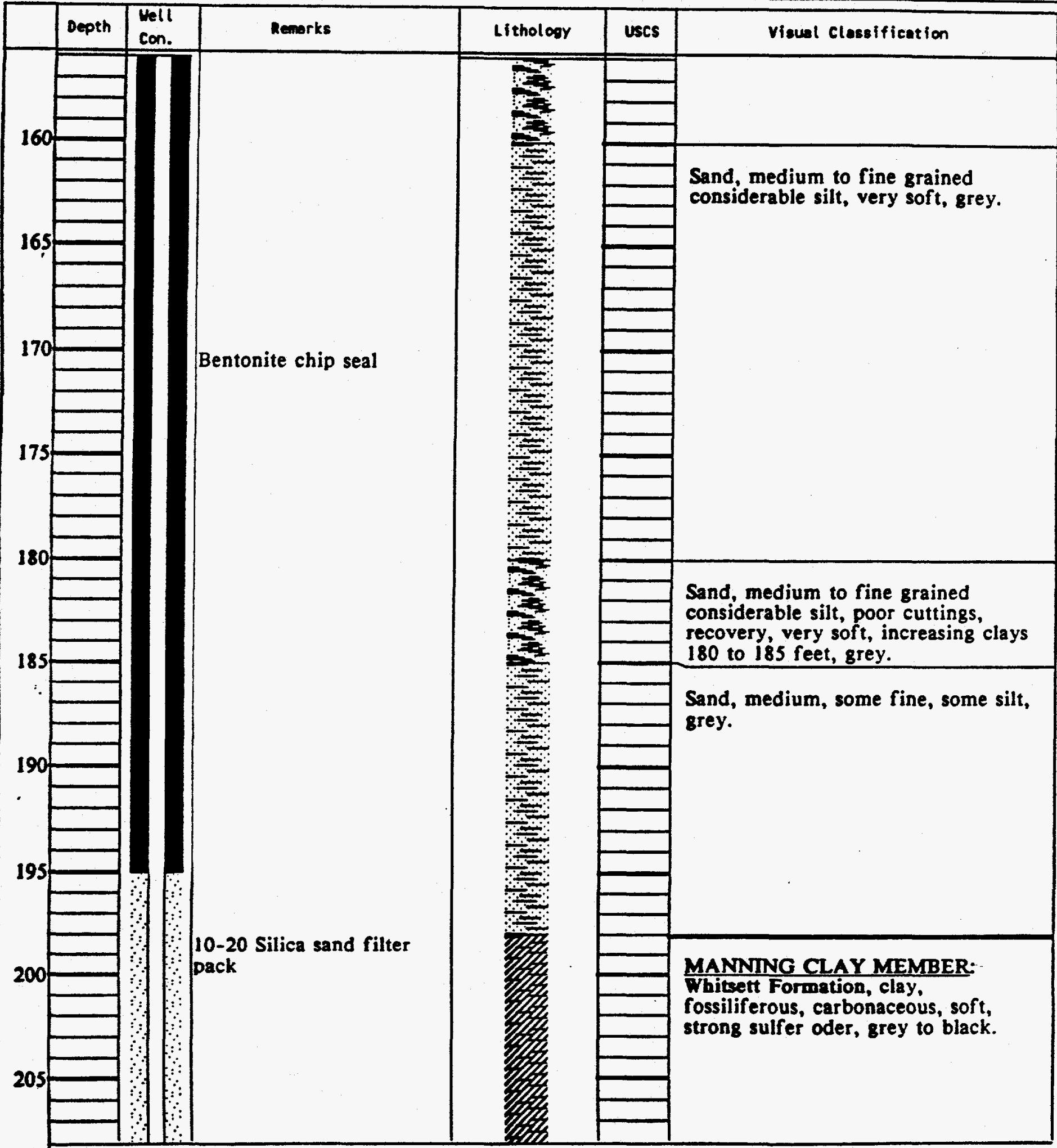

EROUNDWATER

DEPTH HOW

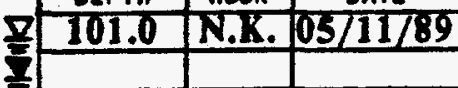


PROJECT UMIRA

FCT03

JOB NO. FCTO

DATE $4 / 12 / 89$

LOG OF TEST BORING NO. 973

SURFACE ELEVATION 435.94

TOP OF CASING ELEVATION 437.99

WELL CASING TYPE

formation of COMpletion Manning Clay

TOTAL OEPTH 230.0 feet

Rlo TrPE Gardner-Denyer 1500

coRING TYPE $8^{n}$ tricone

\begin{tabular}{|l|l|l|l|l|l|}
\hline Depth & $\begin{array}{l}\text { thell } \\
\text { Con. }\end{array}$ & Remarks & Lithology & uscs & Visual classification \\
\hline
\end{tabular}

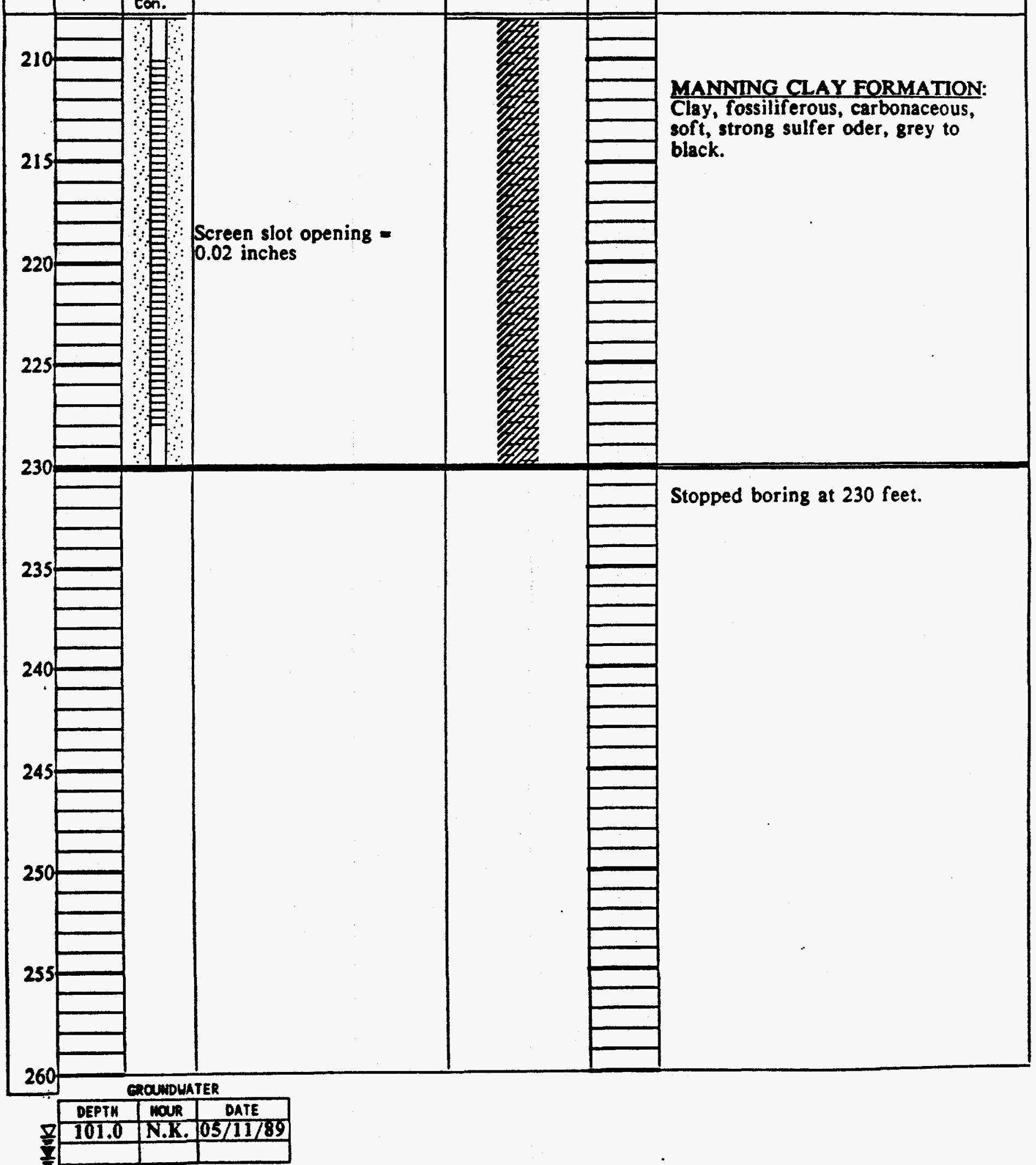




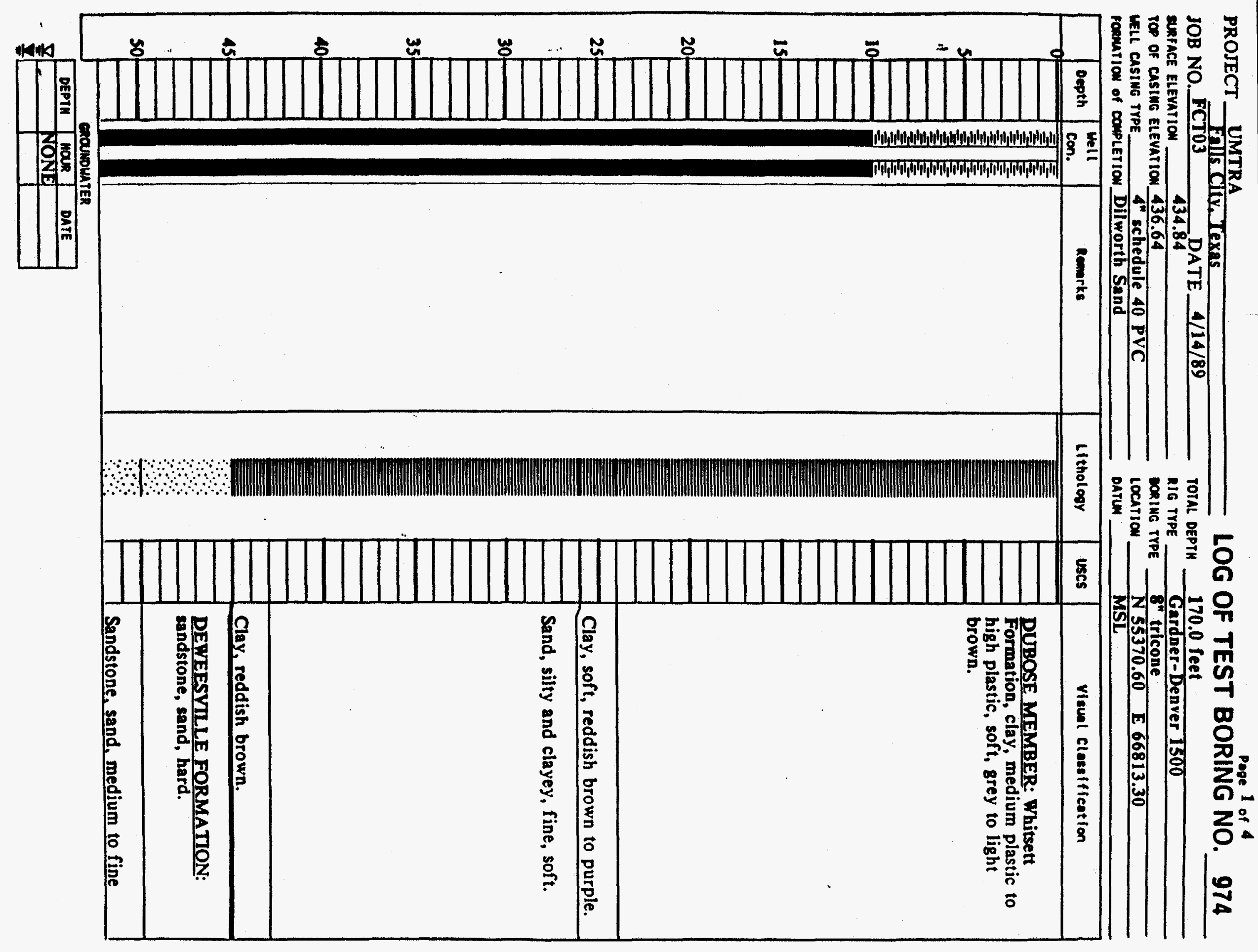


PROJECT UMMRA

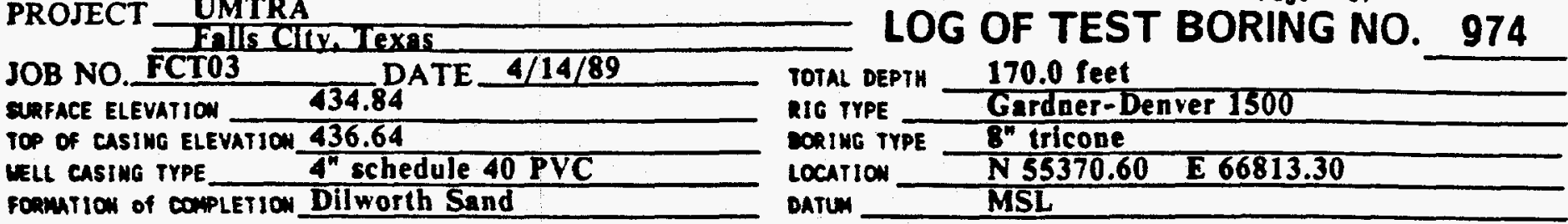

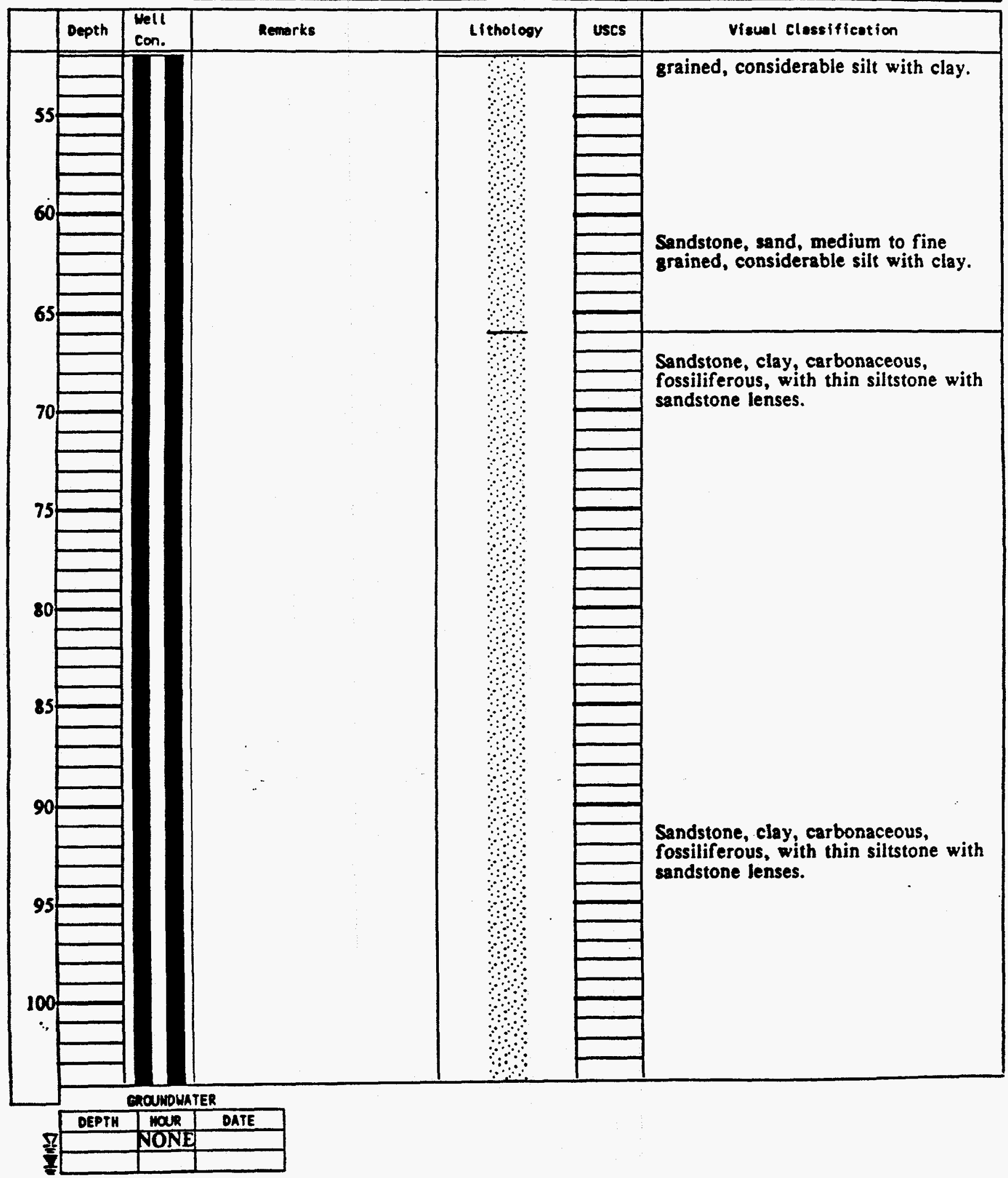


JOB NO. FCT03

enFACE ELEVATION 434.84

TOP OF CASING ELEVATION $\mathbf{4 3 6 . 6 4}$

uL CAsIme TYPE $4^{\prime \prime}$ schedule 40 PVC

fonertion of completion Dilworth Sand
TOTAL DEPTH 170.0 feet

RIG TYPE Gardner-Denver 1500

CORIMG IYPE $8^{n}$ tricone

Location

DATUA MSL

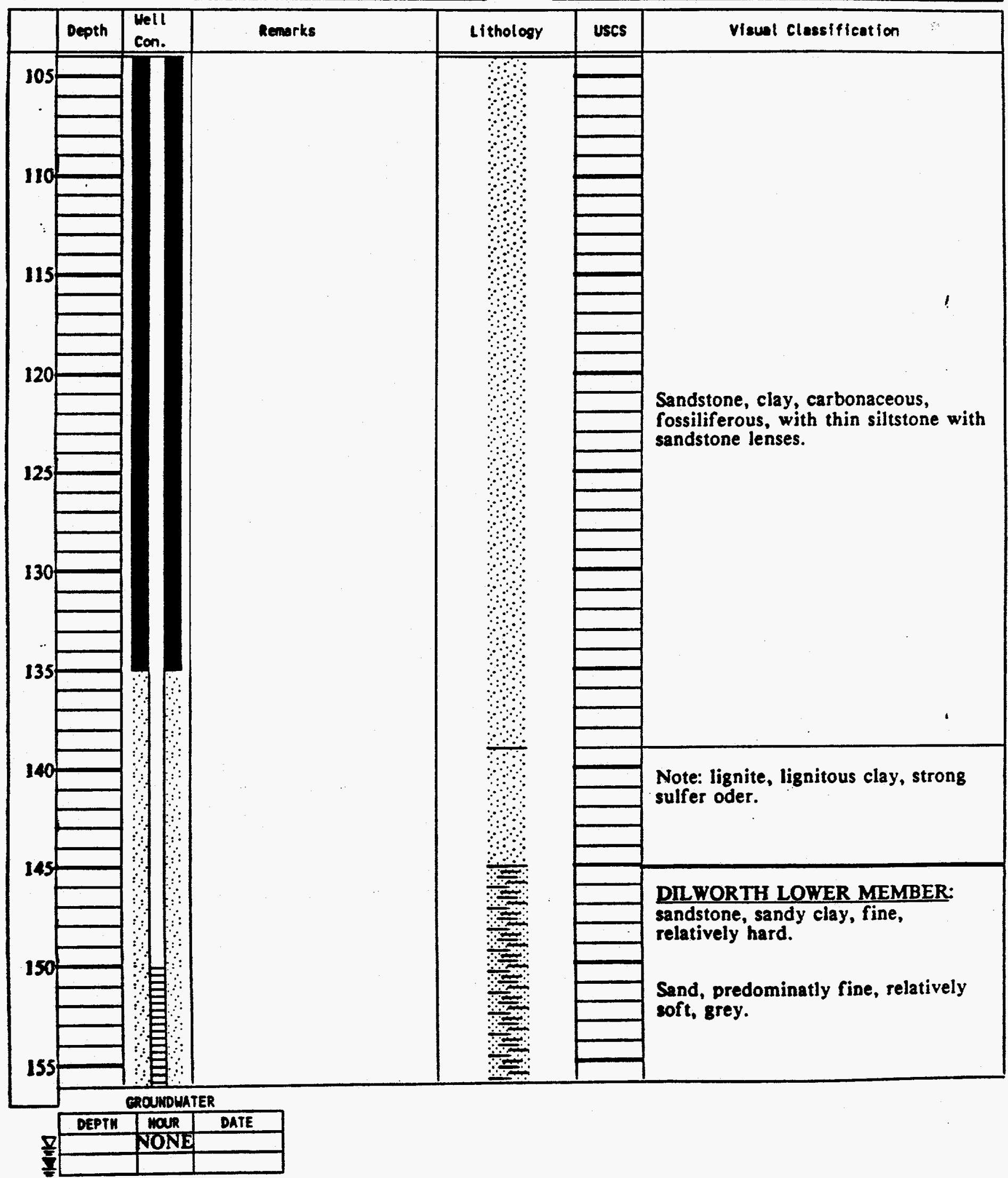


PROJECT $\frac{\text { UMIR A }}{\text { Fills Cify Texas }}$

JOB NO. FCTO3 DATE 4/14/89

LOG OF TES'T BORING NO. 974

SURFACE ELEVATION $\quad \mathbf{4 3 4 . 8 4}$

TOP OF CASING ELEVATION 436.64

UELL CAsIMG TYPE

Formation of COMPLETION Dilworth Sand

TOTAL DEPTH 170.0 feet

RIG TYPE Gardner-Denver 1500

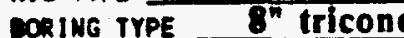

Locarion N 55370.60 E 66813.30

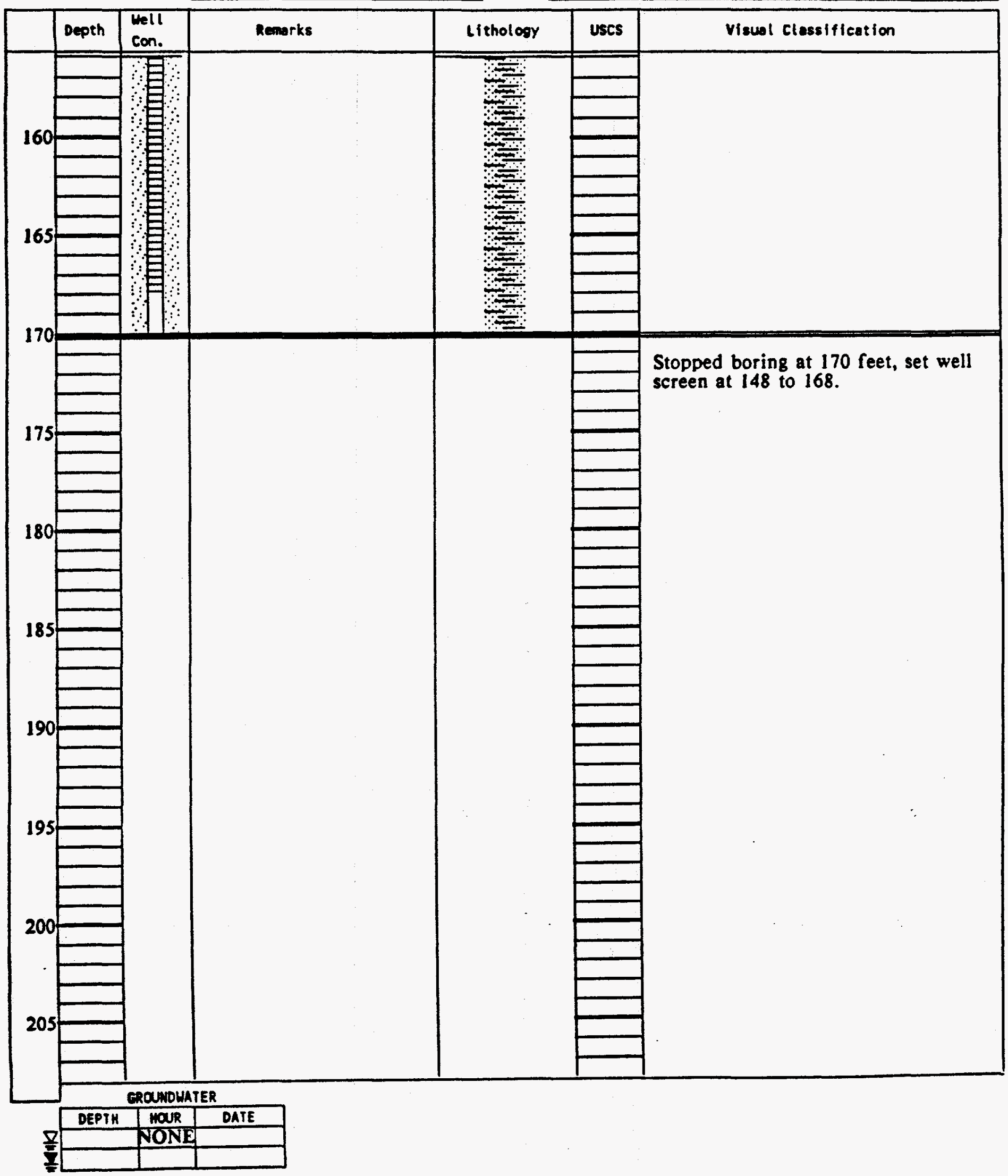


PROJECT UMTRA

Page 1 of 5

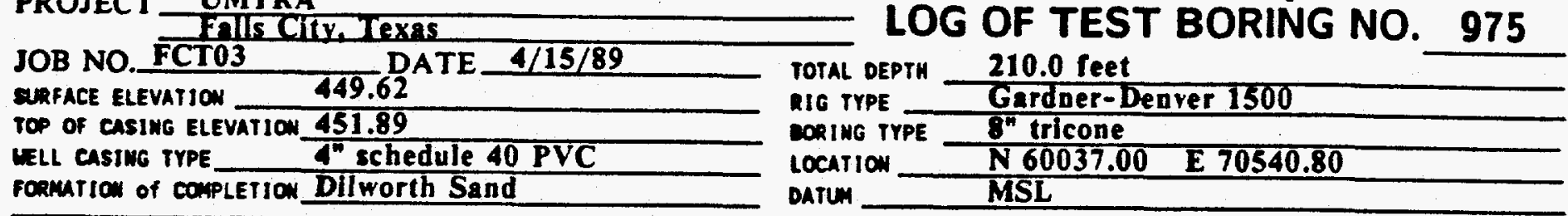

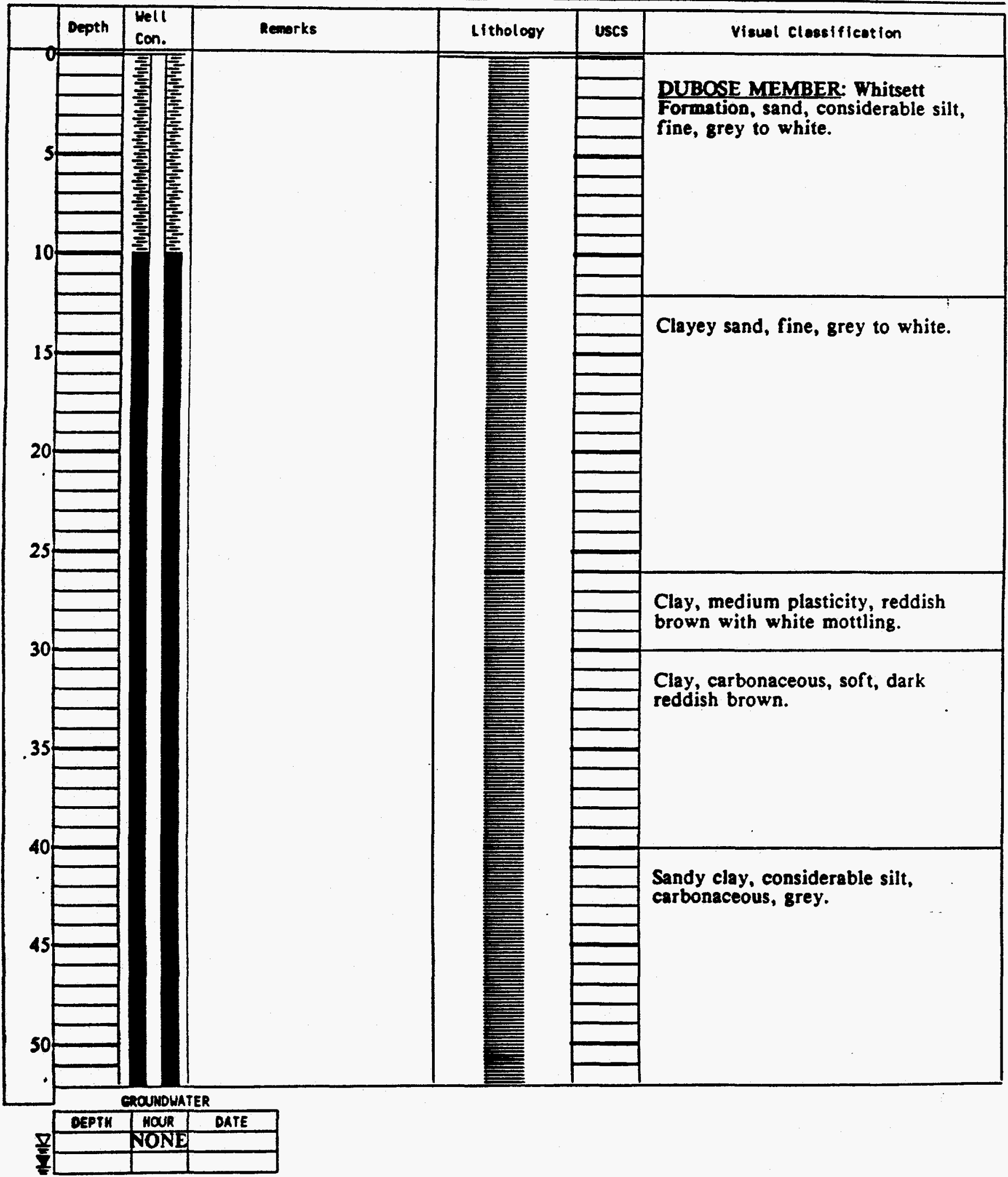




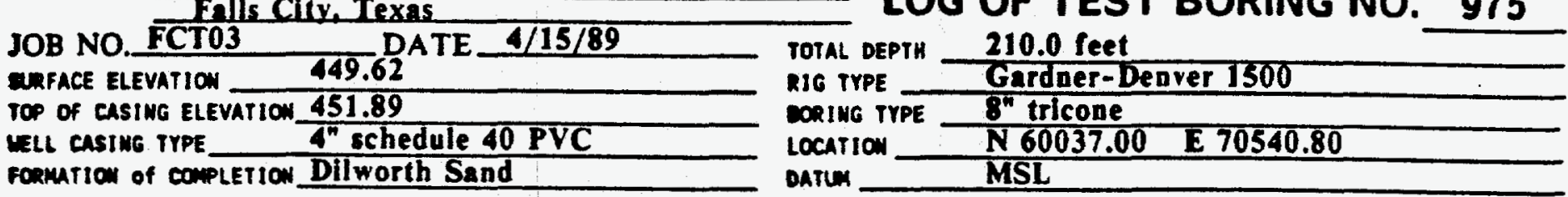

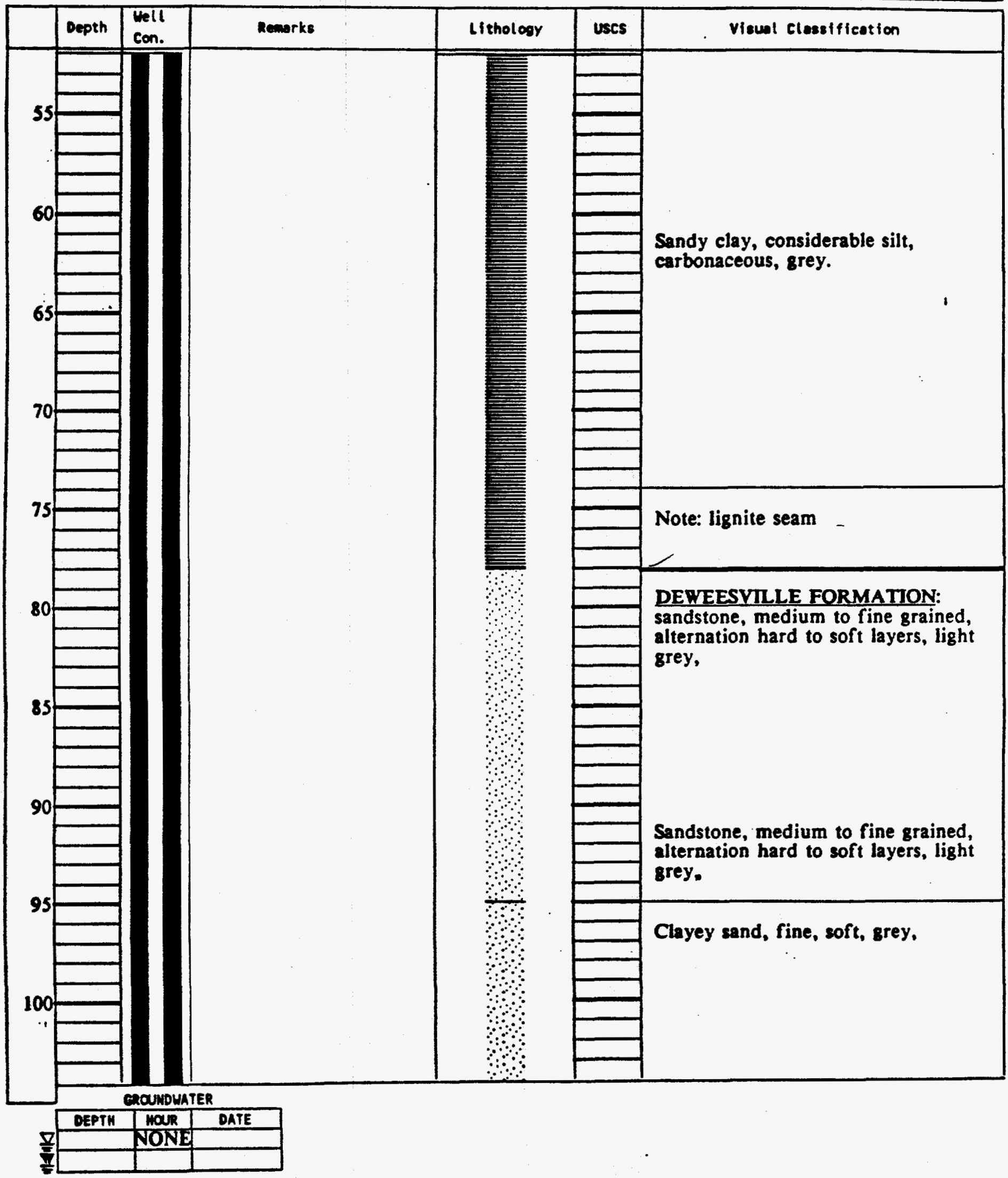


JOB NO. FCTO3

MafACE ELEVATION

DATE $4 / 15 / 89$

To of Casing ELEVATION 451.89

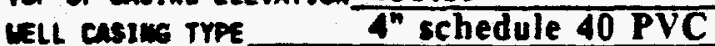

Formurion of Completion Dilworth Sand

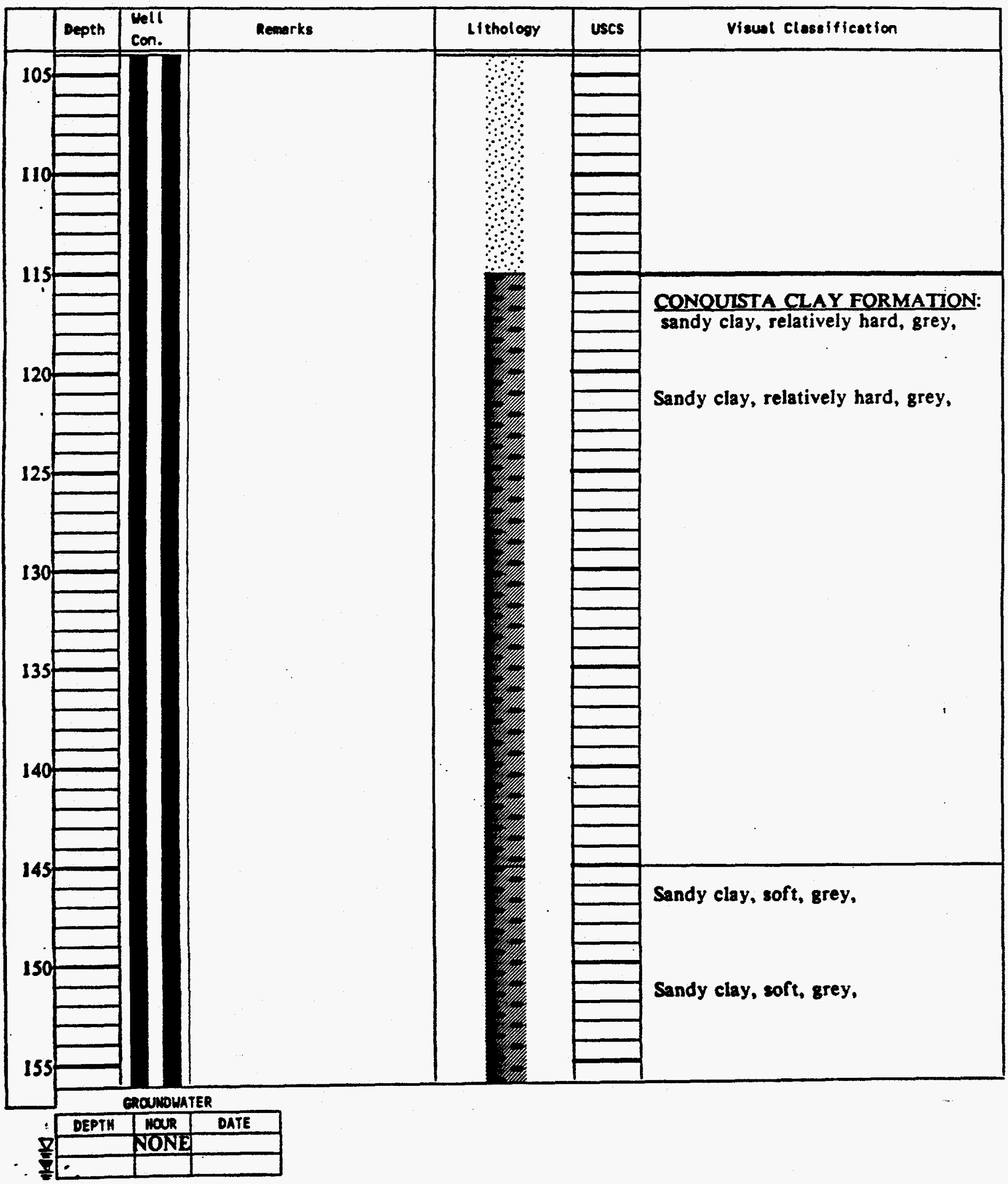

TOTAL DEPTH 210.0 feet

RIG TYPE Gardner-Denver 1500

coning trpe $\mathrm{g}^{\prime \prime}$ tricone

Location N60037.00 MSL
CONOUTISTA CLAY FORMATION:

sandy clay, relatively hard, grey,

Sandy clay, relatively hard, grey, 


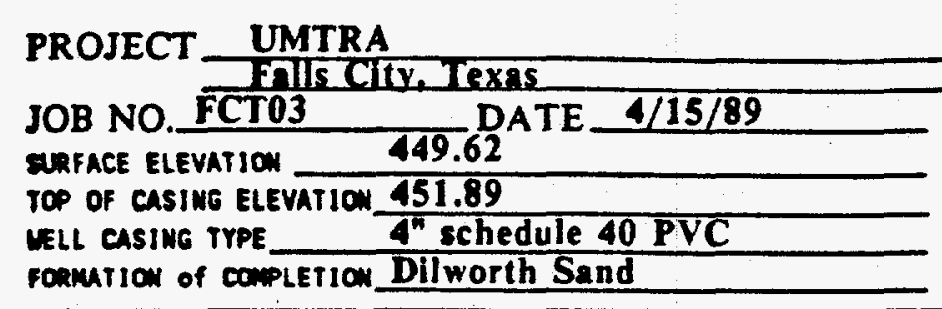

Page 4 of 5

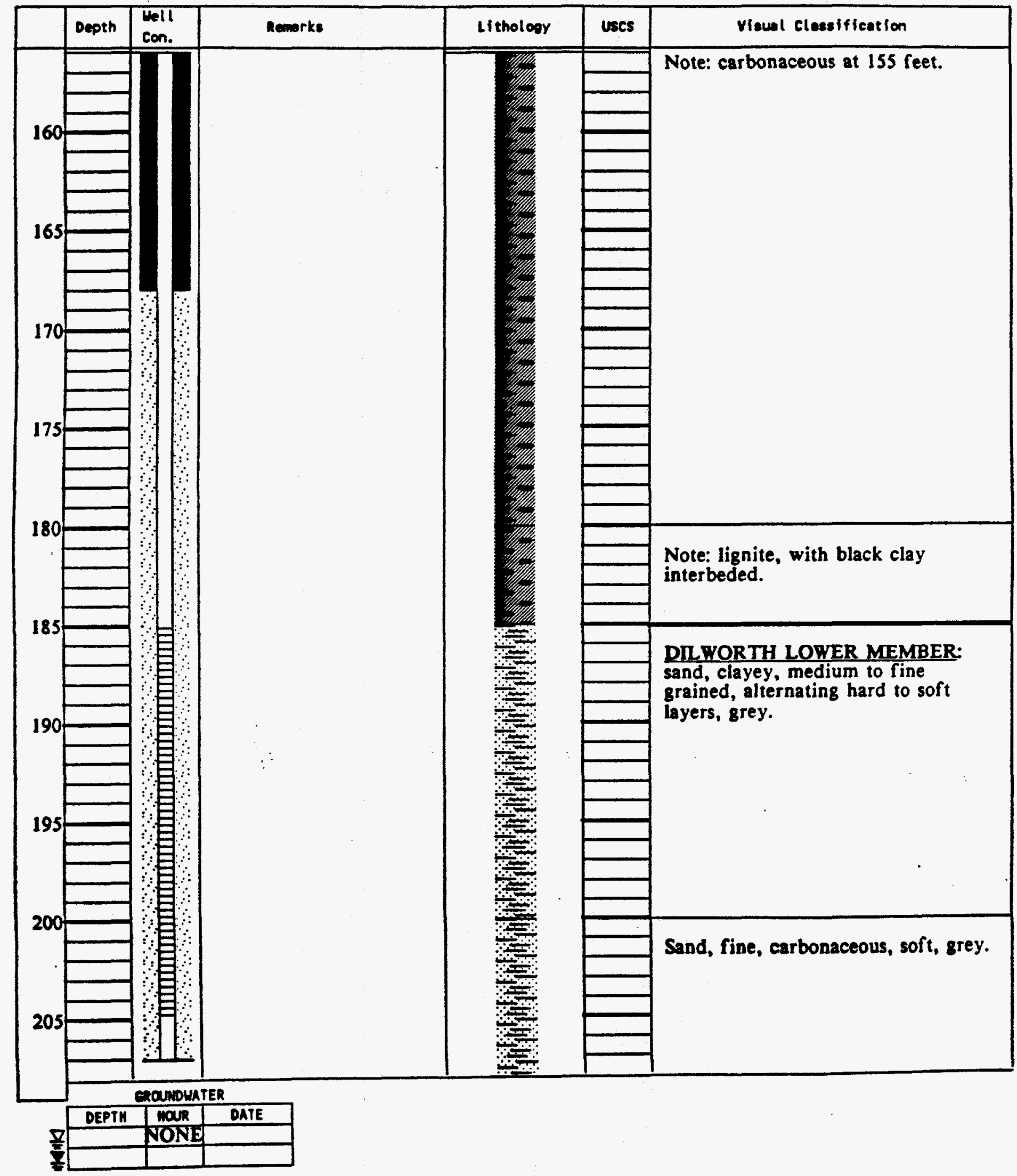


PROJECI UMTRA

JOB NO FCT03

DATE $4 / 15 / 89$

LOG OF TEST BORING NO. 975

ERFACE ELEVATIO 449.62

TOP of Casing ELEVATION $\mathbf{4 5 1 . 8 9}$

IELL CasIng TrPE

formution of conpletion Dllworth Sand

TOTAL DEPTH 210.0 feet

nIG TrPE Gardner-Denver 1500

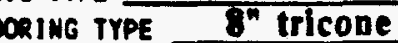

Location N60037.00 E 70540.80

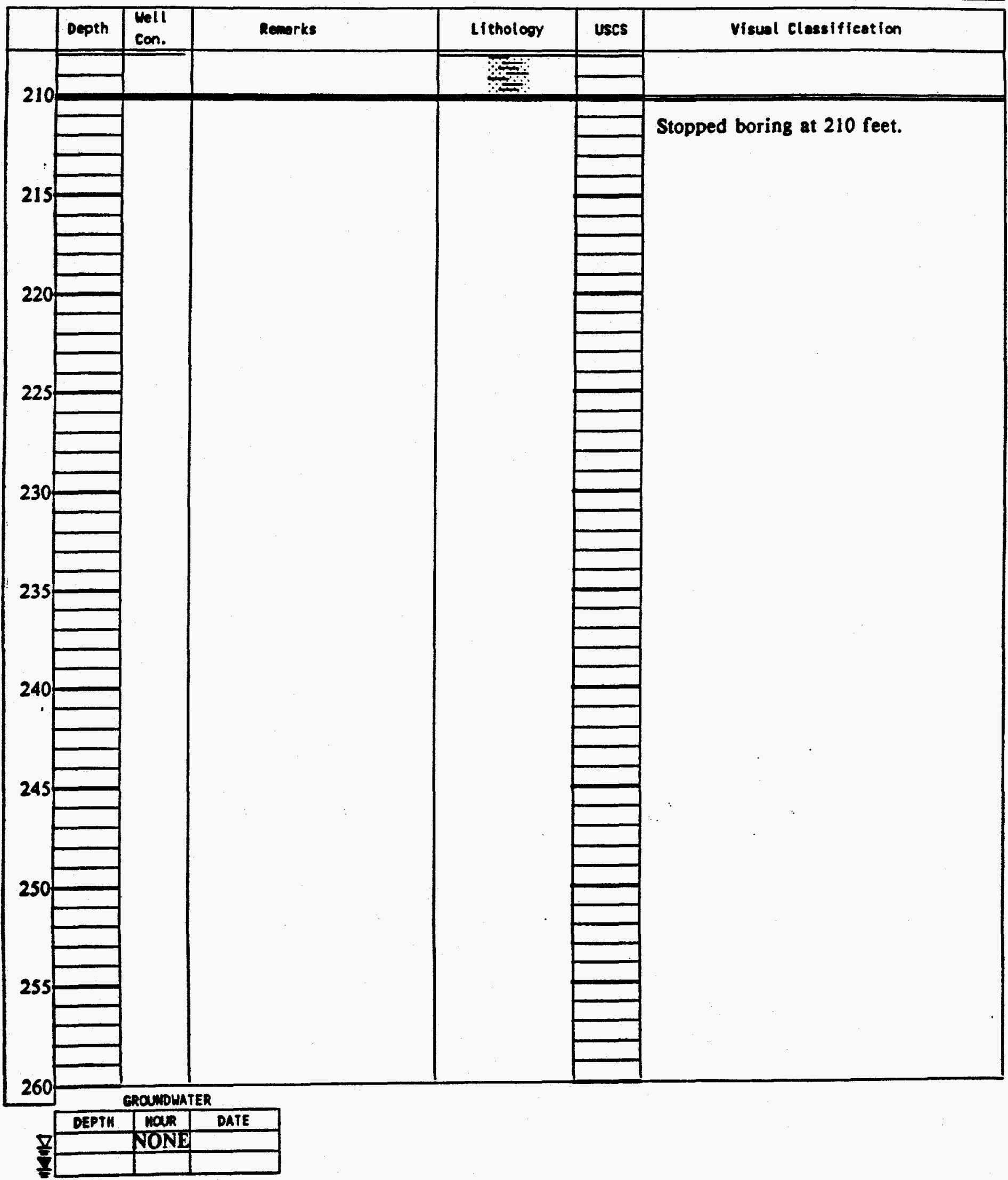


JOB NO. FCT03

ERRACE ELEVATION 359.42 DATE $4 / 26 / 89$

TOP OF CASING ELEVATION 361.27

VeLL CASING TYPE ForMATION of COMPLETION Upper Dilworth
LOG OF TEST BORING NO. 976

TOTAL DEPTH 110.0 feet

RIG TYPE Gardner-Denver 1500

CORING IYPE $8^{\prime \prime}$ tricone

Location N

oAtum MSL

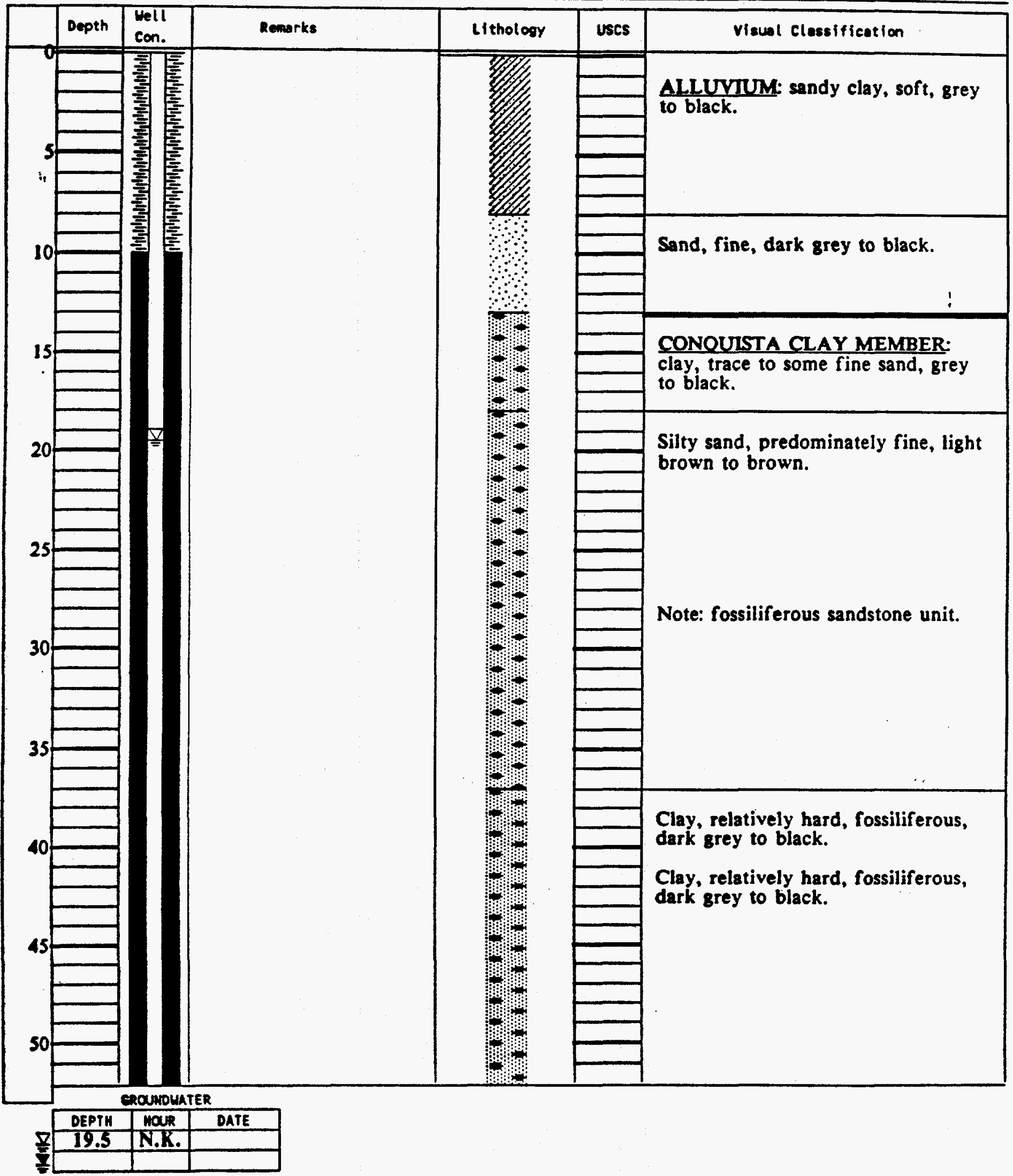




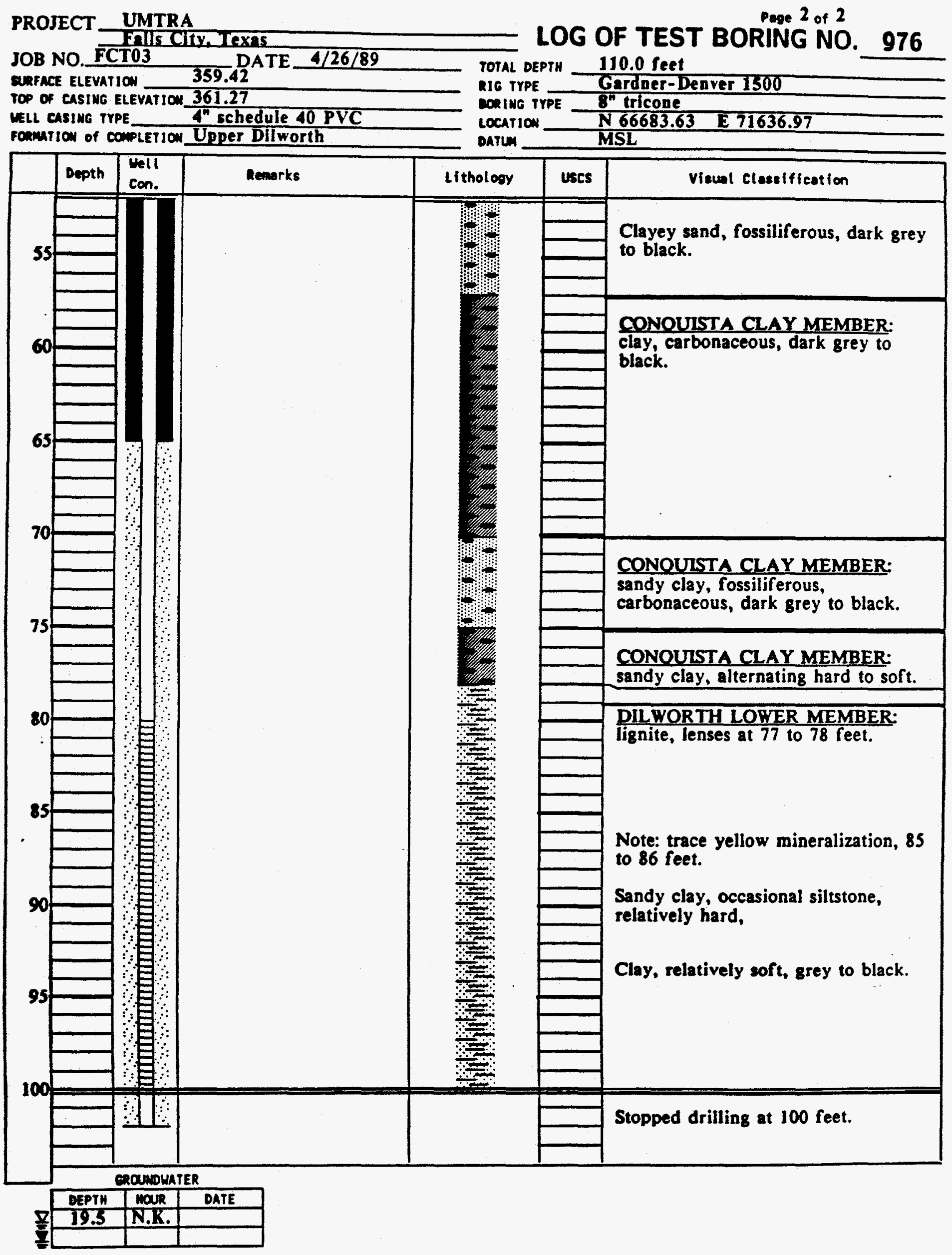




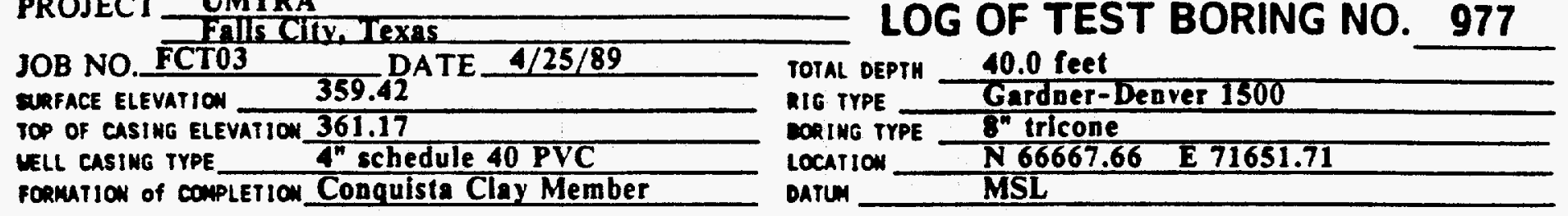

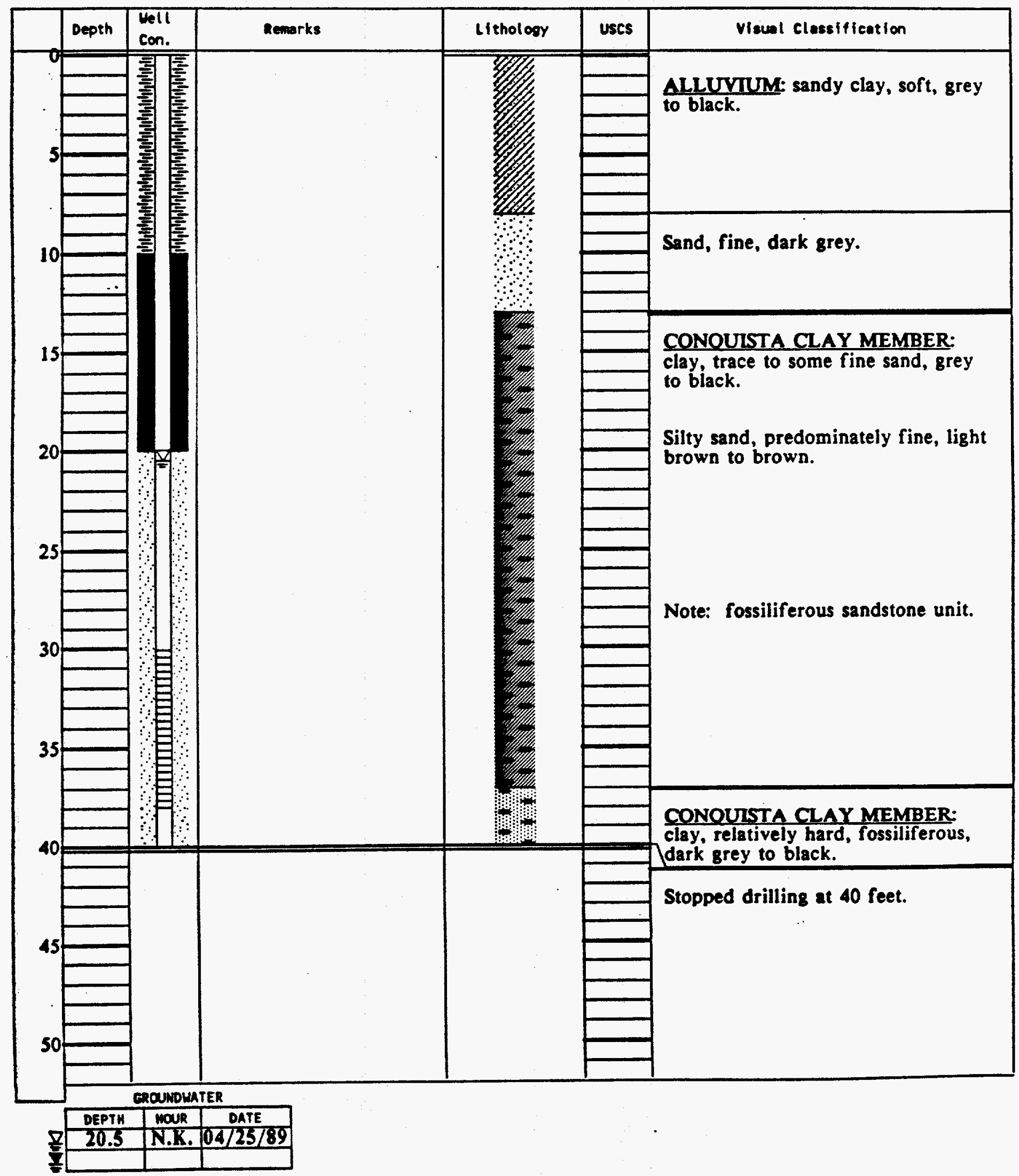


PROJECT UMTRA

Fills City. Texas

LOG OF TEST BORING NO. 978

JOB NO. FCT03 DATE 4/28/89

SURFACE ELEVATION $\mathbf{4 1 4 . 6 3}$

TOP OF CASING ELEVATION 417.12

WeLL CASING TYPE

formutjow of completjow Manning Clay Formation

TOTAL DEPTH 140.0 feet

RIG TYPE Gardner-Denver 1500

OORING TYPE $8^{\text {" tricone }}$

Lochtion N 64822.20 E 63668.70

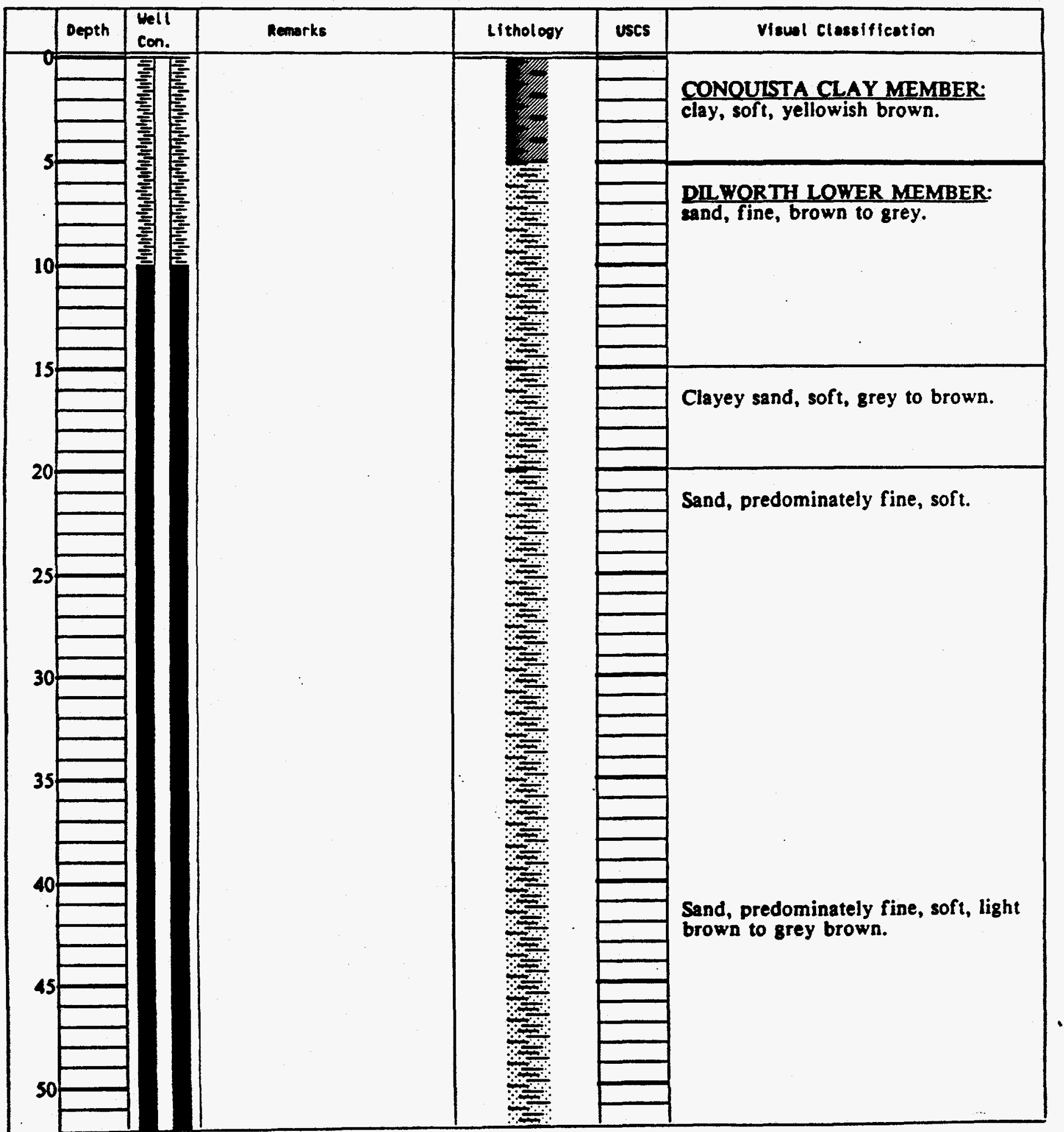

GeOMDUATER

i

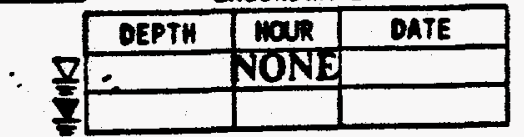




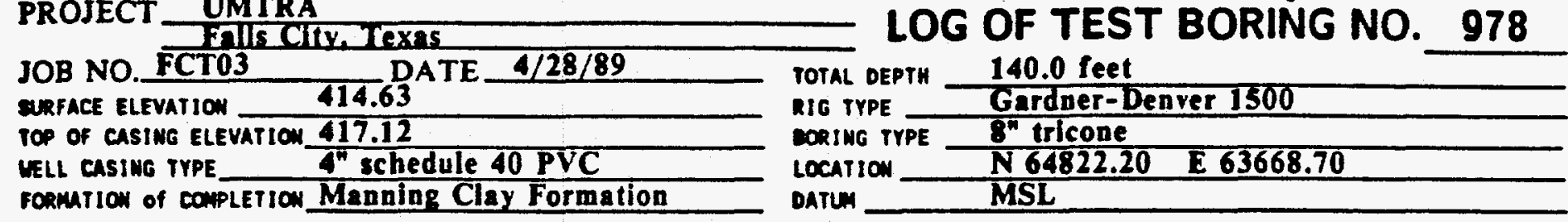

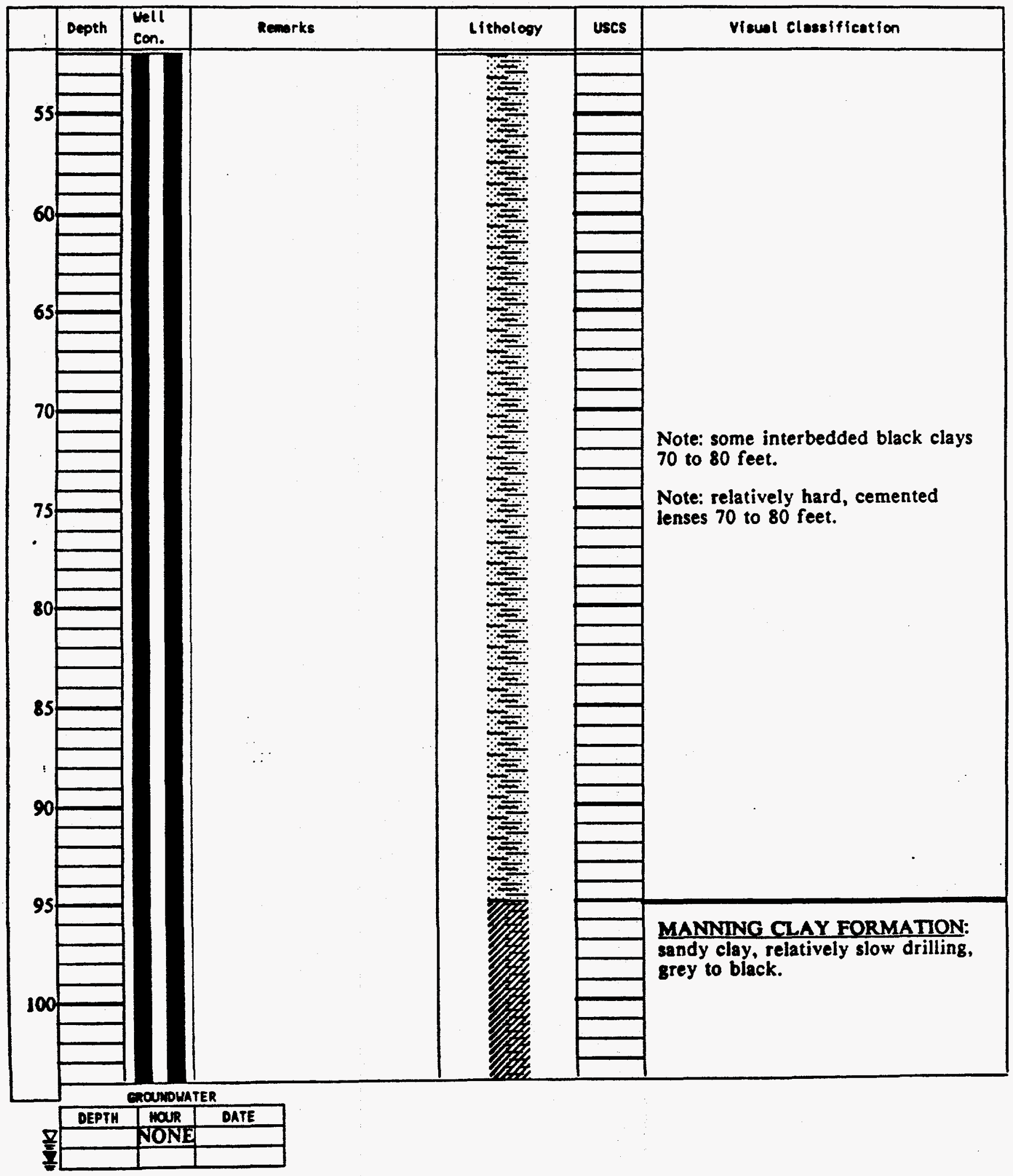




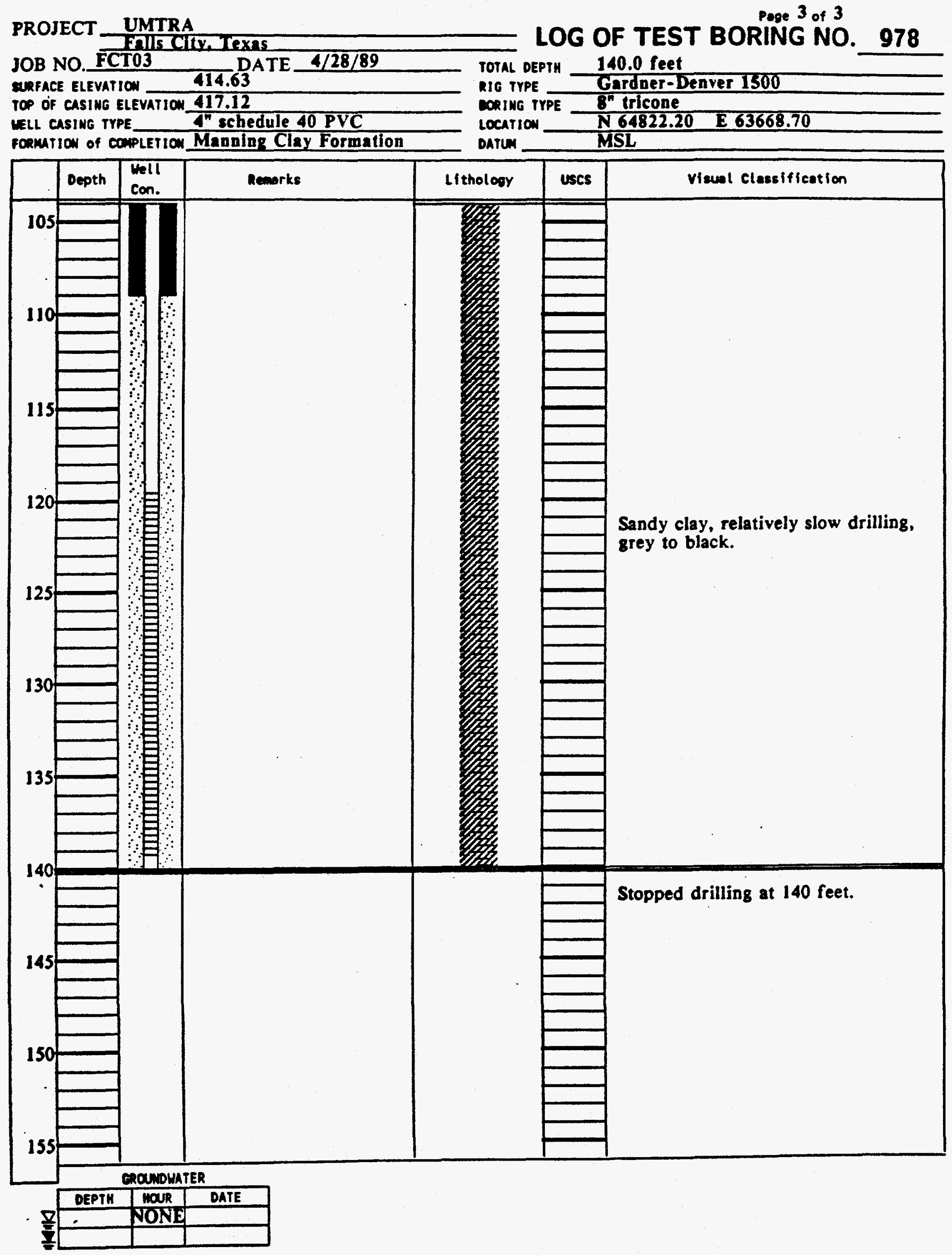


JOB NO. FCTO3

ERFACE ELEVATION 418.40

DATE $4 / 18 / 89$

TOP OF CASIMG ELEVATION $\mathbf{4 2 0 . 8 1}$

WELL CASING TYPE

roamuriow of completiow Dilworth Sand Whitsett Formationarum

LOG OF TEST BORING NO. 979

TOTAL DEPTH 102.0 feet

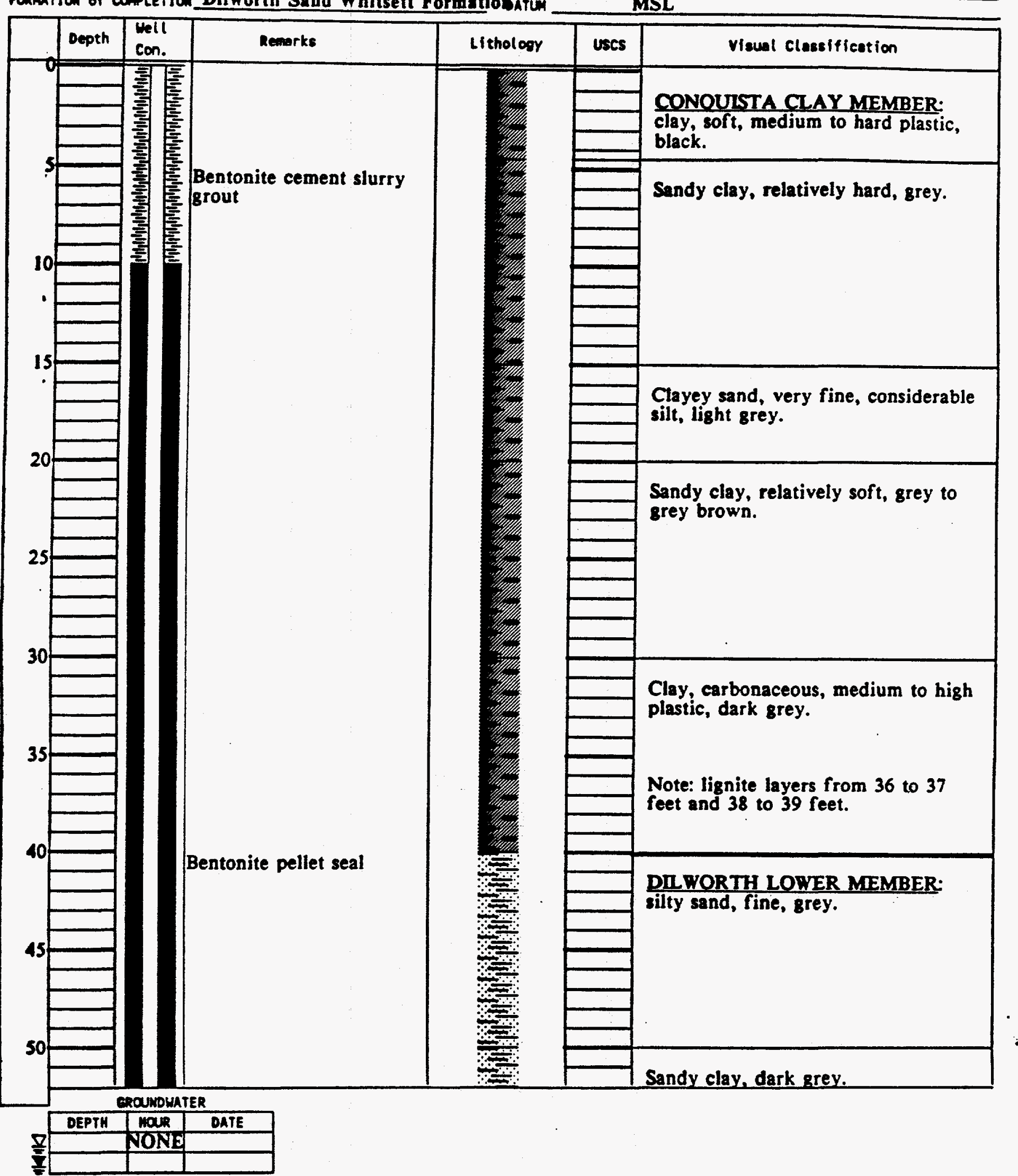


PROJECT UMTRA

Page 2 of 2

JOB NO. FCT03

ERFACE ELEVATION

418.40

DATE $4 / 18 / 89$

LOG OF TEST BORING NO. 979

TOP OF CASING ELEVATION $\mathbf{4 2 0 . 8 1}$

velL casing TrPE. $4^{*}$ schedule 40 PVC

formation of completion Dilworth Sand Whitsett Formationatu

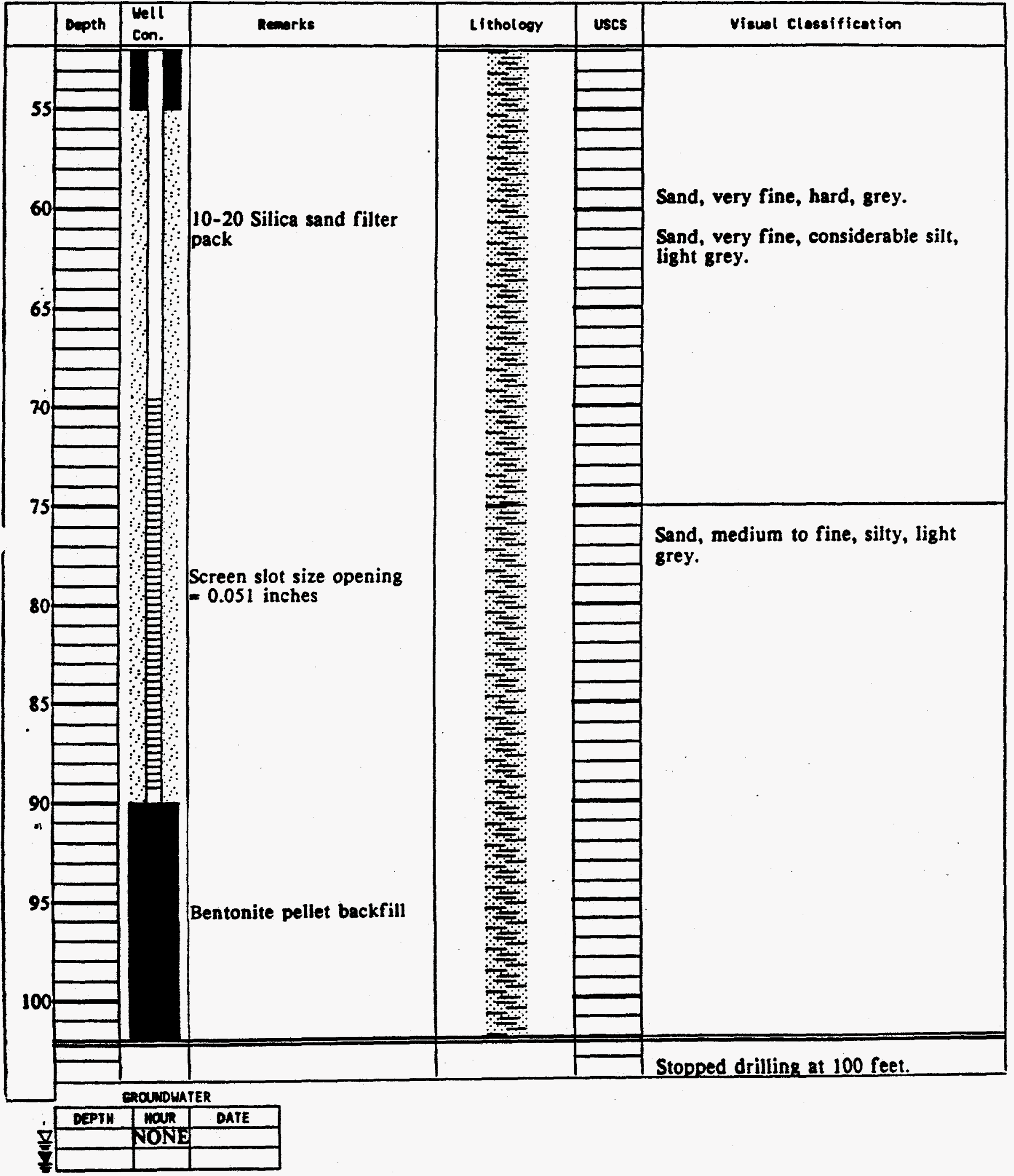


PROJECT $\frac{\text { Falls Ciry Site }}{\text { Texos }}$

JOB NO. FCTO1 DATE

SURFACE ELEVATION

DEPTH OF SEAL

WELL CASING TYPE 4-in D, Sched.40 PVC

COMPLETION

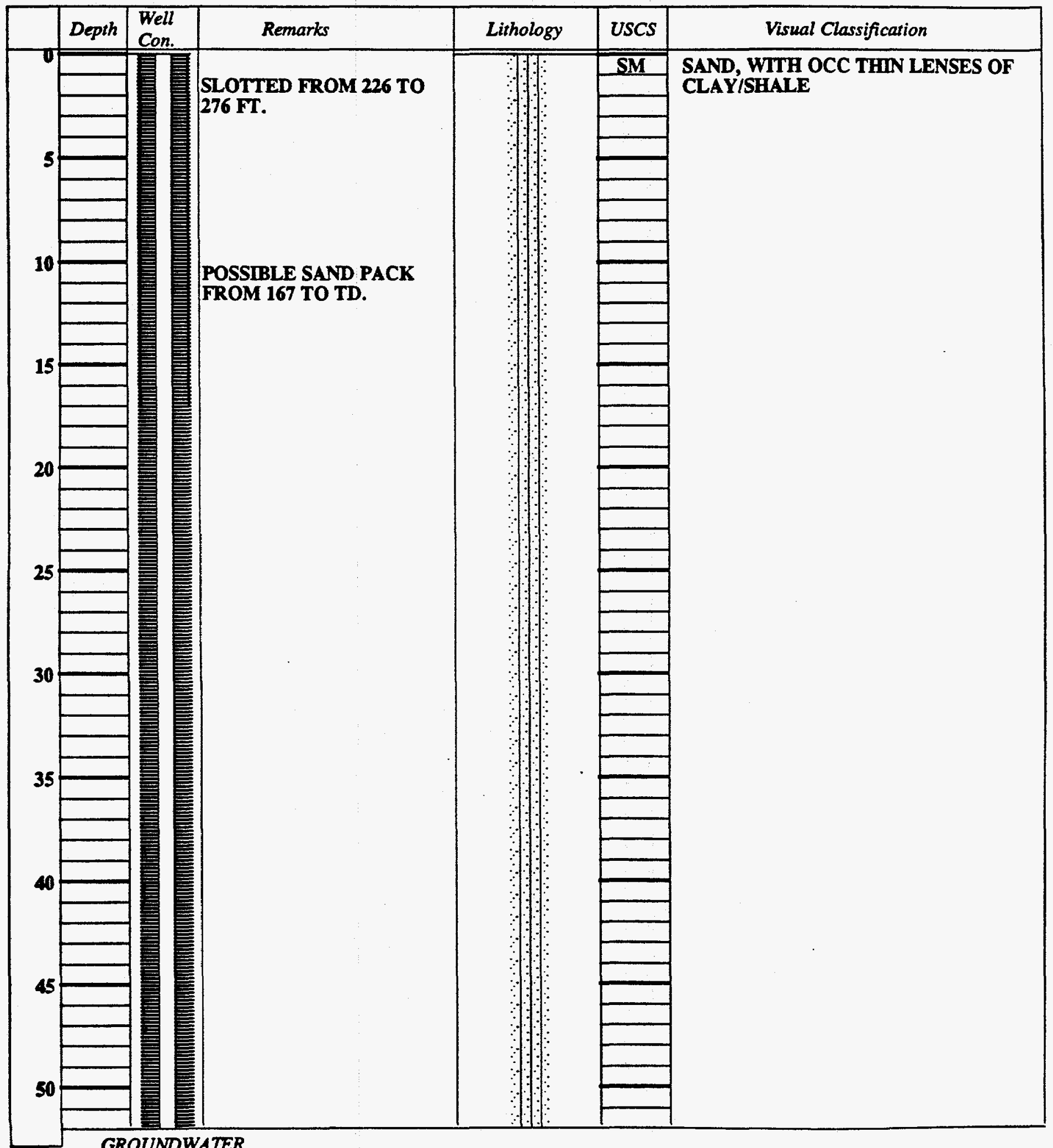

TOTAL DEPTH 284.0 feet

WELL OWNER

BORING TYPE

LOCATION N $E$

$N$ E

E

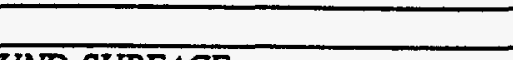

LOG OF WELL BORING NO. 1012 
PROJECT Falls Ciny Site

JOB NO. FCTOI DATE

SURFACE ELEVATION

DEPTH OF SEAL

COMPLETION
WELL CASING TYPE 4-in D, Sched.40 PVC

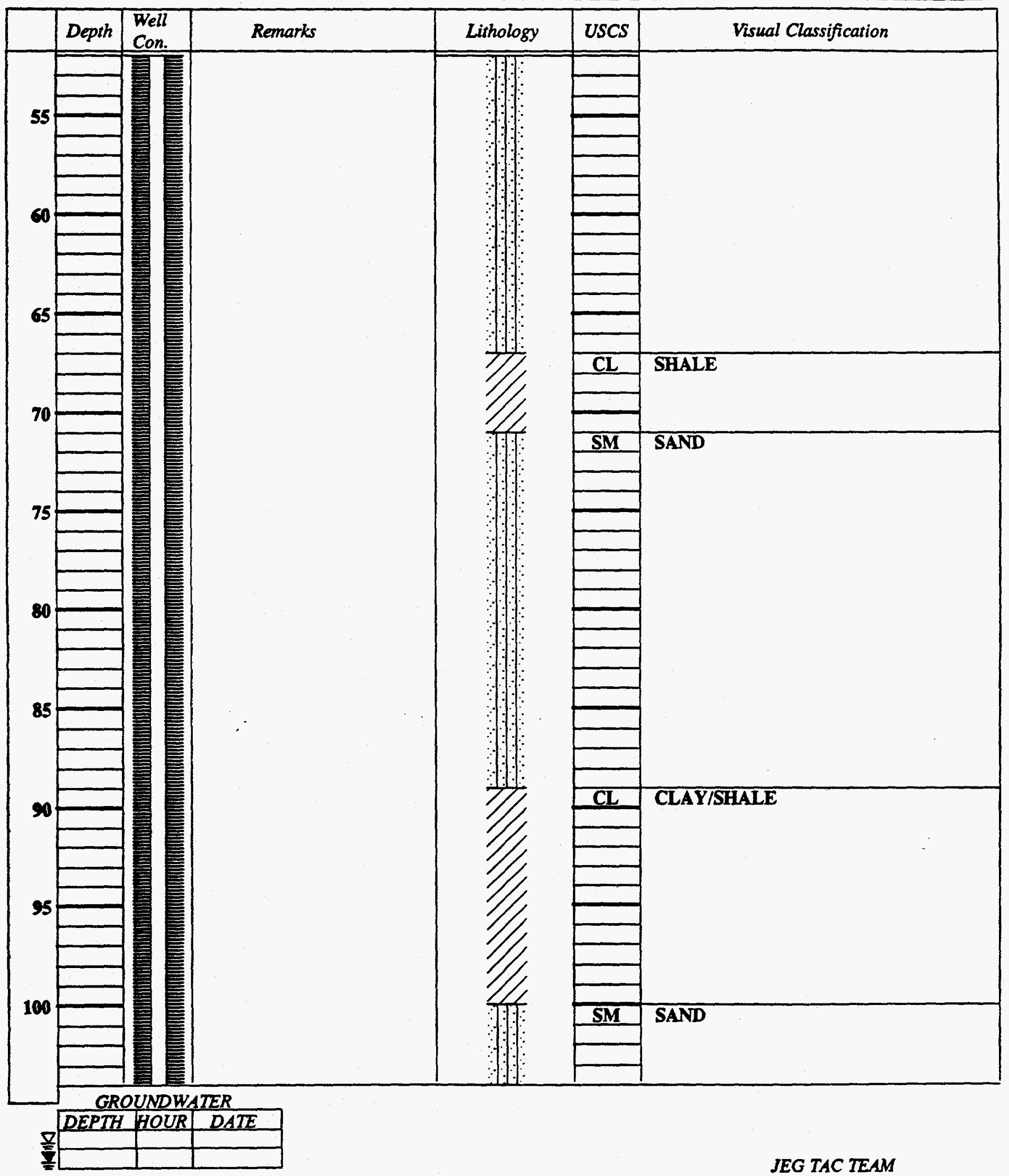

LOG OF WELL BORING NO. 1012

TOTAL DEPTH 284.0 feet

WELL OWNER

BORING TYPE LOCATION $N$

N E

\begin{tabular}{l|l|l} 
ithology & USCS & Visual Classification
\end{tabular}

LOCATION MSL GROUND SURFACE 
PROJECT Falls Cin Site

Page $^{3}$ of 6

JOB NO. FCTO1 DATE

LOG OF WELL BORING NO.

1012

SURFACE ELEVATION

DEPTH OF SEAL

WELL CASING TIPE 4-in D.Sched.40 PVC

COMPLETION

TOTAL DEPTH 284.0 feet

WELL OWNER

COMPLEITON

Well
$\longrightarrow$

BORING TYPE

LOCATION N $E$

DATUM MSL, GROUND SURFACE

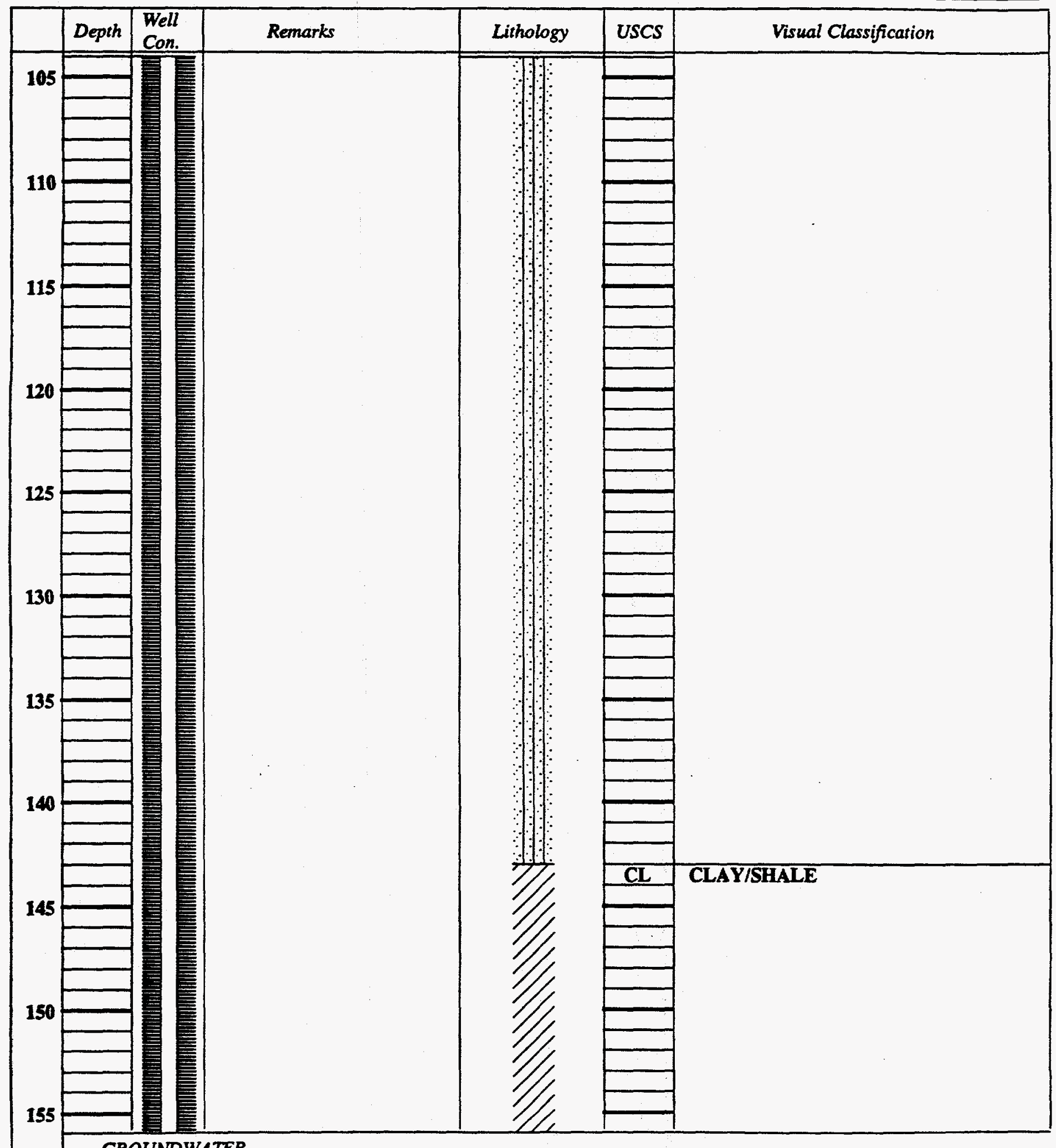

GROUNDWATER

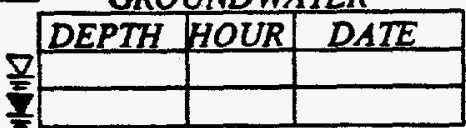


SURFACE ELEVATION

DEPTH OF SEAL

WELL CASING TIRE 4-in D. Sched.40 PVC

COMPLETION

DATE

TOTAL DEPTH 284.0 feet

WELL OWNER

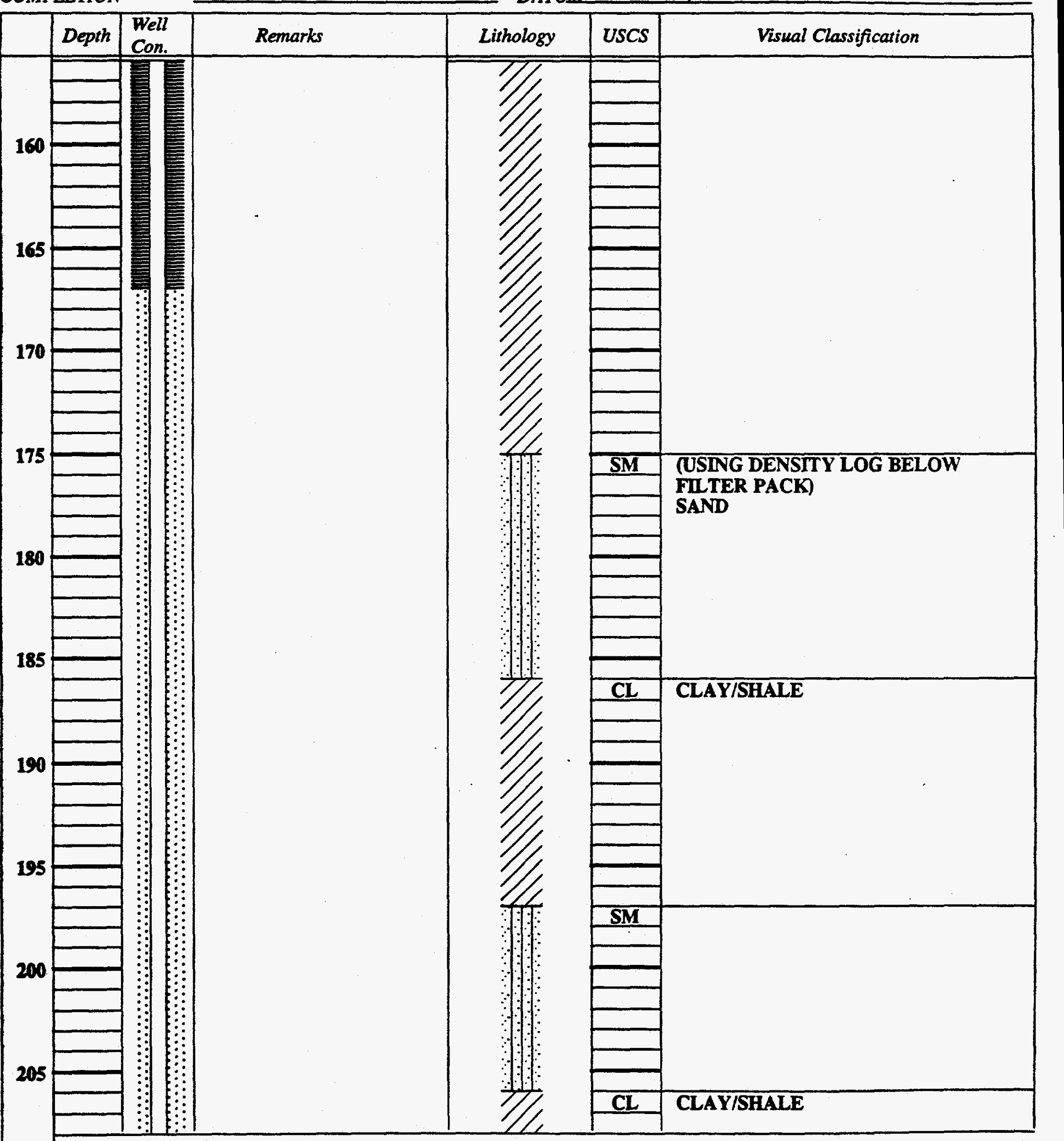

GROUNDWATER

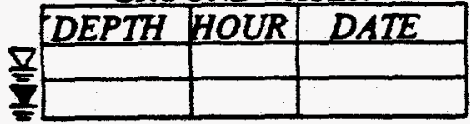


PROJECT Falls City Site

JOB NO. FCTOL DATE

SURFACE ELEVATION

DEPTH OF SEAL

WELL CASING IIPE 4-in D. Sched.40 PVC

COMPLETION
Page 5 of 6

LOG OF WELL BORING NO. 1012

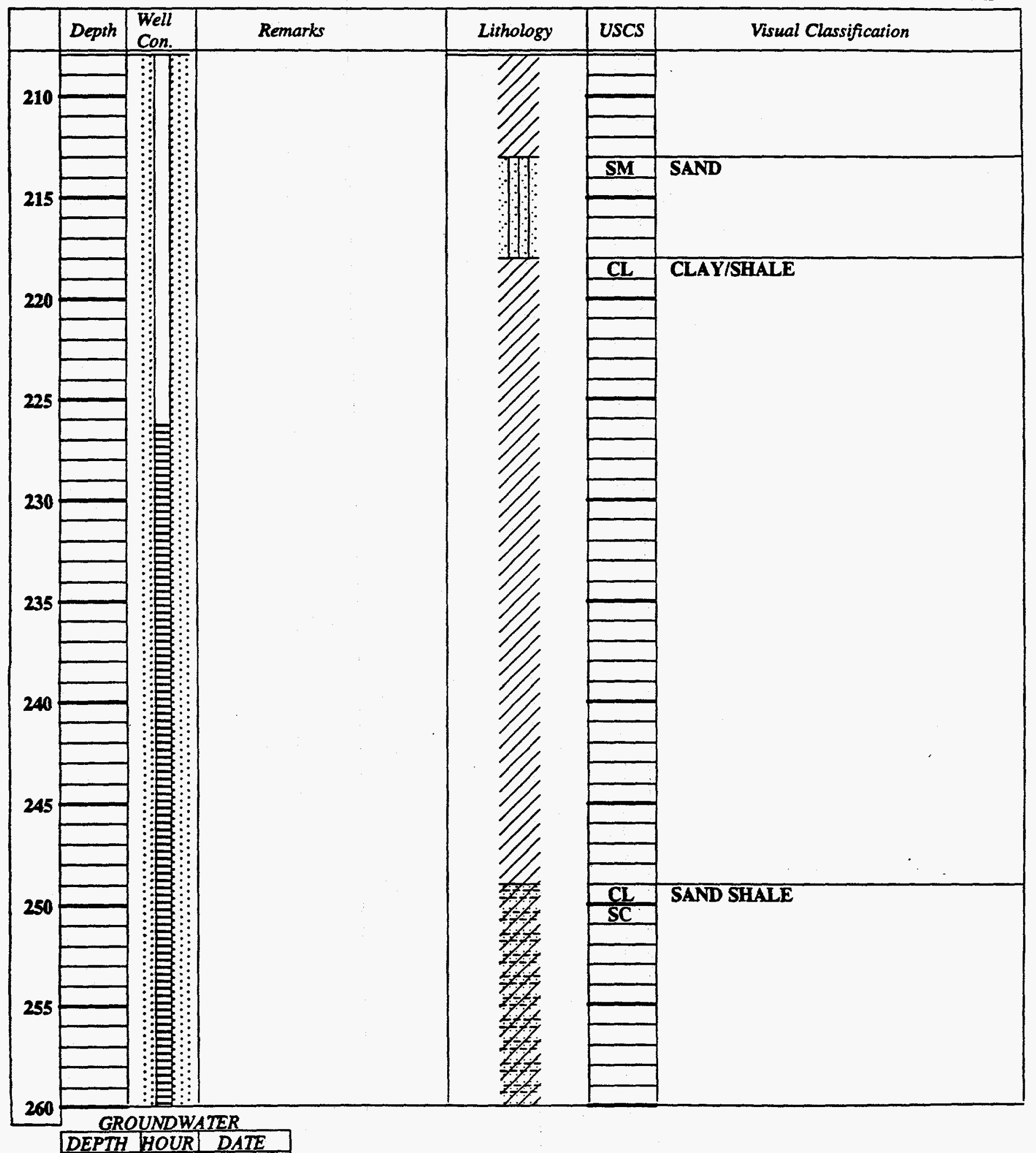


JOB NO. FCTOI DATE

SURFACE ELEVATION

DEPTH OF SEAL

WELL CASING TIPE 4-in ID.Sched.40 PVC

COMPLETION
LOG OF WELL BORING NO

1012

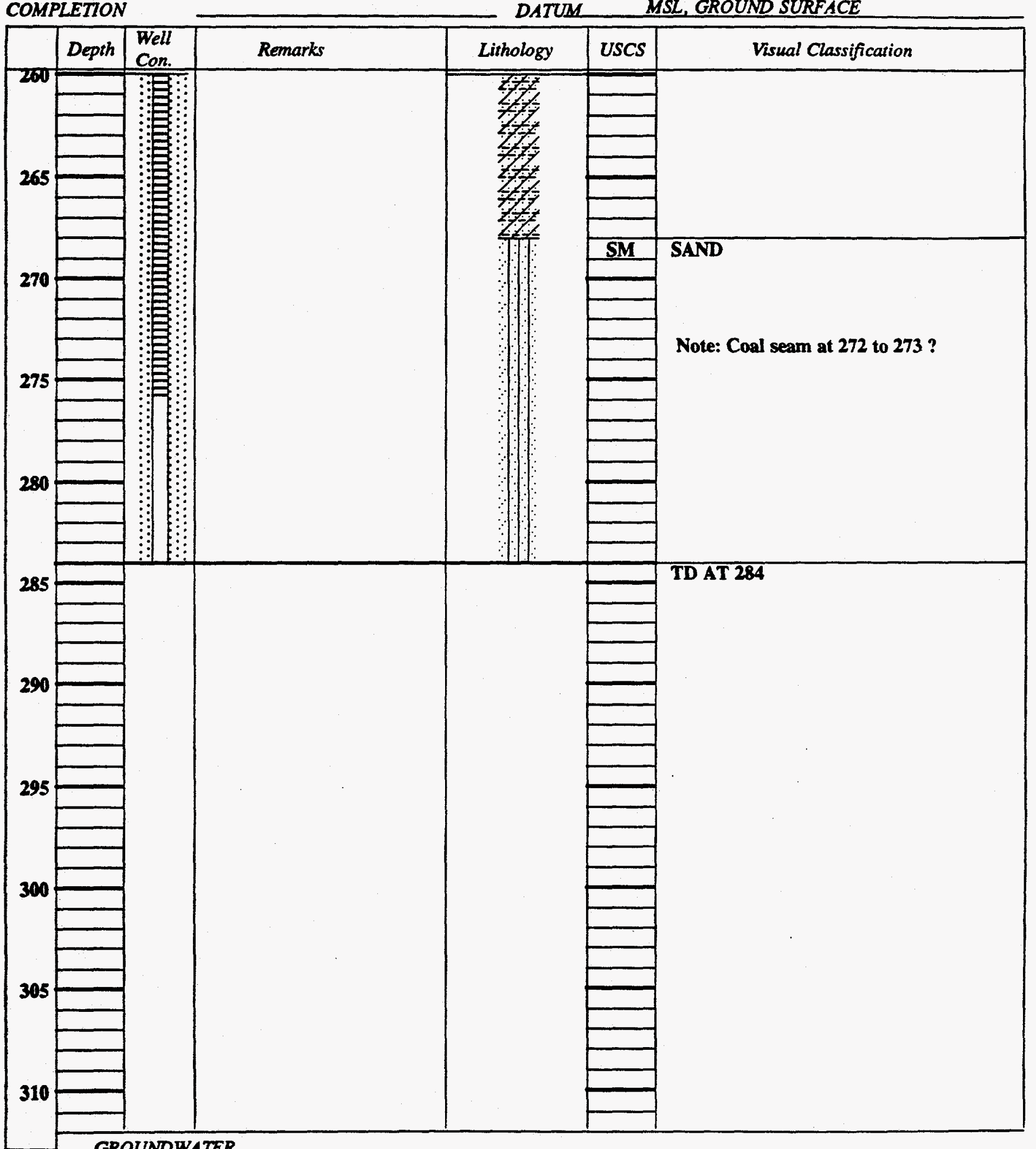

GROUNDWATER

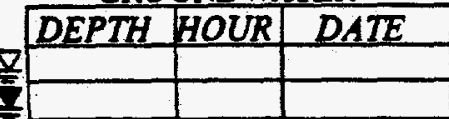


PROJECT Falls City Site

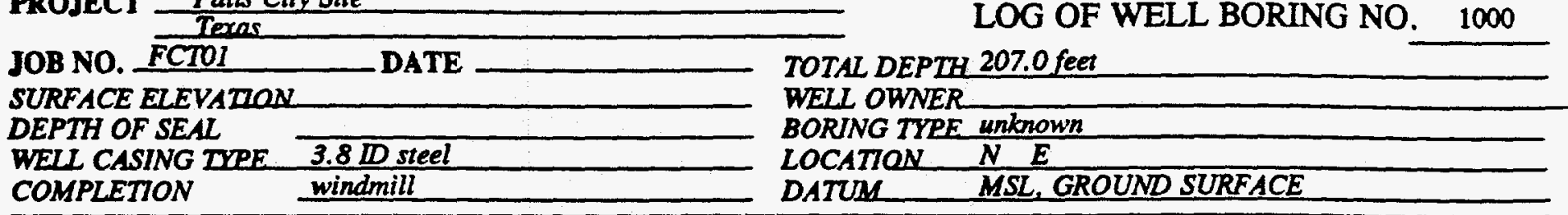

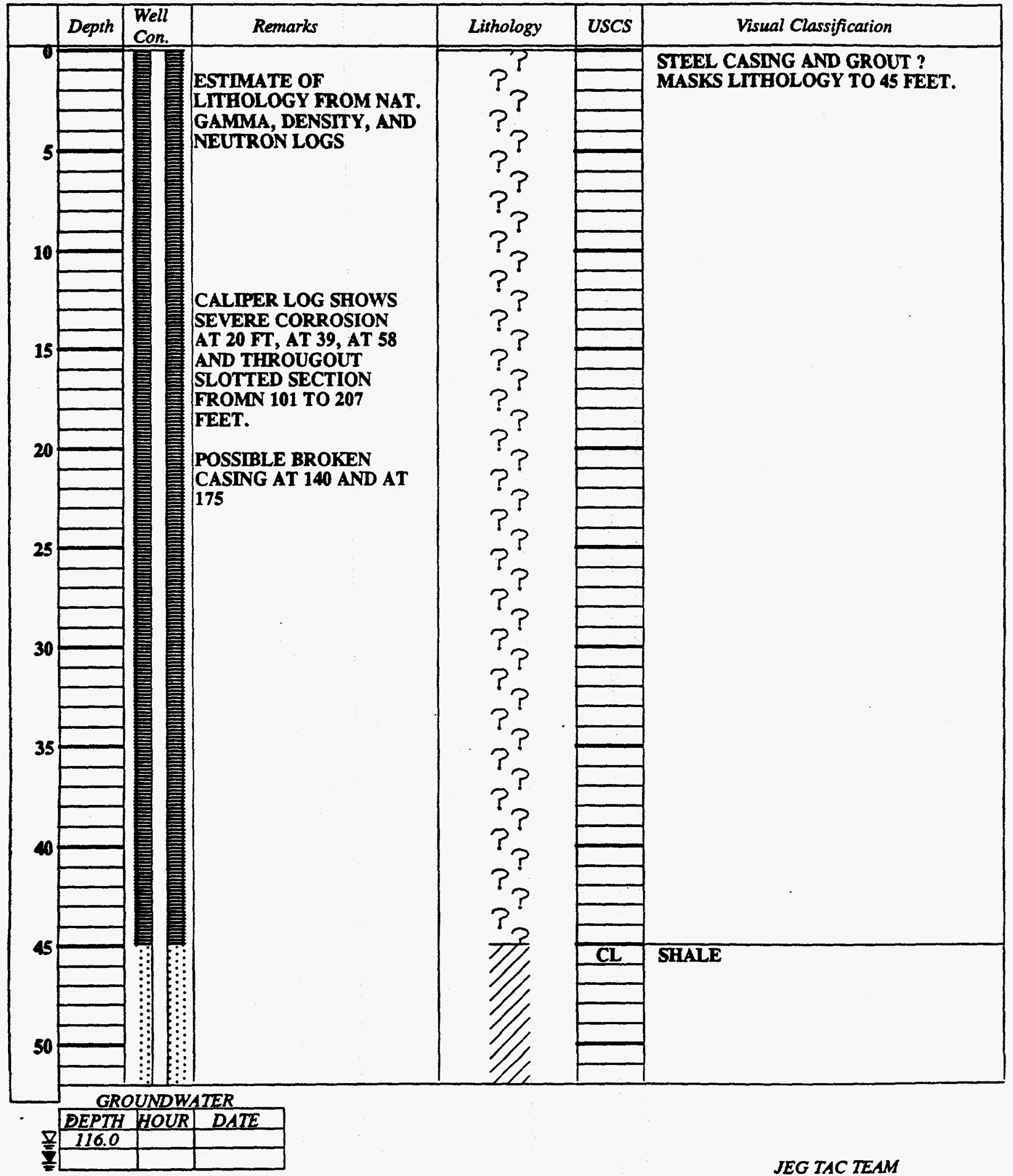


PROJECT Falls City Site

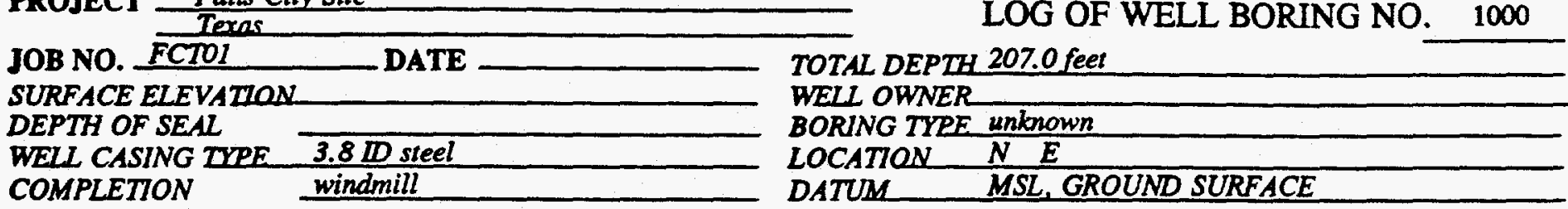

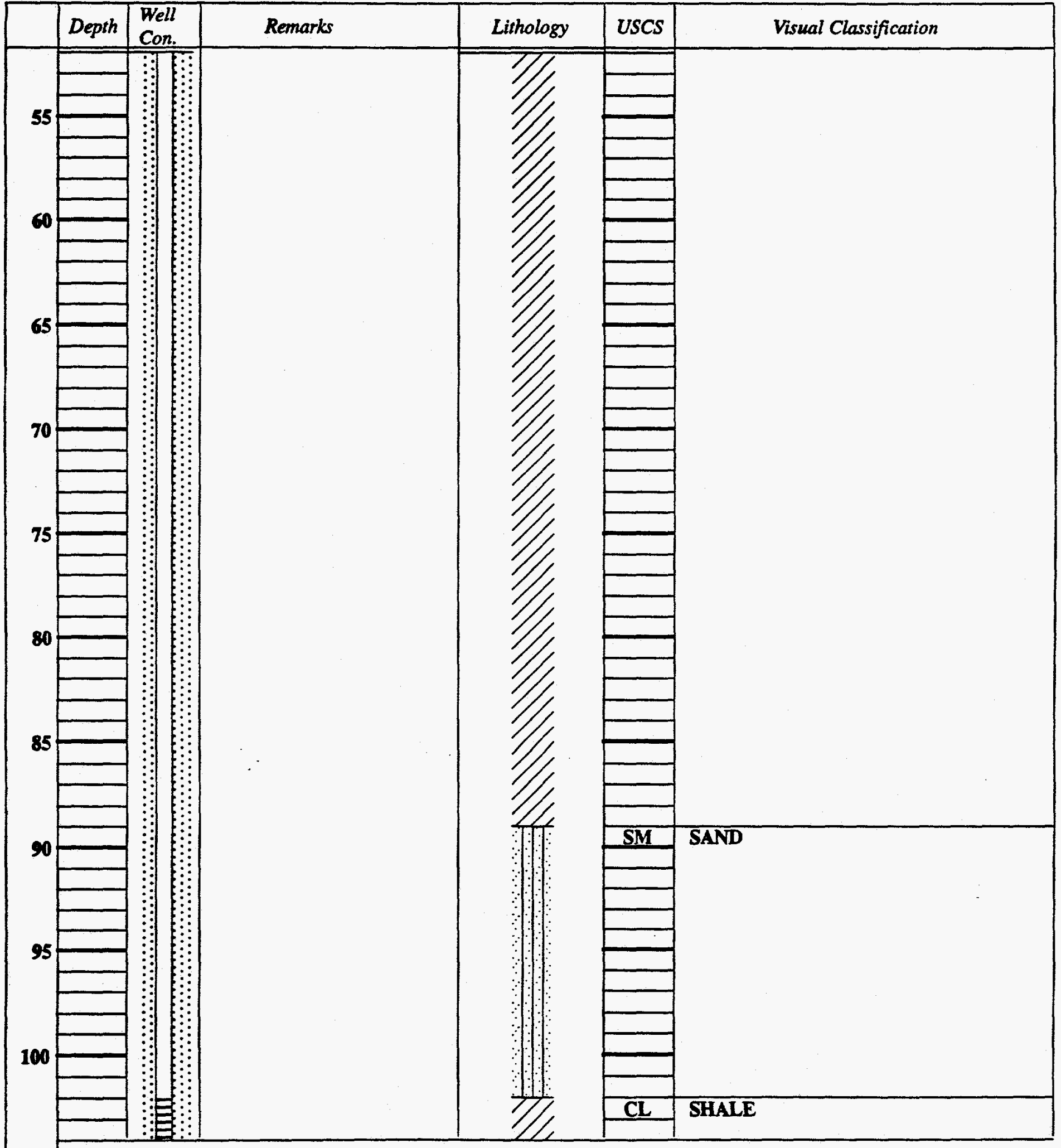

GROUNDWATER

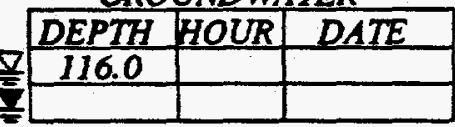


PROJECT Falls City Site

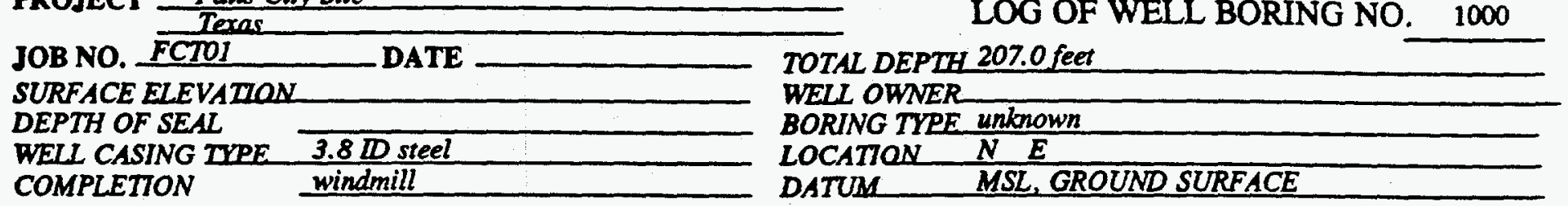

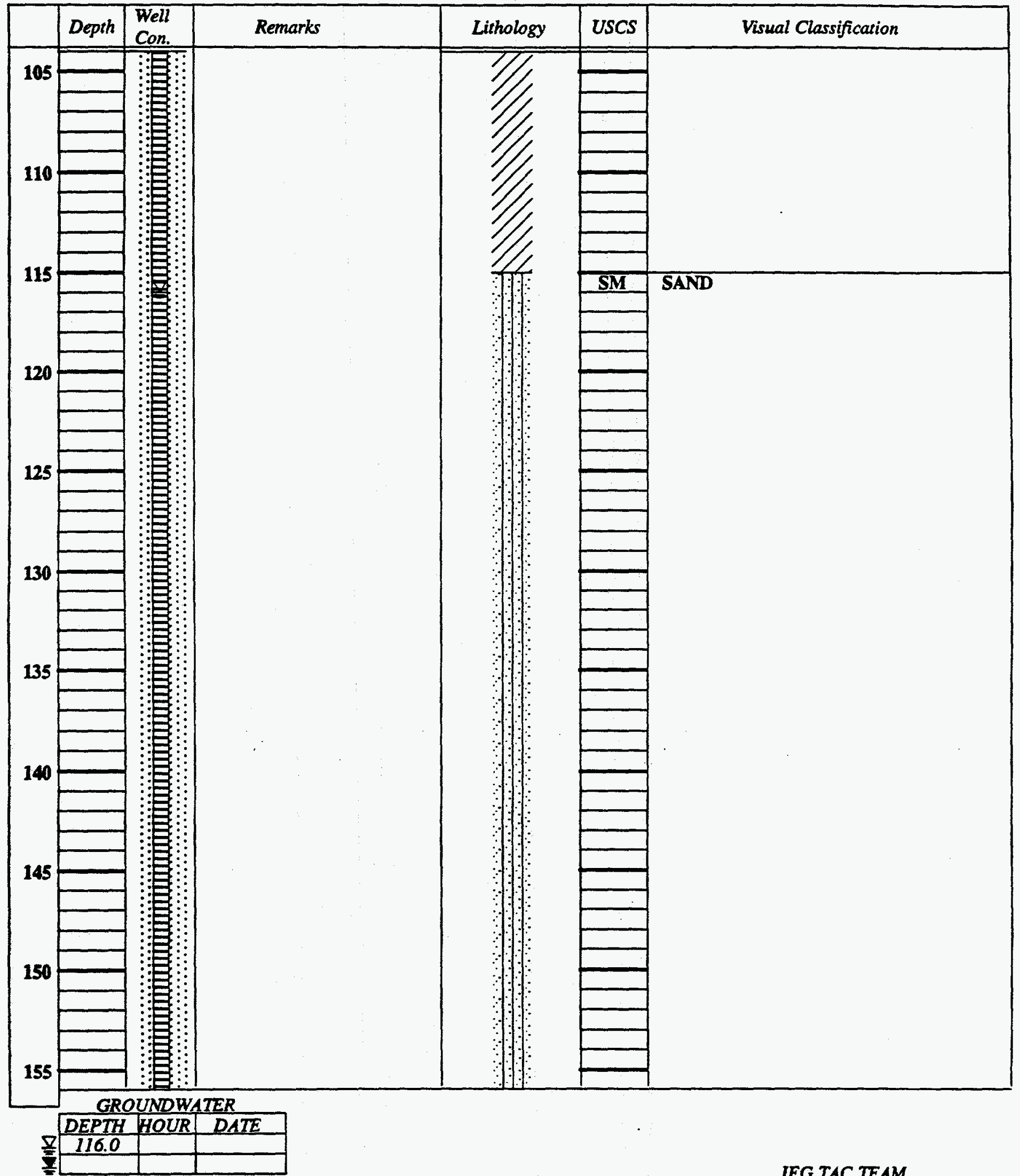


PROJECT Falls Ciry Site

JOB NO. FCTO1 DATE

LOG OF WELL BORING NO. 1000

SURFACE ELEVATION

DEPTH OF SEAL

WELL CASING TYPE $3.8 \mathrm{D}$ steel

COMPLETION windmill

TOTAL DEPTH 207.0 feet

\begin{tabular}{|l|l|l|l|l|l|l|}
\hline Depth & $\begin{array}{l}\text { Well } \\
\text { Con. }\end{array}$ & Remarks & Lithology & USCS & Visual Classification \\
\hline
\end{tabular}

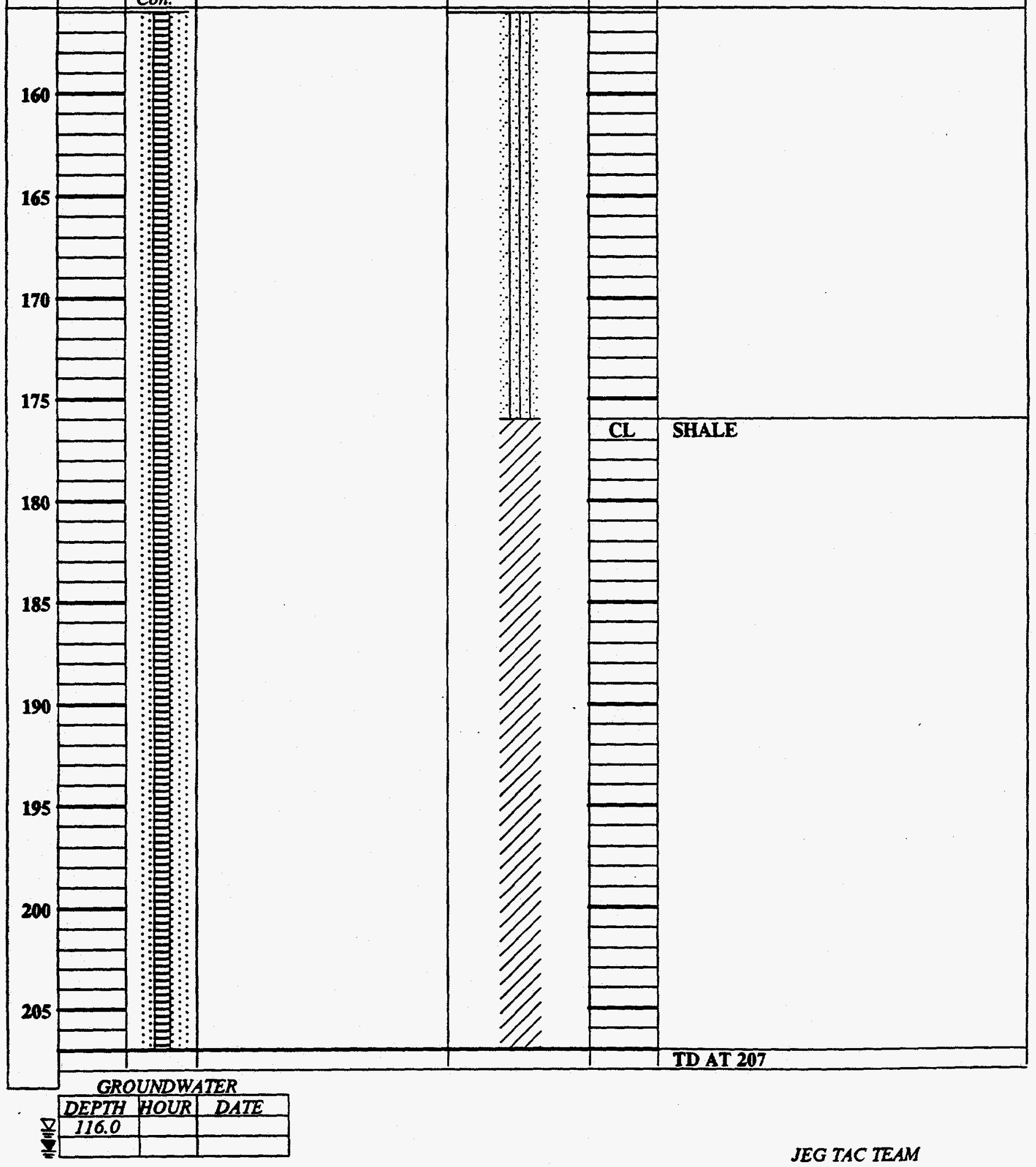


SURFACE ELEVATION

DEPTH OF SEAL

WELL CASING TYRE $3.85 \mathrm{DD}$ steel

COMPLETION windmill

TOTAL DEPTH 435.0 feet

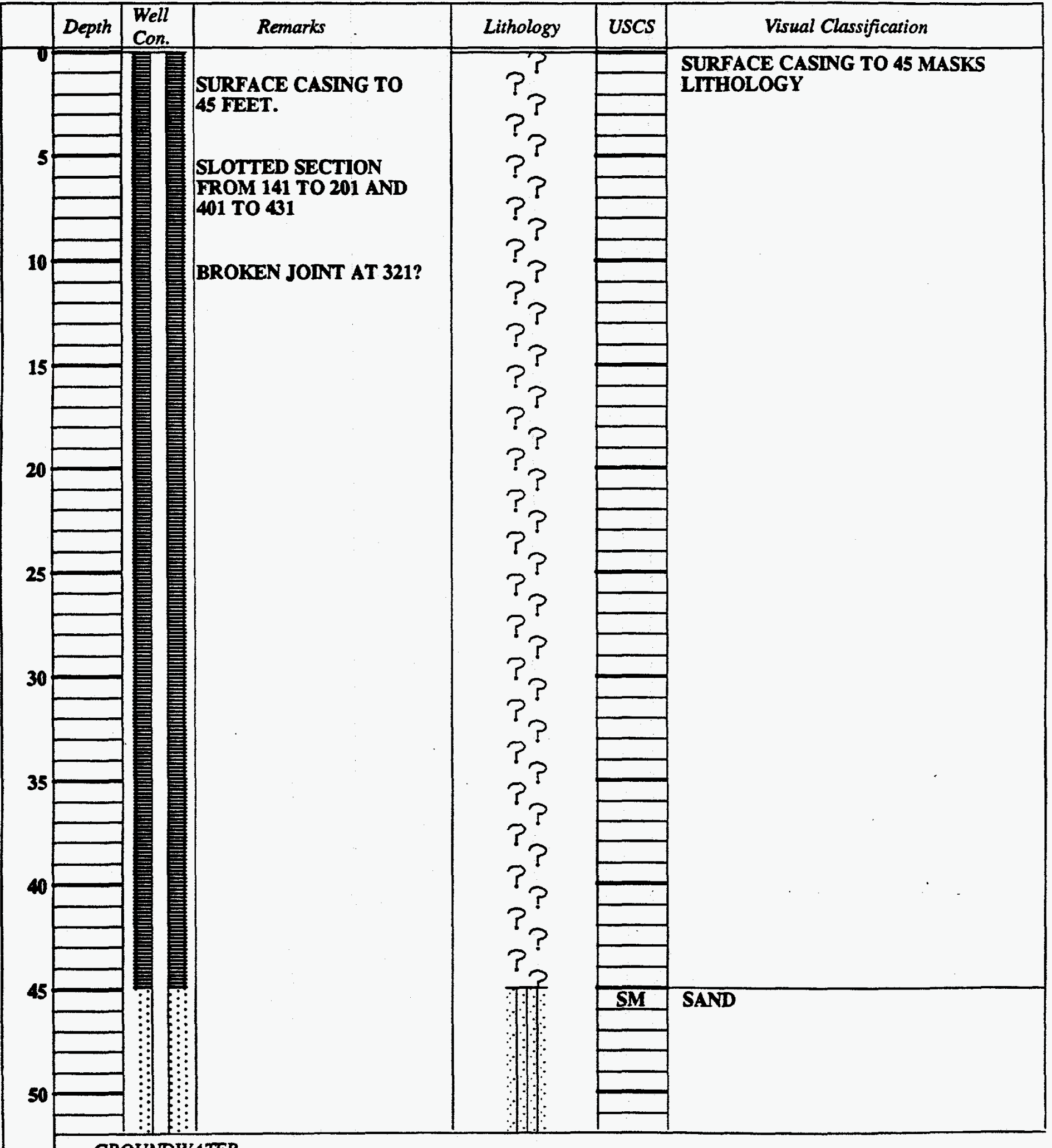

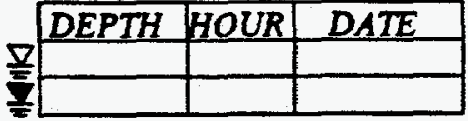


PROJECT Falls City Site

Page $^{2}$ of 9

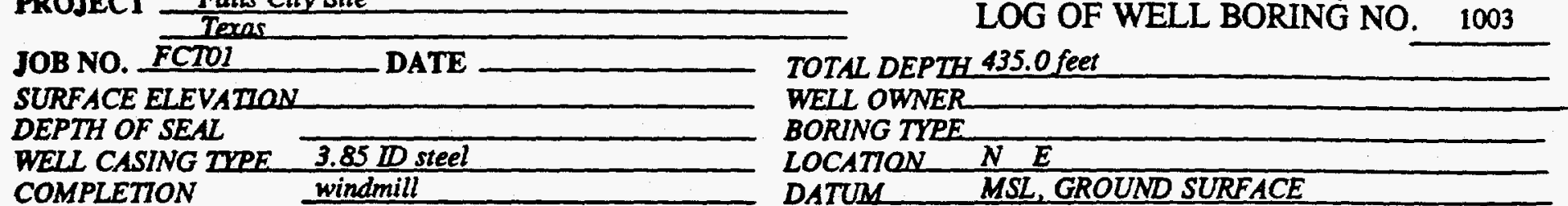

\begin{tabular}{|l|l|l|l|l|l|l|}
\hline & Depth & $\begin{array}{l}\text { Well } \\
\text { Con. }\end{array}$ & Remarks & Lithology & USCS & Visual Classification \\
\hline
\end{tabular}

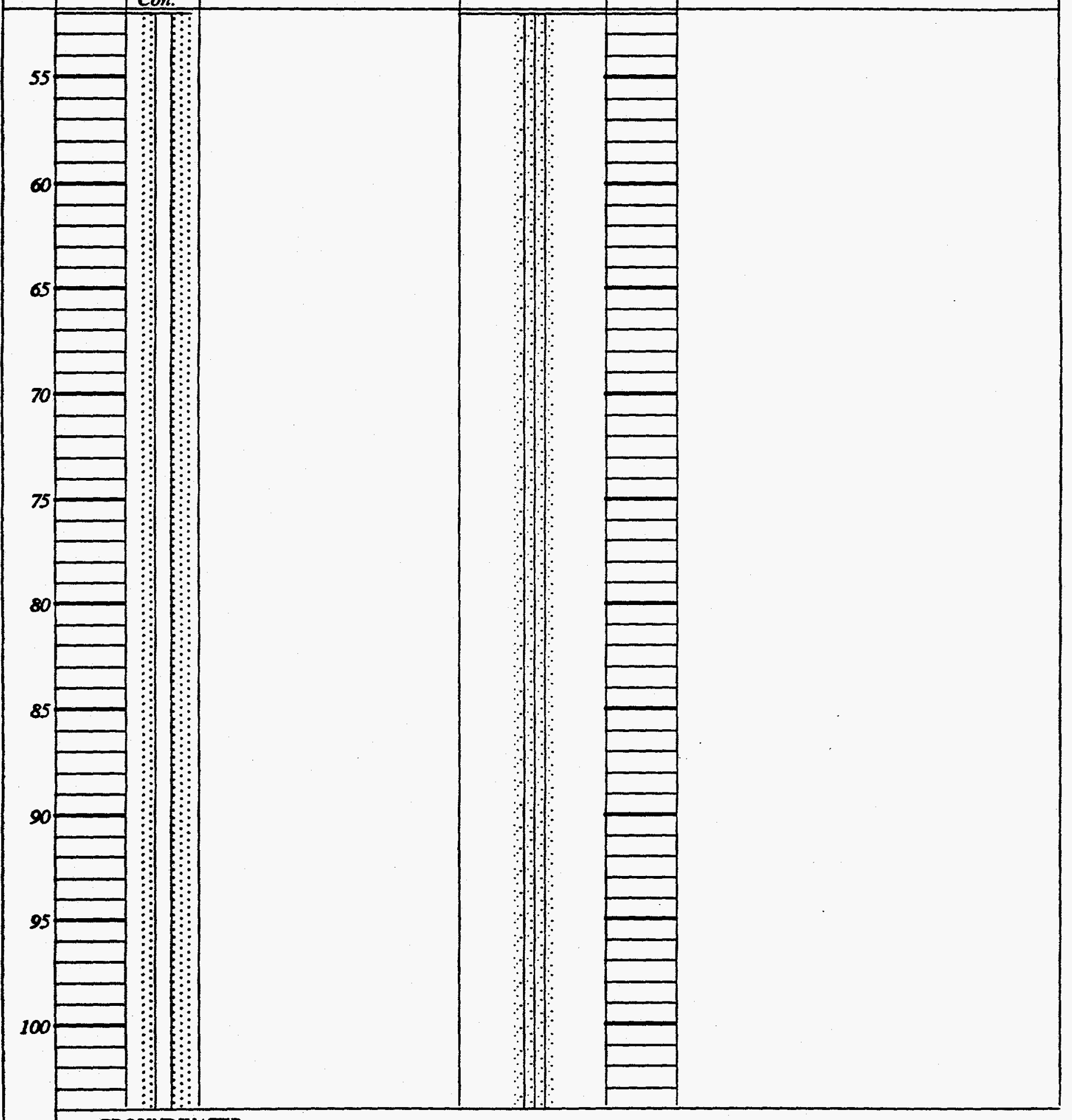

GROUNDWATER

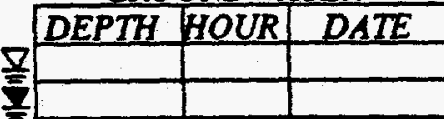


PROJECT Falls Ciry Size

JOB NO. FCTOI DATE

LOG OF WELL BORING NO. 1003

SURFACE ELEVATION

DEPTH OF SEAL

WELL CASING TIRE

$3.85 \mathrm{DD}$ steel

COMPLETTON

TOTAL DEPTH 435.0 feet

\begin{tabular}{|l|l|l|l|l|l|l|}
\hline & Depth & $\begin{array}{l}\text { Well } \\
\text { Con. }\end{array}$ & Remarks & Lithology & USCS & Visual Classification \\
\hline
\end{tabular}

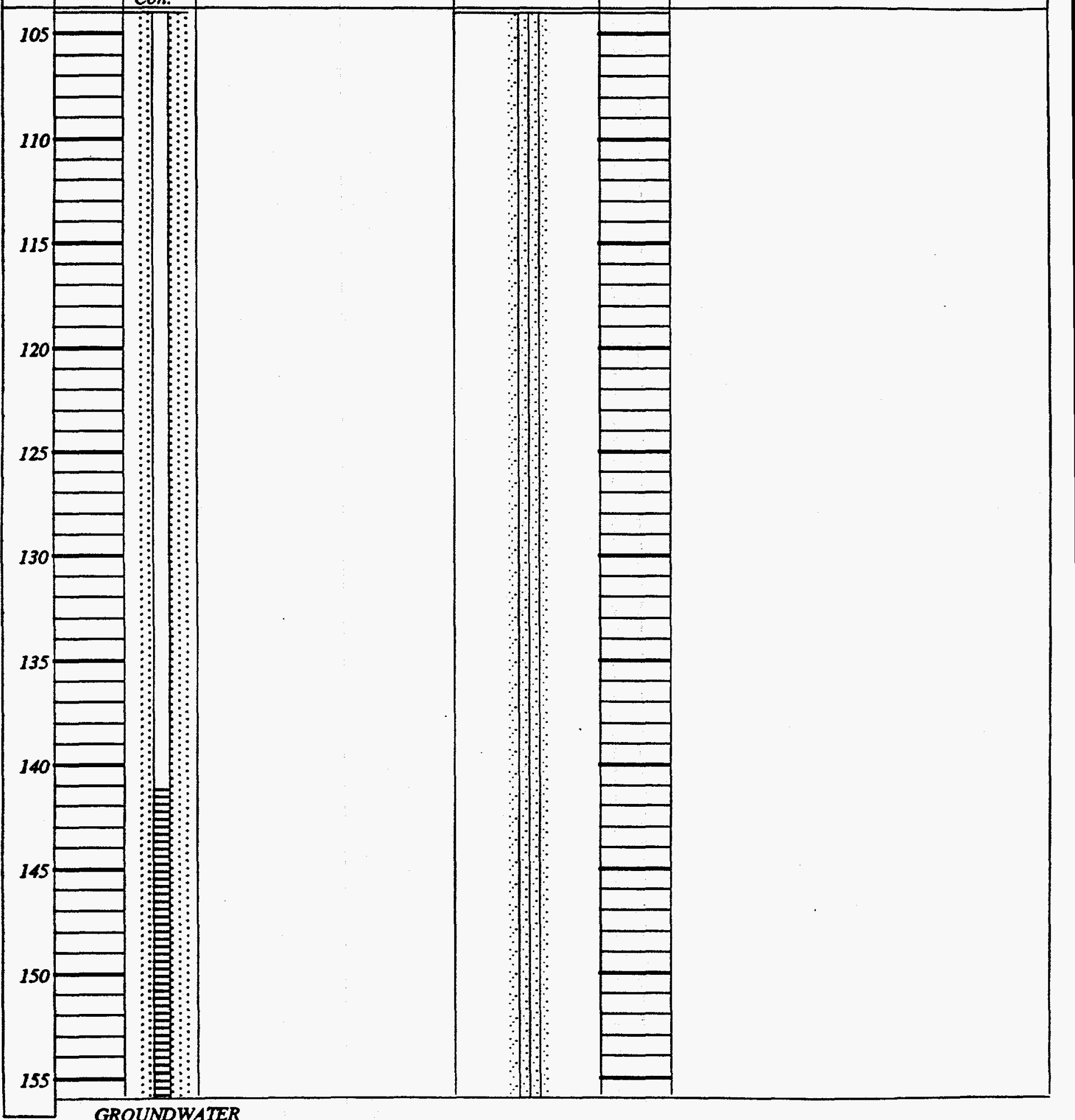

GROUNDWATER

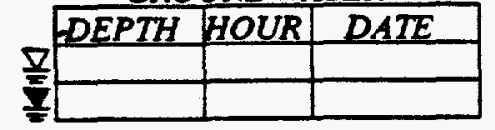


PROJECT Falls City Site

Page 4 of 9

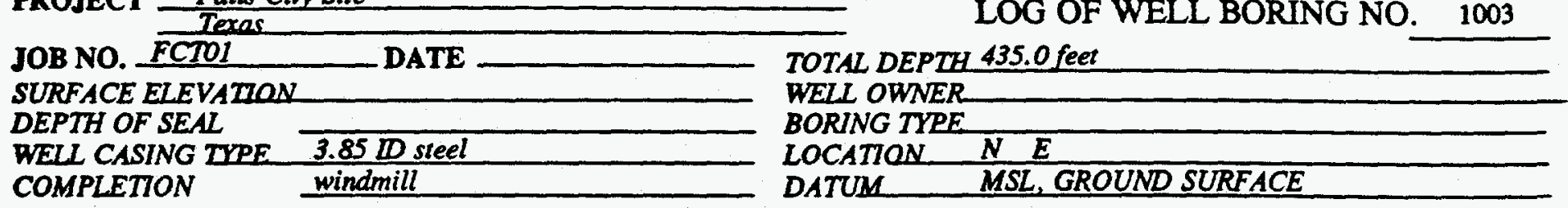

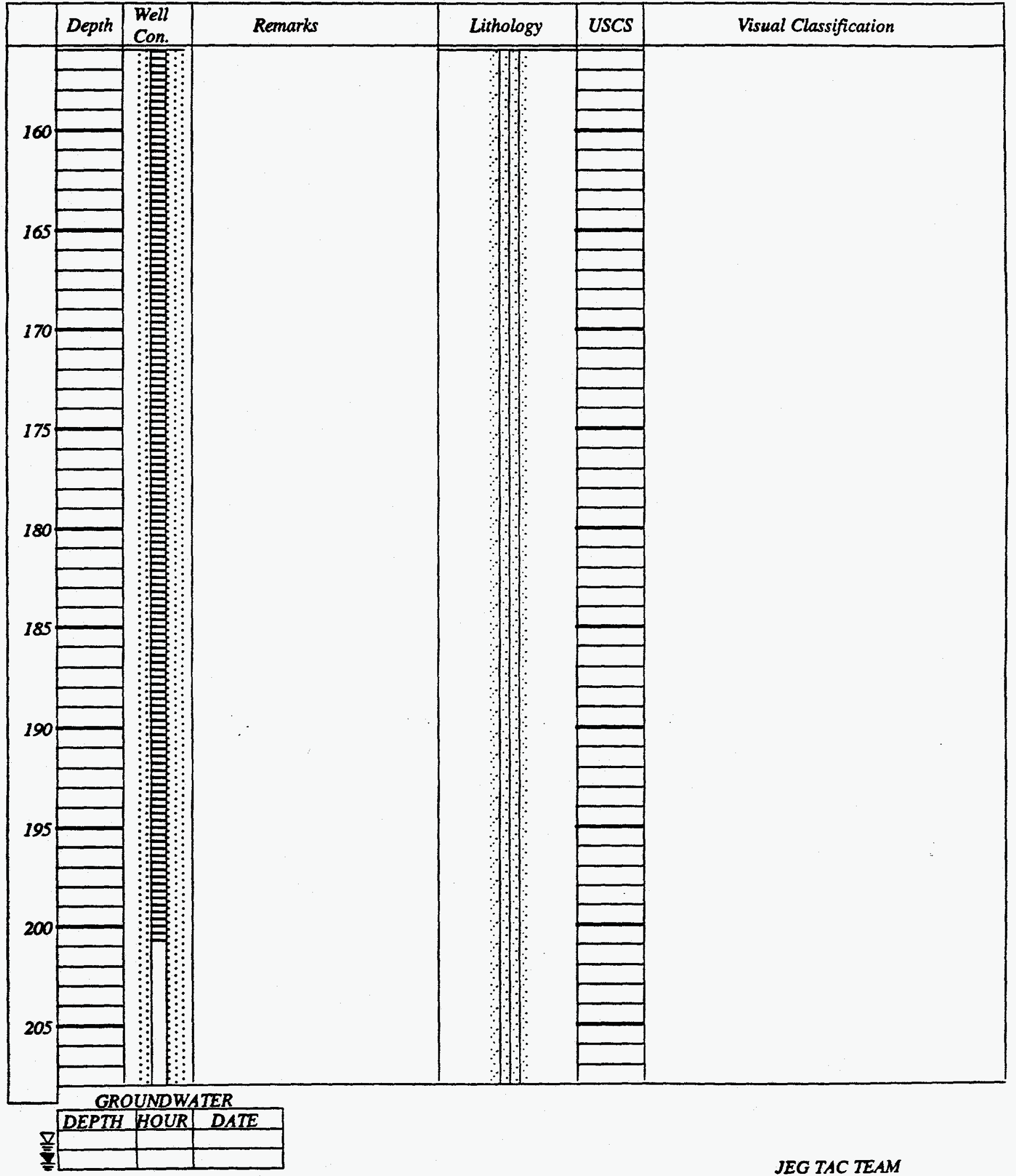


PROJECT Falls City Site

Page 5 of 9

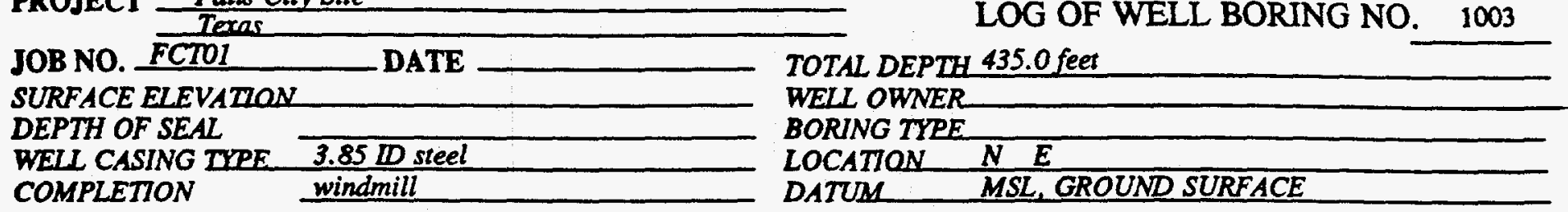

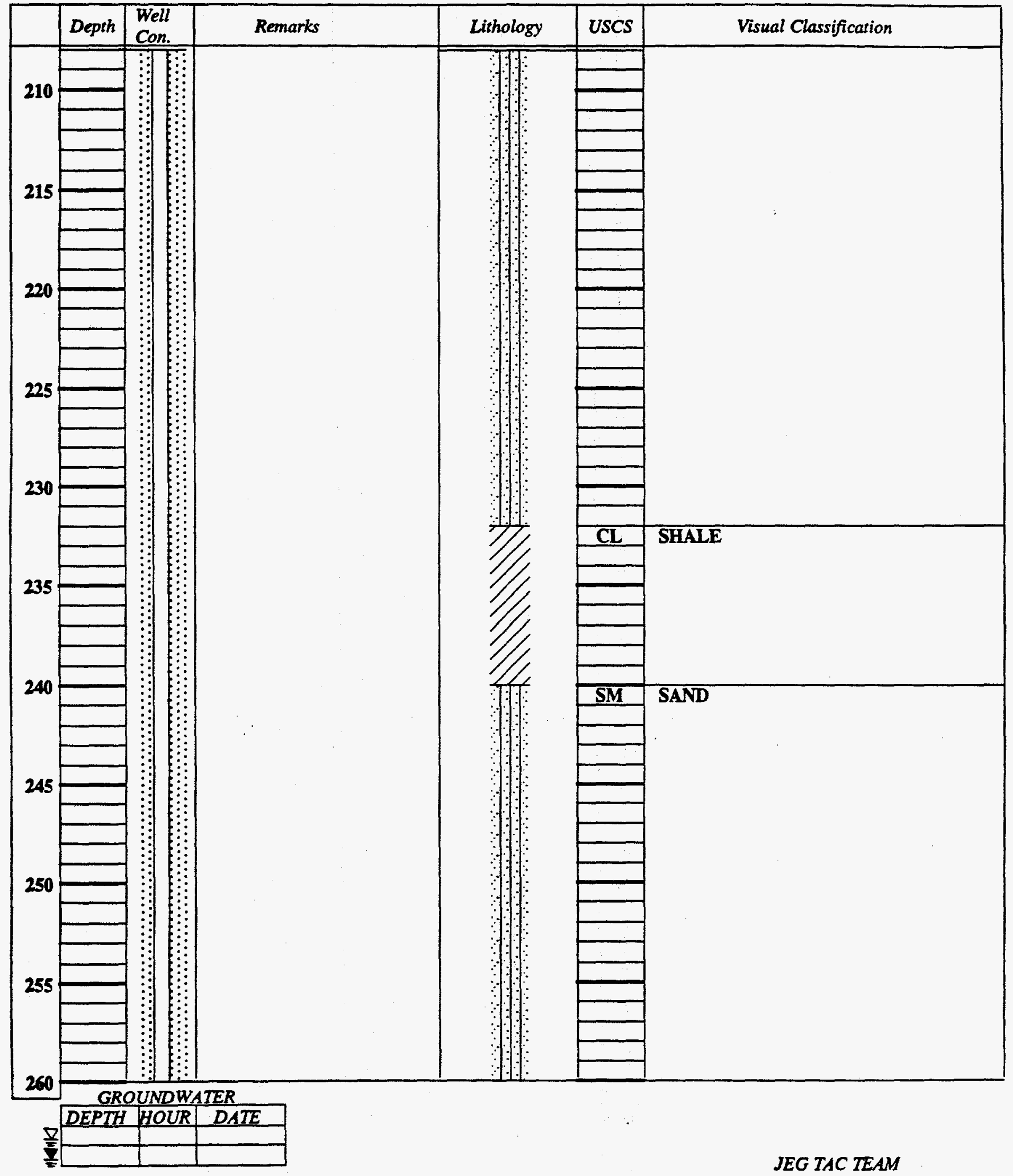


JOB NO. $\frac{\text { Texas }}{\text { FCTO1 DATE }}$

SURFACE ELEVATION

DEPTH OF SEAL

WELL CASING TIRE $3.85 \mathrm{~W}$ steel

COMPLETION windmill

TOTAL DEPTH 435.0 feet

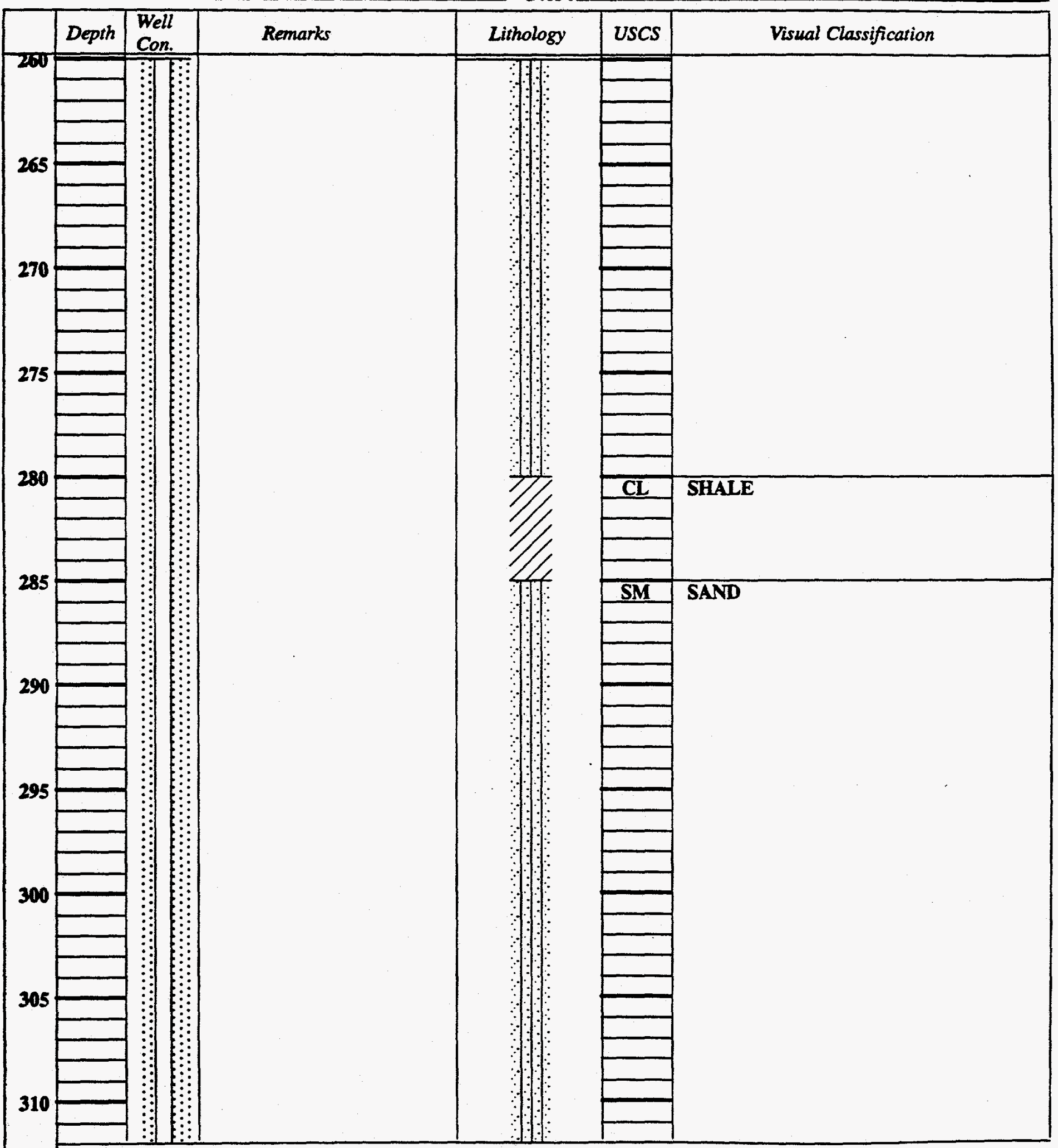

GROUNDWATER

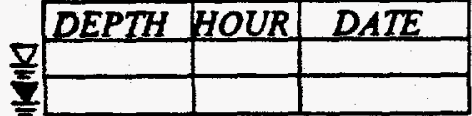


PROJECT Falls City Site

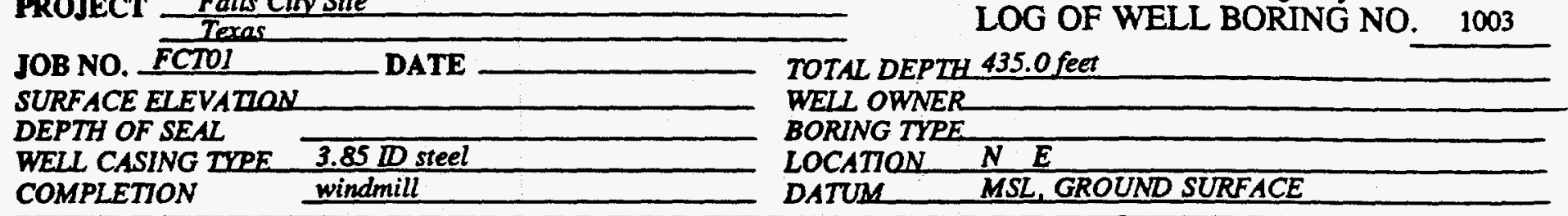

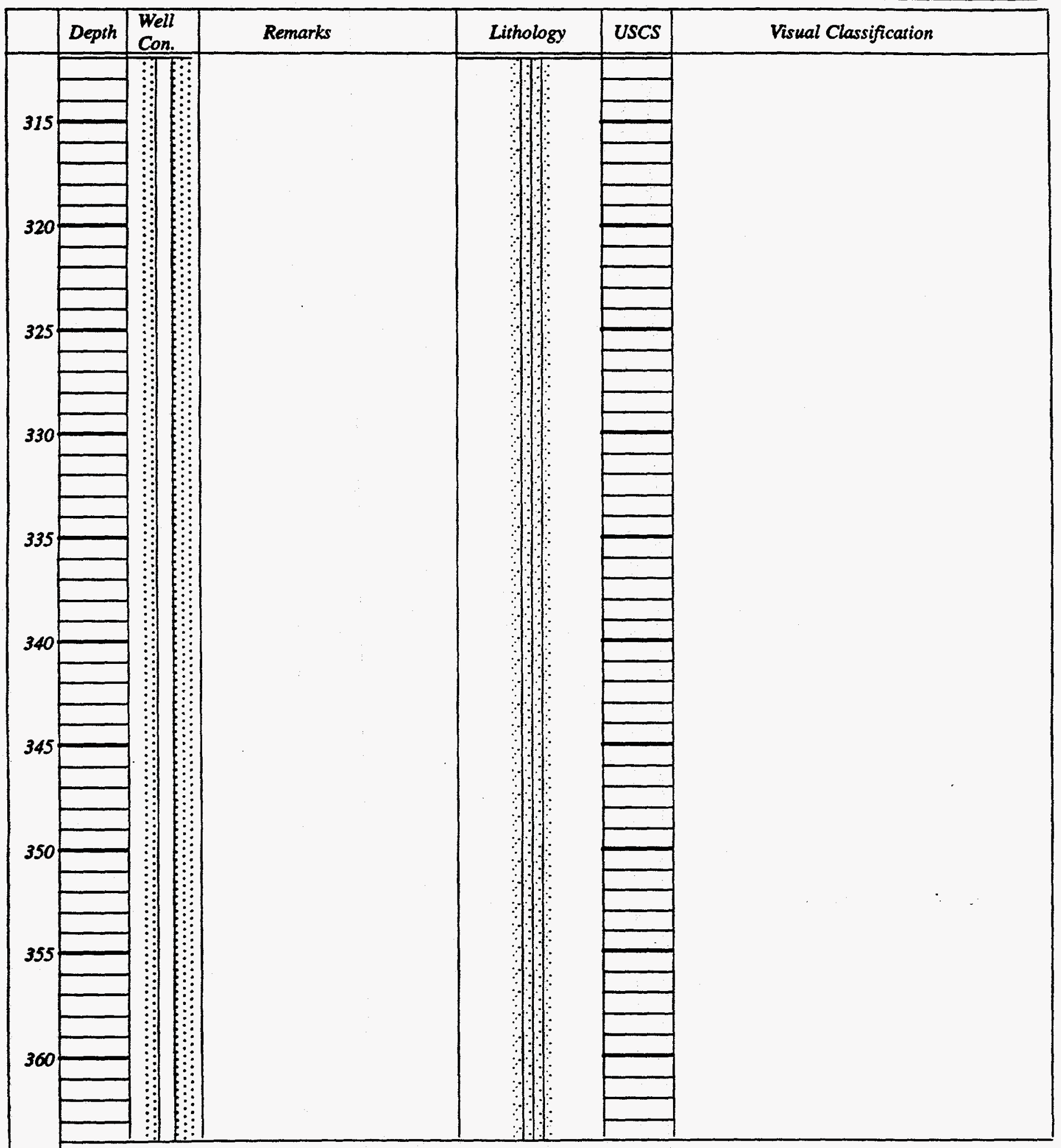

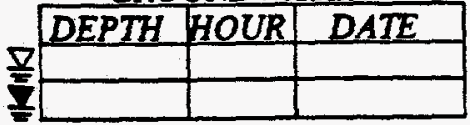




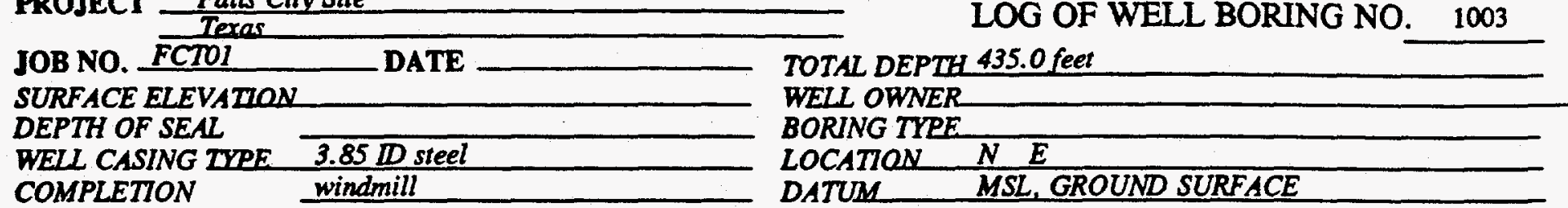

\begin{tabular}{|l|l|l|l|l|l|l|}
\hline Depth & $\begin{array}{l}\text { Well } \\
\text { Con. }\end{array}$ & Remarks & Lithology & USCS & Visual Classification \\
\hline
\end{tabular}

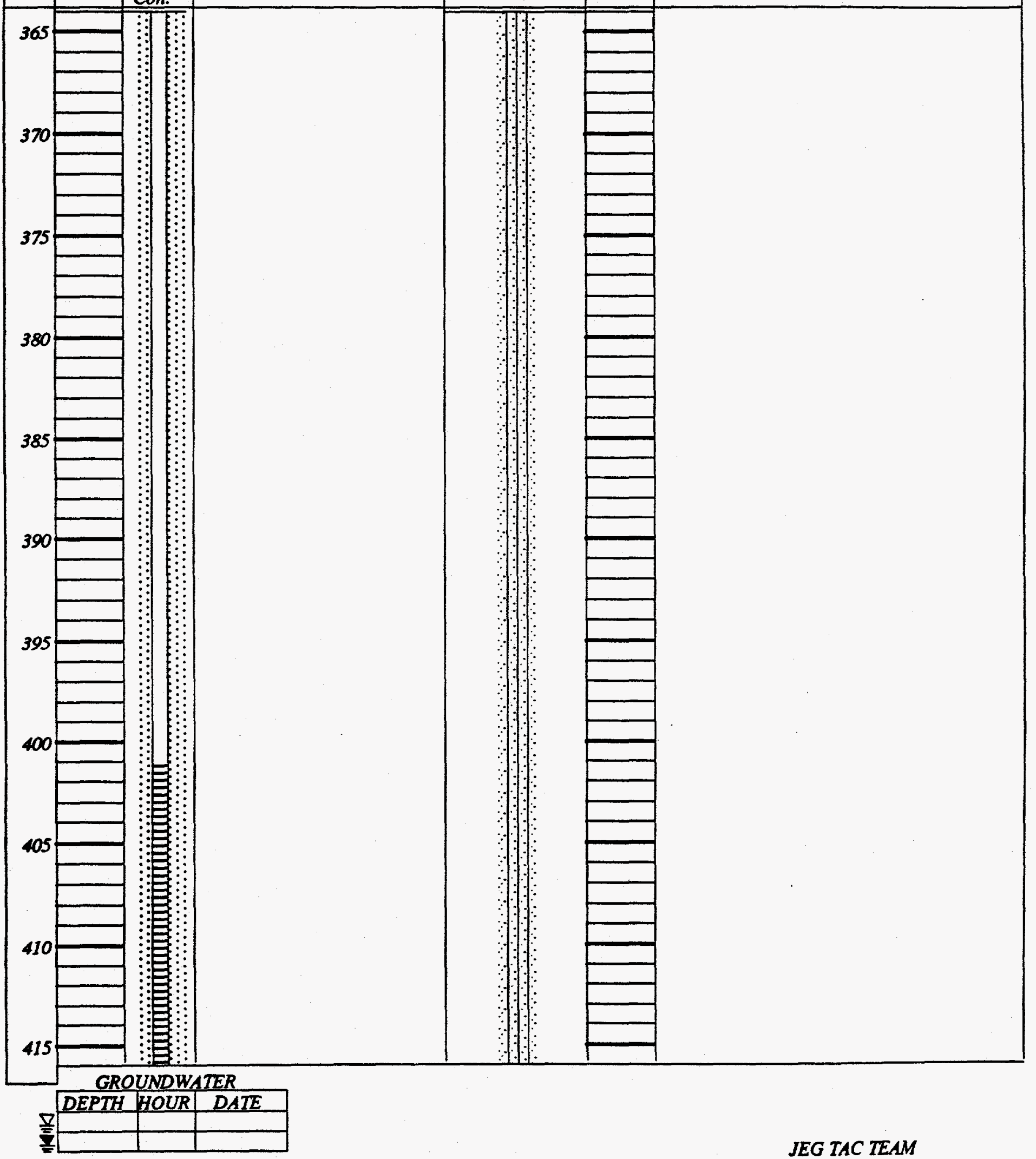


PROJECT Falls Ciny Site

JOB NO. FCTOI DATE

SURFACE ELEVATION

DEPTH OF SEAL

WELL CASING TIPE $3.85 \mathrm{D}$ steel

COMPLETION
LOG OF WELL BORING NO.

1003

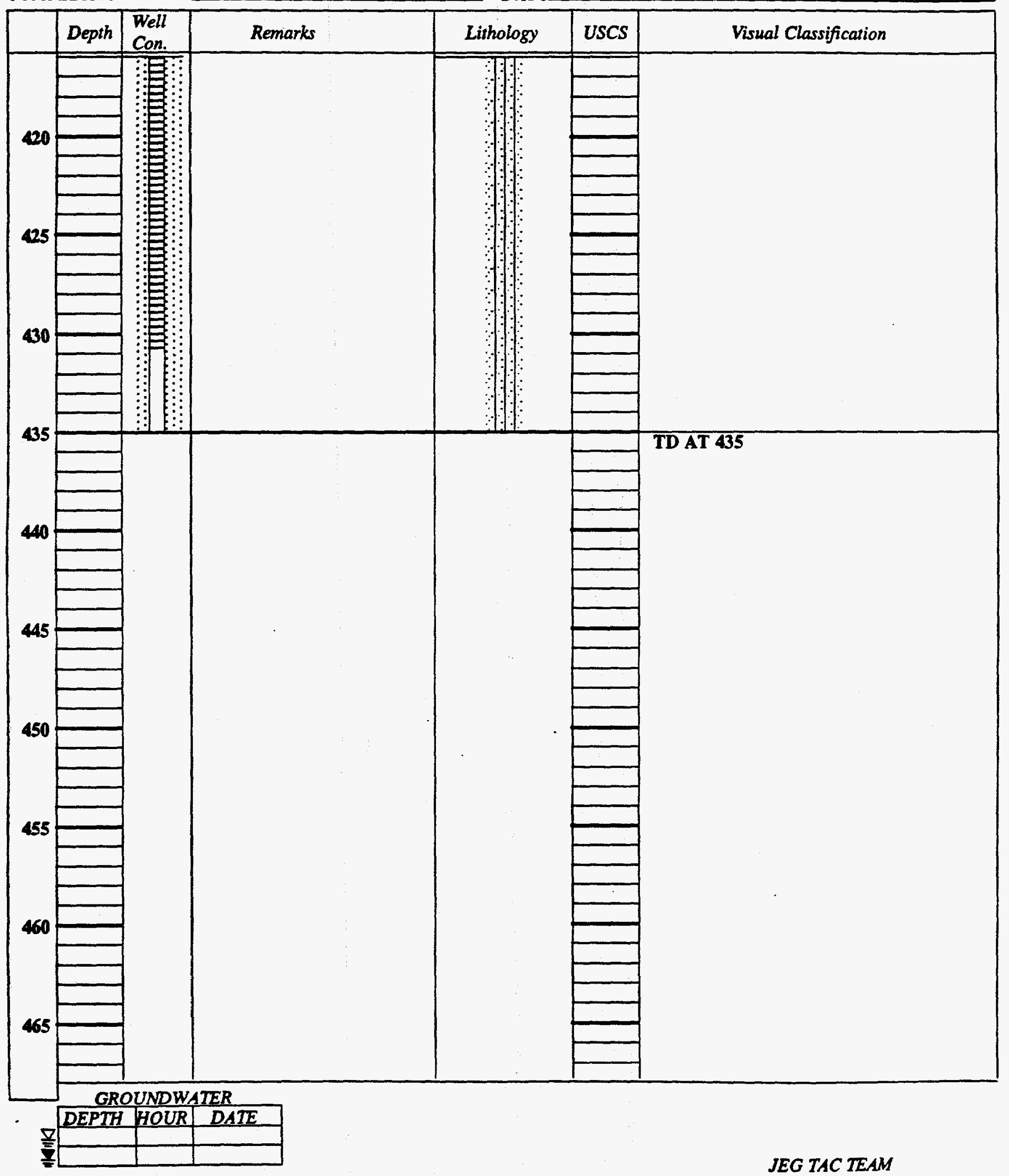

TOTAL DEPTH 435.0 feet

WELL OWNER

BORING TYRE

LOCATTON N E

DATUM MSL, GROUND SURFACE

\begin{tabular}{l|l|l} 
& USCS & Visual Classification
\end{tabular}


PROJECT $\frac{\text { Falls City Site }}{\text { Teras }}$

Page 1 of ${ }^{3}$

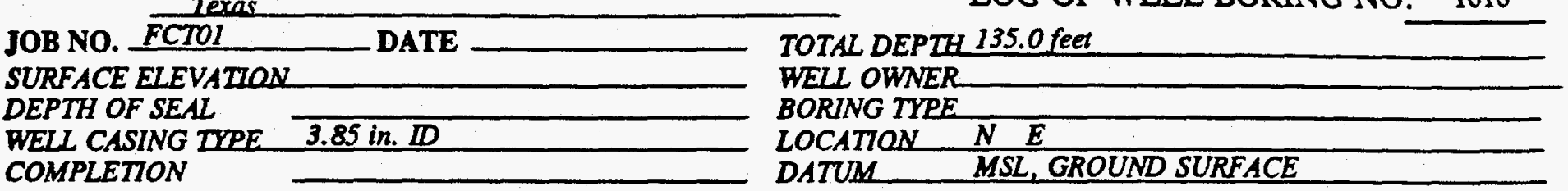

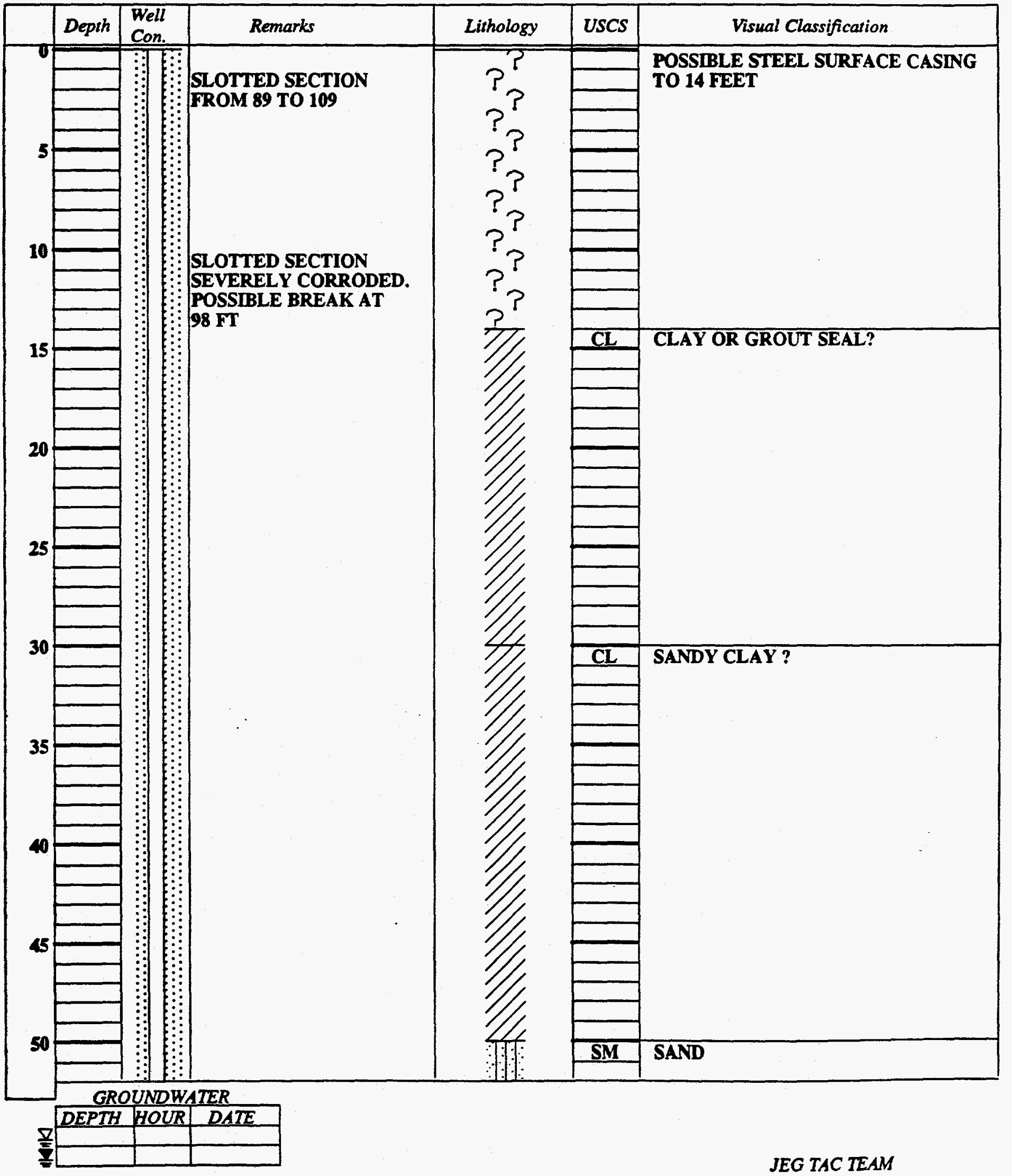


PROJECT Falls City Site

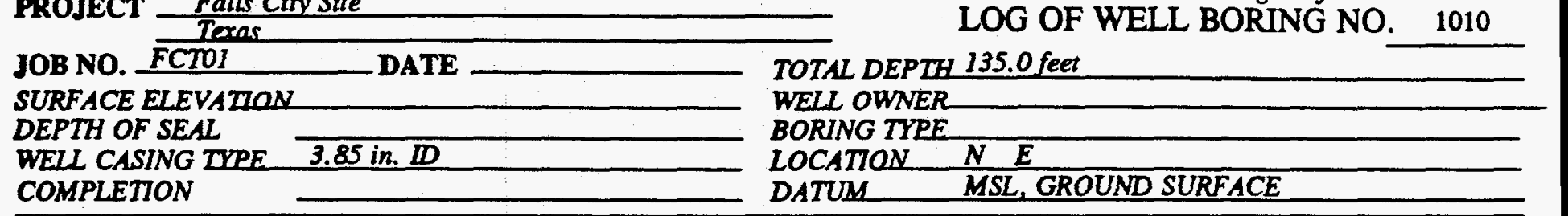

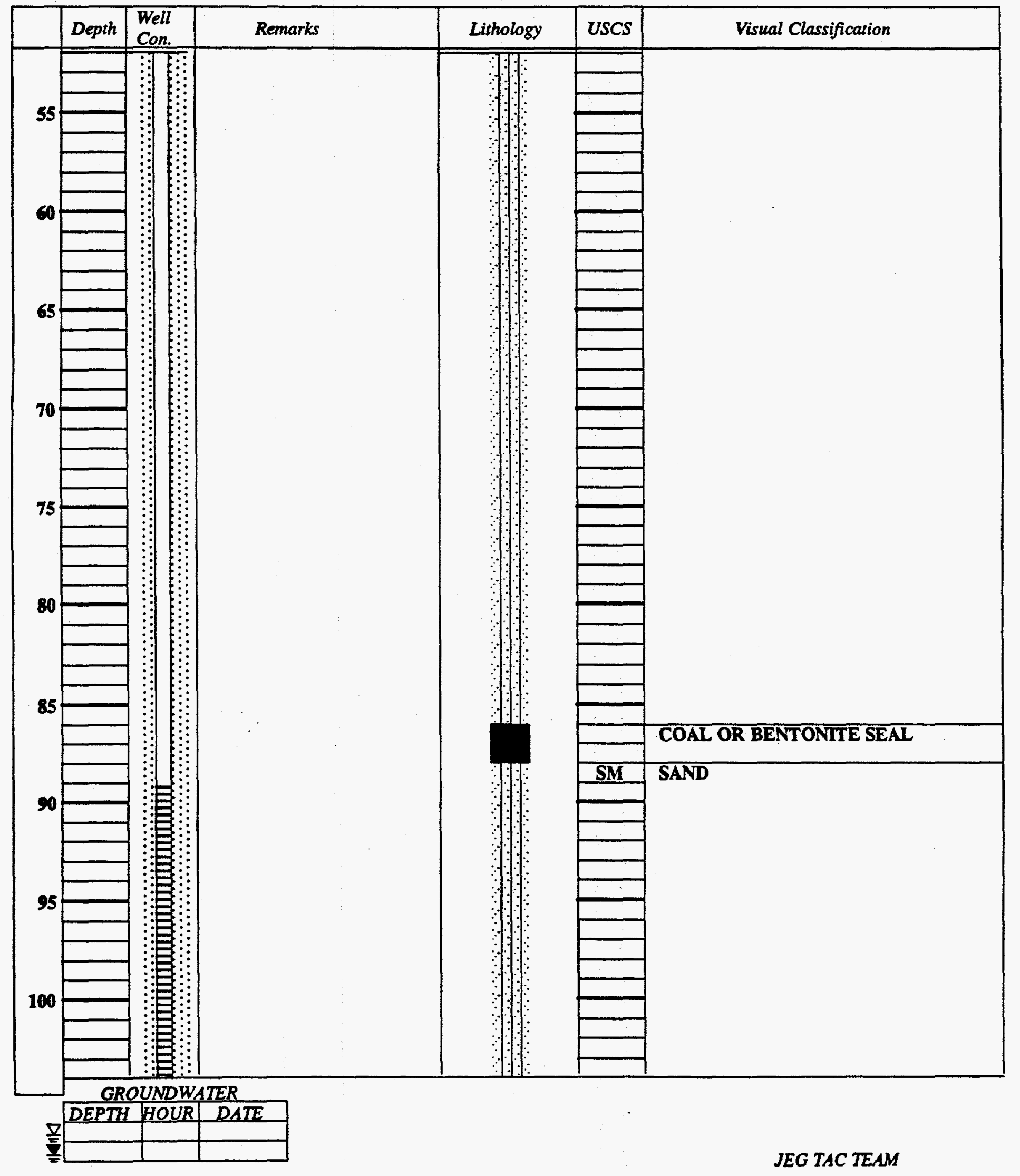


PROJECT Falls City Site

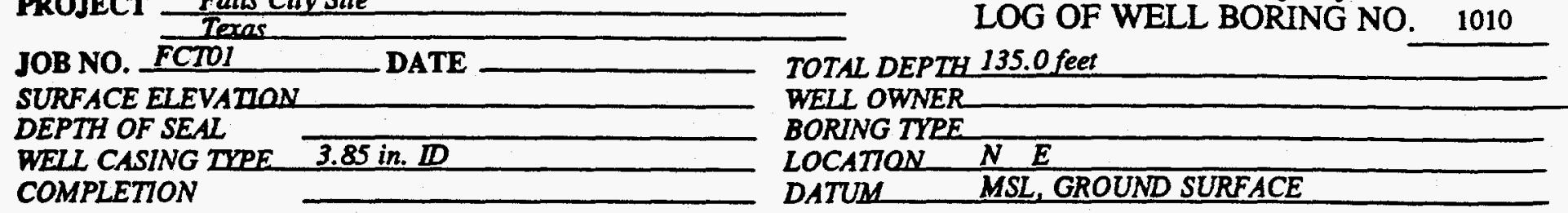

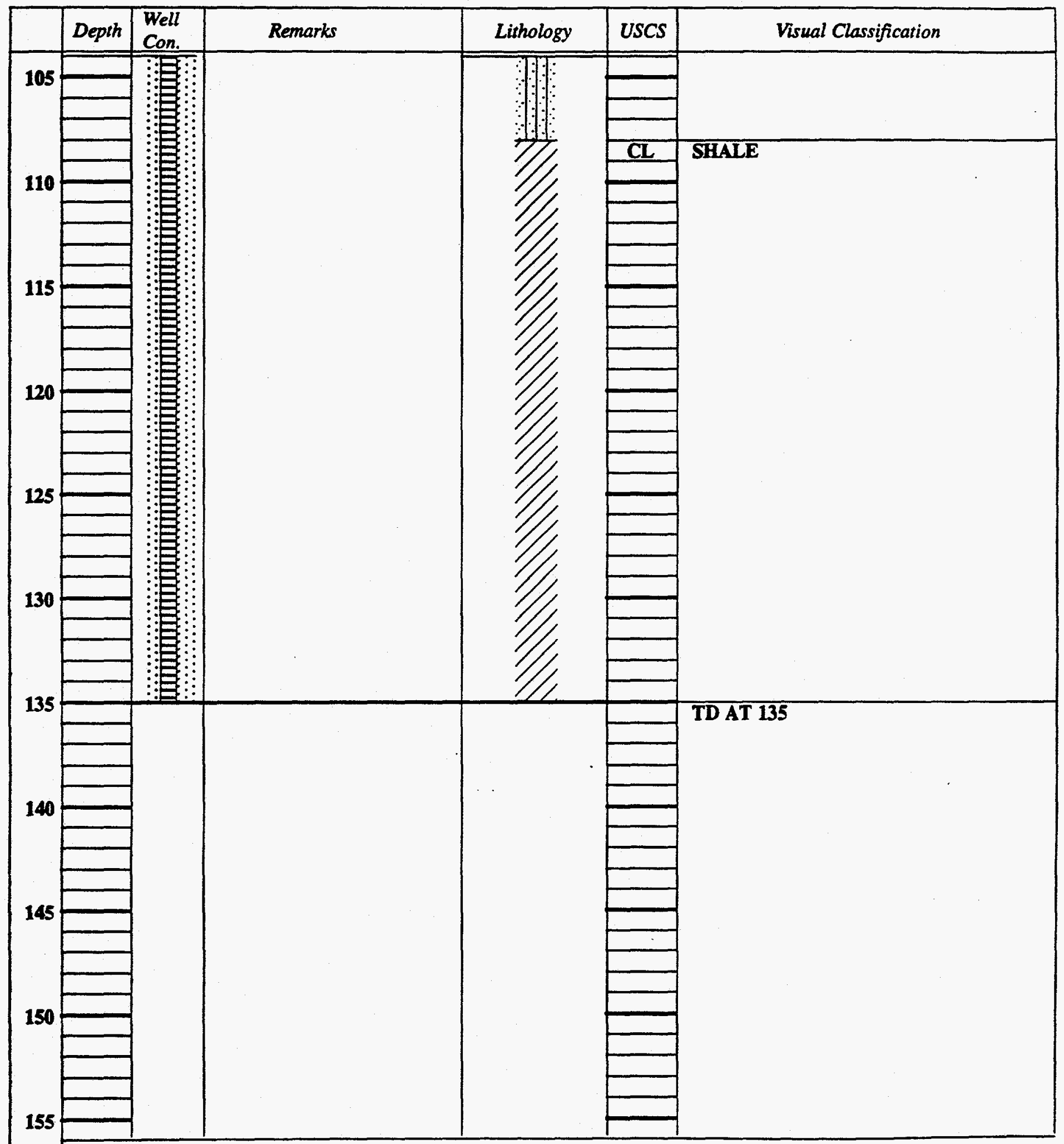

GROUNDWATER

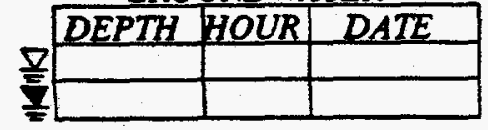


PROJECT Falls City Site

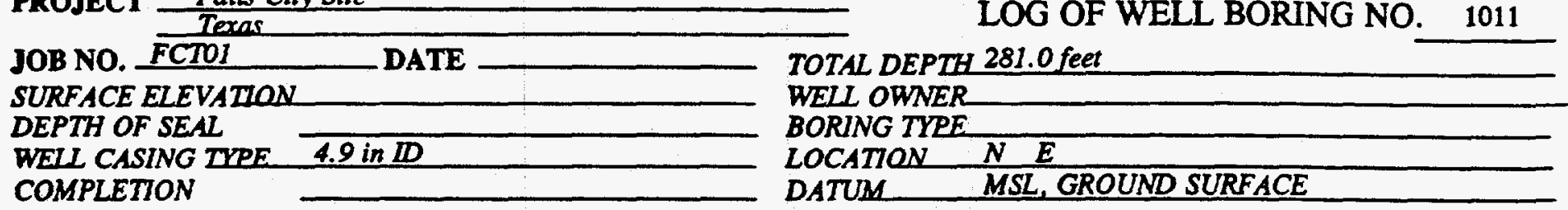

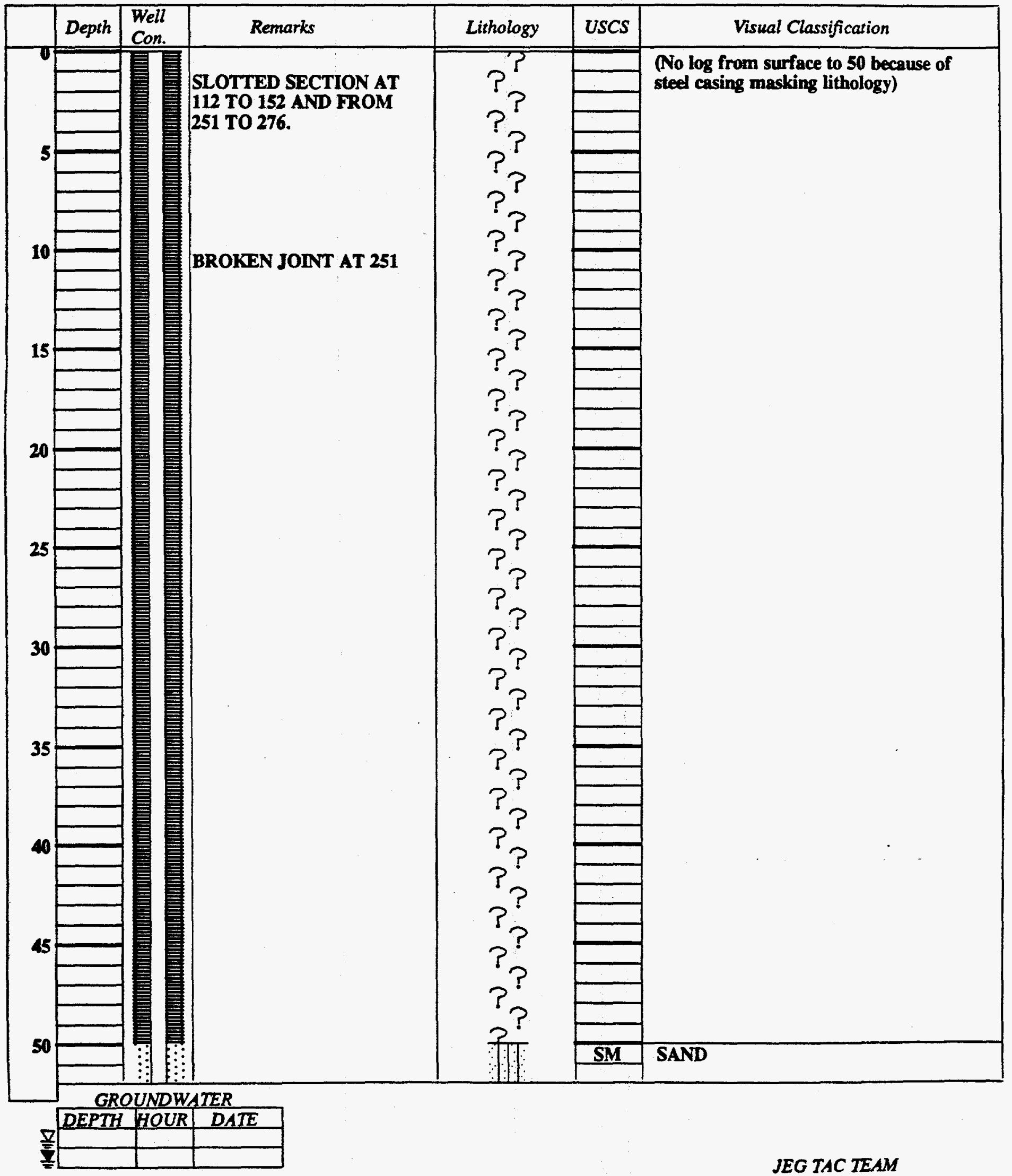


PROJECT $\frac{\text { Falls Ciry Site }}{\text { Teras }}$

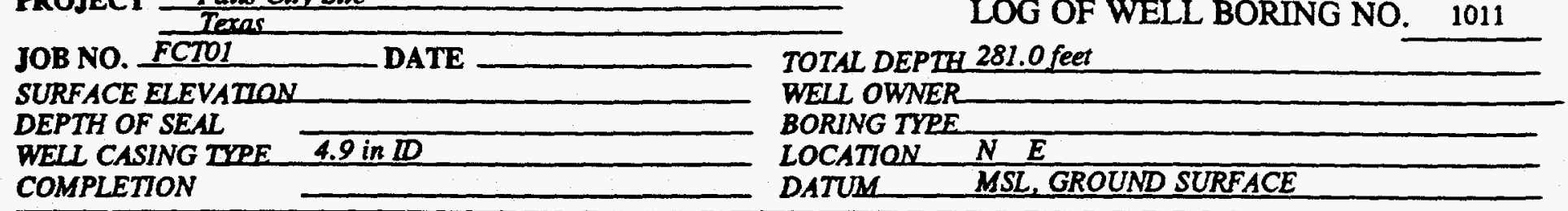

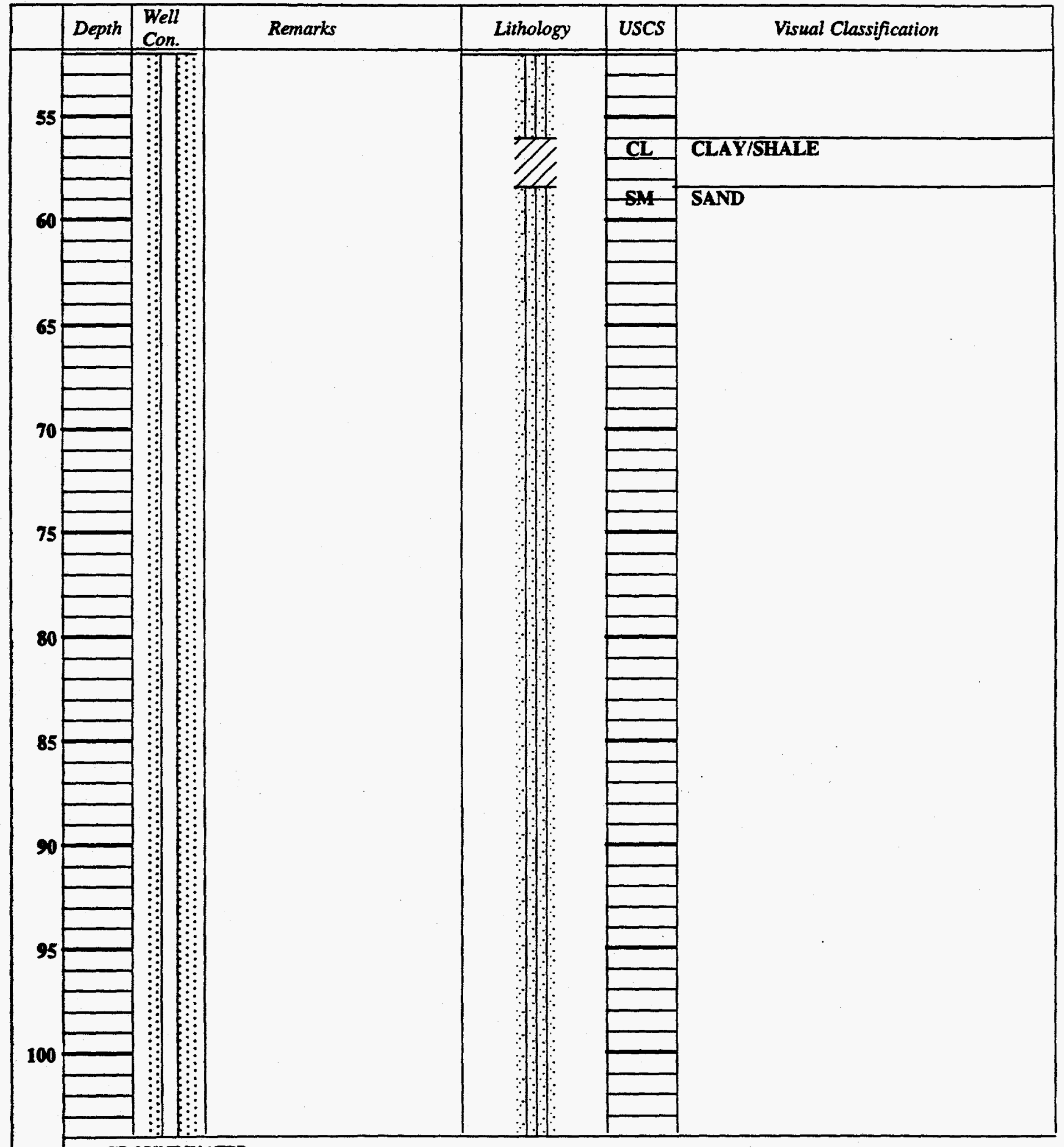

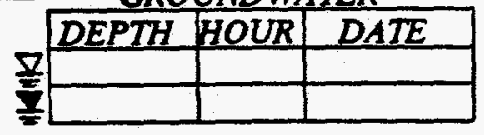


PROJECT Falls Ciry Site

Page $^{3}$ of 6

LOG OF WELL BORING NO. 1011

JOB NO. FCTO1 DATE

SURFACE ELEVATION

DEPTH OF SEAL

WELL CASING TYPE 4.9 in D

COMPLETION

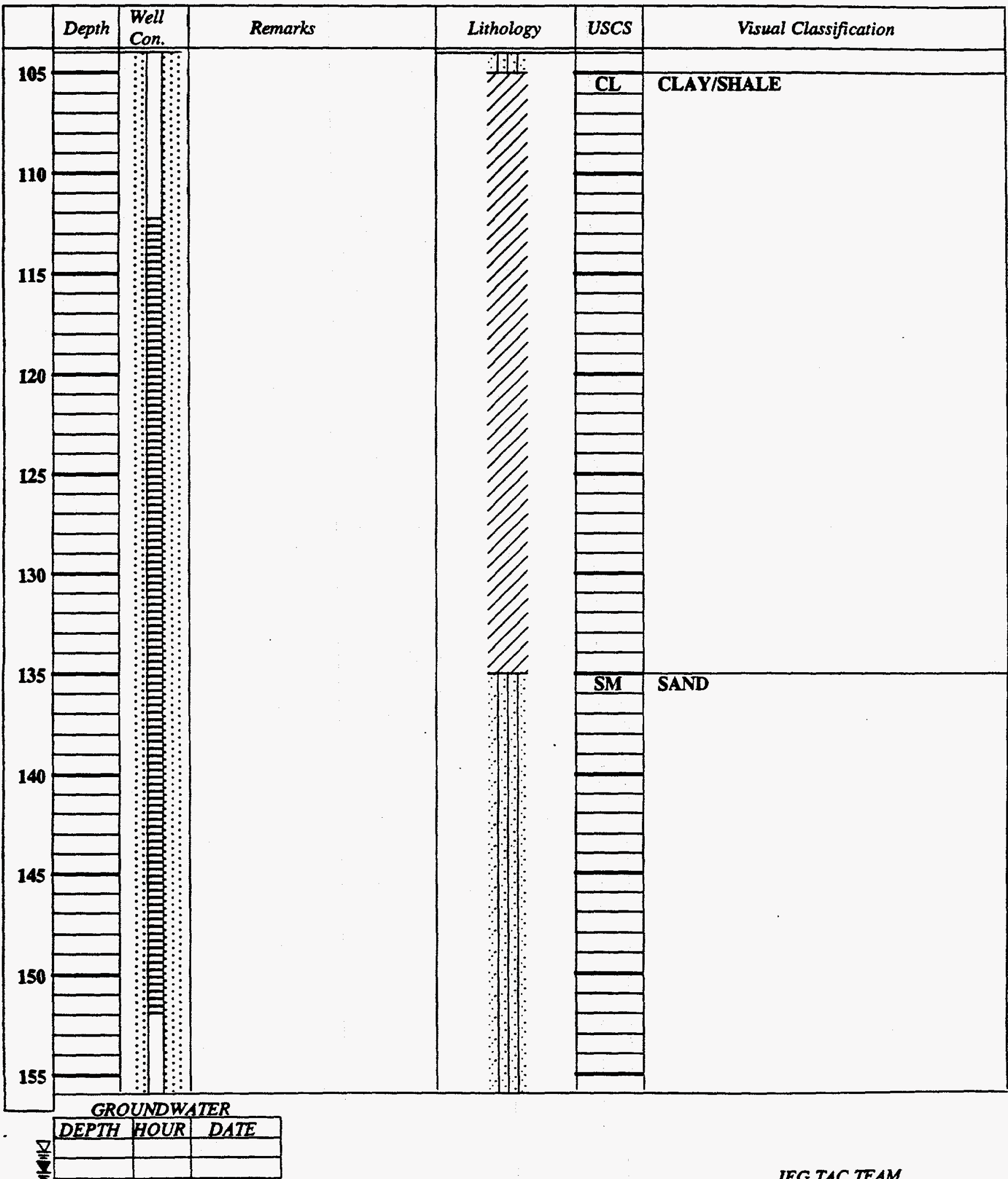


PROJECT Falls Ciry Site

JOB NO. FCTOI DATE

SURFACE ELEVATION

DEPTH OF SEAL

WELL CASING TYPE 4.9 in ID

COMPLETION

LOG OF WELL BORING NO

1011

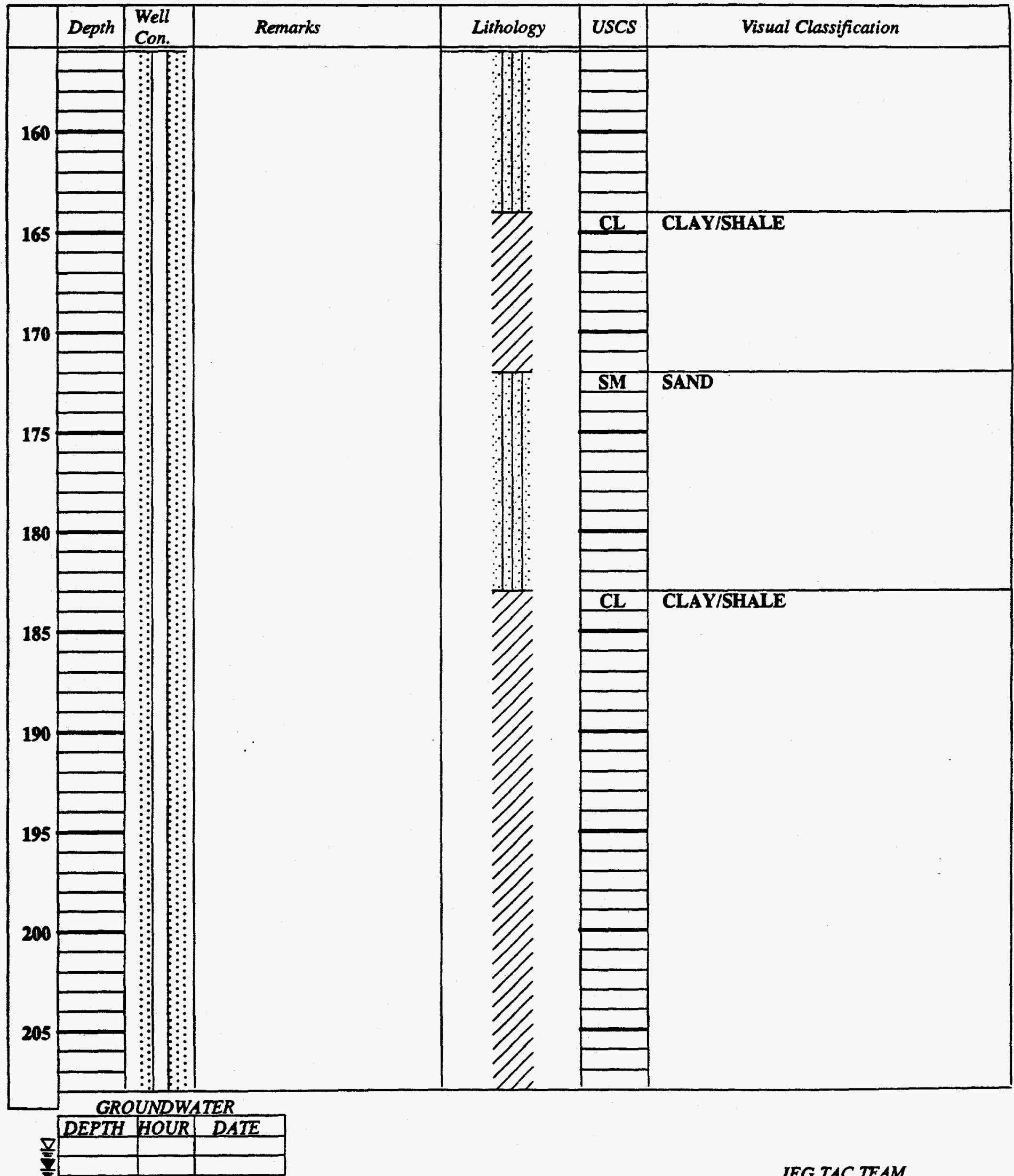


PROJECT Falls Ciry Site

Page 5 of 6

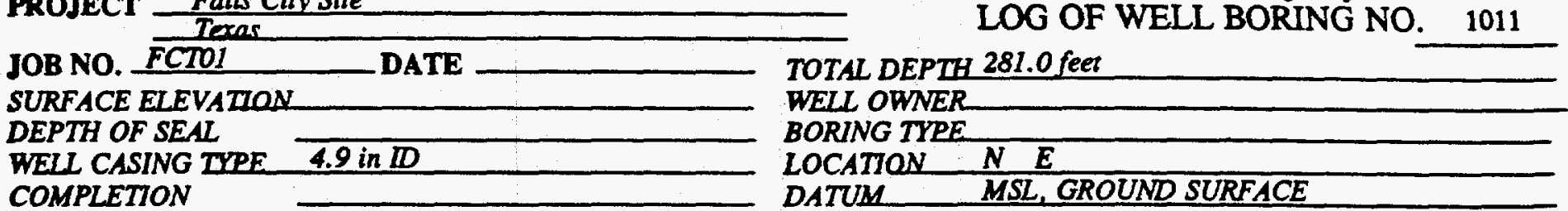

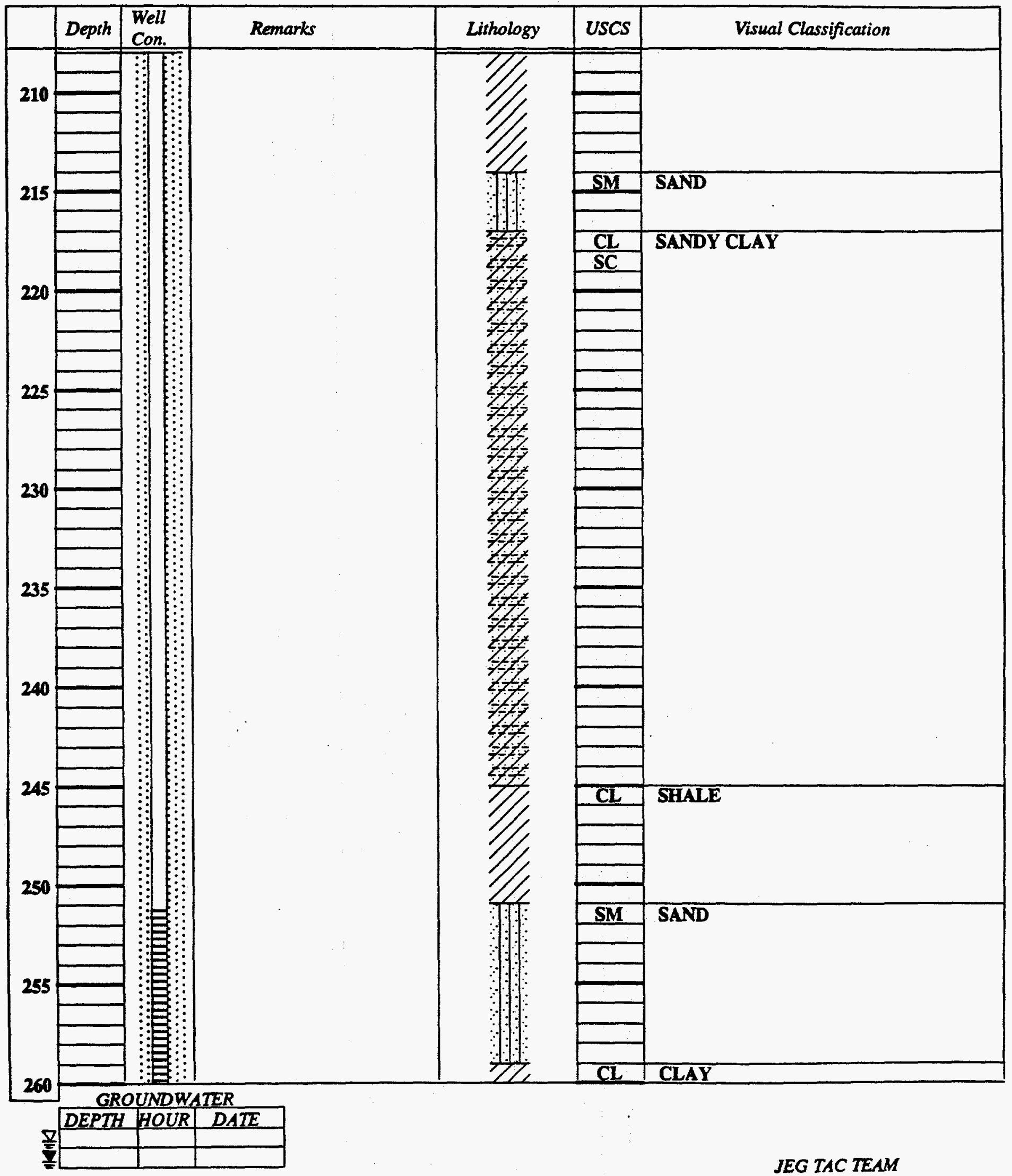


PROJECT Falls Cin Site

Page $^{6}$ of 6

JOB NO. FCTO1 DATE

SURFACE ELEVATION

DEPTH OF SEAL

WELL CASING TIPE $4.9 \mathrm{in} \mathrm{DD}$
COMPLETION

DATE TOTAL DEPTH 281.0 feet

LOG OF WELL BORING NO

1011

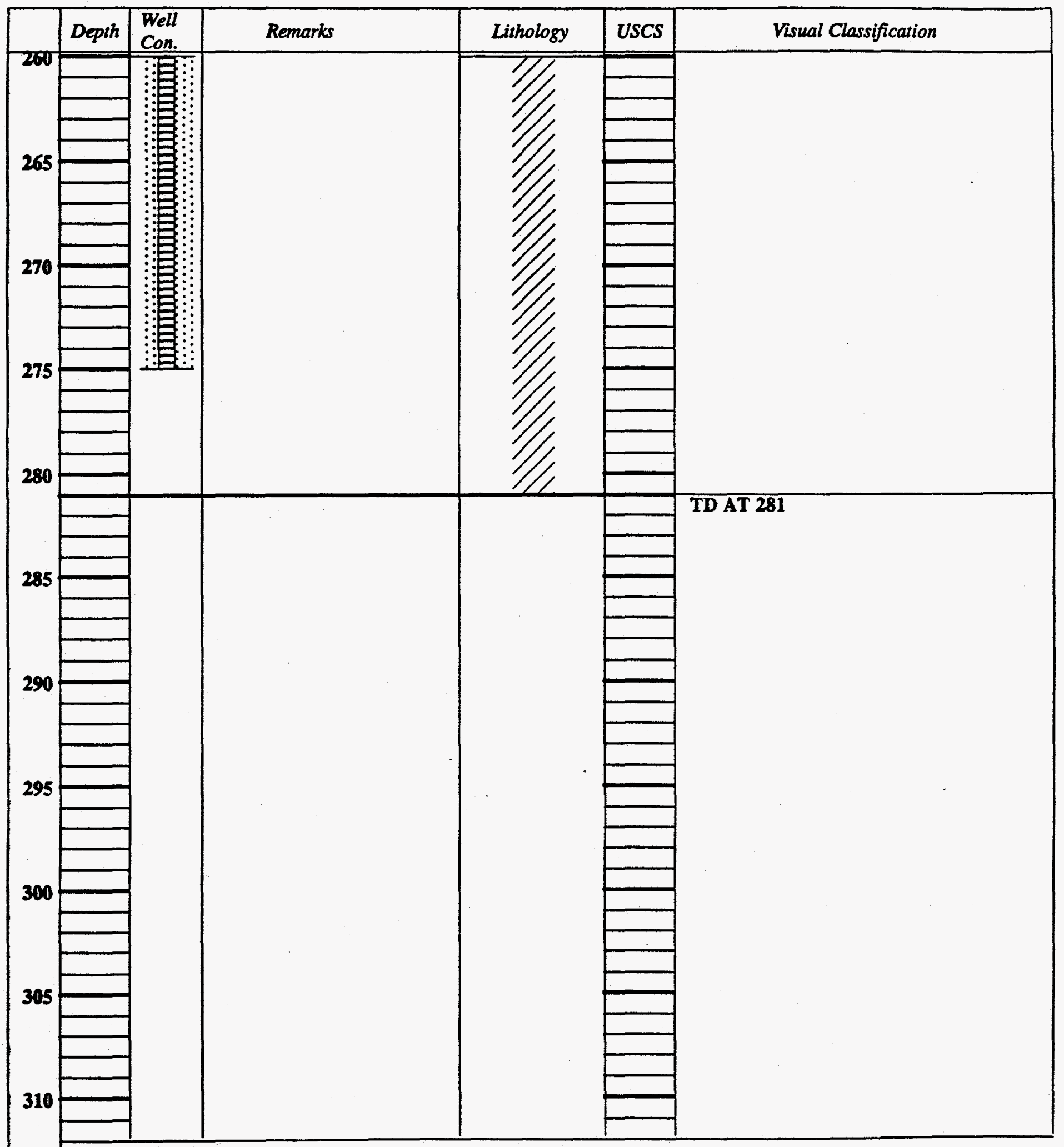

GROUNDWATER

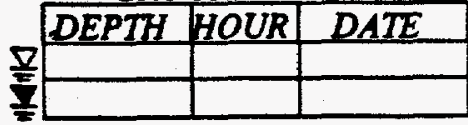

